A 966723

II arek Czajkowski

Przestrzeń kosmicżna

w strategil bezpieczeństwa $\therefore$ narodowego

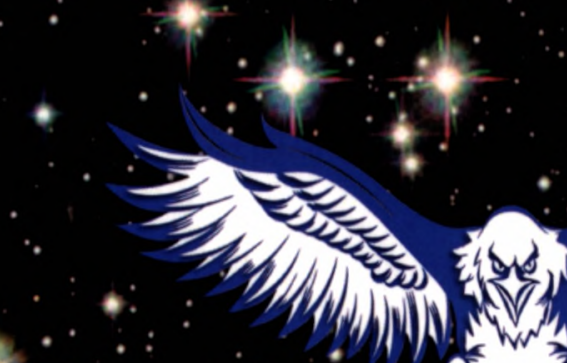

USAS

हो)

री०
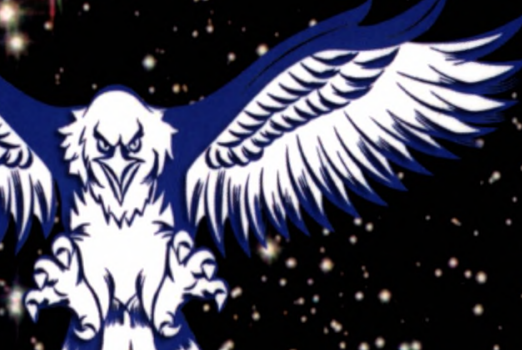

3)

त्रि

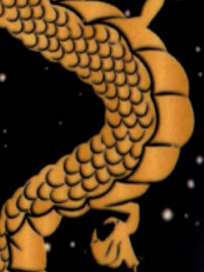

If

23

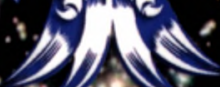

$+8 ; 4+8$ 



\section{PrZESTRZEŃ KOSMICZNA W STRATEGII BEZPIECZEŃSTWA NARODOWEGO USA}




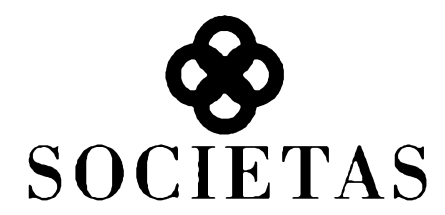

seria pod redakcja

BOGDANA SZIACHTY

127 
Marek Czajkowski

Przestrzeń kosmiczNa

W STRATEGII BEZPIECZEŃSTWA

NARODOWEGO USA

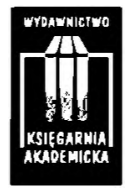

Kraków 
(C) Copyright by Marek Czajkowski, 2020

\section{Recenzja}

dr hab. Irma Słomczyńska, UMCS

\section{Redakcja}

Patrycjusz Pilawski

Projekt okładki i opracowanie graficzne ilustracji

Darius T. Petžkevičus

Na okładce wykorzystano materiały z portalu pl.freepik.com oraz NASA, www.nasa. gov: Hubble Sees an Ancient Globular Cluster, https://www.nasa.gov/content/god dard/hubble-sees-an-ancient-globular-cluster i Brilliance at Night: The Americas in Darkness, https://www.nasa.gov/image-feature/brilliance-at-night-the-americas-indarkness

Książka dofinansowana przez Wydział Studiów Międzynarodowych i Politycznych Uniwersytetu Jagiellońskiego

ISBN 978-83-8138-181-9 (druk)

ISBN 978-83-8138-229-8 (on-line, pdf)

https://doi.org/10.12797/9788381381819

\section{WYDAWNICTWO KSIĘGARNIA AKADEMICKA}

ul. św. Anny 6, 31-008 Kraków

tel./faks: 124312743,124211387

e-mail: akademicka@akademicka.pl

Księgarnia internetowa:

https://akademicka.pl 


\section{Spis treści}

Wykaz skrótów

Wprowadzenie

1. Przestrzeń kosmiczna a bezpieczeństwo - wymiar epistemologiczny i prawny

1.1. Pojęcie spacepower $w$ nauce o stosunkach międzynarodowych

Paradygmat realistyczny ................................................................. 28

Paradygmat liberalny............................................................ $\quad 30$

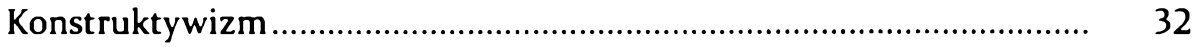

Geostrategia przestrzeni okołoziemskiej .......................................... $\quad 35$

1.2. Teoria spacepower .............................................................................. 39

James E. Oberg: Space Power Theory ................................................. 40

Everett C. Dolman: Astropolitik ............................................................ 43

Brent Ziarnick: Developing National Power in Space: A Theoretical

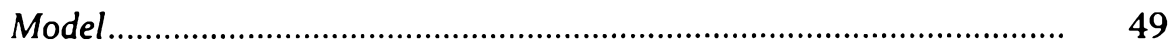

Podsumowanie - trzy wymiary spacepower....................................... 55

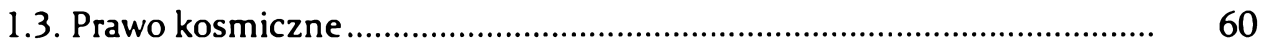

Ewolucja prawa kosmicznego .......................................................... 62

Traktat o przestrzeni kosmicznej z 1967 roku .................................... 67

Inne akty prawne .................................................................................. 71

Perspektywy rozwoju prawa kosmicznego ............................................ 73

2. Specyfika przestrzeni kosmicznej w kontekście bezpieczeństwa .......... 81

2.1. Przestrzeń kosmiczna i jej cechy charakterystyczne............................ 82

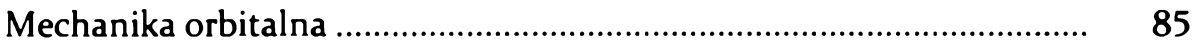

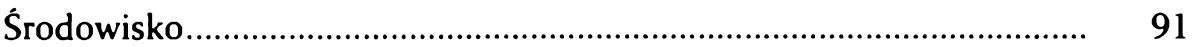


2.2. Wpływ wykorzystania przestrzeni kosmicznej na bezpieczeństwo narodowe i międzynarodowe................................................................ 96

Cechy przestrzeni kosmicznej a bezpieczeństwo................................. 97

Praktyczne zadania systemów kosmicznych w działaniach na rzecz

bezpieczeństwa.......................................................................... 102

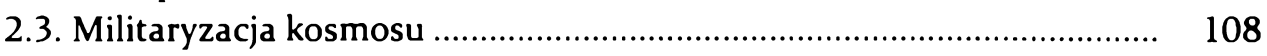

Militaryzacja bierna - wsparcie sił zbrojnych ................................... 111

Czynna militaryzacja kosmosu - broń kosmiczna .............................. 112

Broń przeciwsatelitarna ............................................................... 115

Obrona przeciwrakietowa ........................................................ 117

Ocena i perspektywy .............................................................. 117

3. Geneza i ewolucja polityki bezpieczeństwa USA w przestrzeni

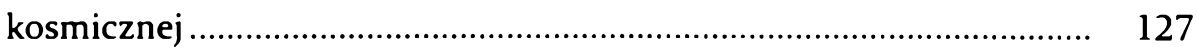

3.1. Poznawanie kosmosu i pierwsze perspektywy jego wykorzystania ...... 130

3.2. Kształtowanie się polityki USA wobec militaryzacji kosmosu .............. 137

3.3. Sputnik Moment.......................................................................... 146

3.4. Wyścig kosmiczny ...................................................................... 154

3.5. Dalszy rozwój zastosowań systemów orbitalnych ................................. 163

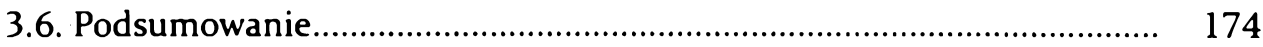

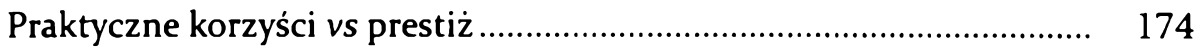

Wyścig kosmiczny ...................................................................... 176

Charakter militaryzacji kosmosu ................................................... 177

4. Przestrzeń kosmiczna we współczesnej strategii bezpieczeństwa USA 179

4.1. Strategia bezpieczeństwa narodowego USA - ewolucja i ogólne uwarunkowania

Kształtowanie się militarnego instrumentu polityki zagranicznej

Stanów Zjednoczonych

Kluczowe elementy polityki zagranicznej i strategii bezpieczeństwa

USA - rola sił zbrojnych

Czynniki ewolucji strategii bezpieczeństwa USA u schyłku drugiej

dekady XXI wieku - rola sił zbrojnych

4.2. Przestrzeń kosmiczna w strategii bezpieczeństwa USA - wymiar deklaratywny spacepower

Narodowa strategia bezpieczeństwa z 2017 roku

Narodowa strategia obronna z 2018 roku

Narodowa strategia wojskowa z 2015 roku

Narodowa polityka kosmiczna z 2010 roku

Narodowa strategia bezpieczeństwa kosmicznego z 2011 roku. 
Dokumenty dotyczące polityki kosmicznej administracji Donalda Trumpa

Space Force - nowy wymiar strategii kosmicznej USA?

Podsumowanie..

4.3. Znaczenie przestrzeni kosmicznej dla bezpieczeństwa USA podsumowanie.

Rola przestrzeni kosmicznej w strategii bezpieczeństwa USA.

Charakterystyka amerykańskiej spacepower

Perspektywy ewolucji amerykańskiej spacepower

5. Stany Zjednoczone a bezpieczeństwo kosmiczne - wybrane problemy

5.1. Space 2.0 - (r)ewolucja w eksploracji kosmosu.

Ewolucja systemów nośnych

Systemy satelitarne - rewolucja miniaturyzacyjna, nowe misje.

Podsumowanie i perspektywy

5.2. Stany Zjednoczone a aktualne zagrożenia dla bezpieczeństwa w kosmosie.

Zagrożenia dla bezpieczeństwa systemów kosmicznych ....

Konsekwencje ewentualnego wystąpienia zagrożeń dla bezpieczeństwa amerykańskich systemów kosmicznych

Przeciwdziałanie zagrożeniom systemów kosmicznych - wybrane aspekty teoretyczne i praktyczne

5.3. Perspektywa dalszej militaryzacji kosmosu - debata nad bronią kosmiczną

Militaryzacja czynna kosmosu - broń na orbicie 307

Argumenty „za” tworzeniem broni kosmicznych

Argumenty „przeciw” tworzeniu broni kosmicznych

Podsumowanie i prognoza

Podsumowanie

Bibliografia

Źródła

Raporty.

Książki

Artykuły naukowe.

Publicystyka

Indeks osobowy 



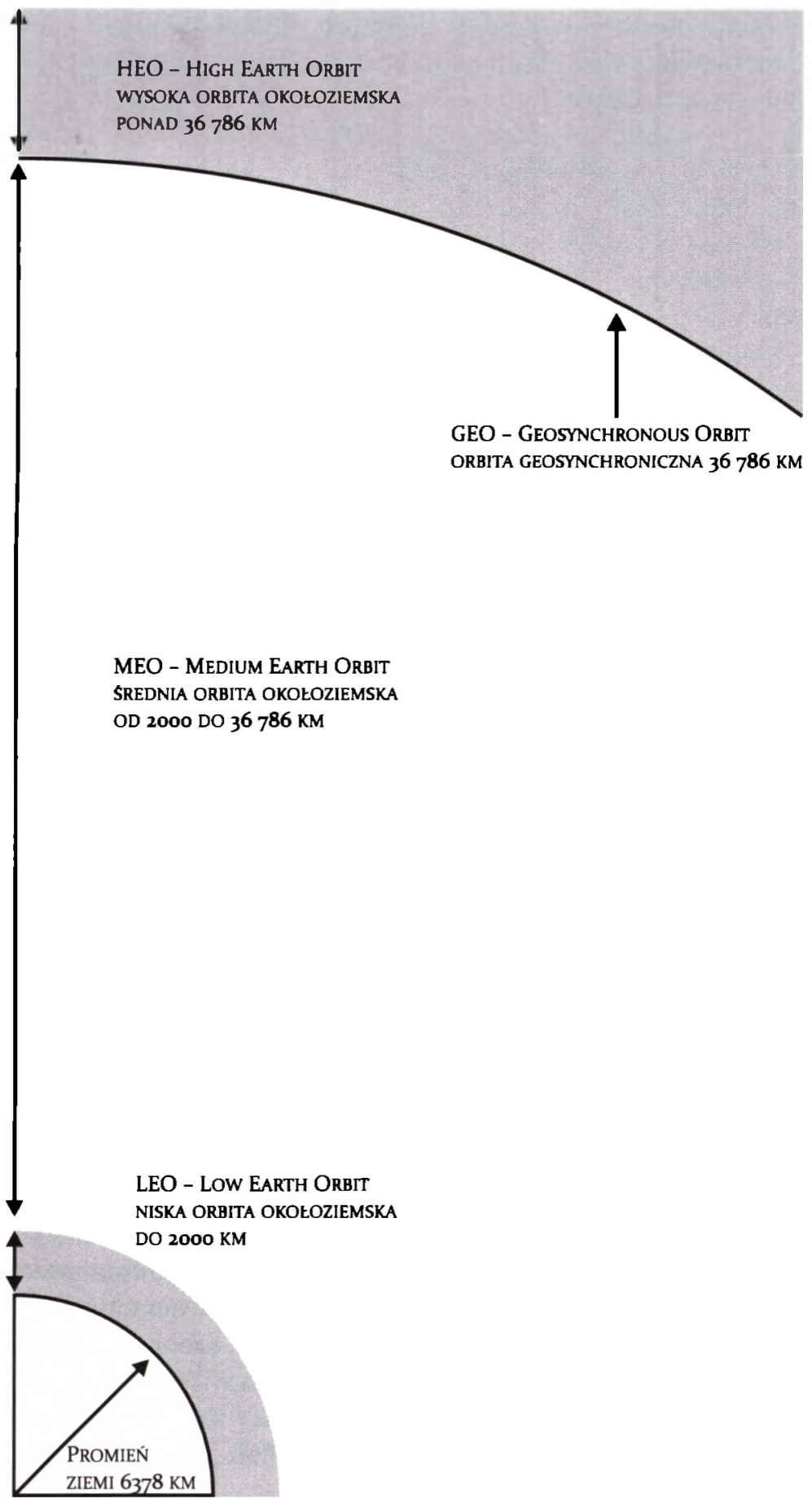

1. Klasyfikacja orbit okołoziemskich (źródło: opracowanie własne). 



\section{Wykaz skrótów}

ASAT - Anti-Satellite Weapon - broń przeciwsatelitarna

ARPA - Advanced Research Projects Agency - Agencja Zaawansowanych Projektów Badawczych

BMDS - Ballistic Missile Defense System - system obrony przeciwrakietowej USA

$\mathrm{C}_{4}$ ISR - Command, Control, Communications, Computers, Intelligence, Surveillance and Reconnaissance - ogólne określenie systemu zarządzania zbieraniem informacji oraz działaniami bojowymi, zawierającego podsystemy dowodzenia, zarządzania, komunikacji, przetwarzania danych, wywiadu, rozpoznania i nadzoru

Caltech - California Institute of Technology - Kalifornijski Instytut Technologiczny

co-orbital ASAT - broń przeciwsatelitarna bazowania kosmicznego

COPUOS - Committee of the Peaceful Uses of Outer Space - Komitet do spraw Pokojowego Wykorzystania Przestrzeni Kosmicznej

CSG - Carrier Strike Group - grupa uderzeniowa lotniskowca

direct-ascent ASAT - broń przeciwsatelitarna bazowania lądowego

DSP - Defense Support Program - program wsparcia obrony, amerykański system satelitarny służący do wykrywania rakiet balistycznych

GEO - Geostationary Equatorial Orbit - orbita geostacjonarna

GSO - Geosynchronous Earth Orbit - orbita geosynchroniczna

GTO - Geostationary Transfer Orbit - orbita transferowa do geostacjonarnej

HGV - Hypersonic Glide Vehicle - hipersoniczny pojazd szybujący

ICBM - Intercontinental Ballistic Missile - międzykontynentalny pocisk balistyczny

IGY - International Geophysical Year - Międzynarodowy Rok Geofizyczny 
ISS - International Space Station - Międzynarodowa Stacja Kosmiczna

ITU - International Telecommunication Union - Międzynarodowy Związek Telekomunikacyjny

JPL - Jet Propulsion Laboratory - Laboratorium Napędu Odrzutowego

$\mathrm{KH}$ - Key Hole - amerykańskie satelity zwiadu optycznego

LEO - low Earth orbit - niska orbita okołoziemska

NASA - National Aeronautics and Space Administration - Narodowa Agencja Aeronautyki i Przestrzeni Kosmicznej

NOAA - National Oceanic and Atmospheric Administration - Narodowa Służba Oceaniczna i Atmosferyczna

NRL - Naval Research Laboratory - laboratorium badawcze marynarki wojennej

NRO - National Reconnaissance Office - Narodowe Biuro Rozpoznania

SDI - Strategic Defense Initiative - Inicjatywa Obrony Strategicznej

SLS - Space Launch System - Kosmiczny System Nośny

STS - Space Transportation System - System Transportu Kosmicznego (tzw. prom kosmiczny)

ULA - United Launch Alliance

USAF - United States Air Force - Siły Powietrzne USA

USAAF - United States Army Air Force - Siły Powietrzne Armii USA 


\section{Wprowadzenie}

[...] Era kosmiczna ani nie usuwa, ani nie uwypukla ludzkich konfliktów, rozciaga jedynie normalnq politykę na nowy obszar - imperatyw międzynarodowy i ludzka niedoskonałość pozostajq zatem niezmienne. Kosmiczna technologia może, poprzez swoje instytucjonalne potomstwo, zmieniać i społeczeństwa, i ekonomię, ale nigdy nie zmieni swoich rodziców: systemu międzynarodowego składającego się z państw oraz ciekawskiego, ambitnego ludzkiego ducha'.

Walter A. McDougall

Motto niniejszej pracy, autorstwa amerykańskiego historyka, bardzo dobrze określa znaczenie kosmosu, z punktu widzenia ludzkości pojmowanego współcześnie jako kolejne rozszerzenie przestrzeni, w której żyjemy i gospodarujemy. Podobnie jak wcześniej zagospodarowane domeny morza i przestrzeń powietrzna - wykorzystanie obszarów poza atmosferą ziemską przynosi człowiekowi ogromne korzyści, zarówno w ujęciu zbiorowości ludzkich, jak i w perspektywie indywidualnej. Systemy kosmiczne są bowiem zdolne do wykonywania wielu ważnych funkcji znacznie lepiej i skuteczniej niż urządzenia naziemne, morskie lub znajdujące się w przestrzeni powietrznej. Dziedziny, w których są one najszerzej stosowane, to przede wszystkim telekomunikacja, obserwacja powierzchni Ziemi oraz pozycjonowanie. Wyniesienie odpowiednich urządzeń na orbitę okołoziemską radykalnie ułatwiło realizację rozlicznych szczegółowych

1 W. A. Mc Dougall, The Heavens and the Earth:A Political History of the Space Age, Baltimore 1997, s. 414. Wszystkie thumaczenia z języka angielskiego - Marek Czajkowski. 
zadań w tych sferach, wprowadzając wręcz nową jakość w zakresie szybkości i efektywności ich realizacji.

Trudno jest zatem przecenić rolę przestrzeni kosmicznej i w ogólnym ujęciu ekonomicznym oraz praktycznym, i w zakresie realizacji indywidualnych aspiracji ludzi. Co więcej, jako ludzkość stoimy obecnie u progu, lub nawet właśnie ten próg przekraczamy, kolejnej rewolucji technicznej, która dość wyraźnie może zmienić oblicze wykorzystania kosmosu. Zmniejszenie kosztów wynoszenia ładunków na orbitę wraz z postępującą miniaturyzacją i obniżeniem cen komponentów stosowanych w systemach orbitalnych służy znaczącemu upowszechnieniu się zastosowań kosmicznych ${ }^{2}$. Jeszcze niedawno działalność w kosmosie była domeną państw oraz najbogatszych korporacji prywatnych, dziś podejmuje ją coraz więcej średnich i małych podmiotów. I nie są to tylko podmioty gospodarcze, ale także uniwersytety i ośrodki badawcze. Droga otwarta jest również dla prywatnych, niekomercyjnych systemów satelitarnych.

Ilustracją powyższych stwierdzeń niech będzie w pierwszej kolejności fakt, że w najtrudniejszej, a jednocześnie podstawowej dziedzinie wynoszenia ładunków na orbitę oprócz szeregu podmiotów państwowych i wielkich korporacji działa kilkadziesiąt mniejszych przedsiębiorstw. Przynajmniej kilkanaście $\mathrm{z}$ nich ma szansę na wdrożenie swoich systemów startowych i osiągnięcie komercyjnego sukcesu już w najbliższych latach. Ponadto w segmencie satelitarnym w szybkim tempie upowszechnia się technologia niewielkich obiektów, które stosunkowo niewielkim kosztem mogą z powodzeniem wykonywać szereg zadań, zarezerwowanych dotychczas dla dużych i drogich urządzeń. Według danych za czerwiec 2019 roku satelitów należących do najmniejszych klas, takich jak: cubesat, nanosat i pikosat, wystrzelono już 2396, z czego 991 określa się jako działające (operational) ${ }^{3}$. Warto $w$ tym miejscu dodać, że według stanu na początek marca 2019 roku na orbitach okołoziemskich znajdowały się 2062 aktywne satelity ${ }^{4}$. W przyszłości należy spodziewać się dalszego

2 Mamy pełną świadomość tego, że określenie „zastosowania kosmiczne” jest mało elegancką kalką z języka angielskiego, w którym upowszechnione jest określenie space applications. Nie ma jednak $w$ języku polskim terminu na tyle ogólnego, by dał się zastosować w tym kontekście.

3 Database, Nanosats Database, 2019, https://airtable.com/shrafcwXODMMKeRgU/tbld $J_{0 O B P}$ wINOJQY?blocks=hide.

4 USC Satellite Database, Union of Concerned Scientists, 31.03.2019, https://www.uc susa.org/nuclear-weapons/space-weapons/satellite-database. 
rozwoju ilościowego systemów kosmicznych, szczególnie w segmencie najmniejszych obiektów, choćby dlatego, że wiele przedsiębiorstw prowadzi zaawansowane prace mające na celu stworzenie ogromnych konstelacji składających się z setek, a nawet tysięcy niewielkich orbiterów dostarczających powszechnych i tanich usług odbiorcom na Ziemi.

Niniejsza praca ma za zadanie uchwycić część zarysowanej powyżej, bardzo rozległej problematyki. Nie unikając omówienia stosunkowo rozległego tła, postaramy się w niej przede wszystkim przyjrzeć się ewolucji, stanowi obecnemu i perspektywom zastosowania przestrzeni kosmicznej dla realizacji zadań z dziedziny bezpieczeńst wa narodowego w wymiarze zewnętrznym przez Stany Zjednoczone Ameryki oraz niektórym problemom bezpieczeństwa międzynarodowego z tym związanym. Tematyka ta wiąże się z zainteresowaniami autora problematyką bezpieczeństwa, szczególnie międzynarodowego, w której porusza się on już od dwóch dekad. Przedstawione poniżej rozważania są efektem kilkuletnich badań nad problematyką bezpieczeństwa kosmicznego, których wyniki ukazały się w postaci szeregu artykułów opublikowanych w ostatnich latach. $\mathrm{Ni}$ niejsza książka zawiera oczywiście przedstawione dotychczas konkluzje, znacznie jednak uzupełnione i połączone w całość, która wobec tego nie jest, jak mniemamy, jedynie kompilacją dotychczasowych wyników badań, ale osobnym i niezależnym źródłem wyjaśniania naukowego.

Poruszając kwestię motywów podjęcia tematu, nie można pominąć bardziej osobistych inspiracji autora, wynikających z głębokiej fascynacji fenomenem kulturowym, jakim jest niewątpliwie fantastyka naukowa z jej wizjonerami, takimi jak: Herbert George Wells, Jules Verne, Isaac Asimov, Arthur C. Clarke, Ray Bradbury, Stanisław Lem, Robert A. Heinlein, Arkadij i Boris Strugaccy oraz wielu innych. Właściwa temu nurtowi literatury zaduma nad człowiekiem stojącym wobec ogromu i złożonej różnorodności otaczającej go przestrzeni jest niewątpliwie częścią tożsamości autora niniejszej pracy.

Podstawowym pojęciem, jakiego będziemy używać, próbując opisać to, w jaki sposób państwo zdolne jest wykorzystywać przestrzeń kosmiczną dla swoich celów, jest spacepower ${ }^{5}$. Aczkolwiek nie jest ono współcześnie

5 Słowo to oznacza dosłownie „siłę kosmiczną” czy też „siłę w kosmosie”, jego właściwa zawartość jest jednak nieprzetłumaczalna na język polski w sposób umożliwiający wygodne stosowanie ewentualnego polskiego odpowiednika. 
w pełni skonceptualizowane i wciąż wymaga dookreślenia, to jednak jest, jak się zdaje, pożyteczną „etykietą” dla omawiania zdolności kosmicznych państw. Będziemy je zatem często stosować $z$ uwzględnieniem poniżej zarysowanych definicji, które należy uznać przede wszystkim jako operacjonalizację pojęcia na potrzeby niniejszej pracy.

Zazwyczaj przyjmuje się, że spacepower to zdolność konkretnego kraju do wykorzystania przestrzeni kosmicznej w swoim interesie. W najczęściej spotykanej konotacji oznacza to, w tradycyjnie realistycznym duchu, element siły państwa, który w połączeniu $\mathrm{z}$ innymi instrumentami służy do zapewniania mu bezpieczeństwa w związku z faktycznymi bądź potencjalnymi zagrożeniami zewnętrznymi. Są to zatem przede wszystkim zdolności, które można wykorzystać dla potrzeb sił zbrojnych czy też instytucji wywiadowczych. Takie ujęcie spotykamy w wielu pracach, które zajmują się teorią wojny kosmicznej czy militarnym wykorzystaniem kosmosu, nawet jeśli pojęcie spacepower nie pojawia się w nich expressis verbis. Wspomnieć tu należy klasyczną i wyczerpującą pozycję Stevena Lambakisa On the Edge of Earth: The Future of American Space Power ${ }^{6}$ czy też aktualną pracę Joan Johnson-Freese Space Warfare in the 21st Century: Arming the Heavens?.

Pojęcie spacepower można także rozumieć szerzej, uwzględniając warstwę ekonomiczną i społeczną, co wynika z jednej strony $\mathrm{z}$ rozpowszechnienia zastosowań niemilitarnych przestrzeni kosmicznej, a z drugiej ze wzrostu ekonomicznego znaczenia przemysłu kosmicznego. W takim ujęciu mówić należy nie tylko o systemach kosmicznych i ich wykorzystaniu, ale także o całym zapleczu przemysłu kosmicznego, edukacji, instytucjach, doktrynach politycznych etc. To podejście widoczne jest u klasyków współczesnej teorii spacepower, takich jak Everett C. Dolman czy James E. Oberg, choć ich wizje mają wciąż bardzo konserwatywne, państwocentryczne zabarwienie i ostatecznie sprowadzają się do siły państwa jako uczestnika stosunków międzynarodowych konfrontowanego z zagrożeniem stwarzanym przez innych uczestników stosunków międzynarodowych.

6 S. Lambakis, On the Edge of Earth: The Future of American Space Power, Lexington 2001.

7 J. Johnson-Freese, Space Warfare in the 21st Century: Arming the Heavens, New York 2017. 
Jednak wobec rosnącego znaczenia działalności transgranicznej, także kosmicznej, wobec rewolucji w zastosowaniach kosmicznych polegającej na ich szybkim upowszechnianiu można by też pokusić się o przedstawienie pojęcia spacepower $\mathrm{w}$ duchu liberalnych teorii stosunków międzynarodowych. Akcentowałyby one rolę kosmosu jako res communis i poszukiwały siły państwa w szerokiej współpracy międzynarodowej oraz $\mathrm{w}$ instytucjach i rozwiązaniach transgranicznych. W takiej optyce spacepower nie byłaby zatem jedynie atrybutem przynależnym państwu, lecz raczej pewną cechą charakterystyczną ogólnego potencjału ludzkości sięgającej w przestrzeń po zasoby, wiedzę i zyski. Abstrahując od wielu oczywistych trudności stojących przed tworzeniem takiej teorii, wydaje się, że szereg charakterystycznych cech przestrzeni pozaziemskiej predestynuje kosmos do bycia bardziej domeną współpracy niż polem konkurencji.

W niniejszej pracy będziemy jednak przede wszystkim odwoływać się do spacepower w stosunkowo dobrze skonceptualizowanym i tradycyjnym ujęciu. Rozumieć ją zatem będziemy jako sumę zdolności państwa związanych z zapewnieniem mu bezpieczeństwa przede wszystkim w ujęciu zewnętrznych zagrożeń, a zatem $w$ tradycyjnej warstwie militarno-politycznej. Do tej problematyki podejdziemy zasadniczo z perspektywy nauk politycznych, pomijając $\mathrm{w}$ większości warstwę przynależną naukom wojskowym, choć niewątpliwie niezbędne będą pewne odniesienia do problematyki technicznej i organizacyjnej związanej z parametrami i możliwościami określonych systemów kosmicznych oraz strukturami, w jakich one funkcjonują. Ponadto w części teoretyczno-pojęciowej przedyskutowane zostaną także ujęcia szersze, wykraczające poza tę realistyczną perspektywę.

A zatem, analizując spacepower, czyli funkcjonowanie „kosmicznego" instrumentu realizacji przez USA zadań z zakresu bezpieczeństwa narodowego w wymiarze zewnętrznym, zajmiemy się ujęciem teoretyczno-pojęciowym, historycznym, doktrynalnym i praktycznym. Ma nam to dać rozległą perspektywę dla oceny roli systemów kosmicznych w całokształcie strategii bezpieczeństwa zewnętrznego USA oraz wpływu tejże roli na stosunki międzynarodowe. W niewielkim stopniu zatem będziemy się zajmować niezwykle rozległą tematyką przemysłu kosmicznego, cywilnych zastosowań czy też ważną sferą społecznej percepcji rozwoju eksploracji kosmosu. 
Pod względem zastosowanych ujęć teoretycznych odwoływać się zatem będziemy przede wszystkim do ujęcia realistycznego, które, jak się zdaje, jest najlepsze $\mathrm{w}$ przypadku analiz $\mathrm{z}$ dziedziny bezpieczeństwa w ujęciu militarnym. Jest ono jednak w pewnym zakresie uzupełniane przez inne paradygmaty badawcze. W szczególności ujęcie konstruktywistyczne pomaga zgłębić motywacje działań podejmowanych przez różne podmioty w związku z określoną percepcją zagrożeń i środków służących ich odwracaniu. Ponadto w pewnych obszarach, w których wychodzimy nieco poza ściśle militarną tematykę do szerszych wymiarów spacepower, przydatne są ujęcia neoliberalne.

Ponieważ w niniejszej pracy centralnym pojęciem jest „bezpieczeństwo", należy w tym miejscu zastanowić się nad zastosowaniem tego terminu do przestrzeni kosmicznej. Nie wchodząc w szczegóły, warto pokrótce nadmienić, że określenia „bezpieczeństwo” będziemy używać w kilku różnych związanych z kosmosem kontekstach. Pierwszym i podstawowym jest „bezpieczeństwo kosmiczne” (space security), najbardziej ogólny, ale też z natury rzeczy niezbyt precyzyjny termin, w którym zawiera się niemożliwy do syntetycznego sprecyzowania „ogół” problemów związanych z szeroko pojętym bezpieczeństwem oraz przestrzenią kosmiczną. Bardziej precyzyjne pojęcia, niejako zawierające się w tym ogólnym, to „bezpieczeństwo w kosmosie” (security in space) oraz „bezpieczeństwo poprzez kosmos" (space for security). To pierwsze oznacza samo funkcjonowanie systemów orbitalnych, ich bezpieczeństwo (safety) oraz niezakłóconą pracę, drugie zaś - wykorzystanie przestrzeni kosmicznej do realizowania zadań z dziedziny bezpieczeństwa na rzecz podmiotów znajdujących się na Ziemi. Obydwa ujęcia są oczywiście ze sobą ściśle powiązane.

I jeszcze uwaga dotycząca jednego z podstawowych stosowanych w niniejszej pracy pojęć „przestrzeń okołoziemska”, które nie ma wyraźnej i jednoznacznej definicji typu encyklopedycznego w języku polskim. Encyklopedia PWN nie zawiera w ogóle takiego hasła, ograniczając się do nieskończenie szerokiego pojęcia „przestrzeń kosmiczna”, rozumianego jako przestrzeń rozciągająca się poza atmosferą ziemską, której granice umownie przyjmuje się na $100 \mathrm{~km}$ ponad powierzchnią Ziemi i w której odbywają się loty kosmiczne ${ }^{8}$. Będziemy się jednak posługiwać pojęciem

8 Kosmiczna przestrzeń, Encyklopedia PWN, https://encyklopedia.pwn.pl/haslo/kos miczna-przestrzen;3926141.html. 
„przestrzeń okołoziemska” w rozumieniu analogicznym do angielskiego pojęcia cislunar space, oznaczającego przestrzeń wewnątrz orbity Księży$\mathrm{ca}^{9}$. Czasami pojawia się ono w polskiej literaturze jako przestrzeń przedksiężycowa $^{10}$, ale ze względu na rzadkie stosowanie takiego terminu jest on słabo czytelny. W tym właśnie obszarze zawiera się cała interesująca nas działalność człowieka, poza nią wychodzą obecnie tylko sondy mające stricte badawczy charakter. W dającej się przewidzieć przyszłości to się nie zmieni, może poza niewielkimi wyjątkami.

Zasadniczym celem pracy jest zatem omówienie roli i znaczenia systemów orbitalnych w bezpieczeństwie narodowym USA, głównie dlatego, że kraj ten, jak się zazwyczaj uważa, przoduje w wykorzystaniu przestrzeni kosmicznej. Oznacza to zatem, że:

1. USA posiadają najbardziej rozwiniętą technologię kosmiczną i najbardziej rozbudowany, innowacyjny przemysł kosmiczny.

2. USA osiągają najwięcej korzyści z zastosowania systemów kosmicznych, zarówno w sferze militarnej, jak i na innych polach.

3. USA są najbardziej uzależnione od swoich zdolności kosmicznych", co $\mathrm{w}$ szczególności widać $\mathrm{w}$ sferze związanej $\mathrm{z}$ bezpieczeństwem narodowym.

Można zatem zadać pytanie podstawowe, w czym manifestuje się rzeczona rola kosmosu dla bezpieczeństwa USA oraz jakie jest jego znaczenie dla konkretnych strategii sformułowanych i realizowanych $w$ tym wymiarze. Interesuje nas oczywiście współczesność, choć niezbędne będzie także zarysowanie obszernego tła historycznego. Argumentować będziemy, że zastosowania kosmiczne mają kluczowe znaczenie nie tylko w wymiarze bezpieczeństwa narodowego, ale i z punktu widzenia całości realizowanej przez USA polityki zagranicznej. Mówiąc bardziej szczegółowo, zamierzamy wykazać, że na wszystkich płaszczyznach realizacji polityki bezpieczeństwa w wymiarze zewnętrznym Stany Zjednoczone w ogromnej mierze polegają na zastosowaniach kosmicznych. Ich wyko-

9 Cislunar, Merriam-Webster, 2016, http://www.merriam-webster.com/dictionary/cis lunar.

10 Kopernik, astronomia, astronautyka. Przewodnik encyklopedyczny, pod red. W. Zonna, Warszawa 1973 , s. 236.

11 Jeszcze jeden niezbyt estetyczny termin będący kalką z języka angielskiego (space capabilities), niezbędny jednak z braku w języku polskim innego adekwatnego określenia, które byłoby jednocześnie odpowiednio łatwe w użyciu. 
rzystanie jest wręcz warunkiem koniecznym do realizowania wielu konkretnych zadań z pożądaną efektywnością i skutecznością. Jednocześnie jednak zauważamy, że ewolucja środowiska bezpieczeństwa w wymiarze globalnym i regionalnym stawia pod coraz większym znakiem zapytania właśnie tę efektywność, a nawet samo osiąganie korzyści jako takie. Wynika to zarówno z rosnącej bezpośredniej konkurencji w eksploracji i eksploatacji kosmosu, jak i z rozszerzającej się oraz coraz bardziej dostępnej gamy środków, które mogą zostać zastosowane w celu uniemożliwienia osiągania korzyści z działania systemów satelitarnych. Stany Zjednoczone, powoli tracąc kluczowe przewagi, znajdują się zatem w trudnej sytuacji, nie mają jednak długofalowej, wiarygodnej strategii poradzenia sobie z nią. Jedyną odpowiedzią, jaką dostrzegamy, jest próba wzmocnienia istniejących instrumentów w celu utrzymania stanu rzeczy, która nie zastąpi elastycznej adaptacji.

Do tego zarysu tematyki niniejszej pracy warto jeszcze dodać, że poza systemami orbitalnymi duże znaczenie $\mathrm{z}$ punktu widzenia relacji pomiędzy bezpieczeństwem narodowym państw i przestrzenią kosmiczną mają także niektóre balistyczne pociski rakietowe. Są one zarówno zagrożeniem, jak i instrumentem polityki bezpieczeństwa państwa i na kilka sposobów powiązane są z kosmosem. Po pierwsze, te pociski balistyczne, których zasięg przekracza kilkaset kilometrów, w trakcie wykonywania swoich misji przechodzą przez przestrzeń kosmiczną, po drugie, zabezpieczenie tych działań realizują systemy satelitarne, po trzecie zaś, technicznie i historycznie pociski balistyczne powiązane są z rakietami służącymi do wynoszenia ładunków na orbitę okołoziemską. Konsekwencją tego stanu rzeczy jest $\mathrm{i}$ to, że obrona przeciwko rakietom balistycznym ma także znaczenie $\mathrm{z}$ punktu widzenia bezpieczeństwa kosmicznego. A to dlatego, że po pierwsze, ewentualna walka systemów przeciwrakietowych $\mathrm{z}$ rakietami balistycznymi odbywać się może $\mathrm{w}$ dużej części w przestrzeni okołoziemskiej, po drugie, systemy satelitarne służyć mogą do zabezpieczania tego typu działań defensywnych, a po trzecie, systemy przeciwrakietowe mają wiele wspólnego z bronią przeciwsatelitarną, niektóre mogą być nawet stosowane w tym charakterze.

Nad kwestią balistycznych pocisków rakietowych nie będziemy się jednak głębiej pochylać, pojawią się one w pewnym zakresie przede wszystkim w części teoretyczno-pojęciowej i historycznej. Interesować nas będą o tyle, że po pierwsze, pociski balistyczne dalekiego zasięgu 
wiążą się z satelitarnymi systemami nośnymi, które z kolei muszą zostać uwzględnione jako podstawa zastosowań orbitalnych. Po drugie zaś, znalazły one swoją szczególną rolę w ramach sił ofensywnych głównych mocarstw, przyczyniając się do wielu przewartościowań w zakresie myślenia strategicznego, które z kolei przełożyły się na zapotrzebowanie na systemy kosmiczne. W związku z tym w naszej pracy pojawi się także w pewnym zakresie kwestia obrony przeciwrakietowej.

Praca niniejsza składa się z pięciu rozdziałów. Dwa pierwsze mają za zdanie nakreślić rozległe tło pojęciowe i teoretyczne dalszych rozważań. Wydaje się to niezbędne między innymi dlatego, że, co często podkreślamy i podkreślać będziemy, charakterystyczne cechy przestrzeni kosmicznej na ogół nie są dobrze rozumiane. Przyczynia się do tego przede wszystkim odległość kosmosu od normalnego człowieka i jego codziennego życia, czyniąca go czymś egzotycznym i pojmowanym wyłącznie przez stereotypy. Te z kolei tworzy kultura masowa, w szczególności filmowe i telewizyjne wcielenia nurtu science fiction, pokazujące wiele fiction i prawie w ogóle science. Tymczasem w celu zrozumienia jakiejkolwiek tematyki kosmicznej trzeba zrozumieć kosmos, a w szczególności jego charakterystykę jako przestrzeni, w której obiekty stworzone ludzką ręką oraz sami ludzie poruszają się i wykonują określone czynności. Elementem koniecznym tła niniejszej pracy muszą być także pewne rozważania teoretyczne, jako że chcemy osadzić naszą tematykę na gruncie konkretnej dyscypliny, jaką jest nauka o stosunkach międzynarodowych, musimy zatem odnieść się i do teorii w ogóle, i do szczególnego tematu jej zainteresowania, jakim jest spacepower. Trzeci rozdział książki zawiera rozważania o charakterze historycznym, istotne przede wszystkim dlatego, że zawierają omówienie tego, w jaki sposób tworzyły się do dziś funkcjonujące $w$ dziedzinie bezpieczeństwa kosmicznego mechanizmy. Warto dobrze poznać sposób, w jaki powstawały, aby zrozumieć ich obecną rolę. Co więcej, wydaje się, będziemy tak argumentować, że obecnie mechanizmy te podlegają głębokiej transformacji, pojawiają się także nowe - mamy, jak się zdaje, do czynienia ze swego rodzaju rewolucją w kosmosie. Jeśli tak, to nakreślenie sposobu i przyczyn powstania obecnego stanu rzeczy wydaje się szczególnie ważne, bo może dać trafny obraz punktu wyjściowego obecnych zmian. I wreszcie rozdziały czwarty i piąty mówią o właściwym temacie, czyli o znaczeniu przestrzeni kosmicznej w strategii bezpieczeństwa USA, zarówno w wymiarze doktry- 
nalnym, jak i praktycznym, z uwzględnieniem wybranych kluczowych problemów bezpieczeństwa kosmicznego.

Metodologia zastosowana przy realizacji powyższych celów badawczych sprowadza się w dużej mierze do analizy historycznej oraz analizy mechanizmu decyzyjnego i bieżących procesów politycznych. W tej ostatniej kwestii przydatne są zarówno metoda systemowa, jak i analiza czynnikowa. Warto zwrócić uwagę, że ze względu na specyfikę tematyki wprowadzono szereg ogólnych rozważań z zakresu nauk ścisłych oraz inżynierii kosmicznej, praca ma zatem w pewnym zakresie charakter interdyscyplinarny. Będąc $\mathrm{z}$ założenia pozycją mieszczącą się $\mathrm{w}$ dziedzinie nauk o polityce, a szczególnie nauk o stosunkach międzynarodowych oraz o bezpieczeństwie, podejmuje także wątki $z$ innych dziedzin. Podkreślmy, że taki zabieg jest naszym zdaniem niezbędny ze względu na charakterystykę tematyki, która obejmuje analizę relacji pomiędzy zjawiskami politycznymi oraz techniką, w świetle obowiązujących praw fizyki.

Literatura przedmiotu jest bardzo rozległa, choć w większości ma charakter opisowy, mało jest propozycji syntetycznych, a tym bardziej teoretycznych. $\mathrm{Z}$ najciekawszych pozycji, które wywarły istotny wpływ na kształt niniejszej książki, można wymienić następujące: Toward a Theory of Spacepower ${ }^{12}$ to rozległa praca rozważająca różne kwestie teoretyczne i metodologiczne $\mathrm{z}$ różnych stron, pomagająca formułować tezy i pytania badawcze. Książka ta powstała około dekady temu, lecz pytania, które stawia, pozostają aktualne, cenna jest także przyjęta w niej bardzo rozległa perspektywa badawcza. Na specjalne wyróżnienie zasługuje także Astropolitik ${ }^{13}$ Everetta C. Dolmana, pozycja z 2001 roku, będąca częścią klasyki tematyki bezpieczeństwa kosmicznego. Bez względu na cokolwiek wątpliwą ogólną wymowę tej pracy, pozostaje ona jednak istotnym zbiorem ważnych i przemyślanych opinii na temat wielu kluczowych kwestii związanych z wykorzystaniem kosmosu. W zakresie rozważań dotyczących historii zastosowań kosmicznych w dziedzinie bezpieczeństwa wymienić należy przede wszystkim dwie bardzo dobrze udokumentowane i wartościowe pozycje, które znacząco wpłynęły na nasze zrozumienie tej

12 Toward a Theory of Spacepower, ed. Ch. D. Lutes [et al.], Washington 2011, http:// www.dtic.mil/dtic/tr/fulltext/u2/a546585.pdf.

13 E. C. Dol ma n, Astropolitik: Classical Geopolitics in the Space Age, London 2002, Taylor and Francis Kindle Edition 2005. 
tematyki: Waltera A. McDougalla The Heavens and the Earth: A Political History of the Space Age ${ }^{14}$ i Williama E. Burrowsa This New Ocean: The Story of the First Space Age ${ }^{15}$. W ramach problematyki prawniczej warto wymienić interesującą pozycję Małgorzaty Polkowskiej Prawo kosmiczne w obliczu nowych problemów współczesności ${ }^{16}$. Pomogła ona zarówno w nakreśleniu ogólnych ram prawnych związanych $\mathrm{z}$ bezpieczeństwem kosmicznym, jak i w sprecyzowaniu niektórych ważnych kwestii szczegółowych, także w wymiarze perspektywicznym. Natomiast podstawowe kwestie techniczne będące konsekwencją praw fizyki regulujących mechanikę orbitalną $\mathrm{i}$ inne kwestie związane $\mathrm{z}$ funkcjonowaniem systemów kosmicznych omawiamy głównie na podstawie bardzo kompleksowego opracowania Davida Wrighta, Laury Grego i Lisbeth Gronlund pod tytułem The Physics of Space Security, wydanego w 2005 roku $^{17}$. Warto także wspomnieć, że w świecie publikuje się wiele periodyków o tematyce związanej mniej lub bardziej z problematyką niniejszej książki. Z najszerzej przez nas wykorzystywanych należy wymienić „Astropolitics”, w którego radzie naukowej zasiadają tak znani autorzy, jak: James Clay Moltz, Everett C. Dolman, Roger D. Launius, Roger Handberg, Steven Lambakis czy Brian Weeden.

Na koniec warto zauważyć, że w polskiej literaturze przedmiotu nie ma wiele opracowań, które ujmowałyby tematykę bezpieczeństwa kosmicznego od strony nauki o stosunkach międzynarodowych czy nauki o bezpieczeństwie międzynarodowym. Najczęściej w tak zwanej literaturze fachowej zajmującej się problematyką kosmiczną oraz w literaturze z dziedziny nauk wojskowych spotykamy prace zajmujące się technicznym oraz ściśle militarnym ujęciem tematu. Szersze perspektywy są rzadko spotykane, znane nam jest kilka zaledwie pozycji mających ambicje wykraczania poza wąsko rozumianą analitykę wojskowo-techniczną, autorstwa Rafała Kopcia z Uniwersytetu Pedagogicznego w Krakowie i Pawła Frankowskiego z Uniwersytetu Jagiellońskiego. Poza tym jedy-

$1+$ W. A. McDougall, op. cit.

15 W. E. Burrows, This New Ocean: The Story of the First Space Age, Modern Library Paperbacks, Random House Publishing Group. Kindle Edition.

16 M. Polkowska, Prawo kosmiczne w obliczu nowych problemów współczesności, Warszawa 2011.

17 D. Wright, L. Grego, L. Gronlund, The Physics of Space Security, Cambridge, MA 2005. 
ną obszerną pozycją w polskiej literaturze przedmiotu dotyczącą polityki kosmicznej jest Polityka kosmiczna Unii Europejskiej autorstwa Irmy Słomczyńskiej z UMCS. Wydanych zostało także kilka książek o charakterze prawniczym, do wymienionej powyżej należy przede wszystkim dodać klasyczną pozycję Andrzeja Górbiela Międzynarodowe prawo kosmiczne.

Na zakończenie pozwolę sobie zawrzeć serdeczne podziękowania dla mojej rodziny, która dzielnie wspierała mój wysiłek w ostatnich latach. Dziękuję także bardzo serdecznie dziekanowi Wydziału Studiów Międzynarodowych i Politycznych UJ, dr. hab. Andrzejowi Porębskiemu, prof. UJ, oraz dyrektorowi Instytutu Nauk Politycznych i Stosunków Międzynarodowych UJ, prof. dr. hab. Robertowi Kłosowiczowi za wsparcie wydania niniejszej książki. Osobno chciałbym także podziękować kierownikowi Katedry Bezpieczeństwa Narodowego INPiSM, w której pracuję, prof. dr. hab. Arturowi Gruszczakowi, za wszystkie cenne uwagi i wsparcie organizacyjne moich wysiłków w ostatnich latach. Składam także nieustające podziękowania prof. dr. hab. Erhardowi Cziomerowi, który jest moim mistrzem i w największej mierze ukształtował moją osobowość jako uczonego. 


\section{1. \\ Przestrzeń kosmiczna a bezpieczeństwo - wymiar epistemologiczny i prawny}

Starając się ująć problematykę znaczenia przestrzeni kosmicznej dla zjawisk na Ziemi związanych z działalnością człowieka, musimy odpowiedzieć na pytanie, w jakich ramach teoretycznych będziemy prowadzić nasze rozważania. Ponieważ konkretnym przedmiotem niniejszej pracy jest problematyka bezpieczeństwa narodowego USA w wymiarze zewnętrznym, podstawę teoretyczną powinna stanowić teoria stosunków międzynarodowych ze szczególnym uwzględnieniem problematyki bezpieczeństwa międzynarodowego. A to dlatego, że bezpieczeństwo narodowe $w$ wymiarze zewnętrznym wiąże się $\mathrm{z}$ zewnętrznymi zagrożeniami, a więc przede wszystkim $z$ interakcjami pomiędzy państwami postrzegającymi i realizującymi swoje interesy w przestrzeni międzynarodowej.

Znane teorie $w$ tym zakresie musimy zatem zaadaptować do specyfiki naszej tematyki, zwracając uwagę na ograniczenia naturalne i technologiczne, tak by $w$ efekcie wyprowadzić prawidłowości na temat relacji pomiędzy wykorzystywaniem przestrzeni kosmicznej a stosunkami na Ziemi. Podkreślmy przy tym po raz kolejny, że ze swej natury stan bezpieczeństwa kosmicznego determinowany jest przede wszystkim przez państwa $w$ drodze relacji pomiędzy nimi. Te $z$ kolei wynikają $z$ ich percepcji własnych zagrożeń, interesów i przebiegu realizacji tychże. A zatem rozważania w zakresie nauki o stosunkach międzynarodowych i nauki o bezpieczeństwie międzynarodowym wydają się jak najbardziej właściwe.

Na tematykę tę patrzymy głównie przez pryzmat pojęcia spacepower, które można potraktować jako próbę ujęcia w ściślejsze ramy teoretyczne 
działalności państw w kosmosie, czyli tego, w jaki sposób adaptują one strategie realizacji własnych interesów do możliwości i ograniczeń związanych z kosmosem. Pojęcie spacepower może być zatem ujęte jako kategoria teoretyczna służąca stworzeniu ram wyjaśniania mechanizmów rządzących działalnością państw w kosmosie. I właśnie dlatego poświęcimy mu w tym rozdziale najwięcej uwagi, traktując ten termin właśnie jako ramy teoretyczne, przydatne do analizy działalności państw w kosmosie w związku z ich bezpieczeństwem narodowym.

Omówimy zatem kolejno, w najbardziej ogólnym wymiarze, najpierw to, jakie stanowisko wobec pojęcia spacepower mogą przyjmować główne paradygmaty badawcze $\mathrm{w}$ nauce o stosunkach międzynarodowych, biorąc pod uwagę ich podstawowe cechy charakterystyczne. Da nam to najbardziej ogólne pojęcie o tym, jak teoria stosunków międzynarodowych może postrzegać kosmos i jego zastosowanie. W dalszej kolejności przejdziemy do omówienia konkretnych poglądów dotyczących teorii spacepower, postaramy się je także odpowiednio skomentować.

Uzupełnieniem niniejszego rozdziału będą ogólne rozważania na temat prawa kosmicznego - interesować nas będzie ta część prawa regulującego działania w kosmosie, która jest wynikiem relacji między państwami, a więc odpowiednia część prawa międzynarodowego. Rozważania te być może należałoby umieścić w osobnym rozdziale, wydaje się jednak, że wobec szczupłości interesującej nas dziedziny prawa wystarczy krótkie omówienie jego podstawowych postanowień w ramach rozważań teoretycznych. Kształt prawa kosmicznego jest bowiem podobnie jak teoria podstawą do dalszych rozważań na temat różnych kwestii związanych $\mathrm{z}$ bezpieczeństwem kosmicznym.

\subsection{Pojęcie spacepower w nauce o stosunkach międzynarodowych}

Jak wiemy, spacepower w najbardziej ogólnym znaczeniu to zdolność podmiotu do adaptowania korzyści wypływających z działalności w przestrzeni kosmicznej dla osiągania swoich celów w różnych dziedzinach. W niniejszej pracy zawężamy te kwestie do problematyki bezpieczeństwa zewnętrznego, w praktyce chodzi nam zatem o rolę i znaczenie, jakie kosmos może mieć w strategii i bieżącej polityce zagranicznej oraz w polityce bezpieczeństwa podmiotów. Na spacepower $w$ tym ujęciu składać 
się zatem będzie szereg czynników materialnych związanych z funkcjonowaniem systemów kosmicznych i niematerialnych, czyli postrzeganie zagrożeń, doktryny użycia systemów kosmicznych i ogólne strategie bezpieczeństwa podmiotów. Uwzględniać należy także rozmaite ograniczenia, poczynając od naturalnych, poprzez ekonomiczne, do środków negatywnego oddziaływania na systemy satelitarne.

Pojęcie spacepower ukute zostało w końcu XX wieku przez analogię do pojęcia airpower, które pojawiło się w latach dwudziestych i trzydziestych tegoż wieku i nawiązywało do klasycznej teorii seapower skonceptualizowanej przez Alfreda T. Mahana u schyłku XIX stulecia. Podobieństwo wymienionych pojęć nie oznacza oczywiście, że istnieje swoboda przenoszenia poszczególnych elementów pomiędzy nimi - nie można także przyjmować tu automatyzmu w stosowaniu analogii. Podobieństwo dotyczy raczej głównie tego, że każdy z tych terminów odnosi się do przestrzeni o pewnych specyficznych cechach fizycznych. Wpływają one na jej wykorzystywanie, a w szczególności zmuszają człowieka do stosowania w tym celu określonych technologii. Jednocześnie każda z tych przestrzeni daje pewne specyficzne możliwości, których wykorzystanie sprzyjać może budowaniu siły państwa, jego zdolności oddziaływania, międzynarodowej pozycji czy też realizowaniu jego rozlicznych potrzeb bezpieczeństwa. Przestrzenie te są także obszarami, w których stykają się interesy różnych aktorów międzynarodowych, pojawiają się zatem różne formy interakcji państw i w samych przestrzeniach, i w związku $\mathrm{z}$ ich wykorzystaniem. Jest to oczywiście istotne $\mathrm{z}$ punktu widzenia nauki o stosunkach międzynarodowych, jest zatem także przedmiotem zainteresowania teorii stosunków międzynarodowych.

W niniejszym podrozdziale spróbujemy zatem rozważyć, jak wygląda kwestia przestrzeni kosmicznej i jej wykorzystania przez człowieka z punktu widzenia głównych paradygmatów badawczych obecnych w nauce o stosunkach międzynarodowych, ze szczególnym uwzględnieniem perspektywy bezpieczeństwa międzynarodowego. W szczególności rozważymy to, jak główne nurty teoretyczne mogą definiować spacepower, uwypuklając podstawowe cechy tego pojęcia. Takie podejście wydaje się najbardziej stosowne w świetle podejmowanej przez nas tematyki, ponieważ, powtórzmy, analizujemy wymiar zewnętrzny bezpieczeństwa narodowego, a zatem problematyka stosunków międzynarodowych i bezpieczeńst wa międzynarodowego jest dla nas głównym punktem odniesienia. 
Biorąc pod uwagę ograniczenia i zasadniczy cel niniejszej pracy, podejmiemy rozważania dotyczące dość ogólnie ujmowanych paradygmatów realistycznego, liberalnego i konstruktywistycznego, uzupełnione o krótką refleksję na temat geostrategii przestrzeni okołoziemskiej. Mamy oczywiście pełną świadomość wewnętrznego zróżnicowania i wielkiego bogactwa wariantów w ramach tych nurtów teoretycznych, ograniczymy się jednak do ujęcia modelowego i nieco uproszczonego, choć na nasze potrzeby, jak sądzimy, wystarczającego.

\section{Paradygmat realistyczny}

Paradygmat realistyczny wychodzi od wizji człowieczeństwa nacechowanej hobbesowskim pesymizmem co do jego natury, co dalej przekłada się na przekonanie, że wszelkie działania istot ludzkich zbudowane są na egoizmie i gotowości do agresji wobec słabszych oraz na oczekiwaniu od innych wszystkiego najgorszego. W dziedzinie stosunków międzynarodowych przekłada się to $w$ głównej mierze na przekonanie o tym, że państwo jako uczestnik stosunków międzynarodowych musi przede wszystkim liczyć się z zagrożeniami zewnętrznymi. We wszystkich wersjach paradygmat realistyczny najbardziej akcentuje zatem problematykę bezpieczeństwa państwa i konieczności przeciwstawiania się zagrożeniom zewnętrznym, podkreślając jednocześnie, że państwa są osamotnione w „walce o przetrwanie”. Oczywiście nie oznacza to, że współpraca międzynarodowa nie jest możliwa lub potrzebna, lecz że jej realizowanie wynika jedynie $z$ egoistycznych interesów państwa.

A zatem, $\mathrm{z}$ realistycznego punktu widzenia, w chwili, kiedy człowiek rozpoczął wykorzystywanie nowej przestrzeni, stała się ona niejako automatycznie elementem rywalizacji. Pojęcia, takie jak: „wyścig kosmiczny”, dążenie państw do „zaliczania” kolejnych sukcesów przed innymi, a nade wszystko propagandowa oprawa eksploracji kosmosu, bardzo wyraźnie o tym świadczą. Rywalizacja w kosmosie ma jednak przede wszystkim podstawę materialną, związaną z postrzeganiem interesów bezpieczeństwa państwa i jego zdolnościami do militarnego i politycznego oddziaływania.

Po pierwsze, dlatego, że już we wczesnych fazach eksploracji kosmosu było jasne, iż jego wykorzystanie stanie się kolejną okazją do zwięk- 
szenia siły i możliwości obronnych państwa, a więc „[w]raz z pojawieniem się technologii kosmicznych interes narodowy objął i przestrzeń kosmiczną"1 ${ }^{18}$. Co więcej, wcześnie zrozumiano, że orbita okołoziemska ze względu na swoje charakterystyczne cechy może stać się ultimate high ground, czyli najwyżej w sensie strategicznym położonym miejscem, które szczególnie sprzyja działaniom związanym z panowaniem nad znacznymi obszarami. Po drugie zaś, działalność w kosmosie jest przejawem siły państwa, potęgi jego gospodarki i zdolności technologicznych. Jej prowadzenie, a w szczególności przodowanie w niej, czy też panowanie bądź hegemonia w kosmosie, jest ważnym czynnikiem rywalizacji politycznej, która przekłada się między innymi na zdolność budowania stref wpływów.

Dlatego też, z realistycznego punktu widzenia, państwo winno dla swojego bezpieczeństwa oraz w celu skutecznego prowadzenia rywalizacji politycznej dążyć do opanowania przestrzeni kosmicznej. Najlepiej na wyłączność, a przynajmniej dla szerokiego wykorzystania jej do realizacji praktycznych celów związanych z bezpieczeństwem narodowym, a także dla demonstracji własnej potęgi. Inaczej mówiąc, według realistów taka okazja musi zostać wykorzystana, szczególnie że potencjalni przeciwnicy też na pewno dążą do tego samego, a więc pozwolić im opanować przestrzeń i nie przeciwdziałać to dramatyczny błąd.

A zatem, wedle omawianej szkoły teoretycznej, działania na rzecz opanowania przestrzeni kosmicznej stają się egzystencjalną koniecznością od chwili, w której nauka i technika umożliwiają stworzenie odpowiednich technologii. Najważniejszy przy tym jest oczywiście wymiar bezpieczeństwa państwa, czyli wszelkiego rodzaju zastosowania militarne. Co więcej, w optyce realistycznej jest to absolutnie niezbędne w warunkach anarchii i konkurencji panujących $\mathrm{w}$ stosunkach międzynarodowych. Według prezydenta Kennedy'ego: „[e]ksploracja kosmosu będzie postępować, bez względu na to, czy to my do niej przystąpimy, czy też nie, jest także jedną z największych przygód wszech czasów i żaden kraj, który zamierza przewodzić innym, nie może pozwolić sobie na pozostanie w tyle w wyścigu w kosmos"'.9.

18 R. L. Pfaltzgraff, Jr., International Relations Theory and Spacepower, [w:] Toward a Theory of Spacepower..., s. 37.

19 Ibidem. 
Spacepower będzie zatem rozumiana w perspektywie realistycznej jako siła państwa w kosmosie, jego zdolność do wykorzystania go w ramach międzynarodowej konkurencji i uniemożliwienia innym uzyskania przewagi w tej dziedzinie. Podejście to nie różni się zatem co do zasady niczym od airpower czy seapower, także rozumianych jako instrumenty działania państwa w określonych środowiskach. Bardziej szczegółowo: będzie to zatem suma możliwości systemów kosmicznych, które dają się wykorzystać dla bezpieczeństwa narodowego i dla polityki zagranicznej, wraz ze wspierającym je przemysłem i zapleczem naukowo-badawczym oraz edukacyjnym plus wszelkie inne możliwości działania w kosmosie, takie jak na przykład systemy oddziałujące na obiekty kosmiczne, lecz bazujące na Ziemi. Wszystko po to, aby państwo mogło zapewnić sobie dostęp do przestrzeni kosmicznej, a jednocześnie w miarę możliwości odmówić tego samego innym, pozostając przy tym ze świadomością, że konkurenci będą próbowali tego samego dla siebie.

\section{Paradygmat liberalny}

Liberalny paradygmat $w$ nauce o stosunkach międzynarodowych akcentuje przede wszystkim znaczenie i rolę współpracy międzynarodowej, zarówno w wymiarze bezpieczeństwa, jak i ekonomicznym i kulturowym. Wynika to przede wszystkim z postrzegania człowieka w duchu oświeceniowego optymizmu co do jego natury. Człowiek wraz ze swoimi instytucjami jest zdolny, wedle liberałów, do stworzenia bezpiecznego świata wokół siebie, jeśli tylko zdoła wyeliminować nieufność między państwami, bazującą na doktrynach akcentujących egoistyczne interesy i promujących wrogość. Jeśli będą one zdolne do pozbycia się bagażu tradycyjnej polityki równowagi sił i jeśli dzięki liberalnemu porządkowi będą funkcjonować dla dobra swoich obywateli, zdołają także bez problemu stworzyć porządek międzynarodowy oparty na powszechnej współpracy i wzajemnych korzyściach. Współpraca ma zatem oczywiście utylitarny wymiar, ale także jest pewną wartością sama w sobie i istotnym punktem odniesienia dla wszelkich ludzkich działań.

Tego typu myślenie można bardzo łatwo przenieść na przestrzeń kosmiczną. Z punktu widzenia liberałów jest to kolejna przestrzeń, w której można prowadzić szeroko zakrojoną współpracę międzynarodową, co 
więcej, z wielu przyczyn „[...] rozciągnięcie zasięgu ludzkiego działania na Układ Słoneczny [...] zwiększy potrzebę współpracy" ${ }^{20}$. W dużej mierze dlatego, że działalność w kosmosie jest szczególnie predestynowana, by być domeną współpracy, a to z kilku powodów. Po pierwsze, systemy kosmiczne swoim oddziaływaniem siłą rzeczy obejmują znaczne obszary, a nawet cały świat, a zatem wiele państw może być zainteresowanych korzyściami. Po drugie, systemy kosmiczne są kosztowne w pozyskaniu i eksploatacji, a zatem współpraca poprzez dzielenie kosztów dla wspólnych korzyści narzuca się samoistnie. I wreszcie po trzecie, kosmos to nowa przestrzeń, „zasiedlana” od zera, istnieje zatem możliwość zaprojektowania współpracy $z$ uniknięciem obciążeń w postaci historycznych sporów czy utrwalonych sprzeczności.

To ostatnie, jak się zdaje, ma szczególną wagę, choć nie jest może kwestią bardzo rzucającą się w oczy. Jednak pamiętajmy, że istotną cechą myśli liberalnej w nauce o stosunkach międzynarodowych od jej zarania na początku XX wieku jest przekonanie o tym, że system międzynarodowy oparty na egoistycznych interesach państw jest czymś „nienaturalnym”. Nie wynika z natury ludzkiej, lecz z cech systemu władzy wąskich elit nieuwzględniających interesów społecznych i potrzeb naturalnych człowieka. Kształtował się on przez stulecia i dopiero niedawno został po części zastąpiony przez liberalne państwo demokratyczne, które jednak wciąż boryka się ze skostniałym systemem międzynarodowym, nie mogąc wyrwać się ze spirali egoizmu państw, ich wzajemnej podejrzliwości i wrogości. Tymczasem przestrzeń kosmiczna jest obszarem niezagospodarowanym, w którym nie ma jeszcze wielu norm, a te, które są, mają mocno kooperatywny charakter, co z kolei wynika z fizycznych cech przestrzeni okołoziemskiej. Można zatem rozwijać prawo kosmiczne w duchu kooperatywnym, unikając przynajmniej części niepotrzebnych i szkodliwych obciążeń przeszłości. A zatem można budować ramy wykorzystania kosmosu przez człowieka nastawione na współpracę i ogólnoludzkie korzyści, a nie na egoistyczne interesy państw.

Paradygmat liberalny postrzega ponadto siłę państwa inaczej niż paradygmat realistyczny $\mathrm{i}$ jest to bardzo istotne dla definiowania przezeń spacepower. Siła państ wa wynika zatem nie tylko ze zdolności militarnych czy z potęgi przemysłu zdolnego wytworzyć znaczną liczbę uzbrojenia

20 Ibidem. 
oraz z liczby ludności. Współczesny świat składa się z ogromnej ilości powiązań transgranicznych, które nie są przez państwa w pełni kontrolowane, mają też bardzo złożony charakter ekonomiczno-społeczno-kulturowy. Siła państwa nie opiera się zatem tylko na sile zbrojnej, ale téz na innego rodzaju oddziaływaniach. Za Josephem Nye'em ${ }^{21}$ to zdolność do kooptacji zamiast przymusu, czyli soft power. Jest ona rozumiana jako atrakcyjność wzorca polityczno-społeczno-ekonomicznego i wynikające zeń oddziaływania, które odgrywają wielką rolę w ramach zdolności państwa do realizowania swoich interesów. I tu pojawia się opanowywanie przestrzeni kosmicznej jako element budowania prestiżu państwa, będącego jednym z ważnych elementów soft power. Chodzi tu oczywiście o prestiż nie wynikający z posiadania silnych i sprawnych sił zbrojnych, lecz z wysoko rozwiniętej nauki i techniki oraz skutecznej organizacji. Świadczą one o wyższości modelu ustrojowego i struktury społeczno-ekonomicznej państwa, stają się więc atrakcyjnym wzorcem dla innych. Budowanie wpływów polega zatem w mniejszym stopniu na wykazywaniu własnej siły w kategoriach wojskowych, jest raczej akcentowaniem atrakcyjności wzorców organizacyjnych umożliwiających wszechstronny rozwój. Budowanie współpracy w kosmosie jest w optyce liberalnej doskonałą okazją do tego typu oddziaływania.

\section{Konstruktywizm}

We współczesnej nauce o stosunkach międzynarodowych obok rozlicznych wersji klasycznych teorii pojawiają się także ujęcia postmodernistyczne, akcentujące zupełnie inne cechy rzeczywistości. Najbardziej nośnym poznawczo jest zapewne konstruktywizm, skądinąd nurt bardzo zróżnicowany wewnętrznie i wielowymiarowy. Jego przedstawiciele zresztą na ogół twierdzą, że nie jest on paradygmatem teoretycznym w takim sensie, że nie próbuje orzekać o trwałych cechach rzeczywistości. Oferuje natomiast nowe spojrzenie na bieżącą rzeczywistość, proponując nowy mechanizm wyjaśniania oparty przede wszystkim na analizie tego, w jaki sposób ludzie i ich grupy postrzegają rzeczywistość i jak „konstruują" jej obraz na swoje potrzeby. Inaczej mówiąc, ludzie działają

21 J. S. Nye, Bound to Lead: The Changing Nature of American Power, New York 1990. 
na podstawie pewnego sposobu postrzegania rzeczywistości, wynikającego $z$ intersubiektywnie kreowanego jej obrazu. Ów zaś tworzony jest w przestrzeni stosunków międzyludzkich w wyniku złożonych interakcji pomiędzy ludźmi i ich grupami na bazie pewnych doświadczeń $\mathrm{i}$ istniejących przekonań. W związku z tym wszelkie pojęcia, które w klasycznej teorii służą do opisu rzeczywistości i wydają się niewzruszalne, są w istocie rzeczy umowne i jako takie mogą podlegać zmianie.

Patrząc na przestrzeń kosmiczną poprzez pryzmat konstruktywizmu, dostrzegać będziemy przede wszystkim to, w jaki sposób różne grupy starają się narzucić określoną wizję wpływu, jaki ma kosmos i jego wykorzystywanie na życie społeczne, gospodarcze polityczne oraz na indywidualny los ludzi. Kwestie bezpieczeństwa i prestiżu będą w głównej mierze analizowane pod kątem bieżących interesów politycznych, grupowych i indywidualnych oraz osobistych i korporacyjnych. Wizja opanowania kosmosu, zawierająca także sposób przeprowadzenia tego procesu i cele przyświecające poszczególnym uczestnikom stosunków międzynarodowych, będzie zatem podporządkowana tym, którzy zdołają narzucić innym kształt tejże wizji. Konstruktywiści będą przy tym badać także stan świadomości ludzkiej i społecznej, na którym buduje się te konstrukty, a wynikający przede wszystkim z kontekstów kulturowych i historycznych.

Z konstruktywistycznego punktu widzenia nie będziemy zatem budować teorii spacepower jako takiej, ale będzie nas bardziej interesowało, jak i dlaczego tę teorię budują inni. W rozlicznych konkretnych koncepcjach i działaniach szukać będziemy przede wszystkim bieżących interesów różnych podmiotów, często bardzo krótkoterminowych. Interesować nas też będą funkcjonujące w przestrzeni świadomości społecznej pojęcia zbudowane wokół określonych wartości i pewnego stanu społecznej świadomości. Dostrzeżemy zatem rozliczne powiązania pomiędzy interesami różnych grup i indywiduów a sposobem, w jaki starają się one wpływać na sposób postrzegania rzeczywistości przez społeczeństwa. Dobrym przykładem będzie niewątpliwie pożyteczna analiza pierwszych lat ery kosmicznej w USA pod kątem interesów korporacyjnych, rywalizacji rodzajów sił zbrojnych i ambicji polityków wykorzystujących rzecz instrumentalnie. Ukaże ona bardzo ważne mechanizmy kształtowania się doktryny i polityki nieobejmujące jedynie racjonalnej analizy rzeczywistości $\mathrm{z}$ punktu widzenia racjonalnie postrzeganych interesów państwa jako 
całości, ale także wpływ egoistycznych interesów i często irracjonalnych sposobów postrzegania świata przez ludzi i ich grupy.

W ramach perspektywy konstruktywistycznej istnieją dwa istotne pojęcia, które będą miały wielkie znaczenie przy badaniu problematyki bezpieczeństwa kosmicznego oraz spacepower. Pierwszym z nich jest pojęcie sekurytyzacja, które, najogólniej rzecz ujmując, oznacza akt mowy, nadający danemu pojęciu sens w związku z ogólnym pojęciem bezpieczeństwa. Innymi słowy, jeśli mówimy o danym zjawisku w kontekście bezpieczeństwa, wskazując na zagrożenia, które z niego wynikają, tym aktem mowy tworzymy zagrożenie jako konstrukt myślowy po to, aby inni go przyjęli i także postrzegali dane zjawisko w kontekście bezpieczeństwa. Rozważając zagrożenia w tym duchu, próbujemy zanalizować rzeczywistość, starając się oderwać akt mowy, swego rodzaju etykietę, od faktycznych zjawisk i realnie zachodzących procesów. Badając sekurytyzację, dostrzegamy często znaczne rozejście się realnych zagrożeń od tych postrzeganych i to właśnie jest bardzo cenne dla rzetelności opisu badanych zjawisk. Podejście do problemów bezpieczeństwa kosmicznego z tego punktu widzenia uwypukla to, w jaki sposób zagrożenia są postrzegane, często wyolbrzymiane lub bagatelizowane, co z kolei ma ogromny wpływ na ocenę ważnych procesów w interesującej nas dziedzinie.

Drugie istotne dla problematyki bezpieczeństwa pojęcie wypływające $\mathrm{z}$ koncepcji o podłożu konstruktywistycznym to kultura strategiczna, którą można zdefiniować jako zestaw poglądów, przekonań, stereotypów, ale także wypływających z nich doktryn i motywacji dotyczących siły i jej użycia jako instrumentu działania. Innymi słowy, rozważamy tu kwestię, w jaki sposób siła i jej użycie postrzegana jest w danym państwie (czy przez dany podmiot niepaństwowy) i jakie przydaje się jej miejsce w polityce bezpieczeństwa uczestnika stosunków międzynarodowych. W ramach problematyki kosmicznej kulturę strategicznq badać będziemy w szczególności w kontekście militaryzacji kosmosu, jej przebiegu, motywacji i stojących za nią uzasadnień. Obserwować będziemy, jakie znaczenie ma kosmos dla postrzegania roli siły militarnej w danym państwie, a także jaki ma udział w tworzeniu instrumentów siły wojskowej i reguł oraz doktryn jej zastosowania. To niezwykle ważne zagadnienie w ramach tematyki bezpieczeństwa kosmicznego - także dla określenia charakteru spacepower.

Perspektywa konstruktywistyczna jest zatem niezwykle cenna dla badacza przestrzeni międzynarodowej, ponieważ pokazuje głębię mechani- 
zmów rządzących działaniami państw i innych uczestników stosunków międzynarodowych. Nie może jednak całkowicie zastąpić nurtów klasycznych, gdyż jej stosowanie może łatwo doprowadzić do utraty z oczu szerszych kontekstów międzynarodowych.

\section{Geostrategia przestrzeni okołoziemskiej}

Wymienione powyżej podstawowe paradygmaty nauki o stosunkach międzynarodowych odnoszą się do pewnych realiów i uwarunkowań funkcjonowania ludzi na powierzchni ziemi. Wiele $\mathrm{z}$ tych uwarunkowań przenieść należy do tematyki spacepower, mamy jednak także pewne szczególne kwestie, które wynikają ze specyfiki kosmosu jako przestrzeni posiadającej odrębne cechy charakterystyczne. Najistotniejszą i najwyraźniejszą odmiennością są uwarunkowania geograficzne, które w nauce „ziemskiej” ujmuje się w ramach rozważań z zakresu geopolityki, geostrategii czy też geografii politycznej. Nie zamierzamy w tym miejscu wnikać w dyskusję terminologiczną, pominiemy więc ocenę różnic pomiędzy tymi terminami. Zauważamy jednak, że wszystkie odnoszą się do analizowania wpływu geografii czy, szerzej mówiąc, środowiska naturalnego człowieka na jego funkcjonowanie, a zatem i na politykę, i na bezpieczeństwo. Nie można jednak ziemskich pojęć w tym zakresie przykładać do kosmosu, gdzie nie ma na przykład granic naturalnych, są natomiast punkty potencjalnie strategicznie ważne, związane $z$ oddziaływaniami grawitacyjnymi. Nie mówiąc już o specyfice mechaniki orbitalnej, która narzuca obiektom kosmicznym określone ograniczenia.

Kończąc najogólniejsze teoretyczne rozważania, warto zatem zastanowić się krótko nad „geografią kosmosu”, a w szczególności nad ograniczeniami, jakie narzuca $w$ analogii do rozważań geopolitycznych i geostrategicznych. Mamy przy tym pełną świadomość, że pojęcia „geografia kosmosu”, "geopolityka kosmosu” czy "geostrategia kosmosu” są całkowicie nieadekwatne w warstwie językowej, lecz nie zamierzamy na gruncie języka polskiego wprowadzać nowych terminologii. Musielibyśmy bowiem odwołać się do historycznego pojęcia „kosmografia” i na jego podstawie ukuć pojęcia „kosmostrategia” czy „kosmopolityka”, lecz nie podejmujemy się wprowadzania zupełnie nowych terminów do języka naukowego. Pozornie wygodniejszym pojęciem byłoby słowo „astrografia” 
jako podstawa do tworzenia terminów pochodnych, lecz ma ono pożądaną konotację jedynie w języku science fiction, natomiast według definicji słownikowej w języku polskim jest to synonim pojęcia „astrofotografia”22. A zatem zastosowanie czy to przedrostka kosmo-, czy też astro- wydaje się sztuczne i raczej nie zakotwiczy się w ususie, wolimy zatem zmodyfikować, podobnie jak to się dzieje w nauce anglosaskiej, pojęcia „ziemskie” poprzez dodanie do nich określeń związanych z kosmosem. Z punktu widzenia fizyki jako punktu odniesienia jest to zresztą w gruncie rzeczy zręczne rozwiązanie. Jeśli bowiem zajmujemy się tym, co najbliższe, czyli przestrzenią okołoziemską, odkładając na bok futurystyczne rozważania, na przykład o relacjach kolonie marsjańskie - Ziemia, mamy do czynienia z układem, w którym to nasza planeta jest podstawowym punktem odniesienia determinującym wszystko. Przedrostek geo- w tej perspektywie wydaje się zatem w jakiejś mierze uzasadniony.

Najważniejszą siłą, która kształtuje geografię przestrzeni okołoziemskiej, jest oczywiście grawitacja. To jej prawidła stanowią o tym, jakie przy danym stanie techniki istnieją ograniczenia wykorzystania przestrzeni okołoziemskiej, one także odpowiadają za istnienie szczególnych obszarów tej przestrzeni.

Pierwszym czynnikiem, który należy uwzględnić przy analizie geostrategii kosmosu, są orbity, po których mogą poruszać się statki kosmiczne. Każdy rodzaj orbity ma swoje cechy charakterystyczne z punktu widzenia zastosowań obiektów je zajmujących. I tak na przykład niska orbita okołoziemska to obszar szeroko wykorzystywany przez różne satelity obserwacyjne, jednocześnie stosunkowo łatwo dostępny z Ziemi, zarówno w kontekście umieszczania na nim ładunków, jak i ewentualnego atakowania systemów orbitalnych. $Z$ kolei orbity geosynchroniczna i geostacjonarna są znacznie słabiej dostępne, ale można je wykorzystywać także w celach obserwacyjnych, choć przede wszystkim stosowane są dla szerokopasmowej telekomunikacji. Z punktu widzenia geostrategii przestrzeni kosmicznej orbity, po których poruszają się satelity użyteczne z punktu widzenia bezpieczeństwa, są zatem podstawowymi obszarami zainteresowania, analizy i planowania działań. Należy zatem określić zarówno ich granice, jak i kluczowe drogi wejścia na te orbity oraz stopień

22 Astrografia, Słownik języka polskiego PWN, https://sjp.pwn.pl/szukaj/astrografia. html. 
ich wystawienia na oddziaływania z Ziemi oraz z innych orbit. Różne orbity mają zatem różną wartość dla różnych uczestników stosunków międzynarodowych, choć są i takie, których rola i znaczenie są uniwersalne, w szczególności należy do nich orbita geostacjonarna ze względu na jej unikalne cechy ${ }^{23}$.

Cechą charakterystyczną prawie każdej orbity (poza geostacjonarną) jest to, że znajdujący się na niej satelita przemieszcza się w stosunku do powierzchni Ziemi, „przelatując” nad jej różnymi punktami, a zatem na ogół nad różnymi państwami. Rozwój systemów satelitarnych w pewnym sensie wymusił na państwach rezygnację z suwerenności nad przestrzenią ponad swoimi terytoriami powyżej pewnej wysokości, bez tego systemy satelitarne praktycznie nie mogłyby działać. Ograniczenie suwerenności państwa „od góry” stanowiło zatem wyłom w tradycyjnej logice geostrategicznej i geopolitycznej, ponieważ umożliwiło wgląd w całość terytorium państwa bez naruszenia suwerenności. To ogromnie ważna konsekwencja, zmieniająca bardzo wiele realiów strategicznych i politycznych, ale także ekonomicznych.

Przestrzeń poza orbitą geostacjonarną jest bardzo słabo wykorzystana, poza sporadycznymi wizytami pojazdów badawczych nie prowadzi się tam szerszej działalności. Znajdują się w niej jednak pewne specyficzne obszary, których właściwości wynikają ze wzajemnych oddziaływań grawitacyjnych Ziemi i Księżyca. Są to tak zwane punkty libracyjne, inaczej punkty Lagrange’a, które mają tę właściwość, że znajdujący się w nich mały obiekt będzie pozostawał w bezruchu w stosunku do układu Ziemia-Księżyc. Obszary te, z punktu widzenia różnorodnych zastosowań techniki kosmicznej, mogą mieć olbrzymie znaczenie strategiczne, a zatem mogą odgrywać rolę punktów węzłowych $z$ punktu widzenia bezpieczeństwa podmiotów realizujących działalność kosmiczną.

Współcześnie punkty libracyjne nie są jeszcze wykorzystywane inaczej niż do celów badawczych, ale zważywszy na ich relatywną dostępność, należy się spodziewać, że w nadchodzących dekadach ich znaczenie wzrośnie, także w wymiarze bezpieczeństwa, stąd mają swoje miejsce zarówno w analizach geostrategii kosmosu, jak i teorii spacepower. Przewiduje się dla nich zastosowania związane $z$ telekomunikacją, obserwa-

23 Por. R. Kopeć, Geostationary Belt - State's Territory or Province of Mankind?, „Przegląd Narodowościowy” („Review of Nationalities”) 2018, nr 8. 
cją oraz wsparciem ewentualnych misji załogowych w przestrzeni okołoziemskiej. W razie postępów militaryzacji kosmosu mogą one stanowić teoretycznie dobre pozycje dla umieszczania systemów obronnych lub ofensywnych.

Ten krótki przegląd podstaw geostrategii przestrzeni okołoziemskiej należy podsumować w ten sposób, że do klasycznych zasad geopolityki, geostrategii i geografii politycznej wymiar kosmiczny wprowadza nowe, istotne parametry, modyfikujące geostrategiczne realia. Dlatego też geostrategia kosmosu nie istnieje sama dla siebie, w oderwaniu od Ziemi, w ostatecznym rozrachunku działalność człowieka koncentruje się na powierzchni lądów naszej planety i cała jego aktywność w innych przestrzeniach jest wobec niej służebna. Każda $z$ tych przestrzeni ma swoją specyfikę, w określony sposób wpływając na ograniczenia i możliwości, jakie państwa i inne podmioty mają w ramach kształtowania wzajemnych relacji.

Nowe nurty badawcze w ramach prób ożywienia geopolityki i dostosowania jej do wyzwań nowych przestrzeni, takich jak cyberprzestrzeń i przestrzeń kosmiczna, próbują nadać nowe ramy teoretyczne ujęciu geopolitycznemu, rozumianemu jako specyficzny paradygmat badawczy. Liczne są propozycje łączenia różnego rodzaju nowych czynników z klasyczną geopolityką lub geostrategią. Niektóre z nich nadają się do analizy spacepower, tak jak na przykład propozycja metageopolityki Nayefa Al-Rodhana. Autor ten, wskazując na wiele różnorodnych, wzajemnie się zazębiających wymiarów narodowego i międzynarodowego bezpieczeństwa, proponuje wielowymiarowe podejście do siły państwa, na którą składają się elementy i soft power, i hard power ${ }^{24}$. Bierze przy tym pod uwagę następujące właściwości państwa, rozumiane jako współzależne wymiary jego siły: kwestie społeczne i zdrowotne, politykę wewnętrzną, gospodarkę, środowisko, potencjał ludzki, kwestie bezpieczeństwa i wojskowe oraz dyplomację międzynarodową. Podejście to Al-Rodhan w interesujący sposób przenosi na kosmos, ukazując spójną wizję jego metageopolityki²5, której omówienie wykracza jednak poza ramy niniejszego rozdziału.

24 N. Al-Rodhan, Meta-Geopolitics: The Relevance of Geopolitics in the Digital Age, E-international Relations, 25.05.2014, https:/www.e-ir.info/2014/05/25/meta-geopoli tics-the-relevance-of-geopolitics-in-the-digital-age/.

25 Id e m, Meta-Geopolitics of Outer Space: An Analysis of Space Power, Security and Governance, London 2012. 


\subsection{Teoria spacepower}

Rozwój zastosowań kosmicznych i ich rosnąca rola szczególnie w dziedzinie bezpieczeństwa narodowego państwa skłania już od dawna do prób stworzenia ram teoretycznych dla analizy tejże roli i mechanizmów, jakie nią rządzą. Ma to pomóc zrozumieć zachodzące zjawiska, prognozować przyszłość oraz projektować konkretne działania. Wskazuje się przy tym na to, że $w$ przeszłości $w$ miarę wzrostu znaczenia instrumentów opanowywania przez człowieka kolejnych przestrzeni takie teorie się pojawiały. Dotyczy to zarówno seapower, opisanej przez Mahana i innych, jak i następnie airpower, obecnej w pracach teoretyków wojskowych, Douheta, Mitchella, Trencharda, a następnie po II wojnie światowej rozpropagowanej przez de Severskiego. Jednak, jak zauważa amerykański historyk:

[w] miarę jak działania zbrojne rozprzestrzeniały się z lądu na morze, a następnie $w$ przestrzeń powietrzną, pojawiali się uczeni [...] rozwijający teorie i doktryny, które do dziś są podstawą rozumienia konfliktów w tych przestrzeniach. Nie ma jednak po dziś dzień podobnej wyczerpującej, fundamentalnej teorii w odniesieniu do kosmosu ${ }^{26}$.

Poglądy teoretyczne związane z seapower i airpower sprowadzały się w dużej mierze do stwierdzenia, że dana przestrzeń ma pewne specyficzne cechy charakterystyczne $z$ jednej strony, a duże znaczenie dla ludzkości - z drugiej. Z tych konstatacji wypływało określenie wzajemnych relacji pomiędzy ludzkimi aktywnościami a daną przestrzenią wraz z opisem mechanizmów nią rządzących. I wreszcie pojawiają się w tych teoriach warunki/wskazówki, co należy czynić, by daną przestrzeń skutecznie wykorzystać dla dobra państwa i narodu.

Wydaje się zatem oczywiste, iż podobnego zabiegu należy dokonać w stosunku do przestrzeni kosmicznej, analogia jest tak silna, że we wspomnianej we wstępie książce Toward a Theory of Spacepower, która kompleksowo omawia bardzo różnorodne kwestie związane z wykorzystaniem przestrzeni kosmicznej, rozdział pierwszy poświęcony jest przy-

26 S. B. Joh nson, The History and Historiography of National Security Space, [w:] Critical Issues in the History of Spaceflight, eds. S. J. Dick, R. D. Launius, Washington 2006, s. 544 . 
pomnieniu koncepcji Mahana, ze zwróceniem uwagi na to, w jaki sposób może ona zostać zaaplikowana do kosmosu ${ }^{27}$.

W niniejszym rozdziale zajmiemy się konkretnymi teoriami spacepower, które powstały w ostatnich dwóch dekadach w USA. Oczywiście nie będzie to szczegółowy i pełny przegląd, przedstawimy prace, jak się zdaje, szczególnie istotne, często cytowane - zwłaszcza dwie pierwsze które w dużej mierze wpływają na kształt obecnych poglądów w USA $\mathrm{w}$ tej materii.

James E. Oberg: Space Power Theory

Pogłębiona dyskusja teoretyczna na temat natury spacepower rozpoczęła się w USA w końcu lat dziewięćdziesiątych, kiedy to w ówczesnym dowództwie kosmicznym sił zbrojnych USA prowadzono projekt badawczy pod tytułem Space Power Theory, którego efektem była wydana w 1999 roku książka Jamesa E. Oberga Space Power Theory. John B. Sheldon i Colin S. Gray uważają ją za jedną z pierwszych poważnych prób tworzenia teorii w zakresie spacepower ${ }^{28}$, do dziś pozostaje ona także jedną z nielicznych tak kompleksowych pozycji na ten temat.

Chcąc scharakteryzować naturę spacepower, Oberg w pierwszej kolejności przedstawia znaczenie przestrzeni kosmicznej dla państw, społeczeństw i gospodarek, co jest oczywistym wstępem i tłem, ponieważ wskazuje na wagę tematu. Dodaje także niezwykle ważne rozważania o charakterystycznych cechach przestrzeni kosmicznej, które muszą zostać dobrze wyjaśnione, ponieważ bez zrozumienia odmienności przestrzeni kosmicznej od innych domen, w których działa człowiek, możliwe, a nawet prawdopodobne są fałszywe analogie i wynikające $z$ nich błędne oceny ${ }^{29}$. Dalej przedstawia Oberg wyczerpującą listę czynników, które umożliwiają państwu władanie spacepower, takich jak: infrastruktura, technologia, przemysł, dostępny sprzęt, gospodarka, populacja, edukacja, tradycja i klimat intelektualny, geografia i to, czy zdolności oraz

27 J. Sumida, Old Thoughts, New Problems: Mahan and the Consideration of Spacepower, [w:] Toward a Theory of Spacepower..., s. 4-14.

28 J. B. Sheld on, C. S. Gray, Theory Ascendant? Spacepower and the Challenge of Strategic Theory, [w:] Toward a Theory of Spacepower..., s. 307.

29 J. Oberg, Space Power Theory, Washington 1999, s. 43. 
wiedza dotycząca wykorzystania kosmosu mają charakter ekskluzywny czy powszechny ${ }^{30}$. Notabene wyraźnie widać tu nawiązanie do Mahana, który także wymieniał warunki niezbędne do wykorzystania seapower.

Warto na tym etapie zauważyć, że podejście Oberga jest dość tradycyjne, ponieważ zwraca przede wszystkim uwagę na kwestię siły państwa, choć ma być ona kształtowana nie tylko własnym sumptem instytucji państwowych, lecz także innych podmiotów. O konserwatywnym podejściu świadczy również punkt o wyłączności zdolności oraz wiedzy, co należy rozumieć jako stan pożądany. Jak pisze Oberg, „[p]onieważ doświadczenie wykazuje, że każda z tych korzyści jest skazana na krótki żywot, wysiłek, by zabezpieczyć ich wykorzystanie, musi łączyć się z wysiłkiem na rzecz rozwijania ich sukcesorów" ${ }^{31}$. Autor stawia zatem na samodzielność państwa, na jego własne możliwości.

Niezwykle interesujące są rozważania Oberga na temat przeszkód stojących przed wykorzystaniem spacepower. Z biegłością wynikającą z inżynierskiej wiedzy i 22-letniej praktyki w NASA ${ }^{32}$ wymienia techniczno-organizacyjne ograniczenia, czyli: koszty wyniesienia ładunków na orbitę, wąskie gardła w komunikacji i wrażliwość systemów kosmicznych. Zwraca także uwagę na zagadnienia socjopolityczne, związane ze świadomością zbiorową, percepcją społeczną problemów dotyczących rozwoju nauki i techniki oraz kwestie związane $z$ procesem decyzyjnym.

Oberg rozważa także szeroko ograniczenia wynikajace $\mathrm{z}$ charakterystki środowiska międzynarodowego. Wydaje się mu to niezwykle ważne, jako że spacepower danego uczestnika i to, w jaki sposób on $z$ niej korzysta, znajduje się pod ciągłym wpływem czynników zewnętrznych, od wzmacniających ją sojuszy do ograniczeń wynikających z międzynarodowych traktatów ${ }^{33}$. Szczególnie ta ostatnia kwestia, czyli prawo międzynarodowe i współpraca w jego tworzeniu, wydaje się Obergowi zagrożeniem dla rozwoju spacepower, ponieważ prawo regulujące międzynarodową współpracę w kosmosie jest bardzo słabo rozwinięte i bardzo nieprecyzyjne. Jakkolwiek może ono być pożyteczne, jako regulator współpracy międzynarodowej, to jednak Oberg jest w dość konserwatywnym duchu pesymistą co do jego ewolucji, co wynika z samej natury rozwoju eksploracji kosmosu:

30 Ibidem, s. 44-47.

31 Ibidem, s. 47.

32 Profile, Jamesoberg.com, 2016, http://www.jamesoberg.com/profile.html.

33 J. Oberg, op. cit., s. 78. 
[O]gólnie rzecz biorąc, długofalowe poleganie na traktatach w celu kontrolowania zachowań w kosmosie jest problematyczne w związku z wciąż nierozwiązaną niekompatybilnością pomiędzy dyscypliną bazującą na precedensie (prawo) a bezprecedensową aktywnością tam, gdzie większość związanych z Ziemią analogii jest myląca (kosmos). I, jakkolwiek prawo morza rozwinęło się dopiero po wielu wiekach aktywności morskiej, prawo kosmiczne jest tworzone przed rozpoczęciem działalności, którą ma regulować. Ponieważ prawnicy zajmujący się kosmosem nie mają specjalnych talentów prognostycznych, ich przypuszczenia nie są lepsze niż innych ekspertów od kosmosu, z jednym wyjątkiem: kiedy ich przypuszczenia (wyrażone w traktatach) się nie sprawdzają, ich praca grozi wypaczeniem tego, co $\mathrm{w}$ innych okolicznościach byłoby skutkiem naturalnego rozwoju kosmicznej aktywności ${ }^{34}$.

Podsumowując, James Oberg podkreśla, że kwestia wykorzystywania spacepower nie jest ograniczana jedynie przez technologię, ma także swoje wymiary ekonomiczne, społeczne, polityczne i dyplomatyczne. A zatem strategia tworzenia i wzmacniania spacepower musi obejmować wiele różnych dziedzin. Usprawnianie technologii jest oczywiście podstawą, lecz samo w sobie nie wystarcza, choćby dlatego, że należy także znaleźć niemałe fundusze niezbędne do rozwoju działalności kosmicznej, najlepiej poprzez zwiększenie jej efektywności ekonomicznej. Należy także dobrze zrozumieć zagrożenia dla działalności w kosmosie i im przeciwdziałać. Nieodzowne jest również ustanowienie pozytywnego, a przynajmniej neutralnego kulturowego i prawnego klimatu dla tej działalności 35 .

Nie wchodząc w szczegółową analizę dalszych części książki Oberga, rozwijających dokładniej zarysowane przez nas wątki, zauważyć należy, że jego propozycja teorii spacepower sprowadza się do określenia warunków, w jakich państwo może najlepiej wykorzystać przestrzeń kosmiczną do swoich celów. Najcenniejsze są przy tym, jak się zdaje, rozważania na temat roli i znaczenia oraz ograniczeń wykorzystywania przestrzeni kosmicznej. Przywołując ponownie Sheldona i Graya, wypada się zgodzić, że jakkolwiek cenna i wnikliwa jest wizja Oberga, to jednak „[...] brak jej kompletności, która połączyłaby spacepower z ogólną siłą państwa w spo- 
sób, który wyjaśniłby naturę spacepower, a także zapewne zbytnio skupia się na technologicznym wymiarze kosztem innych" ${ }^{36}$.

\section{Everett C. Dolman: Astropolitik}

Kolejną wartą zanotowania próbą stworzenia modelu teoretycznego spacepower, bardzo ambitną, sięgającą także poza współczesne problemy przestrzeni okołoziemskiej, jest książka Everetta C. Dolmana Astropolitik: Classical Geopolitcs in the Space Age, wydana w 2002 roku $^{37}$. Autor rozważa w niej szczegółowo, na tle historii i rozległej literatury, implikacje rozwoju wynoszących ludzi w kosmos technologii dla zjawisk politycznych. Mamy tu do czynienia $\mathrm{z}$ ujęciem $\mathrm{w}$ ramach określonych przez nas jako geostrategia przestrzeni kosmicznej, choć sam autor używa określenia "geopolityka", postrzegając je w dość tradycyjnym duchu realistycznym.

Już w pierwszych słowach Dolman deklaruje, że Astropolitik to wykład najbardziej ogólnej strategii, w ramach której Ziemia, cała jej powierzchnia zredukowana jest do jednego z komponentów, najważniejszego, owszem, ale jednego $\mathrm{z}$ wielu $^{38}$. Autor wyraźnie pokazuje nam, że tworzy teorię, która ma wyjaśniać rzeczywistość nie tylko w planie dzisiejszym, w ramach obecnego stanu zagospodarowania kosmosu, lecz także w przyszłości, kiedy gatunek ludzki rozprzestrzeni się po Układzie Słonecznym, rozciągając nań swoje charakterystyczne relacje wewnętrzne.

Dolman deklaruje także bardzo wyraźnie realistyczną metodę postrzegania świata, definiuje więc Astropolitik w wąskim sensie jako rozszerzenie zasadniczo dziewiętnasto- i dwudziestowiecznych teorii geopolityki globalnej o szeroki kontekst ludzkiego podboju przestrzeni kosmicznej39. W szerszym znaczeniu jest to uszczegółowiona $w$ duchu realistycznym wizja konkurencji państw $w$ przestrzeni kosmicznej ${ }^{40}$. Autor nie ma zatem także wątpliwości co do przyszłości stosunków międzynarodowych:

Mówiąc prosto, w świecie współczesnych państw narodowych [...] dylematy związane $z$ działaniami kolektywnymi uniemożliwią im koope-

36 J. B. Sheldon, C. S. Gray, op. cit., s. 307.

37 E. C. Dolman, Astropolitik...

38 Ibidem, s. 1.

39 Ibidem.

to Ibidem. 
ratywne eksploatowanie kosmosu, a wysiłki, by przymusić państwa do współpracy, będą miały zerowe, negatywne lub nawet odwrotne skutki. [...] W krótkoterminowej perspektywie, mimo naszych najlepszych intencji, w kosmosie pozostaje nam twardy, pełen sporów, w pełni realistyczny paradygmat ${ }^{41}$.

Dolman używa także pojęcia „astropolityka"42, którą definiuje jako badanie relacji pomiędzy przestrzenią kosmiczną a technologią oraz rozwojem politycznej i militarnej polityki i strategii. Konsekwentnie „astrostrategia" to rozpoznawanie krytycznie ważnych pozycji na Ziemi i w kosmosie, których kontrolowanie może dać wojskową i polityczną dominację w przestrzeni kosmicznej albo przynajmniej spowoduje, że takiej dominacji nie osiągnie potencjalny przeciwnik ${ }^{43}$.

Warto zwrócić szczególną uwagę na determinizm, czy też astrodeterminizm, jak chce Dolman, omawianej teorii, który należy rozumieć jako uznanie za podstawowy fakt uzależnienia człowieka we wszystkich przejawach jego działalności i we wszystkich okresach historycznych od ograniczeń, jakie narzuca mu przestrzeń i środowisko. Ponadto ograniczenia te są odmienne $w$ różnych miejscach na Ziemi, które człowiek pokonuje w różnym tempie i na różne sposoby oraz za pomocą różnych form organizacyjnych, rozwijając przy tym kolejne technologie. Dolman zwraca przy tym szczególną uwagę na to, że społeczeństwa, które rozwinęły się w różnorodnych warunkach środowiska, są w rozmaitym stopniu podatne na różne formy organizacji, co także determinuje zdolność państw do podejmowania działalności kosmicznej i skuteczność w jej ramach ${ }^{44}$.

Rozważając dalej perspektywę astrostrategiczną, autor Astropolitik dostrzega znaną nam już z naszych rozważań prawdę, że topografia przestrzeni kosmicznej to przede wszystkim domena oddziaływań grawitacyjnych i emisji elektromagnetycznych. Z tego powodu słabe punkty sił zbrojnych działających w kosmosie dotyczą orbity, czyli ewentualnego zagrożenia statków kosmicznych, powierzchni Ziemi z jej infrastrukturą komunikacyjną i całym zapleczem logistycznym oraz produkcyjnym, a także łączności w zakresie spektrum elektromagnetycznego, co wiąże

41 Ibidem, s. 2.

42 Astropolitics.

43 E. C. Dolma n, Astropolitik..., s. 13.

44 Ibidem, s. 14-26. 
się z jej możliwymi zakłóceniami ${ }^{45}$. A zatem astropolityka jako przedłużenie klasycznej geopolityki

[...] zawiera wszystkie klasyczne element geostrategii [...]. Logistyczna sieć transportowa Lista, obszary osiowe Mackindera, wąskie gardła, cieśniny strategiczne $\mathrm{i}$ linie handlowe Mahana, żywotne centra i drogi ataku Douheta i Mitchella, modelowanie sferyczne de Seversky'ego i wiele elementów odwrotnej logiki (contrary logic) teoretyków broni jądrowej wszystko to ma swoje odpowiedniki w przestrzeni kosmicznej ${ }^{46}$.

Zdefiniowawszy podstawowe pojęcia i ich miejsce $\mathrm{w}$ dotychczasowym dorobku teoretycznym geopolityki, Dolman przechodzi do bardziej szczegółowych rozważań dotyczących spacepower, którą należy rozumieć w tym miejscu po prostu jako zdolność do działania w przestrzeni kosmicznej. Propozycja kierunków analizy, opartej oczywiście na dotychczasowej teorii, jest następująca:

Po pierwsze, szereg teorii geopolitycznych dotyczących rozwoju narodowej siły zbrojnej jest $w$ pełni kompatybilnych i w pełni adaptowalnych do przestrzeni kosmicznej. Po drugie, najłatwiejsze do zastosowania spomiędzy tych teorii są te, które dotyczą wojskowych ocen pozycji geograficznych w świetle nowych technologii. [...] Po trzecie, szczególny teren przestrzeni Układu Słonecznego dyktuje szczególne taktyki i strategie efektywnego wykorzystania zasobów kosmosu. [...] Po czwarte, koncepcja przestrzeni jako podstawy siły (power base) w klasycznej, szczególnie niemieckiej, myśli geopolitycznej będzie wymagać pewnej modyfikacji, ale łatwo się da zaadaptować do eksploatacji i wykorzystania przestrzeni kosmicznej jako ostatecznej podstawy dla siły. I wreszcie dokładne zrozumienie rozgraniczeń wynikających $z$ astromechaniki i fizyki przestrzeni kosmicznej może okazać się użyteczne dla planistów politycznych i będzie absolutnie krytyczne dla strategów wojskowych. [...] [A]by ożywić te propozycje zgodnie z przykładami przedstawionymi przez Sir Halforda Mackindera i Nicholasa Spykmana, przedstawiamy neoklasyczny, astropolityczny paradygmat. Ten, kto kontroluje niską orbitę Ziemi, kontroluje przestrzeń okołoziemską. Kto kontroluje przestrzeń okołoziemską, panuje nad Ziemią. Kto panuje nad Ziemią, kontroluje przeznaczenie ludzkości ${ }^{47}$. 
Kontynuując w duchu przekładania klasycznej geopolityki na astropolitykę, Dolman, powołując się na klasyczny model geopolityczny Halforda Mackindera, dostrzega cztery regiony astropolityczne, wyróżnione ze względu na swoje charakterystyczne cechy fizyczne. Pierwszym z nich jest Ziemia (Terra) wraz z atmosferą. Drugi to przestrzeń okołoziemska (terran (earth) space), która rozciąga się nieco poza orbitę geostacjonarną. Trzeci to przestrzeń okołoksiężycowa (lunar (moon) space), zaczynająca się nieco ponad orbitą geostacjonarną, a kończąca nieco poza orbitą Księżyca. I wreszcie czwarty obszar, przestrzeń solarna (solar space), czyli reszta Układu Słonecznego ${ }^{48}$.

W przestrzeni okołoziemskiej Dolman dostrzega oczywiście znaczenie szczególnie ważnych orbit ${ }^{49}$, natomiast w okołoksiężycowej - znaczenie punktów libracyjnych ${ }^{50}$, podczas gdy przestrzeń solarna to, jak chce Dolman, Lebensraum dla rozwijającej się ludzkości ${ }^{51}$.

I wreszcie, przechodząc do bardziej konkretnych wskazań do działania, Dolman uważa, że zasadniczym celem państw funkcjonujących w realistycznie rozumianym środowisku międzynarodowej konkurencji jest i powinna być polityka dominacji w kosmosie, a w każdym razie maksymalizacji korzyści z jego wykorzystania i w miarę możliwości odmówienie tego innym. W związku z tym przedstawia sześć wymiarów, w jakich powinna być ujmowana astropolityka w rozumieniu formułowania i stosowania konkretnej polityki ${ }^{52}$.

1. Społeczeństwo i kultura (society and culture). Społeczeństwo astropolityczne (astropolitical society) winno przede wszystkim być entuzjastycznie nastawione do eksploracji kosmosu w ogóle, gotowe na znaczne poświęcenia zbiorowe i indywidualne dla gromadzenia środków na realizację programów kosmicznych. Dolman używa nawet takich pojęć, jak: „fascynacja”, „duch narodowy” czy „poczucie przygody”. Społeczeństwo winno także postrzegać podbój kosmosu jako imperatyw moralny, przy czym nauka i technika winny być przedmiotem ogólnospołecznego szacunku. W razie potrzeby rząd winien taki stan świadomości społecznej stworzyć i wspierać.

48 Ibidem, s. 6o-61.

49 Ibidem, s. 65-67.

50 Ibidem.

51 Ibidem, s. 61.

52 Ibidem, s. 145. 
2. Środowisko polityczne (political environment). Astropolityczne państwo (astropolitical state) musi być efektywnie zorganizowane dla realizacji wielkich publicznych projektów technologicznych, przy czym liberalny kapitalizm jest przez Dolmana uważany za lepszą do tego podstawę niż gospodarki centralnie planowane. Wynika to przede wszystkim $\mathrm{z}$ negatywnych cech centralnego planowania oraz znaczenia politycznej legitymacji władzy w krajach demokratycznych.

3. Przestrzeń (physical environment). Materialne wymagania podróży kosmicznej są takiego rodzaju, że wymagają wielkich przestrzeni na infrastrukturę oraz znacznych zasobów ludzkich, rozległej bazy przemysłowej etc. W związku z tym państwo powinno być rozległe, posiadać zasoby naturalne i odpowiednio liczną ludność, ważną między innymi w kontekście dochodów podatkowych.

4. Wojsko i technologia (military and technology). Ponieważ to siły zbrojne znajdują się na czele kosmicznej eksploracji, muszą być odpowiednio wyszkolone i zorganizowane, aby móc działać w ramach specyfiki zadań w przestrzeni kosmicznej, co wymaga zintegrowania sił zbrojnych wokół tego celu. Państwo winno także bardzo intensywnie zajmować się rozwojem technologii i innowacjami zarówno w postaci centrów badawczo-edukacyjnych, jak i nauk wojskowych, musi też być gotowe na ogromne projekty badawcze.

5. Podstawa gospodarcza (economic base). Przemysł musi być silny, wysoce nasycony najbardziej rozwiniętymi technologiami, innowacyjny i zdolny do ciągłej adaptacji do zmieniających się warunków. Wsparcie rządu dla rozwoju technologicznego, a następnie jego rozpowszechniania w przemyśle cywilnym jest podstawą, ponieważ najważniejszy jest komercyjny sektor kosmiczny. Państwo winno być także gotowe do znacznego wsparcia przemysłu w strategicznie ważnych dziedzinach, nawet jeśli miałoby to stać w pewnej sprzeczności z paradygmatem wolnego rynku.

6. Teoria i doktryna (theory and doctrine). Są one sposobami organizacji wiedzy, sposobami postrzegania świata, dlatego też kosmiczna teoria i doktryna musi zawierać w sobie i spajać przedstawione powyżej wymiary. Do realizacji skutecznej strategii konieczny jest więc plan skoordynowanego rozwoju we wszystkich wymienionych dziedzinach. Strategia musi być zatem kierowana przez doktrynę, ponieważ to ona integruje wszystkie istotne czynnikis3. 
Jak widać, mamy do czynienia z propozycją całkowitej mobilizacji zasobów państwa i społeczeństwa na rzecz maksymalizacji tempa i zakresu kosmicznej eksploracji, która jednak ma się odbywać z zachowaniem podstawowych zasad porządku liberalnego i wolnorynkowego. Inaczej mówiąc, aby wykorzystać kosmos dla swojego dobra, a w szczególności dla zapewnienia sobie bezpieczeństwa, państwo musi skoncentrować całe swoje zasoby do realizacji tego celu. Nie wnikając w szerszą krytykę tego stanowiska, warto zauważyć pewną sprzeczność, która musi się pojawić pomiędzy silnym państwem (realizującym ogromną wizję i mobilizującym dla niej społeczeństwo oraz gospodarkę) a porządkiem demokratycznym, w szczególności wolnym rynkiem. Walter McDougall w swojej analizie wyścigu kosmicznego zwraca szczególną uwagę na rosnący w USA technokratyzm państwa i transformację społeczeństwa liberalnego oraz gospodarki rynkowej w wyniku jego wymagań organizacyjnych i gospodarczych ${ }^{54}$. Ewentualna realizacja strategii wynikającej z przemyśleń Dolmana musiałaby znacząco przyspieszyć ten, i tak postępujący, proces, prowadząc do niemożliwych do przewidzenia skutków społecznych i w sferze świadomościowej. Nie musiałyby one wprawdzie być negatywne, lecz wymagają przemyśleń, których autor Astropolitik nie zapewnia - proponując stworzenie astrospołeczeństwa i astropaństwa, nie wyjaśnia, jak wyglądałby astroczłowiek z całą złożonością jego interakcji społecznych.

Warto także podkreślić często jednostronną argumentację Dolmana, zawartą także w innych jego publikacjach. Popierając rozmieszczenie przez USA broni w kosmosie, argumentuje on, że ma ona $z$ jednej strony wielki potencjał odstraszający, z drugiej zaś - zapewnia stabilność, ponieważ nie daje żadnej przewagi w ramach misji okupacyjnych ${ }^{55}$. Nie jest to jednak prawda, ponieważ moc odstraszająca broni kosmicznej może łatwo przełożyć się na przymus, który $\mathrm{z}$ kolei może zostać zastosowany w celu umożliwienia okupacji. Co więcej, zaprzecza niejako sam sobie, zakładając, że broń kosmiczna będzie po prostu lepszą, bardziej skuteczną bronią, która lepiej zrealizuje już istniejące misje. Nie uwzględnia bowiem operacyjnej specyfiki broni kosmicznej, która przede wszystkim

54 W. A. Mc Dougall, op. cit.

55 E. C. Dolman, New Frontiers, Old Realities, „Strategic Forces Quarterly” 2012, vol. 6, nr 1, s. 90-91. 
charakteryzuje się ogromną wrażliwością na atak i słabą elastycznością taktyczną.

Inny kierunek krytyki poglądów Dolmana reprezentuje między innymi Matthew Burris, oficer USAF i prawnik, który przekonująco dowodzi, że sama koncepcja kosmicznej hegemonii jest błędna i szkodliwa. Co więcej, w sposób bardzo sugestywny podważa historyczną linię argumentacji Dolmana, sugerując, że klasyczna geopolityka oparta na długiej realistycznej tradycji nie daje się w pełni zaaplikować do bezpieczeństwa kosmicznego $^{56}$.

Konkludując, warto powtórzyć za Sheldonem i Grayem, że wizja Dolmana jest rozległa i dobrze udokumentowana, intelektualnie bardzo nośna, choć kontrowersyjna ${ }^{57}$. Sheldon i Gray zwracają także uwagę na istotny minus, jakim jest brak teoretycznej wszechstronności poglądów Dolmana, jako że koncentruje się on przede wszystkim na propozycjach działania dla USA $^{58}$. Ta ostatnia uwaga nie wydaje się jednak w pełni słuszna - Dolman wprawdzie faktycznie bardzo dużo miejsca poświęca konkretom, analizując bieżący stan rzeczy z punktu widzenia Stanów Zjednoczonych, jednak teoretyczne podstawy położone w pierwszych kilku częściach Astropolitik wydają się wystarczająco ogólne, by móc mówić o uogólniającej teorii.

Brent Ziarnick: Developing National Power in Space: A Theoretical Model

Bardziej aktualnym przykładem próby stworzenia generalnej teorii rozwijania spacepower jest praca Brenta Ziarnicka Developing National Power in Space: A Theoretical Model59. Wprawdzie słowami samego autora, notabene oficera USAF, jej celem jest skonstruowanie „[...] poważnej teorii strategicznej typu wojskowego dotyczącej narodowego programu kosmicznego $[. . .]^{\prime \prime 6}$, jednak w pierwszej kolejności buduje on teorię ogólną, którą następnie aplikuje do sfery wojskowej. Z naszego punktu

56 M. Burris, Astroimpolitic: Organizing Outer Space by the Sword, „Strategic Studies Quarterly" 2013, vol. 7, nr 3.

57 J. B. Sheldon, C. S. Gray, op. cit., s. 307.

58 Ibidem, s. 308.

59 B. Ziarnick, Developing National Power in Space: A Theoretical Model, Jefferson 2015. 60 Ibidem, S. 11. 
widzenia te ogólne rozważania są bardzo interesujące, budują bowiem rozległy model teoretyczny, który można wielorako zastosować i który daje ogólny wykład na temat spacepower.

Poczynając od najbardziej ogólnych kategorii, Ziarnick rozumie spacepower $\mathrm{w}$ dwóch formach: pierwsza to surowa, podstawowa forma, czyli zdolność do „zrobienia czegoś w kosmosie”, druga zaś forma spacepower to forma stosowana, kiedy podstawowe zdolności są wykorzystywane przez dany podmiot do szczegółowego celu ${ }^{61}$.

Dalej, posługując się analogiami do wielkich teoretyków zajmujących się militarnymi instrumentami polityki państwa, Mahana i Clausewitza, proponuje $\mathrm{w}$ odniesieniu do spacepower podział na logikę oraz podsta$w y^{62}$, przy czym:

Logika spacepower, przedstawiona w Delcie Logiki, to sztuka wojownika: spacepower wykorzystana do popierania interesów mocarstwa kosmicznego. Logika spacepower dotyczy celów i sposobów, wedle strategicznego paradygmatu cele/sposoby/środki. Podstawy spacepower, opisane w Delcie Podstaw, to sztuka budowniczego: rozwijanie narzędzi, których używa się, by władać spacepower i ją powiększać. Podstawy spacepower to dziedzina środków ${ }^{63}$.

Wspomniane delty to ostrosłupy, których podstawę stanowi figura w kształcie trójkąta równoramiennego o krótszym boku załamanym w kierunku wnętrza figury. Rogi delt odwzorowują elementy spacepower, natomiast ich wierzchołki symbolizują synergię $w$ ramach logiki i podstaw.

A zatem Delta Podstaw składa się z poziomej podstawy figury, której rogi symbolizują: na ostrzejszym końcu „produkcję” (production), która traktowana jest jako najważniejsza, oraz „spedycję" (shipping) i „kolonie" (colonies) - wierzchołek zaś ostrosłupa to „dostęp” (Acces). A zatem „[p]odstawy dotyczą budowania wyposażenia, które pozwala mocarstwu kosmicznemu operować w kosmosie"64. Patrząc na Deltę Podstaw z góry, widzimy, że produkcja oznacza bogactwo wypływające z eksploatacji kos-

61 Autor używa pojęć: logic i grammar, ibidem, s. 16.

62 Ibidem.

63 Ibidem.

64 Ibidem, s. 17. 
mosu, które z kolei staje się kręgosłupem ekonomicznej sfery spacepower; kolonie to rozszerzenie rynku w przestrzeń kosmiczną, ułatwiające handel i sprzyjające produkcji; spedycja zaś to środki przemieszczania produktów, zarówno materialne, oparte na statkach kosmicznych, jak i łączność elektromagnetyczna ${ }^{65}$. Jeśli popatrzymy na Deltę Podstaw z boku, zobaczymy, że leży ona na czymś, co Ziarnick nazywa "fundamentem" (foundations), a są to podstawowe warunki niezbędne do rozwinięcia podstawowych elementów delty. Na drugim poziomie jest właśnie podstawa delty, a powyżej poziom nazywany „połączenia” (combinations), gdzie elementy są ze sobą łączone, co prowadzi do rezultatu, jakim jest "dostęp" do spacepower ${ }^{66}$. Delta Podstaw przedstawia zatem etapowy proces dochodzenia do spacepower, rozwijający się z dołu do góry.

Delta Podstaw według Brenta Ziarnicka
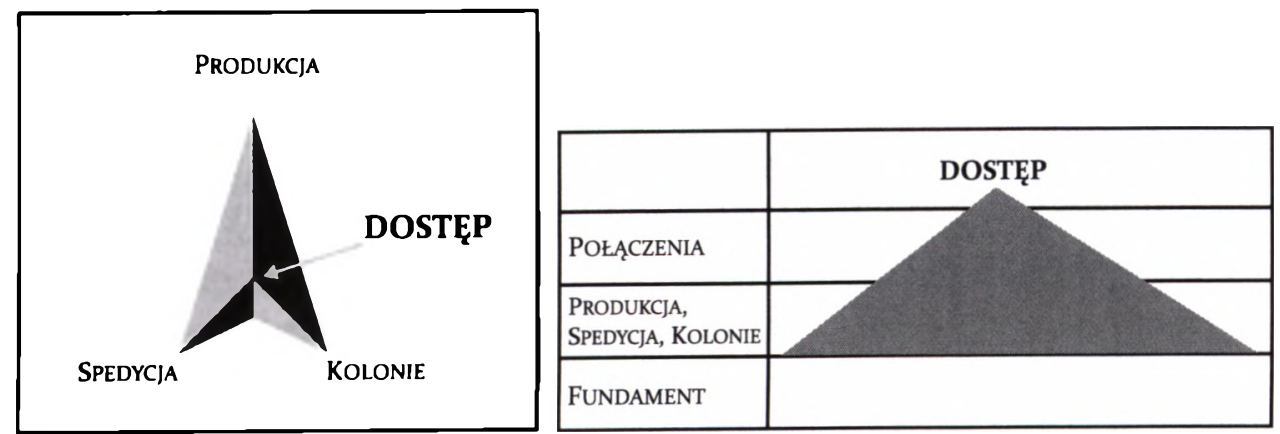

Źródło: B. Ziarnick, Developing..., s. 17-18

Współczesną formę Delty Podstaw, za Ziarnickiem ${ }^{67}$, można zilustrować następująco. „Produkcja” to dobra i usługi, które pojawiają się w wyniku wykorzystania systemów kosmicznych, czyli przede wszystkim usługi telekomunikacyjne i obserwacja Ziemi z kosmosu. W przyszłości zapewne uzupełnione to zostanie o produkcję dóbr i energii w kosmosie, a być może i wydobycie surowców na ciałach niebieskich. „Spedycja” to współcześnie przede wszystkim środki łączności elektromagnetycznej, w mniejszym zakresie statki kosmiczne. W przyszłości, w miarę ewolucji

65 Ibidem.

66 Ibidem, s. 18.

67 Ibidem, s. 20-21. 
produkcji, statki kosmiczne jako środek spedycji będą odgrywały poważniejszą rolę. I wreszcie „kolonie” to dziś satelity, ponieważ to na ich pokładach znajdują się urządzenia służące zarówno produkcji, jak i spedycji. W przyszłości zapewne systemy satelitarne będą coraz większe, z czasem może nastąpić stworzenie kolonii na Księżycu i na innych ciałach niebieskich. „Dostęp” zaś to zdolność do umieszczania w kosmosie obiektu i wykorzystywania go.

Delta Logiki składa się u podstawy z trzech elementów, siły ekonomicznej, politycznej i wojskowej, przy czym na wiodącym, ostrym końcu jest siła gospodarcza, traktowana jako najważniejsza. Natomiast wierzchołek delty to „zdolność" (ability), czyli „[...] spacepower w stanie czystym, ostateczny efekt działania Delty Podstaw"68. A zatem Podstawy, materialna baza spacepower, przechodzą poprzez wierzchołek delty w Logikę, która w związku z tym w ujęciu z boku winna być postrzegana w kierunku od szczytu do poziomej podstawy figury. Mamy tu zatem „zdolność” jako „[...] całkowitą sumę Dostępu wyprowadzoną Delty Podstaw”69, która potem przekształca się we wspomniane elementy siły znajdujące się na poziomej podstawie Delty Logiki. Po drodze, pomiędzy nimi znajduje się poziom nazywany „czynniki przekształcające” (transformers), który Ziarnick charakteryzuje jako

[...] idee i koncepcje używane do przełożenia surowej zdolności, by coś zrobić w kosmosie na konkretną, stosowalną siłę. Czynniki przekształcające zamieniają zdolność do operowania w kosmosie na konkretną siłę wypływającą z wykorzystania kosmosu, którą można zaaplikować do ekonomicznych, politycznych i wojskowych zastosowań do osiągania narodowych celów ${ }^{70}$.

Ponieważ „czynniki przekształcające” to idee czy koncepcje, można wyróżnić ich trzy rodzaje aplikowalne do trzech rodzajów spacepower: biznesplan, koncepcja soft power oraz doktryna wojskowa ${ }^{71}$. Czynniki przekształcające są oczywiście niezbędne do przełożenia surowych zdolności na konkretną spacepower, ponieważ bez opracowanego sposobu wykorzystania zdolności nie można ich przekuć na korzyści. Co więcej,

68 Ibidem, s. 22.

69 Ibidem, S. 23.

70 Ibidem.

71 Ibidem, s. 24. 
jakość czynników przekształcających, czyli skuteczność wytwarzających je struktur, wydaje się także szczególnie istotna $\mathrm{z}$ punktu widzenia spacepower.

A zatem ekonomiczna spacepower to wytwarzanie bogactwa dzięki zastosowaniom kosmicznym (dziś można by zilustrować to poprzez dochody uzyskiwane $z$ zastosowania systemów orbitalnych generowane przez podmioty prywatne lub państwowe). Przynoszą one zysk, dają pracę i skutkują płaceniem podatków, przyczyniając się do dobrobytu - oczywiście wymaga to zastosowania skutecznego biznesplanu. Ziarnick podaje jako przykład sukces komercyjny przedsiębiorstw oferujących satelitarne usługi telekomunikacyjne osiągany dzięki skutecznemu planowaniu działalności ${ }^{72}$. W przyszłości, jak już wspomnieliśmy, dojdzie zapewne do rozwoju kolejnych form przedsiębiorczości kosmicznej, takich jak: turystyka, generowanie energii czy pozyskiwanie surowców.

Polityczna spacepower polega na osiąganiu celów politycznych, rozumianych w kategoriach soft power, czyli kooptacja i atrakcyjność, pozostawiając polityczny przymus domenie militarnej. W praktyce oznacza to budowanie prestiżu państwa poprzez ukazywanie jego zdolności organizacyjnych i technologicznych, a zatem wykazywanie atrakcyjności jego modelu ustrojowego. Niewątpliwie eksploracja przestrzeni kosmicznej może się do realizacji tego celu przyczyniać poprzez realizację planów politycznych dotyczących rozwoju technologii i infrastruktury kosmicznej. Dobrym przykładem będzie tu program Apollo, pomyślany w dużej mierze właśnie jako polityczny projekt budowania prestiżu Stanów Zjednoczonych ${ }^{73}$.

Wojskowa spacepower to oczywiście wykonywanie określonych misji bojowych oraz działań niebojowych wspierających funkcjonowanie sił zbrojnych. Mamy tu zatem współcześnie cały szereg systemów orbitalnych służących wsparciu i zabezpieczeniu działań sił zbrojnych, o czym wspominano wielokrotnie. W przyszłości zaś być może będziemy mieli do czynienia z wprowadzeniem do użytku kosmicznych broni. Czynnikiem przekształcającym jest oczywiście doktryna zastosowania sił zbrojnych jako instrumentu bezpieczeństwa państwa, która oczywiście musi podlegać procesowi ciągłej rewizji i aktualizacji ${ }^{74}$.

72 Ibidem, s. 25.

73 Ibidem.

i4 Ibidem, s. 26. 
Delta Logiki według Brenta Ziarnicka
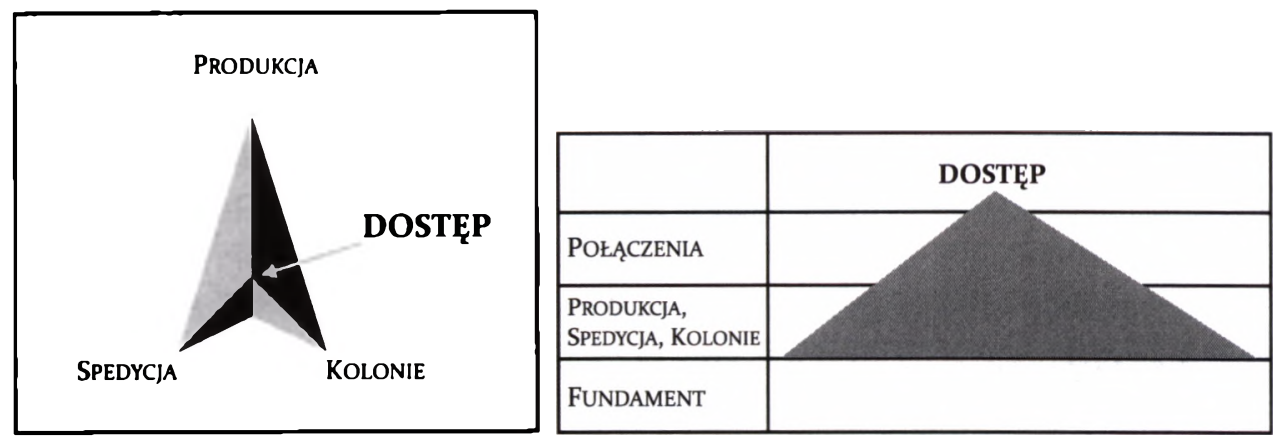

Źródło: B. Ziarnick, Developing..., s. 22-23

Na koniec warto jeszcze raz podkreślić relację pomiędzy Podstawami a Logiką, która w koncepcji Ziarnicka jest kluczem do zrozumienia spacepower i sposobu, w jaki się ona tworzy, jest organizowana i w jaki działa. A zatem:

Delta Podstaw (budulec spacepower) i Delta Logiki (zamiar i aparat stosowania spacepower) są ze sobą powiązane poprzez niezwykle ważne koncepcje „dostęp” i „zdolności”. „Dostęp” to umiejętność umieszczenia elementu w określonym obszarze $w$ kosmosie, natomiast suma całkowita oddzielnych dostępów, którymi dysponuje dane mocarstwo kosmiczne, plus zamiar wykorzystania ich ogółu dla jakiegokolwiek celu to zdolność. „Dostęp” i „zdolność” łączą delty Podstaw i Logiki tak, że tworzą one kompletny i skolimowany model spacepower 75 .

W swojej pracy Ziarnick dostarcza nam także kolejnych, bardziej szczegółowych rozważań na temat omówionych elementów teorii oraz sposobów i metod tworzenia spacepower, pominiemy jednak dalsze detale, ponieważ wydaje się, że zrąb ogólnej teorii został już przedstawiony.

Ma ona, jak się zdaje, znaczny walor jako bardzo użyteczny model wyjaśniający, który można zaadaptować zarówno do różnych sfer działalności kosmicznej, jak i do całego kompleksu polityki kosmicznej. Ma także wymiar prognostyczny, ponieważ model jest tak kompleksowy i tak ogólny, że będzie mógł być wykorzystywany w przyszłości. A zatem jest to narzędzie, właściwa teoria spacepower, którą autor następnie aplikuje do warstwy militarnej, odnosząc ją do USA, ale to już inne zagadnienie. 
Podsumowanie - trzy wymiary spacepower

Rozważania na temat pojęcia spacepower najczęściej dotyczą wąskiego, wojskowego ujęcia, które, jeśli obejmuje inne wymiary, to tylko dlatego, że wspierają one sferę militarną. Inaczej mówiąc, najczęściej mowa jest o tym, że zastosowania systemów kosmicznych znacząco mogą się przyczynić do zwiększenia skuteczności państwa w dziedzinie bezpieczeństwa narodowego rozumianego w wąskim ujęciu militarnym. W ramach takiego podejścia rozważania dotyczące nauki, technologii czy sfery gospodarczej są prowadzone $w$ kontekście ich wpływu na tworzenie zdolności, które można wykorzystać do zwiększenia zdolności wojskowych państwa. Przytoczone $w$ tym podrozdziale propozycje należą do nielicznych bardziej obszernych i bardziej teoretycznie podbudowanych, jednak i one koncentrują się na spacepower jako elemencie ogólnej siły państwa, przede wszystkim w kontekście bezpieczeństwa narodowego. Wyraźnie także są one efektem podejścia do bezpieczeństwa i do stosunków międzynarodowych $\mathbf{w}$ duchu realizmu, w warstwie teoretycznej są zatem nieodłącznie powiązane $z$ głównymi cechami charakterystycznymi tego nurtu i w zasadzie nie wychodzą poza jego ramy, ewentualnie sięgając w kierunku geopolityki, która także jest bliska realizmowi.

To stosunkowo wąskie podejście można określić jako pierwszy wymiar spacepower, mający charakter niejako pierwotny, co wynika z realiów dotychczasowego rozwoju sposobów wykorzystania systemów kosmicznych. Od zarania ery kosmicznej kosmos był przecież domeną działań na rzecz bezpieczeństwa narodowego, takie ujęcie jest zatem i tradycyjne, i aktualne, ponieważ zastosowania militarne nieodmiennie są jedną z głównych, a być może nawet wciąż najważniejszą sferą zainteresowania człowieka w kosmosie.

A zatem spacepower w tym najwęższym ujęciu należy definiować jako zdolność państwa do wykorzystania przestrzeni kosmicznej do realizacji zadań $w$ dziedzinie bezpieczeństwa narodowego $w$ wymiarze zewnętrznym. W pierwszej kolejności będzie tu mowa o systemach kosmicznych, ich roli, znaczeniu i funkcjonowaniu w ramach strategii bezpieczeństwa państwa. Podstawą teoretyczną w badaniach tej problematyki jest oczywiście realizm, jako że najlepiej się on nadaje do analizowania państwa jako podmiotu zapewniającego sobie bezpieczeństwo w środowisku pełnym zagrożeń. 
Można jednak i należy tę analizę rozszerzyć, dodając problematykę obejmującą całość wspierającej funkcjonowanie systemów kosmicznych infrastruktury, od przemysłu, poprzez edukację, system badań naukowych, aż po sposoby formułowania doktryn oraz kwestie dotyczące świadomości społecznej i jej kształtowania się. Inaczej mówiąc, aby dobrze zrozumieć mechanizmy opisujące rolę kosmosu w bezpieczeństwie państwa, należy zbadać uwarunkowania jego polityki bezpieczeństwa w sferze związanej z kosmosem. Do realizacji tego celu badawczego potrzebne są jednak inne perspektywy teoretyczne, wychodzące poza wąskie państwocentryczne ujęcia. I tu pojawia się jedna $\mathrm{z}$ głównych ułomności opisanych wyżej propozycji teoretycznych, które nie potrafią wyjść poza analizę $w$ duchu realistycznym lub też $w$ ramach adaptacji klasycznej bądź poszerzonej geopolityki. Tymczasem w szczególności perspektywa konstruktywistyczna daje możliwość dogłębnego analizowania spacepower w konkretnych przypadkach, ponieważ służy wydobyciu ważnych kwestii świadomościowych, które z kolei są ważnym czynnikiem wyjaśniającym mechanizmy polityczne. Bez zastosowania takich pojęć jak sekurytyzacja czy kultura strategiczna nie można zrozumieć, kto i dlaczego promuje bądź tworzy spacepower, a zatem wyjaśnić, dlaczego polityka i strategia państwa w tym zakresie ma taki, a nie inny kształt.

Zatem, pozostając wciąż w najwęższym ujęciu, spacepower to, powtórzymy, zdolność państwa do wykorzystania przestrzeni kosmicznej do realizacji zadań $w$ dziedzinie bezpieczeństwa narodowego, co można także w miarę potrzeby rozszerzać, dodając rozważania dotyczące uwarunkowań tejże działalności. Zjawisko należy jednak ujmować nie tylko w wąskim, realistycznym kontekście teoretycznym, który akcentuje rolę państwa jako instytucji, lecz także poprzez perspektywę konstruktywistyczną, która może pomóc nam wyjaśnić, jaka jest istota spacepower w konkretnych przypadkach. A zatem, jakkolwiek realizm może prawidłowo identyfikować czynniki materialne determinujące spacepower, należy analizować je również $\mathrm{z}$ uwzględnieniem innych dostępnych perspektyw, a także w ramach metodologii innych dziedzin, na przykład socjologii, psychologii społecznej czy ekonomii. Tylko takie, szerokie podejście metodologiczne pozwoli uniknąć pułapki jednostronnej analizy problemu.

Drugi wymiar definicyjny pojęcia spacepower jest co do zasady podobny, lecz szerzej zakreśla jej rolę i lepiej się nadaje do oceny współ- 
czesności. Dziś bowiem przyspieszeniu ulega komercjalizacja kosmosu, staje się on w coraz większym stopniu domeną zastosowań cywilnych i przestrzenią cywilnej przedsiębiorczości. Wymiar gospodarczy kosmosu, a zatem jego znaczenie dla państwa wychodzące poza zastosowania w dziedzinie bezpieczeństwa, jest współcześnie nie do przecenienia. Dlatego też można rozszerzyć definicję spacepower poza sferę wąsko ujmowanego bezpieczeństwa narodowego, choć wciąż pozostanie ona przede wszystkim atrybutem państwa rozumianym w państwocentrycznej, realistycznej perspektywie. Według tego ujęcia definicję spacepower rozszerzymy jednak w sensie podmiotowym, państwa nie będziemy już traktować jedynie jako instytucji sprawującej władzę na określonym terytorium, ale szeroko - jako podmiot społeczno-ekonomiczno-terytorialny, w ramach którego działają i instytucje publiczne, i aktorzy prywatni, zarówno korporacyjni, jak i indywidualni. Spacepower w tym wymiarze to zatem suma zdolności szeroko rozumianego państwa do wykorzystania przestrzeni kosmicznej do realizacji zarówno celów państwa jako instytucji, jak i podmiotów prywatnych, w kontekście i bezpieczeństwa, i ogólnego dobrobytu społeczeństwa warunkowanego efektywną gospodarką i stabilnością społeczną. W tym wymiarze tradycyjna tematyka militarna musi zostać uzupełniona nie tylko o szerszy kontekst bezpieczeństwa publicznego, lecz także jeszcze rozleglejsze kwestie związane $z$ rozwojem gospodarczym, technologicznym i rolą państwa w zapewnianiu dobrobytu społeczeństwu. W tym wymiarze inne niż realizm perspektywy badawcze będą jeszcze bardziej wyraźnie potrzebne, podobnie jak interdyscyplinarne podejście do tematu badań. Niewątpliwie ten wymiar spacepower jest trudniejszy do analizy nie tylko dlatego, że jest rozleglejszy, ale też z powodu skomplikowanej natury powiązań pomiędzy różnymi dziedzinami życia i płaszczyznami funkcjonowania państwa. Mówimy tu bowiem o całokształcie uwarunkowań wewnętrznych w powiązaniu z międzynarodowymi, które decydują o tym, czym państ wo jest zarówno jako instytucja, jak i w szerszym ujęciu, a które powiązane są z działalnością w kosmosie.

Tu jednak kwestia definiowania spacepower się nie kończy. Wydaje się, że można i należy na potrzeby kompletności wywodu pójść jeszcze dalej i przynajmniej zarysować trzeci wymiar spacepower, który trzeba oderwać od państwa. Współczesny świat pełen jest bowiem podmiotów niepaństwowych, które prowadzą działalność transgraniczną niezależnie 
od państwa, zarówno w sferze ekonomicznej, jak i w innych dziedzinach. W dobie globalizacji, która wbrew pozorom ma się stosunkowo dobrze, rośnie autonomia podmiotów niepaństwowych, są one słabiej kontrolowane przez państwo rozumiane jako instytucja i w większym od niego oderwaniu określają swoje interesy i kształtują strategie ich realizacji. Proces ten, czyli emancypacja aktorów niepaństwowych i wzrost znaczenia więzi transgranicznych, będzie zapewne dalej przebiegał. Co oczywiste, sięgają one także w przestrzeń kosmiczną, traktując ją jako obszar działalności różnego typu, ale także, co niebagatelne, w związku z upowszechnianiem usług satelitarnych, od których liczne podmioty działające na Ziemi są w rosnącym stopniu uzależnione.

Coraz trudniej zatem ocenić działalność człowieka w kosmosie tylko poprzez perspektywę państwa jako instytucji pełniącej określone funkcje wobec określonego kręgu podmiotów w ramach danego terytorium. Trzeba więc sięgnąć po teorie, które pomogą nam to opisać i przeniosą kwestie spacepower na wyższy wymiar, już nie tylko jako (choć to oczywiście pozostanie) instrument działalności państwa. Należy także poszukać interpretacji tego pojęcia w świecie, w którym nie tylko państwa mają znaczenie. Należy ponadto zwrócić uwagę na to, że kosmos jawi się jako przestrzeń $\mathrm{w}$ pewnym sensie podatna na rozumowanie $\mathrm{w}$ duchu transnarodowych wizji stosunków międzynarodowych. Ponadto współczesne prawo międzynarodowe regulujące działalność człowieka w kosmosie z wielu przyczyn opiera się na pojęciu res communis, a zatem w kosmosie nie ma jeszcze niektórych przeszkód, takich jak przestrzennie rozciągnięta suwerenność narodowa, która determinuje ziemskie stosunki. Oczywiście, w przestrzeni tej dalej działają aktorzy „ziemscy” uwikłani w cały bagaż stosunków wzajemnych, ale nie muszą oni przenosić w kosmos swoich wszystkich instytucji kształtujących wzajemne relacje. Niektórych nawet przenieść nie mogą, co jest bodaj najważniejsze, a niezwykle trudne do uchwycenia, szczególnie bez dobrej znajomości realiów techniczno-organizacyjnych eksploracji kosmosu.

Trzeci wymiar definicji spacepower jest zatem, jak się zdaje, możliwy do uchwycenia i potrzebny, choć autorowi niniejszej pracy nie jest znana próba jego stworzenia. Poniższa propozycja ma zatem charakter bardzo wstępny, nie jest podbudowana szerokimi rozważaniami, stanowi raczej próbę intuicyjnego $w$ dużej mierze wejścia na słabo rozpoznany teoretycznie teren. Mowa tu ponadto o perspektywie wynikającej z zacho- 
dzących obecnie procesów, których charakterystyczne cechy ewoluują, a które same wymagają dobrego skonceptualizowania, zanim zostaną zoperacjonalizowane - wymaga to znacznej pracy, niemieszczącej się w ramach niniejszej pozycji.

A zatem spacepower można ujmować jako całość zdolności wykorzystania przestrzeni kosmicznej przez różnorodne podmioty, które można scharakteryzować w trzech grupach.

Po pierwsze, państwa, rozumiane jako instytucje publiczne $\mathrm{i}$ jako podmioty tworzące określony porządek prawny na określonych terytoriach, który także sięga w kosmos poprzez: podporządkowanie obiektów kosmicznych prawu państwowemu, unilateralne określenie uprawnień podmiotów podporządkowanych państwu $w$ przestrzeni kosmicznej i poprzez konstruowanie wielostronnych, powszechnie obowiązujących norm prawnych. Tak rozumiane państwa realizują przede wszystkim swoje funkcje, w tym $w$ pierwszej kolejności ochronną, a następnie organizatorską.

Po drugie, podmioty niepaństwowe rozumiane jako działające autonomicznie, ale utożsamione $z$ określonym państwem poprzez przyporządkowanie do jego porządku prawnego, a które realizują swoje indywidualne czy też korporacyjne interesy. W szczególności są to interesy gospodarcze, ale nie tylko, mogą mieć też charakter społeczny, polityczny czy naukowy.

I wreszcie po trzecie, podmioty transgraniczne rozumiane jako aktorzy niepaństwowi nie tylko autonomiczni, ale i niepowiązani instytucjonalnie z konkretnym państwem; jest to coraz liczniejsza grupa podmiotów, których nie można w pełni utożsamić $z$ jakimkolwiek państwem, a które realizują interesy ekonomiczne, polityczne, społeczne i inne.

Mówiąc o trzecim wymiarze spacepower, mamy zatem na myśli nie tylko państwa, ale też wielkie korporacje różnego typu w tym transnarodowe, a także inne podmioty gospodarcze, sieci informacyjne, sieci społecznościowe, transnarodowe zespoły naukowe czy organizacje pozarządowe wewnątrzpaństwowe oraz międzynarodowe i wreszcie grupy obywateli bądź indywidualne osoby. Tak rozszerzona podmiotowo spacepower jest nie tylko sumą zdolności poszczególnych wymienionych podmiotów, ale nade wszystko ich synergią i jako taka wymaga badania w świetle tych paradygmatów, które tejże synergii oddziaływań transnarodowych przydają znaczenie i posiadają instrumenty do ich badania. 
Będą to zatem rozmaite teorie w zakresie stosunków międzynarodowych oparte na myśli liberalnej i neoliberalnej. Przydatny niewątpliwie będzie i konstruktywizm.

\subsection{Prawo kosmiczne}

Prawo kosmiczne jest częścią prawa międzynarodowego publicznego „[...] odnoszącą się do przestrzeni ponad dolnymi warstwami atmosfery ziemskiej i rządzi postępowaniem w niej"76. Obejmuje ono jednak tylko najbardziej ogólne zasady regulujące ludzką działalność w kosmosie, a w szczególności kwestie bezpieczeństwa międzynarodowego i ogólnych ram współpracy międzynarodowej. Oprócz tego działalność w kosmosie reguluje szczegółowo narodowe ustawodawstwo poszczególnych państw, ponieważ obiekty kosmiczne podlegają prawu państwa rejestracji, co z kolei wynika $z$ prawa międzynarodowego. Prawo wewnętrzne może także szczegółowo określać przestrzenne granice suwerenności państwowej, co ma znaczenie $\mathrm{z}$ punktu widzenia zdefiniowania działalności kosmicznej. Istnieje również międzynarodowy dorobek traktatowy dwu- i wielostronny, który dotyczy regulacji konkretnych przejawów współpracy, także z udziałem podmiotów prywatnych. W praktyce większość konkretnych uregulowań oraz duża część orzecznictwa związanego z działalnością kosmiczną dotyczy sfery komercyjnego zastosowania systemów kosmicznych. Można zatem mówić o prawie kosmicznym z dwóch perspektyw. Pierwsza to prawo międzynarodowe publiczne, które bezpośrednio dotyczy państw stron traktatów, w których jest ono zawarte, oraz pośrednio podmiotów podlegających suwerenności państw stron. Druga to narodowe prawo kosmiczne poszczególnych państw, zawierające przede wszystkim uregulowania dotyczące szczegółów działalności podmiotów podlegających ich suwerenności, bez względu na to, czy dane państwo jest stroną traktatów międzynarodowych, czy też nie.

Poniżej omówimy jedynie podstawowe kwestie związane $z$ prawem kosmicznym w pierwszym z powyższych znaczeń. Ponieważ w niniejszej pracy zajmujemy się tematyką bezpieczeństwa narodowego w wymiarze

76 Space law, Encyclopaedia Britannica, 27.12.2017, https://www.britannica.com/topic/ space-law. 
zewnętrznym oraz bezpieczeństwem międzynarodowym, takie zawężenie tematyki prawa kosmicznego wydaje się niejako naturalne. Zajmiemy się zatem w pierwszej kolejności pewnymi ogólnymi rozważaniami o charakterze prawa kosmicznego, a następnie jego ewolucją i głównymi postanowieniami traktatowymi. Całość uzupełnią krótkie rozważania na temat ewentualnego przyszłego rozwoju prawa kosmicznego.

Prawo kosmiczne jako system norm regulujących działalność człowieka w przestrzeni kosmicznej ma swoją specyfikę, która wynika przede wszystkim ze szczególnych cech kosmosu jako środowiska działalności człowieka. Dlatego też nie można o nim myśleć jedynie jako o przedłużeniu w górę zasad prawa międzynarodowego. Dzieje się tak tylko do pewnego stopnia, prawa fizyki wymuszają jednak istotne różnice.

Najbardziej ogólnie cel prawa kosmicznego można zdefiniować jako:

[...] zapewnienie racjonalnego i odpowiedzialnego podejścia do eksploracji i wykorzystania przestrzeni kosmicznej dla dobra oraz $w$ interesie ludzkości. W tym celu prawo kosmiczne zajmuje się wieloma kwestiami, takimi jak: ochrona środowiska kosmicznego i ziemskiego, odpowiedzialność za szkody dokonane przez obiekty kosmiczne, rozwiązywanie sporów, zabezpieczenie interesów narodowych, ratowanie astronautów, dzielenie się informacjami na temat potencjalnych zagrożeń w kosmosie, zastosowanie technologii kosmicznych, współpraca międzynarodowa ${ }^{77}$.

Podstawowym pytaniem prawnym u zarania ery kosmicznej była kwestia przysługującej państwu suwerenności i tego, jak się ona ma do przestrzeni kosmicznej. Tradycyjnie przyjmowano, że rozciąga się ona ponad terytorium państwa w nieskończoność, zgodnie z rzymską zasadą cuius est solum, eius est usque ad coelum ${ }^{78}$. Na tej zasadzie budowano między innymi prawo lotnicze, określające wyraźnie, że suwerenność państwa rozciąga się na jego przestrzeń powietrzną. Problem ten obrazuje omówiony bliżej w rozdziale trzecim amerykański dylemat $z$ lat pięćdziesiątych, dotyczący tego, jak ZSRR zareaguje na przeloty pierwszych satelitów nad jego terytorium. Moskwa jednak nie miała takiego problemu, pierwszy satelita pospiesznie wystrzelony w październiku 1957 roku

-; Education Curriculum on Space Law, UNOOSA, 2014, s. 9, http://www.unoosa.org/ res/oosadoc/data/documents/2014/stspace/stspace64_o_html/st_space_o64E.pdf.

i8 „Do kogo należy ziemia, do tego należy wszystko ponad nią aż do nieba”. 
ustanowił precedens polegający na tym, że skoro państwa, nad którymi sputnik przelatywał, nie wyraziły sprzeciwu, to $w$ takim razie powstała $\mathrm{z}$ dnia na dzień norma prawa $z$ wyczajowego ${ }^{79} \mathrm{w}$ ramach istniejącego prawa lotniczego, dopuszczająca taki przelot ${ }^{80}$. Stanowiło to podstawę do przyjęcia później zasady, że przestrzeń kosmiczna jest dobrem wspólnym, które można porównać do statusu otwartego morza, choć nie w pełni.

Drugim podstawowym problemem prawnym powiązanym ściśle z powyższym, który pozostał aktualny po dziś dzień, była kwestia granicy przestrzeni kosmicznej, czyli na jakiej wysokości zaczyna się obszar, w którym suwerenność państwowa przestaje obowiązywać. Propozycji w tym zakresie może być wiele ${ }^{\mathbf{}_{1}}$, a próbując to określić, można przyjmować różnorodne kryteria. Najbardziej powszechnie uznaje się za granicę kosmosu wysokość $100 \mathrm{~km}$ ponad poziomem morza, choć nie jest to usankcjonowane żadnymi powszechnie obowiązującymi przepisami międzynarodowymi. Dyskusja na ten temat wciąż się toczy, proponowane są różnego rodzaju podejścia, są nawet mocne argumenty przeciwko demarkacji przestrzeni powietrznej i kosmicznej ${ }^{82}$.

\section{Ewolucja prawa kosmicznego}

Jak wspomnieliśmy, w chwili, w której człowiek rozpoczął eksplorację kosmosu, nie było szczegółowych uregulowań dla tej działalności, nie było także zgody co do elementarnych zasad, jakie mają nią rządzić. To rzeczywistość, czyli faktyczny rozwój techniki i zastosowań kosmicznych, wymusiła szybkie zajęcie się problemem. Nie udało się jednak stworzyć ścisłych i rozległych norm, ponieważ dziedzina była nowa i poszczególne kraje, a w szczególności mocarstwa, nie zdawały sobie w pełni sprawy z przyszłych korzyści, nie chciały więc wiązać się nadmiarem zobowiązań, które mogłyby w dalszej przyszłości stanowić kłopotliwy czy wręcz szkodliwy bagaż.

Zgromadzenie Ogólne ONZ przyjęło pierwszą rezolucję (nr 1348) w sprawie przestrzeni kosmicznej 13 grudnia 1958 roku. Jej najistotniej-

79 Instant customary law, por. M. Polkowska, op. cit., s. 31.

80 Ibidem, s. 32.

81 Por. E. C. Dolman, Astropolitik.., s. 100.

82 M. Polkowska, op. cit., s. 39-47. 
szym praktycznym efektem była decyzja o powołaniu Komisji ad hoc do spraw pokojowego wykorzystania przestrzeni kosmicznej (COPUOS), którą rok później przekształcono w stałą ${ }^{8_{3}}$. Co jednak ważniejsze, po raz pierwszy użyto $w$ tej rezolucji stwierdzenia, które stanie się podstawą całego prawodawstwa kosmicznego, że „[...] wykorzystanie przestrzeni kosmicznej jedynie w celach pokojowych jest wspólnym celem [...]"84 $\mathrm{Na-}$ rodów Zjednoczonych.

W 1961 roku na forum ONZ sformułowano pierwszy zestaw „zasad przewodnich", które miały przyświecać dalszym pracom nad prawem kosmicznym. W rezolucji 1721 postanowiono rozciągnąć obowiązywanie prawa międzynarodowego na przestrzeń kosmiczną i ciała niebieskie, co było niejako podstawowym aktem inkorporacji nowej domeny ludzkiej działalności do określonej dziedziny prawa. Drugim głównym postanowieniem, precyzującym ogólne stwierdzenia wspomnianej rezolucji 1348 było stwierdzenie, że ani kosmos, ani ciała niebieskie nie podlegają zawłaszczeniu przez jakiekolwiek państwo, są natomiast otwarte dla eksploracji oraz wykorzystania zgodnie z postanowieniami prawa międzynarodowego ${ }^{85}$. Dodatkowo rezolucja 1721 wezwała wszystkie kraje do rejestrowania umieszczonych przez siebie na orbicie satelitów w COPUOS, a także do współpracy w przestrzeni kosmicznej. To ostatnie dotyczyło szczególnie działań w ramach Światowej Organizacji Meteorologicznej oraz Międzynarodowej Unii Telekomunikacyjnej, ponieważ zastosowanie systemów satelitarnych dawało potencjalnie wielkie możliwości realizacji celów tych wyspecjalizowanych agend ONZ.

Pomimo braku mocy obowiązującej rezolucja 1721 była bardzo ważnym, wręcz nie do przecenienia, kamieniem milowym w ewolucji prawa kosmicznego. Wymienione jej główne postanowienia stały się bowiem bazą do późniejszych regulacji. Szczególnie fakt rozciągnięcia prawa międzynarodowego w kosmos zdeterminował dalszy rozwój prawa kosmicznego jako gałęzi prawa międzynarodowego, a zatem na podstawie jego rozległego dorobku traktatowego, ustalonych procedur i znanego sposobu obowiązywania.

83 International Co-operation in the Peaceful Uses of Outer Space, Rezolucja ZO ONZ 1472 (XIV), 12.12.1959, http://www.unoosa.org/pdf/gares/ARES_14_1472E.pdf.

84 Question of the Peaceful Use of Outer Space, Rezolucja ZO ONZ 1348 (XIII), 13.12.1958, http://www.unoosa.org/pdf/gares/ARES_13_1348E.pdf.

85 International Co-operation in the Peaceful Uses of Outer Space, Rezolucja ZO ONZ 1721 (XVI), 20.12.1961, http://www.unoosa.org/pdf/gares/ARES_16_1721E.pdf. 
W miarę bardzo burzliwego w latach sześćdziesiątych rozwoju metod i sposobów wykorzystania kosmosu rosło, co oczywiste, zapotrzebowanie na regulacje tejże działalności w związku z tym, jak wpływała ona na interakcje między państwami. Szczególnie istotny był fakt coraz szerszego wykorzystywania systemów kosmicznych do celów związanych z bezpieczeństwem narodowym - rosnąca rola kosmosu w tej kluczowej sferze wymagała prawnie wiążących regulacji.

$\mathrm{Z}$ jednej strony bowiem oba supermocarstwa, a szczególnie Stany Zjednoczone ze względu na większe zaawansowanie technologiczne, zainteresowane były bezpieczeństwem swoich systemów kosmicznych - ich rola szybko rosła $w$ ramach rozwijającej się telekomunikacji satelitarnej $i$, co szczególnie ważne, w systemie strategicznego rozpoznania. Z drugiej zaś - analizowały one, i znowu przodowały w tym USA ${ }^{86}$, perspektywę związaną z umieszczaniem na orbitach systemów uzbrojenia przeznaczonego zarówno do niszczenia obiektów satelitarnych wroga, jak i do atakowania celów na Ziemi. Amerykanie szybko jednak doszli do wniosku, że w każdym wypadku broń kosmiczna będzie droga, niepraktyczna, a przede wszystkim wysoce niepewna. Skoro zatem kosmos nie jest dobrym miejscem dla broni, argumentacja na rzecz porozumienia, które tworzyłoby prawne ramy dla bezpieczeństwa w kosmosie, była jeszcze bardziej przekonująca. Po stronie ZSRR także pojawiło się zainteresowanie tego typu regulacją sprzyjającą stabilizacji relacji w kosmosie. Oprócz podobnych jak w USA argumentów, szczególnie ważnych $w$ dobie rozpędzającego się strategicznego wyścigu zbrojeń i ogromnych ofiar z tym związanych, w ZSRR zdawano sobie sprawę z opóźnienia w kosmicznej technologii.

W ten sposób, biorąc pod uwagę swoje praktyczne interesy, supermocarstwa zdecydowały się istniejący stan rzeczy w dziedzinie bezpieczeństwa kosmicznego przenieść na płaszczyznę formalnoprawną. Po pierwsze po to, aby zabezpieczyć pewność korzystania z dotychczas zyskanych zdolności, po drugie zaś, by uniknąć wejścia na ścieżkę kolejnego wyścigu zbrojeń, tym razem w przestrzeni okołoziemskiej. Byłby on z pewnością bardzo kosztowny i oczywiście wpływałby negatywnie na bezpieczeństwo, nie dając jednocześnie jasnej perspektywy osiągnięcia

86 Por. na przykład B. Ziarnick, P. Garretson, Starfleet Was Closer than You Think, „The Space Review”, 16.03.2015, http://www.thespacereview.com/article/2714/1. 
wymiernych korzyści. Ta logika doprowadziła do podpisania 27 stycznia 1967 roku Traktatu o przestrzeni kosmicznej (Outer Space Treaty - OST) ${ }^{8_{7}}$, który do dziś pozostaje podstawowym dokumentem regulującym zasady współpracy międzynarodowej w przestrzeni kosmicznej i na ciałach niebieskich. Część bardziej praktycznych postanowień traktatu znalazła następnie swoje uszczegółowienie w trzech dalszych umowach, które dotyczyły ratownictwa kosmicznego i związanych z nim problemów ${ }^{88}$, odpowiedzialności za szkody wyrządzone przez obiekty kosmiczne ${ }^{89}$ oraz o rejestracji obiektów wystrzelonych w przestrzeń kosmiczną9o.

W 1979 roku został podpisany Traktat księżycowy ${ }^{91}$, który miał stanowić kolejny, jakościowo odmienny etap rozwoju prawa kosmicznego. Zawiera on regulacje dotyczące całości tematyki eksploatacji przestrzeni kosmicznej, z jednej strony potwierdzając postanowienia OST, z drugiej - rozszerzając je. Traktat ten wszedł wprawdzie w życie, nie ma jednak praktycznego znaczenia, ponieważ nie jest powszechnie obowiązującym prawem. Ratyfikowało go bowiem zaledwie 18 państw, pomiędzy którymi nie ma żadnego kosmicznego mocarstwa. Cztery kolejne kraje,

8; Pełna nazwa traktatu brzmi: Układ o zasadach rządzących działalnością państw w ramach eksploracji i wykorzystania przestrzeni kosmicznej, łącznie z Księżycem i innymi ciałami niebieskimi (Treaty on Principles Governing the Activities of States in the Exploration and Use of Outer Space, including the Moon and Other Celestial Bodies, w skrócie Outer Space Treaty - OST). Przyjęty rezolucją ZO ONZ 2222 (XXI), 19.12.1966, wszedł w życie 10.10.1967.

88 Porozumienie o ratowaniu astronautów, powrocie astronautów i zwrocie obiektów wystrzelonych w przestrzeń kosmiczną (Agreement on the Rescue of Astronauts, the Return of Astronauts and the Return of Objects Launched into Outer Space, w skrócie Rescue Agreement - ARRA), przyjęte rezolucją ZO ONZ 2345 (XXII), 19.12.1967, weszło w życie 3.12.1968.

89 Konwencja o międzynarodowej odpowiedzialności za szkody wyrządzone przez obiekty kosmiczne (Convention on International Liability for Damage Caused by Space Objects, w skrócie Liability Convention - LIAB), przyjęta rezolucją ZO ONZ 2777 (XXVI), 29.11.1971, weszła w życie 1.09.1972.

90 Konwencja o rejestracji obiektów wystrzelonych w przestrzeń kosmiczną (Convention on Registration of Objects Launched into Outer Space, w skrócie Registration Convention - REG), przyjęta rezolucją ZO ONZ 3235 (XXIX), 12.11.1974, weszła w życie 15.09.1976.

91 Pełna nazwa: Porozumienie rządzące działalnością państw na Księżycu i innych ciatach niebieskich (Agreement Governing the Activities of States on the Moon and Other Celestial Bodies, w skrócie Moon Agreement - MOON), przyjęte rezolucją ZO ONZ 34/68, 5.12.1979, weszło w życie 11.07.1984. 
z ważniejszych jedynie Francja i Indie, podpisały Traktat księżycowy, ale bez ratyfikacji ${ }^{92}$.

Podsumowując, w ramach ONZ mamy przede wszystkim pięć porozumień o randze wielostronnego traktatu dotyczących prawa kosmicznego. Dodać do tego należy sześć deklaracji zasad, które znajdują się w rezolucjach ZO ONZ, pięć kolejnych ważnych rezolucji dotyczących regulacji współpracy w przestrzeni kosmicznej i wreszcie dwa ważne dokumenty COPUOS, które odnoszą się do kosmicznych śmieci oraz do problemu energii nuklearnej w kosmosie ${ }^{93}$. Niektóre inne akty prawa międzynarodowego dotyczą także w pewnym stopniu działalności człowieka w przestrzeni okołoziemskiej, na przykład Traktat o ograniczeniu prób jądrowych ${ }^{94}$. Istnieje także wspomniany już dorobek prawny wynikający z dwu- i wielostronnej współpracy międzynarodowej w badaniu i wykorzystaniu kosmosu. Największe znaczenie ma on w dziedzinie cywilnej, komercyjnej telekomunikacji, ale jego rola rośnie w miarę rozszerzania się i upowszechniania działalności kosmicznej. Coraz większego znaczenia nabiera dziś szczególnie kwestia komercyjnej obserwacji powierzchni Ziemi i problemy prawne $\mathrm{z}$ tym związane.

$\mathrm{Z}$ naszego punktu widzenia, w związku z tematyką dotyczącą bezpieczeństwa narodowego i wykorzystaniem kosmosu w tym właśnie celu, podstawowym aktem prawnym jest oczywiście OST. To jego postanowienia regulują podstawy relacji pomiędzy państwami w tym obszarze, determinując zatem w znacznym stopniu obecną rolę kosmosu w bezpieczeństwie międzynarodowym. Jego szczególna rola i wielkie znaczenie wynikają w głównej mierze $\mathrm{z}$ tego, że określa on kluczowe zasady wykorzystania przestrzeni kosmicznej przez państwa.

92 Stan na 1.01.2019, za: Status of International Agreements Relating to Activities in Outer Space as at 1 April 2019, COPUOS, 1.04.2019, http://www.unoosa.org/documents/pdf/ spacelaw/treatystatus/AC105_C2_2019_CRPo3E.pdf.

93 Space Law: Resolutions, UNOOSA, 2019, http://www.unoosa.org/oosa/en/ourwork/ spacelaw/resolutions.html.

94 Pełna nazwa: Układ o zakazie prób broni nuklearnej w atmosferze, w przestrzeni kosmicznej i pod wodą (Treaty Banning Nuclear Weapon Tests in the Atmosphere, in Outer Space and Under Water, w skrócie Limited Test Ban Treaty - LTBT), podpisany 5.08.1963, wszedł w życie 10.10.1963. 
Traktat o przestrzeni kosmicznej z 1967 roku

Ze swojej natury OST ${ }^{95}$ jest porozumieniem dotyczącym bezpieczeństwa międzynarodowego oraz współpracy międzynarodowej. Tworzy fundamentalne mechanizmy służące stabilności strategicznej i regulujące interakcje państw $w$ dziedzinie eksploatacji kosmosu.

Już jego preambuła w kilku miejscach podkreśla, że przestrzeń kosmiczna ma być wykorzystywana do celów pokojowych i drogą międzynarodowej współpracy. Traktat określa przy tym kosmos jako obszar będący dobrem całej ludzkości, którego eksploracja oraz użytkowanie ma odbywać się „dla dobra wszystkich narodów, bez względu na stopień ich rozwoju gospodarczego lub naukowego". Warto jednak zauważyć już na wstępie, że traktat jest nieprecyzyjny i wzbudza wątpliwości interpretacyjne nawet co do podstawowych zasad określających charakter przestrzeni kosmicznej i ludzkiej w niej działalności ${ }^{96}$.

Te najważniejsze zasady znajdują swoje odzwierciedlenie w trzech pierwszych artykułach traktatu. Stanowią one, że „przestrzeń kosmiczna, Księżyc oraz pozostałe ciała niebieskie są domeną całej ludzkości" (the province of all mankind), a ich badanie oraz wykorzystywanie ma odbywać się „bez dyskryminacji, na zasadzie równości i zgodnie z prawem międzynarodowym, a dostęp do wszystkich obszarów ciał niebieskich jest wolny". To ostatnie ma szczególne znaczenie w kontekście mocno podkreślanej swobody badań naukowych. Ostatecznie traktat wyraźnie stwierdza, że „przestrzeń kosmiczna, łącznie z Księżycem i innymi ciałami niebieskimi nie jest przedmiotem zawłaszczenia na zasadzie praw suwerennych, w drodze użytkowania, za pomocą okupacji ani w jakikolwiek inny sposób". W sposób jasny oznacza to, że kosmos ma być traktowany jako res communis, ze wszystkimi konsekwencjami tego stanu rzeczy.

Kolejny, czwarty artykuł dotyczy wykorzystania przestrzeni kosmicznej, Księżyca i ciał niebieskich w celach wojskowych. Zobowiązuje on

95 Omówienie traktatu OST oraz pozostałych źródeł prawa kosmicznego dokonujemy na podstawie tekstów oryginalnych, zawartych w cytowanej powyżej publikacji UNOOSA, International Space Law: United Nations Instruments. Polski oficjalny tekst: Dz.U. 1968, nr 14, poz. 82.

96 M. Polkowska, op. cit., s. 51-6o. 
strony do „nieumieszczania na orbicie okołoziemskiej broni jądrowej oraz innej broni masowego rażenia, nieinstalowania takiej broni na ciałach niebieskich i niestacjonowania jej w kosmosie w jakikolwiek inny sposób". Jak już zwracaliśmy na to uwagę, nie oznacza to zakazu tranzytu broni jądrowej przez kosmos, pod warunkiem że nie osiągnie ona orbity okołoziemskiej, a zatem nie zostanie stacjonowana bądź zainstalowana w kosmosie, czyli nie znajdzie się w kosmosie na stałe. Artykuł ten zabrania także „ustanawiania baz wojskowych, instalacji i fortyfikacji, testowania jakichkolwiek rodzajów broni i przeprowadzania manewrów wojskowych na ciałach niebieskich", ponieważ mają one być wykorzystywane „wyłącznie w celach pokojowych”. Personel wojskowy może jednak zostać wykorzystany w ramach „badań naukowych oraz do innych pokojowych celów”, można także „wykorzystywać jakikolwiek sprzęt techniczny i budowle potrzebne do pokojowej eksploracji Księżyca i innych ciał niebieskich".

Kolejne artykuły traktatu zawierają dalsze, nieco bardziej praktyczne i konkretne reguły wykorzystania przestrzeni kosmicznej. I tak artykuł piąty określa, że astronautów należy traktować jako „wysłanników całej ludzkości” i należy im udzielać „każdej możliwej pomocy w razie wypadku" i na inne sposoby działać na rzecz ich bezpieczeństwa. Szósty artykuł OST nakłada na państwa strony odpowiedzialność za „narodową aktywność w kosmosie, łącznie z Księżycem i ciałami niebieskimi, bez względu na to, czy są one prowadzone przez agendy rządowe, czy przez podmioty nienależące do rządu". Państwa mają także zapewnić, że podległe im podmioty będą stosować się do postanowień traktatu, w przypadku podmiotów pozarządowych muszą one otrzymywać zezwolenie od państwa i być przez nie kontrolowane. Postanowienia o odpowiedzialności uzupełnia artykuł siódmy, który nakłada na kraj, który przeprowadza lub zleca start obiektu w kosmos, oraz na państwo, „z którego terytorium lub urządzenia start się odbył”, odpowiedzialność „za szkody wyrządzone przez taki obiekt lub jego części innemu państwu stronie lub jego osobom prawnym bądź fizycznym na Ziemi, w przestrzeni powietrznej i w kosmosie, łącznie z Księżycem i innymi ciałami niebieskimi”. I wreszcie artykuł ósmy postanawia, że „państwo, w którego rejestrze znajduje się obiekt wystrzelony w kosmos, zachowuje jurysdykcję i kontrolę nad nim oraz jego personelem zarówno w przestrzeni, jak i na ciele niebieskim". Jurysdykcja ta zostaje utrzymana także przypadku, kiedy obiekt kosmiczny znajdzie 
się na Ziemi poza granicami danego państwa, powinien on także zostać zwrócony do kraju rejestracji.

Artykuły od dziewiątego do dwunastego ustanawiają bardziej szczegółowe ramy współpracy w zakresie eksploracji i wykorzystania przestrzeni kosmicznej, która winna być przede wszystkim realizowana w duchu wzajemnej pomocy. Państwa strony mają także prowadzić swoją działalność „z należytym uwzględnieniem interesów wszystkich innych państw stron", unikając przy tym zanieczyszczania środowiska kosmicznego oraz ziemskiego. Traktat ustanawia także praktykę wzajemnego obserwowania przez państwa strony swojej kosmicznej działalności, poprzez zachęcanie do udzielania na zasadzie „równości zgody do obserwacji wystrzelonych obiektów, oraz ustanowienie zasady, że „wszystkie stacje, urządzenia, wyposażenie i pojazdy kosmiczne na Księżycu i innych ciałach niebieskich są dostępne na zasadzie wzajemności dla przedstawicieli innych państw stron". Ponadto winny one jak najszerzej informować i ONZ, i opinię międzynarodową o swojej kosmicznej działalności.

Postanowienia końcowe, zawarte w artykułach od trzynastego do siedemnastego, zawierają typowe dla traktatu międzynarodowego klauzule. Jest on zatem bezterminowy, może do niego przystąpić każde państwo, podlega ratyfikacji, może też zostać zmodyfikowany w określony sposób, istnieje także ustalona procedura wystąpienia $\mathrm{z}$ niego.

Traktat ma w praktyce charakter powszechnie obowiązującego prawa, ponieważ jego stronami są wszystkie główne państwa prowadzące działalność kosmiczną oraz znaczna liczba innych. Według stanu na 1 stycznia 2019 roku traktat ratyfikowało 109 krajów, a 23 dalsze go podpisały97.

Podkreślmy ponownie, że zawarte w OST przepisy prawa są podstawą całego prawa kosmicznego, warto jednak zauważyć, iż zasady owe są raczej proste i bardzo ogólne. Były one wystarczające w czasie, kiedy przestrzeń kosmiczna była jeszcze słabo wykorzystana, w dodatku eksplorację prowadziły jedynie dwa największe mocarstwa. Jak się zdaje, obaj zimnowojenni rywale zdecydowali się ustanowić swego rodzaju modus vivendi w podstawowych sprawach dotyczących statusu przestrzeni kosmicznej, kluczowych kwestii bezpieczeństwa i podstawowych zasad współpracy,

97 Status of International Agreements Relating to Activities in Outer Space as at 1 January 2019, COPUOS, 1.04.2019, http://www.unoosa.org/documents/pdf/spacelaw/treatysta tus/AC105_C2_2019_CRPo3E.pdf. 
pozostawiając na przyszłość uregulowania bardziej szczegółowe. Wydaje się, że było to logiczne wyjście w sytuacji, gdy środki i metody eksploracji kosmosu były jeszcze w powijakach i było niezbyt jasne, do jakich korzyści eksploatacja kosmosu mogła doprowadzić w kolejnych dekadach. Podsumować to można celnymi spostrzeżeniami Everetta Dolmana, który zauważa, że:

[d]la przywykłych do tradycyjnej równowagi sił oraz politycznej intrygi polityków praktyczna wartość ogłoszenia przestrzeni kosmicznej dziedzictwem całej ludzkości była jasna. Oto bogactwa kosmosu i całość korzyści z kontrolowania tej przestrzeni były nieznane, a zatem żadne z supermocarstw nie było pewne, jakie możliwości działania uzyska drugie w przyszłości. Wydawało się więc rozsądnym zapobiec dominacji przeciwnika - ogłoszono zatem kosmos jednolitą przestrzenią dla wszystkich ludów, pracując jednocześnie pospiesznie nad zdobyciem środków technicznych i prawnych uzasadnień dla zdobycia kontroli nad tą przestrzenią. Retoryka kosmicznej współpracy była więc przykrywką, by zyskać na czasie. Dla krajów niebędących supermocarstwami, a które miały pewne ambicje kosmiczne, takie rozwiązanie było równie korzystne, pozostawiało bowiem otwarte pole do czasu, aż będą one gotowe i zdolne do wypracowania sobie korzystnej pozycji [w kosmosie] ${ }^{98}$.

Ta swoista prowizorka legislacyjna utrzymała się aż do dzisiaj, ponieważ optymizm na temat możliwości zdobycia stałych pozycji w kosmosie okazał się być na wyrost. Jednocześnie jednak ogólność traktatu stała się podstawową przesłanką jego trwałości, a jego główne postanowienia są wciąż wygodne dla wszystkich najważniejszych państw, szczególnie w kontekście bezpieczeństwa międzynarodowego.

Z drugiej jednak strony OST nie przystaje w pełni do bieżącej rzeczywistości, w której ekonomiczne wykorzystanie przestrzeni kosmicznej jest coraz szersze, a adekwatnych regulacji o charakterze powszechnie obowiązującego prawa nie ma, poza ogólnikowym postanowieniem o pokojowym wykorzystaniu przestrzeni kosmicznej i nieprzeszkadzaniu w wykorzystywaniu jej przez innych. Na przykład zapewne stosunkowo bliski jest dzień, w którym bogactwa naturalne asteroid będą mogły być wydobywane, tymczasem traktat zostawia bardzo poważne wątpliwo- 
ści co do statusu prawnego tego typu przedsięwzięć. Pojawia się zatem fundamentalne skądinąd pytanie, czy prywatna firma, która wydobędzie i sprowadzi na Ziemię surowce, będzie musiała podzielić się zyskiem, zgodnie z zasadą wspólnego dziedzictwa ludzkości, ze wszystkimi krajami świata? A może - zgodnie z zasadą suwerenności nad obiektami kosmicznymi - uznamy, że materiały pozyskane w kosmosie, które znajdą się na pokładzie statku kosmicznego, stają się przedmiotem tej suwerenności. Nie ma przecież w takiej sytuacji próby zawłaszczenia jakiegokolwiek obszaru ciała niebieskiego. Ten prosty przykład obrazuje znacznie szerszą tematykę i wielość problemów, na które współczesne prawo kosmiczne nie znajduje odpowiedzi. Dlatego też traktat niewątpliwie wymaga rozszerzenia lub zastąpienia nowym dokumentem, lecz brakuje dziś woli ze strony państw kosmicznych, by czegoś takiego dokonać, o czym wspomnimy nieco dalej.

\section{Inne akty prawne}

Trzy kolejne, wymienione już porozumienia, czyli o ratownictwie kosmicznym, odpowiedzialności i rejestracji, stanowią $w$ istocie rozwinięcie postanowień OST i biorąc pod uwagę zasadniczą treść niniejszej pracy, nie ma potrzeby omawiać ich bardziej szczegółowo. Wszystkie trzy przyjęte zostały przez znaczną liczbę państw, w tym wszystkie istotne $z$ punktu widzenia faktycznej ich roli w wykorzystaniu przestrzeni kosmicznej ${ }^{99}$.

Zupełnie inaczej rzecz się ma z Traktatem księżycowym, który wbrew nazwie obejmuje postanowienia znacznie szersze, w zamyśle miał on uszczegółowić i zastąpić OST w funkcji podstawowego traktatu o prawie kosmicznym. Mimo że nie stanowi on powszechnie obowiązującego prawa, warto przyjrzeć się pokrótce jego postanowieniom, ponieważ dają one pojęcie o kierunku ewolucji prawa kosmicznego, który nie znalazł uznania na tyle, by zmienić obraz prawa kosmicznego, lecz wciąż może być, przynajmniej po części, modelem dla jego ewolucji. 2019, COPUOS, 1.04.2019, http://www.unoosa.org/documents/pdf/spacelaw/treatys tatus/AC105_C2_2019_CRPo3E.pdf. 
Traktat przede wszystkim szczegółowo rozwija postanowienia OST na temat badań i użytkowania powierzchni Księżyca i innych ciał niebieskich, z których najistotniejsze odnoszą się do kwestii wykorzystania ich zasobów. Traktat księżycowy kilkakrotnie podkreśla i powtarza frazę o wspólnych korzyściach z eksploatacji wspólnego dobra, jakim są ciała niebieskie, a które winny dotyczyć wszystkich państw, bez względu na ich rozwój ekonomiczny i technologiczny. Mówią o tym wyraźnie artykuły 4 i 11 traktatu, nakłada on ponadto obowiązek utworzenia międzynarodowego reżimu $z$ odpowiednimi procedurami, który regulowałby kwestie związane z wydobyciem surowców, kiedy tylko stanie się to możliwe. Artykuł 11 zawiera także bardzo szczegółowe postanowienia zakazujące posiadania jakichkolwiek praw suwerennych lub własności przez jakiekolwiek podmioty prywatne czy też publiczne.

Inaczej mówiąc, wedle tego traktatu, prawo do eksploatacji nie obejmuje własności wydobytych surowców, które mają być następnie dzielone pomiędzy sygnatariuszy traktatu bez względu na ich wkład. Nie ulega wątpliwości, że takie sformułowanie głównych pryncypiów, skrajnie niekorzystne z punktu widzenia krajów kapitalistycznych, było efektem przewagi w procesie legislacyjnym, jaką w Zgromadzeniu Ogólnym ONZ miały w owym czasie kraje socjalistyczne i kraje rozwijające się. $Z$ tego także przede wszystkim powodu traktat nie stał się powszechnie obowiązującym prawem, trudno sobie było wyobrazić ratyfikowanie go przez USA czy inne kraje zachodnie, a nawet Chiny.

Ten brak powszechności traktatu wynika też z innych przyczyn, z których zapewne dość istotny był gwałtowny wzrost napięcia globalnego w latach osiemdziesiątych, a następnie wielka transformacja lat dziewięćdziesiątych, zmieniająca dość wyraźnie obraz świata. Nie bez znaczenia jest i to, że do dziś nie wiadomo, w jakich formach i w jaki sposób, i czy w ogóle będzie można eksploatować bogactwa ciał niebieskich. Główne państwa kosmiczne nie chcą sobie wiązać rąk, więc tym bardziej nie chciały tego przed czterdziestu laty. Dziś główną motywacją uniemożliwiającą wejście tego traktatu do powszechnego użytku jest zatem to, że powstawał $w$ zupełnie innych realiach politycznych i technologicznych i raczej nie przystaje do współczesnej rzeczywistości.

Wspomniano także o konwencjach szczegółowych regulujących współpracę międzynarodową w dziedzinie telekomunikacji, które mniej lub bardziej dotyczą kwestii wykorzystania kosmosu. Konwencji takich, 
według COPUOS, jest dziesięć, poczynając od konwencji ustanawiającej ITU, poprzez konwencje dotyczące regionalnej współpracy satelitarnej do aktów prawnych ustanawiających międzynarodowe agencje kosmiczne. Doniosłe znaczenie mają szczególnie konwencje telekomunikacyjne, ponieważ to jest właśnie główna niewojskowa sfera, w której wykorzystuje się systemy orbitalne. Istnieje także bogaty dorobek orzecznictwa w związku z praktycznym realizowaniem postanowień tych konwencji, lecz nie jest to przedmiotem zainteresowania niniejszej pracy, wspominamy o tym jedynie dla porządku.

Na marginesie dotychczasowych rozważań warto dodać, że w 1976 roku siedem krajów położonych na równiku, czyli Zair (dziś Demokratyczna Republika Konga), Uganda, Kenia, Kongo, Ekwador, Kolumbia oraz Indonezja, do których dołączyła jako obserwator Brazylia, sporządziło dokument nazwany Deklaracja z Bogoty ${ }^{100}$. Jej sygnatariusze postanowili rozciągnąć swoją suwerenność nad częściami orbity geostacjonarnej znajdującymi się ponad ich terytoriami. Deklaracja ta stoi w oczywisty sposób w sprzeczności z postanowieniami Traktatu o przestrzeni kosmicznej, czemu mocy dodaje fakt, że Indonezja, Ekwador, Brazylia, Kenia i Uganda ratyfikowały OST, a Demokratyczna Republika Konga i Kolumbia go podpisały, jedynie Kongo pozostaje całkowicie poza traktatem. Mimo całej swojej słabości Deklaracja z Bogoty pozostaje jednak w mocy, utrzymywana zapewne jako swego rodzaju argument przetargowy, którego wykorzystanie może być pomocne w procesie tworzenia w przyszłości nowego reżimu prawa kosmicznego ${ }^{101}$.

\section{Perspektywy rozwoju prawa kosmicznego}

Powyższe rozważana wykazują przede wszystkim, że dorobek prawa kosmicznego jest, $w$ porównaniu $z$ innymi gałęziami prawa międzynarodowego, relatywnie szczupły. Jest to skutkiem splotu wielu czynników, z których bodaj najważniejszym jest wielokrotnie wspominany fakt, że

100 Pełna nazwa: Declaration of the First Meeting of Equatorial States (Deklaracja z pierwszego spotkania państw równikowych) Adopted on December 3, 1976, The Bogotá Declaration, https://bogotadeclaration.wordpress.com/declaration-of-1976/.

101 F. Lyall, P. B. Larsen, Space Law, New York 2016, S. 253-256. 
w przestrzeni kosmicznej ludzkość wciąż dopiero rozpoczyna swoją działalność. Dlatego też u zarania ery kosmicznej poszczególne państwa, nie mając przed sobą jasnej perspektywy co do przyszłych możliwości techniczno-organizacyjnych i ewentualnych długofalowych interesów, które z tych możliwości mogłyby wynikać, wolały słabe i giętkie uregulowania, które do niedawna jeszcze w zupełności wystarczały.

Przykładem takiego podejścia, ale i wyczerpywania się tegoż, może być, fundamentalny skądinąd, problem rozgraniczenia przestrzeni kosmicznej znajdującej się pod reżimem OST i przestrzeni powietrznej, podlegającej prawu lotniczemu. Przebieg tej granicy nie został ustalony, jedynie Międzynarodowa Federacja Lotnicza ustanowiła pułap $100 \mathrm{~km}$ jako granicę przestrzeni powietrznej, jest to jednak organizacja sportowa i jej postanowienia dotyczą tylko jej działalności. A zatem na gruncie prawa międzynarodowego wiemy tylko tyle, że przestrzeń powietrzna i kosmiczna to odrębne obszary, ale nie jest sprecyzowane, gdzie się jeden kończy, a drugi zaczyna.

Ten stan rzeczy nie miał jednak dotychczas większego znaczenia z przyczyn organizacyjno-technicznych. Jak wiemy, działalność w kosmosie oznacza umieszczanie obiektów na orbicie, co w praktyce dotyczy wysokości zaczynających się mniej więcej od $200 \mathrm{~km}$. W przestrzeni powietrznej natomiast praktyczna działalność kończy się obecnie, poza niewielkimi wyjątkami, na 20-25 km. Jak dotąd nie było zatem powodu, aby bliżej zastanawiać się nad rozgraniczeniem, które i tak istniało $w$ praktyce $z$ przyczyn niejako naturalnych. Przyjmuje się zatem, że pułap $100 \mathrm{~km}$ to dolna granica przestrzeni kosmicznej, pokrywająca się mniej więcej z tak zwaną linią Kármána ${ }^{102}$. Na tę ogólną zasadę godzi się większość państw albo w sposób dorozumiany poprzez brak regulacji wewnętrznych konkretyzujących górną granicę suwerenności państwowej, akceptując jedynie, że takowa istnieje, albo deklarują ogólną zgodę na zasadę Kármána, jednocześnie podkreślając, że ewentualne jej uszczegółowienie zależeć będzie od rozwoju technologii ${ }^{103}$.

102 To teoretycznie obliczona wysokość nad Ziemią, na której pojazd poruszający się dzięki sile nośnej wytwarzanej w wyniku ruchu w powietrzu musi poruszać się tak szybko, że osiąga prędkość wystarczającą do zrównoważenia grawitacji przez siłę odśrodkową, staje się więc obiektem orbitalnym i nie wymaga napędu.

103 Por. na przykład stanowisko Austrii z 2017 roku w: Definition and Delimitation of Outer Space: Views of States Members and Permanent Observers of the Committee. Austria, 
Prowadząc dalej ten przykład, zauważamy, że oto na naszych oczach pojawiają się technologie i zastosowania praktyczne, które wchodzą w obszary, w których dotychczas istotnej działalności nie było, co dotyczy obecnie dwóch kategorii obiektów. Pierwsze to upowszechniające się balistyczne loty suborbitalne, które mogą przebiegać ponad pułapem $100 \mathrm{~km}$, ale nie skutkować wprowadzeniem obiektu na orbitę. Dziś takie loty planuje się na potrzeby naukowe i komercyjne, mogą one jednak nabrać znaczenia militarnego, na przykład w formie nowego typu platform obserwacyjnych lub transportowych, a nawet bojowych. Drugi rodzaj nowych obiektów latających to pojazdy nazywane hipersonicznymi, które mogą operować na granicy przestrzeni kosmosu, posługując się siłą aerodynamiczną, a zatem co do zasady podobnie do samolotów, lecz poza teoretyczną granicą przestrzeni powietrznej. Dziś ta technologia wchodzi do służby pod postacią szybowców hipersonicznych (HGV), które wykorzystywane są militarnie jako pociski o różnym zasięgu. W dalszej perspektywie mogą się pojawić kolejne zastosowania, także cywilne. Można zatem postawić ważkie pytanie, w jaki sposób traktować te perspektywiczne kategorie obiektów, jakiemu reżimowi prawnemu mają one podlegać. Jest to oczywiście niezwykle doniosła z punktu widzenia bezpieczeństwa narodowego i międzynarodowego kwestia, co do której nie istnieją jednak adekwatne rozwiązania prawnomiędzynarodowe.

Kolejnym aspektem, który trzeba wziąć pod uwagę, analizując obecny stan prawa kosmicznego i jego ewentualny rozwój, jest ewolucja technologii, gospodarczych zastosowań kosmosu i środowiska bezpieczeństwa międzynarodowego, co rzutuje znacząco na szeroko pojęte bezpieczeństwo kosmiczne. W szczególności można tu wymienić następujące zjawiska.

Po pierwsze, wejście Chińskiej Republiki Ludowej na pozycję supermocarstwa kosmicznego, de facto równoprawnego $\mathrm{z}$ dotychczasowymi liderami: USA i Rosją. Chiny nie są wprawdzie tak zaawansowane technicznie jak one, dysponują jednak znacznymi funduszami, z wielu powodów są także zdeterminowane, by budować swoją potęgę kosmiczną, dokonują zatem szybkich postępów w praktycznie każdej dziedzinie.

Po drugie, upowszechnienie technologii umieszczania ładunków na orbicie okołoziemskiej, jak również wspomniany rozwój lotów suborbital-

COPUOS, 03.03.2017, http://www.unoosa.org/oosa/oosadoc/data/documents/2017/ aac.105/aac.1051112add.3_o.html. 
nych. Coraz więcej państw pracuje nad własnymi rozwiązaniami w tym zakresie, pojawiło się także wiele prężnych firm prywatnych inwestujących $w$ ten sektor ${ }^{104}$, który będzie się niewątpliwie szybko rozwijał także w przyszłości.

Po trzecie, rozpowszechnienie techniki satelitarnej doprowadziło do tego, że stała się ona niezbędnym elementem globalnej gospodarki i niezastąpionym przedmiotem powszechnego użytku społeczeństw. Proces ten będzie się zapewne dalej pogłębiał, rozwiną się prawdopodobnie kolejne dziedziny zastosowań kosmicznych, poczynając od turystyki, poprzez produkcję, do pozyskiwania surowców z ciał niebieskich.

Po czwarte, rośnie liczba krajów dysponujących systemami satelitarnymi zdolnymi do wykonywania misji na rzecz bezpieczeństwa narodowego $^{105}$. Zwiększa się także dostępność rozlicznych usług komercyjnych, które mogą być zastosowane do działań wpływających na bezpieczeństwo międzynarodowe zarówno przez państwa, jak i uczestników niepaństwowych.

Po piąte, rozprzestrzeniają się zdolności negatywnego oddziaływania na systemy satelitarne, do których można zaliczyć przede wszystkim przejmowanie kontroli, oślepianie, zakłócanie i niszczenie obiektów orbitalnych. Obecnie już nie tylko najbardziej rozwinięte mocarstwa mogą prowadzić takie działania, należy się także spodziewać szybkiego postępu tego procesu, dotyczącego zarówno państw, jak i uczestników niepaństwowych.

Po szóste, rośnie zagrożenie dla środowiska przestrzeni okołoziemskiej, które sprowadza się przede wszystkim do jego zaśmiecenia, co może doprowadzić do degradacji niektórych lub nawet wszystkich orbit i ograniczyć bądź wręcz całkowicie wstrzymać dostęp do kosmosu.

I wreszcie po siódme, rozwijające się technologie materiałowe i informatyczne przybliżają moment, w którym pojawią się pojazdy zdolne do względnie swobodnego manewrowania pomiędzy przestrzenią kosmiczną a przestrzenią powietrzną i w jej górnych warstwach. Technologie

104 Na przykład w 2021 roku loty suborbitalne ma zaoferować przedsiębiorstwo SpaceForest z Gdyni, por. Space Projects, SpaceForest, 2018, https://spaceforest.pl/portfolio/ space-projects/.

105 Według stanu na 31.03.2019 roku 24 kraje posiadały obiekty satelitarne zarejestrowane jako wojskowe, w tym na przykład ZEA, Meksyk i Chile, za: UCS Satellite Database... 
napędów to umożliwiających są obecnie w opracowaniu. Takie obiekty oczywiście wciąż będzie obowiązywała mechanika orbitalna ze wszystkimi jej konsekwencjami oraz ograniczenia masowe, ale będą one znacznie bardziej elastycznymi instrumentami czy to działalności cywilnej, czy też wojskowej.

Taka ewolucja istotnych z punktu widzenia bezpieczeństwa kosmicznego zjawisk nie tylko ilustruje rosnącą rolę przestrzeni kosmicznej, lecz także ukazuje słabość prawa kosmicznego, które nie ma instrumentów, aby odpowiedzieć na te zmiany. W nadchodzących dekadach będą one więc konieczne, by uniknąć chaosu oraz polityki „faktów dokonanych”, która byłaby potencjalnie bardzo niebezpieczna. Zasadnicze problemy prawne, których rozwiązanie jest niezbędne do utrzymania skuteczności prawa kosmicznego, są następujące.

Po pierwsze, kwestia własności pozyskanych w kosmosie surowców naturalnych - w tej dziedzinie już mamy do czynienia $z$ jednostronnymi działaniami. W 2015 roku Kongres Stanów Zjednoczonych przyznał to prawo podmiotom, które wydobędą dane surowce ${ }^{106}$. Ta regulacja nie ma zakotwiczenia $\mathrm{w}$ prawie międzynarodowym ${ }^{107}$, może zatem być nie tylko zarzewiem wielopłaszczyznowego sporu, ale także precedensem, który wpłynie na przyszłe rozwiązania prawne.

Po drugie, narasta problem podziału dostępu do wartościowych z punktu widzenia gospodarczego i ewentualnie militarnego obszarów na ciałach niebieskich, a także atrakcyjnych rejonów przestrzeni okołoziemskiej bądź okołoksiężycowej, takich jak orbita geostacjonarna ${ }^{108}$ czy punkty libracyjne. $Z$ tym wiąże się też delimitacja granicy pomiędzy przestrzenią kosmiczną pozostającą jako res communis, pod rządami prawa kosmicznego, a przestrzenią powietrzną, która zgodnie $\mathrm{z}$ prawem lotniczym podlega suwerenności państwa.

I wreszcie po trzecie, niezwykle ważne są kwestie związane $z$ uregulowaniami dotyczącymi bezpieczeństwa w kosmosie. I nie chodzi tu jedynie o broń kosmiczną, czyli o to, co dotyczy bezpośrednio prawa kos-

106 Space Resource Exploration and Utilization Act of 2015, U.S. Congress, 2015, https:// www.govtrack.us/congress/bills/114/s976.

10: A. Basu, A. Kurleka r, Highway to the Danger Zone: United States Legislative Framework Regulating the Commercial Space Sector, „Astropolitics” 2016, vol. 14, nr 1, s. 59-6o. 108 R. Kopeć, Geostationary Belt... 
micznego, lecz przede wszystkim o broń przeciwsatelitarną bazowania naziemnego oraz inne negatywne oddziaływania na systemy satelitarne.

Ważnym czynnikiem, który w dużej mierze zdeterminuje ewentualne zmiany w prawie kosmicznym, jest międzynarodowa konkurencja, która ma nie tylko materialny, ale także prestiżowy wymiar. Nie jest też jedynie domeną racjonalnego działania w duchu komercyjnym i poprzez wielostronnie korzystną współpracę międzypaństwową, ale także działań irracjonalnych oraz egoistycznych. Utrudni to dojście do ewentualnego kompromisu, który będzie musiał zostać wypracowany przez główne mocarstwa kosmiczne, aby można było mówić o ewolucji prawa kosmicznego.

Dalszym utrudnieniem na drodze do umocnienia prawa kosmicznego jest to, że dziś mamy trzy główne mocarstwa kosmiczne, więc w efekcie sytuacja negocjacyjna jest raczej niestabilna. Jeszcze bardziej komplikuje ją fakt, że w kosmosie działają także mocarstwa drugorzędne, takie jak: Indie, Japonia czy Francja jako główna siłą stojąca za Europejską Agencją Kosmiczną. Dalszym problemem jest niechęć wobec rozszerzenia regulacji kosmicznych ze strony Stanów Zjednoczonych, a przecież bez tego państwa powszechnie obowiązujących rozwiązań wypracować się nie da. Tymczasem w USA częste są głosy, że uszczegółowienie zasad i generalne wzmocnienie prawa kosmicznego:

- mogłoby ograniczyć możliwości przyszłych systemów kosmicznych działających na rzecz bezpieczeństwa narodowego, poprzez ewentualne wprowadzenie ograniczeń dotyczących rozwoju broni kosmicznych; spowolnienie czy też zatrzymanie rozwoju militarnej techniki kosmicznej mogłoby zamknąć drogę do przyszłych, potencjalnie rewolucyjnych technologii, które mogłyby służyć pogłębieniu przewagi USA w kosmosie;

- ograniczenia traktatowe mogłyby doprowadzić do zmniejszenia amerykańskiej przewagi, którą w USA często nazywa się hegemonią, a która ma nie tylko wielkie znaczenie praktyczne, ale także jest elementem amerykańskiego międzynarodowego prestiżu, a co za tym idzie amerykańskiej soft power;

- wielostronne zobowiązania mogłyby także podnieść status innych państw i dać im do ręki instrument ograniczania pola manewru Stanów Zjednoczonych, tak w dziedzinie bezpieczeństwa, jak i w wymiarze politycznym oraz gospodarczym; szczególnie dotyczy to Chin, coraz wyraź- 
niej postrzeganych w USA jako główny konkurent, który coraz szybciej skraca dystans do USA.

Skoro zatem Stany Zjednoczone mogą obawiać się, że ewentualne ograniczenia traktatowe $w$ ramach prawa kosmicznego spowodują utratę obecnej przewagi poprzez nałożenie ograniczeń na rozwój różnorodnych technologii, szczególnie w dziedzinie bezpieczeństwa narodowego, nic dziwnego, że istnieją, i to od dawna, głosy skrajne, sugerujące, że USA powinny wypowiedzieć OST i zastąpić go reżimem prawnym, który umożliwiałby przede wszystkim zgłaszanie prywatnych roszczeń do surowców znajdujących się na ciałach niebieskich poza Ziemią i ich powierzchni. W ten sposób USA pozbawione ograniczeń traktatowych mogłyby skorzystać ze swojej aktualnej przewagi i ustanowić pełną hegemonię w kosmosie, nie tylko militarną ${ }^{109}$.

Podsumowując kwestie prawa kosmicznego, zauważmy, że jesteśmy obecnie w okresie szybkiej ewolucji zastosowań kosmicznych oraz środowiska międzynarodowego w sensie i politycznym, i ekonomicznym, a zatem rozwiązania prawne, które dotychczas wystarczały, a które pochodzą z początkowych lat ery kosmicznej, stają się coraz mniej adekwatne. Zmiany te mogą wymusić pojawienie się szczegółowych rozwiązań, zarówno dotyczących podstawowych kwestii, jak delimitacja przestrzeni kosmicznej, jak i spraw szczegółowych komercyjnych i niekomercyjnych. Jednak przeszkody na drodze umocnienia prawa kosmicznego są takiego rodzaju, że nie należy się spodziewać całościowych, rozległych regulacji, lecz raczej reaktywnego i wycinkowego tworzenia regulacji szczegółowych tam, gdzie będzie to i konieczne, i niezbędne.

W najbliższym czasie oczekujemy zatem raczej polityki „faktów dokonanych" i prób jednostronnego tworzenia reżimów prawnych korzyst nych dla poszczególnych państw. Szczególnie odnosić się to będzie zarówno do aktualnych mocarstw kosmicznych, jak i do państw aspirujących do tego statusu. Dopiero później, w trudnej do przewidzenia przyszłości, może dojść do negocjacji uwzględniających ustabilizowany status quo, o ile takowy w ogóle zaistnieje. Wynikiem tego procesu mogą być nowe, powszechnie obowiązujące normy prawa kosmicznego, lecz trudno dziś przewidzieć ich kształt. Ta prognoza jest dość pesymistyczna, wydaje się 
jednak realistyczna, zniweczyć ją jednak mogą przełomy technologiczne lub inne gwałtowne i niemożliwe do przewidzenia wydarzenia, które mogą całkowicie przewartościować ważne kwestie, zarówno związane z wykorzystaniem kosmosu, jak i z sytuacją na Ziemi. Takie przełomy i gwałtowne zmiany ze swej natury są nieprzewidywalne, stawiając każdą prognozę pod znakiem zapytania. 


\section{2. \\ Specyfika przestrzeni kosmicznej \\ w kontekście bezpieczeństua}

Kolejna problematyka, jaką musimy podjąć, aby zrealizować zasadniczy cel niniejszej pracy, to praktyczne uwarunkowania działalności kosmicznej, szczególnie tej, która realizowana jest przez państwa w związku z ich bezpieczeństwem narodowym. Takie podejście jest niezbędne, ponieważ przestrzeń kosmiczna jest tak odmiennym środowiskiem w stosunku do innych, w których działa człowiek, że wiele ważnych kwestii w tym zakresie jest bardzo słabo zrozumianych nie tylko pośród szerszej publiczności, ale i wśród ekspertów od problematyki politycznej czy ekonomicznej. Na ogół przyjmuje się, że systemy kosmiczne po prostu są i działają „gdzieś tam", bez głębszej refleksji nad determinującymi to działanie prawami fizyki.

Ten dość powszechny brak zrozumienia relacji pomiędzy fizyką i techniką a realnymi możliwościami, jakimi dysponuje człowiek w kosmosie, utrudnia, co oczywiste, zrozumienie charakteru całokształtu jego kosmicznej działalności. Co za tym idzie, trudno jest pojąć polityki kosmiczne państw w pełni ich złożonych uwarunkowań, także $w$ interesującym nas wymiarze bezpieczeństwa narodowego. $W$ dalszej kolejności umknąć może też sens ważnych zjawisk w dziedzinie bezpieczeństwa międzynarodowego.

Powtórzmy zatem: to fizyka i jej prawa oraz istniejące możliwości techniczne determinują parametry i możliwości systemów orbitalnych oraz stan wszystkich ograniczeń i zagrożeń związanych z ich eksploatacją, zarówno naturalnych, jak i antropogenicznych. W związku z tym niniejszy 
rozdział należy potraktować jako próbę naświetlenia ważnych kwestii praktycznych ograniczających i warunkujących działalność człowieka, co jest niezbędne jako tło wszelkich dalszych rozważań. Zamierzamy zatem w ogólnych kategoriach ukazać, jak fizyka i technika determinują to, co człowiek obecnie w kosmosie może zrobić, a także jak jego działalność kosmiczna może wpływać na różne aspekty życia na Ziemi. Niejako uszczegóławiając to ujęcie, rozważymy podstawowe kwestie praktyczne związane i z możliwościami, i z ograniczeniami wykorzystania przestrzeni wokółziemskiej $\mathrm{w}$ celach realizowania potrzeb bezpieczeństwa narodowego państw, w szczególności w wymiarze zewnętrznym.

Zajmiemy się zatem w pierwszej kolejności przestrzenią kosmiczną jako środowiskiem, które ma pewne cechy charakterystyczne rzutujące na jej wykorzystanie przez człowieka. Następnie przedstawimy w sposób syntetyczny praktyczne zadania, które systemy kosmiczne mogą realizować i realizują w dziedzinie bezpieczeństwa. Potraktować to należy jako podstawowy katalog możliwych zadań wraz z oceną potencjalnej skuteczności ich wykonania oraz innych ważnych aspektów praktycznych. I wreszcie zajmiemy się bardziej szczegółowo problemem militaryzacji kosmosu, oceniając obecny stan tego zjawiska oraz jego perspektywy. Mamy świadomość, że dwie ostatnie kwestie się ze sobą zazębiają, będą to jednak ujęcia odmienne, pierwsze będzie miało wymiar praktyczny, drugie - bardziej pojęciowy i teoretyczny oraz prognostyczny.

\subsection{Przestrzeń kosmiczna i jej cechy charakterystyczne}

Człowiek jest produktem ewolucji, która, przynajmniej w późniejszych fazach, dokonała się na suchym lądzie. W związku z tym jego właściwym habitatem jest tenże ląd, tylko tu może on żyć w stanie naturalnym, to znaczy bez wspomagania urządzeniami technicznymi. Ponadto, w bardzo ograniczonym zakresie, człowiek może korzystać ze środowiska wodnego - w niewielkiej odległości od brzegu, wyznaczanej umiejętnością pływania, nurkowania swobodnego i obserwacji pod wodą.

Od momentu, kiedy człowiek zastosował pierwsze narzędzia, najpierw naturalne, a potem będące wynikiem przetwórstwa, używał ich między innymi do sięgania $w$ głąb środowiska wodnego, a także w powietrze. Pierwsze sieci i inne narzędzia do połowu fauny wodnej usprawniły wy- 
korzystanie środowiska wodnego, a wykorzystująca lot atmosferyczny broń miotana ułatwiła polowania, także na zwierzęta poruszające się w powietrzu. Jednak człowiek pozostawał nadal przywiązany do swojego habitatu, wszystkie działania w środowisku wodnym i powietrznym służyły jego funkcjonowaniu na lądzie.

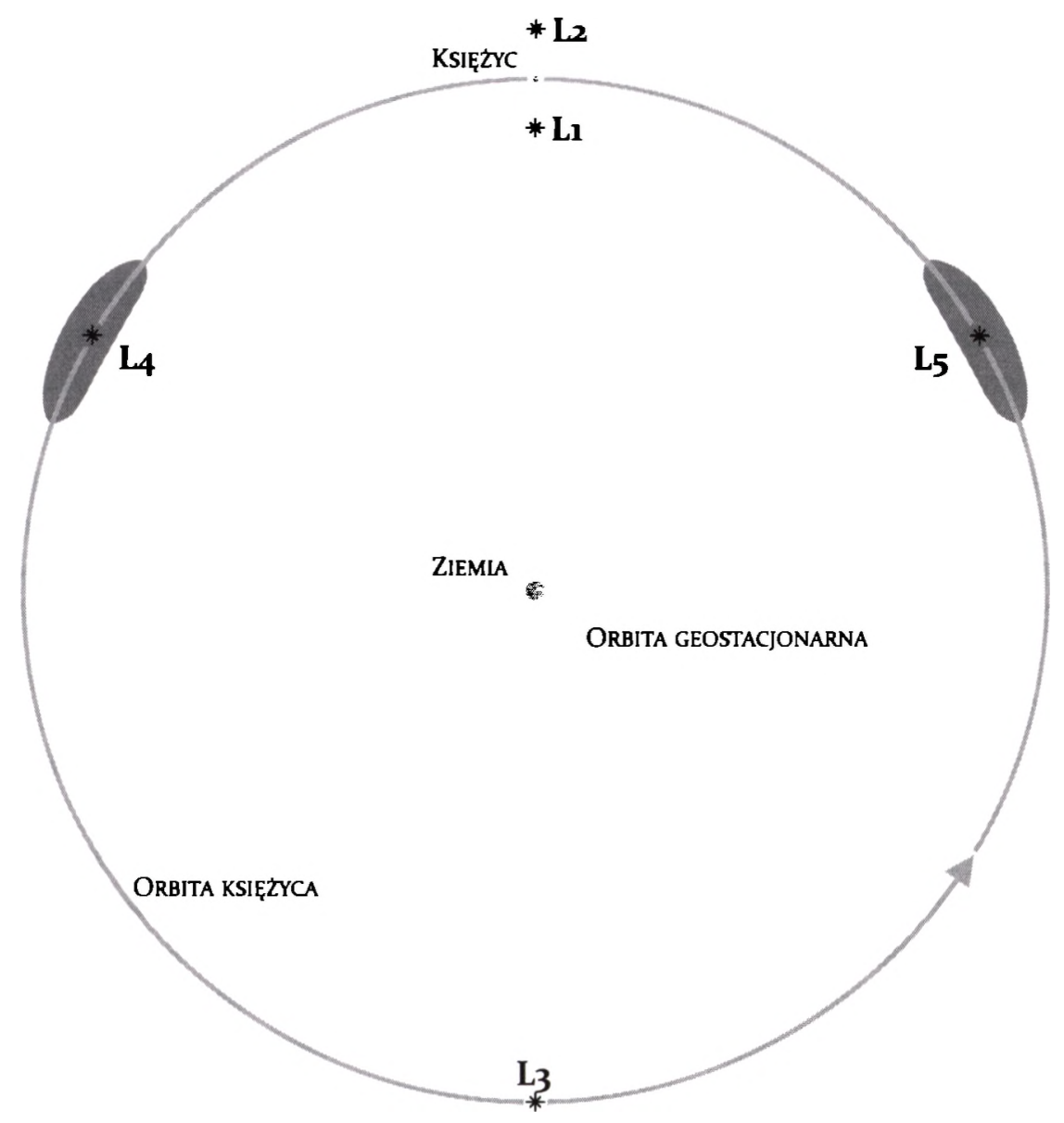

2. Przestrzeń okołoziemska (źródło: opracowanie własne).

Do dziś, mimo gigantycznego przyrostu zdolności technologicznych, nic $w$ tym zakresie się nie zmieniło. Obszary wodne i przestrzeń powietrzna są wykorzystywane do różnych celów, ale człowiek wciąż zamieszkuje wyłącznie lądy. Na wodzie / pod wodą i w powietrzu może znajdować 
się jedynie dzięki bardzo skomplikowanym urządzeniom technicznym bazującym na technologiach opracowanych w ciągu tysiącleci rozwoju cywilizacji.

Mówi się zatem często o tym, że człowiek „opanował” te przestrzenie, lecz pojęcie to nie jest w pełni właściwe. Człowiek jedynie zdołał wytworzyć pewne umiejętności, a przede wszystkim techniczne wsparcie dla wysiłków zmierzających do wykorzystania przestrzeni, które nie są jego naturalnym środowiskiem. Jest w nich jednak wciąż albo krótkotrwałym gościem, jako pływak w wodzie, albo też musi zabierać ze sobą wytwory techniki, które zapewniają mu przetrwanie w czasie dłuższych podróży przez przestwór wody oraz w powietrzu. Trudno zatem mówić o opanowaniu przestrzeni wodnej czy powietrznej przez człowieka w analogii do panowania przez niego nad lądem. Można co najwyżej stwierdzić, że w pewnym zakresie człowiek jest w stanie te domeny wykorzystywać, ale przecież zawsze na rzecz życia na lądzie.

Kosmos jest kolejną przestrzenią o specyficznych cechach fizycznych, którą człowiek w ostatnich kilku dekadach zaczął wykorzystywać - i tu często mówi się o jej opanowaniu. W tym przypadku jest to jeszcze bardziej nieścisły termin, ponieważ przestrzeń kosmiczna jest jeszcze bardziej wroga człowiekowi i jeszcze trudniejsza do wykorzystania. Decydują o tym w dużej mierze właśnie cechy fizyczne, które w połączeniu z obecnym stanem nauki i techniki określają z jednej strony możliwości, z drugiej zaś - ograniczenia w wykorzystaniu tej przestrzeni.

Próbując katalogować właściwości przestrzeni kosmicznej, można przyjąć różnego rodzaju perspektywy, które z kolei rzutować będą na zastosowane kryteria, a w szczególności na wagę przydawaną poszczególnym cechom. Na przykład perspektywa astrofizyczna, która podkreśli stan i wzajemne relacje pomiędzy podstawowymi prawami natury kształtującymi kosmos, będzie odmienna od perspektywy kosmologicznej, rozważającej strukturę i ewolucję wszechświata. Podobnie $z$ innymi ujęciami z zakresu nauk ścisłych, ale także nauk społecznych, które mogą badać kosmos, a raczej jego wpływ na społeczności ludzkie.

Nas interesuje przede wszystkim bliskie otoczenie naszej planety i jego relacja z Ziemią oraz z działalnością człowieka na jej powierzchni, a zatem jest to perspektywa geocentryczna i antropocentryczna. W związku z tym patrzymy na kosmos poprzez pryzmat tych jego cech, które najbardziej wpływają na sposób jego wykorzystania przez człowieka, a w szcze- 
gólności na ograniczenia z tym związane. W tym kontekście dobrze nam odpowiada ujęcie prezentowane w dokumencie Komitetu Połączonych Sztabów sił zbrojnych USA, pod tytułem Space Operations, który zawiera doktrynę planowania połączonych operacji kosmicznych. $W$ redakcji z 2013 roku wymienia on następujące cechy przestrzeni kosmicznej wpływające na operacje wojskowe:

- brak granic geograficznych,

- mechanika orbitalna,

- środowisko,

- zależność od łączności radiowej" ${ }^{110}$.

Ten sam dokument z 2018 roku dodaje współzależność przestrzeni kosmicznej i cyberprzestrzeni" ${ }^{11}$, co jest niejako rozszerzeniem powyżej wymienionej kwestii łączności, podkreślając jej współczesną złożoność pod względem technicznym i zależność od oprogramowania i algorytmów tworzących przestrzeń wirtualną.

Poniżej zajmiemy się bliżej w pierwszej kolejności mechaniką orbitalną, a następnie charakterystyką środowiska przestrzeni okołoziemskiej, ponieważ prawa natury nimi rządzące decydują zarówno o możliwościach jej wykorzystania, jak i o występujących ograniczeniach.

\section{Mechanika orbitalna}

Podstawowym czynnikiem determinującym charakterystykę przestrzeni kosmicznej z punktu widzenia jej praktycznych zastosowań jest tak zwana mechanika orbitalna. Opisuje ona zasady ruchu sztucznych obiektów w przestrzeni kosmicznej i jako taka jest pochodną mechaniki niebieskiej, której podstawowe prawa sformułował Johannes Kepler w 1609 roku. Mechanika orbitalna ma także ścisły związek z prawem powszechnej grawitacji Newtona i jego zasadami dynamiki ogłoszonymi w 1687 roku. Mimo pewnej oczywistości przytoczonych praw fizyki na ogół nie rozumie się w pełni ich praktycznych konsekwencji, a to przede wszystkim dlatego,

110 Space Operations, Joint Publication 3-14, Joint Chiefs of Staffs, 29.05.2013, s. x, http:// www.dtic.mil/dtic/tr/fulltext/u2/1013622.pdf.

111 Space Operations, Joint Publication 3-14, Joint Chiefs of Staffs, 10.04.2018, s. viii, https: //www.jcs.mil/Portals/36/Documents/Doctrine/pubs/jp3_14.pdf. 
że ruch w przestrzeni kosmicznej ma zupełnie inną charakterystykę niż dobrze znany i intuicyjnie pojmowany ruch na lądzie, w wodzie czy nawet w powietrzu.

Najlepiej jest wytłumaczyć to obrazowo, poprzez porównanie do sposobu przemieszczania się samolotu, który jest powszechnie rozumiany. Otóż latający obiekt atmosferyczny utrzymuje się w powietrzu, czyli równoważy oddziaływanie siły grawitacji, dzięki sile nośnej wynikającej z faktu przemieszczania się w powietrzu. Istotną konsekwencją tego stanu rzeczy jest opór atmosferyczny jako siła przeciwdziałająca sile napędzającej pojazd atmosferyczny. Tymczasem w przestrzeni kosmicznej nie ma powietrza, a więc i oporu, a zatem obiekt poruszający się tu z działającym napędem będzie stale zwiększał swoją prędkość względem układu odniesienia związanego z Ziemią. Znane z wielu filmów i mocno zakorzenione $w$ kulturze masowej wizje kosmicznego napędu działającego cały czas i jednocześnie utrzymującego zadaną prędkość są więc dalekie od rzeczywistości. Warto przy okazji zwrócić uwagę i na to, że w realnym świecie poruszanie się ze stale rosnącą prędkością jest na ogół niepraktyczne, większość zadań, których realizacji oczekujemy od obiektów kosmicznych, wymaga stałej prędkości.

Dlatego też ruch w kosmosie odbywa się co do zasady w sposób zupełnie odmienny niż ruch obiektów latających w atmosferze. Wszystkie stworzone przez człowieka obiekty umieszczone w przestrzeni okołoziemskiej poruszają się siłą bezwładności po zamkniętych torach o kołowym lub eliptycznym kształcie zwanych orbitami. Dzieje się tak dlatego, że została im nadana prędkość wystarczająca, aby wynikająca z niej siła odśrodkowa zrównoważyła grawitację. Prędkość ta jest bardzo znaczna, na pułapie $200 \mathrm{~km}$ nad powierzchnią morza dla orbity kołowej wynosi $7,8 \mathrm{~km} / \mathrm{s}$ (ponad $28000 \mathrm{~km} / \mathrm{h}$ ), na $1000 \mathrm{~km}$ jest to $7,4 \mathrm{~km} / \mathrm{s}$, z kolei na $5000 \mathrm{~km}$ to $5,4 \mathrm{~km} / \mathrm{s}$, a na $36000 \mathrm{~km}$ prędkość orbitalna wynosi $3,1 \mathrm{~km} / \mathrm{s}$. Ruch orbitalny jest zatem ruchem co do zasady bezwładnym, odbywającym się po zamkniętych torach o kształtach zgodnych z zasadami mechaniki Keplera.

Podkreślmy zatem, że ruch na powierzchni Ziemi, w wodzie lub w powietrzu na ogół odbywa się poprzez ciągłe dostarczanie energii poruszanemu obiektowi, a zatem ciągłe napędzanie go; ruch bezwładny, czyli bez użycia napędu, jest znacznie rzadszy, przykładem może być staczanie $z$ góry bezwładnego przedmiotu czy też lot pocisku wystrzelonego 
z broni palnej lub miotanej. Tymczasem obiekty poruszające się w przestrzeni okołoziemskiej i międzyplanetarnej, które są przedmiotem naszego zainteresowania, poruszają się przede wszystkim i prawie wyłącznie dzięki prawu bezwładności. Ale to nie wszystko. Obiekty poruszające się w dobrze znanych nam ośrodkach zmieniają swój tor ruchu, wykorzystując opór ośrodka, w jakim się znajdują, bądź tarcie o powierzchnie, po których się poruszają. W przestrzeni kosmicznej natomiast nie ma ani oporu ośrodka, ani tarcia powierzchni, dlatego zmianę kierunku przemieszczania możemy osiągnąć tylko, dostarczając obiektowi energii przy pomocy napędu. A zatem obiekty orbitalne są w trakcie ruchu bezwładnego całkowicie niesterowalne, a ich lot napędzany, w którym mogą być sterowane, jest jedynie wyjątkiem od reguły.

Podkreślmy jeszcze raz to bezdyskusyjne stwierdzenie, ponieważ ma ono wiele fundamentalnych, choć już niekoniecznie oczywistych konsekwencji. Wszystkie obiekty operujące dziś w przestrzeni kosmicznej, jak i wszystkie perspektywiczne tego rodzaju obiekty poruszają się i będą się poruszać głównie siłą bezwładności. Wyposażone w silniki rakietowe systemy nośne nadają im w czasie swojej krótkotrwałej pracy prędkość orbitalną równoważącą grawitację dzięki sile odśrodkowej. Nie można zatem stworzyć na podstawie dzisiejszych technologii „samolotu kosmicznego" przez analogię do samolotu z silnikiem przepływowym lub śmigłowym, który mógłby lecieć i swobodnie manewrować, czyli ciągle zmieniać pułap, skręcać i zawracać z napędem działającym przez długi okres. Materiały pędne $w$ tym wypadku musiałyby mieć tak wielką masę, razem z konstrukcją je zawierającą, że potencjalne rozmiary takiego obiektu wykluczają jego jakąkolwiek użyteczność. Ponadto pojazd taki przyspieszałby nieustannie, co także ograniczałoby jego użyteczność.

Drugą ważną dla ruchu obiektów konsekwencją braku powietrza w przestrzeni kosmicznej jest to, że systemy napędowe, które można tu zastosować, to przede wszystkim takie silniki odrzutowe ${ }^{112}$, które nie pobierają tlenu niezbędnego $\mathrm{w}$ procesie spalania $\mathrm{z}$ otaczającej przestrzeni, jak czynią to klasyczne odrzutowe silniki przepływowe. Są to tak zwane silniki rakietowe, które są niezwykle wydajne energetycznie, ale jednocześnie zużywają ogromną ilość paliwa i utleniacza na jednostkę wypro-

112 Inne typy napędu charakteryzują się bardzo małą mocą jednostkową, są zatem praktyczne tylko w nielicznych typach zadań. 
dukowanej energii. Aby zatem wysłać na orbitę przysłowiowy kilogram ładunku, należy zużyć środki napędowe o wielokrotnie większej masie, wziąwszy pod uwagę, że na masę startową składa się też konstrukcja rakiety nośnej, zbiorniki, silniki etc. Ładunek użyteczny jest zatem niewielkim ułamkiem całości rakiety kosmicznej. W przypadku powszechnie stosowanych $w$ ostatnich dekadach rakiet nośnych jest to $2,5-4 \%$ masy całości dla orbit rzędu $200-300 \mathrm{~km}$, a w przypadku orbity geostacjonarnej jest to $1-1,5 \%{ }^{113}$. Wprowadzane obecnie do użytku silniki rakietowe nowej generacji mogą nieco poprawić te parametry, lecz ponieważ oparte są na tych samych podstawowych zasadach fizyki, zmiana nie jest znacząca najnowocześniejszy produkt firmy SpaceX, Falcon Heavy, ma te współczynniki na poziomie 4,5\% i 1,9\% w konfiguracji bez odzysku wypalonych stopni startowych ${ }^{114}$. Paliwożerność współczesnych silników rakietowych powoduje, że stopnie startowe rakiet nośnych mają czas działania rzędu kilku-kilkunastu minut. Przykładowo, pierwszy stopień aktualnie używanej wersji rakiety nośnej Falcon 9 firmy SpaceX ma maksymalny czas pracy silników 162 sekundy, a drugi stopień 397 sekund $^{115}$, daje to sumarycznie zaledwie nieco ponad dziewięć minut ciągu.

Biorąc zatem pod uwagę wydajność dostępnych silników i złożoność konstrukcyjną oraz koszty, widzimy, że do tej pory technika pozwala umieścić w kosmosie tylko stosunkowo niewielkie obiekty. Najpotężniejszy z dziś stosowanych systemów nośnych, wspomniany Falcon Heavy, może wynosić na niskie orbity ładunki do 64 ton, a na orbitę przejściową do geostacjonarnej do 26 ton. Dalsza perspektywa wzrostu tych możliwości nie jest jasna, prace rozwojowe nad rakietami nośnymi zdolnymi do posłania na LEO ładunek rzędu 100 ton i więcej prowadzone są w USA (SLS), w Chinach (Long March 9), pojawiają się także niezbyt pewne doniesienia o pracach rosyjskich. W przypadku chińskim stopień zaawansowania nie jest znany, a w przypadku amerykańskim istnieją poważne wątpliwości co do samej zasadności przedsięwzięcia' ${ }^{116}$. Pojawiają się też niezbyt jasne projekty potężnych rakiet amerykańskich firm prywat-

113 D. Wright, L. Grego, L. Gronlund, op. cit., s. 77.

114 Falcon Heavy, SpaceX, https://www.spacex.com/falcon-heavy.

115 Falcon 9, SpaceX, 2019, https://www.spacex.com/falcong.

116 Por. na przykład R. Handberg, Shaping Up: The Future of US Space Transportation,

"The Space Review", 9.03.2015, http://www.thespacereview.com/article/2710/1. 
nych $^{117}$, ale nie można określić, na ile są one realistyczne. Inaczej mówiąc, w dającej się przewidzieć przyszłości masa jednorazowo wynoszonych na orbitę ładunków raczej nie wzrośnie w sposób radykalny.

Podsumowując dotychczasową problematykę, należy zauważyć, że mimo wzrostu nośności rakiet i poprawy efektywności napędów relacja pomiędzy ładunkiem użytecznym a masą systemu nośnego nie zmienia się radykalnie. Mimo że w ostatnich latach koszty wyniesienia ładunków na orbitę spadły nawet o połowę i być może będą spadać dalej, to autentycznej rewolucji w tym zakresie nie widać. Radykalne zmiany w zakresie zastosowań kosmicznych przynosi natomiast miniaturyzacja systemów, którą spadek kosztów wyniesienia jedynie wzmacnia, a nie warunkuje.

Drugim fundamentalnym ograniczeniem zastosowań systemów orbitalnych wynikającym z praw fizyki są niewielkie możliwości manewrowe satelitów. Pamiętajmy, obiekt orbitalny porusza się siłą bezwładności, zatem żeby wykonać jakikolwiek manewr, musi uruchomić silniki i zwiększyć prędkość wzdłuż wektora swojego lotu, zmniejszyć ją lub zaaplikować ciąg w kierunku innym niż wektor lotu. Nie ma tu żadnej analogii do intuicyjnie rozumianego sterowania pojazdami lądowymi lub powietrznymi, które wykorzystują tarcie podłoża lub opór powietrza do zmiany kierunku ruchu.

Każdy manewr na orbicie wymaga ponadto wielokrotnego uruchomienia silników, na przykład do prostej zmiany orientacji, czyli obrócenia satelity wokół jednej z jego osi, trzeba najpierw uruchomić na chwilę dwa silniki pracujące prostopadle do tejże osi w przeciwnych kierunkach w odległości od siebie zapewniającej powstanie odpowiedniej dźwigni. W wyniku tego impulsu satelita rozpoczyna rotację, którą następnie trzeba zatrzymać. W takim przypadku działają tylko niewielkie silniki manewrowe, ale i one wymagają znacznych ilości paliwa, szczególnie w przypadku dużych obiektów. Ponadto do większych zmian prędkości niezbędnych do poważniejszych manewrów satelita musi uruchamiać swój główny napęd (jeśli go posiada) lub na dłużej włączać silniki manewrowe. Wszystko to oznacza masę paliwa, która musi zostać wyniesiona na orbitę, co wobec przytoczonych powyżej ograniczeń zmniejsza masę ładunku użytecznego. A zatem, jeśli masa orbitera jest tylko ułamkiem

11; Por. na przykład koncepcję rakiety Starship firmy SpaceX: Making Life Multiplanetary, SpaceX, 2018, https://www.spacex.com/mars. 
masy systemu startowego, masa właściwego ładunku użytecznego jest także częścią, na ogół stosunkowo niewielką, masy satelity, włączając $w$ to jego konstrukcję. Relacja między manewrowością a możliwościami realizacji zadań przez ładunek użyteczny satelity jest zatem prosta: im większa manewrowość, tym mniej miejsca na ładunek, a zatem mniejsze możliwości realizacji zadań przez system orbitalny.

Nie wnikając w tym miejscu w szczegóły, możemy stwierdzić, że obiekt wyniesiony na orbitę, aby mógł dokonywać złożonych i/lub wielokrotnych manewrów, musiałby posiadać na pokładzie ilość paliwa będącą wielokrotnością jego masy, co przy wskazanych ograniczeniach systemów startowych powoduje, że ładunek ów byłby stosunkowo niewielki. Tym wyraźniej to widać, jeśli uświadomimy sobie, że w przypadku każdego jednostkowego manewru masa satelity, jaką trzeba uwzględniać przy kalkulacji masy potrzebnego paliwa, to ładunek użyteczny plus całe paliwo na każdy następny manewr.

Upraszczając pewne niuanse, weźmy na przykład satelitę o masie użytecznej 1 tony. Wynosimy satelitę na niską orbitę kołową $400 \mathrm{~km}$. Jeśli ma on następnie zmienić miejsce na tej orbicie, później podnieść ją do $1000 \mathrm{~km}$, następnie zmienić inklinację, a na końcu zdeorbitować w czasie 10 minut, musi mieć na to 5,2 tony paliwa ${ }^{118}$. Warto dodać, że w przykładzie tym zbiorniki paliwa będą tak duże, że ich masa zajmie zdecydowaną większość masy użytecznej. Dodając do tego konstrukcję i masę silników oraz instalacji, na właściwe instrumenty i ich zasilanie zostanie bardzo niewiele miejsca, co postawi pod znakiem zapytania użyteczność takiego pojazdu.

Dlatego właśnie co do zasady satelity, które raz znajdą się na jakiejś orbicie, bardzo rzadko ją zmieniają, ale i wtedy utrzymanie zadanej wysokości wiąże się ze zużyciem paliwa z powodu konieczności przeciwdziałania różnym czynnikom, które sprzyjają degradacji orbity. Dalszą, fundamentalnie ważną konsekwencją niewielkiej zdolności manewrowej systemów orbitalnych jest to, że ułatwia to przewidywanie ich przyszłego położenia. Skoro dany satelita nie może swobodnie manewrować, skoro jest łatwo obserwowalny z Ziemi za pomocą odpowiednich środków tech-

118 Przybliżone wyliczenie autora na podstawie danych zawartych w: D. Wright, L. Grego, L. Gronlund, op. cit., s. 71 i 79. 
nicznych, można zatem bardzo łatwo obliczyć, gdzie się będzie znajdował w przyszłości.

W perspektywie najbliższych lat niewiele się w tym względzie może zmienić, ponieważ nowe technologie napędowe, takie jak na przykład napęd jonowy, mają wprawdzie długi czas działania, ale dają niewielkie przyspieszenie, mogą zatem nadawać się jedynie do utrzymywania pozycji satelity, każdy inny manewr wykonywany za ich pomocą trwałby nieakceptowalnie długo.

\section{Środowisko}

Podobnie jak w przypadku środowiska wodnego i przestrzeni powietrznej charakterystyczne cechy przestrzeni kosmicznej, w interesującym nas obszarze przestrzeni okołoziemskiej, determinują w dużej mierze jej użyteczność w danych warunkach technologicznych i ekonomicznych. Dzieje się tak dlatego, że wyznaczają one pewne konieczności w związku z funkcjonowaniem człowieka i jego urządzeń technicznych w tej domenie. Najogólniej można powiedzieć, że przestrzeń kosmiczna jest bardzo nieprzyjaznym środowiskiem, co jest pewną oczywistością, wymaga jednak uściślenia, które jest istotne dla zrozumienia podstawowych uwarunkowań użyteczności przestrzeni kosmicznej dla człowieka.

Wymienić zatem należy następujące cechy przestrzeni okołoziemskiej, istotne z punktu widzenia działalności systemów orbitalnych, zarówno załogowych, jak i bezzałogowych.

Po pierwsze, w miarę oddalania się od powierzchni Ziemi ciśnienie atmosferyczne spada, a za granicę przestrzeni kosmicznej przyjmuje się na ogół wysokość $100 \mathrm{~km}$ ponad poziomem morza. Jest to jednak wartość arbitralna, mimo że pokrywa się mniej więcej z już mniej arbitralnym i dość użytecznym pojęciem „linia Kármána”. Nie jest to jednak punkt, w którym ciśnienie spada do zera i pojawia się absolutna próżnia, przyjmuje się, że atmosfera Ziemi stopniowo rozprasza się i zmienia swoje właściwości do wysokości około $10000 \mathrm{~km}$. Większość satelitów operuje zatem w istocie rzeczy wewnątrz atmosfery, bardzo rozrzedzonej, o specyficznym składzie i różnych własnościach fizycznych na różnych pułapach, lecz o niezerowym ciśnieniu, co ma pewne konsekwencje dla funkcjonowania systemów orbitalnych. 
Po drugie, w przestrzeni kosmicznej, rozumianej w sensie normatywnym, choć faktycznie jeszcze w wyższych warstwach atmosfery, pojawia się szereg rodzajów promieniowania związanego przede wszystkim z funkcjonowaniem naszego Słońca. Spośród nich pewne zagrożenie dla satelitów może stanowić promieniowanie rentgenowskie, szczególnie w okresach tak zwanych rozbłysków słonecznych. Znacznie większym problemem są jednak cząsteczki naładowane, także pochodzące ze Słońca, w szczególności dlatego, że są one przechwytywane przez pole magnetyczne Ziemi i tworzą wokół niej skoncentrowane pasy radiacji, zwane pasami Van Allena, rozciągające się mniej więcej na pułapach 500-550 km oraz 12 00o-22 $000 \mathrm{~km}$. W przypadku obu pasów gęstość cząsteczek naładowanych jest największa w ich środkowych strefach. Słońce okresowo wyrzuca także większą ilość tych cząsteczek w postaci koronalnych wyrzutów masy, co może zwiększać ich koncentrację także w obszarach przestrzeni i poza pasami Van Allena.

I wreszcie po trzecie, w przestrzeni okołoziemskiej występują także powszechnie mniejsze lub większe naturalne obiekty, które mogą zakłócać funkcjonowanie systemów kosmicznych. Najmniejsze z nich to bardzo rozpowszechnione mikrometeoroidy o rozmiarach mikrometrów lub nawet nanometrów. Meteoroidy to obiekty od $1 \mathrm{~mm}$ do $10 \mathrm{~m}$, najmniejsze z nich są także bardzo pospolite. Większe niż $10 \mathrm{~m}$ obiekty nazywamy asteroidami, mogą one przybrać znaczne rozmiary, choć prawdopodobieństwo napotkania ich w przestrzeni okołoziemskiej jest tym mniejsze, im większych obiektów poszukujemy.

Skutki opisanych właściwości przestrzeni kosmicznej dla funkcjonowania, a zatem dla użyteczności systemów orbitalnych mieszczą się w kilku grupach tematycznych.

Po pierwsze, w przestrzeni kosmicznej człowiek nie może się znajdować bez bardzo złożonej infrastruktury wytwarzającej odpowiedni habitat i chroniącej go przed zewnętrznym oddziaływaniem. Załogowy obiekt orbitalny musi nie tylko zaspokoić potrzeby ludzkiej fizjologii na określony czas bez utrzymania kontaktu z naturalnym, ziemskim środowiskiem. Musi także ochronić człowieka przed oddziaływaniem promieniowania rentgenowskiego, cząsteczek naładowanych, mikrometeoroidów i meteoroidów. Wszystko to oznacza konieczność wyekspediowania na orbitę znacznej masy, której zadaniem jest tylko utrzymanie przy życiu człowieka. Przy długotrwałych pobytach ludzi w kosmosie 
pojazd orbitalny musi mieć ponadto objętość wystarczającą do zachowania przez załogę minimalnej chociaż kondycji fizycznej i psychicznej, ze względu przede wszystkim na niekorzystne dla organizmu oddziaływanie nieważkości oraz zamkniętej przestrzeni. Wskazane jest umieszczenie także odpowiednich urządzeń do ćwiczeń i przestrzeni rekreacyjnej. Wszystko to oczywiście oznacza dalszy wzrost masy pojazdu orbitalnego. I wreszcie pojazd musi mieć możliwość bezpiecznego sprowadzenia człowieka na Ziemię, co wymaga paliwa na deorbitację pojazdu lub jego części (lądownika), zainstalowania zabezpieczenia przed ciepłem w czasie wejścia $w$ atmosferę $\mathrm{i}$ wreszcie wyposażenia pojazdu w skuteczne urządzenia hamujące i wspomagające lądowanie. Dodać jeszcze należy ewentualne przyrządy naukowo-badawcze, łączności etc. - znowu mamy kolejną masę, którą wcześniej trzeba wprowadzić na orbitę. Dla przykładu, współczesny statek kosmiczny Sojuz, którego zadaniem jest wyniesienie na niską orbitę trojga ludzi na zaledwie kilka-kilkanaście dni, bez żadnych wygód, ewentualnie $\mathrm{z}$ niewielkim dodatkowym ładunkiem, oraz zapewnienie im bezpiecznego powrotu, waży około 7 ton, co w stosunku do masy ludzi, powiedzmy $300 \mathrm{~kg}$, daje relację około $23: 1$. Natomiast Międzynarodowa Stacja Kosmiczna, przewidziana obecnie na stały pobyt i pracę 6 osób, ma masę ponad 400 ton. Zakładając ponownie, że masa maksymalnej załogi z osobistym wyposażeniem wynosi około $600 \mathrm{~kg}$, mamy stosunek 680 : 1. Pamiętać przy tym należy, że stacja kosmiczna nie może zapewnić przetrwania jej mieszkańcom na dłużej niż kilka miesięcy bez zaopatrzenia z Ziemi.

Po drugie, przestrzeń kosmiczna stanowi także znaczne zagrożenie dla struktury i wyposażenia pojazdów kosmicznych, również bezzałogowych. Nieustanne bombardowanie mikrometeoroidami powoduje, że powierzchnie stają się porowate, co w pierwszej kolejności powoduje degradację paneli słonecznych. Większe meteoroidy mogą uszkodzić te panele, obiektywy urządzeń obserwacyjnych, w skrajnych przypadkach naruszyć żywotne elementy wyposażenia satelity, czyniąc go bezużytecznym. W przypadku pojazdu załogowego może to oznaczać pojawienie się bezpośredniego zagrożenia dla ludzkiego życia lub zdrowia. Promieniowanie rentgenowskie oraz naładowane cząsteczki są także zabójcze dla urządzeń elektronicznych w przypadku wystawienia ich na dłuższe oddziaływanie. Jakkolwiek w przypadku promieni Roentgena jako ochrona wystarcza kilka centymetrów aluminium, w przypadku naładowanych 
cząsteczek już nie. Szczególnie narażone są satelity pracujące w pasie van Allena (na przykład GPS), które muszą stosować masywne ołowiane osłony ${ }^{119}$. W przypadku nagłego wzrostu natężenia cząsteczek naładowanych nawet te osłony mogą okazać się niewystarczające. Promieniowanie jest oczywiście także groźne dla ludzkiego życia, pojazdy załogowe, przeznaczone do długotrwałego pobytu astronautów wymagają zatem specjalnych zabezpieczeń. Oczywiście wszystkie systemy zabezpieczające stosowane $w$ systemach bezzałogowych i załogowych powodują wzrost masy orbiterów.

Po trzecie wreszcie, konsekwencją praw fizyki jest to, że orbity satelitów podlegają degradacji, o czym już pokrótce wspomniano. W największym stopniu dotyczy to oczywiście satelitów krążących po najniższych orbitach, których zresztą jest najwięcej, a które najsilniej podlegają tarciu atmosferycznemu. Na orbicie kołowej $150 \mathrm{~km}$ satelita utrzyma się zaledwie jedną dobę $e^{120}$, natomiast ISS, operująca obecnie na orbicie o średniej wysokości $402 \mathrm{~km}$, była w ciągu 2019 roku (do 4 września) „podnoszona” już 6 razy, ponieważ utrata przez nią wysokości wynosi około o,3-0,4 km miesięcznie ${ }^{121}$. Tego typu manewry wymagają oczywiście odpowiednich silników oraz paliwa - im dłużej dany obiekt ma stacjonować na orbicie, tym więcej. A zatem Międzynarodowa Stacja Kosmiczna nie utrzymałaby się na orbicie od 1998 roku, kiedy to wystrzelono jej pierwszy komponent, bez uzupełniania paliwa oraz wykorzystywania zadokowanych statków kosmicznych jako „ciągników”. W przypadku bezzałogowych i w konsekwencji bezobsługowych statków kosmicznych na orbitę musi zostać wyniesiona jednorazowo całość paliwa potrzebnego do utrzymania pozycji w przewidzianym okresie. Jednak nie tylko tarcie o atmosferę sprzyja degradacji orbit satelitów. Należy także uwzględnić precesję, czyli efekt grawitacyjny Słońca, oraz fakt, że kula ziemska nie jest w pełni regularną bryłą, a oś magnetyczna się przemieszcza, stąd jej środek masy oscyluje w stosunku do orbity satelity. W związku z tym nawet satelity geostacjonarne, dalekie od oddziaływania atmosfery, także muszą posiadać silniki manewrowe - dziś coraz częściej są to bardzo oszczędne silniki jonowe, co nieco ułatwia sprawę.

119 Ibidem, s. 37-38.

120 J. Oberg, op. cit., s. 29.

121 Height of ISS, Heavens-Above, 2019, http://www.heavens-above.com/IssHeight.aspx. 
Podsumowując, można wymienić następujące podstawowe konsekwencje praw fizyki, rzutujących na właściwości systemów orbitalnych, które z kolei wpływają na cechy charakterystyczne obecnego etapu eksploracji przestrzeni okołoziemskiej w kontekście przede wszystkim ograniczeń funkcjonowania systemów satelitarnych.

Po pierwsze, stosowanie systemów załogowych jest raczej wyjątkiem niż regułą. Od samego początku ery kosmicznej trwa zresztą dyskusja na temat użyteczności systemów załogowych vs systemy zrobotyzowane. Argumentem przeciw eksploracji załogowej są przede wszystkim koszty oraz zagrożenie życia ludzkiego, które nie kompensują niższej użyteczności, mniejszej elastyczności i trwałości systemów automatycznych. Wydaje się jednak, że sam fakt, iż obecność człowieka w kosmosie ma charakter sporadyczny i dotyczy wyjątkowych celów, świadczy o tym, że do bieżącego wykorzystywania przestrzeni wokółziemskiej systemy automatyczne są bardziej użyteczne, dlatego też bezzałogowe systemy satelitarne są regułą, a załogowe wyjątkiem.

I po drugie, w związku z powyższym praktycznie wszystkie systemy satelitarne wykorzystywane komercyjnie, wojskowo bądź naukowo wykonują większość swoich funkcji autonomicznie, podlegając jedynie nadzorowi z Ziemi. Oznacza to również, że w razie uszkodzenia bądź zużycia poszczególnych elementów nie ma praktycznie możliwości dokonania napraw na orbicie, byłyby one zbyt drogie, mogą dotyczyć ewentualnie zupełnie unikatowych i szczególnie kosztownych pojazdów - na przykład teleskop Hubble’a był serwisowany pięciokrotnie od czasu jego wystrzelenia w 1990 roku. By zachować trwałość, systemy satelitarne muszą zatem posiadać odpowiednią redundancję oraz podlegać okresowej wymianie elementów orbitalnych. To ostatnie wymuszane jest nie tylko przez relatywnie krótki czas funkcjonowania poszczególnych komponentów satelitów w niesprzyjającym środowisku, ale także nieuchronne ich schodzenie z zadanych orbit po wyczerpaniu paliwa.

Oczywiście, w wymienionych powyżej sprawach zaznacza się w ostatnich dekadach pewien postęp. Satelity są coraz mniejsze, a jednocześnie coraz bardziej efektywne, wprowadza się nowe techniki przedłużające ich żywotność, lecz zasada pozostaje niezmienna. Przestrzeń okołoziemska, w kontekście wykorzystania jej przez człowieka, jest domeną bezzałogowych systemów orbitalnych, kosztownych w produkcji, umieszczaniu i funkcjonowaniu. Dzieje się tak w wyniku splotu czynników naturalnych 
oraz czynników ekonomicznych i technologicznych, kwestie te nie będą jednak dalej rozszerzane, aby nie zaciemniać zasadniczej problematyki. Warto jedynie podkreślić poniekąd oczywisty fakt, że realne możliwości systemów orbitalnych, a zatem i ich rola w polityce dysponenta - bez względu na to, czy jest to państwo czy korporacja - zależą wprost od poziomu technologii, jaką on dysponuje, oraz funduszy, jakie jest w stanie wygenerować.

\subsection{Wpływ uykorzystania przestrzeni kosmicznej}

na bezpieczeństwo narodowe i międzynarodowe

Powyżej omówiono te charakterystyczne cechy przestrzeni kosmicznej, które są najważniejsze z punktu widzenia wykorzystania jej przez człowieka. Dalszym krokiem w stronę podstawowej problematyki niniejszej pracy jest ujęcie tych kwestii w kontekście bezpieczeństwa, w szczególności narodowego, ale także międzynarodowego. Zasadniczym celem tego podrozdziału jest zatem ukazanie, w jaki sposób charakterystyka przestrzeni kosmicznej, rzutując na możliwości systemów orbitalnych, wpływać może na efektywność realizowania przez uczestników stosunków międzynarodowych określonych zadań związanych $\mathrm{z}$ ich bezpieczeństwem narodowym, co z kolei wpływa na stan bezpieczeństwa międzynarodowego.

Omówimy zatem w pierwszej kolejności pokrótce to, jakie cechy przestrzeni kosmicznej są najbardziej doniosłe z punktu widzenia bezpieczeństwa. Następnie, dalej uszczegóławiając problematykę, przedstawimy typologię funkcji, które mogą, przy obecnym stanie techniki, wykonywać systemy satelitarne, uwzględniając także nieodległą perspektywę w ramach rysujących się i przewidywalnych trendów. I wreszcie, dodając kolejne typologie, dojdziemy do wyspecyfikowania zadań w dziedzinie bezpieczeństwa, które mogą być wykonywane przez systemy satelitarne.

Zgodnie z zasygnalizowanymi wcześniej definicjami podjęta w tym rozdziale tematyka zawiera się w ogólnym pojęciu „bezpieczeństwo poprzez kosmos". A to dlatego, że ukazuje sposób, w jaki wykorzystanie przestrzeni kosmicznej wpływa lub wpływać może na bezpieczeństwo podmiotów na Ziemi, w szczególności w ujęciu bezpieczeństwa narodowego, ale także bezpieczeństwa międzynarodowego. Bezpieczeństwo 
w kosmosie, jego obecny stan i perspektywy, zostanie ujęte szerzej w kolejnym podrozdziale oraz, w szczególności, w rozdziale piątym.

\section{Cechy przestrzeni kosmicznej a bezpieczeństwo}

Z punktu widzenia bezpieczeństwa wysokość zawsze miała znaczenie. Im wyżej udało się ustanowić punkt obserwacyjny, tym lepiej. Wojska, znajdując się wyżej od przeciwnika, także na ogół miały ułatwione zadanie z punktu widzenia skuteczności prowadzenia działań. Strategia i taktyka walki przez wieki obracała się zatem między innymi wokół poszukiwania najwyższego miejsca (high ground). Wykorzystanie przestrzeni powietrznej do obserwacji i prowadzenia walki znacząco rozszerzyło możliwości w tym zakresie, stała się ona niejako automatycznie owym najwyższym miejscem, a walka o panowanie $w$ niej kluczowym zadaniem w czasie wojny i pokoju. Nic zatem dziwnego, że przestrzeń kosmiczna traktowana jest jako ultimate high ground, czyli najwyższe dostępne miejsce, to, z którego, przynajmniej w teorii, widać praktycznie wszystko i skąd można dotrzeć wszędzie.

Pojazd orbitalny może zatem znaleźć się dosłownie nad każdym punktem na Ziemi w zależności od tego, jak zostanie pokierowany, jego obszar obserwacji bądź pole bezpośredniego rażenia są zaś bardzo duże. Na przykład satelita znajdujący się na wysokości 500 km może obserwować kolisty obszar o promieniu $1500 \mathrm{~km}$, co przekłada się na około $1,5 \%$ powierzchni Ziemi. Przyjmując wysokość $1000 \mathrm{~km}$, jest to odpowiednio 2500 $\mathrm{km}$ i 3,6\%, natomiast $\mathrm{z}$ orbity geostacjonarnej widać obszar o promieniu prawie $8000 \mathrm{~km}$, co odpowiada $34 \%$ powierzchni Ziemi ${ }^{122}$. Są to wartości nieporównywalne z tymi, które da się osiągnąć przy użyciu platform poruszających się w atmosferze. W związku z tym użyteczność systemów satelitarnych daje się najprościej ująć w kilku teoretycznych kategoriach, które można także najbardziej ogólnie nazwać funkcjami systemów sa-

122 Zakładając, że w stosunku do obserwowanego obszaru satelita utrzymuje się w elewacji co najmniej o stopni ponad horyzontem, co zapewnia minimalną teoretyczną efektywność obserwacji. Wszystkie dane za: D. Wright, L. Grego, L. Gronlund, op. cit., s. 35 . 
telitarnych w ramach zadań dotyczących bezpieczeństwa narodowego. Systemy orbitalne mogą zatem:

1. zabezpieczać prowadzenie lub przygotowywanie działań sił zbrojnych (jednostek morskich, lądowych, powietrznych oraz działających w cyberprzestrzeni), zarówno w ramach misji bojowych, jak i niebojowych;

2. wspierać na różne sposoby działalność wywiadowczą, niekoniecznie bezpośrednio związaną z działaniami zbrojnymi lub przygotowaniami do nich;

3. prowadzić walkę przeciwko obiektom na ziemi, wodzie i w powietrzu; 4. dokonywać inspekcji obcych obiektów na orbicie, zdejmować je z niej, utrudniać wykonywanie ich zadań, a wreszcie uszkadzać je bądź niszczyć oraz

5. przeprowadzać badania naukowe i eksperymenty związane z opracowywaniem bądź rozwijaniem technologii służących działaniom w sferze bezpieczeństwa.

Oczywiście nie są to jedyne środki do prowadzenia wymienionych działań, lecz ze względu na swoje cechy charakterystyczne systemy orbitalne mogą wiele $\mathrm{z}$ tych zadań wykonać lepiej, często radykalnie lepiej niż odpowiednie systemy bazowania lądowego, morskiego czy zainstalowane na platformach powietrznych. Co więcej, niektóre konkretne misje realizowane przez systemy satelitarne w ramach wymienionych powyżej funkcji w ogóle nie mogą być realizowane innymi środkami. Satelity mogą zatem znacząco uzupełniać gamę konwencjonalnych instrumentów, często zwielokrotniając dostępne możliwości. Stąd, z wojskowego punktu widzenia, bardzo często zalicza się je do kategorii środków zwanych force multipliers, czyli systemów lub taktyk, które samoistnie nie mają wielkiego znaczenia, lecz jednocześnie mogą pomnożyć zdolności bojowe poszczególnych jednostek, ich zgrupowań bądź całości sił zbrojnych.

Opisane potencjalne korzyści - wynikające, powtórzmy, z praw fizyki i aktualnego stanu techniki - nie są jednak absolutne. Istnieje wiele przeszkód związanych z wykorzystaniem satelitów w ramach realizacji zadań $\mathrm{z}$ dziedziny bezpieczeństwa narodowego w wymienionych obszarach.

Najistotniejsze jest to, że systemy satelitarne są bardzo wrażliwe na przeciwdziałanie. Satelity mają małą manewrowość, ich przyszłą pozycję łatwo precyzyjnie ustalić, są także wrażliwe na bezpośredni atak ze względu na relatywną słabość konstrukcji. Oczywiście, teoretycznie można próbować temu zaradzić, ale, jak wiemy, jakiekolwiek zwiększenie 
zdolności manewrowych czy opancerzenie satelitów radykalnie zwiększa ich masę, stawiając pod znakiem zapytania ich użyteczność. Podstawowe utrudnienia w zastosowaniu systemów satelitarnych, poza wymienionymi już naturalnymi ograniczeniami, można zatem streścić następująco.

1. Zastosowania bojowe. W związku ze swoją wrażliwością, pomijając szczegóły, które zostaną przytoczone w innym miejscu, systemy satelitarne w praktyce niezbyt się nadają na broń do atakowania celów naziemnych. Większość możliwych misji znacznie lepiej, bardziej pewnie i o wiele taniej wykonają środki konwencjonalne ${ }^{123}$. Podobnie w przypadku obrony przeciwlotniczej bądź przeciwrakietowej obiektów naziemnych - każda ewentualna satelitarna konstelacja defensywna musiałaby być bardzo rozległa i kosztowna, zarówno z powodu zasadniczych trudności, jakie stoją przed każdą obroną przeciwrakietową ${ }^{124}$, jak i w związku ze specyfiką mechaniki orbitalnej. Podobnie w przypadku użycia satelitów do zwalczania obiektów orbitalnych zadanie to w większości przypadków znacznie skuteczniej wykonają środki bojowe bazowania lądowego lub morskiego. Pamiętać ponadto należy o wspomnianej wrażliwości systemów satelitarnych na atak z Ziemi.

2. Zastosowania niebojowe. Misje wspierające działania zbrojne, służące ich przygotowaniu, lub też misje zwiadowcze oraz inne zadania niepowiązane bezpośrednio $z$ działaniami bojowymi mogą być skutecznie wykonywane tylko pod warunkiem, że przeciwnik albo nie posiada broni przeciwsatelitarnej, albo nie zdecyduje się na użycie jej lub nieniszczących metod zakłócania pracy satelitów. Współczesna proliferacja różnorodnych środków przeciwsatelitarnych ${ }^{125}$ utrudnia wykorzystanie systemów orbitalnych w czasie pokoju, a w przypadku kryzysu lub wojny byłyby one $\mathrm{z}$ pewnością poważnie zagrożone. W skrajnym przypadku systemy satelitarne mogą całkowicie odmówić posłuszeństwa lub nawet zostać zniszczone i jest to zupełnie realna perspektywa.

Podsumowując powyższe punkty, należy stwierdzić, że jakkolwiek potencjalnie systemy orbitalne mogą być niezwykle użyteczne w realizacji

123 Ibidem, s. 89-104.

124 M. Czajkowski, Obrona przeciwrakietowa w stosunkach międzynarodowych, Kraków 2013, s. 59-92.

125 Por. na przykład Counterspace Weapons 101, Center for Strategic and International Studies, 4.04.2019, https://aerospace.csis.org/aerospace1o1/counterspace-weapons-101/. 
zadań z dziedziny bezpieczeństwa narodowego, to jednak ich wrażliwość powoduje, że użyteczność ta jest uzależniona od zdolności przeciwdziałania przeciwnika. Może on bowiem relatywnie łatwo, co do zasady, zakłócać pracę satelitów bądź nawet je niszczyć, niwecząc przewagę wynikającą z ich zastosowania.

W szerszym kontekście bezpieczeństwa międzynarodowego efekty stosowania systemów kosmicznych dla potrzeb bezpieczeństwa narodowego poszczególnych państw są także znaczące, choć być może mniej wyraźne. Zauważyliśmy już powyżej, że uczestnicy stosunków międzynarodowych wykorzystują przestrzeń kosmiczną dla swojego bezpieczeństwa, co określamy jako bezpieczeństwo poprzez kosmos. Jednocześnie jednak ci sami bądź inni aktorzy podejmują działania, by tego typu korzyści odmówić swoim przeciwnikom lub chociaż zakłócić pracę ich systemów. Mamy zatem do czynienia ze wzajemnym i wielostronnym negatywnym oddziaływaniem, które może przyjąć rozliczne formy, wpływa zatem na powstawanie zagrożeń w ramach innego wymiaru bezpieczeństwa kosmicznego, czyli bezpieczeństwa w kosmosie. I dotyczy to nie tylko uczestników podejmujących wobec siebie działania agresywne, ale także wszystkich innych podmiotów działających w kosmosie.

Mamy zatem do czynienia ze znacznym potencjałem napięć i konfliktów wynikającym, po pierwsze, z międzynarodowej rywalizacji o miejsce w kosmosie (w której biorą też udział podmioty ponadnarodowe i niepaństwowe), a po drugie, z rosnącej i potencjalnie coraz większej roli kosmosu w bezpieczeństwie militarnym. Ta druga kwestia przejawia się między innymi w postaci rosnących obaw co do dalszej militaryzacji kosmosu, które przekształcić się mogą i już się przekształcają w klasyczne dylematy bezpieczeństwa, przed którymi staje wiele państw ${ }^{126}$. To bardzo istotna dla bezpieczeństwa międzynarodowego kwestia, ponieważ jakiekolwiek działania w kosmosie, czyli przeciw obiektom kosmicznym, mogą poważnie dotknąć nie tylko rywalizujące strony, ale i wszystkie podmioty zainteresowane działalnością w kosmosie, jak również, pośrednio, całą ludzkość. A to poprzez degradację cyberprzestrzeni, w której przebiega część realizacji działań systemów satelitarnych, jak też poprzez degradację samej przestrzeni kosmicznej w wyniku wzrostu ilości kosmicznych śmieci. To ostatnie w skrajnym przypadku może prowadzić nawet

126 J. Johnson-Freese, Space as a Strategic Asset, New York 2007, s. 6 i n. 
do tak zwanego efektu Kesslera, czyli do gwałtownego przyrostu liczby obiektów będących szczątkami orbiterów, które na zasadzie zbliżonej do reakcji łańcuchowej niszczą kolejne i kolejne pojazdy. Może do tego dojść zarówno w wyniku splotu przypadkowych zdarzeń, jak i świadomej działalności, na przykład w efekcie prowadzenia działań przeciwsatelitarnych czy też zaplanowanych działań mających celu uniemożliwienie dalszego wykorzystania przestrzeni okołoziemskiej. To zaś przekłada się na zagrożenia i potencjalną niestabilność w wymiarze niemilitarnym, ponieważ gospodarczy i społeczny aspekt wykorzystania przestrzeni kosmicznej nabiera znaczenia, zakłócenia $w$ tym zakresie mogą zatem sprzyjać destabilizacji w tych dziedzinach.

$\mathrm{Z}$ drugiej jednak strony działania uczestników stosunków międzynarodowych podejmowane dla realizacji ich potrzeb bezpieczeństwa mogą mieć także stabilizujący wpływ na bezpieczeństwo międzynarodowe. Nie jest to bynajmniej jedynie potencjalna możliwość czy też jakaś odległa perspektywa powszechnej pokojowej współpracy w kosmosie dla dobra ludzkości. Od początku ery kosmicznej informacje dostarczane przez zwiad satelitarny przyczyniały się w bardzo praktyczny sposób do utrzymania strategicznej stabilności, o czym mowa będzie $w$ rozdziale trzecim. W ten sposób można mówić o bezpieczeństwie międzynarodowym w ujęciu bezpieczeństwa przez kosmos, które można by pokrótce zdefiniować jako wykorzystywanie systemów kosmicznych do osiągnięcia i utrzymania stanu równowagi strategicznej, a także ułatwienie obniżania napięcia poprzez wsparcie rozbrojenia w ramach środków budowy zaufania oraz instrumentów weryfikacji porozumień o kontroli zbrojeń.

Ta ostatnia perspektywa jest $z$ jednej strony bardzo istotna $\mathrm{i}$ jej badanie niewątpliwie przynieść może wiele korzyści, lecz jest ona jednocześnie bardzo trudna do skonceptualizowania. A to dlatego, że po pierwsze, dochodzi do bardzo dynamicznego przyrostu liczby uczestników stosunków międzynarodowych działających w kosmosie oraz szybkiego przyrostu ich możliwości działania, nie ma już więc prostego, dwubiegunowego układu znanego z zimnej wojny. Z natury rzeczy był on bardziej podatny na działania stabilizujące i łatwiejszy do analizy niż układy wielobiegunowe. Po drugie zaś, znaczenie kosmosu w różnych dziadzinach rośnie bardzo prędko, trudno zatem uchwycić efekty oddziaływania oraz rolę szybko pojawiających i dynamicznie rozwijających się, często nieprzewidzianych wcześniej procesów. 
Praktyczne zadania systemów kosmicznych $w$ działaniach na rzecz bezpieczeństwa

Uszczegóławiając powyższe rozważania, przedstawimy poniżej praktyczne zadania, które systemy kosmiczne mogą współcześnie i w dającej się przewidzieć perspektywie wykonywać, ze szczególnym uwzględnieniem tych realizowanych na rzecz bezpieczeństwa narodowego państw. Podkreślmy, że poniższych typologii nie należy traktować jako oderwaną od realiów teorię, lecz jako katalog faktycznie możliwych do wykonania zadań. Wcześniej jednak, dla ścisłości wywodu, wprowadzimy kilka definicji dotyczących ważnych pojęć, które dotychczas stosowaliśmy niejako intuicyjnie.

A zatem „system kosmiczny” to całość urządzeń, których funkcją jest prowadzenie działań w przestrzeni kosmicznej za pomocą wysyłanych tam obiektów. System kosmiczny (czasem wymiennie będziemy używać pojęcia "system satelitarny”) składa się z komponentu umieszczonego na orbicie, wykonującego właściwe zadanie oraz komponentu naziemnego w postaci urządzeń kontroli i łączności wspierających to działanie lub wykonujących część podstawowej misji. W skład systemu satelitarnego wchodzi także łącze elektromagnetyczne, które wprawdzie nie jest urządzeniem ani nawet przedmiotem materialnym, lecz jego istnienie, czyli fakt realizowania łączności (a nie samo istnienie środków łączności), decyduje o funkcjonowaniu całości. Pojęcia „system orbitalny” będziemy używać w rozumieniu kosmicznej części systemu satelitarnego, jest to zatem jego komponent umieszczony na orbicie okołoziemskiej. System orbitalny to zatem satelita (wymiennie używać będziemy słowa „orbiter") bądź satelity, czyli obiekty poruszające się dookoła naszej planety ruchem bezwładnym po orbitach. Ściślej mówiąc, są to sztuczne satelity, w odróżnieniu od naturalnych, lecz dla uproszczenia będziemy pomijać słowo „sztuczne”. Systemy orbitalne składające się z więcej niż jednego satelity można nazywać konstelacjami, choć na ogół pojęcie to wykorzystuje się do systemów składających się z dużej liczby orbiterów. Pamiętać przy tym należy, że system satelitarny nie istnieje sam dla siebie, lecz dostarcza odbiorcom określonych usług $w$ funkcji niebojowej lub realizuje misje bojowe. Te zaś polegają na wywołaniu określonego efektu w postaci uszkodzenia lub zniszczenia konkretnych obiektów lub urządzeń albo też wyłączenia możliwości działania osób poprzez ich zabicie, zranienie 
lub obezwładnienie. Osobną kwestią jest ewentualna walka w cyberprzestrzeni, ale i tu należałoby uznać, że systemy satelitarne są raczej elementem zabezpieczenia działań jako część tejże cyberprzestrzeni, w której bronią są algorytmy, a celem zniszczenie algorytmów przeciwnika lub jego substancji materialnej.

Zadania wykonywane przez systemy satelitarne można różnorodnie klasyfikować. Poczynając, gwoli kompletności wywodu, od najbardziej ogólnych kwestii, warto przyjąć typologię z punktu widzenia wymiernych efektów odpowiadających tym zadaniom, a zatem według podziału na podstawowe funkcje. Zwróćmy uwagę na to, że systemy satelitarne, jak już wspomnieliśmy, służą do realizacji określonej usługi na rzecz określonego usługobiorcy, tu rozumianego na ogół w sensie technicznym bądź organizacyjnym, nie osobowym. Podstawowe funkcje systemów są zatem następujące.

Telekomunikacja, czyli retransmisja i transmisja danych w postaci plików i strumieni, oraz pośredniczenie w łączności dwustronnej, która odbywa się przede wszystkim w paśmie fal radiowych. Są one oraz pozostaną w przyszłości podstawowym medium komunikacyjnym, choć coraz częściej spotyka się łączność laserową, która ma zarówno wady, jak i zalety w stosunku do radia. $W$ tej funkcji systemy orbitalne są na ogół częścią rozległych systemów, na które składają się większe i mniejsze stacje kontrolne i retransmisyjne oraz naziemne urządzenia łączności laserowej. Odbiorcami usług systemów satelitarnych realizujących tę funkcję są różnorodne urządzenia odbiorcze oraz nadawczo-odbiorcze.

Pozycjonowanie, które co do zasady polega na transmisji danych służących do określenia przez odbiornik położenia geograficznego oraz jego wysokości ponad poziomem morza. System satelitarny tego rodzaju składa się zatem z konstelacji orbiterów zarządzanych przez kontrolę naziemną, które dostarczają usługi w postaci transmisji określonych danych. Odbiorcami tych usług są naziemne odbiorniki, umieszczone na różnych platformach oraz doręczne, które dokonują właściwych obliczeń na podstawie dostarczonych danych oraz zapisanych w pamięci informacji i algorytmów.

Obserwacja Ziemi, czyli powierzchni lądów, obszarów wodnych, przestrzeni powietrznej, ale także głębin wodnych oraz badania geologiczne i geofizyczne. Dokonywane są one w paśmie widzialnym spektrum elektromagnetycznego, w podczerwieni oraz na częstotliwościach 
radiowych poprzez sensory umieszczone na orbiterach i przekazywane do centrów naziemnych, zarówno do interpretacji i analizy, jak i do bezpośredniego wykorzystania, także w czasie rzeczywistym. Usługą zatem są surowe dane pochodzące $z$ obserwacji, a usługobiorcami naziemne terminale czasu rzeczywistego lub odbiorniki przekazujące dane satelitarne do przechowania lub analizy.

Obserwacja innych ciał niebieskich Układu Słonecznego, gwiazd oraz obiektów głębokiego kosmosu. Prowadzona może być za pomocą różnorodnych technik w zakresie spektrum elektromagnetycznego, a uzyskane dane transmitowane są do ośrodków badawczych w celu opracowania i interpretacji. I tu usługą są surowe dane, a usługobiorcą odbiorniki przekazujące je dalej, do przechowania i analizy.

Prowadzenie walki zbrojnej przy użyciu systemów satelitarnych może polegać na rażeniu różnorodnych obiektów na ziemi i pod ziemią, na wodzie i pod wodą, w powietrzu oraz w kosmosie. Może się to odbywać przy użyciu uzbrojenia oddziaływającego kinetycznie, a zatem różnorodnych pocisków, lub też broni energetycznych, które oddziałują na swoje cele za pomocą różnego typu promieniowania. W przypadku pocisków mogą one oddziaływać jedynie przy pomocy swojej energii kinetycznej, mogą być też wyposażone w głowice o ładunkach konwencjonalnych lub w broń masowego rażenia. Jeśli można w tym przypadku mówić o usłudze, to jest nią efekt wywarty przez broń przenoszoną przez system satelitarny, a usługobiorcą jest dysponent broni zainteresowany tym efektem.

Prowadzenie działań badawczych, mających na celu rozwój nowych technologii istotnych z punktu widzenia dysponenta systemu satelitarnego. Usługą jest efekt w postaci określonej wiedzy wynikającej z przeprowadzenia pewnych części procesu badawczego, a usługobiorcą podmiot zlecający, który organizuje całość procesu badawczego.

Produkcja to działalność polegająca na wytwarzaniu przedmiotów w przestrzeni kosmicznej na pokładach orbiterów należących do odpowiednio wyposażonych systemów satelitarnych. Usługą są wykonane przedmioty, a usługodawcą podmiot je zlecający.

I wreszcie turystyka, czyli działalność służąca zapewnieniu określonym osobom pobytu w przestrzeni kosmicznej dla celów niekomercyjnych, a więc dla przyjemności. Usługą jest samo umieszczenie określonych osób na określony czas w habitacie w przestrzeni okołoziemskiej, 
usługobiorcą bezpośrednim jest operator turystyczny, lecz w ostatecznym rozrachunku jest nim określona osoba, bez której usługa ta nie istnieje.

Powyższy katalog jest, przypomnijmy, kompletną, choć ogólną listą funkcji systemów kosmicznych realizowanych w przestrzeni okołoziemskiej współcześnie i możliwych do realizacji w przewidywalnej przyszłości. Dla porządku należy zwrócić uwagę, że nie zamieszczono w nim często ostatnio poruszanego pozyskiwania minerałów $z$ asteroid. A to dlatego, że nie zostały jeszcze opracowane nawet technologie, dzięki którym taka funkcja mogłaby być realizowana, pozostają one wciąż w fazie koncepcyjnej.

Nim zawęzimy tematykę do bezpieczeństwa, warto zwrócić uwagę na dwie kwestie, które w najogólniejszym stopniu charakteryzują wykorzystanie przestrzeni kosmicznej.

Po pierwsze, jak już zauważyliśmy wcześniej i co trzeba nieustannie podkreślać, co akcentowaliśmy w powyższym katalogu, systemy satelitarne mają usługowy charakter w stosunku do ich ziemskich zastosowań. Jest to oczywistość, lecz warta powtarzania - systemy satelitarne nie istnieją same dla siebie ani jedynie dla zadań realizowanych w kosmosie, lecz wspomagają działania, które człowiek podejmuje w swoim właściwym habitacie na Ziemi, dla swojego dobrobytu, skuteczności realizacji rozlicznych działań czy pomnażania wiedzy, która dalej służy, co do zasady, wszechstronnemu rozwojowi człowieka. Systemy satelitarne, ich działanie i wszystko, co za tym idzie, należy zawsze analizować z „ziemskiej" perspektywy, taka jest zresztą logika pojęcia spacepower i tego, co ono sobą reprezentuje.

Po drugie zaś, zauważmy wielość działań, jakie podejmuje się i można podejmować w przestrzeni kosmicznej. Wprawdzie niektóre ze wskazanych funkcji są dopiero $w$ fazach eksperymentalnych, lecz wielce prawdopodobne, że rozwiną się w przyszłości w szybkim tempie, wraz z zachodzącymi zmianami w dostępności techniki kosmicznej, zarówno w wymiarze praktycznym, jak i ekonomicznym.

Aby dojść ostatecznie do zastosowań systemów kosmicznych w dziedzinie bezpieczeństwa, należy powyższy katalog uzupełnić drugą typologią, czyli podziałem ze względu na dziedzinę ludzkiej działalności, w ramach której są wykorzystywane. To także pokazuje, jakim podmiotom one służą bezpośrednio i pośrednio. Systemy satelitarne wykorzystuje się zatem w następujących formach aktywności. 
Bezpieczeństwo narodowe w wymiarze zewnętrznym. Dysponentem systemów satelitarnych $w$ tej dziedzinie jest przede wszystkim państwo, które czyni to $w$ ramach wykonywania podstawowych zadań z zakresu swojej funkcji zewnętrznej. W tej dziedzinie mieszczą się: wsparcie sił zbrojnych, instytucji wywiadowczych, służby dyplomatycznej, zadania bojowe oraz działalność związana $\mathrm{z}$ rozwojem naukowo-technicznym w dziedzinie obronności i wywiadu.

Służba publiczna. Agencje państwowe oraz wykonujące zadania zlecone podmioty prywatne wykonują działania dla zabezpieczenia funkcjonowania społeczeństwa i gospodarki. Systemy satelitarne wspierają zatem służby meteorologiczne, monitorujące środowisko, antykryzysowe, ratownicze, policję i inne służby. Funkcja ta uzupełnia i łączy się w pewnym zakresie z poruszoną powyżej problematyką bezpieczeństwa narodowego, o czym wspomnimy jeszcze poniżej.

Cywilna nauka. Działalność mająca na celu powiększenie zasobu wiedzy zarówno na temat Ziemi, jak i przestrzeni kosmicznej, realizowana przez rozmaite podmioty, tak publiczne, jak i prywatne.

Działalność komercyjna. Dotyczy sprzedawania usług oraz towarów, prowadzona jest przez podmioty komercyjne, czyli takie, których podstawowym zadaniem jest osiąganie zysków, państwowe bądź prywatne. Warto zauważyć, co wyraźne jest w przestrzeni kosmicznej, że w przypadku komercyjnych podmiotów państwowych ich cel zasadniczy niejednokrotnie zazębia się $z$ realizacją różnorodnych interesów państwa, podobnie zresztą jak w przypadku wielu podmiotów prywatnych silnie powiązanych z państwem. Trzeba jednak zaznaczyć, że liczba obecnych w kosmosie podmiotów komercyjnych w pełnym tego słowa znaczeniu, czyli określających swoje interesy autonomicznie w stosunku do państwa, rośnie.

Warto zwrócić także uwagę na praktyczne przenikanie się wymienionych funkcji, a w szczególności współzależność dwóch pierwszych. Według współczesnych, szerokich definicji bezpieczeństwa zarówno to, co określiliśmy jako bezpieczeństwo narodowe w wymiarze zewnętrznym, jak i służba publiczna dotycząca w przeważającej mierze bezpieczeństwa wewnętrznego są niejako stronami tego samego medalu i jako takie pozostają w ścisłej współzależności.

$Z$ punktu widzenia celów niniejszej pracy interesują nas oczywiście zadania z zakresu bezpieczeństwa narodowego $w$ wymiarze zewnętrz- 
nym, wiążące się także z polityką zagraniczną, ze względu na funkcje w dziedzinie bezpieczeństwa, jakie ona pełni. Korzystając zatem z pierwszej z wyżej wymienionych typologii, zauważamy, że w interesującej nas sferze systemy satelitarne wykonują i mogą wykonywać wiele szczegółowych zadań na rzecz sił zbrojnych oraz służb wywiadowczych i dyplomatycznych. Są to:

- telekomunikacja,

- pozycjonowanie,

- obserwacja,

- działalność badawczo-rozwojowa oraz

- prowadzenie działań bojowych przeciwko celom naziemnym (morskim, lądowym i powietrznym) oraz kosmicznym.

Podkreślić należy, iż ta ostatnia funkcja, aczkolwiek technicznie wykonalna, nie jest jednak obecnie realizowana, choć istnieje niemałe prawdopodobieństwo, że to się zmieni w nadchodzących dekadach.

Podsumowując ogólną problematykę roli systemów satelitarnych w realizacji zadań z zakresu bezpieczeństwa narodowego w wymiarze zewnętrznym, należy przede wszystkim zauważyć, że aktualnie ich jedyną rolą jest wsparcie funkcjonowania dyplomacji, służb wywiadowczych i sił zbrojnych. Oznacza to, że systemy kosmiczne realizują zadania niewymagające użycia przez nie jakiegokolwiek uzbrojenia.

Należy także nadmienić, że systemy satelitarne nie są jedynymi środkami, które mogą być zastosowane w ramach realizacji powyższych zadań, co więcej, w zasadzie wszystkie one mogą być realizowane bez ich użycia. Dla przykładu, siły zbrojne każdego państwa posiadają rozbudowane, wielopasmowe systemy łączności, w ramach których systemy satelitarne są tylko częścią - bardzo ważną, może kluczową, ale jednak tylko częścią. A zatem, kontynuując ten przykład, łączność na każdym szczeblu, nawet w planie globalnym, może być realizowana dzięki sieci radiowych stacji nadawczo-odbiorczych, a także dzięki łączności kablowej, również z wykorzystaniem cywilnej infrastruktury. Łączność satelitarna wpływa jednak mocno na skuteczność całego systemu poprzez zwiększenie szybkości obiegu i objętości przekazywanej informacji.

Jednakże ogromna rola systemów kosmicznych nie oznacza, że mogą one zastąpić wszystkie inne środki realizowania określonych zadań. Po pierwsze dlatego, że satelity mogą z różnych powodów przestać działać, a ich naprawienie czy zastąpienie jest procesem trudnym, kosztownym 
i czasochłonnym. Po drugie, mają one także wiele ograniczeń, które wynikają z samej natury zastosowanych technologii oraz z nieubłaganych praw fizyki. Na przykład obserwacja satelitarna może dostarczyć znaczną ilość cennych danych wywiadowczych, przede wszystkim w ramach zwiadu optycznego i elektronicznego, jednak nie zastąpi to w pełni działalności agenturalnej instytucji wywiadowczych, w szczególności w zakresie zbierania informacji dotyczących przebiegu procesu decyzyjnego u przeciwnika.

Ostatecznie należy stwierdzić, że siły zbrojne i inne instytucje państwowe zajmujące się bezpieczeństwem zewnętrznym bardzo szeroko wykorzystują wymienione zdolności systemów satelitarnych. Rośnie także ich de facto zależność od zastosowań orbitalnych, ponieważ wielu zadań w ramach bezpieczeństwa narodowego nie dałoby się bez nich wykonać tak skutecznie, jak to się dzieje obecnie - wielu nie dałoby się wykonać w ogóle - dotyczy to szczególnie USA, ale nie tylko. Stąd właśnie bierze się rosnące nasycenie sił zbrojnych i innych instytucji aplikacjami wykorzystującymi zarówno wojskowe, jak i komercyjne systemy satelitarne. Najbardziej powszechnymi i mającymi największe znaczenie aplikacjami są urządzenia łączności satelitarnej, odbiorniki systemów pozycjonujących i terminale odbierające wizualne transmisje satelitów obserwacyjnych. Znajdują się one na wszystkich szczeblach struktury organizacyjnej sił zbrojnych oraz innych instytucji zajmujących się bezpieczeństwem zewnętrznym, co wynika z ich niewielkich rozmiarów i łatwości obsługi.

\subsection{Militaryzacja kosmosu}

Niniejszy podrozdział ma za zadanie przybliżyć jedno z podstawowych pojęć, które szeroko stosuje się $w$ ramach interesującej nas problematyki związanej $\mathrm{z}$ realizacją zadań $\mathrm{z}$ zakresu bezpieczeństwa zewnętrznego państwa w przestrzeni kosmicznej. Należy mu się przyjrzeć z kilku powodów. Po pierwsze dlatego, że pojawia się ono bardzo często i w literaturze przedmiotu, i w dyskursie politycznym oraz w przestrzeni medialnej. Po drugie, problematyka wojskowego zastosowania przestrzeni kosmicznej jest kluczowym elementem obszaru badawczego niniejszej pracy, dlatego należy doprecyzować pojęcia $\mathrm{z}$ tym związane oraz odnieść się do istotnych praktycznych kwestii, determinujących kształt i znaczenie milita- 
ryzacji kosmosu. Po trzecie, będzie to okazja do przeglądu tych wątków niniejszego rozdziału, które dotyczą wojskowych zastosowań przestrzeni kosmicznej; nie będzie to jednak proste powtórzenie już przedstawionych treści, lecz ich podsumowanie i rozszerzenie o warstwę definicyjną i terminologiczną. Po czwarte zaś, rozważania o pojęciu „militaryzacja kosmosu" dadzą nam okazję, by sięgnąć nieco w przyszłość i ocenić pokrótce, jak może przebiegać i jakie konsekwencje może mieć dalszy rozwój wojskowych zastosowań systemów kosmicznych.

„Militaryzacja kosmosu” oznacza w najprostszym i najczęściej spotykanym ujęciu po prostu „wojskowe zastosowanie przestrzeni kosmicznej". W takim kształcie jest to jednak pojęcie zbyt ogólne, niezbyt nadające się do zastosowania w naukowej analizie. Jest bowiem raczej hasłem, a także często używanym w obiegu politycznym i medialnym słowem wytrychem i jako takie nie niesie za sobą treści na tyle jednoznacznie sprecyzowanej, by można było go używać bez szczegółowego określenia, jaka jest jego zawartość.

W każdym jednak wypadku, biorąc pod uwagę znaczenia, jakie się za tym pojęciem kryją, czy to w ogólnym stereotypowym i obiegowym pojęciu, czy też po zastosowaniu bardziej precyzyjnych definicji, militaryzacja kosmosu jest szczególnie istotną kwestią z punktu widzenia spacepower. I to zarówno tak, jak rozumiemy to pojęcie, odnosząc je głównie do perspektywy bezpieczeństwa narodowego w wymiarze zewnętrznym, jak i w ujęciu procesów zachodzących w sferze bezpieczeństwa międzynarodowego, które także będziemy w pewnym zakresie poruszać. Inaczej mówiąc, szeroko pojęty wymiar militarny zastosowań kosmicznych ma szczególne znaczenie $w$ ramach bezpieczeństwa narodowego $w$ wymiarze zewnętrznym, stąd pojęcie do niego się odnoszące musi stać się naszym przedmiotem zainteresowania. Jego omówienie jest zatem, jak wspomniano, dalszym doprecyzowaniem i uszczegółowieniem omówionych powyżej kwestii praktycznych. Warto na marginesie dodać, że jest to także istotny problem $w$ świetle prawa międzynarodowego, uregulowania są szczupłe i nie w pełni precyzyjne, a tymczasem rozwój technologii możliwej do militarnego zastosowania daje coraz większej rzeszy uczestników stosunków międzynarodowych coraz większe możliwości.

Jak wiemy, współczesne zastosowania systemów kosmicznych w sferze militarnej sprowadzają się praktycznie wyłącznie do wspierania procesu przygotowania oraz prowadzenia działań zbrojnych. Obejmują one jed- 
nak nie tylko systemy bezpośrednio podporządkowane siłom zbrojnym, ale i takie, które należą do instytucji wywiadowczych oraz innych agend państwowych. Co więcej, do wsparcia działań wojskowych często z powodzeniem można zastosować rozwiązania i systemy komercyjne. Proste i oczywiste, jakby się zdawało, kojarzenie militaryzacji kosmosu z działalnością państwa nie daje się zatem przeprowadzić. Poszerza się więc zawartość i tak już obszernego pojęcia, co utrudnia jego konceptualizację. Ale to nie koniec trudności, ponieważ należy uwzględnić i to, że pewne systemy bojowe, które nie mieszczą się w definicji systemu kosmicznego, mają duże znaczenie dla bezpieczeństwa w kosmosie lub bezpieczeństwa poprzez kosmos. Nie można zatem mówić o wojskowym znaczeniu przestrzeni kosmicznej czy też wojskowym jej zastosowaniu, uwzględniając tylko systemy satelitarne.

Pojęcie „militaryzacja kosmosu” w najbardziej ogólnym ujęciu jawi się nam bardzo szeroko, aby więc przedstawić jego treść, musimy wyjść poza sferę czysto wojskową, poza domenę podmiotów państwowych, ale także poza przestrzeń okołoziemską, czyli z powrotem na ziemię. By uściślić i doprecyzować interesujący nas termin, należy zatem odwołać się do ujęcia funkcjonalnego, poprzez wskazanie na zadania, jakie wykonują lub wykonywać mogą różnorodne systemy, mające znaczenie z punktu widzenia militarnego zastosowania przestrzeni kosmicznej. Dzięki temu będzie można określić także to, w jaki sposób szeroko pojęta militaryzacja wpływa na zjawiska w dziedzinie szeroko pojętego bezpieczeństwa kosmicznego.

Ażeby o militaryzacji kosmosu mówić bardziej konkretnie, należy uwzględnić cztery jej wymiary, które częściowo zazębiają się i uzupełniają, a których jednak nie należy traktować jako typologii w ścisłym tego słowa znaczeniu. Stworzenie takowej byłoby zresztą bardzo trudne ze względu na złożoność i rozległość powiązań kosmosu ze sferą wojskową ${ }^{127}$. Przedstawiamy zatem pewne aspekty wojskowego zastosowania przestrzeni kosmicznej, które zazębiając się i uzupełniając, stanowią w sumie treść pojęcia „militaryzacja kosmosu”. Omówimy zatem pokrótce pojęcia: „bierna militaryzacja kosmosu”, „czynna militaryzacja kosmosu”, „broń przeciwsatelitarna” oraz „obrona przeciwrakietowa”.

127 G. Sa riak, Between a Rocket and a Hard Place: Military Space Technology and Stability in International Relations, „Astropolitics” 2017, vol. 15, nr 1. 


\section{Militaryzacja bierna - wsparcie sił zbrojnych}

To najpowszechniejsza dziś forma wojskowego zastosowania przestrzeni kosmicznej, polegająca na wykorzystaniu systemów kosmicznych do zabezpieczenia działań wojskowych. A zatem systemy satelitarne nie wykonują zadań polegających na prowadzeniu walki zbrojnej, jedynie ją wspierają, dostarczając określonych usług podmiotom wojskowym. Są to wymienione już działania w zakresie obserwacji, łączności, pozycjonowania i prowadzenia działalności badawczo-rozwojowej związanych $\mathrm{z}$ wojskowością.

Ten wymiar militaryzacji kojarzy się na ogół z systemami satelitarnymi należącymi do wojska, co jest jednocześnie i oczywistością, i znaczącym uproszczeniem. Wiele instytucji cywilnych, państwowych i komercyjnych wykorzystujących systemy satelitarne dostarcza usług uzupełniających, często znacząco, funkcjonowania systemów wojskowych.

A zatem, po pierwsze, wojsko częstokroć wykorzystuje dane obserwacyjne dostarczane przez podmioty zewnętrzne, w szczególności dotyczy to zdjęć satelitarnych wykonywanych przez firmy prywatne, ale i danych pogodowych ze służb cywilnych opierających się na wykorzystaniu międzynarodowych konstelacji satelitów obserwacyjnych oraz narodowych systemów cywilnych. Po drugie, w zakresie telekomunikacji wojsko często wykorzystuje systemy cywilne, uzupełniając za ich pomocą własne kanały. I wreszcie po trzecie, w zakresie pozycjonowania, oprócz systemów wojskowych istnieją i powstają nowe systemy cywilne, które mogą być stosowane przez siły zbrojne.

Ten proces militaryzacji systemów cywilnych jest najbardziej widoczny w przypadku sił zbrojnych państw, które mają mniej rozwinięty sektor kosmiczny, lub też nie mają go w ogóle, lecz mimo to chcą wykorzystywać możliwości dawane przez systemy satelitarne. Jest to współcześnie bardzo szeroko stosowana procedura, jako że wyspecjalizowane firmy pochodzące $z$ krajów najbardziej technologicznie rozwiniętych mają często większe możliwości techniczne niż niejedno państwo. W ten sposób komercyjnie pozyskiwane usługi dostarczane przez komercyjne systemy satelitarne wspierają siły zbrojne państw $w$ ramach wykonywania przez nie ich funkcji w ten sam, co do zasady, sposób, jak czynią to dedykowane systemy wojskowe.

Nie dotyczy to jednak tylko państw biedniejszych, także te kraje, które posiadają rozwinięte wojskowe systemy kosmiczne, nie stronią od współ- 
pracy z publicznymi czy komercyjnymi systemami. Nawet niekwestionowany lider w zakresie systemów militarnych, Stany Zjednoczone, także wykorzystuje konstelacje cywilne, na przykład do rozszerzenia możliwości wojskowej telekomunikacji w zakresie transmisji mniej wrażliwych informacji. Można nawet zauważyć istotne symptomy rozszerzania tej praktyki na kolejne funkcje, takie jak obserwacja w różnych zakresach spektrum elektromagnetycznego. Dzięki temu siły zbrojne mogą, dzięki współpracy z cywilnymi operatorami, relatywnie niskim kosztem zapewnić wsparcie swoich działań przy jednoczesnym zwiększeniu redundancji całości wykorzystywanych systemów. To ostatnie jest szczególnie ważne wobec wzrostu poziomu zagrożeń dla obiektów znajdujących się w przestrzeni okołoziemskiej.

Jak zatem widać, militaryzacja bierna, czyli wsparcie funkcjonowania sił zbrojnych, nie jest wyłącznie domeną wojska i ewentualnie wyspecjalizowanych państwowych instytucji wywiadowczych, lecz także należy tu uwzględniać zadania licznych systemów komercyjnych oraz służb publicznych, również organizacji międzynarodowych. To bardzo ważna kwestia i swego rodzaju signum temporis. Jeszcze niedawno bowiem, w czasach, kiedy kosmos był domeną państw, i to zaledwie kilku, militaryzacja była obszarem ograniczającym się do ich własnych systemów kosmicznych. Dziś jednak, wobec szybkiego przyrostu liczby podmiotów działających w kosmosie, a co za tym idzie - wobec radykalnego wzrostu dostępności usług zapewnianych przez systemy kosmiczne znaczna liczba podmiotów komercyjnych jest zdolna do dostarczania usług, które z kolei mogą posłużyć do zabezpieczenia działań sił zbrojnych państw. A zatem militaryzacja bierna ma, paradoksalnie, coraz bardziej cywilne oblicze, jako że usługi, które mogą służyć wsparciu funkcjonowania sił zbrojnych, są coraz częściej dostarczane przez cywilnych operatorów.

\section{Czynna militaryzacja kosmosu - broń kosmiczna}

Ta forma militaryzacji (czasem używa się określenia „drugi etap militaryzacji”"128, „drugi stopień” czy też „pogłębiona militaryzacja”) ozna-

128 R. Kopeć, Broń antysatelitarna. U progu drugiego etapu militaryzacji kosmosu, „Politeja" 2018, vol. 53, $\mathrm{nr} 2$. 
cza pojawienie się broni kosmicznej. Broń (uzbrojenie) kosmiczną definiujemy jako obiekty na stałe znajdujące się w przestrzeni kosmicznej, czyli bazujące na orbitach okołoziemskich, służące bezpośrednio do prowadzenia walki zbrojnej. Czasem używa się tu pojęcia „efektory”, wywodzącego się z języka angielskiego, w odróżnieniu od „sensorów”, które bronią nie są, choć często stanowią element uzbrojenia. W tym ujęciu broń kosmiczna to systemy, które mają przynajmniej część efektorów umieszczonych na orbitach okołoziemskich. W literaturze anglojęzycznej istnieje ponadto bardzo użyteczne pojęcie weaponization ${ }^{129}$, niestety nie da się go spolszczyć w taki sposób, aby było wygodne w użyciu, będziemy jednak ten termin sporadycznie stosować.

Taka definicja broni kosmicznej ma wyraźnie techniczny charakter, podkreślając fakt stacjonowania w kosmosie konkretnych systemów przeznaczonych bezpośrednio do prowadzenia walki zbrojnej. Oznacza to, z technicznego punktu widzenia, że broń musi się znajdować na obiektach odpowiadających pojęciu „sztuczny satelita ziemi”. Zatem rakiety balistyczne, mimo że częstokroć poruszają się w trakcie wykonywania zadania bojowego poprzez przestrzeń kosmiczną, nie są, według tego ujęcia, klasyfikowane jako broń kosmiczna. Ich tranzyt jest bowiem krótkotrwały, nie osiągają one ponadto prędkości orbitalnej, choć często apogeum ich trajektorii sięga tysiąca i więcej kilometrów. Definicję taką wspiera także prawo międzynarodowe, które nie uznaje rakiet balistycznych z bronią jądrową na pokładzie za uzbrojenie zakazane w kosmosie właśnie dlatego, że nie osiągają one prędkości orbitalnej, nie są zatem stacjonowane w kosmosie. Z drugiej zaś strony bronią kosmiczną w tym ścisłym znaczeniu nie są także te systemy służące do walki w kosmosie, które nie stacjonują na orbitach, o czym szerzej w następnym punkcie. Dla porządku warto dodać, że niektórzy eksperci proponują szerszą definicję broni kosmicznej, obejmującą także broń do walki w kosmosie bazowania naziemnego ${ }^{130}$.

Jak wspomniano, broń kosmiczna może realizować szereg działań bojowych, które już pokrótce wymieniliśmy. Najbardziej generalną typo-

129 Por. rozdział 5.3.

130 Por. na przyklad Y. Butt, Can Space Weapons Protect U.S. Satellites?, „The Bulletin of Atomic Scientists", 22.07.2008, https://thebulletin.org/2008/07/can-space-weapons -protect-u-s-satellites/. 
logią tych działań jest podział na broń służącą do wywołania efektu na ziemi, czyli na lądzie i pod nim, na morzu i pod wodą oraz w atmosferze rozumianej jako obszar, w którym poruszają się lotem swobodnym obiekty wykorzystujące siłę nośną. Drugi rodzaj uzbrojenia kosmicznego obejmuje urządzenia do walki z innymi obiektami kosmicznymi rozumianymi jako obiekty orbitalne.

Typologia ta nie jest jednak ścisła ze względu na to, że istnieją kategorie celów, które broń kosmiczna może w teorii zwalczać, których nie można jednoznacznie przypisać do przestrzeni powietrznej, a które jednocześnie nie są obiektami orbitalnymi. Są to, po pierwsze, pociski balistyczne poruszające się częściowo w przestrzeni powietrznej, częściowo w kosmosie, które, jak wiemy, nie są obiektami orbitalnymi oraz nie posługują się aerodynamiczną siłą nośną, często poruszając się poza nominalną granicą atmosfery. Po drugie, wchodzą obecnie do służby bojowe szybowce hipersoniczne, które poruszają się na pograniczu obydwu ośrodków; wynoszone są one prze rakiety balistyczne, część swojego lotu pokonują torem bezwładnym w przestrzeni kosmicznej, a część, wykorzystując siłę nośną w najwyższych warstwach atmosfery, którą mogą także opuścić, jakby „odbijając się” od niej i wykonując ponowny bezwładny lot suborbitalny.

Uściślając, można zatem przyjąć następujące kategorie celów, które może zwalczać broń kosmiczna:

- obiekty naziemne/podziemne, nawodne/podwodne,

- obiekty poruszające się $w$ atmosferze lotem aerodynamicznym,

- obiekty poruszające się lotem balistycznym w atmosferze i poza nią,

- obiekty znajdujące się na orbitach okołoziemskich.

Broń, która mogłaby wykonać powyższe zadania, ma współcześnie wciąż charakter teoretyczny, lecz nie hipotetyczny. Każda z wymienionych misji jest w najogólniejszym ujęciu wykonalna przy współczesnym stanie techniki, w szczególności przy zastosowaniu ładunków jądrowych. Niemniej jednak jak dotychczas broń taka nie została wdrożona do użytku, choć plany w tym zakresie tworzono i tworzy się nadal. 
Broń przeciwsatelitarna

Ten rodzaj broni omawiamy osobno, ponieważ niekoniecznie ma ona kształt broni kosmicznej omówionej powyżej. Systemy bojowe tego rodzaju, znane często pod skrótem ASAT, mogą być umieszczane także na platformach naziemnych, morskich oraz powietrznych. Niemniej jednak, ponieważ służą do prowadzenia walki zbrojnej w kosmosie, czyli do niszczenia obiektów satelitarnych, muszą być uwzględnione w rozważaniach o militaryzacji. Ich istnienie wpływa bowiem w fundamentalny sposób na użyteczność systemów satelitarnych, użycie zaś może stanowić poważny problem $w$ ujęciu bezpieczeństwa $w$ kosmosie, ponieważ mogą one przyczynić się do degradacji środowiska kosmicznego. Wpływ broni przeciwsatelitarnej na bezpieczeńst wo kosmiczne jest zatem ogromny, po pierwsze dlatego, że mogą pozbawić przeciwnika kosmicznych środków zabezpieczenia bądź prowadzenia działań zbrojnych, a po drugie dlatego, że degradacja orbit wpływa na bezpieczeństwo wszystkich systemów orbitalnych niezależnie od kraju pochodzenia i przeznaczenia.

W największym skrócie broń przeciwsatelitarną ${ }^{131}$ (antysatelitarną) można podzielić na dwa rodzaje. Pierwszy to broń bazowania naziemnego, a więc nie broń kosmiczna sensu stricto, choć przeznaczona jest ona do prowadzenia walki z systemami satelitarnymi. Ma ona dziś formę pocisków rakietowych, które odpalane są z wyrzutni lądowych, morskich bądź z samolotów. W terminologii anglosaskiej ten typ uzbrojenia nazywa się direct ascent $A S A T$, co można luźno przetłumaczyć jako „broń przeciwsatelitarna bezpośredniego działania". Ponieważ termin ten nie jest wygodny, będziemy o takim uzbrojeniu mówić jako o broni antysatelitarnej „bazowania naziemnego”. Istnieje pewne prawdopodobieństwo, że pociski rakietowe w funkcji naziemnego ASAT zostaną wkrótce uzupełnione o systemy bazujące na broni energetycznej. Już dziś stosuje się lasery do oślepiania, a nawet uszkadzania sensorów satelitów, stąd droga jest otwarta, przynajmniej w teorii, do ich niszczenia, choć niektórzy uczeni zwracają uwagę na immanentne trudności w zastosowaniu takiej broni' ${ }^{132}$.

131 Por. bardziej szczegółowa klasyfikacja: R. Kopeć, Broń antysatelitarna..., s. 51-55.

132 Por. na przykład J. Hecht, $A$ "Star Wars" Sequel? The Allure of Directed Energy for Space Weapons, „Bulletin of the Atomic Scientists” 2019, vol. 74, $\mathrm{nr}$ 10, s. 162-170. 
Druga kategoria to właściwa broń kosmiczna, czyli umieszczone na orbicie satelity przeznaczone do zwalczania innych satelitów. Takie uzbrojenie nosi nazwę co-orbital $A S A T$, czyli, znów spolszczając raczej, niż tłumacząc wprost, „broń przeciwsatelitarna bazowania orbitalnego”. Systemy tego typu mogą razić wrogie satelity za pomocą pocisków różnego rodzaju oraz ewentualnie broni energetycznej, mogą także, zbliżając się do obcego obiektu, dokonać samozniszczenia, jednocześnie niszcząc wrogi obiekt. Różnica pomiędzy obydwoma rodzajami ASAT polega na tym, że broń bazowania orbitalnego może długotrwale przebywać w przestrzeni kosmicznej, nim zostanie użyta, broń bazowania naziemnego startuje w kosmos dopiero w chwili, kiedy zostanie podjęta decyzja o jej użyciu.

Nie wchodząc w tym miejscu w szczegóły, należy wspomnieć, że podstawowe założenia techniczne i odpowiednie technologie dotyczące broni przeciwsatelitarnej obydwóch rodzajów zostały opracowane przez Związek Radziecki i Stany Zjednoczone jeszcze w czasie zimnej wojny. Wprawdzie żaden $\mathrm{z}$ tych krajów nie rozmieścił po dziś dzień operacyjnie dedykowanego systemu przeciwsatelitarnego, jednak USA posiadają rozbudowaną obronę przeciwrakietową, która może zostać użyta w funkcji ASAT. Rosja także posiada pewne zdolności w zakresie obrony przeciwrakietowej oraz opracowuje dedykowane systemy przeciwsatelitarne kilku rodzajów. Prototypami tego typu uzbrojenia dysponują także Chiny (od 2007 roku) oraz Indie (od 2019 roku). Ponadto, ze względu na dostępność komponentów, istnieje prawdopodobieństwo, że wkrótce technologia ASAT pojawi się także $w$ dyspozycji innych państw, a nawet uczestników niepaństwowych ${ }^{133}$.

Na koniec krótkiego omówienia tego ważnego wątku, który będzie wracał jeszcze wielokrotnie, należy wspomnieć, że problem broni przeciwsatelitarnej to fragment szerszej kwestii, jaką jest szeroko pojęte negatywne oddziaływanie na systemy satelitarne, które niekoniecznie ma charakter bojowy, czyli niszczący, a co zostanie omówione szerzej w rozdziale piątym.

133 Por. M. Czajkowski, Non-State Actors and Space Security, „Вісник Львівського університету. Серія “Міжнародні відносини»”, „Visnyk of the Lviv University. Series International Relations" 2018, $\mathrm{nr}$ 44, s. 119-134. 


\section{Obrona przeciwrakietowa}

W kontekście militaryzacji kosmosu obrona przeciwrakietowa ma dwa ważne wymiary. Pierwszy z nich to udział systemów kosmicznych w walce $z$ pociskami balistycznymi i manewrującymi. Odbywa się on poprzez zabezpieczanie działań systemów naziemnych w formie użycia sensorów bazowania kosmicznego, satelitarnej transmisji danych oraz wsparcia pozycjonowania zaangażowanych platform. Ta funkcja nie różni się jednak od wsparcia zwalczania innych celów, a zatem nie byłaby poruszana osobno, gdyby nie dalsze kwestie. Otóż walka z wieloma typami pocisków balistycznych odbywa się w przestrzeni kosmicznej, często na wysokości orbit zatłoczonych systemami orbitalnymi. Oznacza to, że skutki takiej walki, w postaci odłamków lub też pozostałości eksplozji jądrowych, przyczynić się mogą do degradacji niektórych orbit. Stąd, ze względu na efekt wywierany na kosmos i bezpieczeństwo w nim, broń przeciwrakietowa, a przynajmniej niektóre jej rodzaje, powinna być brana pod uwagę przy omawianiu problematyki militaryzacji kosmosu.

Drugi, ważniejszy wymiar, zasygnalizowany już wcześniej, to to, że broń przeciwrakietowa może być łatwo zaadaptowana do zwalczania systemów satelitarnych, co wiąże ją ściśle z bronią przeciwsatelitarną. Jeżeli istniejące systemy przeciwrakietowe znajdujące się na uzbrojeniu USA, Rosji, Izraela, Chin i Indii mogą śledzić i zwalczać poruszające się po torach balistycznych w przestrzeni okołoziemskiej obiekty, to nic, co do zasady, nie stoi na przeszkodzie, by były nimi satelity, a nie pociski balistyczne przeciwnika.

\section{Ocena i perspektywy}

W ramach szeroko pojętej militaryzacji kosmosu współcześnie ma ona formę przede wszystkim bierną jako force multiplier. Ponadto rozwijają się także systemy przeciwsatelitarne oraz obrona przeciwrakietowa. Gdyby w najbardziej ogólny sposób ocenić perspektywy rozwoju tego zjawiska, można stwierdzić, że oba kierunki zapewne będą się rozwijać, a jednocześnie zależność między nimi będzie rosnąć. Militaryzacja bierna może bowiem rozszerzać się i pogłębiać. To znaczy, że sfera wojskowa może coraz powszechniej stosować aplikacje kosmiczne ze względu na rosnącą 
łatwość tworzenia i dostarczania usług w tym zakresie i jednocześnie może się poszerzać krąg podmiotów je wykorzystujących. Z drugiej jednak strony szybki rozwój technik przeciwsatelitarnych i ich proliferacja, nie mówiąc już o ewentualnym użyciu, może postawić pod znakiem zapytania użyteczność systemów satelitarnych w ogóle, a zatem zanegować dalszy rozwój militaryzacji biernej. W skrajnym przypadku, w sytuacji rozległej degradacji orbit $w$ wyniku użycia broni przeciwsatelitarnej, obecna rola przestrzeni kosmicznej może ulec zmniejszeniu bądź nawet marginalizacji. I to nie tylko w wymiarze wojskowym.

Co do broni kosmicznej sensu stricto, sytuacja dziś wygląda w ten sposób, że bardzo wiele na ten temat się mówi, pojawia się, szczególnie w USA, szereg propozycji „uzbrojenia” kosmosu, lecz konkretnych i realistycznych, a w szczególności efektywnych pod względem kosztów pomysłów nie ma. Nic zresztą dziwnego, opracowanie broni dowolnego rodzaju wymaga znacznych nakładów i wieloletnich wysiłków. W przypadku tak złożonego zadania, jakim jest broń kosmiczna, wysiłki te oraz koszty muszą być ogromne, być może nawet niemożliwe do poniesienia przez jakikolwiek kraj czy grupę krajów. Powtórzmy zatem, że broń kosmiczna, a zatem militaryzacja kosmosu w ujęciu czynnym jest wciąż kwestią przyszłości. Dodajmy do tego wspomniany już fakt, że broń kosmiczna ma co do zasady bardzo wiele zalet, ale jednocześnie tak wiele wad, że jej użyteczność jest wątpliwa, szczególnie w kontekście ekonomicznym.

Rozwijają się natomiast dość burzliwie systemy przeciwsatelitarne bazowania naziemnego, co więcej, uważa się często, że jest to zjawisko niepowstrzymane. Przestrzeń okołoziemska może zatem stać się polem walki, systemy satelitarne mogą zostać zniszczone, lecz, podkreślmy raz jeszcze, współczesne i perspektywiczne systemy ASAT nie są elementem militaryzacji czynnej kosmosu, należy to traktować jako osobną kategorię w ramach szeroko pojętej militaryzacji przestrzeni kosmicznej.

Najwcześniej do etapu militaryzacji czynnej kosmosu doprowadzić może stworzenie satelitów niszczycieli, testowanych już przez ZSRR w czasie zimnej wojny. Współcześnie zapewne będą miały formę stosunkowo niewielkich obiektów o zminiaturyzowanych systemach kontrolnych i sporym ładunku paliwa niezbędnego do manewrów. Wysłane na orbitę pozostawałyby uśpione, być może na pokładzie większego nosiciela, $w$ razie potrzeby byłyby aktywowane $w$ celu zmiany orbit dla zbliżenia się do obcych satelitów i ich niszczenia. Ale i taka broń nastręcza nie- 
wątpliwie niemało trudności technicznych oraz finansowych. Choćby dlatego, że z powodu prawideł mechaniki orbitalnej musiałoby ich być bardzo dużo, aby zapewnić systemowi sensowny czas reakcji i elastyczność użycia. Przeciwnik ponadto zapewne łatwo domyśliłby się ich przeznaczenia, stałyby się one zatem pierwszorzędnym celem już w pierwszej minucie ewentualnego konfliktu.

Oceniając realistycznie ogólną perspektywę militaryzacji kosmosu, oczywiście w ramach dającej się przewidzieć przyszłości, należy zatem mówić przede wszystkim o ewentualnym rozwoju systemów ASAT bazowania naziemnego. Dynamika tego procesu decydować będzie o użyteczności systemów kosmicznych o przeznaczeniu wojskowym, rzutując na militaryzację w szerokim ujęciu. Obecnie najbardziej chyba rozpowszechnione są poglądy o nieuchronności militaryzacji rozumianej jako rozwój ASAT bazowania naziemnego. Jest to rozległa argumentacja, mocno osadzona w realistycznej perspektywie badawczej, którą bliżej omówimy w rozdziale piątym. Główną jej osią jest proste stwierdzenie, że skoro rozpowszechniają się możliwości techniczne dające perspektywę stworzenia zagrożenia dla przeciwnika w ważnym dla niego aspekcie, to prędzej czy później przyjmą one realną postać. Inaczej mówiąc, skoro można skonstruować jakąś broń, to kiedyś ktoś ją skonstruuje, a następnie rozmieści. W tym kontekście warto przytoczyć często cytowane, także przez nas, zdanie Thomasa Schellinga, że „[...] poza powszechną operacją mózgu nic nie wymaże pamięci o broni i o tym, jak ją budować [...]"134.

Ta konstatacja jest jak najbardziej słuszna, szczególnie że krajów posiadających przetestowaną broń przeciwsatelitarną jest już cztery, wiele kolejnych może wejść w posiadanie podobnego uzbrojenia w najbliższym czasie. Stałe rozszerzanie katalogu posiadaczy ASAT, potencjalnie także niepaństwowych, bardzo sprzyja rozwojowi tego typu uzbrojenia, ponieważ radykalnie komplikuje rozwiązanie dylematów bezpieczeństwa stojących przed uczestnikami stosunków międzynarodowych, skłaniając ich do łatwiejszych, bo samodzielnych rozwiązań w duchu unilateralnym, czyli opracowywania i rozmieszczania broni dla zwiększenia własnego potencjału odstraszania. Można tu zauważyć dwie podstawowe

13+ Th. C. Schelling, The Role of Deterrence in Total Disarmament, „Foreign Affairs”, April 1962, http://www.foreignaffairs.com/articles/23393/thomas-c-schelling/the-role-ofdeterrence-in-total-disarmament?page=show. 
potencjalne sytuacje mające odmienne konsekwencje, w tym odmienny potencjał destabilizacji. Po pierwsze, uzbrojenie przeciwsatelitarne mogą posiadać państwa, które same polegają na systemach kosmicznych $\mathrm{w}$ ramach realizacji swoich strategii bezpieczeństwa - w takiej sytuacji możliwość wzajemnego zniszczenia infrastruktury orbitalnej może działać stabilizująco. Taką zresztą sytuację mamy współcześnie. Po drugie, może pojawić się uczestnik stosunków międzynarodowych, który sam nie posiadałby systemów kosmicznych mających dla niego istotne znaczenie $z$ militarnego punktu widzenia. Taki aktor nie obawiałby się symetrycznego odwetu, mógłby on zatem łatwo brać jako zakładników systemy satelitarne różnych państw, także mocarstw, traktując to zarówno jako element wsparcia własnej polityki poprzez zastosowanie przymusu, jak i jako asymetryczne odstraszanie ${ }^{135}$ silniejszych przeciwników. Taka sytuacja byłaby skrajnie destabilizująca, a jednocześnie uzyskanie takich zdolności jest potencjalnie bardzo atrakcyjne dla wielu uczestników stosunków międzynarodowych, może zatem dopingować ich do starań w celu pozyskania systemów ASAT.

Dodatkowym czynnikiem sprzyjającym rozwojowi i proliferacji broni przeciwsatelitarnej jest fakt, że istnieje przekonanie, iż Stany Zjednoczone, jako globalny militarny hegemon, uzależnione są od systemów satelitarnych, bez nich przewaga USA zmaleje bądź zniknie. Bez względu na to, czy teza taka jest w pełni słuszna, pozostaje dla globalnych i lokalnych przeciwników USA swego rodzaju zachętą do starań na rzecz pozyskiwania środków przeciwsatelitarnych, czy to w postaci broni, czy też innych metod negatywnego oddziaływania na systemy kosmiczne. W tym właśnie kontekście wskazuje się przede wszystkim na Rosję i Chiny, sugerując, że dążą one do stworzenia takich systemów uzbrojenia przeciwsatelitarnego, które mogłyby zagrozić amerykańskiej przewadze w kosmosie ${ }^{136}$, a co za tym idzie - ograniczyć zdolności militarne USA na ziemi.

A zatem wydaje się niejako nieuchronne, według logiki wyścigu zbrojeń, że z powodu niestabilności współczesnego systemu międzyna-

135 G. Sariak, op. cit., s. 60.

136 Por. relatywnie uproszczona, choć przekonująca argumentacja w: M. D u ra, Nadchodzi wojna w kosmosie? Chiny i Rosja zagrożeniem dla amerykańskich satelitów, Defencez4, 5.02.2018, http://www.defence24.pl/nadchodzi-wojna-w-kosmosie-chiny-i-rosja-za grozeniem-dla-amerykanskich-satelitow. 
rodowego i także $z$ innych przyczyn militaryzacja kosmosu będzie postępować, przybierając formę rozwoju naziemnych systemów przeciwsatelitarnych. Istnieje jednak alternatywna wersja rozwoju sytuacji w tej dziedzinie, której logika bazuje również na trzeźwo pojętych interesach mocarstw. Wskazać tu należy prawdopodobieństwo, że potencjalny lawinowy rozwój ASAT może pchnąć główne mocarstwa kosmiczne do prawnego uregulowania statusu broni przeciwsatelitarnej czy to drogą pogłębienia regulacji w zakresie prawa kosmicznego, czy też poprzez niezależne porozumienia. Takie uregulowania mogłyby dotyczyć nałożenia ograniczeń ilościowych, jakościowych, a także dotyczących badań rozwojowych, przeciwdziałania proliferacji, a nawet ostatecznie delegalizacji systemów przeciwsatelitarnych. Jakkolwiek w obecnej i dającej się przewidzieć sytuacji międzynarodowej taki obrót spraw wydaje się nieprawdopodobny, to jednak istnieje, w gruncie rzeczy niemałe, prawdopodobieństwo, że główne mocarstwa kosmiczne uświadomią sobie, iż w tej sprawie ich interesy są zbieżne pomimo ostrej konkurencji czy wręcz wrogości.

Ta zbieżność interesów wynika z prostego faktu, że wszystkie kraje, które można uznać za mocarstwa kosmiczne, w rosnącym stopniu uzależnione są od wykorzystania systemów kosmicznych, i to nie tylko w interesującej nas kwestii bezpieczeństwa narodowego w wymiarze zewnętrznym. Warto podkreślić, że korzyści, o których mowa, są tego rodzaju, że dotyczą nie tylko przebiegu ewentualnej wojny. W czasie pokoju, a szczególnie wobec kryzysu czy konfliktu niebędącego wojną na pełną skalę, niezakłócone wykorzystywanie systemów satelitarnych jest nie do przecenienia, zarówno w kontekście misji bojowych, jak i niebojowych. A zatem pewność codziennego korzystania z dobrodziejstw militaryzacji biernej może być uznana przez mocarstwa za większą wartość niż posiadanie zdolności do ewentualnego zniszczenia satelitów przeciwnika w sytuacji ostrego kryzysu w stosunkach wzajemnych czy też na wypadek wojny. Takie sytuacje bowiem mogą, ale nie muszą nastąpić, a tymczasem codzienna telekomunikacja, pozycjonowanie i obserwacja są bezcenne, a korzyści mają tu charakter ciągły, nie zaś jednorazowy.

$\mathrm{Z}$ tego właśnie powodu, dodając kwestie ekonomiczne, w czasie zimnej wojny broń przeciwsatelitarna, mimo że opracowana, nie została rozmieszczona w ilościach, które miałyby militarne znaczenie. Obie strony wolały pozostać przy realnych i bieżących korzyściach i nie ryzykować spirali zbrojeń dotyczącej nowego, bardzo kosztownego uzbrojenia, które 
mogłoby nigdy nie zostać wykorzystane, a jednocześnie samo jego istnienie wpływałoby skrajnie destabilizująco na stosunki wzajemne. Dziś jest podobnie. Mocarstwa, realizując swoje interesy, wykorzystują siły zbrojne do ich wsparcia nie tylko w sensie obrony czy odstraszania, ale także przez aktywne działanie bojowe i niebojowe wspierające bieżącą politykę zagraniczną. Dotyczy to najbardziej oczywiście USA z ich zdolnością do globalnej projekcji siły, lecz nie tylko.

W szczególności Chiny podążają podobną co Ameryka ścieżką, rozwijając systemy satelitarne w ramach powiększania zdolności bojowych nie tylko w ujęciu obrony i odstraszania. Dlatego też z pragmatycznego punktu widzenia Pekin jest nie mniej zainteresowany bezpieczeństwem systemów kosmicznych, a więc w praktyce ograniczeniem broni przeciwsatelitarnej, niż Waszyngton. Jak się często zauważa,

[k]rytycznie ważną cechą chińskiej strategii $A 2 / A D$ jest zdolność do atakowania sił przeciwnika w dużej odległości, to zaś najlepiej można zrealizować, polegając na najwyżej położonym miejscu, jakim jest kosmos. Daje on idealną pozycję do identyfikowania sił przeciwnika i namierzania ich, do komunikowania się i naprowadzania systemów bojowych oraz do określania rozmiaru zniszczeń po ataku'37.

A zatem, choć systemy ASAT są dla Chin jednym z ważnych czynników przeciwdziałania militarnej przewadze USA, to jednak zagrożenie dla chińskich systemów wynikające $z$ ewentualnego rozwijania przez Stany Zjednoczone analogicznej broni może skłaniać Pekin do umiaru w tym zakresie. Warto też dodać, że uważa się czasem, iż chińskie zdolności w zakresie broni przeciwsatelitarnej nie są aż tak duże w stosunku do rozległego, rozproszonego i wielofunkcyjnego amerykańskiego wojskowego systemu satelitarnego, a więc zyski z ewentualnego użycia takiej broni byłyby raczej niewielkie ${ }^{138}$.

Z kolei Rosja jako państwo słabnące, choć wciąż aspirujące do mocarstwowego statusu, mogłaby także być zainteresowana porozumieniem tego typu. Po pierwsze, potwierdzałoby ono jej pozycję jako mocarstwa

137 J. P. Finch, Bringing Space Crisis Stability Down to Earth, „Join Forces Quarterly" 2015, nr 76, s. 17.

138 J. Sa nka ra n, Limits of the Chinese Antisatellite Threat to the United States, „Strategic Studies Quarterly" 2014, vol. 8, nr 4, s. 20-47. 
militarnego, po drugie, dawałoby tak pożądany argument $\mathrm{w}$ szerszych stosunkach z USA, a po trzecie, zmniejszałoby koszty mocarstwowej polityki wojskowej. Inne, mniej rozwinięte mocarstwa mogłyby także odetchnąć z ulgą, niejako zwolnione z konieczności włączenia się do kosztownego wyścigu zbrojeń w nowej dziedzinie.

Przestrzeń okołoziemska ma także coraz większe znaczenie komercyjne $\mathrm{i}$ jest to drugi czynnik, który mógłby ewentualnie być brany pod uwagę przez mocarstwa jako motywacja dla ograniczenia rozwoju bądź nawet likwidacji broni przeciwsatelitarnej. Cywilny sektor kosmiczny ma coraz większe znaczenie $w$ gospodarce wielu państw, zarówno bezpośrednio, jako zyski z działalności przedsiębiorstw, jak i pośrednio, ze względu na gospodarcze znaczenie usług dostarczanych przez systemy satelitarne. Tymczasem ewentualne użycie bojowe systemów ASAT przeciwko systemom wojskowym, choćby tylko ograniczone do jednego bądź kilku celów w ramach międzynarodowego kryzysu, a nie wojny na pełną skalę, doprowadzić musi do zanieczyszczenia określonych orbit znaczną ilością odłamków. To z kolei może doprowadzić do przypadkowego zniszczenia satelitów cywilnych. Każdy taki przypadek prowadzić może do kolejnych, ponieważ produkuje kolejne tysiące mniejszych i większych odłamków. W ten sposób nawet tylko kilka ataków przeciwsatelitarnych może doprowadzić do kaskadowego wzrostu ilości kosmicznych śmieci na zasadzie analogicznej do reakcji łańcuchowej, co w skrajnym przypadku może całkowicie zablokować niektóre orbity. Doprowadziłoby to, co oczywiste, do wielkich strat gospodarczych, szczególnie dotyczących tych państw, w których sektor kosmiczny jest rozwinięty i których gospodarki w znacznej mierze polegają na usługach dostarczanych przez systemy satelitarne. Do takich państw zaliczają się nie tylko USA, ale także Chiny, które bardzo konsekwentnie rozwijają wszystkie sektory kosmicznej działalności ${ }^{139}$.

139 Szczegółowo na temat chińskich osiągnięć w dziedzinie opanowania kosmosu por. na przykład K. Pollpeter [et al.], China Dream, Space Dream: Chinas's Progress in Space Technologies and Implications for the United States. A Report Prepared for the U.S.-China Economic and Security Review Commission, University of California's Institute on Global Conflict and Cooperation, 2.03.2015, https://www.uscc.gov/Research/ china-dream-space-dream-chinas-progress-space-technologies-and-implicationsunited-states. 
Degradacja orbit, która może nastąpić w wyniku użycia broni przeciwsatelitarnej, jest czynnikiem powodującym, że broń ta z wysokim prawdopodobieństwem może stać się obosieczną, co jest kolejnym istotnym argumentem za jej ograniczeniem. Trudno bowiem przewidzieć skutki uboczne ewentualnego ataku przeciwsatelitarnego, może on zatem doprowadzić w konsekwencji do poniesienia znacznych strat także przez atakującego. I to nie w wyniku kontrakcji zaatakowanego, ale właśnie z powodu degradacji orbit skutkującej zniszczeniem własnych systemów i ograniczeniem dalszego ich wykorzystania.

Wobec tego świadomość rozlicznych zagrożeń związanych z ewentualnym użyciem systemów przeciwsatelitarnych może skłonić główne mocarstwa kosmiczne do podjęcia starań na rzecz stworzenia regulacji w tym zakresie. Paradoksalnie, wzrastający potencjał broni zdolnej do niszczenia systemów orbitalnych może wpłynąć na jej ograniczenie. Istnieje jednak szereg przeszkód, które mogą zniweczyć taki scenariusz, przy okazji są to kolejne, bardziej szczegółowe argumenty na rzecz poglądu o nieuchronności militaryzacji kosmosu w formie upowszechnienia systemów ASAT.

Po pierwsze, wielkie mocarstwa kosmiczne mogą nie dostrzegać faktu, że $\mathrm{w}$ kosmosie mają $\mathrm{z}$ bardzo wielu różnych względów wspólne interesy, przedkładając ponad nie inne wartości. W szczególności dotyczy to USA, które mogą uznać wizję utrzymania bądź powiększenia swojej przewagi w kosmosie za ważniejszą niż współpraca międzynarodowa - i to bez względu na realność tejże wizji.

Po drugie, ze względu na znaczną liczbę zainteresowanych podmiotów, może być bardzo trudno wypracować odpowiednie regulacje, ponieważ współcześnie znacznie trudniej jest o osiągnięcie równowagi niż w przypadku systemu dwubiegunowego. Partykularne interesy i często nieracjonalna percepcja stosunków wzajemnych wielu uczestników mogą więc „rozerwać” ewentualne porozumienie lub rozwodnić je do poziomu niefunkcjonalności.

Po trzecie, bardzo istotnym praktycznym problemem będzie także realistyczna weryfikacja, bez której jakiekolwiek porozumienie rozbrojeniowe nie ma sensu. Rzecz jest szczególnie złożona, ponieważ dotyczy między innymi szeroko rozpowszechnionych technologii rakiet balistycznych. Znajdują się one $w$ arsenałach wielu państw, które $z$ nich raczej nie zrezygnują, a zatem system weryfikacji tego, czy arsenały bali- 
styczne mają zdolności przeciwsatelitarne, byłby bardzo skomplikowany i wymagałby szczegółowych rozwiązań.

I wreszcie po czwarte, istnieje bodaj jeszcze trudniejsza przeszkoda praktyczna, czyli kwestia obrony przeciwrakietowej. W tym przypadku nie ma wątpliwości, wiele współczesnych systemów przeciwrakietowych ma immanentne zdolności przeciwsatelitarne, bez względu na deklaracje dysponentów. Musiałyby one zatem zostać uwzględnione w ewentualnym porozumieniu, co byłoby niewątpliwie niezmiernie trudne. Niełatwo bowiem od dysponentów obrony przeciwrakietowej oczekiwać, że porzucą rozwinięte uzbrojenie defensywne bez jednoczesnego zagwarantowania im bezpieczeństwa przed rakietami balistycznymi przeciwników.

Podsumowując, po rozważeniu powyższych kwestii można założyć, że jakkolwiek główne państwa będą zapewne zdawały sobie sprawę $\mathrm{z}$ korzyści ograniczenia broni przeciwsatelitarnej, nie zdołają one jednak w dającej się przewidzieć przyszłości wypracować sformalizowanego porozumienia $w$ tej materii. Jednocześnie wydaje się jednak, że rysująca się równowaga wzajemnego zniszczenia systemów satelitarnych wraz z możliwością degradacji orbit będzie skutkować praktycznym ograniczeniem rozwoju dedykowanych systemów przeciwsatelitarnych, być może także na zasadzie porozumień nieformalnych. Inaczej mówiąc, i Chiny, i Rosja rozmieszczą zapewne niezauważenie ograniczoną liczbę systemów ASAT, by utrzymać zagrożenie dla amerykańskich systemów satelitarnych, lecz prawdopodobnie nie zdecydują się na kosztowny wyścig zbrojeń na pełną skalę, który notabene nie dałby nadziei na poważniejsze korzyści praktyczne. Taka sytuacja będzie jednak niestabilna i nie zapobiegnie proliferacji środków przeciwsatelitarnych, dlatego też przewidywanie $w$ dłuższej perspektywie jest bardzo trudne. 



\section{3. \\ Geneza i ewolucja polityki bezpieczeństwa USA w przestrzeni kosmicznej}

W niniejszym rozdziale stosunkowo rozlegle zajmiemy się przede wszystkim pierwszą dekadą ery kosmicznej, próbując wyjaśnić genezę i logikę rozwoju eksploracji kosmosu w owym czasie, przede wszystkim od strony wpływających na ten proces zjawisk politycznych. W szczególności interesowało nas będzie zastosowanie systemów orbitalnych do celów związanych $\mathrm{z}$ bezpieczeństwem narodowym, co jest oczywistą perspektywą nie tylko zresztą w świetle założonej tematyki całej naszej pracy. Od samego początku bowiem, mimo roztaczanych pozorów, myślano o eksploracji kosmosu przede wszystkim w kategoriach wojskowych, nic więc dziwnego, że ta perspektywa pojawia się na pierwszym planie w każdej analizie problematyki kosmicznej. Przedstawiając główne etapy rozwoju techniki kosmicznej w jej wczesnych stadiach, postaramy się zatem uwypuklić zarówno jej znaczenie praktyczne, jak i polityczne uwarunkowania związane $\mathrm{z}$ rozwojem zastosowań kosmicznych, wskazując przede wszystkim na przyczyny oraz implikacje tego procesu w sferze bezpieczeństwa narodowego i międzynarodowego.

Szerokie potraktowanie tej tematyki wynika $\mathrm{z}$ naszego przekonania, że jest ona bardzo istotna $z$ dwóch zasadniczych powodów. Po pierwsze dlatego, że ma dać niejako „obowiązkową" perspektywę historyczną omawianego zjawiska współczesnego, pomagającą zrozumieć jego ewolucję, a zatem i współczesny stan. Jest to zatem ważny element tła niezbędnego do omówienia interesujących nas najbardziej zjawisk. Po drugie, i może nawet ważniejsze, w pierwszych dekadach ery kosmicznej pojawiły się 
i utrwaliły mechanizmy, zarówno te związane z praktycznym wykorzystaniem kosmosu, jak i z politycznym wymiarem tegoż w sferze bezpieczeństwa i nie tylko. Większość z tych mechanizmów, obejmujących sposoby i szczegółowe cele wykorzystania przestrzeni kosmicznej dla potrzeb bezpieczeństwa, oraz wzajemne relacje między państwami $w$ tej materii pozostają aktualne po dziś dzień.

Oczywiście warto tu dodać, wyprzedzając nieco narrację, że współcześnie coraz szybciej kumulują się procesy, których przebieg prawdopodobnie zmieni w najbliższych dekadach obraz wykorzystania kosmosu. Zatem i mechanizmy, które zamierzamy ukazać, także prawdopodobnie ulegną transformacji. W szczególności przyspieszy zachodząca zresztą od wielu dekad zmiana proporcji pomiędzy militarnym wykorzystaniem kosmosu a innymi obszarami zastosowań systemów satelitarnych, co znacząco wpłynie na ewolucję charakteru bezpieczeństwa kosmicznego. Ale tym bardziej warto dokładnie rozważyć perspektywę historyczną, by zapewnić sobie swego rodzaju punkt obserwacyjny dla rejestrowania zachodzących obecnie zmian.

Istnieje bardzo obszerna bibliografia dotycząca historii militarnych zastosowań techniki kosmicznej, najciekawsze $\mathrm{z}$ nich i najbardziej reprezentatywne wymienia Stephen B. Johnson ${ }^{140}$. W analizie ewolucji związanych z tym zjawisk warto, za amerykańskim historykiem, zauważyć, że z jednej strony mamy do czynienia $z$ ogromną liczbą dostępnych materiałów, jako że instytucje wojskowe są szczególnie inklinowane do dokumentowania swojej działalności, z drugiej jednak - borykamy się z głęboką tajnością, co znacząco utrudnia pracę historyka ${ }^{141}$. Z naszego jednak punktu widzenia to ostatnie nie jest szczególnym problemem, ponieważ koncentrujemy się na najbardziej ogólnych kwestiach dotyczących rozwoju podstawowych technologii warunkujących zastosowania wojskowe oraz na ich roli w polityce bezpieczeństwa państwa. Nie jest zatem potrzebna mnogość szczegółów, co więcej, ich nadmiar zaciemniałby obraz całości, w ramach której tematyka historyczna jest tylko, przypomnijmy, elementem tła.

Nie będziemy zatem dokładnie omawiać rozwoju jakościowego i ilościowego poszczególnych rodzajów systemów orbitalnych, skoncentruje- 
my się przede wszystkim na tym, jak tworzyła się doktryna ich użycia. Była ona $z$ jednej strony warunkowana przez dającą się zastosować technikę, czyli przez misje, jakie mogły pełnić systemy orbitalne, a z drugiej przez sytuację międzynarodową oraz ogólną strategię USA. Zasadniczo chodzi nam zatem o pokazanie procesu kształtowania się zastosowań kosmicznych w dziedzinie wojskowej, który warunkowałby możliwości techniczne oraz ewoluujące potrzeby strategii bezpieczeństwa.

Dlatego też najbardziej istotny jest dla nas okres lat pięćdziesiątych i wczesnych sześćdziesiątych, kiedy to koncepcje, wizje i doktryny wojskowego wykorzystania kosmosu w Stanach Zjednoczonych dopiero się wyłaniały w związku z narastającą rywalizacją z ZSRR. W tym czasie zapoczątkowany został także tak zwany wyścig kosmiczny, który stał się jedną z definiujących cech stosunków radziecko-amerykańskich, a więc kształtował politykę i strategię USA. To bardzo szczególne zjawisko ogromnie wpłynęło na zastosowania militarne przestrzeni kosmicznej, ale także na rozwój cywilnych programów. Wymaga zatem omówienia, nawet jeśli nie w pełni odpowiada naszej tematyce jako proces wychodzący poza zastosowania militarne.

Wprawdzie zasadniczym tematem niniejszej pracy są zastosowania systemów satelitarnych, niemniej jednak w tym rozdziale będziemy musieli zająć się także do pewnego stopnia ewolucją balistycznych pocisków rakietowych. A to dlatego, że istotnym elementem zarówno wyścigu kosmicznego, jak i rozwoju zastosowań militarnych systemów kosmicznych był rozwój rakiet nośnych, a te z kolei mają w sensie technicznym ogromnie wiele wspólnego z rakietami balistycznymi, szczególnie międzykontynentalnymi. W niejakim uproszczeniu można zauważyć, że rozwój dużych rakiet $\mathrm{i}$ ich silników w kontekście ich użycia jako systemów nośnych oraz pocisków balistycznych od samego początku postępował równolegle. Widać to od najbardziej pierwotnych faz rozwoju techniki rakietowej - niemieckie pociski balistyczne A-4/V-2 powstały na bazie projektów, które zrodziły się z marzeń o podróżach kosmicznych Wernhera von Brauna $\mathrm{i}$ jego kolegów.

Ponieważ praca niniejsza traktuje o amerykańskiej polityce bezpieczeństwa, skupimy się w tym rozdziale na rozwoju amerykańskiej techniki rakietowej i kosmicznej oraz na jej znaczeniu dla amerykańskiej strategii. Wszystko to działo się jednak w ramach rywalizacji z ZSRR i wobec postrzeganego w Stanach Zjednoczonych zagrożenia ze strony tego kraju 
musimy także zająć się po części tym, co robili Rosjanie, traktując to jako tło i punkt odniesienia dla omawiania amerykańskich prac badawczo-rozwojowych i ewolucji polityki kosmicznej USA.

\subsection{Poznawanie kosmosu i pierwsze perspektywy jego wykorzystania}

Choć kosmos jest dostępny każdemu człowiekowi do bezpośredniej obserwacji, wręcz narzuca się swoją obecnością w każdą pogodną noc, to jednak myśl o opanowaniu tej domeny jest względnie nowa. A to dlatego, że stosunkowo niedawno przestała być ona nieokreśloną przestrzenią zapełnioną bóstwami, a zatem dostępną tylko w sposób magiczny. Poznanie faktycznej natury przestrzeni kosmicznej datuje się na ostatnie kilka wieków, poczynając od przewrotu kopernikańskiego. Mikołaj Kopernik, Tycho de Brahe, a potem Johannes Kepler i Galileusz opisali kształt Układu Słonecznego i prawa rządzące ruchem ciał niebieskich, zmieniając na trwałe to, jak ludzkość postrzega swoje miejsce we wszechświecie. Ostatni z wymienionych uczonych zasłużył się dodatkowo upowszechnieniem teleskopu jako narzędzia wzmacniającego ludzką percepcję. Dalsze, przełomowe prace Isaaca Newtona nad naturą grawitacji doprowadziły do udoskonalenia w XIX wieku narzędzi matematycznych, zwiększano także systematycznie skuteczność narzędzi obserwacyjnych. Warto w tym kontekście pamiętać, że po raz pierwszy odległość do innej niż Słońce gwiazdy zmierzona została dopiero $\mathrm{w} 1838$ roku, a naturę galaktyk zrozumiano dopiero w latach dwudziestych XX wieku dzięki pracom Edwina Hubble'a.

Myśl o wyjściu człowieka w przestrzeń kosmiczną jest zatem względnie nowa, ponieważ dopiero niedawno okazało się to realne wraz z rozwojem nauki i zrozumieniem podstaw budowy przestrzeni otaczającej naszą planetę. Wiek XIX, w którym skumulowało się wiele przełomowych odkryć naukowych, przyniósł także ważne literackie wizje podróży kosmicznych oraz kontaktów z innymi cywilizacjami, by wspomnieć choćby prace Jules'a Verne'a i Herberta G. Wellsa. Nie jest to błaha kwestia, ponieważ księżycowa wyprawa opisana przez Verne’a inspirowała i Konstantina Ciołkowskiego ${ }^{142}$, i Roberta Goddarda, i Hermanna

142 Ciołkowski był także autorem opowiadań i powieści fantastycznonaukowych, jego najważniejsza książka (Poza Ziemiq̨) została opublikowana w 1920, a w Polsce w 1979 roku. 
Obertha ${ }^{143}$, by wspomnieć najważniejszych pionierów techniki rakietowej końca XIX i początku XX wieku (Goddard ponadto był szczególnie oddanym miłośnikiem Wellsa' ${ }^{144}$ ). Dlatego też dopiero druga połowa XIX wieku to czas szybko rozwijającego się zainteresowania przestrzenią kosmiczną, podsycanego też rozbudzającymi wyobraźnię odkryciami rzekomych sztucznych kanałów na Marsie. Nieco później te same inspiracje dotarły i do Wernhera von Brauna ${ }^{145}$, którego rola w rozwoju techniki rakietowej jest nie do przecenienia.

Zainteresowanie to wraz z narastającą wiedzą astronomiczną zaowocowało w pierwszej kolejności wizją podróży kosmicznych Konstantina Ciołkowskiego. Opracował on wiele teoretycznych zagadnień dotyczących mechaniki ruchu orbitalnego sztucznych obiektów oraz ich napędu; jego prace były jednymi z fundamentów późniejszego burzliwego rozwoju techniki rakietowej i astronautyki. Ciołkowski inspirował między innymi niemieckich uczonych z von Braunem i Oberthem na czele, którzy od lat dwudziestych XX wieku pracowali nad rakietami kosmicznymi. W 1927 roku powstało nawet Towarzystwo Podróży Kosmicznych ${ }^{146}$, skupiające głównie pasjonatów bez większego przygotowania, ale także pierwszorzędnych uczonych. To w Niemczech następował najszybszy przyrost wiedzy teoretycznej i praktycznej dotyczącej budowy statków kosmicznych i ich napędów. To niemiecka armia już w 1932 roku rozpoczęła finansowanie prac młodych uczonych, którzy bardzo szybko skorzystali z hojnej oferty wojska, „[...] porzucając cywilną technikę rakietową, by budować broń w zamian za regularną pensję [...], a pierwszym z nich był Wernher von Braun"147. W ramach przygotowań wojennych w 1937 roku powstał ośrodek w Peenemünde, z biegiem czasu coraz hojniej finansowany. I w Europie, i w USA, i w ZSRR rozwijała się także bardzo burzliwie literatura science fiction, przyczyniając się do wzrostu zainteresowania kosmosem w ogóle i podróżami kosmicznymi w szczególności.

II wojna światowa znacząco przyspieszyła prace związane $z$ opanowaniem przestrzeni kosmicznej, ponieważ niemieccy uczeni w coraz

143 W. E. Burrows, op. cit., loc. 868-869.

144 Ibidem, loc. 1195-1198.

145 D. Piszkiewicz, The Nazi Rocketeers. Dreams of Space and Crimes of War, Mechanicsburg 2007, s. 21.

146 Verein für Raumschiffahrt (VfR).

147 W. E. Burrows, op. cit., loc. 1975. 
większym stopniu wprzęgani byli do wysiłku wojennego, budując broń wykorzystującą koncepcje stworzone na rzecz lotów kosmicznych ${ }^{148}$. $\mathrm{Z}$ narastającego $\mathrm{w}$ miarę wojennych niepowodzeń zapotrzebowania na superbroń, która mogłaby odwrócić nieuchronną porażkę III Rzeszy, powstał pierwszy balistyczny pocisk rakietowy dalekiego zasięgu o przeznaczeniu strategicznym $A-4 / V_{-2}{ }^{14}$, używany bojowo od 8 września 1944 roku. Wprawdzie jego faktyczne możliwości w relacji do kosztów były niewielkie ${ }^{150}$, to jednak $\mathrm{z}$ punktu widzenia procesu opanowywania przez człowieka przestrzeni kosmicznej pocisk ten ma ogromne znaczenie. W praktycznych kategoriach dlatego, że od tej właśnie rakiety, zarówno $w$ sensie technicznym, jak i w związku $z$ koncepcją jej zastosowania, wywodzą się późniejsze balistyczne pociski rakietowe dalekiego zasięgu. $\mathrm{Z}$ kolei ich ewolucja, jak wiemy, korespondowała $\mathrm{z}$ rozwojem techniki wynoszenia sztucznych obiektów na orbitę okołoziemską. A-4/V-2 jest zatem protoplastą nie tylko broni rakietowej dalekiego zasięgu, ale i współczesnych rakiet nośnych. Warto też przypomnieć, że niemiecka broń była wynikiem prac zainspirowanych w pierwszej kolejności przez wizję podróży kosmicznych, której Wernher von Braun i jego zespół nigdy nie porzucili. A-4/V-2 była także, co niebagatelne, pierwszym obiektem sztucznym, który w jednym $z$ testów osiągnął i przekroczył powszechnie dziś uznawaną granicę kosmosu. Warto dodać, że zespół von Brauna pracował także nad koncepcjami międzykontynentalnych pocisków balistycznych i szybujących A-9/A-10 151, także w wersji załogowej, oraz zbliżonej do nich rakiety nośnej zdolnej do umieszczania na orbicie znacznych ładunków ${ }^{152}$. Nie można zatem przecenić wkładu zespołu $z$ Peenemünde w rozwój techniki rakietowej, a zatem i wszystkich późniejszych zastosowań orbitalnych.

O niemieckich osiągnięciach wspomina się często także w kontekście późniejszego rozwoju techniki rakietowej w Stanach Zjednoczonych i w ZSRR, ze względu na przejęcie przez oba mocarstwa w ostatnich dniach wojny zarówno technologii rakietowych, jak i uczonych niemiec-

148 W. J. Boy ne, The Influence of Air Power upon History, Gretna 2003, s. 254.

149 Aggregat-4/Vergeltungswaffe-2 - urządzenie nr 4 / broń odwetowa nr 2.

150 W. E. Burrows, op. cit., loc. 2607-2609.

151 Ag/A1o, Encyclopedia Astronautica, 2016, http://www.astronautix.com/a/aga1o.html. $152 A 9 / A 10 / A 11 / A 12$, Encyclopedia Astronautica, 2016, http://www.astronautix.com/a/ agaloanals.html. 
kich nimi się zajmujących. Jednak powszechnie powtarzana teza, że bez niemieckiego wysiłku naukowego nie byłoby rozwoju amerykańskiej i radzieckiej techniki rakietowej, nie jest w pełni słuszna. W obu krajach prowadzono przecież prace nad rakietami i ich napędami oraz rozważania teoretyczne. W USA Robert Goddard pracował nad napędami rakietowymi już od lat trzydziestych, a od 1936 roku podobne eksperymenty prowadzono w Kalifornijskim Instytucie Technologicznym pod kierunkiem Theodore’a von Kármána. Od 1939 roku działalność tego ostatniego wspierało wojsko, a w listopadzie 1943 roku na bazie jego zespołu w Caltech powstało Jet Propulsion Laboratory, jako wojskowy projekt realizowany we współpracy z uczelnią cywilną. Pierwszym ważnym dokumentem opracowanym przez JPL dla USAAF jeszcze w 1943 roku było Memorandum o możliwościach pocisków rakietowych dalekiego zasięgu, mówiące o wielkim potencjale, jaki posiadała ta broń. Raport ten wywołał znaczne zainteresowanie Armii, które wzmogło się od chwili rozpoczęcia użytkowania bojowego V-2 przez Niemców, popchnął także Amerykanów do sięgnięcia po niemieckie osiągnięcia, kiedy tylko ich wojska weszły do Niemiec'53. Także w ZSRR, prócz teoretycznych rozważań otoczonego powszechnym szacunkiem Ciołkowskiego, już od lat trzydziestych prowadzono szeroko zakrojone i obficie finansowane konkretne prace nad napędem rakietowym ${ }^{154}$. A zatem, mimo że wyścig do niemieckiej wiedzy został zasadniczo wygrany przez Amerykanów'155, Rosjanie i tak mieli bardzo dobre pozycje wyjściowe do rozwoju technologii rakietowych po II wojnie światowej. Podsumowując ten wątek, można powiedzieć, że „[n]iemieckie dziedzictwo z pewnością pozwoliło Związkowi Radzieckiemu szybko przebyć ten teren praktycznego doświadczenia, którego pozbawiła ich wojna, a jednocześnie popchnęło Amerykanów na pole wykorzystania technologii rakietowych wcześniej, niżby tam weszli w innym wypadku [...]"156. Niemieckie dokonania nie były jednak jedynym czynnikiem sprawczym rozwoju technologii rakietowych w obu rywalizujących po wojnie supermocarstwach, co najwyżej mogły go jedynie przyspieszyć.

Przy ocenie znaczenia niemieckiego wysiłku istotny jest także fakt, że użycie $A-4 / V-2$ w funkcji broni strategicznej zwróciło w sposób

153 W. E. Burrows, op. cit., loc. 2732-2757.

$15+$ W. A. McDougall, op. cit., s. 36-40.

155 Ibidem, s. 44-46.

156 Ibidem, s. 41. 
spektakularny uwagę na rakietę balistyczną dalekiego zasięgu, która w teorii mogła także posłużyć do wyniesienia sztucznych obiektów na orbitę okołoziemską. To z kolei zwróciło uwagę wojskowych, planistów i inżynierów na przestrzeń kosmiczną jako nowe pole walki, nowy obszar, z którego można kontrolować sytuację na Ziemi, a który nagle zdawał się być na wyciągnięcie ręki. Już zatem w drugiej połowie lat czterdziestych w USA wyobrażano sobie orbitujące bronie kosmiczne, zdolne do obracania w gruzy całych miast bez żadnej możliwości przeciwstawienia się im, a także inne zastosowania militarne kosmosu'57. Zapewne najciekawszą z wczesnych prac na ten temat jest raport sporządzony przez producenta lotniczego Douglas Aircraft pod tytułem: „Wstępny projekt eksperymentalnego statku okołoziemskiego"158. Jego zasadniczą konkluzją było to, że „[...] współczesna technologia doszła już do punktu, w którym projekt pojazdu satelitarnego wydaje się wykonalny"159. Publikacja ta przewidywała zatem szereg konkretnych zastosowań systemów orbitalnych, między innymi w łączności, zwiadzie optycznym i w funkcjach bojowych.

W tym samym mniej więcej czasie, czyli tuż po II wojnie światowej, kwestie wpływu ewentualnej eksploracji przestrzeni kosmicznej na bezpieczeństwo narodowe pojawiły się także w obiegu publicznym. Szereg prominentnych osób w USA wskazywało na zagrożenie, jakie wiązałoby się z ewentualnym opanowaniem kosmosu przez przeciwnika, wzywając jednocześnie do podjęcia wysiłku na rzecz budowy własnych zdolności w tym zakresie. Spektakularnym przejawem tego typu publikacji był artykuł w magazynie „Life”, którego pomysłodawcą był dowodzący siłami powietrznymi armii generał Henry „Hap” Arnold, a w którym opisywano hipotetyczną dewastację Stanów Zjednoczonych dokonaną za pomocą balistycznych pocisków rakietowych. Artykuł, szeroko cytując słowa samego generała, szczegółowo opisuje wojnę nuklearną, w której w ciągu 36 godzin ginie 40 milionów Amerykanów, zamieszczając przy tym szereg bardzo sugestywnych ilustracji ${ }^{160}$. W świadomości społecznej w USA

157 R. D. Launius, National Security: Space and the Course of Recent U.S. History, The $49^{\text {th }}$ Harmon Memorial Lecture, United States Air Force Academy, 2006, http://www. usafa.edu/df/dfh/docs/Harmon49.pdf.

158 Preliminary Design of an Experimental World-Circling Spaceship, Report no. SM-11827,

Douglas Aircraft Company, Inc., 2.05.1946.

159 Ibidem, s. II.

160 The 36-Hour War: Arnold Report Hints at the Catastrophe of the Next Great Conflict, "Life", 19.11.1945, s. 27-35. 
wcześnie kształtowało się zatem przekonanie o konieczności podjęcia wysiłków na rzecz opanowania kosmosu, choćby po to, aby przewagi strategicznej dzięki jego wykorzystaniu nie uzyskał ZSRR, coraz wyraźniej sytuowany na pozycji śmiertelnego wroga Ameryki. Świadomość ta wzmacniana była także dzięki oddziaływaniu wciąż bardzo popularnej w Ameryce literatury fantastycznonaukowej, o nieuchronnej militaryzacji kosmosu pisał między innymi Robert A. Heinlein, jeden z najbardziej poczytnych pisarzy lat czterdziestych i wczesnych pięćdziesiątych.

W drugiej połowie lat czterdziestych konflikt z ZSRR, zidentyfikowany i skonceptualizowany już w 1946 roku przez George’a Kennana, faktycznie narastał, USA musiały zatem zacząć brać poważnie pod uwagę wykorzystanie przestrzeni kosmicznej do celów bezpieczeństwa. Cechy charakterystyczne systemów satelitarnych czyniły je przede wszystkim potencjalnie bardzo skutecznymi narzędziami zdobywania bardzo potrzebnych informacji na temat radzieckiego potencjału strategicznego, a w szczególności rodzącej się w ZSRR technologii strategicznych rakiet balistycznych ${ }^{161}$. Nie tylko zatem rozpoczęto prace, które zostaną omówione poniżej, ale także, już w późnych latach czterdziestych, zarysowała się w USA silna rywalizacja pomiędzy poszczególnymi rodzajami sił zbrojnych, które na własną rękę prowadziły programy związane z militarnymi zastosowaniami przestrzeni kosmicznej, ale i z bronią jądrową, i rakietami balistycznymi ${ }^{162}$ :

Broń jądrowa i środowisko kosmiczne były zupełną nowością, co oznaczało, że żaden $\mathrm{z}$ rodzajów sił zbrojnych nie miał wyraźnego, niepodważalnego roszczenia do technologii nuklearnych czy też do kosmosu. Armia uważała, że pociski balistyczne to w pewnym sensie rozszerzenie możliwości artylerii. USAF $\mathrm{z}$ kolei postrzegały poruszanie się $\mathrm{w}$ przestrzeni kosmicznej jako naturalne przedłużenie latania. Natomiast Marynarka Wojenna wierzyła, że przestrzeń kosmiczna ma unikalne właściwości, kluczowe dla jej misji na powierzchni oceanu i pod nią, nie chciała zatem, aby to Armia czy Lotnictwo zmonopolizowały kosmos ${ }^{163}$.

W latach czterdziestych mamy więc do czynienia w USA ze stosunkowo szybkim przyrostem potencjału rozwojowego $w$ dziedzinie techniki 
kosmicznej, co wynikało zarówno z dotychczasowych osiągnięć uczonych amerykańskich, jak i z potencjału drzemiącego $w$ technologii i ludziach przejętych w Niemczech. Na powyższe nakładały się wynikająca z narastającego konfliktu z ZSRR potrzeba tworzenia nowych możliwości militarnych oraz chęć zapobieżenia osiągnięciu przez ZSRR przewagi w kosmosie, co postrzegano jako bardzo groźną perspektywę.

Jednak mimo tego dość szybkiego startu amerykańskie postępy na drodze do technologii rakietowych zostały u schyłku lat czterdziestych znacznie spowolnione. Stało się tak z kilku zasadniczych powodów. Po pierwsze, polityka dyscyplinowania wprowadzanego ponownie na tory pokojowe budżetu wymagała cięć wydatków wojskowych i to właśnie administracja prezydenta Harry'ego S. Trumana uczyniła, ograniczając znacznie wydatki na zbrojenia. Po drugie, uznano, że przewaga powietrzna w bombowcach strategicznych wyposażonych w broń jądrową oraz dysponujących dogodnymi bazami nieopodal terytorium ZSRR wystarczy jako najbardziej ekonomiczna forma odstraszania, co wpływało na decyzje o alokacji kurczących się funduszy. Po trzecie wreszcie, wielu czołowych uczonych amerykańskich nie podzielało w owym czasie optymizmu co do szybkich postępów w dziedzinie praktycznego zastosowania przestrzeni kosmicznej. $Z$ tych właśnie powodów, zanim jeszcze zdano sobie na dobre sprawę $\mathrm{z}$ radzieckich postępów $\mathrm{w}$ technologiach rakietowych, wydawanie istotnej części ograniczonych coraz bardziej środków na nowe, niepewne technologie wydawało się niepraktyczne ${ }^{164}$. Tymczasem z drugiej strony zapadającej coraz szybciej „żelaznej kurtyny" ZSRR, upośledzony w stosunku do USA w sensie geostrategicznym, w sposób planowy i systematyczny alokował znaczne zasoby na rzecz rozwoju i tak już zaawansowanej techniki rakietowej, dążąc do skompensowania amerykańskiej przewagi w bombowcach ${ }^{165}$. Inaczej mówiąc, Stany Zjednoczone nie potrzebowały rakiet międzykontynentalnych tak bardzo jak Związek Radziecki, mniej więc spieszyły się z ich rozwojem. To $\mathrm{z}$ kolei przekładało się na oddalanie się perspektywy powstania rakiet nośnych niezbędnych do eksploracji kosmosu. W latach czterdziestych postęp $w$ tej dziedzinie był zatem niewielki pomimo nagromadzonej

164 M. Mowthorpe, The Militarization and Weaponization of Space, New York-Toronto-

Oxford 2014, s. 13.

165 E. C. Dolma n, Astropolitik..., s. 77-78. 
w USA wiedzy oraz możliwości technicznych, wspieranych przez ogromną bazę przemysłową. Jak zauważa amerykański historyk:

Historia amerykańskich projektów satelitarnych jest niemal identyczna jak rakiet międzykontynentalnych: krótki wybuch entuzjazmu po wojnie poprzedzający cięcia budżetowe i likwidacje programów, a po kilku latach nagłe odrodzenie $w$ reakcji na radzieckie postępy ${ }^{166}$.

\subsection{Kształtowanie się polityki USA wobec militaryzacji kosmosu}

Podejście do rozwijania systemów kosmicznych zmieniło się, kiedy wojna koreańska, wraz z wcześniejszym kryzysem berlińskim, ostatecznie ukazała oblicze nowego przeciwnika. Zmusiło to USA do istotnych przewartościowań dotyczących polityki obronnej, mimo że administracja prezydenta Dwighta D. Eisenhowera, podobnie jak poprzednia, starała się o dyscyplinę budżetową. Sytuacja dojrzała jednak do określenia nowej, długofalowej strategii obronnej w związku narastającym poczuciem zagrożenia za strony ZSRR. Jednym $\mathrm{z}$ istotnych elementów tego zagrożenia było złamanie amerykańskiego monopolu nuklearnego przez Moskwę i rozwój rakiet balistycznych jako środków przenoszenia strategicznej broni jądrowej. Niemałe znaczenie dla intensyfikacji działań na rzecz eksploracji kosmosu miały też: gwałtowny rozwój literatury science fiction, kosmiczny futuryzm z jego wspaniałymi wizjami przyszłości, rozwój organizacji społecznych i naukowych w postaci towarzystw międzyplanetarnych i tym podobnych i wreszcie szerząca się UFO-mania ${ }^{167}$.

Zwiększono zatem finansowanie projektów rozwoju rakiet balistycznych jako ewentualnych nosicieli broni jądrowej. W styczniu 1951 roku' ${ }^{168}$ Siły Powietrzne przyznały firmie Convair, która już w latach 1945-1947 prowadziła prace nad pociskiem dalekiego zasięgu ${ }^{169}$, kontrakt na rozwój ICBM, znanego później jako Atlas. Notabene nie tylko stał się on pierwszym amerykańskim pociskiem tej klasy, ale jego warianty używane były także jako rakieta nośna do 2004 roku $^{170}$. Równolegle, także od połowy

166 W. A. McDougall, op. cit., s. 100.

167 W. E. Burrows, op. cit., loc. 3366-3541.

168 Atlas A, Encyclopedia Astronautica, 2016, http://www.astronautix.com/a/atlasa.html. 169 Hiroc, Encyclopedia Astronautica, 2016, http://www.astronautix.com/h/hiroc.html. 170 Dziś używana rakieta nośna Atlas V to zupełnie nowy projekt pod starą nazwą. 
lat czterdziestych, Armia pracowała przy pomocy zespołu von Brauna nad pociskiem krótszego zasięgu Redstone, bezpośrednio bazującym na V-1. U.S. Navy natomiast realizowała w ramach Naval Research Laboratory projekt rakiety meteorologicznej Viking, która wystartowała po raz pierwszy 3 maja 1949 roku, a którą planowano przystosować do wynoszenia niewielkich satelitów.

Istotnym krokiem w rozwoju amerykańskiej techniki satelitarnej był tak zwany Raport Killiana ${ }^{171} \mathrm{z}$ lutego 1955 roku. Dotyczył on rozległej tematyki bezpieczeństwa strategicznego i stał się między innymi niezwykle istotnym impulsem rozwojowym $\mathrm{w}$ dziedzinie zastosowań kosmicznych. Raport powstał na życzenie prezydenta Eisenhowera w związku z obawami dotyczącymi ewentualnego zaskakującego ataku nuklearnego ze strony ZSRR. Miał za zadanie ocenić to zagrożenie, perspektywę jego ewolucji i przedstawić propozycje ewentualnych środków zaradczych.

Raport Killiana stwierdzał przede wszystkim, że USA są wrażliwe na atak, a systemy obronne i wczesnego ostrzegania są stanowczo zbyt słabo rozwinięte, niezbędny jest także rozwój środków ofensywnych do utrzymania realistycznego odstraszania. Raport wprawdzie niewiele mówił wprost o wykorzystaniu przestrzeni kosmicznej, podkreślał jednak znaczenie szeregu dziedzin, w których należało dokonać radykalnych postępów, a w których systemy orbitalne mogły, co wiadomo było z wcześniejszych rozważań technicznych, mieć kapitalne znaczenie dla skuteczności wykonywania określonych misji. I tak raport podkreślał w wielu miejscach znaczenie globalnej, szybkiej i niezakłóconej, komunikacji strategicznej, wskazując między innymi na potrzebę zbadania potencjału systemów satelitarnych w tym zakresie ${ }^{172}$. Jednak jeszcze ważniejszym, również szeroko omawianym problemem była informacja strategiczna dotycząca zamiarów i potencjału przeciwnika oraz jego ewentualnych działań. Raport z całą mocą podkreśla, że

[...] musimy ${ }^{173}$ znaleźć sposoby, by zwiększyć liczbę twardych faktów, na których opieramy nasze oceny wywiadowcze, tak aby zapewnić lepsze ostrzeganie strategiczne, zminimalizować zaskoczenie co do sposobu

171 Report by the Technological Capabilities Panel of the Science Advisory Committee, 14.02.1955, [w:] Foreign Relations of the United States, 1955-1957, National Security Policy, vol. 19, s. 41-55, https://history.state.gov/historicaldocuments/frus1955-57v19/dg. 172 Ibidem, s. 55.

173 Wyróżnienie w oryginale. 
ataku i ograniczyć groźbę znacznego wyolbrzymienia albo zminimalizowania zagrożenia. W tym celu rekomendujemy podjęcie energicznych programów obejmujących szerokie zastosowanie najbardziej zaawansowanej wiedzy i technologii w ramach procedur wywiadowczych ${ }^{174}$.

Wynika z tego, że w miarę pojawiania się pierwszych, ograniczonych informacji o rozwoju radzieckiego programu rakietowego coraz bardziej pilny był problem szczegółowej wiedzy na jego temat. Eisenhower był bardzo zaniepokojony tą sytuacją, ponieważ brak informacji mógł prowadzić, jak to podkreślał Raport Killiana, i do przecenienia, i do niedocenienia sił strategicznych ZSRR. Administracja, wciąż walcząc o zrównoważony budżet, chciała wydawać jak najmniej, lecz jednocześnie nie zamierzała dać się zaskoczyć radzieckiej przewadze. Wymagało to jednak posiadania odpowiednich środków rozpoznawczych, zdolnych przekazywać konkretne informacje na temat potencjału militarnego ZSRR. Pewnym rozwiązaniem był wysokościowy samolot rozpoznania strategicznego Lockheed U-2, w pośpiechu opracowany i rzucony do misji wywiadowczych już w 1956 roku. Ale z natury rzeczy musiało to być rozwiązanie tymczasowe, szczególnie wobec przewidywanego wzrostu możliwości radzieckiej obrony przeciwlotniczej. Tymczasem orbitujący posterunek obserwacyjny $w$ postaci wyposażonego $w$ odpowiednie przyrządy rozpoznawcze sztucznego satelity Ziemi, jak to sugerowano jeszcze w najwcześniejszych opracowaniach, był natychmiast narzucającym się pomysłem, prace koncepcyjne były już zresztą zaawansowane w wielu ośrodkach.

Podejście administracji amerykańskiej do techniki rakietowej i jej zastosowań w połowie lat pięćdziesiątych można najogólniej opisać następująco:

Rozważania Eisenhowera podążały w dwóch kierunkach: dorównać radzieckim możliwościom i zapewnić wiarygodne odstraszanie, ale jednocześnie nie dopuścić, by środki przeznaczane na potrzeby wojska wyrwały się spod kontroli. A zatem w ramach pewnych pułapów budżetowych Eisenhower zaakceptował paletę programów rakietowych wystarczających, aby zabezpieczyć kraj przed przyszłym radzieckim „potrząsaniem rakietami"175. Nie miało jednak [dla niego] znaczenia, czy Stany Zjedno-

$17+$ Report by the Technological Capabilities Panel..., s. 54.

175 W oryginale „rocket-rattling”, jako analogia do określenia „saber-rattling”, tłumaczonego na język polski jako „potrząsanie szabelką”. 
czone będą pierwsze w tym lub owym, ale aby były zdolne do rozmieszczenia równej lub większej liczby pocisków rakietowych mających wyższy poziom celności, przeżywalności i niezawodności. Jednocześnie Eisenhower miał nadzieję, że przełom na polu dyplomatycznym ograniczy wyścig zbrojeń i ochroni amerykańskie społeczeństwo przed wpływem rozrastającej się technokracji ${ }^{176}$.

A zatem podstawową przesłanką polityki rozsądnej wystarczalności środków odstraszających, na której tak zależało Eisenhowerowi, było posiadanie wiarygodnych informacji na temat radzieckiego programu rakietowego. Chodziło o zabezpieczenie się przed sytuacją, kiedy szczupłość sił odstraszających zachęci przeciwnika do wykorzystania przewagi, ale jednocześnie o niedopuszczenie do nadmiernego ich rozrostu, co mogłoby skłonić drugą stronę do desperackich prób wyrwania się z poczucia zagrożenia. To ostatnie mogło oznaczać różnorodne nieprzewidywalne sytuacje w postaci na przykład ataku wyprzedzającego lub innego gwałtownego wydarzenia. Na marginesie warto zauważyć, że z początkiem lat sześćdziesiątych doszło właśnie do takiej sytuacji. Umieszczając rakiety średniego zasięgu na Kubie, Chruszczow podjął desperacką próbę osiągnięcia elementarnej równowagi przez stworzenie wiarygodnego czynnika odstraszającego właśnie dlatego, że USA posiadały w tym czasie miażdżącą przewagę strategiczną nad ZSRR ${ }^{177}$. Przewaga ta zaś wynikała $z$ przeszacowania $w$ połowie lat pięćdziesiątych radzieckich możliwości, w związku z przekonaniem panującym w USA o rzekomej przewadze Moskwy w bombowcach (bomber gap) i pociskach balistycznych (missile gap).

Zwiadowcze systemy satelitarne mogły ponadto nie tylko dostarczać informacji służących do określania właściwego stanu równowagi strategicznej i szczegółowych informacji na temat celów na wypadek wojny. Mogły także stać się ważnym, by nie rzec kluczowym, środkiem weryfikacji i kontroli w przypadku zawarcia porozumień rozbrojeniowych. W ten sposób na wielu różnych płaszczyznach systemy orbitalne postrzegano coraz wyraźniej jako krytycznie ważne dla bezpieczeństwa narodowego USA, w szczególności w kontekście równowagi strategicznej.

176 W. A. McDougall, op. cit., s. 133.

177 R. S. Norris, H. M. Kristensen, The Cuban Missile Crisis: A Nuclear Order of Battle, October and November 1962, „The Bulletin of Atomic Scientists” 2012, vol. 68, nr 8, s. 85-91. 
Ale to wszystko wymagało rozwiązania problemu przelotu satelitów ponad suwerennym terytorium państw. Spór dotyczący tego, jak z punktu widzenia suwerenności traktować przestrzeń kosmiczną ${ }^{17^{8}}$, nie miał tylko charakteru prawniczego, lecz ogromną wymowę praktyczną i polityczną. Bez jego rozwiązania jakiekolwiek użycie systemów satelitarnych mogło oznaczać natychmiastowy i szybko eskalujący konflikt dotyczący najbardziej żywotnych z punktu widzenia bezpieczeństwa kwestii. Dlatego też amerykańska polityka w zakresie zastosowania przestrzeni kosmicznej była w dużej mierze nakierowana na rozwiązanie tego problemu w duchu koncepcji swobody przelotu obiektów orbitalnych.

Warto w tym miejscu podkreślić ten właśnie znamienny fakt: w przeddzień ery kosmicznej głównym problemem do rozwiązania, jaki dostrzegano w USA, były nie kwestie techniczne, lecz prawne oraz ich polityczne implikacje. Planując uzupełnić swoje informacje wywiadowcze przy użyciu systemów satelitarnych, Stany Zjednoczone zamierzały wypromować i utrwalić zasadę otwartego kosmosu analogiczną do otwartego morza. Ale amerykańscy decydenci mieli świadomość, że będzie się ona zderzać z zasadą suwerenności przestrzeni powietrznej, która nie obejmuje swobody przelotu. Inaczej mówiąc, pojawił się problem, jak umieścić na orbicie satelitę rozpoznawczego, tak aby nie wywołać międzynarodowego sporu.

Najbardziej obiecującym pomysłem, który przedstawiła już w 1950 roku RAND Corporation, było wysłanie na orbitę cywilnego satelity naukowego, który dawałby największe szanse na ustanowienie odpowiednich precedensów ${ }^{179}$. Rozwijając tę koncepcję, grupa amerykańskich uczonych zasugerowała Międzynarodowej Radzie Stowarzyszeń Naukowych ogłoszenie kolejnego międzynarodowego roku badań polarnych w 25 lat po poprzednim. Dałoby to możliwość wysłania na orbitę polarną satelity badawczego, który w swej naturze nie byłby kontrowersyjny, mógłby także uniknąć przelotu nad ZSRR, dając w ten sposób szansę na ustalenie praktyki wolnego dostępu do orbity okołoziemskiej dla satelitów naukowych. Mogłoby to być pierwszym krokiem do ustanowienia zasady swobody poruszania się po orbitach okołoziemskich, która, jak wspomniano, miała stać się podstawą amerykańskiej polityki w tym zakresie. 
Międzynarodowa Rada przyjęła propozycję, rozszerzyła jednak pierwotną koncepcję na całą Ziemię, ogłaszając Międzynarodowy Rok Geofizyczny, który miał trwać od czerwca 1957 do grudnia 1958 roku. USA i ZSRR wkrótce ogłosiły, że w jego ramach wyślą satelity badawcze, które dostarczą informacji naukowych dotyczących naszej planety. Priorytetem było zatem nadanie pierwszym obiektom orbitalnym niemilitarnego kształtu, by ułatwić ukształtowanie odpowiednich precedensów. IGY był zatem idealną okazją, by w ramach międzynarodowej współpracy i cywilnego wysiłku zrealizować kwestie kluczowo ważne dla bezpieczeństwa narodowego USA.

$\mathrm{Z}$ drugiej jednak strony $w$ chwili ogłoszenia przez oba rywalizujące mocarstwa zamiaru umieszczenia pierwszych obiektów na orbicie okołoziemskiej rozwój techniki satelitarnej stał się czymś więcej niż tylko kwestią bezpieczeństwa narodowego - wykrystalizował się wyraźnie nowy i jakże istotny wątek polityczny. Kosmos stał się już nie tylko polem potencjalnej konkurencji w sensie praktycznego jego wykorzystania militarnego czy naukowego, ale także areną ogromnie ważnej, politycznej walki o międzynarodowy prestiż. Eksploracja kosmosu, odkrywanie nowych granic ludzkości, przesuwanie barier poznania etc. dawały nadzieję na wywarcie wpływu na światową publiczność i zademonstrowanie swojej wyższości w ramach już utrwalonej konkurencji mocarstw. Szczególnie ZSRR nie miał tu nic do stracenia, a wiele do zyskania - wysyłając pierwszy sztuczny obiekt na orbitę wokółziemską, udowadniałby niezbicie swoją wyższość technologiczną, a co za tym idzie - wyższość własnego systemu społeczno-politycznego. Zarysował się zatem pierwszy etap tak zwanego wyścigu kosmicznego, w którym obok kwestii praktycznych liczył się także bardzo mocno prestiż. Wyprzedzając nieco narrację, zauważyć można, że podczas gdy Rosjanie od samego początku bardzo mocno stawiali na propagandowy skutek zwycięstw na kolejnych etapach wyścigu, Amerykanie myśleli o tym jako o czymś pożądanym, lecz nie najważniejszym, praktyczne cele stawiając wyżej.

Deklarując w połowie 1955 roku udział w Międzynarodowym Roku Geofizycznym, Stany Zjednoczone stanęły jednak przed problemem wyboru systemu nośnego, który wbrew pozorom nie miał bynajmniej czysto technicznego charakteru. Podjęte w tej materii decyzje w ogromnej mierze wpłynęły na przebieg pierwszych etapów wyścigu kosmicznego, kształtując jego charakter przede wszystkim z politycznego punktu widzenia, co dalej rzutowało i na kwestie praktyczne. 
Pierwszy, wstępny amerykański projekt, pod nazwą Orbiter powstał na mocy porozumienia między Armią i Marynarką. W jego skład wchodziły pocisk balistyczny Redstone, należący do Armii, a dostosowany do funkcji rakiety nośnej poprzez dodanie dwóch dodatkowych stopni, i satelita przygotowywany w NRL. Wkrótce jednak marynarka zaproponowała nowe, całkowicie własne rozwiązanie łączące wspomnianą już rakietę meteorologiczną Viking, odpowiednio dostosowaną do roli systemu nośnego, i satelitę NRL. W ten sposób w szranki stawały dwa systemy: stosunkowo słaby i wymagający znacznego rozwinięcia, ale niewątpliwie cywilny Viking albo już dojrzały pocisk balistyczny Redstone, który można było wyposażyć albo w satelitę NRL, jak przewidywał projekt Orbiter, albo w nowy pojazd opracowywany w JPL. Ten ostatni ośrodek już od 1954 roku współpracował $\mathrm{z}$ von Braunem $\mathrm{i}$ jego zespołem $\mathrm{z}$ arsenału w Huntsville.

Ostatecznie 29 czerwca 1955 roku prezydent Eisenhower ogłosił, że w ramach Międzynarodowego Roku Geofizycznego pierwszy amerykański sztuczny satelita Ziemi zostanie wyniesiony za pomocą systemu należącego do Marynarki, który nazwano projektem Vanguard. Do dziś decyzja ta sprawia na pierwszy rzut oka dziwne wrażenie, ponieważ w niej właśnie upatrywać należy głównego źródła późniejszego radzieckiego sukcesu na pierwszym etapie wyścigu kosmicznego. A to dlatego, że niedopracowany jako rakieta nośna Viking potrzebował dużo czasu, zanim osiągnął techniczną dojrzałość. Tymczasem po drugiej stronie wewnątrzamerykańskiej barykady rakieta nośna Jupiter-C już w pierwszej próbie 20 września 1956 roku wykonała lot suborbitalny na odległość $5300 \mathrm{~km}$, osiągając pułap ponad $1000 \mathrm{~km}$ i maksymalną prędkość $\mathrm{Ma}=18$. Był to ni mniej, ni więcej, tylko sprawdzony Redstone w przedłużonej wersji ze wspomnianymi powyżej dodatkowymi stopniami, których jednak nie uruchomiono $^{180}$. Oznaczało to, że Jupiter-C miał już w tym momencie odpowiednią moc, by umieścić sztucznego satelitę na orbicie okołoziemskiej. Inaczej mówiąc, zespół von Brauna nie tylko wyprzedzał Marynarkę, ale mógł także znacząco wyprzedzić Rosjan.

Kolejnym ewentualnym systemem nośnym była rakieta Thor, opracowywana od grudnia 1956 roku przez Siły Powietrzne. Był to pocisk

180 Jupiter-C, Encyclopedia Astronautica, 2016, http://www.astronautix.com/j/jupiterc. html. 
balistyczny o zasięgu $2400 \mathrm{~km}$, który miał być uzupełnieniem dla ICBM, mógł także szybciej powstać ${ }^{181}$. I ten pocisk także mógł być zdolny do sięgnięcia orbity, gdyby zdecydowano się rozwijać go w tym kierunku już w owym czasie. A zatem gdyby decyzja polityczna była inna, Amerykanie mieliby pierwszego sztucznego satelitę co najmniej kilka miesięcy przez Sputnikiem.

Wybór gorszej rakiety nośnej był jednak przemyślany i miał charakter stricte polityczny, i to w kilku wymiarach. Redstone/Jupiter był balistycznym pociskiem rakietowym projektowanym i rozwijanym przez zespół US Army z Huntsville, którego szefem był Wernher von Braun i w którym pracowało wielu niemieckich naukowców, wywodził się ponadto w sensie technicznym wprost z V-2. Nie chciano zatem, by pierwszy amerykański spektakularny sukces był $\mathrm{z}$ nimi łączony, a ponadto „[...] satelita wystrzelony przez rakietę wojskową zaprojektowaną przez zespół z Peenemünde, bez względu na to, jak mały i jak bardzo naukowy, mógłby sprowokować Rosjan do podważenia legalności jego przelotu"182. Pewne znaczenie przy podejmowaniu tej decyzji była generalna niechęć do Niemców, którzy zaledwie dziesięć lat po wojnie stali się konkurentami amerykańskich naukowców na ich własnym terenie ${ }^{18_{3}}$. Eisenhowerowi zależało zatem bardziej na kwestiach prawnych i politycznych, dających długofalową perspektywę niezakłóconego wykorzystania potencjalnie szczególnie ważnych dla bezpieczeństwa narodowego narzędzi, niż na prestiżu wynikającym z „zaliczenia” pierwszeństwa.

W efekcie w USA wykrystalizowały się w połowie lat pięćdziesiątych dwa kierunki rozwoju techniki związanej z wykorzystaniem przestrzeni kosmicznej. Jeden to możliwie szybki rozwój balistycznych pocisków rakietowych dla USAF i Armii, w formie ICBM (Atlas, potem Titan) i rakiet średniego zasięgu (Jupiter Armii, a potem Thor Sił Powietrznych). Drugi to projekt wprowadzenia na orbitę pierwszego sztucznego satelity Ziemi o charakterze naukowym jako pierwszy krok do satelitów rozpoznawczych. Obydwa kierunki uważano za całkowicie niezbędne i w pełni uzupełniające się.

$\mathrm{Z}$ perspektywy czasu może wydawać się błędem, że Eisenhower nie postawił bardziej na szybkość i nie zdecydował na rzecz Jupitera. Osta-

181 Thor, Encyclopedia Astronautica, 2016, http://www.astronautix.com/t/thor.html. 182 W. A. McDougall, op. cit., s. 123.

183 W. E. Burrows, op. cit., loc. $4082-4087$. 
tecznie „Sputnik był silnym policzkiem dla amerykańskiej dumy i, co więcej, sugerował istnienie technicznej i wojskowej równości pomiędzy ZSRR i Zachodem, która z kolei podważała założenia, na których bazowała obrona Zachodu"184. Tego jednak nikt wówczas nie przewidywał mimo dochodzących informacji o radzieckich postępach nikt nie wierzył, że ZSRR zdoła wyprzedzić Amerykę.

$\mathrm{Z}$ drugiej strony jednak, wychodząc z punktu widzenia uwzględniającego przede wszystkim płaszczyznę realnych i perspektywicznych interesów bezpieczeństwa, wytworzona przez radzieckie „zwycięstwo” sytuacja była na rękę Stanom Zjednoczonym. Wielu zresztą przewidywało to i uważało, że nawet lepiej, jeśli ZSRR będzie pierwszy w kosmosie, szczególnie gdyby próba zapobieżenia temu miała odbić się negatywnie na naukowej wartości pierwszego amerykańskiego lotu ${ }^{185}$. Ostatecznie bowiem, skoro to Moskwa wysłała pierwszego satelitę, nie pytając nikogo o zgodę, trudniej jej będzie zaprzeczać prawu do swobodnego przelotu pojazdów należących do innych państw. A to z kolei, prowadząc w perspektywie do otwarcia możliwości realizowania misji zwiadu strategicznego, odpowiadało najważniejszym amerykańskim interesom bezpieczeństwa. W ostatecznym rozrachunku ZSRR ułatwił zatem Amerykanom sytuację, a „porażka" USA na pierwszym etapie wyścigu kosmicznego, poza wymiarem politycznym i propagandowym, była $w$ istocie rzeczy ogromnym sukcesem, jakkolwiek nie w pełni zamierzonym. A zatem, biorąc pod uwagę realne korzyści, to USA od samego początku znacznie wyprzedzały ZSRR w wykorzystaniu kosmosu, nawet jeśli przegrały pierwszy etap propagandowego wyścigu, sprawiając wrażenie, że pozostają w tyle za ZSRR ${ }^{186}$.

Podsumowując, efektem podjętych decyzji strategicznych i politycznych był bardzo szybki rozwój techniki rakietowej i technologii systemów orbitalnych w Stanach Zjednoczonych w latach pięćdziesiątych. Amerykanie szybciej zatem i w większej liczbie budowali rakiety międzykontynentalne, były one ponadto znacznie lepsze od radzieckich. Amerykańskie systemy nośne także były gotowe wcześniej, USA mogły więc szybko przejść do praktycznego wykorzystania systemów satelitarnych, które wkrótce zaczęto produkować w dużych ilościach i które w ciągu kilku lat

$18+$ W. A. McDougall, op. cit., s. 132.

185 W. E. Burrows, op. cit., loc. 4127-4133.

186 W. A. McDougall, op. cit., s. 184. 
osiągnęły dojrzałość pozwalającą czerpać z nich znaczne korzyści. Inaczej mówiąc, jeśli pominąć efekty propagandowe, USA były od samego początku na czele wyścigu kosmicznego w jego praktycznym wymiarze, i to jeszcze przed startem pierwszego sztucznego satelity Ziemi.

\subsection{Sputnik Moment}

Często powtarza się, że wystrzelenie 4 października 1957 roku przez ZSRR Sputnika i było wielkim zaskoczeniem i szokiem dla USA i reszty Zachodu. Jest to oczywiście prawda, ale nie cała. Opinia publiczna i szerokie kręgi polityczne $z$ pewnością przeżyły ogromny szok. Radziecki sukces wywołał wręcz rodzaj psychozy, w ramach której media i politycy doszukiwali się „zacofania” USA w dziedzinie nauki, technologii i edukacji. Według amerykańskiego historyka „[ż]adne wydarzenie od czasów Pearl Harbor nie wywołało takich reperkusji w życiu społecznym"187. Tymczasem ci, którzy byli blisko $\mathrm{z}$ amerykańskim programem rakietowym, zarówno cywile, jak i wojskowi oraz osoby znajdujące się na najwyższych szczeblach władzy, wiedzieli o postępach ZSRR. Rozumiano nieuchronność rozwoju radzieckiej techniki rakietowej, który musiał w końcu przełożyć się na pierwszy lot kosmiczny i pierwsze pociski międzykontynentalne. Rakieta nośna R-7, która później wyniosła na orbitę Sputnika 1, rozpoczęła, zrazu nieskuteczne, próby na poligonie Tiuratam już w maju 1957 roku. Dopiero czwarta, przeprowadzona 21 sierpnia, była udana, po czym doszło do kolejnej, obie śledzone przez amerykańskie radary ${ }^{188}$. Jednak wszyscy, nawet najlepiej poinformowani Amerykanie, spodziewali się, że Vanguard upora się ze swoimi problemami, zanim ZSRR zdoła udoskonalić swój system nośny. Można skwitować to stwierdzeniem, że wyścig kosmiczny trwał w latach pięćdziesiątych w najlepsze, lecz wszem wobec ogłoszony został dopiero jesienią 1957 roku w wyniku potężnego politycznego i społeczny efektu zaskoczenia Sputnikiem ${ }^{189}$.

Jednym z wymiernych następstw tego politycznego trzęsienia ziemi była szybka decyzja, by dać zielone światło także projektowi Armii 
z jej Jupiterem-C. Już w dniu wystrzelenia Sputnika 1 zespół von Brauna obiecywał wyniesienie sztucznego satelity w $90 \mathrm{dni}^{190}$. W tym momencie rozpoczął się zatem wewnątrzamerykański wyścig kosmiczny, odzwierciedlający zaciekłą rywalizację pomiędzy poszczególnymi rodzajami sił zbrojnych. W drugiej połowie stycznia 1958 roku obie rakiety były gotowe - na przylądku Canaveral Jupiter-C oraz Vanguard w bazie Vandenberg w Kalifornii. Starty wielokrotnie przekładano, aż wreszcie 31 stycznia zespół von Brauna wystrzelił pierwszego amerykańskiego sztucznego satelitę ziemi Explorer 1, zbudowanego przez zespół JPL. W lutym Vanguard zawiódł ponownie, podobnie zresztą jak kolejny start Jupitera. W końcu 17 marca marynarka odniosła dawno oczekiwany sukces, na orbicie znalazł się satelita Vanguard 1. Dzięki daleko posuniętej miniaturyzacji oba amerykańskie satelity, w przeciwieństwie do znacznie większego Sputnika 1, wyniosły w przestrzeń precyzyjne przyrządy pomiarowe, były więc w pełni efektywnymi platformami badawczymi. Oba także natychmiast przyniosły doniosłe odkrycia naukowe, Explorer 1 między innymi odkrył pasy Van Allena, Vanguard 1 potwierdził przypuszczenia geologów dotyczące szczegółów kształtu Ziemi, miał także pierwsze baterie słoneczne.

Era pierwszych sputników to także okres kształtowania się konkretnych ram amerykańskiej strategii kosmicznej. Jej tworzenie podporządkowane było trzem zasadniczym imperatywom. Po pierwsze, szybko zrozumiano konieczność rozwijania technologii kosmicznej także z przyczyn prestiżowych. Wynikało to oczywiście z tego, że wyższość modelu gospodarczo-polityczno-społecznego ucieleśnianego przez Stany Zjednoczone była jednym z kluczy do amerykańskich wpływów w świecie. Uznano zatem za absolutnie niezbędne dorównanie.ZSRR także w wymiarze politycznym i propagandowym rysującego się wyścigu kosmicznego. Po drugie, kontynuując zasadniczą politykę ustaloną kilka lat wcześniej, dążono do stworzenia możliwości technicznych i organizacyjnych, które będą mogły wspomóc działania na rzecz bezpieczeństwa narodowego, szczególnie w wymiarze strategicznym, o czym była już mowa. I po trzecie, ważnym imperatywem było utrzymanie powszechnego przekonania, że wszystkie amerykańskie wysiłki związane z wykorzystaniem kosmosu, nie licząc tranzytu ICBM, mają pokojowy, a przede wszystkim naukowy charakter. 
Warto przy tym zwrócić uwagę, że określenie „pokojowy” nie miało oznaczać „niemilitarny”. Przeciwnie, od samego początku Stany Zjednoczone zamierzały używać przestrzeni kosmicznej do celów wojskowych w misjach niebojowych. Planowane wojskowe satelity zwiadowcze miały jednak charakter pokojowy w tym sensie, że przysparzając informacji o radzieckim potencjale, ułatwiały wnioskowanie co do intencji Moskwy. W rezultacie dawały nadzieję na pokój dzięki uniknięciu zagrożeń dla bezpieczeństwa, o których już wspominaliśmy: przecenienie możliwości przeciwnika miałoby całą gamę skutków w postaci nadmiernego wysiłku zbrojeniowego i ewentualnej eskalacji konfliktów, natomiast niedocenienie go mogło z kolei przynieść bezpośrednie zagrożenie bezpieczeństwa USA i sojuszników. Zastosowano więc logikę, która może wydawać się pokrętna, ale dobrze odzwierciedla przekonanie panujące w owym czasie, że demilitaryzacja nie służyłaby sprawie pokoju' ${ }^{191}$. Jednocześnie jednak starano się bardzo usilnie, aby ten wymiar wykorzystania kosmosu nie był publicznie znany, ukrywając go niejako pod programami cywilnymi. Argumentacja o militarnym wykorzystaniu kosmosu w celach pokojowych pojawiła się w przestrzeni publicznej nieco później, wraz z przyznaniem, że systemy, które na początku otaczano najściślejszą tajemnicą, faktycznie istnieją.

Najbardziej obszernym dokumentem omawiającym wczesną koncepcję amerykańskiej strategii kosmicznej był Preliminary Statement of U.S. Policy on Outer Space ${ }^{192}$, przygotowany przez NSC w czerwcu 1958 i zaakceptowany przez prezydenta w połowie sierpnia tegoż roku. Już w pierwszych akapitach zwraca on bardzo mocno uwagę na przewagę w kosmosie, jaką miał dysponować Związek Radziecki w owym czasie, o czym najwyraźniej stanowić miały trzy fakty:

- [...] ZSRR prześcignął $w$ naukowych i technologicznych osiągnięciach w kosmosie Stany Zjednoczone i Wolny Świat, opanowały one wyobraźnię i zyskały podziw ludzi na całym świecie;

- ZSRR, jeśli utrzyma dzisiejszą przewagę w eksploatacji kosmosu, będzie mógł użyć tej przewagi jako środka podważania prestiżu i przywództwa Stanów Zjednoczonych;

191 Ibidem, s. 189.

192 Preliminary Statement of U.S. Policy on Outer Space, National Security Council, 20.06.1958, http://marshall.wpengine.com/wp-content/uploads/2013/o9/NSC-5814Preliminary-U.S.-Policy-on-Outer-Space-18-Aug-1958.pdf. 
- ZSRR, jeśli pierwszy osiągnie istotne z punktu widzenia wojskowego i przeważające zdolności w kosmosie, będzie mógł naruszyć równowagę sił na korzyść bloku chińsko-radzieckiego i stworzyć bezpośrednie zagrożenie wojskowe dla bezpieczeństwa USA ${ }^{193}$.

Dotychczas nie w pełni docenione, prestiżowe znaczenie kosmosu wyjaśniał natomiast następująco:

Początkowe fazy podboju kosmosu przez człowieka charakteryzują się konkurencją międzynarodową i skupiają na technologii. W rezultacie pojawia się tendencja do zrównywania osiągnięć $w$ kosmosie $z$ faktycznym przywództwem w nauce, przewagą w ramach zdolności militarnych, technologii przemysłowej, a także z przywództwem w najogólniejszym rozumieniu' ${ }^{194}$.

Omawiany dokument bardzo precyzyjnie wyjaśnia i klasyfikuje, w jakim zakresie przestrzeń kosmiczna może być użytkowana. W grę wchodzą zatem:

- pojazdy, które swoją misję realizują w kosmosie, w szczególności pojazdy orbitalne, a także te, które udają się na inne niż Ziemia ciała niebieskie;

- transmisje elektromagnetyczne na rzecz komunikacji, pomiarów radarowych czy też przeciwdziałania radioelektronicznego;

- broń, która tylko przechodzi tranzytem przez kosmos, lecz jej cele znajdują się na Ziemi' ${ }^{195}$.

Podział ten, w znacznej mierze aktualny do dziś, uzupełnia katalog możliwych misji pojazdów orbitalnych, podzielony na trzy kategorie ze względu na perspektywę czasową, w jakiej spodziewano się osiągnąć określone zdolności.

1. Jako aktualnie planowane bądź dostępne w najbliższej przyszłości wymieniono:

- balistyczne pociski rakietowe,

- obronę przeciwrakietową i

- satelity zwiadowcze.

193 Ibidem, s. 1.

194 Ibidem, s. 2.

195 Ibidem, s. 5. 
2. Jako możliwe do zastosowania w bliskiej przyszłości uważano:

- satelity pogodowe,

- wojskowe satelity telekomunikacyjne,

- satelity służące walce radioelektronicznej, w szczególności przeznaczone do zagłuszania, oraz

- satelity służące wspomaganiu nawigacji.

3. Dalsze misje określone zostały jako future possibilities, co można rozumieć $w$ ten sposób, że oczekiwano możliwości ich realizacji, lecz perspektywa, w jakiej mogłoby się to stać, wydawała się w 1958 roku nieokreślona. I tak w punkcie tym mowa jest o:

- pojazdach załogowych służących obsłudze i zaopatrzeniu obiektów orbitalnych,

- pojazdach załogowych służących celom obronnym, które mogłyby przechwytywać, neutralizować bądź niszczyć obce obiekty w kosmosie,

- pojazdach załogowych bądź bezzałogowych, służących do bombardowania celów naziemnych, oraz

- załogowych stacjach księżycowych służących celom wojskowym, takim jak retransmisja sygnałów radiowych, rozpoznanie, a być może i wystrzeliwanie pocisków rakietowych do celów na Ziemi ${ }^{196}$.

Warto zwrócić uwagę, wyprzedzając znowu narrację, że jakkolwiek wszystkie misje znajdujące się w pierwszych dwóch kategoriach zostały wkrótce zrealizowane, to trzecia kategoria pozostaje, jak wiemy, przyszłością nawet współcześnie.

Wyrażane w Preliminary Statement obawy co do radzieckiej przewagi uściśla wykaz konkretnych osiągnięć, z zakresu tych, które wówczas wydawały się dostępne, uwzględniający perspektywę czasową ich realizacji przez ZSRR i USA. Uwzględniał on zarówno praktyczne korzyści w postaci opracowywania systemów satelitarnych zdolnych do wykonywania określonych misji na rzecz bezpieczeństwa narodowego, jak i prestiżowe osiągnięcia w postaci okrążenia Księżyca czy lądowania na nim. Przedstawione $\mathrm{w}$ wykazie daty były zdecydowanie pesymistyczne, zakładano, że wszystkie kluczowe zdolności w zakresie techniki kosmicznej ZSRR opracuje jako pierwszy ${ }^{197}$. Warto zauważyć, że rzeczywistość okazała się zgoła odmienna. Wszystkie praktyczne zastosowania systemów orbital- 
nych Amerykanie opracowali jako pierwsi, znacznie wyprzedzając ZSRR, odnieśli także część najbardziej spektakularnych zwycięstw.

Warto jeszcze raz zaakcentować, że omawiany dokument podkreśla wielokrotnie dotychczas traktowaną przez rząd cokolwiek po macoszemu kwestię prestiżowego znaczenia kosmosu i badań kosmicznych. Szczególną uwagę w tym kontekście zwrócono na loty załogowe - można się tu przy okazji dopatrywać i logiki, i argumentacji, która potem stanęła za determinacją w realizacji programu Apollo. Stwierdza się zatem, że

[z] punktu widzenia laika to załogowa eksploracja uosabia właściwy podbój kosmosu. Żaden eksperyment bezzałogowy nie może zastąpić załogowej eksploracji w kontekście jej psychologicznego wpływu na ludzi na całym świecie ${ }^{198}$.

Podsumowując Preliminary Statement, zauważmy w pierwszej kolejności, że dokument ten ukazuje panujące nawet na najwyższych szczeblach władzy w USA przekonanie o radzieckiej wyższości w technice kosmicznej. Tymczasem jedyna realna radziecka przewaga na samym początku wyścigu kosmicznego polegała na tym, że ZSRR posiadał rakietę nośną o większym udźwigu niż amerykańskie odpowiedniki. Przewagę tę niwelowała jednak w znacznym stopniu, skądinąd dostrzegana ${ }^{199}$, wyższość amerykańskiej technologii w zakresie miniaturyzacji komponentów systemów satelitarnych. Przyjęto jednak bardzo pesymistyczne założenia co do radzieckich postępów oraz ich konsekwencji, co w efekcie spowodowało natychmiastowy przyrost wysiłku podejmowanego w Stanach Zjednoczonych w dziedzinie opanowania kosmosu. Skutkiem tego w krótkim czasie było nie tyle „dogonienie” ZSRR, ile raczej powiększenie i tak już znacznej przewagi USA w opracowywaniu praktycznych zastosowań kosmicznych, a następnie zwycięstwo w prestiżowej stronie wyścigu.

$W$ realizacji koncepcji przedstawionej w powyższym dokumencie na miejsce dotychczas rozproszonych wysiłków realizowanych przez poszczególne rodzaje sił zbrojnych oraz rozliczne ciała doradcze stworzono dwie główne instytucje, które miały zajmować się rozwojem technologii i zastosowań kosmicznych. Pierwszą z nich stała się ARPA, powołana $w$ ramach Pentagonu i odpowiadająca za programy militarne, które 
prawie w całości scentralizowano pod jej egidą, pozostawiając Siłom Powietrznym jedynie rozwój ICBM. Jednocześnie na bazie kilku dotychczasowych struktur utworzono NASA, cywilną agencję, której mocno nagłośnionym i politycznie „sprzedawanym” zadaniem było realizowanie zadań cywilnych, poczynając od rakiet nośnych, poprzez loty załogowe, na satelitach badawczych i użytkowych kończąc.

Tymczasem wyścig kosmiczny nabierał tempa, już 3 listopada 1957 roku Rosjanie wysłali na pokładzie satelity Sputnik 2 w kosmos pierwsze żywe stworzenie, psa Łajkę, „zaliczając” kolejny sukces. Następnie, po amerykańskich pierwszych startach z początków 1958 roku, Sputnik 3 wystrzelony 15 maja zawierał aparaturę do badania pasów Van Allena, która jednak częściowo zawiodła. Te pierwsze wysiłki pokazują przy okazji dysproporcje pomiędzy możliwościami obu krajów - podczas gdy Explorer 1 ważył $14 \mathrm{~kg}$, a Vanguard 1 około $1,5 \mathrm{~kg}$, Sputnik 1 miał masę około 80 kg, a Sputnik 3 już $1300 \mathrm{~kg}$. Jednak w grudniu 1958 roku pierwszy Atlas $\mathrm{w}$ funkcji rakiety nośnej wszedł na orbitę z ładunkiem użytecznym o nazwie Score. Wprawdzie miał on masę zaledwie $70 \mathrm{~kg}$, ale całość struktury wyniesionej w kosmos ważyła 4 tony ${ }^{200}$. Jego znaczenie sprowadzało się zatem w dużej mierze do udowodnienia, że amerykańskie rakiety nośne nie ustępują radzieckim. Score był ponadto pierwszym satelitą komunikacyjnym, który mógł służyć do retransmisji sygnału radiowego, zarówno w czasie rzeczywistym, jak i utrwalonych wcześniej wiadomości, udowadniając techniczną wykonalność takiej funkcji systemu orbitalnego.

Także era militarnego zastosowania systemów orbitalnych rozpoczęta została wkrótce przez USA. Już 18 lutego 1959 roku rakieta nośna Thor-Agena wprowadziła na orbitę pojazd o oficjalnej nazwie Discoverer 1 , rozpoczynając tym samym program satelitów obserwacyjnych, których zadaniem było dokonywanie zwiadu fotograficznego. Wprawdzie pierwsze próby były nieudane, ale bliska wydawała się chwila, kiedy USA osiągną etap spełnienia strategicznych nadziei pokładanych $w$ satelitarnym zwiadzie optycznym.

Podsumowując tę fazę rozwoju eksploracji kosmosu, należy zauważyć bardzo wyraźny element konkurencji o prestiż w postaci wyścigu kosmicznego, co miało szczególne znaczenie dla ZSRR. Poza kwestiami mili-

200 Score, Encyclopedia Astronautica, 2016, http://www.astronautix.com/s/score.html. 
tarnymi, dotyczącymi strategicznej równowagi, pokazywanie wyższości nad światem kapitalistycznym miało dla Moskwy niemożliwą do przecenienia rolę propagandową i polityczną. Za sprawą szybkich i działających na wyobraźnię sukcesów w eksploracji kosmosu Związek Radziecki pokazywał, że jeszcze niedawno zacofany kraj, który przyjął nową ideologię, może bardzo szybko dokonać wielkich postępów. Wykazywano i podkreślano, że to nowy system polityczno-społeczno-gospodarczy umożliwiał ZSRR stanie się najbardziej zaawansowanym państwem świata i zdystansowanie dotychczasowych potęg, a szczególnie USA. Był to doskonały argument z zakresu soft power, choć pojęcia tego jeszcze nie używano, szeroko wykorzystywany przez Moskwę w relacjach z mniejszymi krajami, w których ścierały się wpływy Wschodu i Zachodu.

$\mathrm{Z}$ drugiej strony Amerykanie za administracji Eisenhowera rozumieli przede wszystkim uwarunkowania strategiczne i w związku z tym priorytetowo traktowali rakiety międzykontynentalne i satelity zwiadu optycznego. Kwestie prestiżowe spychano na dalszy plan, starając się jednocześnie, aby amerykański program z zewnątrz wyglądał pokojowo i naukowo ${ }^{201}$. Dopiero szok spowodowany wystrzeleniem Sputnika 1 wymusił pewne przewartościowania, których jedną z zapowiedzi był cytowany powyżej Preliminary Statement, jednak USA wciąż nie były gotowe do wyścigu na pełną skalę i nawet nie było pewności, czy chcą go podjąć. I to pomimo silnych argumentów za maksymalizacją zaangażowania oraz mimo że USA znalazły się w politycznej defensywie, a rząd Eisenhowera został zaatakowany na wewnątrzpolitycznym froncie oskarżeniami o zaniechanie kluczowych dla kraju działań. Mobilizacja środków na cele rozwoju techniki kosmicznej oznaczałaby bowiem bezprecedensową w czasach pokojowych koncentrację wydatków i wysiłku organizacyjnego w rękach państwa. Musiałoby ono w takich okolicznościach wziąć na własne barki rozwój technologiczny kraju i alokację jego zasobów, zamiast pozostawić je naturalnym siłom rynkowym. Inaczej mówiąc, przed Sputnikiem Eisenhower starał się, aby równowaga pomiędzy koniecznością rozwoju a niechęcią do tworzenia państwowych molochów, czyli inaczej mówiąc, do rozrastania się państwa, została zachowana. Efekt psychologiczny w USA i globalne polityczne skutki radzieckich „zwycięstw” zmuszały jednak do przemyślenia sytuacji. 
Należy też zwrócić ponownie uwagę i podkreślić ważną kwestię, jaką była w Stanach Zjednoczonych silna konkurencja pomiędzy rodzajami sił zbrojnych. Upatrywały one $w$ rozwoju zastosowań kosmicznych możliwości zwiększania swojego znaczenia ze wszystkimi tego potencjalnymi dobrodziejstwami. Szczególnie Siły Powietrzne argumentowały za koniecznością stworzenia kosmicznych broni, oczywiście pod flagą USAF. Ta tendencja była bardzo silna $w$ drugiej połowie lat pięćdziesiątych, kiedy to rozpoczęto próby mające doprowadzić do stworzenia załogowego samolotu kosmicznego, który mógłby wykonywać orbitalne misje bojowe. Prowadziły do tego i programy $X-15$ i $X-20$ Dyna-Soar. Niestety dla USAF lotnictwo nie potrafiło uzasadnić realnymi korzyściami ogromnych kosztów tych programów. Inaczej mówiąc, trudno było o sensowną misję, którą tak skomplikowany i drogi system załogowy wykonałby lepiej niż o wiele prostszy i tańszy system bezzałogowy. Pozostawały ponadto zawsze kwestie polityczno-strategiczne - stworzenie broni kosmicznej wywołałoby reakcję obawiającej się o własne bezpieczeństwo drugiej strony. W szczególności mogło to przyjąć formę przyspieszenia rozwoju broni przeciwsatelitarnej. To $\mathrm{z}$ kolei postawiłoby pod znakiem zapytania "codzienne" korzyści z systemów orbitalnych wyciąganych z misji niebojowych, które już na tym etapie wydawały się wręcz bezcenne. Praktyka nieuzbrajania kosmosu, tak aby uniknąć rozwoju broni przeciwsatelitarnej, wydawała się zatem najbardziej rozsądna, a działania według tej logiki realizowano także $w$ dalszych latach.

\subsection{Wyścig kosmiczny}

Na bazie omówionych powyżej koncepcji i decyzji podjętych w latach 1958-1959 nastąpiła reorganizacja amerykańskiego wysiłku kosmicznego, polegająca przede wszystkim, w sensie strukturalnym, na zwiększeniu roli państwa w rozwoju technologii. Jej widomym znakiem było utworzenie NASA jako organizacji, która miała koordynować wysiłki cywilne, podczas gdy kwestie wojskowego wykorzystania kosmosu powierzono ostatecznie USAF i ARPA. Jednocześnie toczyła się w USA, najbardziej burzliwie w 1959 roku, dyskusja ekspercka i polityczna na temat tego, czy przystąpić do wyścigu kosmicznego na pełną skalę, czy też nie, co oznaczałoby oczywiście dalsze konsekwencje budżetowe. Dyskusja ta 
odbywała się na tle bez mała histerii panującej w amerykańskich mediach i polityce ${ }^{202}$, wywoływanej kolejnymi radzieckimi sukcesami, takimi jak wysłanie na Księżyc pierwszych próbników, które uderzały w jego powierzchnię, czy wreszcie okrążenie Księżyca przez Łunę 3, którą wystrzelono w drugą rocznicę Sputnika 1 i która przywiozła pierwsze zdjęcia niewidocznej z Ziemi strony naszego satelity. Histeria miała też wymiar strategiczny w postaci missile gap, czyli powszechnego w Stanach Zjednoczonych przekonania o radzieckiej miażdżącej przewadze w międzykontynentalnych rakietach balistycznych.

Dyskusja z 1959 roku przyniosła istotne zmiany w praktycznym myśleniu o wyścigu kosmicznym i o jego prestiżowym wymiarze. Budżet NASA na 1960 rok został zwiększony do 964 mln USD ${ }^{203}$, w przeliczeniu na aktualną wartość dolara wynosiło to 3,6 mld USD, wobec 2,3 mld USD w 1959 roku $^{204}$. Choć jeszcze nie było to podjęcie wyzwania na pełną skalę, oznaczało jednak, że USA decydują się na znaczące zwiększenie wysiłków w wymiarze prestiżowym. Ich istotnym elementem był między innymi program lotów załogowych i rodzący się program ciężkiej rakiety nośnej Saturn. Ta ostatnia konstrukcja miała być oparta na potężnych silnikach F-1, których koncepcję rozwijano już od 1953 roku ${ }^{205}$. Zasadniczym argumentem, jakiego używano, uzasadniając taki przyrost nakładów, była oczywiście kwestia prestiżu, postrzeganego zarówno przez pryzmat polityki zagranicznej, jak i sytuacji politycznej w kraju. Z jednej strony panowało zatem przekonanie, że USA muszą udowodnić światu, że są jednak lepiej rozwinięte technicznie od ZSRR, z drugiej zaś - chodziło o odzyskanie przez naród nadszarpniętej wiary we własne siły.

Stany Zjednoczone podjęły więc u schyłku lat pięćdziesiątych radzieckie wyzwanie w znacznie większym zakresie niż dotychczas, choć w pewnym sensie wciąż niechętnie. Oczywiście niektóre koła polityczne, sfery przemysłowe i wojsko parły entuzjastycznie do maksymalizacji wysiłków, między innymi szermując hasłem missile gap, lecz duża część środowiska naukowego i administracja Eisenhowera nie podzielały tego

202 W. A. McDougall, op. cit., s. 204-205.

203 Ibidem, s. 206.

$20+$ Th. G. Roberts, History of the NASA Budget, Aerospace Security, 4.06.2019, https:// aerospace.csis.org/data/history-nasa-budget/.

205 Saturn V, Encyclopedia Astronautica, 2016, http://www.astronautix.com/s/saturnv. html. 
entuzjazmu. Ukształtował się zatem swego rodzaju chwilowy kompromis, zwiększono wysiłki, wzmocniono struktury, NASA stała się potężną instytucją zajmującą się najbardziej prestiżowymi projektami i zdolną wygenerować znaczny impuls rozwojowy, ale jednocześnie mobilizacji na pełną skalę nie przeprowadzono.

Drugą stroną rozwoju eksploracji kosmosu, uzupełniającą prestiżowo uwarunkowany wyścig kosmiczny, pozostawała znacznie mniej eksponowana kwestia programów ściśle wojskowych. Ukształtował się w ten sposób ostatecznie w USA specyficzny dualizm pomiędzy nagłaśnianą i szczodrze finansowaną sferą cywilną i także dobrze finansowaną, lecz w większości dobrze utajnioną sferą wojskową. W ramach tej ostatniej na widok publiczny wystawiano jedynie program budowy ICBM jako widoczny znak, że USA nie dają się zdystansować w najnowocześniejszych i najpotężniejszych broniach. Akcentowano jednak, że mają one podstawowe znaczenie jako czynnik odstraszania, a zatem ich rola jest jedynie obronna i w gruncie rzeczy służy pokojowi poprzez odstraszanie. Natomiast programy satelitarne, szczególnie rozpoznawcze, pozostawały w głębokim cieniu. Tak już działo się przez cały okres zimnej wojny i w pewnej mierze tak jest do dzisiaj.

Patrząc z szerszej perspektywy, dyskusja na temat ewentualnego udziału w wyścigu kosmicznym wpisywała się w szerszą debatę na temat przyszłości Ameryki, jej światowej pozycji i bezpieczeństwa narodowego, prowadzącej także do pytania o rolę i znaczenie państwa w kreowaniu inwestycji, edukacji, nauki, dobrobytu. Dyskusję tę zdecydowanie wygrały liczne koła optujące za zwiększeniem roli rządu, za uczynieniem go odpowiedzialnym nie tylko za tradycyjne obszary, jak bezpieczeństwo i polityka zagraniczna, ale także za wzrost gospodarczy, dobrobyt społeczeństwa, rozwój nauki i edukację. Z naszego punktu widzenia ma to ogromne znaczenie, ponieważ $\mathrm{z}$ tego właśnie wynikało zwiększenie nakładów na programy kosmiczne, szczególnie cywilne. Wywarło to tė ogromny wpływ na sferę militarną, ponieważ wiele lub nawet większość technologii rozwijanych na potrzeby cywilne miało swoje bezpośrednie bądź pośrednie zastosowanie w dziedzinie bezpieczeństwa narodowego. Tu też można szukać źródła pojęcia spacepower jako atrybutu państwa, tworzonego głównie przez rząd w ramach planowego wysiłku i kontrolowanego przez jego struktury. 
Szczególnie istotny dla dalszego biegu eksploracji kosmosu był wyścig prezydencki w 1960 roku. Zarówno Kennedy, jak i Nixon wiele czasu poświęcali kwestii konieczności zwiększenia wysiłku kosmicznego. Kiedy jednak Kennedy szermował hasłem missile gap i twierdzeniami, że Ameryka przegrywa wyścig kosmiczny, Nixon cytował osiągnięcia poprzedniej administracji, zdecydowanie podkreślając, że tak naprawdę, poza spektakularnymi radzieckimi sukcesami o niewielkiej wartości naukowej, USA wyprzedzają ZSRR zdecydowanie. Istotne jest jednak to, że wątpliwości polityczne co do samej zasadności wzięcia udziału w wyścigu kosmicznym praktycznie odeszły w przeszłość, między innymi pod naciskiem szerokiej publiczności, kręgów wojskowych i przemysłowych oraz wpływowych uczonych zarówno z obszaru nauk ścisłych, jak i politycznych oraz ekonomicznych. Wszystko to razem tworzyło, jak to ujmuje amerykański historyk, „[...] Sputnikowe horror show [...]”206.

Na marginesie warto przypomnieć, że to Nixon miał rację w tym dyskursie, nawet jeśli politycznie go przegrywał. Amerykańskie programy satelitarne, choć nie były spektakularnymi „strzałami w Księżyc” jak radzieckie łuny, dawały zapowiedź zaawansowanych praktycznych zastosowań kosmosu, które w przyszłości przyniosą ogromne korzyści. Już 1 kwietnia 1960 roku za pomocą rakiety nośnej Thor-Able na orbitę wszedł TIROS-1, pierwszy satelita meteorologiczny NASA. Przesłał on między innymi pierwszy telewizyjny obraz Ziemi z kosmosu. 13 kwietnia 1960 roku Thor-Delta wyniósł na orbitę pojazd Transit $1 \mathrm{~B}$, który był pierwszym satelitą nawigacyjnym marynarki wojennej USA. Oba projekty były jeszcze stosunkowo niedojrzałe, miały też ograniczone możliwości, ale były już w pełni funkcjonalne. Szybko zostały uzupełnione przez kolejne elementy tworzonych konstelacji satelitarnych, a następnie zastępowane nowymi ich generacjami.

W końcu sukces odnotował także program zwiadu optycznego, najistotniejszy bodaj z praktycznego punktu widzenia. Najpierw misja Discoverer 13 zakończyła się w sierpniu 1960 roku sukcesem, to znaczy satelita wykonał prawidłowo cały swój cykl operacyjny, poczynając od umieszczenia na stabilnej orbicie do prawidłowej deorbitacji i odzyskania ćwiczebnej kapsuły. Była ona notabene pierwszym na świecie obiektem, który 
powrócił nienaruszony z orbity i został odzyskany, choć publiczność nie wiedziała o tym jeszcze przez wiele lat, program odtajniono dopiero w latach dziewięćdziesiątych. Tydzień później (19 sierpnia) w pełni wyposażona kapsuła Discoverera 14 została odzyskana w czasie opadania na spadochronie przez odpowiednio dostosowany samolot, osiągnięto zatem ostatecznie całkowity sukces. W tym jednym locie trwającym 7 orbit pozyskano fotografie 64 baz lotniczych, 26 nowych, nieznanych baz rakiet przeciwlotniczych i trzeciego stanowiska startowego $\mathrm{w}$ bazie rakietowej w Plesiecku ${ }^{207}$. Było to więcej informacji niż samoloty U-2 zdobyły przez dotychczasowe cztery lata pracy.

Discoverer był także pierwszym z serii amerykańskich programów satelitarnego zwiadu optycznego znanych pod ogólną nazwą Corona, na który składały się serie pojazdów oznaczone od $\mathrm{KH}-1$ do $\mathrm{KH}-6$. Ich operatorem była CIA, a następnie National Reconnaissance Office, instytucja utworzona specjalnie w celu obróbki i interpretacji materiałów dostarczanych przez satelitarny zwiad optyczny. Warto dodać, że ostatni ze 121 satelitów programu wystartował w maju 1972 roku, w sumie zrobiły one 800 ooo zdjęć, „[...] na zawsze zmieniając to, co Stany Zjednoczone wiedziały i jak się tego dowiadywały" ${ }^{208}$. Dążenie Amerykanów do zdobycia informacji strategicznej nabierało zatem realnych kształtów, przełamywano barierę skrytości, jaką roztoczył wokół siebie Związek Radziecki. Ten ogromny sukces zweryfikował przy okazji dość szybko przesadną ocenę radzieckich zdolności militarnych w dziedzinie ofensywnych zbrojeń strategicznych. Okazało się, choć wiedzieli o tym tylko nieliczni, że missile gap faktycznie istniała, lecz $\mathrm{w}$ istocie rzeczy oznaczała ogromną nierównowagę na korzyść USA ${ }^{209}$.

Kolejne wojskowe systemy kosmiczne, zdolne do wykonywania kolejnych misji, pojawiły się już wkrótce. 24 maja 1960 roku Thor-Agena wyniósł na orbitę satelitę Midas 2 (Midas 1 nie osiągnął orbity w lutym w wyniku awarii drugiego stopnia rakiety nośnej), za którym poszły następne tej serii. Jego zadaniem było wykrywanie startów radzieckich rakiet międzykontynentalnych za pomocą czujników podczerwieni. Choć sam Midas nie był zbyt wiarygodnym źródłem informacji ${ }^{210}$, to za nim

207 W. E. Burrows, op. cit., loc. 5319-5320.

208 Ibidem, loc. 5661-5664.

209 S. B. Johnson, op. cit., s. 513.

210 W. E. Burrows, op. cit., loc. 5319-5320. 
poszły kolejne, które sukcesywnie uformowały konstelację DSP, niezwykle ważną do dziś z punktu widzenia równowagi strategicznej. I wreszcie 22 czerwca 1960 roku wystrzelono pierwszego satelitę zwiadu elektromagnetycznego. Był to pierwowzór serii niewielkich satelitów o nazwie GRAB, znany także pod nazwą GREB oraz Sunray, wystrzeliwanych oficjalnie pod nazwą SOLRAD ${ }^{21}$. To zamieszanie w nazewnictwie wynikato $w$ dużej mierze $\mathrm{z}$ tego, że satelita oficjalnie badał aktywność elektromagnetyczną Słońca i głębokiego kosmosu, te same instrumenty służyły jednak do rejestrowania pracy radzieckich stacji radiolokacyjnych, których parametry badane były następnie przez służby wojskowe. Satelity tej serii budowało NRL, ich wojskowe zastosowanie pozostawało tajne przez 40 lat $^{212}$.

W rezultacie dzięki systemom satelitarnym już jesienią 1960 roku USA miały swobodny i dość czytelny wgląd w radzieckie instalacje wojskowe, podczas gdy ZSRR mógł o czymś podobnym jedynie pomarzyć. Przewagę zachowywał tylko w zakresie masy ładunku, który rakieta R-7 mogła wprowadzić na orbitę, lecz już w październiku 1961 roku rozpoczęły się suborbitalne testy rakiety Saturn 1, która w niecałe dwa lata później stała się najpotężniejszym systemem nośnym świata. Jednak, istniejąca wersja Atlasa z drugim stopniem Agena, zdolna do wynoszenia na niską orbitę ładunków użytecznych o wadze około tony, w zupełności wystarczała do realizowania pierwszych etapów programu załogowych lotów kosmicznych.

Warto zwrócić uwagę na to, że niemały wpływ na zwiększenie amerykańskiej determinacji w finansowaniu badań kosmicznych mieli sami Rosjanie. Robili wszystko, żeby umocnić obawy USA i Zachodu oraz swój prestiż w świecie. Od samego początku Chruszczow postrzegał eksplorację kosmosu jako element budowania politycznych pozycji kraju i swoich własnych. Już od 1955 roku wysocy rangą radzieccy politycy wielokrotnie chwalili się sukcesami odnoszonymi $w$ ramach rozwoju rakiet balistycznych. W kwietniu 1956 roku Chruszczow ogłosił, że już wkrótce ZSRR

211 GRAB - Galactic Radiation and Background - tho galaktyczne i promieniowanie; GREB - Galactic Radiation Experimental Background - eksperyment tla promieniowania galaktycznego. Oba skróty i ich rozwinięcia były zupełnie fikcyjne. SOLRAD Solar Radiation - promieniowanie słoneczne.

212 W. P. Daec, The Navy's Spy Missions in Space, „Naval History Magazine” 2008, vol. 22, nr 2. 
będzie miał rakietę $\mathrm{z}$ bombą wodorową, zdolną do zaatakowania dowolnego celu na świecie. Po Sputniku 1 i tak wojownicza retoryka radzieckiego przywódcy dalej się jeszcze zaostrzyła - wskazując na kolejne radzieckie sukcesy, dowodził, że i w dziedzinie militarnej ZSRR przoduje, że będzie zatem budował rakiety balistyczne „jak kiełbasę”. Sukcesy w kosmosie przekładały się zatem w sensie politycznym na odstraszanie strategicz$n^{213}$. Radziecka retoryka zawierała także w sobie zdecydowaną groźbę dla wszystkich amerykańskich sojuszników, szczególnie dla NATO i Europy Zachodniej. Moskwa wyraźnie wskazywała, że amerykańskie instalacje wojskowe są $\mathrm{w}$ zasięgu niepowstrzymanych ataków nuklearnych, co sugerowało wyraźnie, że należy przemyśleć zasadność sojuszu z USA.

Wszystko to było możliwe nie tylko dzięki sprawnej propagandzie, ale także dzięki całkowitej nieprzejrzystości radzieckiego programu kosmicznego. W pierwszych kilku latach nie wiadomo było o nim prawie nic, poza ogólnikami, nawet podstawowe parametry rakiety nośnej R-7 nie były znane. To dzięki temu właśnie społeczeństwa Zachodu nie zdawały sobie sprawy z zasadniczych słabości radzieckiego programu kosmicznego, „[...] oczekując ze zdziwieniem, jakie nowe zdolności zostaną przez ZSRR ujawnione wraz z następną "niespodzianką»"214. Tymczasem niesłychany pośpiech, aby zdążyć z kolejnymi sukcesami przed USA, skutkował wieloma kolejnymi porażkami i podejmowaniem wielkiego ryzyka, które w USA było nie do pomyślenia. Charakterystycznym dla owych czasów wydarzeniem był wypadek z 23 października 1960 roku na kosmodromie Bajkonur. Po tym, jak już trzeci z rzędu start rakiety z próbnikiem na Marsa nie udał się w wyniku nieuruchomienia się silników, marszałek Mitrofan Niedielin, pierwszy dowódca niedawno utworzonych Wojsk Rakietowych ZSRR, nakazał technikom jak najszybciej udać się do rakiety i zacząć badać usterkę. Niedługo potem eksplodowało paliwo, zabijając nieznaną do dziś liczbę (zapewne setki) najlepszych inżynierów wraz z samym Niedielinem ${ }^{215}$.

Wszystko to jednak pozostawało w głębokim ukryciu, Moskwa nigdy nie informowała o startach przed ich przeprowadzeniem, nigdy oczywiście nie ujawniała katastrof. Dobrym porównaniem amerykańskiego

213 M. Sheehan, The International Politics of Space, Routledge 2007, s. 28.

214 W. A. McDougall, op. cit., s. 241.

215 Ibidem, s. 245. 
i radzieckiego podejścia jest także kwestia pierwszego startu człowieka w kosmos. Chruszczow naciskał na głównego architekta radzieckiego programu kosmicznego Sergieja P. Korolowa, aby ten cel zrealizować jak najszybciej, dając światu kolejny dowód wyższości socjalizmu. Pominięto zatem szereg etapów rozwoju programu, które z kolei Amerykanie uważali za konieczne w związku z wymogami bezpieczeństwa. Były to między innymi krótki lot szympansa Hama w lutym w docelowej kapsule Mercury, a następnie loty suborbitalne Alana Sheparda 5 maja i Virgila Grissoma 21 lipca 1961 roku, realizowane za pomocą znacznie zmodyfikowanej rakiety nośnej Redstone. Jednocześnie pracowano nad wersją Atlasa, który sprawdził się już jako nośnik satelitów, tym razem przystosowaną do kapsuły Mercury - jej pierwszy, choć nieudany test odbył się jeszcze 29 lipca 1960 roku. Wiedząc o tym wszystkim, Rosjanie w szaleńczym tempie i bez zachowania środków ostrożności przygotowali kapsułę Wostok 1 dla Jurija Gagarina, wiedząc, że w razie ewentualnej porażki nikt się o niej nie dowie.

Ale radzieckie zwycięstwa, wynikające $\mathrm{z}$ koncentracji na spektakularnych sukcesach osiąganych za pomocą rakiety $\mathrm{R}-7$, miały też odwrotny skutek, to znaczy w pewnym sensie były niekorzystne i dla samego ZSRR. Po pierwsze, oddalało się wejście do służby ICBM z prawdziwego zdarzenia. Siemiorka ${ }^{216}$, będąca „koniem roboczym” misji kosmicznych, w funkcji rakiety bojowej była zbyt trudna w obsłudze, by stanowić sensowną broń. ZSRR długo nie mógł bowiem przełamać pewnych barier konstrukcyjnych, szczególnie związanych ze zmniejszeniem rozmiarów i masy silników oraz wprowadzeniem bardziej bezpiecznego paliwa. Dopiero w 1962 roku rozpoczęto rozmieszczanie pierwszych pocisków $\mathrm{R}-16^{217}$, lecz $\mathrm{w}$ czasie kryzysu kubańskiego $\mathrm{w}$ gotowości pozostawało ich zaledwie 8, wobec amerykańskich 182 rakiet Atlas, Titan i Minuteman ${ }^{218}$. Po drugie, walka o prestiżowe sukcesy ograniczała zasoby, które można było alokować na rozwój systemów satelitarnych, zarówno cywilnych, jak i wojskowych. W ten sposób konserwowano technologiczne zapóźnienie programu kosmicznego w wielu dziedzinach, które w przyszłości okazały się niezwykle ważne. I wreszcie po trzecie, co jest szczególnie istot-

216 Семёрка - rosyjskie potoczne określenie rakiety R-7.

21 - SS-16 w klasyfikacji amerykańskiego departamentu obrony, Saddler w kodzie NATO. 218 R. S. Norris, H. M. Kristensen, op. cit., s. 87. 
ne, sukcesy ZSRR wpłynęły, jak wiemy, niezwykle mobilizująco na Stany Zjednoczone.

Wielki radziecki rakietowy blef, czyli narracja o pociskach produkowanych „jak kiełbasa” połączona ze spektakularnymi sukcesami w eksploracji kosmosu, obrócił się zatem przeciwko Moskwie. Wywołał serię bardzo niekorzystnych zjawisk, które w dalszej perspektywie czasowej przyczyniły się także mocno do upadku ZSRR. A to dlatego, że USA na początku „kupiły” radziecką propagandę, Waszyngton podjął więc gigantyczny wysiłek zbrojeniowy. W dodatku do wcześniejszego programu budowy 1000 strategicznych bombowców B-52 podjęto wspomniane prace nad rozmieszczeniem znacznej liczby ICBM oraz programem stworzenia strategicznej floty podwodnej. USA rozpoczęły także, z czasem prowadzone coraz bardziej zdecydowanie, spektakularne projekty kosmiczne, wyznaczając w końcu Księżyc jako cel dla załogowego lotu. Pod tym naciskiem ZSRR nie tylko poczuł się zmuszony dokonać ogromnego wysiłku, aby osiągnąć, a potem utrzymać parytet strategiczny, ale także podjął wyzwanie księżycowe, choć tego nie ogłosił, marnując na jego realizację ogromne zasoby. Gospodarka radziecka, wielokrotnie mniejsza i słabsza niż amerykańska, straciła w związku z tym w latach sześćdziesiątych jakąkolwiek szansę na pokojowy rozwój. Szaleńcze zbrojenia strategiczne, w dodatku do konwencjonalnych, „przejadały” znaczną część dochodu narodowego, przyczyniając się do spowolnienia, a potem (w latach siedemdziesiątych) faktycznego zatrzymania rozwoju społecznego i gospodarczego kraju. Rezultatem był zastój i wreszcie gospodarcza degradacja państwa, lawinowo postępująca w latach osiemdziesiątych. Można zatem wywodzić, iż rakietowy blef Chruszczowa był jednym z gwoździ do trumny ZSRR, tyle że nie było o tym wiadomo jeszcze przez kilka dekad.

Radziecka polityka została zresztą bardzo szybko przejrzana, między innymi dzięki przyspieszeniu prac badawczo-rozwojowych przez nią samą spowodowanych. Już przecież z początkiem lat sześćdziesiątych Amerykanie dość dobrze znali radziecki potencjał strategiczny, co przełożyło się szybko na polityczną praktykę. W toku kubańskiego kryzysu rakietowego Kennedy dość dobrze wiedział, jak ogromną przewagą dysponuje, i stąd w dużej mierze wzięła się jego stanowczość. Inna rzecz, że do kryzysu doprowadził Chruszczow, który zdawał sobie sprawę, iż amerykańskie satelity rozpoznawcze wkrótce „sprawdzą” jego rakietowy blef, chciał więc, przy użyciu swoistego półśrodka, zagrozić terytorium USA 
za pomocą rakiet średniego i pośredniego zasięgu bazowanych blisko terytorium Stanów Zjednoczonych.

Radziecka polityka rakietowego blefu była wynikiem splotu ekonomicznego i technologicznego zapóźnienia ZSRR z ideologicznie uwarunkowaną potrzebą konkurowania i wykazywania swojej wyższości nad Zachodem oraz z poczuciem zagrożenia wynikającym z miażdżącej przewagi USA pod każdym względem, z której radzieccy przywódcy dobrze sobie zdawali sprawę. Skutkowała między innymi zablokowaniem możliwości osiągnięcia sensownego porozumienia na tym wczesnym etapie wyścigu zbrojeń, ponieważ wymagałoby ono odpowiedniego reżimu weryfikacji, dzięki któremu natychmiast okazałoby się, jak słaby jest ZSRR w dziedzinie zbrojeń strategicznych. Wobec powszechnej propagandy sukcesu byłoby to zabójcze dla prestiżu Moskwy, który traktowała ona jako jeden z podstawowych elementów swojej polityki światowej.

\subsection{Dalszy rozwój zastosowań systemów orbitalnych}

Z początkiem lat sześćdziesiątych USA wyprzedzały zatem ZSRR w technologiach kosmicznych, według niektórych ocen aż o pięć lat, w szczególności dotyczyło to zwiadu optycznego, meteorologii, komunikacji i geodezji ${ }^{219}$. Był to efekt $\mathrm{z}$ jednej strony amerykańskiej przemyślanej polityki w zakresie rozwoju zdolności kosmicznych oraz ogromnych zasobów materialnych i intelektualnych, którymi dysponowała Ameryka, a z drugiej - radzieckiego marnotrawstwa, propagandowego traktowania eksploracji kosmosu i generalnego zapóźnienia technologicznego oraz słabości ekonomicznej. Podobnie rzecz się miała z rozwojem ICBM, które notabene w owym czasie oderwały się w sensie technicznym od systemów startowych, nie będziemy o nich zatem więcej w tym rozdziale wspominać.

W tym samym czasie Amerykanie odkryli także naturę radzieckiego rakietowego blefu, wbrew histerycznym wręcz staraniom ZSRR, by nie dopuścić do użytkowania systemów zwiadu optycznego. Ta postawa Moskwy zresztą nie dziwi, na Kremlu bowiem zdawano sobie sprawę $\mathrm{z}$ potencjału satelitów rozpoznania strategicznego. Wiedziano zatem, jak stwierdzał sam Chruszczow, że Amerykanie dowiedzą się prędzej czy 
później, że Związek Radziecki był w relatywnie słabszej pozycji²20. Na tym tle doszło zatem w latach 1960-1961 do ostrego sporu na forum ONZ, w czasie negocjacji na temat prawa kosmicznego. Amerykanie nalegali na formułę niewykorzystywania kosmosu do celów „agresywnych”, a Rosjanie - do celów „militarnych”. Różnica jest oczywista, ta druga formuła zapobiegałaby także umieszczaniu na orbicie okołoziemskiej satelitów zwiadowczych. Związek Radziecki szermował przy tym argumentem, że tego typu działalność, czyli szpiegostwo, jest generalnie zakazana przez prawo międzynarodowe, jest także przejawem agresywności i przygotowań do ataku. W rzeczywistości jednak wciąż próbowali zakamuflować swoje zacofanie, podczas gdy Amerykanie już rozpoczęli użytkowanie swoich pierwszych systemów wojskowych, oczywiście „[...] nie dlatego, że byli bardziej agresywni, lecz dlatego że byli bardziej zaawansowani w technologiach satelitarnych, bardziej praktyczni w alokacji funduszy i bardziej potrzebowali informacji i przeciwnika" ${ }^{221}$.

Ostatecznie jednak pragmatyzm przeważył i 20 grudnia 1961 roku Rezolucja ZO ONZ 1721 (XVI) stała się pierwszym międzynarodowym dokumentem na temat podstawowych zasad i procedur dotyczących eksploracji kosmosu. Jego główne postanowienia zostały omówione w rozdziale pierwszym, dość wspomnieć, że rezolucja rozciągała obowiązywanie prawa międzynarodowego na przestrzeń kosmiczną oraz otwierała ją do eksploracji oraz wykorzystania zgodnie z normami prawa międzynarodowego. Próbując niejako zachować twarz i zwiększyć ewentualną swobodę manewru, ZSRR zaakceptował prawo do nieszkodliwego przelotu przez przestrzeń wspólną, jaką de iure stał się kosmos. Jednocześnie podkreślił swoje prawo do niszczenia satelitów obcych państw przelatujących nad jego terytorium, które będą zagrażały bezpieczeństwu narodowemu. Powoływał się przy tym na zawarte w prawie międzynarodowym prawo samoobrony i przeciwdziałania wrogim aktom.

Los wyścigu kosmicznego, który tak wiele przyniósł w dziedzinie zastosowań militarnych, został przypieczętowany amerykańską decyzją dotyczącą koncentracji wszystkich koniecznych wysiłków na programie Apollo, tak aby do końca dekady na Księżycu wylądował pierwszy człowiek. To dzięki temu w następnych latach dokonany został w Stanach 
Zjednoczonych bardzo szybki postęp we wszystkich istotnych dziedzinach eksploracji kosmosu, który przełożył się dalej na późniejsze amerykańskie bezapelacyjne zwycięstwo $\mathrm{w}$ prestiżowej części wyścigu kosmicznego. Decyzja ta została jednak podjęta dopiero po locie Gagarina, wcześniej nawet Kennedy nie był w pełni przekonany, czy warto podjąć tak kosztowny wyścig o prestiż, skoro USA i tak były bardziej zaawansowane zarówno w ICBM, jak i technice satelitarnej. W wyniku tej decyzji budżet NASA rósł dalej w szybkim tempie, w 1961 roku wynosił on (w cenach obecnych) 6,5 mld USD, w 1962 - 12 mld USD, w 1963 - 24,5 mld USD, a w 1964 osiągnął prawie 34 mld USD ${ }^{222}$, co stanowiło około $3 \%$ wydatków USA w roku budżetowym $1964^{223}$. Warto dodać dla porównania, że propozycja wydatków NASA na rok budżetowy 2020 opiewa na około 22,5 mld USD ${ }^{224}$, co stanowi mniej więcej o,5\% wydatków budżetowych USA.

Mimo wstępnego sceptycyzmu prezydent USA poddał się zatem szerokiemu naciskowi Kongresu i mediów domagających się politycznych sukcesów, nie chciał popełnić błędu Eisenhowera, który oddał symboliczne pierwszeństwo w kosmosie Związkowi Radzieckiemu. Kennedy miał też dalsze powody, jego aktywna polityka zagraniczna przynosiła zarówno sukcesy, takie jak stawienie czoła Moskwie w czasie kryzysów berlińskiego i kubańskiego, jak i przykre porażki, takie jak nieudana inwazja w Zatoce Świń. Prezydent rozumiał zatem zapotrzebowanie Amerykanów na nową wizję i nowe powody do wiary w siebie, poszukiwał także źródeł wzmacniających prestiż USA w świecie, który uważał za istotny czynnik oddziaływania. Nie bez znaczenia była także konieczność podtrzymania funkcjonowania i rozwoju rozdętego już do znacznych rozmiarów przemysłu aerokosmicznego, który mógł mieć znaczące kłopoty wobec planowanej przez sekretarza obrony Roberta S. McNamarę racjonalizacji wysiłku w dziedzinie obronności ${ }^{225}$. Ostatecznie jednak do podjęcia ogromnego wyzwania ekonomicznego i organizacyjnego, w dodatku z niepewnym skutkiem, przekonało zapewne „[...] mrowienie po kręgosłupie na myśl o pozostawieniu Księżyca Związkowi Radzieckiemu"226.

222 Th. G. Roberts, History of the NASA Budget...

22.3 Historical Tables, Budget of U.S. Government, U.S. Office of Management and Budget, 2010, s. 22 i 190, https://www.govinfo.gov/content/pkg/BUDGET-2010-TAB/pdf/ BUDGET-2010-TAB.pdf.

$22+$ Th. G. Roberts, History of the NASA Budget...

225 W. A. Mc Dougall, op. cit., s. 321.

226 Ibidem, s. 324. 
Zwiększenie finansowania eksploracji kosmosu korespondowało oczywiście $\mathrm{z}$ dalszym doskonaleniem systemów wojskowych. Już w styczniu 1961 roku Samos 2 jako pierwszy wykonał zdjęcia zwiadowcze wysokiej rozdzielczości, a następnie wywołał je, zeskanował i przekazał na Ziemię za pośrednictwem sygnału radiowego. Rozwijały się także systemy komunikacyjne i nawigacyjne, zyskując coraz większe znaczenie, w następnych latach miały zostać uzupełnione o satelity ze skanerami podczerwieni i z czujnikami radarowymi, mogące dokonywać obserwacji nawet przy braku widzialności powierzchni Ziemi. Pojawiły się także lub zostały odświeżone projekty broni kosmicznych, poczynając od bomb orbitalnych, poprzez satelity inspekcyjne, broń przeciwsatelitarną, do pilotowanego samolotu kosmicznego włącznie.

Jednak większość programów ofensywnych została wstrzymana we wczesnej fazie rozwojowej, ponieważ w latach 1962-1963 ukształtowało się $w$ amerykańskiej administracji przekonanie, że jedynym sensownym i skutecznym oraz perspektywicznym sposobem zapewnienia strategicznego bezpieczeństwa było utrwalenie stanu równowagi, w ramach której obie strony mogą się nawzajem w sposób całkowicie pewny zniszczyćc ${ }^{22}$. Kennedy i McNamara zdawali sobie dobrze sprawę, że mimo zbudowania w krótkim czasie przez USA ogromnego arsenału nuklearnego, ZSRR w końcu będzie w stanie osiągnąć parytet ilościowy, a zatem innego rodzaju polityka bezpieczeństwa nie ma sensu. W szczególności absurdem wydawała się próba utrzymania przewagi strategicznej i oczekiwanie, że ewentualną wojnę jądrową będzie można wygrać. Dlatego też wszystko, co przyczyniałoby się do destabilizacji równowagi strategicznej, musiało być albo porzucone, albo przynajmniej odłożone na później. Tak się stato na przykład $\mathrm{z}$ dobrze znanym projektem samolotu kosmicznego $X$-2o Syna-Soar, anulowanym w 1963 roku, ale i z mniej znanymi koncepcjami utworzenia na orbicie okołoziemskiej oraz na Księżycu baz wojskowych ${ }^{228}$ czy opracowania napędu nuklearnego dla floty bojowych okrętów kosmicznych ${ }^{229}$. Na tej samej zasadzie Amerykanie bardzo mocno

227 Logika znana pod określeniem „wzajemne pewne zniszczenie” - Mutually Assured Destruction (MAD).

228 Por. na przykład B. Brumfield, U.S. reveals secret plans for '6os moon base, CNN, 25.07.2014, http://edition.cnn.com/2014/07/24/us/196os-moon-military-base/.

229 B. Ziarnick, P. Garretson, op. cit. 
sprzeciwiali się radzieckim planom budowy orbitalnych systemów bombardujących, które Moskwa planowała na początku lat sześćdziesiątych. Waszyngton podjął zatem działania, jako swego rodzaju ostrzeżenie, mające na celu rozwój systemu przeciwsatelitarnego bazowania naziemnego na podstawie opracowanego właśnie systemu przeciwrakietowego Nike- Zeus $^{230}$. Kwestie te zgrabnie podsumowuje historyk:

Amerykańska strategia wymagała, aby przestrzeń kosmiczna pozostała sanktuarium dla pasywnych satelitów wojskowych i wolna od "destabilizującej” ją broni [kosmicznej]. Chociaż Związek Radziecki przeciwstawiał się tej formule $w$ doktrynie i praktyce, był wciąż o lata wstecz $w$ technologii. [Sądzono również, że] amerykańska wyrozumiałość mogłaby powstrzymać ZSRR od przeniesienia wyścigu zbrojeń w kosmos, a zatem i przyczynić się do zachowania nienaruszalności satelitów szpiegowskich. Dlatego zasada sanktuarium zdominowała amerykańską wojskową politykę kosmiczną na dwie dekady ${ }^{231}$.

Warto przypomnieć, że logika uznania przestrzeni kosmicznej za sanktuarium nie była wcale nowa, już Eisenhower wzdragał się przed uzbrajaniem kosmosu, postrzegając systemy orbitalne jako szczególnie ważne dla bezpieczeństwa kraju. Miały one sprzyjać skuteczności odstraszania i zapewnić, że przeciwnik nie uzyska zdolności do dokonania pierwszego, obezwładniającego uderzenia na USA. Umożliwić miały zatem zarówno pozyskiwanie informacji i weryfikację ewentualnych porozumień, jak i wczesne ostrzeganie oraz zarządzanie ewentualną walką. Tymczasem samo istnienie operacyjnie sprawnych i rozmieszczonych w militarnie istotnych ilościach broni przeciwsatelitarnych rujnowałoby wszystkie te rachuby i stawiałoby pod znakiem zapytania użyteczność wszystkich pasywnych systemów wraz z korzyściami, jakie przynosiły. Jednocześnie jednak broń ASAT musiałaby powstać, gdyby w kosmosie pojawiło się jakiekolwiek uzbrojenie mogące służyć do ataku na cele naziemne. Żadna ze stron po prostu nie mogłaby sobie pozwolić na zignorowanie orbitujących systemów bojowych przeciwnika, systemy przeciwsatelitarne stałyby się zatem nieuchronnie rzeczywistością.

W wypadku podjęcia zbrojeń w kosmosie nieunikniony jednoczesny rozwój i broni kosmicznej, i przeciwsatelitarnej musiałby więc doprowa- 
dzić do skrajnie destabilizującej sytuacji, w której obie strony dysponowałyby bronią orbitalną, mogącą bardzo szybko zniszczyć przeciwnika na Ziemi. Ów jednak dysponowałby systemami przeciwsatelitarnymi, które bardzo szybko mogłyby zniszczyć broń satelitarną. Powstałaby zatem kolejna wersja równowagi strategicznej, byłaby ona jednak z natury rzeczy jeszcze bardziej krucha niż dotychczasowa wersja MAD, ponieważ obie strony dysponowałyby większą ilością broni o ogromnym potencjale zaskakującego, błyskawicznego i niepowstrzymanego uderzenia. Obie byłyby zatem znacznie bardziej podatne na myślenie w kategoriach use it or lose $i t^{232}$, obawiając się czy to nagłego ataku na własne terytorium, a w szczególności na systemy ASAT i naziemny nuklearny potencjał ofensywny, czy to zaskakującego zniszczenia ofensywnego potencjału $w$ kosmosie. W sensie strategicznym taka sytuacja nie wnosiłaby niczego pozytywnego, byłaby za to niezmiernie destabilizująca, już nie mówiąc o zwiększonym prawdopodobieństwie przypadkowego użycia lub ataku wynikającego z niezrozumienia intencji drugiej strony. Do tego wszystkiego trzeba także dodać horrendalne koszty takich zbrojeń, nie tylko czysto finansowe, ale również wewnątrzpolityczną i społeczną cenę niezbędnych wyrzeczeń. Ten ogromny drenaż budżetu mocarstw byłby absolutnie nieuchronny nie tylko ze względu na niewątpliwie znaczne koszty prac badawczo-rozwojowych oraz niewątpliwie wysoką jednostkową cenę broni kosmicznych, ale także dlatego, że ich konstelacje musiałyby być bardzo liczne, po pierwsze, z oczywistych względów operacyjnych, takich jak liczba głowic względem liczby celów wraz z niezbędną redundancją. Po drugie zaś, ze względu na realia mechaniki orbitalnej - aby utrzymać przez cały czas nad celami na odpowiednio niskich orbitach wymaganą przez realia operacyjne ilość uzbrojenia, należałoby dysponować przynajmniej kilkukrotnie większą liczbą systemów bojowych.

Dlatego też USA bardzo ostrożnie kontynuowały rozwój systemów przeciwsatelitarnych, od marca 1964 roku prowadzono kolejne, wciąż jednak wstępne prace, w ramach których $\mathrm{z}$ wyspy Johnston na Pacyfiku startowały rakiety Thor z prostymi urządzeniami symulującymi przechwytywanie satelitów. Było to swego rodzaju zabezpieczenie, aby, słowami nowego prezydenta Lyndona B. Johnsona, „[...] zapewnić, że żaden naród nie ulegnie pokusie wykorzystania przestrzeni kosmicznej jako miejsca 
bazowania broni masowego rażenia [... ${ }^{233}$. Stany Zjednoczone nie miały jednak najmniejszych intencji podnosić militaryzację kosmosu na wyższy poziom, konstruując kosmiczne bronie, ani też budować broni przeciwsatelitarnej, która mogłaby mieć prowokacyjny charakter ${ }^{234}$.

Podobnie rozumowała w owym czasie strona radziecka, dla której priorytetem było utrzymanie równowagi strategicznej, także w duchu wskazanym powyżej, i dojście do ilościowego parytetu w strategicznych broniach ofensywnych. Tym bardziej że ZSRR nie mógł jednocześnie nagle zrezygnować $\mathrm{z}$ kosztownego wyścigu kosmicznego, ponieważ byłoby to przyznaniem się do porażki. Rosjanie zatem kontynuowali rozwój systemów nośnych i, choć nie przyznawano tego głośno, podjęli de facto wyzwanie księżycowe Kennedy'ego. Pojawiły się także pierwsze radzieckie satelity szpiegowskie serii Kosmos, wysyłane od kwietnia 1962 roku. W sierpniu 1964 roku wystrzelono pierwsze satelity nawigacyjne, natomiast pierwszy satelita komunikacyjny serii Mołnia wystartował w kwietniu 1965.

W związku z tym, że ZSRR osiągnął teoretycznie podobne możliwości jak USA, około 1963 roku obie strony skłaniały się już do akceptacji, przynajmniej faktycznej, jeśli nie werbalnej, tego stanu rzeczy - dotyczyło to także działalności satelitów rozpoznawczych ${ }^{235}$. Ukształtowana sytuacja utrwaliła cechy charakterystyczne porządku kosmicznego w dziedzinie bezpieczeństwa, sprzyjając przy okazji kodyfikacji prawa kosmicznego, która, jak wiemy, niebawem nastąpiła. Dla obu stron systemy orbitalne stały się zatem istotnymi elementami zabezpieczenia skuteczności odstraszania jądrowego, przyczyniając się do stabilności równowagi strategicznej, której żadna ze stron nie miała zamiaru naruszać. Ponadto, $z$ wielu różnych powodów,

[p]ociski rakietowe bazowania lądowego i morskiego były bardziej ekonomiczne, efektywne i łatwiejsze do ukrycia niż bomby na orbicie [...]. W sumie zasady zaakceptowane przez obie strony w pierwszym przypływie odprężenia reprezentowały nie tyle zaprzeczenie własnym doktrynom,

233 Cyt. za: L. Grego, A History of Anti-Satellite Programs, Union of Concerned Scientists, January 2012, s. 2, https://www.ucsusa.org/sites/default/files/legacy/assets/do cuments/nwgs/a-history-of-ASAT-programs_lo-res.pdf.

$23+$ S. B. Johnson, op. cit., s. 532-533.

$2.35 \mathrm{Ibidem}, \mathbf{s} .520$. 
ile raczej akceptację przez ZSRR faktu, że w odniesieniu do rozwoju satelitarnych systemów wsparcia bezpiecznych od obcej ingerencji ma takie same interesy jak Stany Zjednoczone ${ }^{236}$.

Systemy kosmiczne stały się więc nieodłącznym elementem bezpieczeństwa narodowego obu głównych uczestników zimnej wojny, z punktu widzenia bezpieczeństwa międzynarodowego były zatem i istotnym czynnikiem globalnego pokoju. Choć jednocześnie obydwa supermocarstwa prowadziły badania nad wykorzystaniem ASAT i broni satelitarnych, było to jednak traktowane jedynie jako zabezpieczenie na niepewną przyszłość. Strategiczna równowaga wyznaczana przez MAD była zatem wspierana przez pasywne systemy wojskowe, których działanie było zapewnione dzięki brakowi systemów przeciwsatelitarnych, które z kolei wobec nieistnienia broni kosmicznych nie były niezbędne.

Systemy kosmiczne w ich funkcji wspierania równowagi strategicznej zadomowiły się więc na stałe $w$ światowym systemie bezpieczeństwa i do dziś tę funkcję pełnią. Ich dalszy rozwój przyniósł jednak bardzo doniosłe rozszerzenie zadań wykonywanych przez satelity wojskowe w kierunku zastosowań na poziomie operacyjnym, a wreszcie taktycznym. W ramach rozwoju systemów zwiadowczych rosła ich dokładność, rozdzielczość, szybkość transmisji danych i niezależność od warunków atmosferycznych. Systemy łączności stawały się coraz bardziej elastyczne, coraz mniejsze i łatwiejsze w obsłudze odbiorniki pozwalały na umieszczanie ich na coraz mniejszych platformach, aż wreszcie stały się indywidualnym wyposażeniem żołnierza. Pojawiły się także bardzo łatwe w użyciu systemy nawigacyjne, radykalnie zmieniające sytuację jednostek bojowych, a nawet poszczególnych żołnierzy na polu walki.

W związku z tym sukcesywnie rosło znaczenie systemów satelitarnych $\mathrm{z}$ punktu widzenia zabezpieczenia codziennego funkcjonowania i działań bojowych wszystkich rodzajów sił zbrojnych i na każdym szczeblu ich organizacji. Jest to proces o wielkiej doniosłości, ponieważ systemy satelitarne $w$ ten właśnie sposób już w latach osiemdziesiątych stały się niezbędnym force multiplier dla amerykańskich sił zbrojnych i jednym z czynników ich miażdżącej przewagi nad każdym przeciwnikiem. Ten stan rzeczy dowodnie ukazała wojna w Zatoce Perskiej, gdzie 
siły zbrojne w codziennym funkcjonowaniu bojowym w wielkim stopniu wykorzystywały łączność, nawigację i zwiad satelitarny. Notabene cywilne zastosowania kosmosu uczyniły $z$ tego konfliktu wojnę telewizyjną na żywo, co także w sposób spektakularny wykazało codzienne, polityczne znaczenie systemów kosmicznych. Systemy kosmiczne uzyskały więc wyraźnie wymiar taktyczny i operacyjny w dodatku do roli strategicznej, wynikało to $z$ kierunków rozwoju obranych jeszcze w latach pięćdziesiątych, a utrwalonych w latach sześćdziesiątych.

Nie będziemy w tym miejscu szczegółowo zajmować się ewolucją poszczególnych systemów kosmicznych ani nawet ich rodzajów, ponieważ nie ma to znaczenia z punktu widzenia podstawowej logiki wojskowego wykorzystania systemów satelitarnych, która ukształtowała się w pierwszej połowie lat sześćdziesiątych na planie strategicznym, później przechodząc na inne zastosowania i schodząc w dół hierarchii sił zbrojnych. Co więcej, w całym procesie rozwoju systemów satelitarnych, od końca lat pięćdziesiątych aż do dzisiaj obserwujemy jedną tylko poważną próbę uczynienia wyłomu w zasadzie nieuzbrajania kosmosu, uznawanej jako czynnik strategicznej równowagi. Mowa oczywiście o „gwiezdnych wojnach" z lat osiemdziesiątych, które były próbą przewartościowania całej logiki bezpieczeństwa strategicznego, skutkując zmianą stanowiska wobec uzbrajania kosmosu.

Przewartościowanie to polegało na zdecydowanym odrzuceniu ${ }^{237} \mathrm{zna}-$ nego nam paradygmatu ofensywnego, opartego na logice MAD. Zadano sobie zatem pytanie, które publicznie wyraził prezydent Ronald Reagan: co jest lepsze - czy bronić obywateli, czy mścić zabitych?238 Takie postawienie sprawy nie tylko ustanawiało zupełnie inny kontekst moralny dla myślenia strategicznego, ale wymuszało przejście do planowania działań defensywnych. Absurdalna wręcz, jak stwierdzono ${ }^{239}$, logika bezpieczeństwa przez stworzenie zagrożenia dla substancji materialnej i demograficznej wroga miała być zastąpiona całkowicie pewnym uniemożliwieniem skutecznego wykonania zadań przez jego siły zbrojne, gdyby

237 J. S. Gansler, Ballistic Missile Defense. Past and Future, Washington 2010, s. 43.

238 Notabene Reagan nie był autorem tych słynnych słów. Pochodzą one z briefingu admirała Jamesa Watkinsa dla Połączonego Komitetu Szefów Sztabów, w: D. R. Ba u com, Origins of SDI 1944-1983, Lawrence 1992, s. 192.

239 Ibidem, s. 132-133. 
podjęły one agresywne działania. Wymagało to nowatorskiego podejścia i nowych zasad działania systemów przeciwrakietowych, a jedną z cech zaproponowanych koncepcji było właśnie szerokie zastosowanie broni kosmicznych. Mowa tu oczywiście o Strategic Defense Initiative, rozległym programie badawczo-rozwojowym zainicjowanym w 1983 roku, do którego wkrótce przylgnęła nazwa "gwiezdne wojny”.

Podstawą koncepcji zwalczania rakiet balistycznych było wyniesienie walki z nimi w przestrzeń kosmiczną i prowadzenie jej przede wszystkim przy użyciu broni, które potencjalnie były najwygodniejsze do tego celu, czyli właśnie broni kosmicznych. Wydawało się to najbardziej logiczne, że systemy uzbrojenia umieszczone na orbicie okołoziemskiej wraz z odpowiednimi sensorami będą miały najlepszy „wgląd” w to, co robi przeciwnik, najszybciej zatem zareagują na atak, będą też miały najszersze z możliwych "pole ostrzału”. Zastosowanie futurystycznych technologii, takich jak: satelitarne systemy laserowe, orbitujące wyrzutnie rakietowe czy też umieszczona na platformach orbitalnych broń cząsteczkowa, miały zapewnić obronie strategicznej odzyskanie przewagi nad środkami ofensywnymi dzięki pokonaniu ograniczeń, które właściwe były dla dotychczas konstruowanych, wielce nieskutecznych systemów obrony przeciwrakietowej ${ }^{240}$.

„Gwiezdne wojny” zostały natychmiast poddane krytyce, samo zresztą potoczne określenie, które przylgnęło do SDI, miało wydźwięk pejoratywny, przyrównując ów program do opowieści z gatunku science fiction, i to w wybitnie nierealistycznym, a jednocześnie nacechowanym uproszczeniami wydaniu. Krytyka sprowadzała się zasadniczo do dwóch kwestii. Po pierwsze, wynikała $\mathrm{z}$ ogólnego braku wiary $\mathrm{w}$ możliwość stworzenia $w$ pełni skutecznej obrony przeciwrakietowej $w$ realiach zbrojeń nuklearnych ${ }^{241}$, kiedy wystarczy „przepuścić” zaledwie kilka z tysięcy głowic, aby doznać niepowetowanych strat. Po drugie, co w pewnym sensie wynika z pierwszego, pojawiła się obawa o strategiczną stabilność, która

240 Por. bardzo wyczerpującą analizę koncepcji technicznej, operacyjnej i ekonomicznej w: Ballistic Missile Defense Technologies, OTA-ISC-254, U.S. Congress, Office of Technology Assessment, U.S. Government printing Office, Washington DC, September 1985, s. 139-218.

241 Por. bodaj najbardziej udaną i wyczerpującą krytykę w publikacji na podstawie badań Unii Zaniepokojonych Naukowców: The Fallacy of Star Wars, ed. J. Tirma n, New York 1984 . 
zostałaby naruszona w wyniku stworzenia broni satelitarnej i miałaby potencjalnie bardzo niebezpieczne konsekwencje, na co już wskazywaliśmy powyżej.

Projekt jednak rozpoczęto, uruchamiając kilkadziesiąt różnych programów badawczych, stawiając w szczególności na programy laserowe, w które mocno wierzono pomimo krytyki wyrażanej szeroko w kołach

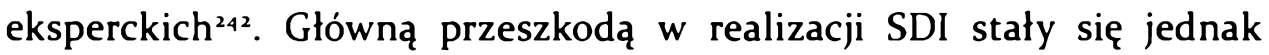
ogromne koszty badań, do których należało oczywiście doliczyć cenę ogromnych konstelacji satelitarnych, niezbędnych z powodów, które już wymieniliśmy. „Gwiezdne wojny” musiałyby być najkosztowniejszym w historii programem zbrojeniowym, którego Stany Zjednoczone nie mogłyby udźwignąć bez radykalnej mobilizacji na zasadzie gospodarki wojennej, a może nawet i to by nie wystarczyło. Ponadto, mimo zapewnień składanych w ramach szerokiej „kampanii promocyjnej”243, napotkano bariery technologiczne, które okazały się nie do przełamania w ramach ówczesnej techniki ${ }^{244}$. Ostatecznie SDI, który od 1990 roku przenosił stopniowo akcent $z$ obrony przed zmasowanym atakiem ze strony ZSRR na obronę przed bardziej ograniczonym atakiem $z$ każdego kierunku ${ }^{245}$, zarzucono $\mathrm{w}$ wyniku przemian politycznych związanych $\mathrm{z}$ ograniczeniem zimnowojennej konfrontacji u schyłku lat osiemdziesiątych, a następnie jej zakończeniem wraz z rozpadem ZSRR i niezdolnością Rosji do kontynuowania konfrontacji z Zachodem.

Kierunek wyznaczony przez "gwiezdne wojny” kontynuował projekt Global Protection Against Limited Strikes ${ }^{246}$. Program ten zrodził się w 1991 roku, już po likwidacji SDI, a miał za zadanie stworzyć globalne zdolności do obrony przed ograniczonymi atakami rakietowymi. Jego podjęcie wynikało z percepcji zagrożenia proliferacją rakietowych pocisków balistycznych $w$ różnych regionach świata, czego znaczenie pokazała dowodnie wojna w Zatoce Perskiej w 1991 roku. W jej trakcie okazało się, że zarówno amerykańskie siły zbrojne, jak i regionalni partnerzy USA

242 C. Peoples, Justifying Missile Defence, Cambridge University Press 2010 (Kindle Edition), s. 137.

243 Ibidem, s. 149.

$24+$ R. D. Burns, The Missile Defense Systems of George W. Bush: A Critical Assessment, Santa Barbara-Denver-Oxford 2010, s. 41 i n.

245 M. Mow thorpe, op. cit., s. 20.

246 GPALS - Globalna Obrona przeciw Ograniczonym Atakom. 
znajdują się pod ciągłym i trudnym do powstrzymania zagrożeniem rakietami balistycznymi krótkiego i średniego zasięgu. I to pomimo potęgi Stanów Zjednoczonych, które musiały zacząć liczyć się z rosnącą siłą relatywnie słabych państw, jeśli tylko w swoich arsenałach posiadały one rakiety balistyczne. Znaczna część potencjału GPALS miała mieć postać broni orbitalnych i sensorów kosmicznych ${ }^{247}$, lecz i w tym przypadku koszty i trudności techniczne uniemożliwiły realizację projektu, który wkrótce został zarzucony na rzecz bardziej konwencjonalnych rozwiązań.

Program SDI i jego następca, mimo że nie doprowadziły wprost do skonstruowania jakiejkolwiek efektywnej broni, nie były jednak całkowitym marnotrawstwem funduszy. $W$ jego ramach przeprowadzono wiele badań podstawowych, powstały także ważne technologie, które zarówno pchnęły do przodu przemysł wojskowy, jak i miały zastosowania cywilne. Wiele $\mathrm{z}$ nich znajdzie swoje miejsce także $\mathrm{w}$ dalszych badaniach nad kolejnymi zastosowaniami wojskowymi systemów kosmicznych i, szerzej, nad technologią satelitarną. Co jednak najważniejsze, mimo próby przewartościowania logiki bezpieczeństwa narodowego, MAD utrzymał się jednak jako najbardziej praktyczna strategia, a co za tym idzie - utrzymano zasadę biernej jedynie militaryzacji kosmosu.

\subsection{Podsumowanie}

Podsumowując krótko to, co z omówionych procesów historycznych ma największe znacznie dla dalszego ciągu naszych rozważań, należy zwrócić uwagę na następujące kwestie.

Praktyczne korzyści vs prestiz

Od samego początku ery kosmicznej obecne były dwa podejścia do eksploracji kosmosu. Pierwsze z nich to akcent na praktyczne korzyści, które w pierwszej kolejności wyciągano na polu wojskowym, co wynikało z sytuacji politycznej i uwarunkowań wynikających z potrzeb bezpieczeństwa narodowego. Ponadto państwo było tu podmiotem, który był 
w stanie udźwignąć ogromne koszty badań rozwojowych i opracowania zupełnie nowych, rewolucyjnych technologii, nic zatem dziwnego, że wykorzystało je przede wszystkim w ramach swojej podstawowej funkcji, jaką jest funkcja ochronna. W związku z tym

[p]ierwsza era kosmiczna [...] była w dużej mierze historią strategicznych potrzeb zimnej wojny. Oczywiście, ludzka ciekawość i gotowość do poszukiwania przygód [...] niewątpliwie przywiodłyby do kosmicznej eksploracji, bez względu na zimną wojnę. Niemniej jednak sposób i tempo, w jakim kosmos został wyeksplorowany i wykorzystany w czasie pierwszej ery kosmicznej, był skutkiem zapotrzebowania wojskowych ${ }^{248}$.

Drugi wymiar eksploracji kosmosu to walka o prestiż, który wiąże się z tym, że wszelka działalność kosmiczna nie tylko działa na wyobraźnię jako taką, ale także w powszechnej świadomości kojarzy się z wysokim rozwojem technologicznym, ekonomicznym i społecznym. Nic dziwnego, że określenie „kosmiczna technologia” nie tylko mówi o jej pochodzeniu, ale także jest $w$ nim element zachwytu nad czymś szczególnym i niezwykłym. Prestiż wynikający z eksploracji kosmosu jest zatem niezwykle przydatnym instrumentem oddziaływania społecznego i politycznego, nie do przecenienia $w$ ramach międzynarodowej konkurencji. Ten wymiar jest szczególnie ważny dla słabszych państw i narodów, które w propagandzie i politycznym oddziaływaniu upatrują szansy na poprawienie swojej relatywnej pozycji względem tradycyjnych potęg o ugruntowanym statusie międzynarodowym. Stąd właśnie podejście ZSRR do propagandowej strony eksploracji kosmosu i radziecka polityka w tym zakresie.

Obydwa podejścia ważne są i dzisiaj, kiedy patrzymy na przykład na program kosmiczny Chin, ma on dokładnie taki sam, dualny charakter. $\mathrm{Z}$ jednej strony buduje się praktyczne zdolności w zakresie zastosowań satelitarnych, rozwoju systemów nośnych etc., z drugiej zaś - Pekin nie zaniedbuje spektakularnych sukcesów, takich jak na przykład pierwsze lądowanie na odwrotnej stronie Księżyca przeprowadzone przez chińską sondę w 2019 roku.

248 W. W. S. Wong, J. Fergusson, Military Space Power. A Guide to the Issues, Santa Barbara-Denver-Oxford 2010. 
Wyścig kosmiczny

Zjawisko to miało $w$ istocie nieco inny przebieg, niż to się na ogół przedstawia, co wynika z tego, że większość praktycznych korzyści z eksploracji kosmosu była przez dekady utajniona, w przeciwieństwie do szeroko rozgłaszanych osiągnięć propagandowych. Dlatego też zwykło się sądzić, że ZSRR prowadził w tym wyścigu przez co najmniej dwie dekady, co jest prawdą jedynie w wymiarze prestiżowym, i to co najwyżej do połowy lat sześćdziesiątych. Amerykańskie osiągnięcia w konstruowaniu ciężkich rakiet nośnych, wraz z programem księżycowym i misjami międzyplanetarnymi, szybko przyćmiły radzieckie sukcesy. Przypieczętowało go w latach osiemdziesiątych wprowadzenie do użytku STS, czyli systemu transportu kosmicznego opartego na pojeździe wielorazowego użytku, zwanym potocznie promem kosmicznym (space shuttle), oraz sieci nawigacji satelitarnej GPS. Oba osiągnięcia szybko trafiły „do cywila”, stając się ponadto jednymi $z$ najbardziej rozpowszechnionych symboli nowoczesności. Uzupełniło to wcześniejsze cywilne zastosowania systemów kosmicznych, które także wyszły z USA, takich jak satelity meteorologiczne, telekomunikacyjne i retransmisyjnych, które pojawiły się jako państwowe i komercyjne przedsięwzięcia jeszcze w latach sześćdziesiątych i siedemdziesiątych.

Drugi wymiar wyścigu kosmicznego, w którym USA prowadziły od samego początku, miał wymiar praktyczny i choć mniej widoczny, a w dużej części utajniony, był on w istocie rzeczy ważniejszy. Stany Zjednoczone prowadziły w nim od samego początku, ponieważ miały znacznie lepszą bazę przemysłową, naukową i edukacyjną, Amerykanie o wiele rozsądniej alokowali także zasoby, których zresztą mieli zdecydowanie więcej niż Rosjanie. Od pierwszych discovererów USA pozostawały w o wiele lepszej pozycji niż ZSRR, wyciągając nieprównanie więcej praktycznych korzyści z eksploracji kosmosu.

Wyścig kosmiczny zapoczątkowany w planie propagandowym startem Sputnika 1 w październiku 1957 roku, a w praktyce uruchomiony jeszcze wcześniej, zakończył się zatem wraz z upadkiem ZSRR, choć przypieczętowany został już u swojego zarania. Nie jest on jednak całkowicie kwestią przeszłości. W XXI wieku rysują się nowe osie mocarstwowej rywalizacji, która ma także swój wymiar w postaci konkurencji w przestrzeni 
kosmicznej ${ }^{249}$. W nieco zmienionej formie pojawiają się nam te same mechanizmy i sposoby podejścia do eksploracji kosmosu jak w przeszłości.

\section{Charakter militaryzacji kosmosu}

W pierwszych latach ery kosmicznej ukształtowały się także podstawowe cechy charakterystyczne wojskowego wykorzystania przestrzeni kosmicznej, które utrzymują się do dziś. Najważniejszą, definiującą cechą jest to, że przestrzeń kosmiczna, jakkolwiek szeroko wykorzystywana w celach wojskowych, wolna jest jednak od broni w tym sensie, że w przestrzeni kosmicznej nie stacjonuje się żadnego uzbrojenia. Poza małokalibrowym działkiem testowanym przez ZSRR, w które miały być wyposażone stacje kosmiczne ${ }^{250}$, oraz strzelbami, które były na wyposażeniu radzieckich załogowych lądowników na wypadek ich przyziemienia w dzikim terenie ${ }^{251}$, nic nie wiadomo o wyniesieniu na orbitę okołoziemską jakiejkolwiek innej broni.

Stało się tak w wyniku splotu praktycznych i finansowych czynników, choć $w$ sensie technicznym opracowanie broni orbitalnych, szczególnie do bombardowania powierzchni Ziemi, było możliwe już w latach sześćdziesiątych. Broń orbitalna byłaby bowiem niesłychanie droga, wnosiłaby także stosunkowo niewiele pozytywnego w stan równowagi strategicznej, miałaby natomiast ogromny potencjał destabilizujący. Jej powstanie wymusiłoby także rozwój systemów przeciwsatelitarnych, które nie tylko mogłyby zniweczyć jakiekolwiek korzyści z posiadania broni na orbicie, ale także zwiększyłyby potencjał destabilizacji.

W związku z tym, w świetle relacji koszt - efekt, oba mocarstwa poprzestały na korzyściach wynikających z militaryzacji biernej, nie chcąc ich narażać, co niechybnie by nastąpiło w wyniku uruchomienia w kosmosie mechanizmu wyścigu zbrojeń oraz jednoczesnego wyścigu broń

244 Por. M. Czajkowski, Nowy wyścig kosmiczny XXI w. - USA, Chiny i Rosja, „Krakowskie Studia Międzynarodowe" 2018, nr 1, s. 117-141.

250 A. Zak, Here Is the Soviet Union's Secret Space Cannon, Popular Mechanics, 16.12.2015, https://www.popularmechanics.com/military/weapons/a18187/here-is-the-sovietunions-secret-space-cannon/.

251 Soviet Cosmonauts Carried a Shotgun Into Space, War Is Boring, 24.08.2017, https:// warisboring.com/soviet-cosmonauts-carried-a-shotgun-into-space/. 
kosmiczna vs broń przeciwsatelitarna. Prowadzono wprawdzie pewne prace badawcze w tym zakresie, lecz miały one charakter bardzo ograniczony, traktowane były raczej jako polisa ubezpieczeniowa, aby nie dać się zaskoczyć jakiemuś nagłemu przełomowi skrycie dokonanemu przez przeciwnika.

Ten mechanizm jest niezmiernie ważny po dziś dzień, ponieważ podejście do militaryzacji czynnej kosmosu i związana z nim ściśle kwestia broni przeciwsatelitarnych pozostały niezmienne. Wprawdzie obserwujemy obecnie odnowienie w Stanach Zjednoczonych dyskusji o broni kosmicznej, następuje także proliferacja technologii przeciwsatelitarnych, która znajduje się już nie tylko na wyposażeniu USA i Rosji, ale także Chin i Indii. Istnieje także ryzyko, że wejdą w jej posiadanie kolejne kraje, a nawet perspektywicznie uczestnicy niepaństwowi ${ }^{252}$, lecz podstawowe realia operacyjne i ekonomiczne pozostaną niezmienione. Istnieje zatem prawdopodobieństwo, że w zmodyfikowanej formie zasada nieuzbrajania kosmosu pozostanie w mocy, choć możliwa jest diametralna zmiana sytuacji w nadchodzących dekadach.

252 Por. M. Czajkowski, Non-State Actors.., s. 119-134. 


\section{4. \\ Przestrzeń kosmiczna \\ we współczesnej strategii bezpieczeństwa USA}

Dotychczasowe rozważania wykazały, jak się zdaje, dowodnie, użyteczność przestrzeni kosmicznej w ramach różnorodnych działań człowieka, a $w$ szczególności $w$ realizacji zadań $z$ zakresu bezpieczeństwa narodowego $w$ wymiarze zewnętrznym. Te rozważania, wraz $z$ przedstawioną również refleksją teoretyczno-pojęciową oraz analizą genezy militarnego zastosowania kosmosu przez USA, prowadzą nas logicznie do niniejszego rozdziału. Ma on za zadanie ukazać, w jaki sposób obecnie zastosowania kosmiczne przyczyniają się do bezpieczeństwa narodowego USA, a zatem jak wygląda i w jaki sposób działa amerykańska spacepower. Oczywiście spacepower w specyficznym, przyjętym przez nas rozumieniu, obejmującym nie tyle kosmiczny hardware i to, co może on zrobić, ile raczej to, w jaki sposób całokształt zastosowań militarnych może być i jest instrumentem szeroko pojętej polityki i strategii bezpieczeństwa. Nie będziemy zatem koncentrować się na szczegółowych analizach technicznych i operacyjnych dotyczących poszczególnych systemów kosmicznych, ponieważ patrzymy na problem bezpieczeństwa narodowego bardziej z punktu widzenia politycznego niż wojskowego. Szukamy zatem raczej odpowiedzi na pytanie o rolę zastosowań kosmicznych w polityce i strategii, ich znaczenie i to, w jaki sposób przyczyniają się do realizacji różnorodnych zadań w sferze bezpieczeństwa, a nie technicznych opisów konkretnych typów systemów satelitarnych. To ostatnie oczywiście także się pojawi, ale w niewielkim zakresie, raczej jako ilustracja zasadniczego wywodu, nie zaś jako jego główny cel. 
Odpowiadając na powyższe, ogólnie zarysowane pytanie o kształt i rolę amerykańskiej spacepower jako instrumentu polityki militarnej, musimy w pierwszej kolejności pokazać, jak wygląda strategia bezpieczeństwa USA i co warunkuje jej kształt i ewolucję. W szczególności zaś musimy przedstawić rolę instrumentu militarnego $w$ tej strategii, a dopiero $\mathrm{w}$ dalszej kolejności można dokładniej zastanawiać się nad tym, jakie miejsce $\mathrm{w}$ ramach tegoż instrumentu militarnego mają zastosowania systemów kosmicznych. Takie podejście wydaje się ze wszech miar uzasadnione, $\mathrm{z}$ braku tych ogólniejszych rozważań nasza zasadnicza tematyka byłaby oderwana od podstawowych kontekstów, które decydują o kształcie i znaczeniu przestrzeni kosmicznej dla działalności człowieka w interesującej nas dziedzinie.

Poniżej zajmiemy się zatem najpierw, oczywiście w kategoriach najbardziej ogólnych, kwestią jak najbardziej podstawową, czyli strategią bezpieczeństwa USA. Dalej pokażemy doktrynalną stronę polityki kosmicznej i polityki bezpieczeństwa kosmicznego USA na tle podstawowych dokumentów określających kształt doktryny bezpieczeństwa i doktryny wojskowej Stanów Zjednoczonych. Wreszcie postaramy się podsumować i ogólnie scharakteryzować całe zagadnienie, wskazując na realną rolę i stan militaryzacji kosmosu oraz jej perspektywy i ograniczenia z punktu widzenia USA.

\subsection{Strategia bezpieczeństua narodowego USA - ewolucja i ogólne uwarunkowania}

W ostatnich latach strategia bezpieczeństwa narodowego USA stała się przedmiotem szczególnie gorącej debaty. Wskazuje się zarówno na wewnętrzne, jak i międzynarodowe przesłanki jej aktualnej ewolucji i rozważa rolę, jaką Ameryka winna odgrywać na scenie globalnej. W ramach tej dyskusji należy jednak przypomnieć, że szersze analizy kontekstu historycznego wykazują, iż mimo wielu meandrów i zmian polityka zagraniczna i bezpieczeństwa USA charakteryzowała się znaczną ciągłością, szczególnie widoczną po II wojnie światowej. Ta konstatacja jest niezwykle istotna $z$ dwóch powodów. Po pierwsze, wszelkie prognozy dotyczące przebiegu przyszłych procesów powinny także uwzględniać potencjał ciągłości, istniejący pomimo ogromnych i spektakularnych zmian zacho- 
dzących we współczesnym świecie. Po drugie zaś, prześledzenie ewolucji amerykańskiej polityki zagranicznej i polityki bezpieczeństwa narodowego w wymiarze zewnętrznym pozwala lepiej zrozumieć jej obecny kształt, ale też kierunki zachodzących zmian. Jest to szczególnie istotne z punktu widzenia przedmiotu niniejszej pracy, w której nie zajmujemy się analizą konkretnych wydarzeń, lecz staramy się określić rolę i znaczenie pewnego instrumentu realizowania polityki bezpieczeństwa oraz polityki zagranicznej, a więc ujmujemy interesujące nas problemy z szerokiej perspektywy.

Niniejszy podrozdział ma stanowić najbardziej ogólne tło dalszych rozważań, nakreślimy zatem najpierw w największym skrócie ewolucję strategii bezpieczeństwa USA, następnie jej najbardziej charakterystyczne cechy współczesne, a wreszcie dające się obecnie zidenty fikować czynniki zmiany. Rozumiemy oczywiście, że jest to tematyka bardzo dobrze znana, szeroko opisana i nieustannie podejmowana w różnorodnych publikacjach, jej kolejny opis może zatem wyglądać nieco banalnie. Wydaje nam się jednak, że w całościowym ujęciu, jakie stara się zaprezentować niniejsza praca, temat ten powinien się znaleźć dla zachowania kompletności wywodu, jako istotny punkt odniesienia do dalszych rozważań.

Piszemy jednak o tym przede wszystkim dlatego, że głównym przedmiotem naszego zainteresowania jest spacepower, rozumiana jako zdolność do wykorzystania przestrzeni kosmicznej w ramach realizacji strategii bezpieczeństwa narodowego w wymiarze zewnętrznym, a zatem w kategoriach militarnych. Musimy zatem dobrze rozumieć, jak działa i jakie ma cechy charakterystyczne ów militarny instrument oddziaływania w związku z charakterystycznymi cechami strategii bezpieczeństwa i polityki zagranicznej. Bez tego trudno będzie wykazywać rolę i znaczenie systemów kosmicznych w polityce bezpieczeństwa USA.

Kształtowanie się militarnego instrumentu polityki zagranicznej

Stanów Zjednoczonych

Od czasu umocnienia niepodległości w początkach XIX wieku przez prawie stulecie USA realizowały stosunkowo prostą politykę w stosunku do swojego otoczenia. Sprowadzała się ona do rozrostu terytorialnego państwa oraz do tworzenia i umacniania strefy wpływów na zachodniej 
półkuli. Polityka ta nie napotykała w XIX wieku poważniejszych przeszkód, jako że dotyczyła słabo zorganizowanych grup pierwotnych mieszkańców Ameryki Północnej oraz posiadłości europejskich imperiów kolonialnych, z wyjątkiem brytyjskiego słabnących już lub będących w stanie rozpadu. Później pojawiły się także słabe wewnętrznie i targane ogromnymi problemami państwa niepodległe powstałe na gruzach kolonii hiszpańskich. W związku z tym Stany Zjednoczone w zasadzie nieniepokojone $z$ zewnątrz rozrastały się terytorialnie oraz rozwijały wewnętrznie mimo pewnych sprzeczności wewnątrzpolitycznych i znacznych czasami zaburzeń gospodarczych. XIX wiek był zatem okresem tworzenia się ogromnej i zróżnicowanej gospodarki oraz budowania zamożności mieszkańców, przedsiębiorstw i wreszcie samego państwa. Przez większość wieku rozwój ten oparty był jednak na zasobach wewnętrznych i rozwoju rynku krajowego, sukcesywnie sięgającego także do konsekwentnie umacnianej strefy wpływów obejmującej w szczególności Amerykę Środkową i Amerykę Południową. Aktywna, złożona i rozbudowana geograficznie polityka zagraniczna nie była potrzebna, nie spieszono się zatem z tworzeniem zaawansowanych jej narzędzi. Instrument militarny nie miał więc nawet $\mathrm{w}$ przybliżeniu takiego znaczenia jak w przypadku ówczesnych państw europejskich.

Wspomniany rozwój z czasem przełożył się na wzrost znaczenia USA z punktu widzenia innych państw rozwiniętych, a także na wzrost roli handlu zagranicznego w rozwoju gospodarki amerykańskiej. Już w ostatnich dekadach XIX wieku poszukiwała ona surowców i rynków zbytu poza tradycyjnym obszarem zainteresowania wyznaczanym doktryną Monroego. Ze względu na geograficzne oddalenie i skomplikowane stosunki międzynarodowe w nowych obszarach zainteresowania, szczególnie na Dalekim Wschodzie, do poparcia interesów ekonomicznych potrzebna była coraz bardziej złożona i coraz bardziej aktywna polityka zagraniczna. Rodziła ona $z$ kolei nie tylko coraz to nowsze wymagania dotyczące instrumentów jej popierania, ale także zagrożenia, które wymagały określonej odpowiedzi. Jednym z kluczowych narzędzi rozszerzającej się polityki zagranicznej i strategii bezpieczeństwa USA stać się musiała flota wojenna, co wynikało z oczywistych przesłanek geograficznych. Potrzebna była także, co również oczywiste, doktryna jej zastosowania, zarówno w czasie wojny, jak i w warunkach pokoju. 
Warto podkreślić ten moment $\mathrm{w}$ historii i mechanizm, jaki nam się w nim ukazuje, ponieważ dobrze ilustruje on relację pomiędzy rozwojem instrumentu militarnego a zapotrzebowaniem na aktywną politykę zagraniczną, wyznaczaną z kolei potrzebami ekonomicznymi. Druga połowa XIX wieku była okresem gwałtownego zwiększania się wymiany handlowej w świecie, w której rozwijające się USA miały rosnący udział. Handel międzynarodowy odbywał się oczywiście głównie drogami morskimi, a co za tym idzie - państwa posiadające znaczne floty wojenne, w pierwszej kolejności Wielka Brytania, zdolne były do kontrolowania w pewnym zakresie przepływu towarów oraz zapewniania bezpieczeństwa swoim interesom na drogach oceanicznych. $\mathrm{Z}$ punktu widzenia amerykańskich interesów przedmiotem rosnącego zainteresowania były przede wszystkim Chiny, sukcesywnie otwierane na handel międzynarodowy po wojnach opiumowych z lat 1840-1842. Chcąc jednak wesprzeć ekspansję na Dalekim Wschodzie i zabezpieczyć swoje interesy na morskich szlakach komunikacyjnych, Stany Zjednoczone musiały, z oczywistych przyczyn, posiadać flotę wojenną. Tymczasem po wojnie secesyjnej U.S. Navy składała się z niewielu jednostek, w większości o charakterze przybrzeżnym, była też niechętnie finansowana przez Kongres i słabo wyposażona.

Jednak ekonomiczne potrzeby zrodziły polityczne zapotrzebowanie, a to przełożyło się na konkretną politykę militarną, która w sposób systematyczny i z rosnącym rozmachem realizowana była od 1883 roku, kiedy to rozpoczęto pierwszy program rozbudowy floty wojennej. Spektakularny rozwój U.S. Navy obrazują proste liczby: w 1886 roku posiadała ona 48 okrętów, w tym zaledwie jeden krążownik, dziesięć lat później pomiędzy 59 okrętami znajdowało się już 16 krążowników i 5 pancerników, w 1906 roku USA dysponowały zaś flotą 180 okrętów, w tym 18 pancerników i 27 krążowników ${ }^{253}$. W okresie I wojny światowej marynarka USA miała już potencjał w przybliżeniu równy Royal Navy. W ciągu czterech dekad pojawił się więc potężny instrument militarny, stworzony planowo w związku z określonymi potrzebami politycznymi i ekonomicznymi. Jednocześnie, co niebagatelne, rozwijała się doktryna użycia sił morskich, której ojcem niewątpliwie był Alfred Thayer Mahan. Był on jednak nie

253 US Ship Force Levels, 1886-present, Naval History and Heritage Command, 17.11.2017, https://www.history.navy.mil/research/histories/ship-histories/us-ship-force-levels. html. 
tylko twórcą strategii prowadzenia nowoczesnej wojny morskiej, ale także wskazywał na marynarkę wojenną jako na instrument bieżącej polityki, wspierający zamorskie wpływy i kontrolujący ważne dla kraju szlaki handlowe. Mahan skonstruował także pojęciową podbudowę pod pojęcie seapower, które obejmuje nie tylko kwestie dotyczące floty wojennej w sensie jej zdolności bojowej. Składają się na nie także różnego rodzaju warunki niezbędne dla tworzenia ogólnej potęgi morskiej państwa, poczynając od warunków naturalnych, poprzez zdolności gospodarki, charakter rządów, do ogólnego nastawienia społeczeństwa do spraw związanych z morzem.

Warto jeszcze raz zaakcentować istotną relację pomiędzy określonym zapotrzebowaniem a realizacją konkretnej polityki, która jest podstawą do zrozumienia roli instrumentu militarnego polityki państwa w kontekście szerszym niż tylko jako narzędzia prowadzenia wojny. Widzimy zatem, jak w drugiej połowie XIX wieku uwarunkowania ekonomiczne i polityczne stworzyły zapotrzebowanie na siły zdolne popierać określone interesy w różnych okolicznościach. W czasie pokoju miały one zapewniać bezpieczeństwo państwa, swoją potęgą odstraszając agresorów, dyscyplinować rosnącą i rozciągającą się coraz dalej od własnego terytorium strefę wpływów oraz uczestniczyć w miarę potrzeb w zabezpieczeniu globalnych szlaków komunikacyjnych. W razie wojny marynarka miała prowadzić działania zapewniające bezpieczeństwo terytorium kraju, zwalczać zagrożenia dla interesów zamorskich, rozszerzać strefę wpływów, bronić szlaków komunikacyjnych. Warto dodać, że w ciągu czterech dekad budowy floty, która praktycznie od zera wyrosła na pierwszoplanową światową potęgę, USA dorobiły się także rozległego zaplecza przemysłowego i technologicznego dla rozwoju marynarki wojennej, która zakotwiczyła się także mocno w świadomości społecznej. To właśnie seapower jako wszechstronny instrument polityki państwa kluczowy do dzisiaj, w podobny sposób rozumiemy także spacepower.

I i II wojna światowa stanowią razem ważną cezurę w amerykańskiej polityce zagranicznej, także w kontekście roli i znaczenia instrumentu militarnego. Zmiana, która nastąpiła, nie polegała jednak na zmianie ogólnej logiki celów i interesów USA, lecz raczej zasięgu prowadzonej polityki i wobec tego zasięgu oddziaływania instrumentu militarnego. Ten ostatni ewoluował także w sensie techniczno-organizacyjnym w związku z ewolucją powierzanych mu zadań, polegającą głównie na ich rozsze- 
rzeniu i komplikowaniu w sensie organizacyjnym, technicznym i geograficznym. Istotna była także szybka ewolucja technologiczna, której najbardziej widocznymi skutkami były rozwój lotnictwa, techniki rakietowej i broni masowego rażenia, w szczególności broni jądrowej.

Zauważmy, że do tej pory Waszyngton starał się dbać o szlaki komunikacyjne i pozycję polityczno-handlową na Dalekim Wschodzie, do czego potrzebna była flota wojenna i sieć baz w odpowiednich miejscach, ewentualna konfrontacja spodziewana była tylko z Japonią, do czego przygotowywano siły i plany operacyjne. Znaczenie ekonomiczne USA w innych regionach także rosło, ale wobec silnej pozycji i aktywnej polityki innych mocarstw, a szczególnie Wielkiej Brytanii, obecność polityczna i wojskowa USA nie była potrzebna w innych obszarach.

Pierwszym zwiastunem zmian tego stanu rzeczy była I wojna światowa, która znacząco osłabiła Wielką Brytanię, a także przyczyniła się do powstania III Rzeszy i ZSRR, które aktywnie zakwestionowały nie tylko sam kształt porządku światowego, lecz także jego podstawowe zasady. Rysująca się konkurencja ideologiczna była czymś nieznanym od czasów rewolucji francuskiej, jej skala i ewentualne następstwa były zresztą trudne do porównania. Nie trzeba w tym miejscu szeroko rozwodzić się nad faktem, jak bardzo świat amerykański i reguły go określające nie zgadzały się z wizją radziecką czy tą reprezentowaną przez nazistowskie Niemcy.

Już zatem w okresie międzywojennym wielu Amerykanów zdawało sobie sprawę z nieuchronności większego zaangażowania globalnego, leżącego zresztą w najlepiej pojętym interesie samej Ameryki, co z kolei musiało pociągnąć wzrost znaczenia instrumentu militarnego. Instrument ten miał jednak wykonywać co do zasady te same zadania w czasie pokoju i wojny jak dotychczas, lecz na rozleglejszym obszarze i wobec bardziej złożonych i poważniejszych zagrożeń. Już zatem w okresie przed II wojną światową USA przygotowywały się do aktywniejszej polityki i starcia z bardziej wymagającymi przeciwnikami. Czyniły to, nie tylko dbając o dalszy rozwój floty wojennej, ale także planując znaczną rozbudowę lotnictwa strategicznego, którego zadaniem miało być w pewnym sensie uzupełnienie marynarki poprzez przeniesienie zdolności oddziaływania sił zbrojnych daleko w głąb lądu.

Zgodnie z przypuszczeniami po II wojnie światowej, wobec wzrostu znaczenia Związku Radzieckiego i ewolucji jego polityki w kierunku globalnej ekspansji, USA zmuszone były rozciągnąć politykę kontroli 
strefy wpływów na cały świat. Wzmocniony po wojnie ZSRR, mimo że znacznie słabszy niż USA, był bardzo poważnym przeciwnikiem, między innymi dzięki temu, że ze względu na swoje cechy zdolny był do znacznej mobilizacji wysiłków. Zdolność ta łatwo przekładała się na instrumenty, jakie ZSRR budował w celu przeciwdziałania amerykańskim wpływom oraz stworzenia zagrożenia wobec terytorium i interesów USA.

Możemy zatem ponownie zaobserwować, jak na przestrzeni dwóch dekad lat trzydziestych i czterdziestych ewoluowało zapotrzebowanie na instrument militarny wynikające ze zmieniających się potrzeb bezpieczeństwa. Globalne interesy USA i globalne zagrożenie ze strony ZSRR wymagały dostosowania amerykańskiego instrumentu militarnego do realizacji zadań wprawdzie podobnych co do zasady, lecz bardziej skomplikowanych technicznie i organizacyjnie. Amerykańskie siły zbrojne musiały zatem rozszerzyć swoją infrastrukturę, zoptymalizować strukturę i zaadaptować doktrynę, aby móc wykonywać zadania w czasie wojny i pokoju o większym stopniu trudności i złożoności oraz na znacznie większą skalę. Zadania te jednak co do zasady pozostały niezmienne: zapewnienie bezpieczeństwa terytorium oraz zabezpieczenie stref wpływów i szlaków komunikacyjnych. Dostosowana do tego doktryna globalnego zaangażowania, opierająca się na doktrynie powstrzymywania wygenerowała także bardziej szczegółowe skutki w postaci doktryny użycia sił zbrojnych. W tej ostatniej coraz większą rolę odgrywało lotnictwo, w dodatku do marynarki, ale i tradycyjnie upośledzone siły lądowe umacniały swoje znaczenie, co wynikało ze stałej obecności wojskowej USA w poszczególnych regionach. Ówczesny szef sztabu U.S. Army, generał George C. Marshall, w swoim sprawozdaniu dla Kongresu dotyczącym wygranej wojny następująco ujął charakterystyczne cechy strategicznej pozycji USA w nowych czasach:

Technika wojny przywiodła Stany Zjednoczone, [amerykańskie] domostwa i fabryki na linię frontu konfliktu światowego.

[...]

Wydaje się zatem, że to, co uznawaliśmy wcześniej za satysfakcjonującą podstawę naszego bezpieczeństwa, czyli obrona zachodniej półkuli, nie jest do utrzymania. Dziś zajmujemy się pokojem całego świata. A pokój mogą utrzymać tylko silni ${ }^{254}$.

254 General Marshall's Report: The Winning of the War in Europe and the Pacific, U.S. War Department, 1945, s. 118. 
Mimo zmieniających się okoliczności widzimy zatem znaczną ciągłość w polityce bezpieczeństwa USA, która w zmieniających się politycznych i gospodarczych okolicznościach nabrała jedynie większego zasięgu i skomplikowała się w praktycznej realizacji. Najistotniejszym czynnikiem zmian w tej polityce nie był jednak sam jej zasięg, poziom zaangażowania czy też inne kwestie praktyczne. Najważniejsze były przewartościowania w warstwie mentalnej. Po pierwsze, ogromny wysiłek wojenny w czasie II wojny światowej i mobilizacja z niego wynikająca zaowocowała „bezprecedensowym publicznym zainteresowaniem zasadami organizacji bezpieczeństwa międzynarodowego i w dodatku publicznym zapotrzebowaniem, aby Stany Zjednoczone pozostały po wojnie silniejsze wojskowo niż w przeszłości"255. Po drugie, pojawił się śmiertelny, potężny przeciwnik, którego dokonania w czasie II wojny światowej były imponujące, a potencjał rozbudzał wyobraźnię. Po trzecie wreszcie, rozwój techniki dostarczył technologii, dzięki którym można było przenosić działania zbrojne na wielkie dystanse oraz dokonywać uderzeń z siłą dotychczas nieznaną, co zaowocowało pojawieniem się po raz pierwszy w historii zagrożenia terytorium USA - i od razu zagrożenie to uzyskało charakter egzystencjalny. Bez względu na to, jak mało bomb i bombowców, a potem rakiet strategicznych ZSRR posiadał, samo ich istnienie działało na świadomość ludzi. Dzięki tym przemianom w społecznej mentalności USA były zdolne po zakończeniu II wojny światowej utrzymać siły zbrojne na poziomie kilkukrotnie wyższym niż przed wojną, zarówno w ujęciu ilościowym, jak i pod względem udziału wydatków wojskowych w PKB ${ }^{256}$. Jak zauważył amerykański historyk, „[s]koro Stany Zjednoczone nie mogły już odgrodzić się od świata i dzielić się amerykańskim eksperymentem jedynie za pomocą przykładu, musiały kierować światem poprzez bardziej aktywne wykorzystanie swojej siły i promowanie swoich wartości"257.

Podsumowując, powtórzmy, że instrument militarny ukształtował się jako jedno z kluczowych narzędzi wsparcia politycznych wpływów, które z kolei wynikały z interesów ekonomicznych. Siły zbrojne zyskały zatem

255 G. Kirk, National Power and Foreign Policy, „Foreign Affairs”, July 1945, http://www. foreignaffairs.com/articles/70436/grayson-kirk/national-power-and-foreign-policy.

256 D. Walker, Trends in U.S. Military Spending, Council on Foreign Relations, 15.07.2014, https://www.cfr.org/report/trends-us-military-spending.

$25 ;$ Ch. A. Kupchan, The Clash of Exceptionalisms: A New Fight Over an Old Idea, „Foreign Affairs", March/April 2018, s. 142. 
szersze znaczenie niż tylko jako narzędzie obrony własnego terytorium. Wymagało to oczywiście dostosowania tego instrumentu do realizowanych przezeń nowych zadań, w szczególności poprzez stworzenie znacznego komponentu ekspedycyjnego, zdolnego do wykonywania rozległego wachlarza misji z dala od własnego terytorium, opierając się na systemie baz zamorskich, o których tak wiele pisał Mahan, a które szybko stały się symbolem amerykańskiej obecności politycznej i ekonomicznej. Warto tu podkreślić, że dzięki długotrwałemu rozwojowi wewnętrznemu USA zdolne były do stworzenia odpowiedniej potęgi bez naruszania imperatywów wzrostu gospodarczego, wzrostu zamożności i swobód politycznych oraz obywatelskich. ZSRR nigdy nie był do tego zdolny, próba dorównania Ameryce w kategoriach militarnych już w latach sześćdziesiątych przesądziła o jego późniejszym upadku.

Kluczowe elementy polityki zagranicznej i strategii bezpieczeństwa USArola sił zbrojnych

Powyższe rozważania dotyczące kształtowania się instrumentu militarnego odnoszą się też w pełni do obecnego stanu rzeczy. Interesy ekonomiczne w ogromnej mierze dyktują strategie polityczne, które pozostają w gruncie rzeczy niezmienne, pomimo meandrów związanych z bieżąca walką wewnątrzpolityczną i mimo zmieniających się realiów stosunków światowych. Strategia bezpieczeństwa Stanów Zjednoczonych ma zatem co do zasady mniej więcej ten sam kształt, nawet jeśli ewoluuje w zmieniających się realiach politycznych. Jej główne elementy pozostają nienaruszone, tak jak niezmienne są wciąż podstawowe jej przesłanki: globalne interesy Ameryki i istnienie potęgi gospodarczej, politycznej, militarnej oraz z zakresu soft power, zdolnej do realizowania tychże globalnych interesów. Jest tak bez względu na trudności, pomiędzy którymi zapewne największą rolę odgrywa fakt, że ukształtowany po II wojnie światowej porządek, choć wciąż żywotny, to jednak słabnie ${ }^{258}$. Zmniejsza się także relatywna przewaga USA nad tak zwaną resztą świata. Jak możemy

258 Summary of the 2018 National Defense Strategy of the United States of America, U.S. Department of Defense, 2018, s. 2, https://dod.defense.gov/Portals/1/Documents/ pubs/2018-National-Defense-Strategy-Summary.pdf. 
przeczytać w jednym z podstawowych dokumentów doktrynalnych polityki zagranicznej i bezpieczeństwa USA:

[przez dekady] mogliśmy rozmieszczać siły w zasadzie, kiedy chcieliśmy, gromadzić je, gdzie chcieliśmy, i używać ich, jak chcieliśmy. Dziś każda przestrzeń jest sporna - powietrze, ląd, morze, kosmos i cyberprzestrzeń 259 .

Poniżej przedstawimy w wielkim skrócie główne elementy strategii bezpieczeństwa narodowego Stanów Zjednoczonych, tak jak ją postrzegamy z perspektywy analitycznej, ze szczególnym uwzględnieniem roli instrumentu militarnego $w$ jej realizacji. Zilustrujemy je, odwołując się do Narodowej Strategii Bezpieczeństwa ${ }^{260}$ (NSS) i cytowanej powyżej Narodowej Strategii Obronnej ${ }^{261}$ (NDS), dwóch głównych dokumentów doktrynalnych z tej dziedziny. Pominiemy natomiast większość szczegółów oraz ogromną literaturę polityczną i analityczną, w której znaleźć można debatę opisującą i wartościującą tę strategię $z$ różnych punktów widzenia. W tym miejscu interesują nas bowiem jedynie najogólniejsze ramy i podstawowe założenia prowadzonej przez USA polityki bezpieczeństwa.

Główną cechą amerykańskich stosunków zewnętrznych jest to, że mają one globalny charakter, o czym wspominaliśmy już wielokrotnie. Jest to równie oczywiste, co brzemienne w skutki, implikuje bowiem aktywne działanie $\mathrm{w}$ celu porządkowania i kontrolowania wszystkich, w miarę możliwości, kluczowych obszarów świata. Jak wiemy, kontrola ta ma na celu takie układanie stosunków lokalnych i globalnych, aby sprzyjały one amerykańskim interesom, w szczególności gospodarczym. Dotyczy to najbardziej obszarów ważnych ze względu na znajdujące się na ich terenie zasoby naturalne i rynki zbytu oraz regionów istotnych ze strategicznego punktu widzenia. W praktyce USA dążą do utrzymania stabilności politycznej i równowagi militarnej oraz są zainteresowane utrzymaniem form rządów i konkretnych opcji politycznych w poszczególnych krajach $w$ takiej formie, aby sprzyjały one pozytywnym relacjom politycznym i w konsekwencji działalności amerykańskich przedsiębiorstw.

259 Ibidem, s. 3 .

260 National Security Strategy, The White House, Washington, December 2017, https:// www.whitehouse.gov/wp-content/uploads/2017/12/NSS-Final-12-18-2017-0905.pdf.

261 Dokument ten jest dostępny jedynie w formie streszczenia. 
To oczywiście podstawowe założenia, ich realizacja napotyka różnorodne trudności, a zatem $w$ różnych punktach świata daje się je zrealizować w różnym stopniu.

Najważniejszymi w amerykańskiej optyce regionami w świecie są: Europa, Bliski Wschód, Daleki Wschód i Azja Południowo-Wschodnia. Mniejszą, choć także bardzo ważną rolę odgrywają obszary południowego Pacyfiku, Ameryka Łacińska, Azja Południowa, Azja Środkowa i Afryka. Jak widać, wymieniliśmy wszystkie regiony naszej planety, do których należy jeszcze dodać przestwór oceanów, gdzie USA utrzymują swoją obecność, starając się kontrolować główne linie komunikacyjne.

Jak wspomnieliśmy, zakres, w jakim USA zdolne są do realizacji swoich celów, w poszczególnych regionach jest różny. Najsilniejsze powiązania występują pomiędzy Stanami Zjednoczonymi a Europą Zachodnią, krajami Dalekiego Wschodu, czyli Japonią, Koreą i Tajwanem, oraz z obszarem południowego Pacyfiku. Wspólne wartości, podobne formy rządów oraz zbliżona filozofia gospodarcza czyni te obszary łatwymi do penetracji i bliskimi, nawet jeśli zaznaczają się w ich relacjach z USA spory, a czasem nawet konflikty.

W pozostałych regionach Waszyngton stara się utrzymać sojuszników i partnerów, z którymi łączą go stosunki o różnej intensywności. Stany Zjednoczone nie są jednak zdolne do swobodnego układania w nich kształtu międzynarodowych relacji ze względu na różnice polityczne, kulturowe i ekonomiczne oraz dlatego, że silni lokalni konkurenci są zdolni do istotnego przeciwdziałania wpływom Waszyngtonu. Spośród nich NSS wprost wymienia Iran i Koreę Północną ${ }^{262}$, ale państw zdolnych przeciwstawić się w pewnym zakresie polityce USA jest znacznie więcej.

Kolejną ważną przeszkodą w realizacji celów i interesów USA są mocarstwa mające aspiracje ponadregionalne, a nawet globalne. Dotyczy to w szczególności Rosji i Chin, które w mniejszym lub większym zakresie dążą do przekształcenia głównych światowych mechanizmów politycznych, ekonomicznych i w dziedzinie bezpieczeństwa tak, aby były w większym stopniu funkcjonalne dla ich specyficznych celów i dążeń. To ostatnie oznacza, niejako automatycznie, że państwa te stają się globalnymi konkurentami USA, dążąc do zmiany stanu rzeczy, który 
ukształtował się w dużej mierze pod dyktando Stanów Zjednoczonych. Jak dobitnie zauważa się w NSS, kraje te „[...] rzucają wyzwanie amerykańskiej potędze, wpływom i interesom, próbując naruszyć bezpieczeństwo i dobrobyt Ameryki"263. Wprawdzie kraje te nie dysponują kompletem atrybutów globalnej mocarstwowości, nie są zatem zdolne w sposób kompleksowy rzucić wyzwania Stanom Zjednoczonym, niemniej jednak mogą w dużej mierze utrudniać realizację celów USA w planie regionalnym i globalnym.

Nie wnikając w dalsze szczegóły, można podsumować, że USA prowadzą aktywną politykę we wszystkich regionach świata, na miarę lokalnych możliwości, starając się dostosować stosunki w nich do swoich oczekiwań. Sprzyja temu amerykańska potęga gospodarcza, soft power i w ogromnym stopniu także siła militarna. Miarą amerykańskiego globalnego zaangażowania są zatem między innymi instalacje wojskowe znajdujące się w bardzo wielu krajach, ogromna liczba stacjonującego w nich personelu oraz rozmieszczone w świecie jednostki bojowe posiadające wszelkiego rodzaju uzbrojenie i wyposażenie, łącznie z taktyczną bronią jądrową. Zdolne są one do prowadzenia długotrwałych działań dzięki bardzo rozwiniętej sieci logistycznej łączącej je z terytorium USA.

Wobec rozlicznych zagrożeń bezpieczeństwa w różnych regionach, wobec przeciwdziałania konkurentów lokalnych i ponadregionalnych nie jest niczym dziwnym, że jednym z kluczowych czynników amerykańskiej polityki jest instrument militarny. Wszelkie polityczne założenia dotyczące globalnej obecności oraz strategia bezpieczeństwa narodowego podkreślają rolę sił zbrojnych wspierających realizację bieżącej polityki państwa oraz zapewniających bezpieczeństwo lokalne i regionalne - NSS wyraźnie mówi w tym kontekście o pokoju poprzez siłę ${ }^{264}$. Siły zbrojne mają zatem szereg zadań $w$ ramach realizacji polityki zagranicznej i strategii bezpieczeństwa i nie są to tylko klasyczne zadania obronne - funkcja z natury rzeczy przeznaczona temu instrumentowi. Ze względu na swoje możliwości oraz potrzeby polityczne jego znaczenie daleko wykracza poza tę normę. Można zatem syntetycznie wymienić następujące role sił zbrojnych USA. 
Po pierwsze, odstraszanie potencjalnych przeciwników, zarówno przed atakiem na terytorium USA, jak i na amerykańskie interesy za granicą. Siły zbrojne muszą nie tylko posiadać, ale także wyraźnie demonstrować zdolność do podjęcia działań bojowych w przypadku każdego zagrożenia. To klasyczna funkcja sił zbrojnych, choć rozszerzona w sensie terytorialnym poza obszar własnego państwa, co jest charakterystyczne dla politycznych struktur typu imperialnego, czyli złożonych i rozbudowanych przestrzennie.

Po drugie, zwalczanie agresji wobec terytorium i zamorskich interesów USA. Oznacza to, że siły zbrojne mają za zadanie prowadzić działania zbrojne w sytuacjach, w których pojawi się zagrożenie wymagające ich użycia. Funkcja to klasyczna, rozszerzona jednak poza podstawową funkcję obrony terytorium. USA mają bowiem rozległe interesy na świecie, których obrona może wymagać zastosowania sił zbrojnych w ich funkcji bojowej, mimo braku faktycznego zagrożenia własnego terytorium. To rozszerzenie funkcji obronnej sił zbrojnych wiąże się ze wskazanym powyżej imperialnym charakterem polityki USA.

Po trzecie, rozszerzone odstraszanie, które obejmuje sojuszników i partnerów USA znajdujących się w poszczególnych regionach, oraz ich obrona w określonych sytuacjach w przypadku, gdy odstraszanie zawiedzie. Ta funkcja także wynika z rozległości interesów amerykańskich oraz ze wspomnianej konieczności polegania na systemie sojuszy wypływającej z globalnych amerykańskich interesów gospodarczych. Zauważyć trzeba, że funkcja ta jest znacznie poszerzona w stosunku do klasycznego, znanego z historii, sojuszu militarno-politycznego, ponieważ obejmuje także stałą obecność wojskową USA na terytoriach lokalnych partnerów oraz wysoki poziom integracji amerykańskich sił zbrojnych $\mathrm{z}$ ich siłami.

Po czwarte, wsparcie bieżącej polityki zagranicznej poprzez manifestację woli politycznej. Siły zbrojne rozmieszczane na stałe bądź tymczasowo stanowią o wadze, jaką USA przykładają do danego państwa czy regionu, przesunięcia w tym zakresie na ogół stanowią także wyraz politycznej woli i determinacji. Szybkie przemieszczenia sił, szczególnie morskich i powietrznych są także nieodłącznym elementem nacisku w ramach realizacji bieżących celów politycznych ${ }^{265}$. Siły zbrojne są zatem

265 Por. reprezentatywne przykłady: J. Masters, Sea Power: The U.S. Navy and Foreign Policy, Council on Foreign Relations, 19.08.2019, https://www.cfr.org/backgrounder/ sea-power-us-navy-and-foreign-policy. 
argumentem politycznym, w razie potrzeby nawet środkiem egzekwowania przymusu poprzez stałą gotowość do użycia zbrojnej przemocy.

I wreszcie po piąte, zadania policyjne, humanitarne i inne misje niebojowe nieujęte w powyższych kategoriach.

Wszystkie te funkcje wzajemnie się uzupełniają i przenikają, siły zbrojne wykonują je niejako równolegle. Na przykład jednostki rozmieszczone za granicą jako demonstracja woli politycznej, ewentualnie jako argument popierający określone żądania, są jednocześnie czynnikiem rozszerzonego odstraszania, mogą także w razie potrzeby w każdej chwili wykonywać zadania bojowe lub nieść pomoc humanitarną. W każdej chwili mogą również zostać wzmocnione lub przerzucone w inne miejsce.

Można zatem skonstatować, że siły zbrojne USA są nie tylko środkiem obrony kraju, ale także jednym z kluczowych instrumentów realizacji przez Stany Zjednoczone swoich licznych interesów w ramach szeroko pojętej polityki zagranicznej. Skuteczne funkcjonowanie tego instrumentu, a więc zdolność do ciągłego realizowania zadań bojowych i niebojowych, jest zatem jednym z filarów amerykańskiej racji stanu w polityce zagranicznej. Słowami NSS:

[s]iła wojskowa Stanów Zjednoczonych pozostaje żywotnym komponentem konkurencji o wpływy. Połączone Siły demonstrują zdecydowanie i zaangażowanie USA, a także dają możliwość, by walczyć i zwyciężyć w każdym możliwym konflikcie, który zagrażałby amerykańskim żywotnym interesom ${ }^{266}$.

Fundamentalnym warunkiem realizacji tych wszystkich funkcji jest postrzeganie amerykańskiej polityki militarnej jako wiarygodnej, w największym stopniu dotyczy to pierwszoplanowej funkcji, jaką jest odstraszanie. Siły zbrojne USA muszą zatem posiadać cechy i parametry przekładające się na konkretne zdolności bojowe, które z kolei gwarantują wykonanie każdego zadania w ramach katalogu przewidzianych dla sił zbrojnych misji. Muszą zatem pozostawać wiarygodną siłą, co do której nie ma większych wątpliwości, że będzie skuteczna. Jest to warunek sine qua non prawidłowego funkcjonowania sił zbrojnych USA, w szczególności funkcji wspierania polityki zagranicznej oraz zapewniania 
bezpieczeństwa poprzez odstraszanie zarówno w ujęciu podstawowym, jak i rozszerzonym. To ostatnie ma szczególną rolę, według NSS:

[m]usimy przekonać naszych adwersarzy, że możemy ich pokonać, i zrobimy to nie tylko poprzez ukaranie ich, w razie gdy zaatakują USA. Musimy zapewnić sobie zdolności do odstraszenia naszych potencjalnych wrogów poprzez zanegowanie ich zdolności, przekonując ich, że nie mogą osiągnąć swoich celów poprzez użycie siły lub inną formę agresji ${ }^{267}$.

W kategoriach praktycznych oznacza to konieczność utrzymywania wyraźnej przewagi nad każdym możliwym przeciwnikiem. Przewaga ta nie może jednak mieć charakteru liczbowego, ponieważ taka doktryna militarna realizowana $w$ planie globalnym oznaczałaby mobilizację sił i środków niemożliwą do przeprowadzenia w ramach istniejących realiów ekonomicznych, ustrojowych i demograficznych. Także przewaga wynikająca z posiadania broni jądrowej może być brana pod uwagę tylko w pewnym zakresie, ze względu na niejako „ostateczny” charakter tej broni. Jest ona bowiem dobrym instrumentem odstraszania na poziomie zagrożeń egzystencjalnych, ale jako mało elastyczna niezbyt nadaje się do prowadzenia codziennej polityki oraz do odstraszania w stosunku do zagrożeń występujących w mniejszej skali.

Idąc dalej, zauważmy, że realizując swoje zadania, siły zbrojne USA muszą mieć zdolność do swobodnego i, co niezwykle ważne, stałego operowania w każdym regionie świata. Oznacza to ni mniej, ni więcej, że muszą być zdolne do przeciwstawienia się każdemu lokalnemu przeciwnikowi z minimalnymi stratami własnymi bądź nawet bez strat. To ostatnie jest jednym z kluczowych elementów długoterminowego powodzenia strategii militarnej USA. Po pierwsze dlatego, że z dobrze znanych społeczno-politycznych powodów demokratyczne społeczeństwa mają awersję do strat w ludziach, co jest zagrożeniem dla politycznej legitymizacji prowadzonych działań wojskowych. Po drugie, nawet ważniejsze w kategoriach praktycznych, straty w sprzęcie lub utrata części infrastruktury wymagają poniesienia kosztów ich uzupełnienia. Jest to bardzo niebezpieczne, ponieważ, jak wiemy, siły USA działają globalnie, mają zatem znaczne rozmiary, lecz budżet wojskowy musi utrzymywać 
się w „rozsądnych" granicach kilku procent PKB, w przeciwnym wypadku także mogłaby nastąpić delegitymizacja działań militarnych w wyniku nadmiernego obciążenia finansów państwa, a zatem i obywateli. Wobec tego częste i znaczne straty bojowe nie tylko byłyby bolesne politycznie, nie tylko wiodłyby do uszczerbku na prestiżu, ale także z przyczyn ekonomicznych postawiłyby pod znakiem zapytania całą filozofię polityki zagranicznej i strategii bezpieczeństwa USA.

Jedyną drogą do połączenia wszystkich rozległych i ambitnych celów polityki militarnej z politycznymi i ekonomicznymi ograniczeniami jest utrzymanie technologicznej przewagi nad wszystkimi faktycznymi i ewentualnymi przeciwnikami. Tylko to może zapewnić pokonanie każdego lokalnego przeciwnika, dlatego że technologia dostarcza kluczowych force multipliers, które zapewniają swobodę działania i pewność odniesienia sukcesu mimo faktycznej przewagi liczbowej przeciwników na danych obszarach w stosunku do zaangażowanych sił amerykańskich. Globalna dominacja sił zbrojnych Stanów Zjednoczonych ma zatem przede wszystkim technologiczny charakter, dzięki temu osiągana jest przy użyciu relatywnie niewielkiego w relacji do PKB budżetu wojskowego. Jak dotychczas jedynie Związek Radziecki był zdolny do efektywnego zakwestionowania tej supremacji, mimo że był nieco zapóźniony technologicznie w stosunku do USA. Dziś podobne działania próbują realizować Chiny i ponownie Rosja, daleko im jednak do faktycznego zakwestionowania przewagi amerykańskiej technologii wojskowej. Rosja oraz do pewnego stopnia Chiny dysponują jedynie możliwościami relatywnie skutecznej obrony swoich terytoriów przed obezwładniającym konwencjonalnym atakiem USA. Oba państwa niezdolne są jednak do efektywnej projekcji siły poza bezpośrednie swoje otoczenie wyznaczane zasięgiem taktycznego lotnictwa bazowanego na własnym terytorium.

Immanentną cechą przewagi technologicznej jest konieczność ciągłego jej umacniania przez nieustanny rozwój technologii i odpowiadających im form organizacyjnych oraz doktryn. Wynika to z oczywistego faktu, że przeciwnicy pracują, o czym już wspomniano, nad zniwelowaniem amerykańskiej przewagi. Dziś jest to szczególnie wyraźne i wyjątkowo widoczne, co podkreślają wszystkie cytowane dokumenty. Wymaga to zwiększania nacisku i nakładów na utrzymanie technologicznej dominacji nad wszystkimi przeciwnikami. NDS ujmuje to następująco: 
[n]ie możemy oczekiwać sukcesu, walcząc w jutrzejszych konfliktach wczorajszą bronią lub wyposażeniem. By odpowiedzieć na skalę i tempo [wzrostu] możliwości oraz ambicji naszych konkurentów i przeciwników, musimy inwestować $w$ modernizację kluczowych zdolności za pomocą trwałych i przewidywalnych budżetów ${ }^{268}$.

Podkreślmy raz jeszcze, kluczowym elementem amerykańskiej długofalowej polityki militarnej jest jej relatywnie niski koszt w stosunku do jej rozmiarów oraz efektów. Koszty te rosły znacząco tylko w czasie poważniejszych konfliktów, takich jak wojny w Korei i w Wietnamie, które były także wojnami zastępczymi dla głównych konkurentów Ameryki, ZSRR i ChRL.

Podsumowując, USA jak dotychczas potrafią skutecznie realizować swoją strategię militarną, która wspiera ogólne cele polityki zagranicznej i realizuje zadania strategii bezpieczeństwa. Wynika to przede wszystkim z przewagi technologicznej dającej dostęp do ważnych force multipliers, umożliwiających egzekwowanie przytłaczającej przewagi nad każdym lokalnym przeciwnikiem. Dzięki temu właśnie siła wojskowa w jej rozlicznych funkcjach jest tak istotnym elementem polityki USA. W związku z tym także określenia, takie jak „[s]iła wojskowa jest najważniejszym dostępnym państwu instrumentem oddziaływania [...]"269, są na porządku dziennym w amerykańskiej literaturze dotyczącej doktryny polityki zagranicznej i strategii bezpieczeństwa. Jest to przejawem ogromnej wagi, jaką przykłada się w Stanach Zjednoczonych do militarnego instrumentu polityki zewnętrznej państwa. Jednym z najważniejszych symboli militarnej potęgi Stanów Zjednoczonych jest grupa uderzeniowa zgromadzona wokół lotniskowca (carrier strike group). Obecność takiej grupy na danym obszarze jest nie tylko faktem o znaczeniu militarnym, lecz i gestem politycznym oraz deklaracją konkretnych intencji, jako nowoczesna i bardzo zaawansowana wersja „dyplomacji kanonierek".

268 Summary of the 2018 National Defense Strategy..., s. 6.

269 J. F. Troxell, Military Power and the Use of Force, [w:] U.S. Army War College Guide to

Strategic Issues, ed. J. B. Bartholomees, Carlisle, PA 2012, s. 217. 


\section{Czynniki ewolucji strategii bezpieczeństwa USA}

u schyłku drugiej dekady XXI wieku - rola sił zbrojnych

Współcześnie coraz częściej zauważa się, że militarny instrument polityki USA jest coraz mniej skuteczny, a amerykańskie siły zbrojne są relatywnie, w stosunku do ponoszonych nakładów, nieefektywne i mało odporne na nowe rodzaje zagrożeń ${ }^{270}$. W szczególności mowa tu o zagrożeniach asymetrycznych, czyli strategiach i taktykach, które mogą być przyjmowane przez przeciwników USA, a które wykorzystują czy to lokalne uwarunkowania, czy też potencjalne słabe punkty sił amerykańskich. W 2018 roku zasłużony państwowy think tank United States Institute of Peace opublikował raport sporządzony na zlecenie Kongresu dotyczący bezpieczeństwa narodowego USA, który zaczyna się następująco:

Bezpieczeńst wo i dobrobyt Stanów Zjednoczonych są bardziej zagrożone niż kiedykolwiek od dekad. Amerykańska przewaga militarna - twardy kręgosłup globalnych wpływów i narodowego bezpieczeństwa - doznała erozji w stopniu niebezpiecznym. Rywale i przeciwnicy rzucają wyzwanie Stanom Zjednoczonym na wielu frontach i w wielu domenach. Amerykańska zdolność do obrony swoich sojuszników, partnerów i własnych żywotnych interesów jest coraz bardziej wątpliwa. Jeśli kraj nie zadziała natychmiast, by zaradzić tej sytuacji, konsekwencje będą poważne i długotrwałe ${ }^{27}$.

Uważamy, że jest to w dużej mierze słuszna diagnoza, zjawiska z tym związane są jednak elementem szerszej ewolucji środowiska bezpieczeństwa międzynarodowego i, szerzej, stosunków międzynarodowych, która zachodzi współcześnie. Zwracają na to uwagę także w wielu punktach wspomniane już dokumenty doktrynalne, można to zatem przyjąć za jeden z podstawowych faktów determinujących obecną i przyszłą strategię USA.

Przechodząc do szczegółów, wymienić można szereg głównych czynników zmian zachodzących we współczesnym świecie oraz w samej Ame-

270 Por. na przykład uwagi bardzo kompetentnego eksperta: W. Wheeler, Not All That It Can Be, „Foreign Policy”, 11.10.2012, http://www.foreignpolicy.com/articles/2012/10/11/ not_all_that_it_can_be.

271 Providing for the Common Defense, United States Institute of Peace, 2018, s. v, https:// www.usip.org/sites/default/files/2018-11/providing-for-the-common-defense.pdf. 
ryce, a które wpływają na skuteczność amerykańskich sił zbrojnych, będąc podstawą wymienionych procesów. Do wewnętrznych należą przede wszystkim:

- poważne i narastające napięcia polityczne, skutkujące między innymi relatywną erozją konsensusu dotyczącego podstawowych zasad i celów polityki zagranicznej i strategii bezpieczeństwa narodowego; Fareed Zakaria nazywa to „dysfunkcjonalną polityką" ${ }^{272}$; jest ona zarówno wynikiem różnic w poglądach na poszczególne sprawy, jak i coraz wyraźniejszego instrumentalnego traktowania polityki zagranicznej przez aktorów sceny wewnętrznej;

- relatywne słabnięcie bazy przemysłowej i technologicznej wynikające między innymi z rosnącego importu produktów wysokotechnologicznych, skutecznie konkurujących z produktami amerykańskimi; niemałe znaczenie ma także kradzież myśli technicznej, dzięki której przedsiębiorstwa w innych krajach przy niewielkich relatywnie nakładach są w stanie prowadzić wspomnianą konkurencję;

- coraz bardziej niestabilne finanse państwa charakteryzujące się lawinowo rosnącym deficytem, okresowymi przerwami w finansowaniu niektórych funkcji państwa i narastającym marnotrawstwie w sferze finansów publicznych, szczególnie wyraźne w sferze wojskowej;

- poważne wyzwania społeczne, związane $z$ jednej strony $z$ pogarszającym się stanem zdrowotności populacji, a $z$ drugiej - $z$ postępującym osłabieniem ekonomicznym klasy średniej, co skutkuje wzrostem frustracji i obaw w społeczeństwie oraz osłabieniem jego dynamizmu, a zatem i zmniejszeniem zainteresowania aktywną polityką zagraniczną; w tej kategorii mieści się także rosnąca niechęć do działań interwencyjnych i obniżenie społecznego uznania dla sił zbrojnych ze wszystkimi tego skutkami.

Natomiast z czynników zewnętrznych należy wymienić:

- wzrost ekonomicznego i społecznego znaczenia wielu regionów poprzez relatywny wzrost PKB i zamożności państw w nich leżących; zwiększa to możliwości konkurentów i przeciwników Ameryki, ale nie tylko w kontekście bezpośredniego przeciwdziałania jej wpływom, lecz także poprzez to, że zdolni są oni do budowania własnych stref wpływów dzięki własnym oddziaływaniom;

272 F. Zakaria, The Future of American Power, „Foreign Affairs” 2008, vol. 87, nr 3, s. 41 i n. 
- innowacyjne stosowanie przez przeciwników USA taktyk i strategii asymetrycznych, zmierzających do zniwelowania korzyści z kluczowych amerykańskich force multipliers; to także sprzyja ograniczaniu skutków amerykańskiej przewagi technologicznej i ułatwia konstruowanie strategii przeciwdziałania USA;

- rozprzestrzenianie się nowoczesnych technologii, także wojskowych, co sprzyja skracaniu dystansu pomiędzy USA a siłami zbrojnymi potencjalnych przeciwników; dominacja technologiczna Stanów Zjednoczonych nie jest już tak wielka jak jeszcze dwie dekady temu;

- rosnące znaczenie i siła lokalnych przeciwników USA, którzy rozbudowują swoje siły zbrojne i różnego typu zdolności oddziaływania nie tylko dzięki rosnącej sile ekonomicznej wpływającej i na ich bazę przemysłową, i na możliwości finansowe państw; nabierają oni coraz większej wprawy w „obchodzeniu” kluczowych amerykańskich zdolności militarnych, mając pełną świadomość źródeł i charakteru amerykańskiej siły;

- rosnąca determinacja i coraz większe możliwości tych uczestników stosunków międzynarodowych, którzy na planie regionalnym bądź lokalnym kontestują stan stosunków międzynarodowych i zasady nimi rządzące; wynika to w dużej mierze z wyżej wymienionych kwestii, niejako je podsumowując; podkreślić należy, że konkurenci owi to nie tylko państwa, lecz także coraz liczniejsi uczestnicy niepaństwowi, działający niezależnie lub w porozumieniu z państwami;

- rosnący poziom komplikacji konfliktów i napięć regionalnych, które mają coraz rozleglejsze konteksty kulturowe, społeczne i ekonomiczne, toczą się bowiem w coraz bardziej złożonych środowiskach szybko ewoluujących w sensie społecznym i ekonomicznym - to jedna z głównych przyczyn składających się na trudność w opracowaniu strategii rozwiązywania czy chociaż ograniczania tych konfliktów.

Wymienione czynniki wzajemnie się warunkują i uzupełniają, razem przyczyniając się do mniejszego zdecydowania w prowadzeniu polityki zagranicznej oraz do relatywnego słabnięcia instrumentu militarnego. Mówi się zatem czasem o nadmiernym rozciągnięciu sił zbrojnych USA i jest to niewątpliwie prawidłowa konstatacja. Jej przejawem jest długotrwała obecność w Afganistanie, Iraku czy realizowana od 2014 roku kampania przeciwko Państwu Islamskiemu skutkująca wojskową obecnością USA w Syrii. Kolejne wyzwania związane z polityką wobec Korei 
Północnej czy Iranu lub relacjami z Rosją i Chinami mogą prowadzić do jeszcze większego „rozciągnięcia” amerykańskich sił i drenażu zasobów, które choć ogromne, nie są jednak nieskończone.

Kolejnym utrudnieniem dla realizowania przez siły zbrojne USA ich rozlicznych funkcji, a wynikającym z wymienionych powyżej czynników jest zmieniający się charakter zagrożeń, które mają coraz bardziej nieregularny charakter. Adaptacja do tych zmian nie jest łatwa, klasyczne siły zbrojne co do zasady przeznaczone są do walki $z$ regularnymi przeciwnikami w postaci jasno zidentyfikowanych sił zbrojnych innych państw.

Pojawiają się także swego rodzaju szare strefy zagrożeń, ale nie tylko w sensie odległych geograficznie obszarów konfliktów. Współcześnie pojawia się „[...] perspektywa, że wrogie kraje sięgną wirtualnie bądź fizycznie bezpośrednio do terytorium USA, aby wykorzystać konflikty polityczne w Ameryce i wpływać na strategiczne decyzje dla swoich korzyści - to w sposób fundamentalny zmienia charakter rywalizacji i ścierania się wielkich mocarstw" 273 . Poważną groźbą są zatem nie tylko klasyczne zagrożenia militarne, lecz także środki walki, które dziś nazywa się hybrydowymi. Wprawdzie nie są one nowością, lecz współcześnie istnieje szczególnie wiele narzędzi sposobnych do prowadzenia działalności wywrotowej, wojny informacyjnej, szpiegostwa oraz oddziaływań w postaci sterowania migracjami czy działalnością przestępczą w celu osłabiania państw. Wszystkie te obszary mogą być i są domenami, w których prowadzi się działania wrogie, zagrażające bezpieczeństwu Stanów Zjednoczonych.

Należy także zwrócić uwagę na poważne skutki i możliwe przyszłe następst wa ogólnego, globalnego kryzysu demokracji i demokratycznych społeczeństw. Wynika on z bardzo wielu przyczyn ekonomicznych, społecznych i politycznych, niemniej jednak wstrząsa posadami zachodnich demokracji, włączając $w$ to USA. Walter Russel Mead przyrównuje obecny kryzys związany $z$ rewolucją informacyjną do długotrwałego i głębokiego, wielopłaszczyznowego kryzysu, który rozpoczął się po wojnie secesyjnej i trwał do końca wieku, a związanego $\mathrm{z}$ rewolucją przemysłową, która przetransformowała wówczas Amerykę w sposób fundamentalny.

273 N. Freier, The Darker Shade of Gray: A New War Unlike Any Other, „Center for Strategic \& International Studies", 27.07.2018, https://www.csis.org/analysis/darker-shadegray-new-war-unlike-any-other. 
Dzisiejsze wyzwania są podobne w charakterze, lecz, jak zauważa Mead, stoimy na początku rewolucji informatycznej i nie wiadomo, gdzie ona nas zaprowadzi ${ }^{274}$. Niepewność z tym związana na pewno odbije się i na bezpieczeństwie narodowym USA, i na polityce zagranicznej państwa.

Efektem zarysowanych zmian $w$ globalnym środowisku bezpieczeństwa jest także trudność $w$ kształtowaniu realistycznych strategii rozwiązywania konfliktów w poszczególnych regionach, przy jednoczesnym istnieniu w USA imperatywu nakazującego to właśnie robić. Wynika to przede wszystkim z często słabego rozpoznania sytuacji w poszczególnych konfliktach, co skutkuje niewłaściwym doborem środków. Co więcej, uważa się nierealistycznie, że każdy konflikt da się w przewidywalnym czasie zażegnać, działając z zewnątrz, co skutkuje tworzeniem strategii i planów niejako „na siłę” w sytuacjach, w których rozwiązania być może w ogóle nie istnieją. Efektem jest nadmierne poleganie na czynniku militarnym, który jawi się nader często jako jedyny klucz otwierający wszystkie drzwi, lecz coraz częściej jest nieskuteczny, a nawet sprzyja zaognianiu się konfliktów. Przykładem może być tak zwana wojna z terroryzmem, prowadzona $\mathrm{w}$ dużej mierze metodami wojskowymi, która nie odnosi skutków, choć oczywiście relatywny wzrost znaczenia współczesnego terroryzmu jako globalnego zagrożenia bezpieczeństwa nie jest jedynie wynikiem błędnej taktyki USA w tym zakresie.

$\mathrm{Na}$ to wszystko nakłada się specyfika polityki USA doby Donalda Trumpa. Wprawdzie w warstwie realnych działań czterdziesty piąty prezydent USA nie zmienił radykalnie polityki zagranicznej kraju. Jest ona bowiem wynikiem długotrwałej ewolucji i pozostaje osadzona bardzo mocno $\mathrm{w}$ bazie instytucjonalnej, a ustrojowe zabezpieczenia $\mathrm{w}$ postaci Kongresu, kontrolując finansowanie państwa, też mają swoje znaczenie. Niemniej jednak przedłużający się chaos zmniejsza efektywność polityki USA i wprowadza globalną niepewność, w szczególności dlatego, że Donald Trump nader często działa w sposób nieprzemyślany, impulsywnie, często zaprzepaszczając lata budowania relacji z partnerami. W rezultacie obecny prezydent USA ewidentnie osłabia amerykańskie przywództwo, które polega na wierze innych krajów we wsparcie i współpracę Ameryki oraz trwałość jej intencji. Najważniejszym i zapewne trwałym pokłosiem prezydentury Trumpa jest umocnienie politycznych i społecz-

274 W. R. Mead, The Big Shift, „Foreign Affairs”, May/June 2018, s. 10-19. 
nych podziałów w Stanach Zjednoczonych, osłabienie wewnętrznej spójności kraju oraz jego instytucji demokratycznych. Odrobienie tych strat będzie bardzo trudne, o ile w ogóle możliwe.

Perspektywy wynikające $z$ przedstawionego powyżej stanu rzeczy można ująć $w$ następujących punktach, oczywiście $w$ ramach obecnie występujących i dających się przewidzieć trendów.

Po pierwsze, Stany Zjednoczone wprawdzie pozostaną w najbliższym czasie najpotężniejszym państwem świata, ich przewaga będzie jednak relatywnie maleć. Będzie się tak działo $w$ wyniku, z jednej strony ogólnego rozwoju tak zwanej reszty świata, jak i dzięki poszukiwaniu przez inne państwa rozlicznych asymetrycznych metod przeciwstawienia się przewadze USA, zarówno w kategoriach militarnych, jak i ekonomicznych czy technologicznych. Podkreślmy przy tym, że nie stoimy na stanowisku, że Ameryka jest skazana na prześcignięcie przez Chiny czy też polityczne „ogranie” przez Rosję. Oba te kraje mają swoje poważne problemy i wcale nie jest pewne, że w przyszłości będą stanowić dla USA równie silną i zdeterminowaną konkurencję, jaką są obecnie.

Po drugie, Stany Zjednoczone pojmą, czego przejawy już mieliśmy okazję obserwować, że ich potęga nie jest absolutna, że jednobiegunowy moment się skończył, a świat staje się wielopoziomowo wielobiegunowy. Ponadto pojawi się zrozumienie, że niektórych lokalnych konfliktów i problemów nie da się rozwiązać, a co za tym idzie - nie da się trwale ustabilizować niektórych regionów. Wraz $\mathrm{z}$ tą konstatacją przyjdzie zmniejszenie globalnej aktywności polityki USA, czy to w formie głębokiego wycofania się na kontynent północnoamerykański, czy też „oddania” niejako niektórych regionów mniej ważnych, a jednocześnie zbyt kosztownych w kontekście prowadzonej w nich polityki, na rzecz umocnienia w innych, bardziej istotnych i „łatwiejszych”, na co często zwraca uwagę wielu prominentnych politycznych komentatorów ${ }^{275}$.

Po trzecie, w efekcie powyższych zjawisk pewnej zmianie ulegnie rola instrumentu wojskowego. Stany Zjednoczone będą w mniejszym zakresie

275 Por. na przykład często powtarzane przez Stephena M. Walta argumenty o konieczności strategicznego umiaru w zaangażowaniu globalnym, na przykład S. M. Walt, Restraint Isn't Isolationism - and It Won't Endanger America, „Foreign Policy”, 22.07.2019, https://foreignpolicy.com/2019/07/22/restraint-isnt-isolationism-and-it-wont-endan ger-america-offshore-balancing-quincy-institute/. 
wykorzystywać go do niebezpiecznej walki o strefy wpływów czy też do porządkowania „gorących” regionów. Pozostanie on jednak elementem umacniania bezpieczeństwa najważniejszych strategicznie, politycznie i ekonomicznie regionów oraz szlaków komunikacyjnych. Nie oznacza to zatem radykalnej redefinicji roli czynnika militarnego, lecz raczej zmianę akcentów w zakresie jego bieżącego wykorzystania.

Dla porządku należy dodać, że istnieje także inny wariant ewolucji amerykańskiej polityki bezpieczeństwa. Polega on na tym, że USA mogą wybrać proponowaną przez wielu politykę aktywnego przeciwstawiania się przemianom w przestrzeni międzynarodowej poprzez swego rodzaju nową politykę powstrzymywania wobec rewizjonistycznych mocarstw ${ }^{276}$. To oznaczałoby wzrost znaczenia czynnika militarnego w polityce USA. Wydaje nam się jednak, że mimo bardzo wielu głosów na ten temat Stany Zjednoczone nie będą miały woli, a także nie będą w stanie takiej polityki prowadzić.

Podsumowując, można zatem powiedzieć, że zasadnicza ciągłość amerykańskiej polityki, w tym rola instrumentu militarnego, zostanie utrzymana. Nie zmienią się także wszystkie imperatywy dotyczące czynnika militarnego, jego kształtu, jakości i sposobu wykorzystania. Jednak ze względu na słabszą pozycję względem innych państw, tak zwanej reszty świata, faktyczne możliwości, szczególnie w zakresie aktywnego wsparcia polityki zagranicznej, będą mniejsze. W kontekście wyborów prezydenckich w 2016 roku wnikliwi obserwatorzy zauważali, że

[n]następny prezydent USA odziedziczy środowisko bezpieczeństwa, w ramach którego USA będą skonfrontowane ze zwiększającą się liczbą zagrożeń, mając jednocześnie do dyspozycji coraz bardziej ograniczone zasoby, a także zmniejszone możliwości i rosnącą niepewność w kraju i za granicą co do woli ochrony swoich przyjaciół i własnych interesów. Rewizjonistyczne mocarstwa w Europie, na zachodnim Pacyfiku i w Zatoce Perskiej - w trzech regionach od dawna uznawanych i przez republikańskie, i przez demokratyczne administracje za żywotne dla narodowego bezpieczeństwa USA - starają się obalić oparty na regułach porządek międzynarodowy ${ }^{277}$.

276 M. Mandelbaum, The New Containment, „Foreign Affairs”, March/April 2019.

277 M. Thornberry, A. F. Krepinevich, Jr., Preserving Primacy, „Foreign Affairs”, September/October 2016, s. 26. 
Wszystko to oznaczać będzie większą konieczność liczenia się z potencjałem militarnym innych państw, mniejszą swobodę operacyjną, a zatem i mniejsze możliwości wykorzystania sił zbrojnych USA w świecie $w$ ramach wspierania polityki zagranicznej $i$ realizowania strategii bezpieczeństwa. Jednocześnie, $w$ dającej się przewidzieć przyszłości, siły zbrojne USA będą jednak wykonywać dalej funkcje, które wymieniliśmy, będą także nadal kluczowym instrumentem amerykańskiej polityki zagranicznej i strategii bezpieczeństwa globalnego. Zasadniczą cechą jego sposobu funkcjonowania wciąż będzie dążenie do utrzymania przewagi technologicznej, którą posiadają dzisiaj, choć zapewne nie będzie to możliwe w takim zakresie, jak USA by sobie tego życzyły. A zatem, choć siły zbrojne USA są wciąż niewątpliwie najpotężniejsze i nie mają rywala co do parametrów i zdolności ${ }^{278}$, to jednak będą one skonfrontowane $\mathrm{z}$ coraz bardziej wymagającymi przeciwnikami, których coraz trudniej będzie pokonać przy niewielkich bądź zerowych stratach. Cała logika amerykańskiej polityki militarnej i jej miejsce w polityce zagranicznej i strategii bezpieczeństwa mogą zatem zostać zakwestionowane, co w dalszej i już trudniejszej do przewidzenia perspektywie może doprowadzić do bardziej radykalnych zmian w polityce zagranicznej i bezpieczeństwa, ale rozważania w tym zakresie wykraczają poza ramy niniejszej pracy.

\subsection{Przestrzeń kosmiczna u strategii bezpieczeństwa USA - wymiar deklaratywny spacepower}

Definiując na potrzeby niniejszej pracy spacepower jako zdolność wykorzystania przestrzeni kosmicznej w celu realizacji interesów państwa w dziedzinie bezpieczeństwa zewnętrznego, deklarujemy, że interesuje nas między innymi problematyka doktrynalna związana z polityką państwa wobec wykorzystania przestrzeni kosmicznej. W niniejszym podrozdziale postaramy się zatem zanalizować podstawowe dokumenty dotyczące bezpieczeństwa narodowego $\mathrm{z}$ punktu widzenia tego, jaką rolę odgrywa w nich przestrzeń kosmiczna i jej wykorzystanie. W związku z tym, niejako przy okazji, będziemy mogli wypunktować szereg pojawiających się w nich elementów spacepower.

278 M. O'Hanlon, D. Petraeus, America's Awesome Military, „Foreign Affairs”, September/October 2016, s. 10. 
Rozpoczniemy od NSS i NDS, wspomnianych już w kontekście ogólnych rozważań o roli sił zbrojnych $w$ polityce zagranicznej i strategii bezpieczeństwa Stanów Zjednoczonych. Będzie to niejako pogłębienie i uszczegółowienie poruszonych powyżej kwestii w kierunku problematyki kosmicznej. Następnie zajmiemy się krótko Narodową Strategią Wojskową ${ }^{279}$ (NSM) i wreszcie przejdziemy do dokumentów zajmujących się szczegółowo kosmosem, czyli do Narodowej Polityki Kosmicznej ${ }^{280}$ (NSP) i Narodowej Polityki Bezpieczeństwa Kosmicznego ${ }^{281}$ (NSSS). Dwa ostatnie dokumenty są wprawdzie stosunkowo stare, ponieważ pochodzą odpowiednio z 2010 i z 2011 roku, pozostają jednak najbardziej kompletną wykładnią polityki kosmicznej i polityki bezpieczeństwa kosmicznego USA, wymagają zatem omówienia. Posłuży to jako podstawa do analizy bieżących dokumentów doktrynalnych dotyczących polityki kosmicznej wydawanych przez administrację prezydenta Donalda Trumpa. Jakkolwiek są one nieco chaotyczne i nietworzące spójnej doktryny, uzupełniają jednak dotychczasowy dorobek i sygnalizują ponadto pewne nowe trendy w postrzeganiu wykorzystania kosmosu zarówno $\mathrm{w}$ dziedzinie bezpieczeństwa, jak i ogólniej - w związku z siłą państwa, jego gospodarki i dobrobytem obywateli.

Należy nadmienić, że istnieją także inne, bardziej szczegółowe dokumenty doktrynalne, w których można doszukiwać się elementów polityki kosmicznej w dziedzinie bezpieczeństwa czy też rozważań na temat spacepower. Są to między innymi Przegląd Polityki Nuklearnej z lutego ${ }_{2018}^{28_{2}}$ i Przegląd Obrony Przeciwrakietowej ze stycznia 2019 roku $^{28_{3}}$. Pierwszy $\mathrm{z}$ nich podkreśla rolę systemów kosmicznych $\mathrm{w}$ ostrzega-

279 The National Military Strategy of the United States of America, US Joint Chiefs of Staffs, June 2015, http://www.jcs.mil/Portals/36/Documents/Publications/National_Milita ry_Strategy_2015.pdf.

280 National Space Policy, The White House, 28.06.2010, https://www.whitehouse.gov/ sites/default/files/national_space_policy_6-28-10.pdf.

281 National Security Space Strategy, Department of Defense and Office of the Director of National Intelligence, January 2011, https://www.dni.gov/files/documents/News room/Reports\%2oand\%2oPubs/2011_nationalsecurityspacestrategy.pdf.

282 Nuclear Posture Review, U.S. Department of Defense, February 2018, https://media. defense.gov $/ 2018 / \mathrm{Feb} / 02 / 2001872886 /-1 /-1 / 1 / 2018$-NUCLEAR-POSTURE-REVIEWFINAL-REPORT.PDF.

283 Missile Defense Review, U.S. Department of Defense, January 2019, https://media.de fense.gov/2019/Jan/17/2002080666/-1/-1/1/2019-MISSILE-DEFENSE-REVIEW.PDF. 
niu przeciw atakom nuklearnym w zarządzaniu siłami nuklearnymi ${ }^{28_{4}}$. Drugi, w podobnym duchu, wskazuje na rolę systemów kosmicznych w wykrywaniu i śledzeniu ataków rakietowych różnego typu oraz w ich zwalczaniu ${ }^{285}$. Pojawia się tu ponadto koncepcja przeciwrakietowych broni kosmicznych. Przegląd przewiduje przeprowadzenie studium wykonalności takich systemów ${ }^{286}$. Istnieją także dokumenty ściśle wojskowe, o znaczeniu operacyjnym, takie jak Operacje Kosmiczne z kwietnia 2018 roku $^{287}$, publikacja Komitetu Połączonych Sztabów sił zbrojnych USA, której zadaniem jest „[...] dostarczenie wspólnej doktryny planowania, wykonywania i oceny operacji kosmicznych" ${ }^{288}$. Nie będziemy jednak tych dokumentów omawiać bardziej szczegółowo, ponieważ nie wniosłoby to istotnych treści na poziomie ogólności, na którym poruszamy się w niniejszej pozycji. Zaznaczamy jedynie ich istnienie, aby unaocznić, jak złożona $w$ warstwie szczegółowej jest doktryna bezpieczeństwa narodowego USA w odniesieniu do wykorzystania przestrzeni kosmicznej i do bezpieczeństwa kosmicznego w jego wszystkich wymiarach.

\section{Narodowa strategia bezpieczeństwa z 2017 roku}

Ten cytowany już powyżej dokument stanowi najbardziej ogólną wykładnię doktrynalną w zakresie bezpieczeństwa narodowego USA, jego aktualna redakcja pochodzi z grudnia 2017 roku. Obejmuje wszystkie aspekty i wszystkie wymiary problematyki bezpieczeństwa, oczywiście, siłą rzeczy, w najbardziej generalny i skrótowy sposób. NSS wydawana jest pod auspicjami prezydenta Stanów Zjednoczonych.

Jednym z kluczowych elementów, definiujących całą Strategię, jest stwierdzenie, że „[...] Stany Zjednoczone stoją wobec niezwykle niebezpiecznego świata, pełnego rozlicznych zagrożeń, które zintensyfikowały się w ostatnich latach" ${ }^{289}$. Umieszczenie tak dramatycznych i jednoznacz-

284 Nuclear Posture Review..., s. 56 i n.

285 Missile Defense Review..., s. 36-37.

286 Ibidem, s. 58.

287 Joint Publication 3-14. Space Operations, Joint Chiefs of Staffs, 10.04.2018, https://www.

jcs.mil/Portals/36/Documents/Doctrine/pubs/jp3_14.pdf.

288 Ibidem, s. i.

289 National Security Strategy..., S. i. 
nych stwierdzeń już $w$ otwierającym dokument przesłaniu prezydenta oznacza, że wizja świata, jaki jawi się przed obecną administracją, jest skrajnie konserwatywna, znamy to już zresztą z dotychczasowych rozważań. Widać to także w wielokrotnie powtarzanych zdaniach wskazujących na konfrontację, w której Ameryka jest samotna i w ramach której musi samodzielnie walczyć o swoje interesy, a w pierwszej kolejności o własne bezpieczeństwo. Wizja, jaką przedstawia NSS, jest zatem bardzo mało kooperatywna, co ma wiele ważnych konsekwencji, także w odniesieniu do sposobów wykorzystania przestrzeni kosmicznej. Co równie ważne w kontekście przestrzeni kosmicznej, Strategia zwiększa rolę sił zbrojnych jako instrumentu bezpieczeństwa, akcentując bardzo mocno paradygmat „pokój poprzez siłę” jako podstawę filozofii bezpieczeństwa narodowego ${ }^{290}$. To z kolei automatycznie uwypukla rolę systemów kosmicznych jako krytycznie ważnego force multiplier, ogromnie wpływającego na skuteczność całych sił zbrojnych w ramach realizacji wszystkich ich funkcji.

NSS dzieli się na cztery filary i choć przestrzeń kosmiczna pojawia się szerzej i jest wyraźnie zaznaczona tylko w jednym $z$ nich, to jednak we wszystkich dostrzegamy kwestie, w których zastosowania kosmiczne mają wielkie znaczenie dla skuteczności podejmowanych działań.

I tak wymienione $w$ filarze pierwszym, dotyczącym bezpieczeństwa terytorium i amerykańskiego sposobu życia zagrożenia w dużej mierze mają związek z przestrzenią kosmiczną. Wiemy bowiem, że systemy orbitalne mają kluczowe znaczenie w realizacji praktycznie wszystkich rodzajów misji dotyczących przeciwdziałania tymże zagrożeniom. Strategia porusza w tym kontekście wiele istotnych kwestii, a przede wszystkim:

- zagrożenie bronią masowego rażenia - zwraca się tu uwagę na obronę przeciwrakietową, wykrywanie i niszczenie wrogich środków przenoszenia, przeciwdziałanie proliferacji i wreszcie operacje przeciwko strukturom terrorystycznym - we wszystkich tych działaniach systemy kosmiczne mają, co oczywiste, fundamentalne znaczenie, dostarczając krytycznie ważnych informacji i zapewniając szybką i pojemną, globalną łączność;

- zwalczanie terroryzmu - systemy obserwacyjne, nawigacyjne i łączności, zabezpieczające realizację misji antyterrorystycznych prowadzo- 
nych przez wojsko i odpowiednie agencje rządowe mają bardzo często kluczowe znaczenie dla powodzenia wielu operacji;

- bezpieczeństwo cybernetyczne - powiązane jest z problematyką kosmiczną na dwa sposoby; po pierwsze, spora część ruchu w ramach przestrzeni wirtualnej obsługiwana jest przez systemy satelitarne; ich bezpieczeństwo i niezakłócone działanie jest zatem kwestią pierwszoplanową z punktu widzenia bezpieczeństwa samej cyberprzestrzeni; po drugie, cyberprzestrzeń jest drogą, przez którą można dokonywać ataków na systemy kosmiczne w celu ich zniszczenia bądź zakłócenia ich działalności, bezpieczeństwo w cyberprzestrzeni oraz bezpieczeństwo w kosmosie są współzależne.

Drugi filar NSS, dotyczący promowania dobrobytu Ameryki, także ma swój wymiar kosmiczny, choćby dlatego, że dotyczy kwestii rozwoju gospodarki i amerykańskiego społeczeństwa. Rozwój przemysłu kosmicznego oznacza oczywiście wzrost zysku dla przedsiębiorstw działających w tej branży, innowacje i rozwój technologiczny. Oprócz tego w sensie rozwojowym to nawet ważniejsza kwestia, tworzy on instrument pomnażania zysków przez przedsiębiorstwa i obywateli korzystających $\mathrm{z}$ dobrodziejstw aplikacji kosmicznych. Wobec tego wskazane w strategii cele, takie jak ożywienie gospodarki czy też utrzymanie przodownictwa w badaniach, innowacjach i rozwoju technologicznym, mają bezpośredni związek ze spacepower zarówno w podstawowym znaczeniu, czyli z punktu widzenia bezpieczeństwa, jak i w szerszym ujęciu, z punktu widzenia całości siły państwa.

Najwyraźniej jednak, w świetle interesującej nas tematyki i pojęcia spacepower, przestrzeń kosmiczna ukazuje się w filarze trzecim NSS, który analizując zdolności militarne USA, odzwierciedla wspomniany już parokrotnie paradygmat „pokój poprzez siłę”, uznawany za podstawę bezpieczeństwa państwa. Zdolności kosmiczne, jako kluczowy force multiplier, niejako automatycznie pojawiają się w tym kontekście. Tu też znajdziemy bezpośrednie odniesienia do przestrzeni kosmicznej i jej zastosowania.

Istotnym punktem wyjścia rozważań Strategii bezpośrednio dotyczących materii wojskowej jest znane nam już i wielokrotnie powtarzane stwierdzenie, że przewaga USA w wymiarze technologicznym i operacyjnym zmalała w ostatnich dekadach, co łączy się także z odnowieniem się rywalizacji wielkich mocarstw. W związku z tym Ameryka musi rów- 
nież odtworzyć swoje zdolności w zakresie sił zbrojnych, bazy przemysłu obronnego, sił nuklearnych, wykorzystania przestrzeni kosmicznej, działań w cyberprzestrzeni i pozyskiwania informacji. Wszystkie te elementy są oczywiście istotne $z$ punktu widzenia wykorzystania przestrzeni kosmicznej, co już wielokrotnie wyjaśnialiśmy - kosmos jest jednym ze spoiw, które łączy wszystkie wskazane obszary.

Przestrzeń kosmiczna pojawia się $w$ tych rozważaniach nie tylko ze względu na jej wagę w ramach zabezpieczania rozlicznych działań militarnych i w zakresie zbierania informacji. Jest ona także ujmowana jako odrębna przestrzeń operacyjna, w której mogą być prowadzone działania zbrojne. Zwraca się przy tym uwagę, że z jednej strony wzrosła zależność Ameryki od zastosowań kosmicznych, z drugiej zaś - swoista „demokratyzacja kosmosu" powoduje, że szereg państw jest w stanie uzyskać zdolności wcześniej im niedostępne. W związku z tym Stany Zjednoczone muszą priorytetowo traktować przestrzeń kosmiczną, popierać rozwój komercyjnego wykorzystania kosmosu oraz podtrzymać przodownictwo w jego eksploracji.

Znaczenie przestrzeni kosmicznej dla USA jest zatem ogromne, podkreśla się więc głębokie przywiązanie do zasady wolności dostępu do kosmosu i gotowość do jej obrony, nawet siłą:

Wiele państw pozyskuje satelity po to, by wesprzeć strategiczne działania własnych sił zbrojnych. Inne wierzą, że zdolność do zaatakowania kosmicznych zasobów da im asymetryczną przewagę i w związku z tym rozwijają wiele rodzajów broni przeciwsatelitarnych.

[...]

Stany Zjednoczone uważają niezakłócony dostęp i wolność operowania w kosmosie za swój żywotny interes. Jakiekolwiek zakłócenia lub ataki na krytyczne komponenty naszej kosmicznej architektury bezpośrednio naruszają żywotne interesy USA i spotkają się z przemyślaną odpowiedzią, która nastąpi w czasie, miejscu, i w przestrzeni, jaką wybierzemy, oraz w sposób, jaki będzie nam odpowiadał ${ }^{291}$.

I wreszcie czwarty filar amerykańskiej strategii bezpieczeństwa, czyli rozszerzanie wpływów Ameryki. Oznacza to wspieranie partnerów Stanów Zjednoczonych w świecie, umacnianie, a raczej uczynienie bardziej skutecznymi, międzynarodowych instytucji oraz promocję amerykań- 
skich wartości. We wszystkich tych punktach przestrzeń kosmiczna ma swoją rolę, zarówno w takim sensie, że systemy kosmiczne zapewniają wsparcie polityce zagranicznej oraz strategii bezpieczeństwa, jak i na zasadzie soft power. To ostatnie ma szczególne znaczenie i to pomimo relatywnie mało kooperatywnej polityki USA. NSS podkreśla niezmienne znaczenie roli przyciągającej amerykańskiego przykładu w ramach tworzenia i utrzymywania stref wpływów. Nowoczesne i technologiczne wymagające aplikacje różnego typu mogą odegrać szczególną rolę w takiej polityce, przodownictwo w technice kosmicznej wskazuje zatem wyraźnie na wiodącą pozycję Ameryki w świecie, sprzyjając budowaniu politycznej pozycji Stanów Zjednoczonych.

Podsumowując, można stwierdzić, że Narodowa Strategia Bezpieczeństwa Stanów Zjednoczonych podkreśla szczególnie znaczenie przestrzeni kosmicznej, deklarując jednocześnie, że USA podejmują się przywództwa w ramach utrzymania i organizowania swobody dostępu do tej dome$n^{292}$. Znaczenie to wynika ze znanego nam już dobrze faktu, że wiele kluczowych misji i działań w zakresie bezpieczeństwa narodowego i nie tylko jest w coraz większym stopniu uzależnionych od wykorzystania systemów orbitalnych. W związku z tym USA, w świetle swoich podstawowych potrzeb bezpieczeństwa i globalnej strategii politycznej, nie mogą sobie pozwolić na oddanie przewagi w kosmosie, ponadto muszą działać tak, aby utrzymać wyraźną wyższość nad swoimi konkurentami i przeciwnikami. Ci ostatni są zdeterminowani i groźni, ponieważ posiadają znaczne zdolności szkodzenia USA, także w przestrzeni kosmicznej i poprzez przestrzeń kosmiczną.

\section{Narodowa strategia obronna z 2018 roku}

Dokument ten, wspominany już pokrótce powyżej, dostępny w obiegu publicznym jedynie w formie podsumowania ${ }^{293}$, jest ogólną, polityczną wykładnią strategii obronnej USA, sygnowaną przez sekretarza obrony. Zawiera podstawowe deklaracje dotyczące miejsca sił zbrojnych w systemie instrumentów działania państwa oraz podstawowych elementów doktryny ich użycia. Jak stwierdza się w pierwszych zdaniach, 
[s]tałą misją Departamentu Obrony jest utrzymywanie w gotowości bojowej sił zbrojnych niezbędnych do odstraszania i zapewniania bezpieczeństwa państwa. Jeśli odstraszanie zawiedzie, Połączone Siły są gotowe, by zwyciężyć. Wzmacniając tradycyjne amerykańskie narzędzia dyplomatyczne, Departament dostarcza opcji militarnych, by zapewnić prezydentowi i naszym dyplomatom możliwość negocjowania z pozycji siły ${ }^{294}$.

Mimo tego bardzo optymistycznego określenia misji sił zbrojnych, na kolejnych stronach Strategii pojawia się jednak bardziej wyważona konstatacja, że globalna przestrzeń operacyjna jest naznaczona coraz większą konkurencją, co oznacza rosnące wyzwania dla sił zbrojnych w ramach wykonywania powyższych zadań. Powtarza się zatem to, co znamy i z NSS, i z wcześniejszych naszych rozważań, że współczesne środowisko bezpieczeństwa charakteryzuje się między innymi rozpowszechnianiem kluczowych technologii, skutkujących zmniejszeniem się przewagi technologicznej USA w ostatnich latach. Jeśli ten proces przebiegać będzie dalej, może „[...] doprowadzić do tego, że Połączone Siły będą dysponować przestarzałymi systemami, nieskutecznymi w obronie naszego narodu" ${ }^{295}$.

Te stwierdzenia są kluczowe, ponieważ kryje się za nimi zdecydowana wola utrzymania przewagi i niedopuszczenia do relatywnej degradacji amerykańskiego instrumentu wojskowego, co postawiłoby pod znakiem zapytania całą amerykańską strategię i całą rację stanu w polityce zagranicznej. Dalszym efektem byłaby degradacja amerykańskich wpływów i ograniczenie, a po części i eliminacja korzyści, jakie z nich wypływają. Ma to oczywiste konsekwencje z punktu widzenia wykorzystania przestrzeni kosmicznej, ponieważ, jak dobrze wiemy, systemy satelitarne są jednym z kluczy do technologicznej przewagi sił zbrojnych USA. W związku z tym ich rozwój musi być jednym z priorytetów polityki militarnej, szczególnie dlatego, że „[p]ojawiają się nowe zagrożenia dla komercyjnego i wojskowego wykorzystania kosmosu [...]"296. Oznacza to ni mniej, ni więcej, że i w przestrzeni kosmicznej Ameryka napotyka wyzwania polegające na tym, że jej technologiczna przewaga jest kwestionowana i ograniczana. Ponieważ jednak kosmos ma szczególne znaczenie 
jako force multiplier, osłabienie w tej dziedzinie negaty wnie oddziałuje na wszystko inne.

Widać to szczególnie w punkcie, w którym Strategia wymienia cele modernizacyjne, czyli obszary, w których należy dokonywać inwestycji i które należy traktować priorytetowo, tak aby osiągnąć stawiany cel, czyli utrzymanie amerykańskiej przewagi militarnej poprzez przewagę technologiczną. Jednym $z$ nich, wymienionym na drugim miejscu, jest kosmos jako przestrzeń prowadzenia walki. Ponadto wszystkie pozostałe przytoczone cele mają oczywisty związek z zastosowaniami kosmicznymi - są to między innymi cyberprzestrzeń jako domena prowadzenia działań, system gromadzenia informacji i zarządzania siłami zbrojnymi (C4ISR), obrona przeciwrakietowa, skuteczność działania w przestrzeniach zagrożonych, manewrowość sił, logistyka i systemy bezzałogowe ${ }^{297}$.

Departament obrony deklaruje zatem wzrost inwestycji w zdolności operacyjne, odtworzenie i zwiększenie żywotności infrastruktury systemów kosmicznych ${ }^{298}$. Zarówno w związku z tym, że przestrzeń kosmiczna coraz wyraźniej staje się polem walki, jak i dlatego, że wszystkie wymienione powyżej cele modernizacyjne wymagają rozwijania zdolności kosmicznych, ponieważ w każdym z nich systemy kosmiczne dają unikalne możliwości skutecznego realizowania misji różnego typu. Kosmos jest więc, jak to już zauważyliśmy, swego rodzaju zwornikiem, wspólnym mianownikiem elementów potęgi wojskowej, kluczowym force multiplier. Dziś jednak podstawowym problemem jest to, że kosmiczna domena nie jest już bezpieczna, a systemy satelitarne mogą być zagrożone. To z kolei implikuje podejmowanie działań na rzecz zabezpieczenia funkcjonowania systemów satelitarnych i utrzymania ich przewagi nad przeciwnikiem. O tym jednak strategia nie wspomina szczegółowo (przynajmniej w dostępnej publicznie wersji), poza ogólnymi stwierdzeniami dotyczącymi konieczności modernizacji odpowiednich zdolności.

\section{Narodowa strategia wojskowa z 2015 roku}

Jest to dokument szczegółowo analizujący rolę sił zbrojnych w ramach polityki bezpieczeństwa narodowego, w obecnej redakcji pochodzi 
z 2019 roku, lecz pozostaje nieujawniony i być może taki pozostanie ${ }^{299}$, musimy zatem posłużyć się poprzednią wersją. W głównych zrębach wymowa NSM jest kompatybilna z powyżej omówionymi dokumentami, wymienia ona między innymi misje, jakie wykonują siły zbrojne w ramach zintegrowanych operacji globalnych ${ }^{300}$. I znowu we wszystkich przypadkach widzimy, że do ich efektywnego wykonywania niezbędne są rozwinięte zdolności satelitarne. Strategia podkreśla zatem ogromne znaczenie systemów kosmicznych dla utrzymania przewagi militarnej Stanów Zjednoczonych, także w kontekście wzrostu możliwości w tym zakresie innych krajów, przy czym:

[s]zczególną obawą napawają: proliferacja balistycznych pocisków rakietowych, technologii broni precyzyjnych, systemów bezzałogowych, zdolności kosmicznych i w cyberprzestrzeni oraz broni masowego rażenia technologii zaprojektowanych tak, aby przeciwstawić się amerykańskiej przewadze wojskowej i ograniczyć dostęp do domen globalnych ${ }^{30}$.

Mamy zatem ponownie potwierdzenie obaw dotyczących amerykańskiej przewagi, jak też zwrócenie uwagi na to, że jednym z ważnych wymiarów tego zjawiska jest wzrost zdolności innych podmiotów do działania w przestrzeni kosmicznej, co z kolei może ograniczyć skuteczność najważniejszego amerykańskiego force multiplier. Bardziej szczegółowe zapisy powtarzają to, co już wiemy, poczynając od tego, że wymienione przez NSM misje ${ }^{302}$ sił zbrojnych wymagają dla swojej skuteczności efektywnego wsparcia systemów kosmicznych, kluczowej z punktu widzenia wielokrotnie przez nas podkreślanej potrzeby utrzymania efektywności kosztowej działań. Akcentuje się także konieczność dalszego budowania krytycznych zdolności, takich jak między innymi kosmiczne i naziemne systemy wykrywania i ostrzegania, zintegrowane i elastyczne platformy ISR, transport strategiczny, broń precyzyjna dalekiego zasięgu, technologie obrony przeciwrakietowej, systemy podmorskie, zdalnie sterowane

299 A. Mehta, The Pentagon's National Military Strategy Is Done, and It's Unclear if the Public will Ever See It, Defense News, 13.02.2019, https://www.defensenews.com/pen tagon/2019/02/13/the-pentagons-national-military-strategy-is-done-and-its-unclearif-the-public-will-ever-see-it/.

300 The National Military Strategy..., s. 10-13.

301 Ibidem, s. 3.

302 Ibidem, s. 10-13. 
pojazdy i związane z tym technologie, siły operacji specjalnych i siły do zadań w cyberprzestrzeni ${ }^{303}$.

\section{Narodowa polityka kosmiczna z 2010 roku}

Znacznie dokładniejsze rozważania na temat spacepower spotkać można w dokumentach ściślej odnoszących się do wykorzystania przestrzeni kosmicznej. Podstawowym z nich jest National Space Policy ${ }^{304}$, opublikowany w lipcu 2010 roku pod auspicjami prezydenta USA. Dotyczy on szerokiej tematyki, w mniejszym stopniu bezpieczeństwa jako takiego, a bardziej spacepower w szerszym znaczeniu. Warto jednak przytoczyć pokrótce jego główne postanowienia, bo chociaż pochodzi z czasów poprzedniej administracji, jest jednak wciąż najbardziej wyczerpującym dokumentem $w$ tej materii. W znacznej mierze stanowi więc bazę i punkt odniesienia dla obecnej prezydentury, ponadto dotychczasowy dorobek doktrynalny administracji Trumpa nie zmienia jak dotąd w sposób fundamentalny obrazu, jaki wyłania się z NSP.

Już na pierwszej stronie cytaty z przemówień prezydentów Eisenhowera i Obamy wyraźnie wskazują na to, że zdolności do wykorzystania przestrzeni kosmicznej są uznawane za bardzo ważny element szeroko rozumianych możliwości oddziaływania państwa, a więc jego siły. Pierwszy prezydent ery kosmicznej wspomina zatem między innymi o tym, że wykorzystanie przestrzeni okołoziemskiej może poprawiać życie na Ziemi, Obama zaś wskazuje, że rozwijanie zdolności kosmicznych posłuży wzmocnieniu amerykańskiego przywództwa ${ }^{305}$. Pojawia nam się zatem wyraźnie, choć bez tego określenia, spacepower jako element ogólnej siły i możliwości działania państwa.

Zwraca się zatem uwagę na rozwój bazy przemysłowej oraz innowacji, jako podstawę rozwoju całego sektora kosmicznego, co z kolei w sposób oczywisty wpływa na umiejętność budowania zdolności kosmicznych i wykorzystywania ich na rzecz siły i zdolności oddziaływania państwa. Istotna jest także kwestia prestiżu, budowanego między innymi dzięki 
działalności naukowej w kosmosie i wykorzystywaniu go do badań istotnych z punktu widzenia całej ludzkości. Do tych elementów rozwoju gospodarczego oraz soft power dochodzą kwestie bezpieczeństwa w bardziej tradycyjnym wymiarze, związane z koniecznością zapewnienia systemom kosmicznym niezakłóconego działania ${ }^{306}$.

W dalszej kolejności dokument dość szczegółowo wymienia zalecenia (guidelines), które winny być realizowane dla osiągnięcia celów polityki kosmicznej. Nie ma tu miejsca, by je dokładnie wymieniać. Z naszego punktu widzenia najistotniejsze jest to, że bardzo wyraźnie podkreśla się konieczność umocnienia przodującej roli USA w zakresie technologii kosmicznych, konieczność działań na rzecz bezpieczeństwa kosmicznego związanego zarówno $z$ ewentualnymi wrogimi działaniami, jak i zagrożeniami dla środowiska kosmicznego, rozwój odpowiedniej bazy przemysłowej, naukowej i edukacyjnej oraz oczywiście utrzymanie i unowocześnienie zastosowań kosmicznych $\mathrm{w}$ dziedzinie bezpieczeństwa narodowego ${ }^{307}$.

Pojawia się zatem w tym dokumencie dość wyraźnie spacepower, choć terminu tego nie używa się w znaczeniu bardzo szerokiej sumy możliwości militarnych i cywilnych, służącej wykorzystaniu przestrzeni kosmicznej do realizacji rozlicznych interesów państwa. Obejmuje on zatem nie tylko sam kosmos i systemy kosmiczne, ale i wspierającą je bazę przemysłową, naukowo-techniczną i edukacyjną. Co więcej, mocno się akcentuje, że nie jest to tylko domena państwa działającego przez swoje organy, ale także prywatnych przedsiębiorstw, które może być bardzo dobrym partnerem, a zatem państwo winno na różne sposoby wspierać „[...] krajowy przemysł kosmiczny [...]"308.

Narodowa strategia bezpieczeństwa kosmicznego z 2011 roku

Drugim podstawowym dokumentem dotyczącym strategii kosmicznej USA, który także pochodzi z czasów poprzedniej administracji, lecz nie przestał być aktualny, jest National Security Space Strategy, oficjalnie

306 Ibidem, s. 4.

307 Ibidem, s. 5 i n.

308 Ibidem, s. 10. 
dostępny jedynie $w$ wersji streszczenia ${ }^{309}$. Strategia ta oczywiście koncentruje się na tematyce bezpieczeństwa, co właśnie jest głównym przedmiotem naszego zainteresowania, należy ją zatem prześledzić względnie dokładnie. Wydana została pod auspicjami Departamentu Obrony oraz Biura Dyrektora Narodowego Wywiadu.

Podstawowym stwierdzeniem, najbardziej istotnym dla praktyki wykorzystania przestrzeni kosmicznej jest to, że jest ona coraz bardziej „[...] zatłoczona, zagrożona i konkurencyjna” ${ }^{1 \circ}$. Zatłoczenie oznacza ogromny i szybki przyrost liczby obiektów w kosmosie, zarówno aktywnych satelitów, jak i śmieci różnego rodzaju, co stwarza zagrożenie dla funkcjonowania systemów orbitalnych. Podobnie dzieje się ze spektrum częstotliwości radiowych wykorzystywanych przez poszczególne systemy, co zwiększa możliwości występowania zakłóceń. Zagrożenie oznacza, że „[w]spółczesne systemy kosmiczne i infrastruktura je wspierająca stają wobec szeregu zagrożeń ze strony człowieka, które mogą uniemożliwić korzystanie, ograniczyć efektywność, zaburzyć działanie lub [je] zniszczyć [...]"”․ Zagrożeniem są przy tym nie tylko rozwijające się zdolności kosmiczne oraz środki przeciwdziałania systemom kosmicznym znajdujące się $w$ dyspozycji państw, ale także działalność aktorów niepaństwowych. Ci ostatni są nie tylko zagrożeniem dla USA, ale również dla bezpieczeństwa środowiska kosmicznego. Zwraca się przy tym uwagę, że działania przeciwko systemom satelitarnym mogą mieć poważne konsekwencje, w szczególności mogą przerwać dostarczanie przez systemy satelitarne kluczowo dla gospodarek ważnych usług komercyjnych. I wreszcie konkurencyjność oznacza, że choć USA nadal przodują w eksploracji i eksploatacji kosmosu, to jednak ,[...] amerykańska przewaga w technologii podlega erozji w kilku obszarach, w miarę jak wiedza w innych państwach się rozwija" ${ }^{312}$. Jest to wynikiem nie tylko rozwoju technologii jako takiego, ale także rosnącego „urynkowienia” techniki kosmicznej w miarę jej komercjalizacji.

Mimo tych trendów „[a]merykańskie wspólnoty obronna i wywiadowcza będą nadal polegać na systemach kosmicznych dla celów realizacji

309 National Security Space Strategy...

310 Wyróżnienia w oryginale, ibidem, s. 1.

311 Ibidem, s. 2.

312 Ibidem, s. 3. 
operacji wojskowych, gromadzenia informacji wywiadowczych $\mathrm{i}$ innych podobnych działań; dostęp do tych zdolności musi zostać zapewniony" ${ }^{313}$. W związku z tym NSSS, bazując na NSP, stwierdza konieczność realizacji „,...] następujących celów, w ramach narodowego bezpieczeństwa kosmicznego:

- umocnienie bezpieczeństwa (safety), stabilności i bezpieczeństwa (security) w kosmosie,

- utrzymanie i wzmocnienie przewagi strategicznej, którą zapewnia Stanom Zjednoczonym przestrzeń kosmiczna i

- pobudzenie bazy przemysłu kosmicznego, który wspiera bezpieczeństwo narodowe USA" ${ }^{114}$.

W dalszej kolejności strategia rozwija powyższe punkty, wskazując bardziej szczegółowo na działania, jakie w tym zakresie należy podejmować. Są to między innymi kwestie dotyczące współpracy międzynarodowej w zakresie zasad odpowiedzialnego zachowania w kosmosie, zapewnienie przyrostu możliwości własnych systemów satelitarnych w ramach ich misji oraz innowacyjność i rozwój technologiczny bazy przemysłowej. W niniejszej pracy nie ma jednak potrzeby, aby bardziej szczegółowo rozwijać te kwestie.

W konkluzji omawianego dokumentu podkreśla się po raz kolejny, że „[...] Stany Zjednoczone utrzymają przywództwo w kosmosie poprzez wzmocnienie swojego własnego potencjału i współpracę z podmiotami na świecie" ${ }^{315}$. W związku z przedstawionymi na początku omawiania NSSS cechami zmieniającego się środowiska kosmicznego Strategia przewiduje "[...] zestaw następujących, wzajemnie się uzupełniających polityk:

- zamierzamy przeciwdziałać zatłoczeniu poprzez ustanowienie norm, wzmocnienie świadomości sytuacyjnej w kosmosie i popieranie większej transparentności i wymiany informacji.

[...]

- zamierzamy przeciwdziałać zagrożeniu środowiska kosmicznego poprzez wielowarstwowe odstraszanie. Będziemy wspierać ustanawianie norm prawnomiędzynarodowych i dotyczących przejrzystości działań oraz środków budowy zaufania w kosmosie, w pierwszej kolejności, 
aby promować bezpieczeństwo lotów kosmicznych, ale także aby zniechęcić do agresywnego zachowania i spowodować pojawienie się międzynarodowych jego konsekwencji. Zachowamy prawo i odpowiednie zdolności do działania w samoobronie, jeśli odstraszanie zawiedzie.

[...]

- zamierzamy radzić sobie z konkurencyjnościq w kosmosie poprzez wzmacnianie własnych zdolności, poprawianie procedury zamówień, promowanie zdrowej, krajowej bazy przemysłowej i wzmocnienie współpracy międzynarodowej"316.

Jaka widać, NSSS zawiera wszystkie elementy spacepower, w pierwszej kolejności w podstawowym ujęciu związanym $\mathrm{z}$ bezpieczeństwem narodowym, lecz rozumianej stosunkowo szeroko. Świadczy o tym przede wszystkim podkreślanie roli bazy przemysłowej, która ma przecież szerszy wymiar niż tylko bezpieczeństwo narodowe, a także roli i znaczenia innowacyjności i rozwoju technologicznego, co również wykracza poza wąskie ramy bezpieczeństwa narodowego w wymiarze zewnętrznym.

Dokumenty dotyczqce polityki kosmicznej administracji Donalda Trumpa

W warstwie deklaratywnej, którą w tym przypadku można określić jako warstwę propagandową, Donald Trump odcina się od polityki poprzedniego prezydenta, budując swoją tożsamość polityczną w dużej mierze jako swego rodzaju anty-Obama. W związku z tym przestrzeń publiczna pełna jest deklaracji i enuncjacji prezydenta na temat różnych polityk państwa, które dezawuują poprzednią administrację, lecz niekoniecznie tworzą nowe fakty w warstwie rzeczywistej. Podobnie rzecz się ma z polityką kosmiczną, gdzie mamy szereg nowych deklaracji, rzekomo radykalnie transformujących amerykańską politykę w tym zakresie, a więc i podejście do spacepower. Jednak w praktycznych kategoriach nie zmieniają one wiele, przynajmniej na razie.

Pomijając liczne tweety i chaotyczne wypowiedzi prezydenta, w sferze polityki kosmicznej do sierpnia 2019 roku pojawiło się tylko kilka dokumentów, które należy omówić. Najważniejsze z nich to cztery teksty noszące nazwę Dyrektywa Polityki Kosmicznej (SPD), wydane w formie 
memorandum prezydenckiego, a zatem mające charakter obowiązujący jako decyzje wykonawcze. Opublikowano ponadto jeden niemający mocy obowiązującej dokument, który można nazwać deklaracją intencji w zakresie strategii kosmicznej, oraz jeden szczegółowy raport zawierający propozycje konkretnych działań. Poniżej omówimy je wszystkie pokrótce i postaramy się skomentować wypływające $\mathrm{z}$ nich wnioski.

11 grudnia 2017 roku prezydent Trump podpisał dokument pod tytułem Prezydenckie Memorandum Dotyczące Ożywienia Amerykańskiego Programu Załogowych Badań Kosmicznych ${ }^{317}$, znany pod nazwą Dyrektywa Polityki Kosmicznej nr 1 (Space Policy Directive-1, SPD-1). Jest to bardzo krótki tekst, stanowiący formalnie jedynie poprawkę do NSP z 2010 roku, wprowadzający do niej następujące postanowienie:

[USA mają] prowadzić innowacyjny i realistyczny program eksploracji [kosmosu] razem z komercyjnymi i międzynarodowymi partnerami, aby umożliwić ekspansję ludzi w systemie słonecznym, która ma przynieść Ziemi wiedzę i możliwości. Poczynając od misji poza niską orbitę okołoziemską, Stany Zjednoczone będą przodować w powrocie ludzi na Księżyc dla długotrwałej eksploracji i wykorzystania, za którą pójdą misje na Marsa i w innych kierunkach ${ }^{318}$.

Znamienne jest to, że tekst ten zastąpił w NSP paragraf, który brzmiał:

[NASA ma] ustanowić dalekosiężne cele kosmicznej eksploracji. Do 2025 roku mają rozpocząć się załogowe loty poza orbitę Księżyca, łącznie $\mathrm{z}$ wysłaniem ludzi na asteroidę. W połowie lat 30. XXI wieku ludzie maja zostać wysłani na orbitę Marsa, $z$ której powinni powrócić bezpiecznie na Ziemię 319 .

Łatwo zauważyć, że Donald Trump nie oferuje tu w gruncie rzeczy niczego nowego, a rzekome „ożywienie” oznacza deklaratywne rozwodnienie bardziej konkretnych celów stawianych przez poprzednią administrację, jest zatem raczej krokiem wstecz niż naprzód w eksploracji kos-

317 Presidential Memorandum on Reinvigorating America's Human Space Exploration Program, White House, 11.12.2017, https://www.whitehouse.gov/presidential-actions/ presidential-memorandum-reinvigorating-americas-human-space-exploration-pro gram/.

318 Ibidem.

319 National Space Policy..., s. 11. 
mosu. Co ciekawe, jednocześnie opublikowane zostało przez Biały Dom oświadczenie pod tytułem Prezydent Donald J. Trump uczyni Amerykę ponownie liderem $w$ eksploracji kosmosu ${ }^{320}$. Jego tekst odwołuje się do SPD-1, wychodząc jednak znacznie poza brzmienie dyrektywy. Powtarza zatem w bombastycznym stylu zapewnienia o zamiarze wysłania ludzi na Księżyc, ale także wskazuje na przemysł prywatny jako na ważnego partnera dla rozwijania zdolności kosmicznych, oraz podkreśla, że USA utraciły zdolność do wysyłania ludzi w kosmos. Jeśli z tych krótkich i wyraźnie nakierowanych na efekt propagandowy zdań można wydobyć coś konkretnego na temat spacepower, to jest to z jednej strony próba stworzenia celu, którego osiąganie będzie stymulować rozwój, a z drugiej - deklaracja, że ma on dotyczyć także rozwoju przemysłu w szerokim sensie. Warto przy tym podkreślić te stwierdzenia zawarte $w$ oświadczeniu, które wskazują na swego rodzaju upadek amerykańskich zdolności kosmicznych, czego symbolem jest brak możliwości dokonywania lotów załogowych. Pomiędzy wierszami wyczytać można, że ten stan rzeczy jest skutkiem zaniedbań poprzedniej administracji, a odzyskanie tej zdolności za pomocą rodzimej techniki i rodzimego przemysłu jawi się jako jeden z kluczowych dla Ameryki celów. Nie jest to jednak nic nowego ani zaskakującego w ramach ewoluującej od dawna doktryny polityki kosmicznej, podobnie jak coraz szersze angażowanie prywatnych partnerów w ramach podboju kosmosu. Obecny rozwój współpracy NASA i innych agend rządowych $\mathrm{z}$ takimi przedsiębiorstwami jak SpaceX czy Blue Origin wynika $z$ tradycyjnej, przemyślanej i prowadzonej z rozmachem polityki partnerstwa państwa i podmiotów prywatnych znacznie rozszerzonej przez administrację Baracka Obamy.

23 marca 2018 roku Biały Dom opublikował oświadczenie pod tytułem Prezydent Donald J. Trump ujawnia Narodową Strategię Kosmiczną America First ${ }^{321}$. Sygnowane jest ono jako "materiał informacyjny” (fact sheet), nie jest zatem całkiem jasne, czy jest to skrót niejawnego dokumentu, czy też niezobowiązująca werbalizacja generalnego zamysłu dotyczącego

320 President Donald J. Trump Will Make America a Leader in Space Exploration Again, The White House, 11.12.2017, https://www.whitehouse.gov/briefings-statements/presi dent-donald-j-trump-will-make-america-leader-space-exploration/.

321 President Donald J. Trump Is Unveiling an America First National Space Strategy, The White House, 23.03.2018, https://www.whitehouse.gov/briefings-statements/ president-donald-j-trump-unveiling-america-first-national-space-strategy/. 
kształtu polityki kosmicznej USA doby Trumpa. Z jednej strony wpisuje się ono w budowę kultu jednostki opartego na tworzeniu alternatywnej, pożądanej rzeczywistości przez obecnego prezydenta, z drugiej zaś - powtarza w dużej części podstawowe zapisy omówionej powyżej NSS, nie wnosząc zatem wiele nowego. Można to jednak potraktować jako ogólny zarys tego, w jaki sposób administracja Donalda Trumpa postrzega podstawowe elementy polityki kosmicznej.

Materiał ten składa się z pięciu części. Pierwsza, pod tytułem Ameryka pierwsza pomiędzy gwiazdami (America First Among the Stars), akcentuje konieczność rozwijania sektora kosmicznego dla ogólnego rozwoju Stanów Zjednoczonych, ich wielkości i światowej pozycji. Stwierdza również, że porozumienia międzynarodowe $w$ dziedzinie eksploracji kosmosu muszą sprzyjać amerykańskim interesom. I wreszcie podkreśla znaczenie „[...] dynamicznych i nacechowanych współpracą interakcji pomiędzy kosmicznymi sektorami należącymi do sfery bezpieczeństwa narodowego oraz komercyjnym i cywilnym [...]"322. Mamy tu typowe elementy szerokiego ujęcia spacepower wraz $\mathrm{z}$ bardzo konserwatywnym podejściem do egoistycznych celów państwa, także $w$ relacjach $z$ innymi krajami.

Druga część, Prymat Ameryki dzięki amerykańskiemu duchowi (American Preeminence Through the American Spirit), wnosi niewiele, podkreślając amerykańską tradycję rozwoju technologii i przywództwa w eksploracji kosmosu i zapewniając, że „[...] zapewnienie naukowych, komercyjnych i związanych z bezpieczeństwem międzynarodowym korzyści z kosmosu jest najwyższym priorytetem tej administracji" ${ }^{223}$.

Tytuł trzeci, Pokój poprzez siłę (Peace Through Strength), obejmuje kwestie najbardziej nas intersujące, czyli dotyczące roli kosmosu w bezpieczeństwie narodowym. Bazując na znanych nam już postanowieniach NSS, stwierdza się zatem w pierwszej kolejności, że „[...] zapewnienie niezakłóconego dostępu i swobody działania w kosmosie służy bezpieczeństwu Ameryki, gospodarczemu dobrobytowi i wiedzy naukowej"324, a zatem leży w żywotnym interesie Stanów Zjednoczonych. W związku z tym zagrożenie bezpieczeństwa systemów kosmicznych spotka się ze 
zdecydowaną odpowiedzią USA ${ }^{325}$ (co jest notabene dosłownym cytatem z NSS, przedstawionym już powyżej). Należy zatem być przygotowanym do prowadzenia działań w przestrzeni kosmicznej, którą, jak się stwierdza, konkurenci i przeciwnicy Ameryki przekształcili w pole walki zbrojnej ${ }^{326}$. I choć Stany Zjednoczone wolą, by kosmos pozostał wolny od konfliktów, będą gotowe poradzić sobie z wszelkimi wyzwaniami, które mogą się pojawić. USA będą zatem odstraszać przeciwników, przeciwdziałać wrogim poczynaniom i bronić się przed zagrożeniami w przestrzeni kosmicznej. Mimo braku precyzji i skrótowości dokumentu możemy w tych określeniach dostrzec spacepower, rozumianą jako jedną z krytycznych zdolności budujących bezpieczeństwo Stanów Zjednoczonych.

Czwarta część dokumentu nosi tytuł Cztery filary jednolitej polityki (Four Pillars for a Unified Approach). Wskazuje on na to, że strategia kosmiczna wymaga współdziałania wszystkich segmentów administracji i bazuje na czterech elementach: transformacji architektury kosmicznej dla zwiększenia jej odporności, wzmocnieniu odstraszania i zwiększeniu liczby opcji w ramach działań zbrojnych (warfighting options), poprawie fundamentalnych zdolności struktur i procesów oraz zapewnieniu korzystnego wewnętrznego i międzynarodowego środowiska. Jest to kontynuacja poprzedniego punktu, wymieniająca kompleksowo niezbędne do podjęcia działania dla zapewnienia, że spacepower będzie działać jak należy.

I wreszcie piąta część, Nowy kierunek dla amerykańskich wysiłków kosmicznych ( $A$ New Direction for U.S. Space), nie wnosi niczego nowego, przypomina jedynie o już podjętych działaniach, czyli o odtworzeniu przez Trumpa Narodowej Rady Kosmicznej pod przewodnictwem wiceprezydenta, która zebrała się w październiku 2017 roku, i o przyjęciu dyrektywy nr 1, o której była już mowa.

Podsumowując dokument, który jest dotychczas najszerszą wykładnią polityki kosmicznej Donalda Trumpa, można stwierdzić przede wszystkim, że nie wnosi on praktycznie nic do dotychczasowej doktryny i jej realizacji. Także ze względu na jej niejasny status „strategia kosmiczna” czterdziestego piątego prezydenta nie ma żadnego praktycznego znaczenia, choć ma niewątpliwie swoje miejsce, i to zapewne prominentne,

326 Używa się tu bardzo jednoznacznego określenia warfighting domain. 
w grze pozorów, jaką prowadzi on z amerykańską publicznością. Nie jest to jednak przedmiotem analizy niniejszej pracy.

Dwie kolejne dyrektywy polityki kosmicznej, numer $2^{327}$ i numer $3^{328}$, wydane zostały odpowiednio w maju i czerwcu 2018 roku. Pierwsza z nich, zatytułowana Ograniczenie regulacji dotyczących komercyjnego wykorzystania kosmosu, zawiera szczegółowe wskazówki odnoszące się do przeglądu poszczególnych dziedzin prawa regulującego działalność kosmiczną w celu ich usprawnienia i ułatwienia działalności komercyjnej. W szczególności dotyczy to licencjonowania startów i powrotów do atmosfery, komercyjnego obrazowania $z$ orbity oraz wykorzystania częstotliwości radiowych. Jest to w swojej naturze akt o charakterze wykonawczym, a nie doktrynalnym, choć jego realizacja może przynieść zmiany legislacyjne, które w pewnym zakresie ukształtują politykę kosmiczną USA. Jeśli takie zmiany nastąpią i rzeczywiście będą obejmowały deregulacje i inne ułatwienia działalności gospodarczej, będzie to wyraźny dowód na to, że w ramach spacepower rośnie znaczenie swobody działalności gospodarczej, która co do zasady sprzyjać ma rozwojowi państwa. Ale jest to kwestia przyszłości i ewentualnie przyjętych kierunków działania oraz polityk, na razie dyrektywa zobligowała jedynie niektóre organy rządowe do dokonania przeglądu istniejących uregulowań prawnych.

Dyrektywa Polityki Kosmicznej nr 3 nosi tytuł Polityka w zakresie zarządzania ruchem $w$ kosmosie. Jest to stosunkowo szczegółowy zestaw ocen, zasad i reguł, dotyczących zarządzania przestrzenią kosmiczną w celu utrzymania bezpieczeństwa ruchu i użytkowania obiektów kosmicznych. Jego sens polega głównie na konstatacji, że rozwijające się gwałtownie wykorzystanie kosmosu z nowymi zjawiskami, takimi jak nowe sensory, wielkie konstelacje orbiterów, kosmiczne śmieci etc., wymaga nowego i kompleksowego podejścia do zarządzania przestrzenią. Ameryka winna zatem rozwijać takie podejście i przodować w poszukiwaniu międzynarodowych rozwiązań w tym zakresie. Jest to niewątpliwie istotny dokument o charakterze praktycznym, uściśla i uszczegóławia

327 Space Policy Directive-2, Streamlining Regulations on Commercial Use of Space, The White House, 24.05.2018, https://www.whitehouse.gov/presidential-actions/spacepolicy-directive-2-streamlining-regulations-commercial-use-space/.

328 Space Policy Directive-3, National Space Traffic Management Policy, The White House, 18.06.2018, https://www.whitehouse.gov/presidential-actions/space-policy-directive3-national-space-traffic-management-policy/. 
konkretne zadania w ramach konkretnych celów, ustalając zasady koordynacji pracy różnych agend i organów rządowych. Nie ma on jednak istotnej roli politycznej, choć oczywiście można w nim znaleźć wiele postanowień, których implementacja może spowodować pojawienie się nowych podejść i nowych polityk. Jest to jednak kwestia bliżej nieokreślonej przyszłości, ponieważ jakkolwiek dyrektywa proponuje pozytywne zmiany, odpowiadające $w$ dużej mierze ewoluującemu zapotrzebowaniu, jej wprowadzenie $w$ życie wciąż jednak wymaga szeregu działań organizacyjnych i w szczególności legislacyjnych ${ }^{329}$.

Space Force - nowy wymiar strategii kosmicznej USA?

W pewnym sensie odrębną kwestią jest realizowana przez administrację Donalda Trumpa koncepcja utworzenia Sił Kosmicznych (Space Force) jako osobnego, szóstego, rodzaju sił zbrojnych wraz z całą odpowiednią strukturą administracyjną. Po dłuższych dyskusjach w sierpniu 2018 roku rozpoczęto wdrażanie tego pomysłu pomimo obaw, wyrażanych nawet $w$ kręgach wojskowych, że utworzenie nowego rodzaju sił zbrojnych w żadnym wypadku nie zwiększy zdolności kosmicznych USA, natomiast stworzy dodatkową, kosztowną machinę biurokratyczną 330.

Zmiany w strukturze sił zbrojnych, związane $\mathrm{z}$ tworzeniem Space Force mogą w istotny sposób zaważyć na amerykańskiej spacepower, jednak nie jest to wcale pewne. W chwili obecnej jesteśmy na wczesnych etapach formułowania podstawowych zrębów koncepcji, nie wiadomo zatem, czym będą Siły Kosmiczne. Czy koncepcja ta odzwierciedli nowy etap militaryzacji kosmosu, polegający na powstaniu broni kosmicznych i struktury nimi zarządzającej? Czy może będzie to tylko reorganizacja i racjonalizacja wysiłku $w$ ramach istniejących koncepcji, ewentualnie obudowanych polityczno-propagandową osłoną $w$ ramach tworzenia przez Donalda Trumpa kolejnej warstwy alternatywnej rzeczywistości?

329 T. J. Muelhaupt [et al.], Space Traffic Management in the New Space Era, „Journal of Space Safety Engineering" 2019, vol. 6, nr 2, s. 84.

330 R. Burns, Pentagon Redoing Space Defenses, but Will Trump Demand More?, Defense News, 4.08.2018, https://www.defensenews.com/space/2018/o8/o3/pentagon-redo ing-space-defenses-but-will-trump-demand-more/. 
W każdym razie warto prześledzić, przynajmniej pobieżnie, dorobek doktrynalny związany z tworzeniem Space Force, powstały do sierpnia 2019 roku.

Podstawowym dokumentem racjonalizującym decyzję o utworzeniu Sił Kosmicznych jest Ostateczny raport na temat struktury organizacji i zarządzania komponentów kosmicznych bezpieczeństwa narodowego należących do Departamentu Obrony ${ }^{331}$, który został ogłoszony w sierpniu 2018 roku. Jego głównym przesłaniem jest znane nam skądinąd stwierdzenie, że przestrzeń kosmiczna jest „[...] integralną częścią amerykańskiego stylu życia oraz współczesnych działań zbrojnych" ${ }^{332}$. Podkreśla się przy tym, co także dobrze znamy, że choć amerykańskie systemy kosmiczne utrzymują technologiczną przewagę nad resztą świata, to jednak współcześnie potencjalni przeciwnicy intensywnie rozwijają środki służące ograniczeniu tej przewagi. W związku z tym USA muszą zaadaptować swoje zdolności kosmiczne wraz z odpowiednią doktryną, aby zabezpieczyć swoje interesy. W tym właśnie celu

[...] Departament Obrony zgromadzi zasoby kosmiczne w ramach Sił Kosmicznych. Siły Kosmiczne będą zabezpieczać naszą gospodarkę poprzez odstraszanie agresywnych działań, zapewnią, że nasze systemy kosmiczne spełniają wymagania bezpieczeństwa narodowego i dostarczą żywotnych zdolności dla połączonych i koalicyjnych sił w całym spektrum konfliktów ${ }^{333}$.

Raport przewiduje również, że proces ustanowienia Sił Kosmicznych będzie wielopłaszczyznowy i rozłożony na etapy. W pierwszym, w ramach istniejących uprawnień, Departament Obrony ustanowi kilka komponentów tych sił. W drugiej fazie Kongres winien powołać Siły Kosmiczne jako osobny rodzaj (branch) sił zbrojnych, ponieważ to legislatywa ma zgodnie $z$ amerykańskim prawem uprawnienia do podjęcia takiej decyzji.

331 Final Report on Organizational and Management Structure for the National Security Space Components of the Department of Defense, Report to Congressional Defense Committees, U.S. Department of Defense, 9.08.2018, https://media.defense.gov/2018/ Aug/o9/2001952764/-1/-1/1/ORGANIZATIONAL-MANAGEMENT-STRUCTUREDOD-NATIONAL-SECURITY-SPACE-COMPONENTS.PDF.

332 Ibidem, s. 1. 3.3 Ibidem. 
W trybie natychmiastowym Departament ma zatem zając się tworzeniem następujących komponentów:

- Agencja Rozwoju Kosmosu (Space Development Agency, SDA),

- Siły Operacji Kosmicznych (Space Operations Force, SOF),

- Wsparcie i Zabezpieczenie (Services and Support, S\&S),

- Dowództwo Kosmiczne (Space Command, SC).

Według cytowanego Raportu SDA ma być „[...] połączoną organizacją, której zadaniem jest szybki rozwój i rozmieszczanie zdolności nowej generacji” 334 . Z kolei SOF to „[...] siły złożone z zawodowych ekspertów od kosmosu, [...] którzy w ramach swoich profesji zajmują się walką w kosmosie i tworzą kosmiczną wspólnotę inżynierów, ekspertów od wywiadu, operatorów, strategów etc. [...]"335. Komponent pod nazwą S\&S ma natomiast być efektywną i niedrogą strukturą poddaną nadzorowi cywilnemu, zapewniającą wsparcie i zabezpieczenie dla Sił Kosmicznych ${ }^{336}$. I wreszcie SC ma służyć „[...] zwiększeniu skuteczności i ewolucji walki zbrojnej w kosmosie, łącznie $\mathrm{z}$ integrowaniem innowacyjnych struktur, koncepcji operacyjnych, doktryn, taktyk, technik i procedur"337.

W dniu publikacji Raportu, 9 sierpnia 2018 roku, prezydent wydał także polecenie, by podjąć działania na rzecz realizacji zawartego w nim

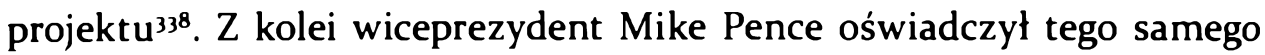
dnia, że administracja będzie stała się doprowadzić do legislacji na temat powstania Space Force już w 2020 roku ${ }^{339}$.

Space Command zostało oficjalnie utworzone na mocy prezydenckiej decyzji z 18 grudnia 2018 roku $^{340}$. Donald Trump nakazał w niej Depar-

$33+$ Ibidem, s. 4.

335 Ibidem.

336 Ibidem.

337 Ibidem.

338 President Donald J. Trump Is Building the United States Space Force for a 21st Century Military, The White House, 9.08.2018, https://www.whitehouse.gov/briefings-statements/ president-donald-j-trump-building-united-states-space-force-21st-century-military/. 339 C. Rou lo, Space Force to Become Sixth Branch of Armed Forces, U.S. Department of Defense, 9.08.2018, https://www.defense.gov/News/Article/Article/1598071/space-forceto-become-sixth-branch-of-armed-forces/.

340 Text of a Memorandum from the President to the Secretary of Defense Regarding the Establishment of the United States Space Command, The White House, 18.12.2018, https://www.whitehouse.gov/briefings-statements/text-memorandum-presidentsecretary-defense-regarding-establishment-united-states-space-command/. 
tamentowi Obrony utworzenie dowództwa operacyjnego (unified combatant command) pod nazwą Dowództwo Kosmiczne Stanów Zjednoczonych (United States Space Command) oraz przedstawienie kandydatur na dowódcę tej jednostki. Dokument powierza jednostce następujące zadania:

(1) wszystkie ogólne obowiązki dowództwa operacyjnego;

(2) zadania związane z kosmosem, które wcześniej były przypisane do Dowództwa Strategicznego Stanów Zjednoczonych i

(3) zadania połączonego dostawcy sił [Joint Force Provider] i podmiotu szkolącego [Joint Force Trainer] dla Sił Operacji Kosmicznych [Space Operations Forces] ${ }^{3+1}$.

Ta decyzja oznacza, że z Dowództwa Sił Strategicznych wyjęto pewien zakres zadań i przekazano go do nowego dowództwa operacyjnego. Ma ono jednak spełniać także zadania szersze niż typowe dowództwo operacyjne. Co do zasady jest ono bowiem jedynie użytkownikiem powierzonych mu sił (force user), które przygotowują i szkolą inne struktury. Space Command ma, wedle aktualnego stanu rzeczy, być i użytkownikiem, i dostawcą sił (force provider) oraz podmiotem szkolącym (force trainer). Być może nawet taka struktura będzie docelowa; ze względu na specyfikę działalności kosmicznej wszystkie te funkcje mogą pozostać w jednym dowództwie, podobnie jak to się dzieje w przypadku Dowództwa Operacji Specjalnych (Special Operations Command). Jednakże zapowiedź utworzenia Space Operations Force wskazuje, że to ta struktura ma mieć charakter zabezpieczającej siły dla działań kosmicznych, a SC przekształci się w typowego force user, nie znajduje to jednak potwierdzenia w przedstawionych poniżej wskazówkach dotyczących dalszego procesu legislacyjnego.

19 lutego 2019 roku opublikowana została dyrektywa polityki kosmicznej numer 4 pod tytułem Utworzenie Sił Kosmicznych Stanów Zjednoczonych $^{342}$. W pierwszej kolejności dokument ten powtarza znane nam już bardzo dobrze słowa o zagrożeniu oraz osłabieniu amerykańskiej

341 Ibidem.

342 Text of Space Policy Directive-4: Establishment of the United States Space Force, White

House, 19.02.2019, https://www.whitehouse.gov/presidential-actions/text-space-poli cy-directive-4-establishment-united-states-space-force/. 
przewagi w kosmosie ze wszystkimi tego konsekwencjami, które także dobrze znamy. W związku z tym zadaniem dyrektywy jest skupienie istniejących zasobów na rzecz odstraszania i przeciwdziałania zagrożeniom w kosmosie. Departament Obrony ma zatem przedstawić propozycję legislacyjną na temat utworzenia Sił Kosmicznych jako szóstego rodzaju sił zbrojnych. Ich zadaniem ma być organizowanie, szkolenie i wyposażanie jednostek działających w kosmosie, zarówno bojowych, jak i wspierających działania zbrojne. Space Force pierwotnie ma się znajdować w ramach Departamentu Sił Powietrznych, w dalszej przyszłości powinien powstać osobny Departament Sił Kosmicznych. Siły Kosmiczne mają realizować następujące priorytety:

(a) zabezpieczać interesy narodowe w kosmosie oraz pokojowe wykorzystanie kosmosu dla wszystkich odpowiedzialnych aktorów, w zgodzie z prawem, w tym międzynarodowym;

(b) zapewnić Stanom Zjednoczonym niezakłócone wykorzystanie przestrzeni kosmicznej dla celów bezpieczeństwa narodowego i gospodarki, dla amerykańskich obywateli oraz amerykańskich partnerów i sojuszników;

(c) odstraszać przed agresją i bronić państwa, sojuszników Stanów Zjednoczonych i amerykańskich interesów przed wrogimi działaniami w kosmosie i z kosmosu;

(d) zapewnić, że niezbędne zdolności kosmiczne będą zintegrowane i dostępne dla wszystkich dowództw operacyjnych Stanów Zjednoczonych;

(e) rozwijać siły zbrojne [project military power] w kosmosie, z kosmosu i w kierunku kosmosu dla wsparcia naszego interesu narodowego $\mathrm{i}$

(f) rozwijać, utrzymywać i ulepszać wspólnotę profesjonalistów skupionych na wymaganiach narodowego bezpieczeństwa $w$ przestrzeni kosmicznej ${ }^{343}$.

A zatem według SPD-4 Departament Obrony otrzymał rozległe zadanie przygotowania skomplikowanej inicjatywy ustawodawczej, które następnie ma znaleźć się w Kongresie USA. Dyrektywa zawiera jeszcze dalsze szczegółowe wskazówki, wedle których ma powstawać projekt legislacyjny, z których najistotniejsze są, jak się zdaje, następujące:

1. NASA, NOAA, NRO i inne cywilne agencje nie mają zostać wchłonięte przez Space Force, mają one natomiast przejąć personel cywilny 
i mundurowy zajmujący się bezpośrednim prowadzeniem i wspieraniem operacji kosmicznych, zatrudniony we wszystkich rodzajach sił zbrojnych podlegających Departamentowi Obrony.

2. Finansowanie Sił Kosmicznych ma pojawić się już $w$ budżecie na 2020 rok.

3. Ma zostać utworzone stanowisko podsekretarza stanu do spraw Sił Kosmicznych w departamencie obrony oraz stanowisko szefa sztabu Sił Kosmicznych, który winien zasiadać w Komitecie Połączonych Sztabów.

4. Tak jak przewidywała decyzja o utworzeniu Space Command, ma ono pełnić zadania nie tylko force user, ale także force provider i force trainer.

I wreszcie dyrektywa stwierdza, że:

[w] miarę jak Siły Kosmiczne Stanów Zjednoczonych będą dojrzewać i w miarę potrzeb bezpieczeństwa narodowego konieczne będzie utworzenie odrębnego departamentu, który ma mieć nazwę Departament Sił Kosmicznych [Department of the Space Force]. Departament ten przejmie część lub całość odpowiedzialności za Siły Kosmiczne Stanów Zjednoczonych od Departamentu Sił Powietrznych. Sekretarz obrony ma przeprowadzać okresowe przeglądy, by stwierdzić, kiedy należy prezydentowi zarekomendować legislację dotyczącą utworzenia takiego departamentu.

W chwili obecnej tworzenie Sił Kosmicznych sprowadza się przede wszystkim do powołania Space Command, które ma otrzymać siły i zadania dotychczas rozproszone w systemie sił zbrojnych. Dowództwo to podjęło swoje obowiązki w sierpniu 2019 roku, przejmując operacyjną kontrolę nad 87 jednostkami zarządzającymi systemami kosmicznymi, w których były zatrudnione 642 osoby personelu ${ }^{344}$. Pozostałe komponenty przewidziane $w$ ramach pierwszej fazy budowy Space Force pozostają w sferze koncepcyjnej. W marcu 2019 roku utworzono Space Development Agency. Zostało jej, zgodnie z pierwotnym planem, powierzone zintegrowanie i przyspieszenie realizacji zadań związanych $\mathrm{z}$ rozwojem zdolności kosmicznych w dziedzinie bezpieczeństwa. Według stanu na sierpień 2019 roku wiele programów rozwojowych pozostało jednak

$34+$ A. Mehta, Space Command to launch Aug. 29, Defense News, 20.08.2019, https:// www.defensenews.com/space/2019/o8/20/space-command-to-launch-aug-29/. 
w poszczególnych departamentach, zakładana integracja jest zatem jak dotąd iluzoryczna ${ }^{345}$. Budzi to wątpliwości co do trwałości SDA, przynajmniej w obecnym kształcie. Jej dalsza transformacja lub ewentualna likwidacja będzie oznaczać zaburzenie planów zamieszczonych w powyższych dokumentach doktrynalnych.

Dalszy etap, czyli właściwe Siły Kosmiczne jako osobny rodzaj sił zbrojnych, znajdują się w fazie przygotowywania projektu legislacyjnego, który choć zaawansowany jako ogólny plan, wymaga ogromnej pracy nad jego uszczegółowieniem, a następnie zapewnienia finansowania, jak dotąd nieistniejącego ${ }^{346}$, oraz ostatecznej decyzji Kongresu. Tymczasem trwa debata na temat militaryzacji kosmosu w ogóle i stosunku USA do tego problemu i to jej przebieg bądź ewentualny wynik zadecyduje o dalszym rozwoju i uszczegółowieniu doktryny Space Force. Na los Sił Kosmicznych wpływ także będą miały zapewne i przyszłe wydarzenia polityczne w USA, a w szczególności wybory prezydenckie 2020 roku.

\section{Podsumowanie}

Ta krótka analiza kilku zaledwie podstawowych dokumentów wskazuje na to, że Stany Zjednoczone realizują złożoną i kompleksową strategię rozwoju zdolności kosmicznych, które przekładać się mają na zdolności realizowania przez państwo jego celów i interesów. Gdybyśmy zatem spróbowali określić na podstawie tych rozważań, co może oznaczać spacepower, powtórzylibyśmy, że jest to zdolność państwa do wspierania swoich interesów, wzmacniania zdolności oddziaływania i zapewniania bezpieczeństwa przy użyciu systemów kosmicznych wraz z infrastrukturą w postaci bazy przemysłowej, naukowo-badawczej i edukacyjnej zwią-

345 N. Strout, Is the Space Development Agency Here to Stay?, C4ISRnet, 2.08.2019, https://www.c4isrnet.com/battlefield-tech/space/2019/o8/o1/is-the-space-develop ment-agency-here-to-stay/.

346 J. DiMascio, L. Hudson, What Was in the Space Force Report, What Wasn't, and What It Mean, „Aviation Week \& Space Technology”, 14.08.2018, http://aviationweek. com/defense/what-was-space-force-report-what-wasn-t-and-what-it-means? $\mathrm{NL}=$ AW-05\&Issue $=A W-05 \_20180815 \_A W-05 \_23 \& s f v c 4$ enews $=42 \& \mathrm{cl}=$ article_1\&utm_rid

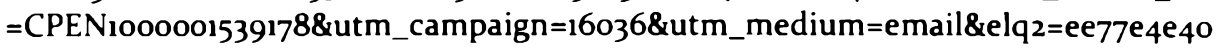
$79 c_{4} 85 \mathrm{~d} 84409$ eccofdc $48 \mathrm{c} 7$. 
zanej z eksploracją kosmosu. Dodać warto, że spacepower ma komponenty soft i hard, jako że dotyczy zarówno militarnych, jak i niemilitarnych zastosowań oraz w niemałym stopniu także prestiżu.

Doktryna bezpieczeństwa narodowego Stanów Zjednoczonych bardzo wyraźnie podkreśla rolę systemów orbitalnych szczególnie w związku z zabezpieczaniem działalności sił zbrojnych. Wyraźnie rozumie się ich krytyczną rolę $w$ tym zakresie jako kluczowego force multiplier, przyczyniającego się $w$ niemałym stopniu do technologicznej przewagi USA nad tak zwaną resztą świata. Przewaga ta zaś jest jednym z głównych czynników determinujących pozycję Ameryki jako mocarstwa globalnego, zdolnego do egzekwowania swoich interesów w skali całego świata.

W dającej się przewidzieć przyszłości nic się w tym zakresie nie zmieni, co najwyżej uzależnienie sił zbrojnych i innych instrumentów bezpieczeństwa zewnętrznego od systemów satelitarnych będzie rosło. Jednocześnie jednak wszystkie wymienione rozliczne dokumenty podkreślają zagrożenia, zarówno dla samych systemów orbitalnych USA, jak i w związku z malejącą przewagą Stanów Zjednoczonych w zakresie wykorzystania militarnego kosmosu. To oznacza, że przewaga technologiczna, tak kluczowa dla Ameryki, zmniejsza się. Te niekorzystne zjawiska stawiają w gruncie rzeczy pod znakiem zapytania wszystkie korzyści osiągane przez USA z wykorzystania kosmosu, w szczególności skutkując relatywnym spadkiem skuteczności sił zbrojnych, który będzie postępować. W tym kontekście dziwić wręcz może dalsze poleganie na kosmosie, a w szczególności polityka prowadząca do jeszcze głębszego uzależnienia się od systemów satelitarnych. Inaczej mówiąc, chcąc zapobiec zmniejszeniu się ogólnej przewagi technologicznej nad „resztą świata”, Stany Zjednoczone stawiają, między innymi, na poprawę skuteczności istniejących force multipliers z nadzieją, że uda im się utrzymać dystans. Nadzieja te jest stosunkowo niepewna, ponieważ USA nie mają już monopolu na większość kluczowych technologii, a nowe, potencjalnie przełomowe rozwiązania są dopiero we wczesnych fazach prac badawczo-rozwojowych, nie wiadomo zatem, czy przyniosą obiecywane korzyści.

Można jednak to skomentować w ten sposób, że Stany Zjednoczone nie mają innego wyjścia, niż dalej stawiać na zastosowania kosmiczne, rozumiane jako jeden $\mathrm{z}$ kluczowych elementów wsparcia sił zbrojnych, ponieważ nic tego nie może zastąpić, przynajmniej w przewidywalnej perspektywie. Stąd też dalszy rozwój technologiczny systemów kosmicznych, 
przy czym jego najbardziej wyraźną współczesną cechą jest to, że zwraca się szczególną uwagę na zagrożenia dla systemów kosmicznych, starając się zwiększyć ich przeżywalność i odporność na czynniki zakłócające. Inaczej mówiąc, USA bardzo mocno koncentrują się na przystosowaniu kosmicznego komponentu do skutecznego działania w kontestowanym środowisku, jakim stała się przestrzeń okołoziemska. Będziemy o tym szerzej wspominać $w$ rozdziale piątym.

Podsumowując, warto także podkreślić zróżnicowany charakter dorobku doktrynalnego administracji Donalda Trumpa w dziedzinie wykorzystania przestrzeni kosmicznej. Z jednej strony mamy niewiele znaczące, ogólnikowe polityczne deklaracje nakierowane w dużej mierze na wywołanie efektów propagandowych. Z drugiej zaś - pojawiły się dość konkretne działania mające na celu wzmocnienie amerykańskiej spacepower w jej ogólnym wymiarze, poprzez ułatwienie eksploatacji kosmosu i uczynienie jej bezpieczniejszą. Działania te, mimo znacznego potencjału, pozostają jednak w sferze projektów i ogólnych koncepcji, nie przekładają się jak dotąd na istotne zmiany.

Podobnie dzieje się z tym aspektem spacepower, który dotyczy bezpieczeństwa narodowego w wymiarze zewnętrznym i jest obecny przede wszystkim w koncepcji powołania Sił Kosmicznych jako osobnego rodzaju sił zbrojnych. Tu także pozostajemy w praktyce jedynie na etapie projektu legislacyjnego, ponieważ utworzenie Space Command w ramach Sił Powietrznych niewiele zmienia co do zasady. Skądinąd zauważmy, że utworzenie Space Force wydaje się najistotniejszym celem administracji obecnego prezydenta. Nie jest to zresztą niczym niespotykanym, ponieważ spektakularnie wyglądające, działające na wyobraźnię projekty i działania odgrywają jedną z kluczowych ról w strategii rządów Donalda Trumpa. Z tego też powodu należy obawiać się, że traktuje on tę kwestię instrumentalnie, mniej zwracając uwagę na podstawowe pytanie: czym mianowicie, w ostatecznym rozrachunku, mają być Siły Kosmiczne. Koncepcji ich powołania nie wróży dobrze także zdecydowanie negatywna ocena ze strony prominentnych członków Partii Demokratycznej ${ }^{347}$, co w niemałej mierze wynika też zapewne ze złożonej sytuacji politycznej w USA.

347 Por. na przykład J. Gould, Space Force 'Not the Way to Go,' Says Key Democrat, Defense News, 13.08.2018, https://www.defensenews.com/congress/2018/o8/13/space-for ce-not-the-way-to-go-says-key-democrat/. 
Warto na koniec wspomnieć o ściśle wojskowych dokumentach przedstawiających założenia operacyjnego funkcjonowania sił zbrojnych USA, w których znajdują się podobne odniesienia, sprowadzone do konkretnych kwestii militarnych ${ }^{34^{8}}$. W nich także podkreśla się znaczenie systemów orbitalnych, zagrożenie, jakiemu podlegają w warunkach coraz mniejszej przewagi technologicznej oraz konieczność zabezpieczenia ich funkcjonowania w przyszłości poprzez unowocześnianie ich i rozbudowywanie oraz wypracowywanie nowych koncepcji stosowania systemów kosmicznych. Ich omówienie wykracza jednak poza ramy niniejszej pracy, lecz należy pamiętać, że doktryna wykorzystania przestrzeni kosmicznej na potrzeby bezpieczeństwa państwa jest bardzo rozbudowana w szczegółach, a najbardziej w wymiarze stricte wojskowym.

\subsection{Znaczenie przestrzeni kosmicznej dla bezpieczeństwa USA - podsumowanie}

W niniejszym podrozdziale postaramy się zreasumować dotychczasowe rozważania, tak aby w syntetyczny sposób określić rolę przestrzeni kosmicznej w strategii bezpieczeństwa USA, scharakteryzować główne cechy amerykańskiej spacepower i spróbować określić czynniki dalszej ewolucji interesujących nas procesów. Nie będzie to zatem zwykłe powtórzenie głównych punktów dotychczasowego wywodu, lecz raczej próba ich syntezy i udzielenia $w$ ten sposób odpowiedzi na podstawowe pytania niniejszej pracy.

348 Por. na przykład U.S. Army Operating Concept. Win in a Complex World, TRADOC Pamphlet 525-3-1, Department of the Army Headquarters, United States Army Training and Doctrine Command, 31.10.2014, http://www.tradoc.army.mil/tpubs/pams/ tp525-3-1.pdf; A Cooperative Strategy for $21^{\text {st }}$ Century Seapower, U.S. Navy, March 2015, http://www.navy.mil/local/maritime/150227-CS21R-Final.pdf oraz Air Force Future Operating Concept, U.S. Air Force, September 2015, https://www.af.mil/Portals/1/im ages/airpower/AFFOC.pdf. 
Rola przestrzeni kosmicznej $w$ strategii bezpieczeństwa USA

Wspominaliśmy już wielokrotnie o tym, że zastosowanie systemów satelitarnych znacznie ułatwia realizację wielu typów zadań służących bezpieczeństwu narodowemu. Dotyczą one misji związanych zarówno z obroną terytorium kraju, jak i ze wsparciem polityki i interesów USA poza granicami. Jest to zatem nie tylko force multiplier w sensie czysto wojskowym, rozumianym w kategoriach obrony państwa. Ma też wymiar polityczny: po pierwsze, poprzez wzmacnianie możliwości sił zbrojnych rozumianych jako instrument wsparcia polityki zagranicznej, a po drugie, poprzez wzmacnianie strategicznego i politycznego wywiadu oraz łączności. W najbardziej syntetycznym ujęciu możemy wymienić dwie istotne cechy tego wzmocnienia, czy też może płaszczyzny, na których ono występuje.

Pierwsza płaszczyzna, co podkreśla się zawsze i co też rzuca się najbardziej w oczy, to zwiększenie skuteczności działań. Dzięki systemom kosmicznym i naziemnym aplikacjom współpracującym z nimi wiele misji sił zbrojnych i instytucji wywiadowczych realizowanych jest o wiele skuteczniej niż w przypadku ich braku. Łączność satelitarna pozwala pokonać fizyczne ograniczenia klasycznej łączności uzależnionej od rzeźby terenu i właściwości atmosfery. Satelitarna nawigacja pozwala na bardzo szybkie uzyskiwanie wyników na większości obszaru naszej planety i w jej przestrzeni powietrznej - dotyczy to nie tylko ludzi, pojazdów, statków czy samolotów, ale także uzbrojenia kierowanego, co zwiększa jego skuteczność. I wreszcie możliwości zbierania informacji są zwielokrotnione dzięki systemom satelitarnym, ponieważ umożliwiają one pokonanie dotychczasowych ograniczeń geograficznych oraz tych, które wynikają z suwerenności terytorialnej państw.

Dodatkową korzyścią jest to, że w ramach wymienionych zadań systemy satelitarne $w$ wielu przypadkach realizują misje całkowicie niedostępne przy użyciu innych środków. Dotyczy to głównie funkcji wywiadowczych, związanych ze zbieraniem informacji o faktycznych i potencjalnych przeciwnikach. Objęcie obserwacją całości terytorium adwersarza poprzez rozmieszczenie licznych pasywnych i aktywnych sensorów jest niemożliwe inaczej niż $z$ kosmosu lub poprzez podjęcie działań nielegalnych, co jednak oznacza podjęcie ryzyka politycznego, które w przypadku systemów satelitarnych jest znacznie mniejsze. 
Podsumowując ten wątek, należy powtórzyć, że technologia satelitarna jest jednym z podstawowych czynników przewagi technologiczno-organizacyjnej, jaką cieszą się Stany Zjednoczone w wymiarze globalnym. Przewaga ta ma oczywiście różne oblicza, w zależności od tego, o jakim rodzaju misji w danym momencie mówimy, od regionu, gdzie jest ona realizowana, i od obiektu tejże misji. Na przykład Federacja Rosyjska skonstruowała na swoim terytorium wiele tysięcy stacji zakłócających pracę GPS, dzięki czemu ewentualne zadania bojowe w jej przestrzeni powietrznej $\mathrm{z}$ użyciem nawigacji satelitarnej byłyby znacznie trudniejsze niż w sytuacji prowadzenia działań wobec mniej zaawansowanych przeciwników. Podobnie rzecz się ma w przypadku zadań wywiadu strategicznego realizowanego przeciwko podmiotom zdolnym do stosowania zaawansowanych form maskowania i ukrywania kluczowych obiektów. Tu przy okazji pojawia nam się ważna cecha zastosowań kosmicznych: wiele ich kluczowych parametrów i właściwości jest bardzo dobrze znanych przeciwnikom, więc mogą oni podejmować działania, by ograniczyć skuteczność systemów orbitalnych, o czym bliżej powiemy w innym miejscu. Systemy satelitarne nie są zatem instrumentem absolutnym i wszechmocnym, mają swoje poważne ograniczenia.

Druga płaszczyzna wzmocnienia zdolności wojskowych i wywiadowczych dzięki wykorzystaniu systemów satelitarnych polega na tym, że, podobnie jak $w$ przypadku innych amerykańskich atutów związanych z przewagą technologiczną, znacząco ogranicza koszty realizacji określonych misji. Jest to może mniej widoczna perspektywa, ale także bardzo ważna. Wspominano już o tym, że jednym z kluczowych elementów skuteczności amerykańskiej strategii ciągłego, globalnego zaangażowania jest utrzymanie kosztów jej realizacji w akceptowalnych przedziałach względem PKB i budżetu. Warto w tym miejscu zauważyć, iż współcześnie czynnik ten ma szczególne znaczenie, ponieważ Stany Zjednoczone, podobnie jak cały świat, cierpią z powodu poważnych strukturalnych zaburzeń gospodarczych. Stawiają one pod znakiem zapytania trwałość rozwoju ekonomicznego i ciągły wzrost poziomu życia obywateli jako stanowiące ważną część ideologicznych podstaw funkcjonowania państwa. Dlatego też ekonomiczność różnorodnych działań jest dziś ważniejsza niż kiedykolwiek.

Koszty realizacji wymagających, rozległych misji bojowych i niebojowych, i to prowadzonych w długim okresie, odgrywają zatem ogromną rolę 
w amerykańskiej strategii. Jak wiemy, rozwiązaniem, jakie z powodzeniem do tej pory się realizuje, jest utrzymanie technologicznej przewagi, dzięki czemu stosunkowo szczupłe siły są w stanie odstraszyć i ewentualnie pokonać znacznie liczniejszego przeciwnika bez ponoszenia istotnych strat i bez długotrwałych wyczerpujących kampanii. Modelowym przykładem jest niewątpliwie pierwsza wojna w Zatoce Perskiej, w czasie której relatywnie niewielkie w sensie ilościowym siły amerykańskie i sojusznicze całkowicie rozbiły rozbudowane i względnie nowoczesne siły zbrojne Iraku - odbyło się to w dodatku bardzo szybko i przy minimalnych stratach. Podobnie dzieje się z zadaniami typu niebojowego, czyli przede wszystkim z realizowaniem wysuniętej obecności wojskowej. Relatywnie niewielkie w sensie ilościowym siły są w stanie długotrwale utrzymywać gotowość do prowadzenia skutecznych działań istotnych w planie strategicznym. W największej mierze dotyczy to marynarki wojennej ${ }^{349}$, a przykładem jest tu lotniskowcowa grupa uderzeniowa (carrier strike group). W typowym składzie jest to zaledwie 8-10 okrętów wojennych, na których stacjonuje około 80-90 statków powietrznych i parę setek pocisków manewrujących dalekiego zasięgu, a ich załoga liczy zaledwie 7-8 tysięcy ludzi. Zespół taki jest mimo to w stanie zrealizować wszelkiego rodzaju zadania bojowe, pokonać wielokrotnie liczniejsze siły powietrzne przeciwników (zależnie od ich poziomu zaawansowania technologicznego), a następnie dokonać rujnujących ataków na infrastrukturę lądową. Aby osiągnąć podobne cele, jakiekolwiek inne państwo musiałoby wystawić siły wielokrotnie liczniejsze, w większości przypadków przekraczające ich możliwości.

Systemy satelitarne w ogromnym zakresie przyczyniają się do utrzymania tej sytuacji, ograniczając ogromnie koszty zaangażowania. Satelitarne systemy łączności oraz nawigacji pozwalają na wykonywanie znacznie mniejszej liczby misji bojowych i użycie o wiele mniejszej ilości uzbrojenia w celu realizacji danego zadania niż w przypadku braku systemów orbitalnych. Dzieje się to na wielu płaszczyznach, których szczegółowy opis wykracza poza ramy niniejszego opracowania, poczynając od zmniejszenia liczby ludzi zaangażowanych w zadanie bojowe, poprzez ograniczenie wykorzystania resursu sprzętu i materiałów eksploatacyjnych, zmniejszenie ilości użytej amunicji, na szybszym czasie realizacji 
określonych działań kończąc. Nieco upraszczając, można powiedzieć, że dzięki zastosowaniom satelitarnym ewentualne zniszczenie danego celu odbywa się pewniej, szybciej i taniej, co jest nie tylko istotne dla przebiegu określonych zadań bojowych, ale także dla skuteczności odstraszania. A to dlatego, że wszystkie te zdolności są dobrze znane amerykańskim przeciwnikom i konkurentom, którzy wobec tego muszą się z nimi liczyć w ramach własnych strategii i planów operacyjnych.

Podsumowując rolę systemów satelitarnych jako force multiplier, powtórzymy raz jeszcze, że wykorzystanie przestrzeni kosmicznej jest jednym z kluczowych czynników zapewniających realizację polityki bezpieczeństwa USA w całym zakresie szerokiego spektrum, w jakim jest ona prowadzona. Jest to zatem jeden z podstawowych elementów potęgi, ważny czynnik globalnego oddziaływania, stanowiący nierozerwalny element militarnego instrumentu polityki państwa. Co za tym idzie, systemy orbitalne, wzmacniając skuteczność i efektywność ekonomiczną tegoż instrumentu, są krytycznie ważne dla amerykańskiej strategii bezpieczeństwa i, szerzej, dla polityki zagranicznej.

Idąc dalej, można bezpiecznie założyć, że bez tego czynnika, czyli bez rozległego i efektywnego stosowania systemów satelitarnych, tak rozwiniętego i tak skutecznego, amerykańskie oddziaływanie w świecie nie byłoby możliwe w takiej skali, w jakiej jest dziś realizowane. I nie jest to bynajmniej kwestia ściśle teoretyczna, na zasadzie rozważań, co by było, gdyby zastosowania kosmiczne się nie rozwinęły. Istnieje dziś bardzo realna możliwość, że amerykańska przewaga w kosmosie stosunkowo szybko zmaleje, i to nawet do tego stopnia, że przestanie mieć znaczenie. Komponent kosmiczny może także zniknąć całkowicie, wraz z możliwym zniszczeniem infrastruktury orbitalnej systemów kosmicznych. O tym, jak realne jest takie zagrożenie, niech świadczy fakt, że amerykańskie siły zbrojne prowadzą szeroko zakrojone badania rozwojowe technologii, które mogą uzupełnić lub zastąpić systemy satelitarne, oraz regularne ćwiczenia polegające na prowadzeniu działań w sytuacji ich degradacji. Te ostatnie realizowane są bardzo często, mimo że jest to przyczyną poważnych zakłóceń funkcjonowania lotnictwa cywilnego ${ }^{350}$.

350 B. Carey, FAA Mulls Recommendations For Planned GPS Interference, „Aviation Week \& Space Technology", 1.08.2018, http://aviationweek.com/commercial-aviation/ faa-mulls-recommendations-planned-gps-interference. 
Rozważania dotyczące utraty przewagi, wynikające ze zmniejszenia przewagi w technologii albo zniszczenia infrastruktury, nie są zatem czystą teorią lub też intelektualnym ćwiczeniem. Jest to realne zagrożenie, na które wskazują wszystkie wymienione wyżej strategie, i tu nam się pojawia drugi wymiar analizy roli przestrzeni kosmicznej w ramach problematyki bezpieczeństwa narodowego USA. Jest to jak gdyby druga strona medalu: czyli zdolności kosmiczne są ważnym narzędziem bezpieczeństwa i warunkiem powodzenia obecnych strategii, ich rola może jednak zostać ograniczona lub całkowicie zlikwidowana, co z kolei postawi pod znakiem zapytania wszystkie wspomniane strategie.

Analizując zagrożenia w tym właśnie kontekście, w pierwszej kolejności należy zwrócić uwagę na fakt, że inni uczestnicy stosunków międzynarodowych także rozwijają zdolności kosmiczne, co oznacza, że systemy orbitalne jako force multiplier nie są już wyłączną domeną Stanów Zjednoczonych. Inne kraje, a zapewne także uczestnicy niepaństwowi, intensywnie pracują nad emulowaniem amerykańskich zdolności, co w pewnej mierze niweluje amerykańskie przewagi. Czyni to nie tylko Rosja, bazująca na doświadczeniach ZSRR, ale także zasobne w środki Chiny oraz inne państwa. Wydawałoby się, że zasoby amerykańskie, obecna wiedza i przewaga są takiej natury, że nie ma w świecie takiej siły ekonomiczno-technologicznej, która mogłaby ten stan rzeczy naruszyć, nie jest to jednak założenie słuszne, $\mathrm{z}$ trzech zasadniczych powodów.

Po pierwsze dlatego, że znacznie łatwiej jest konkurentom opanowywać technologie już istniejące i używane przez USA, wprowadzając do służby systemy na nich oparte. Sprzyja temu między innymi działalność szpiegowska, transfer technologii cywilnej czy też generalny wzrost poziomu wiedzy w sowicie przez państwo wyposażanych ośrodkach badawczych. Szczególnie widać to w przypadku Chin, których strategia rozwoju technologicznego opiera się między innymi na zagranicznej edukacji tamtejszych uczonych i inżynierów. Kolejne generacje systemów satelitarnych i kolejne technologie wprowadza się zatem w świecie szybciej, niż robili to wcześniej Amerykanie. Konkurenci mogą też robić to znacznie taniej, odtwarzając jedynie zdolności, które zostały już wielkim kosztem opracowane w Stanach Zjednoczonych.

Po drugie, by utrzymać swoją przewagę, USA muszą inwestować w dalszy rozwój technologii, w nowe odkrycia i nowe podejścia, które kosztują znacznie więcej niż dotychczasowe, dają też relatywnie wolniejszy 
postęp. W wielu dziedzinach nie jest on już możliwy, biorąc pod uwagę istniejące zasady działania, a ewentualnych przełomów technologicznych nie da się przewidzieć. W efekcie konkurenci szybciej opanowują istniejące technologie, niż Amerykanie opracowują nowe, przez co przewaga, choć wciąż duża, sukcesywnie maleje.

I wreszcie po trzecie, konkurenci Stanów Zjednoczonych nie muszą powtarzać dokładnie tych samych struktur i wszystkich etapów dotychczasowego rozwoju. Aby otrzymać potrzebne im zdolności satelitarne, nie muszą kopiować całości amerykańskiej, bardzo rozbudowanej infrastruktury kosmicznej. W ramach swoich, ograniczonych w stosunku do amerykańskich, potrzeb mogą skoncentrować się od razu na docelowych aplikacjach, na mniejszych, a zatem tańszych systemach, które także można szybciej umieścić. Mimo to będą miały one podobną skuteczność i podobnie wzmocnią ich odpowiednie zdolności w ramach strategii poszczególnych państw, jak to się dzieje w przypadku USA.

A zatem istnieje prawdopodobieństwo, że konkurenci Ameryki zdolni będą do zmniejszania dystansu w takim sensie, że ich własne systemy satelitarne będą coraz bardziej skutecznym force multiplier w ramach ich sił i strategii. Ale to jeszcze nie koniec. Drugą stroną tego procesu jest bowiem rozprzestrzenianie się technologii skonstruowanych specjalnie w celu zanegowania amerykańskich zdolności satelitarnych, czyli asymetryczna odpowiedź na przewagę USA. Jest to jeszcze ważniejsza kwestia niż powyższa, ponieważ zdolności negacyjne mogą w wielu przypadkach okazać się łatwiejsze do opracowania i tańsze $w$ realizacji niż omówiona powyżej odpowiedź o charakterze symetrycznym. Inaczej mówiąc, przeciwnicy Ameryki wybierają, i proces ten będzie się nasilał, także rozwijanie zdolności do utrudniania bądź uniemożliwiania Stanom Zjednoczonym osiągania założonych korzyści z działania własnych systemów satelitarnych. Już dziś istnieje szereg możliwości uszkadzania bądź niszczenia infrastruktury naziemnej, zakłócania połączeń $w$ ramach systemu czy też utrudniania pracy, uszkadzania bądź nawet niszczenia orbiterów - może się to odbywać zarówno w wyniku oddziaływań fizycznych, elektromagnetycznych, jak i poprzez cyberprzestrzeń. 


\section{Charakterystyka amerykańskiej spacepower}

Patrząc na amerykańskie zdolności kosmiczne od strony spacepower, definiowanej na nasze potrzeby przede wszystkim w wymiarze pierwszym, czyli w ramach bezpieczeństwa narodowego, zauważamy szereg jej cech charakterystycznych. Wiążą się one $\mathrm{z}$ technologią i doktryną oraz zapleczem przemysłowym, jednak charakterystyka na podstawie tej warstwy definicyjnej będzie, jak sądzimy, niekompletna, a zatem nie będzie miała odpowiedniej mocy wyjaśniającej. Dlatego też poniżej sięgniemy i do szerszych wymiarów spacepower, by scharakteryzować jej amerykańską wersję.

Pierwsza cecha, którą warto wymienić właśnie na początku, jest może mniej oczywista, mniej rzucająca się w oczy, jednak fundamentalna. Otóż charakter amerykańskiej spacepower wykracza daleko poza czynnik bezpieczeństwa narodowego i w związku $\mathrm{z}$ tym jako całość nie daje się zamknąć w definicji pierwszego stopnia. Od chwili, kiedy pojawiły się cywilne zastosowania, trwa proces transformacji spacepower $w$ pojęcie rozleglejsze niż tylko warstwa dotycząca bezpieczeństwa narodowego. Oczywiście, do niedawna jeszcze zastosowania z tej dziedziny miały absolutny priorytet i w przeważającej mierze stanowiły o tym, co Ameryka robiła w kosmosie. Współcześnie jednak ucywilnianie przestrzeni okołoziemskiej postępuje coraz szybciej, co przejawia się na kilku płaszczyznach. Po pierwsze, tak zwany przemysł kosmiczny gwałtownie rośnie $\mathrm{w}$ siłę, a jego klientem nie jest już wyłącznie państwo - z ponad $300 \mathrm{mld}$ USD wartości tego przemysłu działalność komercyjna obejmuje już $3 / 4^{351}$. Inaczej mówiąc, przemysł kosmiczny w ogóle, a w szczególności wiodący $w$ tej dziedzinie przemysł amerykański, jest już przeważnie cywilny $w$ takim sensie, że działa przede wszystkim na potrzeby cywilne ${ }^{352}$. Oczywiście $i$ on musi być postrzegany $w$ kategoriach bezpieczeństwa narodowego, niemniej jednak analizowanie spacepower wyłącznie $\mathrm{z}$ tego punktu widzenia jest współcześnie błędne. Przestrzeń kosmiczna stała się zatem

351 Dane za 2016 rok, za: Space Foundation Report Reveals Global Space Economy at \$329 Billion in 2016, Space Foundation, 3.08.2017, https://www.spacefoundation.org/2017/08/ 03/space-foundation-report-reveals-global-space-economy-329-billion-2016.

352 C. Knip fer, Congress and Commerce in the Final Frontier (part 1), „The Space Review”, 10.12.2018, http://www.thespacereview.com/article/3619/1. 
rozległym polem działalności gospodarczej, której wartość szybko rośnie, przyczyniając się zatem do ogólnej siły państwa, dobrobytu obywateli, a w konsekwencji do budowania międzynarodowego znaczenia kraju. Można zatem powiedzieć - i jest to bardzo istotne stwierdzenie - że amerykańska spacepower jest atrybutem państwa o charakterze ogólnym, a nie tylko $w$ dziedzinie bezpieczeństwa. Jest to więc zdolność do działania w kosmosie państwa i mniej lub bardziej z nim związanych podmiotów komercyjnych, a skutkiem tej działalności jest nie tylko bezpieczeństwo i wsparcie polityki zagranicznej, ale także przyczynienie się do ogólnego rozwoju kraju w wymiarze ekonomicznym i społecznym.

Druga cecha, będąca niejako dalszą konsekwencją wymienionych powyżej zjawisk, to fakt, że amerykańska spacepower ma charakter cokolwiek amorficzny i niesterowalny, wymyka się doktrynalnym założeniom i świadomej polityce państwa. Jest bowiem efektem nie tylko planowania i alokowania środków $w$ ramach doktryn i realizowanych przez władze polityk odpowiadających sformułowanym przez te władze oczekiwaniom, które $\mathrm{z}$ kolei są rezultatem szerszych rozważań na temat interesów państwa, racji stanu etc. Do niedawna jeszcze tak było, niewątpliwie fundamenty pod spacepower położyło państwo, dziś jednak kierunki rozwoju wyznaczają także indywidualne decyzje biznesowe bardzo wielu firm oraz oczekiwania konsumentów, zarówno indywidualnych, jak i korporacyjnych. A zatem już nie tylko państwo, via NASA, Departament Obrony czy inne instytucje rządowe, wraz $z$ tradycyjnymi partnerami w postaci wielkich korporacji, jak: ULA, Lockheed, Raytheon, Boeing i innych, decyduje o rozwoju spacepower. Pojawia się bardzo wielu nowych, silnych graczy prywatnych, takich jak: SpaceX, Blue Origin, Google i inne, oraz cała gama startupów, z których przynajmniej część rozwinie się w kwitnące przedsiębiorstwa. To ich decyzje biznesowe, odpowiadające na rosnące zapotrzebowanie, w coraz większym stopniu stanowią o obliczu amerykańskiej spacepower. Podobny efekt przynosi rosnące zapotrzebowanie osób fizycznych i przedsiębiorstw na poszerzające się spektrum usług, w których dostarczaniu systemy satelitarne odgrywają kluczową rolę. W tym kontekście mieści się także świadoma polityka oddawania przez NASA niskiej orbity okołoziemskiej przedsiębiorstwom prywatnym. Tradycyjnie agencja zamawiała produkty, takie jak systemy transportowe, którymi operowała, zarządzała i za które odpowiadała. W ciągu ostatniej dekady zmienia się to radykalnie, NASA zamawia komplekso- 
wą usługę u prywatnego przedsiębiorcy i ją odbiera. Tak się dzieje od 2010 roku i z programem lotów załogowych, w ramach którego nastąpił pełny outsourcing usług na rzecz podmiotów prywatnych, które wkrótce rozpoczną ich wykonywanie. Podobne podejście realizuje się obecnie w kwestii platform orbitalnych, które będą przejmować zadania od ISS w związku z bliskim końcem jej użytkowania ${ }^{353}$.

Po trzecie, przechodząc do bardziej szczegółowych kwestii związanych $\mathrm{z}$ węższą tematyką spacepower, rozumianą według pierwszej definicji, co jest oczywiście naszym głównym przedmiotem zainteresowania, zauważamy przede wszystkim, że istotną cechą amerykańskiej spacepower jest jej rola jako jednej z kluczowych sił sprawczych polityki bezpieczeństwa. A zatem zdolności do działania w przestrzeni okołoziemskiej są jednym z fundamentalnych narzędzi realizacji „ziemskich” strategii bezpieczeństwa. Spacepower w tym znaczeniu nie jest zatem instrumentem samym dla siebie, lecz służy ogólnym interesom państwa $w$ dziedzinie bezpieczeństwa narodowego, wspierając instytucje polityczne poprzez zbieranie informacji przede wszystkim o sytuacji na Ziemi oraz wspierając siły zbrojne głównie w ramach realizacji przez nie zadań na powierzchni naszej planety.

Po czwarte, fundamentalną cechą amerykańskiej spacepower w ujęciu bezpieczeństwa narodowego jest to, że ma ona charakter pasywny. Mimo prób i badań, a nawet mimo opracowania pewnych typów broni kosmicznych, Stany Zjednoczone powstrzymują się od czynnej militaryzacji kosmosu. Amerykańskie zdolności kosmiczne mają wyłącznie charakter wspierający i jest to wynik polityki deklarowanej i realizowanej od samego początku ery kosmicznej. Dzieje się tak głównie dlatego, i to już od czasów Eisenhowera, że USA osiągają wielkie korzyści z kosmosu $\mathrm{w}$ dziedzinie bezpieczeństwa $\mathrm{w}$ ramach militaryzacji biernej. W związku z tym zmiana jej charakteru, z całym ryzykiem w postaci zagrożenia dla własnych systemów orbitalnych, nie jest Stanów Zjednoczonych korzystna. Szczególnie biorąc pod uwagę ewentualne koszty i wciąż wątpliwą efektywność dających się skonstruować wedle dzisiejszej wiedzy kosmicznych systemów bojowych. Wprawdzie toczy się w USA poważna

353 M. Carreau, NASA Eager To Share Low Earth Orbit, „Aviation Week \& Space Technology", 19.09.2019, https://aviationweek.com/world-satellite-business-week/nasa-eagershare-low-earth-orbit. 
dyskusja na temat ewentualnej dalszej militaryzacji kosmosu, ale w każdym wypadku na jej konkluzję, a potem ewentualny namacalny efekt trzeba będzie poczekać. Tematykę tę będziemy rozważać szerzej w kolejnej części pracy.

I wreszcie po piąte, amerykańska spacepower na płaszczyźnie bezpieczeństwa narodowego w wymiarze zewnętrznym jest wynikiem bardzo złożonego wysiłku. Składają się nań działania poszczególnych rodzajów sił zbrojnych oraz wielu rządowych agencji cywilnych, takich jak na przykład NOAA. Wysiłek ten jest zatem z jednej strony wszechogarniający, czyli obejmujący wiele podmiotów, $\mathrm{z}$ drugiej zaś - ma on charakter cokolwiek rozproszony - służby oraz agencje konkurują ze sobą mniej lub bardziej otwarcie. Tworzenie i rola spacepower jest także przedmiotem politycznej gry pomiędzy głównymi partiami, ale także na niższym szczeblu, prowadzonej przez polityków dbających o swoich wyborców i ich miejsca pracy. $W$ rezultacie amerykański wysiłek ma charakter w pewnej mierze chaotyczny, nie w pełni sterowalny, nie można w jego ramach ani stworzyć, ani zrealizować jednolitych i spójnych strategii. Strategie te istnieją tylko na bardzo ogólnym, państwowym poziomie, natomiast szczegóły podlegają ciągłym, bieżącym przetargom w ramach państwa, i w przestrzeni pomiędzy jego agendami a sektorem komercyjnym. Ma to istotne pozytywne następstwa, ponieważ konkurencja sprzyja nowatorskim rozwiązaniom i ogólnemu rozwojowi. $Z$ drugiej jednak strony rywalizacja i niespójność programów zmniejszają ich efektywność. A zatem amerykańska spacepower, w ujęciu procesu tworzenia oraz wykorzystania określonego instrumentu, nie jest w pełni efektywna w takim sensie, że nie w pełni skutecznie wykorzystuje istniejące zasoby i możliwości organizacyjne. Jest jednak bardzo innowacyjna dzięki zróżnicowaniu i rosnącej konkurencji.

\section{Perspektywy ewolucji amerykańskiej spacepower}

Problem przyszłej ewolucji sektora kosmicznego, procesów składających się na bezpieczeństwo kosmiczne czy też polityki państwa w tym zakresie jest oczywiście bardzo złożony, tak jak złożona jest cała problematyka związana ze spacepower. Ze względu na ogólny charakter niniejszej pracy musimy zatem w tym miejscu dokonać niezbędnego skrótu tema- 
tyki, choć jednocześnie powinniśmy ją potraktować możliwie kompleksowo. Dlatego też poniżej postaramy się poruszyć jak najwięcej istotnych z punktu widzenia całości tematu kwestii, pozostając jednocześnie na poziomie możliwie ogólnym. Wydaje się nam, że takie podejście jest jak najbardziej właściwym uzupełnieniem i uporządkowaniem zagadnień poruszanych powyżej, zarówno w tym, jak i w poprzednich podrozdziałach. Podkreślamy, że nie podejmujemy się w sposób szczegółowy przewidywać przebiegu poszczególnych procesów, wskazujemy raczej możliwie szeroko na czynniki, które wpływać będą na tenże przebieg.

W pierwszej kolejności należy zidentyfikować główne procesy i zjawiska zachodzące obecnie w dziedzinie eksploracji kosmosu przez człowieka, które będą miały w dającej się przewidzieć przyszłości wpływ na dalszą jego ewolucję. W tym kontekście należy dostrzec przede wszystkim: - ewolucję, która, jak się zdaje, coraz bardziej przypomina rewolucję prowadzącą do obniżania kosztów i ogólnego ułatwienia prowadzenia działalności w kosmosie;

- postępującą komercjalizację, która obejmuje także coraz to nowsze sektory, w których pojawiają się nowe podmioty dostarczające istniejących usług oraz podmioty zmierzające do zaoferowania nowych sposobów wykorzystania przestrzeni kosmicznej;

- ogólny wzrost zapotrzebowania na usługi związane bezpośrednio lub pośrednio z działalnością kosmiczną;

- zwiększanie liczby aktorów aktywnych w kosmosie, zarówno państwowych, jak i niepaństwowych, w tym komercyjnych;

- szybki wzrost liczby systemów satelitarnych i orbiterów.

Procesy te oczywiście są współzależne. Na przykład otwieranie czy też rozszerzanie działalności w nowych sektorach usług rodzi i pobudza popyt, który z jednej strony napędza działalność, a z drugiej - oznacza wzrost zapotrzebowania. To z kolei powoduje, że pojawiają się nowi aktorzy chętni do zaspokajania rosnących potrzeb, co dalej wpływa na szybki wzrost liczby i rozmiarów systemów satelitarnych. Wszystko to razem stanowi o obecnym stanie i perspektywach eksploracji kosmosu. Najogólniej mówiąc, wymienione procesy prowadzą do następujących skutków praktycznych:

- zagęszczenie przestrzeni okołoziemskiej, szczególnie niektórych, najbardziej atrakcyjnych orbit, do których tradycyjnie należy orbita geostacjonarna, ale w związku z rozwojem wielkich konstelacji satelitarnych znaczenia nabierają orbity między 500 a 1000 km; 
- rosnące prawdopodobieństwo katastrof w postaci zderzeń satelitów ${ }^{354}$ bądź niekontrolowanych ich upadków na Ziemię;

- wzrost znaczenia kosmosu dla bezpieczeństwa narodowego państw i dla bezpieczeństwa międzynarodowego;

- przyrost wartości i znaczenia przemysłu kosmicznego;

- zwiększanie społecznej roli systemów kosmicznych jako dostarczycieli ważnych usług, które w pewnym zakresie stanowią o stanie współczesnych społeczeństw, takich jak internet czy też inne formy komunikacji.

Część z powyższych kwestii omówimy jeszcze dokładniej w kolejnym rozdziale, niemniej jednak obraz w najogólniejszych kategoriach jest taki, że znaczenie i rola kosmosu w ramach funkcjonowania ludzkiej cywilizacji rośnie. Jego wykorzystanie nie tylko wiąże się z konkretnymi korzyściami dla państw, przedsiębiorstw czy pojedynczych osób, ale także zaczyna tworzyć się pewnego rodzaju efekt synergii polegający na tym, że globalna suma zastosowań kosmicznych generuje swego rodzaju wartość dodaną, która wynika z powstawania i umacniania się na bazie zastosowań kosmicznych powiązań gospodarczych i w sferze społecznej. Pojawia nam się tu zatem i perspektywa, i nawet pewna możliwość analizy spacepower $w$ jej trzecim wymiarze, nie będziemy jednak się tym zajmować.

$\mathrm{Z}$ punktu widzenia Stanów Zjednoczonych i spacepower w wymiarze drugim, czyli dotyczącym całości interesów i funkcjonowania państwa, powyższe zjawiska i ich konsekwencje mają daleko idące skutki. Można je ująć w ramach kilku procesów zachodzących obecnie, a które najprawdopodobniej będą dalej ewoluować także w przyszłości. Są to:

- znaczenie sektora kosmicznego dla państwa, jego siły i znaczenia rośnie i będzie rosnąć, spacepower będzie zatem czynnikiem coraz bardziej wpływającym na stan gospodarki, dobrobyt społeczeństwa i pozycję międzynarodową USA, w tym na jego prestiż;

- jednocześnie jednak tak ujmowana spacepower wymyka się spod kontroli państwa i ten proces także będzie narastał, w miarę jak kolejne przedsiębiorstwa prywatne, organizacje naukowe i edukacyjne

354 M. Wall, European Satellite Dodges Potential Collision with SpaceX Starlink Craft, Space.com, 3.09.2019, https://www.space.com/spacex-starlink-esa-satellite-collisionavoidance.html?utm_source=sdc-newsletter\&utm_medium=email\&utm_campaign $=20190904$-sdc. 
i wreszcie osoby prywatne będą realizowały swoje własne, niezależne strategie rozwojowe w przestrzeni okołoziemskiej;

- międzynarodowa konkurencja oraz rywalizacja przedsiębiorstw są coraz ostrzejsze i będą dalej się zaostrzać, w miarę jak zwiększa się rola i możliwości dostawców usług startowych i satelitarnych aplikacji z Chin, Indii oraz innych krajów, a także wzrasta znaczenie coraz większej liczby przedsiębiorstw, zarówno mających charakter narodowy, jak i transnarodowy;

- USA utrzymują generalną przewagę nad resztą świata zarówno w liczbie, jak i możliwościach systemów satelitarnych i dotyczy to zarówno państwa, jak i podmiotów prywatnych ulokowanych w USA lub transnarodowych $\mathrm{z}$ istotnym udziałem amerykańskim; przewaga ta będzie się jednak zmniejszać, zarówno w sensie procentowego udziału Ameryki w eksploracji kosmosu (licząc różne wskaźniki, takie jak liczba satelitów czy wartość przemysłu kosmicznego etc.), jak i w dystansie, jaki dzieli USA od konkurentów w poszczególnych dziedzinach, choć jednocześnie nie należy w dającej się przewidzieć przyszłości spodziewać się całkowitego zniwelowania tej przewagi.

W związku z ostatnim punktem warto zwrócić uwagę na bardzo niepokojące sygnały o procesach, które wskazują na relatywną degradację sektora technologii kosmicznych, w tym obronnych w USA. Jak zauważa się $\mathrm{w}$ raporcie dla Kongresu,

[...] w związku z realiami biznesowymi, trendami rynkowymi, globalizacją łańcucha dostaw i kosztami wytworzenia przyszły dostęp do rodzimych źródeł przemysłu kosmicznego, łącznie z mikroelektroniką, jest niepewny. Rosnące zagrożenie cybernetyczne, niepewne lańcuchy dostaw, przejęcia z zagranicy, poleganie na wrażliwych zasobach zagranicznych, polityki ekonomiczne państw rywalizujących [z USA] (w formie subsydiów, preferencji dla rodzimych dostawców etc.) oraz zmienne zapotrzebowanie stanowią dla Stanów Zjednoczonych zagrożenia polegające na utracie zasadniczych zdolności i krytycznych umiejętności ${ }^{355}$.

355 Industrial Capabilities. Annual Report to the Congress, Fiscal Year 2018, Office of the Under Secretary of Defense for Acquisition and Sustainment, Office of the Deputy Assistant Secretary of Defense for Industrial Policy, 23.05.2019, https://www.businessde fense.gov/Portals/51/Documents/Resources/2018\%20AIC\%20RTC\%2005-23-2019\%20 -\%2oPublic\%2oRelease.pdf?ver=2019-06-07-111121-457. 
Przedstawione powyżej przewidywania oparte są na założeniu, że zachodzące procesy będą faktycznie przebiegać w obecnym lub podobnym kształcie i kierunku. Istnieją jednak dwie kwestie, które mogą radykalnie zmienić obraz sytuacji w tym zakresie. Po pierwsze, w najbliższym czasie mogą pojawić się przełomy technologiczne, których siłą rzeczy nie da się przewidzieć, a które mogą przyspieszyć proces eksploracji kosmosu poprzez wprowadzenie istotnych zmian jakościowych. Po drugie, może nastąpić degradacja przestrzeni okołoziemskiej, zarówno z przyczyn naturalnych, jak i, co bardziej prawdopodobne, wywołana przez człowieka, co ograniczy lub zlikwiduje całkowicie wszelkie zdolności kosmiczne, radykalnie zmieniając sytuację.

Ta ostatnia kwestia wskazuje na zagrożenia, a zatem zbliża nas do płaszczyzny bezpieczeństwa, a więc i do tytułowej kwestii bezpieczeństwa narodowego USA i spacepower $w$ jej pierwszym znaczeniu. W tej dziedzinie dostrzegamy następujące istotne procesy:

- rośnie i będzie rosnąć znaczenie systemów kosmicznych w ramach strategii bezpieczeństwa narodowego i polityki zagranicznej Stanów Zjednoczonych;

- rośnie i będzie rosnąć ogólne zagrożenie bezpieczeństwa systemów orbitalnych wynikające ze wzrostu liczby obiektów kosmicznych, czyli zarówno orbiterów, jak i tak zwanych śmieci kosmicznych;

- wzrastają możliwości innych państw, przede wszystkim amerykańskich konkurentów i wrogów, w ramach strategii negowania zdolności kosmicznych USA; w szczególności dotyczy to tych aplikacji, które są istotne $z$ punktu widzenia bezpieczeństwa narodowego i realizowania przez Stany Zjednoczone strategii globalnego zaangażowania;

- pojawiają się zatem i rozwijają środki służące zakłócaniu pracy bądź niszczeniu systemów satelitarnych; co więcej, poszerza się katalog uczestników stosunków międzynarodowych, którzy mogą używać tych środków; dotyczy to nie tylko państw, ale także aktorów niepaństwowych;

- szczególną rolę w przyszłości może odgrywać ewentualna dalsza militaryzacja kosmosu, która staje się coraz bardziej realną perspektywą; znaczenie ma zwłaszcza rosnące prawdopodobieństwo rozpowszechnienia i rozmieszczenia $w$ istotnych ilościach broni przeciwsatelitarnej, niekoniecznie umieszczonej na orbicie, ale zdolnej do rażenia znajdujących się tam obiektów; 
- rosną także możliwości państw i innych uczestników stosunków międzynarodowych, którzy tworzą i rozwijają własne komponenty satelitarne wspierające ich strategie bezpieczeństwa i koncepcje polityki zagranicznej.

Z punktu widzenia USA, konsekwencje tychże procesów będą miały wpływ i na stan bezpieczeństwa narodowego, i na faktyczne znaczenie i rolę spacepower, a zwłaszcza w ujęciu relatywnym, w stosunku do konkurentów i wrogów Ameryki. Konsekwencje te można wymienić następująco:

- rośnie i będzie rosnąć wrażliwość amerykańskiego komponentu kosmicznego na ewentualne negatywne oddziaływanie konkurentów i wrogów, co będzie wymagać z jednej strony kosztownych prac modernizacyjnych i wzmacniających własny potencjał, a z drugiej - poszukiwania asymetrycznych środków odpowiedzi na zagrożenia w postaci na przykład wdrażania rozwiązań alternatywnych dla systemów satelitarnych lub prowadzenia przygotowań na wypadek ograniczenia ich skuteczności;

- szczególne znaczenie ma kwestia czynnej militaryzacji kosmosu, czyli ewentualnego powstania broni kosmicznej; USA są temu wciąż, co do zasady, przeciwne, jednak proces ten rozpocząć się może na pełną skalę $w$ dwóch sytuacjach: albo inne państwo opracuje i rozmieści broń na orbicie, a Stany Zjednoczone będą zmuszone za nim nadążyć, albo to Ameryka rozpocznie zbrojenia $w$ kosmosie na zasadzie działania wyprzedzającego, lub też w wyniku podjęcia decyzji na podstawie nieracjonalnych przesłanek w ramach walki wewnątrzpolitycznej;

- jednocześnie jednak rośnie zależność wrogów i przeciwników Stanów Zjednoczonych, którzy rozwijając własne zdolności kosmiczne, także coraz bardziej polegają na systemach satelitarnych, które z kolei są wrażliwe na ewentualne potężne przeciwdziałanie Stanów Zjednoczonych; proces ten będzie postępował stosunkowo szybko, w szczególności w związku z rozwojem zdolności militarnych Chin;

- na powyższą kwestię należy zwrócić szczególną uwagę, ponieważ oznacza ona rysującą się wzajemną wrażliwość, która będzie się pogłębiać szczególnie $w$ relacji pomiędzy trzema głównymi mocarstwami kosmicznymi; to z kolei może doprowadzić do pojawienia się swoistej wersji równowagi wzajemnego zniszczenia, która miałaby bardzo istotne konsekwencje dla przyszłego stanu bezpieczeństwa kosmicznego. 
Podsumowując relację pomiędzy przestrzenią kosmiczną a bezpieczeństwem narodowym USA w wymiarze prognostycznym, należy powtórzyć, że Ameryka pozostaje i pozostanie liderem w tej dziedzinie, tak jak w przypadku ogólnej eksploracji kosmosu. Niemniej jednak pozycja ta nie jest już niezagrożona i USA nie mogą swobodnie planować działalności w przestrzeni kosmicznej. Będzie ona także realizowana z przeszkodami, wymagać będzie znacznie szerszego brania pod uwagę planów i możliwości konkurentów. USA muszą zatem liczyć się z trudnościami i ograniczeniami oraz z faktem, że ich przewaga się zmniejsza, oraz z tym, że inne kraje także osiągają znaczne korzyści w ramach kosmicznego wsparcia swoich strategii bezpieczeństwa. Jednocześnie rośnie ryzyko, że w wyniku postępującej militaryzacji wykorzystanie przestrzeni kosmicznej zostanie zagrożone w samej swojej istocie, poprzez degradację tejże przestrzeni w wyniku traktowania jej jako pola walki zbrojnej. Dlatego też amerykańskie podejście do spacepower będzie coraz bardziej przesycone świadomością, że kosmos jest przestrzenią kontestowaną, w której coraz silniejsza konkurencja zmusza do wzmagania wysiłków dla ocalenia korzyści, jakie USA wynosi z jej wykorzystania.

Paradoksalnie jednak wzrost zdolności kosmicznych konkurentów Ameryki może być czynnikiem stabilizacji i poprawy stanu bezpieczeństwa międzynarodowego. Uzależniając się w zakresie istotnych dla bezpieczeństwa narodowego zdolności od komponentów kosmicznych, muszą sobie oni zdawać sprawę z rosnącej własnej wrażliwości. Jeśli zatem rozumują pragmatycznie, powinni przyjąć podobne do amerykańskiego podejście, czyli: systemy kosmiczne są pożyteczne w trybie ciągłym w czasie pokoju, nie ma więc sensu tworzyć uzbrojenia zagrażającego mu, miałoby ono bowiem znaczenie tylko w czasie wojny, i to bardzo krótkotrwałe, ponieważ jego użycie oznaczałoby szybkie zniszczenie całego potencjału wojujących stron. W związku z tym istnieje prawdopodobieństwo, że wiodące kraje, a szczególnie Chiny, pójdą tą samą pragmatyczną drogą, którą wyznaczyła jeszcze administracja Eisenhowera, a której trzymały się wszystkie kolejne amerykańskie administracje, polegającej na powstrzymaniu się od militaryzacji czynnej kosmosu. Takie stanowisko może nawet w dłuższej perspektywie doprowadzić do pojawienia się wiążących porozumień $w$ tej materii, których dążeniem byłoby zinstytucjonalizowanie korzystnego dla wszystkich stanu rzeczy w celu zabezpieczenia przed niepotrzebną, kosztowną i potencjalnie groźną eskalacją, 
4. Przestrzeń kosmiczna we wspótczesnej strategil bezpieczeństwa L'SA

która prowadzić by mogła nawet do wyścigu zbrojeń ze wszystkimi jego skutkami. Kwestie te zostaną omówione bardziej szczegółowo w kolejnym rozdziale. 


\section{5. \\ Stany Zjednoczone a bezpieczeństwo kosmiczne - wybrane problemy}

Rozdział niniejszy jest dalszym podsumowaniem dotychczasowych rozważań, tym razem $w$ formie uszczegółowienia niektórych bardziej ogólnych kwestii poruszanych powyżej. Można także powiedzieć, że jest ilustracją ważnych zjawisk determinujących znaczenie przestrzeni kosmicznej, szczególnie w wymiarze bezpieczeństwa narodowego USA w ujęciu zewnętrznym. Ma także za zadanie pokazać w sposób nieco bardziej szczegółowy, jak wygląda amerykańska spacepower w interesujących nas wymiarach, co się na nią w praktycznych kategoriach składa i jakie są perspektywy jej dalszej ewolucji.

Poruszone tu, wybrane kwestie uważamy za najważniejsze, najpełniej też określają i determinują amerykańską politykę bezpieczeństwa związaną z przestrzenią kosmiczną oraz spacepower i w wymiarze ogólnym, i w odniesieniu do bezpieczeństwa narodowego w wymiarze zewnętrznym. Mają one bowiem największe znaczenie z punktu widzenia efektywności realizowanych przez państwo strategii oraz z punktu widzenia rozwoju gospodarczego i społecznego. Nie jest to jednak pełny katalog problemów bezpieczeństwa kosmicznego i spacepower, poniższe tematy nie są także omówione w pełni szczegółowo, choćby dlatego, że każdy nadaje się do zamieszczenia $w$ osobnej pozycji typu monograficznego. Rezygnujemy także, zgodnie z założeniami niniejszej publikacji, z większości szczegółów technicznych, choć rozdział ten niewątpliwie będzie zawierał ich więcej niż poprzednie. 
Zajmiemy się zatem w pierwszej kolejności tym, co najbardziej wpływa dziś i wpłynie w przyszłości na stan spacepower oraz na bezpieczeństwo kosmiczne zarówno w wymiarze ewoluujących potrzeb bezpieczeństwa, jak i pojawiających się możliwości technicznych związanych z zagrożeniami. Nie będą to jednak rozważania dotyczące stricte bezpieczeństwa, spróbujemy raczej nakreślić ogólny stan obecnego etapu eksploracji kosmosu, uwypuklając jego cechy charakterystyczne i perspektywy. W dalszej kolejności rozważymy węższą kwestię, czyli podstawowe wymiary aktualnego stanu bezpieczeństwa kosmicznego z punktu widzenia USA, w szczególności w kontekście ewolucji zagrożeń i tego, jak wpływają one na stan i perspektywy ewolucji spacepower. I wreszcie ujmiemy osobno kwestię militaryzacji kosmosu, przede wszystkim z punktu widzenia potencjalnej militaryzacji czynnej poprzez analizę jej głównych uwarunkowań techniczno-organizacyjnych oraz związanej z tym problemem dyskusji.

\subsection{Space 2.0 - (r)ewolucja w eksploracji kosmosu}

W niniejszej książce zajmujemy się zasadniczo tymi zastosowaniami systemów kosmicznych, które służą bezpieczeństwu narodowemu w wymiarze zewnętrznym. Jak już jednak wielokrotnie zauważaliśmy, nie da się tego oderwać od szerszego kontekstu spacepower, który wyznaczany jest przede wszystkim ogólnym stanem eksploracji kosmosu, dostępnością określonych zdolności technicznych oraz kosztami i sposobem organizacji wysiłku różnych podmiotów. Dlatego też chcąc mówić o problemach bezpieczeństwa kosmicznego, najpierw trzeba wskazać na charakterystyczne cechy aktualnego stanu eksploracji kosmosu i na perspektywy dające się przewidzieć w ramach obecnie zachodzących procesów. Ma to szczególne znaczenie dlatego, że pewnego rodzaju zastój w eksploracji przestrzeni okołoziemskiej, który trwał od lat siedemdziesiątych XX wieku, najprawdopodobniej przekształca się obecnie w szybki rozwój zastosowań kosmicznych zmieniający tradycyjny obraz tego, jak wyglądało wykorzystanie kosmosu przez człowieka. W wielu aspektach zmiany te są tak szybkie i tak gruntowne, że przybierają charakter pewnego rodzaju rewolucji przynoszącej nowe jakości, a nie tylko ilościową ewolucję w ramach dotychczasowych technologii i zastosowań. I choć ich 
efektów nie da się dziś w pełni przewidzieć, z natury rzeczy zmiany jakościowe wymykają się temu procesowi, na pewno jednak należy poddać analizie ich bieżący stan i dostrzegalne dziś perspektywy.

Niniejszy podrozdział jest swego rodzaju dalszym ciągiem, ale także istotnym rozwinięciem niektórych tematów prezentowanych w rozdziale drugim. Omówimy zatem najpierw obecny stan i perspektywy rozwoju możliwości systemów startowych, przede wszystkim w wymiarze technicznym. Następnie zajmiemy się zmianami w sektorze orbitalnym, które związane są w największej mierze z miniaturyzacją systemów kosmicznych oraz nowymi sposobami wykorzystania przestrzeni okołoziemskiej. Całość zamknie krótkie podsumowanie, w którym spróbujemy syntetycznie uchwycić cechy współczesnego etapu eksploracji kosmosu.

\section{Ewolucja systemów nośnych}

W latach sześćdziesiątych, w epoce bardzo szybkiego przyrostu zdolności technicznych w zakresie wynoszenia ładunków w kosmos, uważano, że proces ten będzie przebiegał także $w$ kolejnych dekadach. Spodziewano się zatem, że dzięki temu nastąpi szybkie zagospodarowanie przestrzeni okołoziemskiej za pomocą dużych konstrukcji orbitalnych, a następnie ruszy eksploracja Księżyca w postaci budowy baz naukowych i przemysłowych. Wizje tego typu, pojawiające się nie tylko w utworach science fiction, ale też $w$ pozycjach popularnonaukowych i naukowych, nie były pozbawione prawdopodobieństwa. Rakieta Saturn V mogła wynieść na niską orbitę okołoziemską, według różnych źródeł uwzględniających różne parametry orbity docelowej, od $118^{356}$ do $140^{357}$ ton tadunku. Wydawato się więc niejako oczywiste, że przy takich możliwościach stosunkowo szybko powstanie potężna infrastruktura kosmiczna, a następnie, w kolejnych dekadach, dalsze generacje systemów nośnych będą miały jeszcze większe możliwości.

Na przeszkodzie temu rozwojowi, który w sensie technologicznym zapewne był możliwy, stanęły jednak jego ogromne koszty w porównaniu

356 Saturn V...

357 Alternatives for Future U.S. Space-Launch Capabilities, A CBO Study, Congress of United States, Congressional Budget Office, October 2006, s. 1, https://www.cbo.gov/sites/ default/files/109th-congress-2005-2006/reports/10-09-spacelaunch.pdf. 
$\mathrm{z}$ relatywnie skromnymi w owym czasie potrzebami. Z punktu widzenia rządu i bieżących potrzeb państwa znaczenie miało przede wszystkim wsparcie sił zbrojnych, instytucji wywiadowczych i służb publicznych, co zapewnić mogły konstelacje orbiterów o masie kilku do kilkunastu ton każdy. Przedsiębiorst wa prywatne działające w branży telekomunikacyjnej i ściśle współpracujące $z$ rządem USA także nie potrzebowały możliwości Saturna, a tym bardziej jeszcze większych rakiet, jako że satelity geostacjonarne $\mathrm{i}$ inne systemy telekomunikacyjne opłacalne $\mathrm{z}$ operacyjnego punktu widzenia również miały masę zaledwie kilku ton. Należy w tym miejscu przypomnieć, że produkt programu księżycowego Saturn V wprawdzie przyniósł opracowanie wielu kluczowych technologii, które niewątpliwie ułatwiły i przyspieszyły ogólny rozwój eksploracji kosmosu i techniki w ogóle, sam w sobie jednak był projektem politycznym, który stracił rację bytu, kiedy prestiżowy cel został osiągnięty.

$\mathrm{W}$ istniejących wówczas realiach trudno było zatem wyobrazić sobie nowe misje, wymagające wykorzystania wszystkich możliwości istniejących systemów startowych oraz dalszego ich rozwoju w kierunku wynoszenia w kosmos coraz większych ładunków. Mogłyby one, w teorii, obejmować rozbudowane badania naukowe przy użyciu dużych konstrukcji orbitalnych oraz dalszą eksplorację załogową poza orbitę Ziemi. Jednak z punktu widzenia budżetu państwa nie były to projekty warte niezbędnego gigantycznego wysiłku finansowego. Oczywiście można było pokusić się także o tworzenie dużych instalacji wojskowych poza Ziemią, w postaci orbitujących lub też księżycowych baz, ale i to uznano za absolutnie niepraktyczne i nieefektywne finansowo. Mimo że Saturn oferował relatywnie, nawet na skalę dzisiejszą, niskie koszty wynoszenia ładunków na orbitę 358 , nikt nie miał zamiaru budować takich ładunków. W rezultacie, po zaledwie dwunastu startach, najpotężniejsza rakieta nośna w historii została uziemiona po ostatnim locie w grudniu 1972 roku - po prostu zabrakło dla niej misji.

Nie wchodząc w tym miejscu w detale techniczne i rozległą, wielowymiarową dyskusję na temat charakteru eksploracji kosmosu, należy stwierdzić, że amerykański program kosmiczny po wygaszeniu progra-

3585200 USD/kg na LEO, w dolarach z 2018, za: H. W. Jones, The Recent Large Reduction in Space Launch Cost, ICES-2018-81, 48th International Conference on Environmental Systems 8-12.07.2018, Albuquerque, New Mexico, s. 8 
mu księżycowego był efektem przecięcia realnych potrzeb i kosztów ich zaspokojenia. Potrzeby zaś, przynajmniej te, które dawały się finansować, obejmowały przede wszystkim orbitę okołoziemską i jej wykorzystanie przy użyciu zautomatyzowanych konstelacji satelitarnych. Dla takich potrzeb w zupełności wystarczały nieporównywalnie tańsze, w sensie kosztu jednostkowego, znacznie mniejsze rakiety rodziny Titan o udźwigu do kilkunastu ton, które były końmi roboczymi amerykańskiego programu kosmicznego wojskowego i cywilnego do momentu wejścia do służby w 1981 roku systemu STS, powszechnie znanego pod nazwą "prom kosmiczny” (Space Shuttle). Ten opracowywany od 1968 roku środek transportu znacznie bardziej odpowiadał amerykańskim potrzebom, ponieważ był statkiem kosmicznym wielorazowego użytku. Miał zdolność dostarczenia na niską orbitę ładunku rzędu 27 ton (z czasem ograniczonego do 24 ton) ${ }^{359}$, co w zupełności wystarczało do wynoszenia wszystkich systemów satelitarnych, które uważano za potrzebne i efektywne pod względem kosztowym. Miał on ponadto możność serwisowania obiektów w kosmosie i sprowadzania ich na Ziemię, co radykalnie zwiększało elastyczność transportu orbitalnego. Z drugiej jednak strony okazało się szybko, że jakkolwiek w wielu misjach prom kosmiczny był niezastąpiony, to jednak do „codziennych” działań, takich jak umieszczanie na orbicie kilkutonowych satelitów, się nie nadawał. Po pierwsze dlatego, że był bardzo drogi w sensie kosztu jednostkowego wyniesienia ładunku ${ }^{360}$, po drugie dlatego, że takie „zwykłe” misje zużywały resurs promu tak samo jak duże i ważne zadania, a po trzecie, rutynowa czynność orbitowania zwykłego satelity nie wymagała załogowej misji, która byłaby zatem marnotrawstwem. Dlatego też STS uzupełniało kilka typów rakiet nośnych wdrożonych jeszcze w latach osiemdziesiątych i dziewięćdziesiątych, które używane były do wynoszenia różnych typów ładunków. Na przykład w 2001 roku na 6 misji załogowych promu kosmicznego przypadało 13 startów bezzałogowych systemów nośnych ${ }^{361}$.

359 Space Shuttle, Encyclopedia Astronautica, 2017, http://www.astronautix.com/s/space shuttle.html.

360 Koszt wyniesienia jednego kilograma ładunku przez prom kosmiczny na niską orbitę był 12 razy wyższy niż w przypadku Saturna V, a 6 razy w przypadku rakiety Delta III, w dolarach z 2018, za: H. W. Jones, op. cit., s. 8

361 Orbital Launches of 2001, Gunter's Space Page 2019, https://space.skyrocket.de/doc_ chr/lauzoor.htm. 
Dla porządku należy w tym miejscu zamieścić pewną dygresję. Otóż mówiąc o ładunku umieszczanym na orbicie, mówimy zawsze o tym, co można na nią wynieść i co na niej pozostanie. Prom kosmiczny w pełni załadowany miał masę 110 ton i taka właśnie masa była wynoszona na orbitę przez jego system startowy, co stanowiło wynik zbliżony do Saturna. Jednak, jako że masa własna orbitera wynosiła 78 ton, mówimy o jego możliwościach ładunkowych, czyli o tym, co mógł on pozostawić na orbicie, a nie o możliwościach całego systemu startowego.

Przez czterdzieści lat od wycofania Saturna V sytuacja w zakresie zdolności transportowych w przestrzeni kosmicznej nie zmieniła się zatem radykalnie. Ładunki, jakie można było wynosić w przestrzeń kosmiczną, miały masę rzędu 13-15 ton na niską orbitę w latach siedemdziesiątych, a następnie dwudziestu kilku w latach osiemdziesiątych. Odbywało się to przy użyciu załogowego promu kosmicznego, który wykonywał bardziej wymagające misje wojskowe, misje naukowe oraz umieszczał na orbicie elementy stacji kosmicznej ISS. STS uzupełniały systemy bezzałogowe, które brały na siebie „codzienną” pracę rozmieszczania konstelacji satelitarnych. Możliwości systemów startowych pozostawały zatem w zakresie dwudziestu kilku ton - najpotężniejszą rakietą jednorazowego użytku, która weszła do służby w 2004 roku, była Delta IV Heavy, zdolna umieścić na niskiej orbicie ladunek o masie ponad 28 ton $^{362}$.

W 2011 roku nastąpił jednak znaczny regres $\mathrm{w}$ omawianej dziedzinie. Wraz z wycofaniem floty starzejących się promów kosmicznych USA utraciły unikalną zdolność sprowadzania ładunków z orbity, a także zdolność wysyłania w kosmos ludzi. I choć masa możliwych do wyniesienia ładunków nie spadła, to liczba możliwych do wykonania typów misji znacznie się zmniejszyła.

Powtórzmy zatem, że do niedawna utrzymywała się sytuacja, w której jednorazowy ładunek, który można było wysłać na niską orbitę, mógł ważyć niecałe trzydzieści ton. Różne wersje rakiet Delta wraz z rakietami rodziny Atlas wystarczały do wszystkich zadań, które były gotowe finansować rząd USA i korporacje telekomunikacyjne. Dodatkowo należy zwrócić uwagę na faktyczny monopol kilku tradycyjnych dostawców, którzy łącząc się sukcesywnie sformowali ostatecznie w 2006 roku spółkę

362 Delta IV, United Launch Alliance, 2019, https://www.ulalaunch.com/rockets/delta-iv. 
United Launch Alliance - proces ten niewątpliwie hamował zainteresowanie wydatkami na rozwój oferty. Dla porównania dodać można, że systemami nośnymi o zdolności do wysłania na niską orbitę ładunków powyżej 20 ton dysponowała także Rosja i Europejska Agencja Kosmiczna, w 2016 roku do ligi tej dołączyły także Chiny.

W 2011 roku, w chwili wycofywania promów kosmicznych, podjęto w USA inicjatywę budowy superciężkiej rakiety nośnej pod nazwą Space Launch System. Parametrami ma ona dorównać Saturnowi, stając się jądrem nowego programu załogowej eksploracji kosmosu - projekt ten zastąpił wcześniejszą koncepcję pod nazwą Constellation, która zakładała powrót ludzi na Księżyc około 2020 roku. Operatorem SLS ma być NASA, wersja o nośności 95 ton miała, według pierwotnych założeń, wejść do służby w 2025 roku, a docelowa, 130-tonowa, po 2030. Trudno w tym miejscu rozwodzić się szczegółowo nad meandrami programu, zmianami przeznaczenia i terminów oraz kwestiami budżetowymi, nie mówiąc już o wielostronnej krytyce samej zasadności budowy tak dużego systemu nośnego. Mimo zapowiedzi administracji Donalda Trumpa o wysłaniu ludzi na Księżyc finansowanie SLS, która ma być głównym elementem tego programu ${ }^{363}$, pozostaje niepewne. Trwają jednak przygotowania do pierwszego, eksperymentalnego lotu przewidzianego na 2020 lub 2021 rok $^{364}$.

Podstawowym czynnikiem zmian, które obecnie zachodzą w zakresie możliwości wynoszenia ładunków na orbitę, jest jednak pojawienie się zupełnie nowych, prywatnych przedsiębiorstw, spoza dotychczasowego państwowo-prywatnego establishmentu kosmicznego. Najważniejszym z nich, tym, które do dziś pozostaje pionierem rozwoju technicznego systemów nośnych, jest SpaceX, ufundowane jako prywatne, w pełni komercyjne przedsięwzięcie przez amerykańskiego miliardera Elona Muska. W 2006 roku przedsiębiorstwo to umieściło na orbicie okołoziemskiej pierwszy ładunek za pomocą rakiety nośnej Falcon 1. W 2010 roku wystartowała po raz pierwszy rakieta nośna Falcon 9, która stała się

363 I. Klot z, NASA Says No Moon Landing Without Orion And SLS, „Aviation Week \& Space Technology", 12.07.2019, https://aviationweek.com/apollo/nasa-says-no-moonlanding-without-orion-and-sls?utm_rid=CPEN1000001539178\&utm_campaign $=20427$ \&utm_medium =email\&elq2=8c7a114a6ofa4d7eb4bf9fb4a81725c5.

$36+$ Waiting for Artemis i Schedule Update, Official Decision on SLS Green Run, NASA spaceflight.com, 8.07.2019, https://www.nasaspaceflight.com/2019/07/waiting-arte mis-1-schedule-decision-sls-green-run/. 
„koniem roboczym” firmy, do sierpnia 2019 roku wykonała ona 79 startów, z czego zaledwie trzy zakończyły się niepowodzeniem ${ }^{365}$. Najmocniejsza, docelowa wersja rakiety, która używana jest od 2015 roku, ma możliwość wyniesienia ponad 22 ton na niską orbitę.

Najważniejszą jednak cechą systemu nośnego należącego do SpaceX jest to, że od samego początku konstruowano go $\mathrm{z}$ myślą o ponownym wykorzystaniu jego komponentów. Podstawową filozofią firmy od jej zarania było bowiem obniżenie kosztów umieszczania ładunków na orbicie. Długotrwałe badania i testy doprowadziły do tego, że w 2014 roku po raz pierwszy zrealizowano pełny cykl bezpiecznego lądowania stopnia startowego rakiety na pokładzie odpowiednio wyposażonej, zdalnie sterowanej barki znajdującej się na Atlantyku. Od tego momentu takie lądowania stały się rutyną, a w 2015 roku Falcon 9 po raz pierwszy wystartował ze stopniem startowym odzyskanym z wcześniejszej, udanej operacji lądowania, a następnie bezpiecznie powrócił na ziemię. Recykling elementów statków kosmicznych stał się faktem, a wkrótce był już normalną, codzienną procedurą, choć nie zawsze się udaje i nie zawsze jest $\mathrm{z}$ różnych przyczyn podejmowany. W 2018 roku po raz pierwszy stopień startowy poleciał po raz trzeci i znowu bezpiecznie wylądował. Wprawdzie profil lotu przewidujący odzyskanie członów startowych rakiet nośnych wymaga zaoszczędzenia pokaźnej ilości paliwa na manewry i lądowanie, w związku z czym ładunki w takim przypadku są mniejsze, jednak fakt odzyskania części rakiety obniża znacznie koszty jednostkowe usług startowych oferowanych przez SpaceX w porównaniu $z$ innymi dostawcami.

Przedsiębiorstwo Elona Muska przoduje jednak nie tylko w recyklingu komponentów rakiety nośnej, lecz także w masie ładunku, jaki dostarczyć można na orbitę. 6 lutego 2018 roku z przylądka Canaveral wystartowała rakieta Falcon Heavy, która składa się z trzech połączonych ze sobą stopni startowych Falcona 9. Ma ona maksymalną nośność $63800 \mathrm{~kg}$ na niską orbitę okołoziemską ${ }^{366}$, co ponaddwukrotnie przekracza możliwości dotychczas stosowanych, najpotężniejszych systemów startowych zarówno amerykańskich, jak i zagranicznych. Wprawdzie pierwszym wy-

365 Falcon 9 Family, Gunter's Space Page, 2019, https://space.skyrocket.de/doc_lau_fam/ falcon-9.htm.

366 Falcon Heavy, SpaceX, 2018, https://www.spacex.com/falcon-heavy. 
słanym przez nią w kosmos ładunkiem był jedynie samochód elektryczny należący do właściciela SpaceX, który został wprowadzony na eliptyczną orbitę wokółsłoneczną przecinającą się $\mathrm{z}$ orbitą Marsa, jednak drugi i trzeci start w 2018 i 2019 roku miały już charakter w pełni komercyjny. Falcon Heavy już w pierwszym locie zaprezentował zdolność do realizacji procedury powrotu stopni startowych na Ziemię. Dwa boczne człony wylądowały precyzyjnie na Cape Canaveral, a środkowy o kilkaset metrów minął platformę morską na Atlantyku (wykonał prawidłową sekwencję lądowania, lecz zabrakło mu paliwa, by dotrzeć do platformy). Warto dodać, że wspomniany lot Falcona Heavy z czerwca 2019 roku, w którym rakieta wyniosła 24 satelity, w tym 2 należące do Departamentu Obrony ${ }^{367}$, odbył się przy użyciu tych samych bocznych stopni startowych co komercyjny start z $2018^{368}$.

Porównując oferty ULA dotyczące sprawdzonej rakiety Atlas V, której głównym komponentem są relatywnie proste i tanie silniki RD-18o produkcji rosyjskiej, z produktami SpaceX, widzimy znaczną dysproporcję. ULA oferuje swoją rakietę $w$ cenie od $109 \mathrm{mln}$ USD za jeden lot ${ }^{369}$, co należy rozumieć jako cenę startu najsłabszej konfiguracji, 401, zdolnej do wyniesienia na orbitę transferową do geostacjonarnej ładunku 4750 kg. SpaceX zaś proponuje za podobną usługę ( $5500 \mathrm{~kg}$ na GTO) - zrealizowaną przy użyciu Falcona 9 - cenę $62 \mathrm{mln}$ USD. Falcon Heavy może natomiast umieścić na tej samej orbicie ładunek $8000 \mathrm{~kg}$ za $90 \mathrm{mln}$ USD, i to przy częściowym odzyskaniu stopni startowych ${ }^{370}$. Dodajmy, że najpotężniejszy produkt ULA, Delta IV Heavy, jest w stanie dostarczyć na orbitę przejściową do geostacjonarnej 14 ton ładunku za $350 \mathrm{mln}$ USD ${ }^{371}$. Podsumowując, jeden kilogram ładunku umieszczonego na GTO przez Atlasa V 401 kosztuje 22947 USD, a w przypadku Falcona 9 jest to 11 272 USD. Falcon Heavy zaś oferuje prawie dwukrotnie większy ładunek za 11250 USD od kilograma, podczas gdy za kilogram wyniesiony na GTO przez Deltę IV Heavy trzeba zapłacić około 25000 USD. Bardziej

367 STP-2 Mission, SpaceX, 2019, https://www.spacex.com/stp-2. $368 \mathrm{Ibidem}$.

369 Dokładne sformułowanie brzmi: „starting at $\$ 109 \mathrm{mln”}$, za: Atlas V, ULA, 2018, https:// www.ulalaunch.com/rockets/atlas-v.

370 Capabilities $\mathcal{E}$ Services, SpaceX, 2018, https://www.spacex.com/about/capabilities.

37 E. Howell, Delta IV Heavy: Powerful Launch Vehicle, Space.com, 20.04.2018, https:// www.space.com/40360-delta-iv-heavy.html. 
szczegółowe wyliczenia specjalisty z NASA pokazują jeszcze większą przewagę SpaceX w odniesieniu do niskiej orbity okołoziemskiej ${ }^{372}$.

Firmy prywatne, ze SpaceX na czele, oferują dalsze, przyszłościowe systemy, które będą miały jeszcze większe zdolności wynoszenia obiektów na orbitę. Propozycja Elona Muska o nazwie Starship ma mieć udźwig do 150 ton na LEO. Przedprototypowy egzemplarz pod nazwą Starhopper odbył już pierwsze udane „podskoki” z napędem ${ }^{373}$, a dwa kolejne, pełnoskalowe prototypy są $w$ budowie ${ }^{374}$. Właściciel SpaceX sugeruje, że nowy produkt będzie nawet dziesięć razy bardziej ekonomiczny w sensie kosztu jednostkowego ładunku wyniesionego na orbitę niż Falcon $9^{375}$. Lecz tu wraca znany nam $z$ lat siedemdziesiątych problem misji, jakie systemy te mogłyby wykonywać, to znaczy skąd wziąć tak duże ładunki i do czego one mogłyby służyć. Pojawiają się więc między innymi koncepcje eksploracji, a nawet kolonizacji kosmosu ${ }^{376}$, szybkiego transportu Ziemia Ziemia $^{377}$ via orbita lub lotem suborbitalnym ${ }^{378}$. Są to jednak wszystko kwestie przyszłości, która w mniejszym stopniu zależy od tego, jak nisko spadną koszty wynoszenia ładunków na orbitę, a bardziej od tego, czy owe ładunki powstaną. Nawet bowiem jeśli koszty startów będą się nadal obniżać, to czy państwa lub korporacje pokuszą się na przykład o za-

372 E. Zapata, The State of Play US Space Systems Competitiveness. Prices, Productivity, and Other Measures of Launchers $\mathcal{E}$ Spacecraft, Presentation to the Future In-Space Operations (FISO) Seminar October 11, 2017, NASA 2017, s. 7-8, https://ntrs.nasa.gov/ archive/nasa/casi.ntrs.nasa.gov/20170009967.pdf.

373 G. Norris, Starhopper Verifies Raptor Performance For Starship, „Aviation Week \& Space Technology 29.08.2019, https://aviationweek.com/world-satellite-businessweek/starhopper-verifies-raptor-performance-starship.

374 Elon Musk Will Update the Status of Starship Development on August 24, Arstechnica, 4.08.2019, https://arstechnica.com/science/2019/o8/elon-musk-will-update-the-sta tus-of-starship-development-on-august-24/.

375 Elon Musk na Twitterze, 11.02.2019, https://twitter.com/SpaceRho_/status/1094796778 514382848 .

376 E. Musk, Making Life Multiplanetary, SpaceX, 29.09.2017, YouTube, https://www.youtube.com/watch?v=tdUX $3 y$ pDVwl.

377 V. Insinna, One Possible Job for SpaceX's BFR Rocket? Taking the Air Force's Cargo in and Out of Space, Defense News, 2.08.2018, https://www.defensenews.com/space /2018/o8/o2/one-possible-job-for-spacexs-bfr-taking-the-air-forces-cargo-in-andout-of-space/.

378 M. Brown, SpaceX Starship: Those 30-Minute, Cross-Planet Flights Will Be Punishing, Inverse, 27.06.2019, https://www.inverse.com/article/57135-spacex-starship-rocketswill-get-you-from-paris-to-nyc-in-3o-minutes. 
projektowanie znacznych konstrukcji orbitalnych bądź o przyspieszenie eksploracji załogowej orbity okołoziemskiej, Księżyca czy nawet dalszych obszarów przestrzeni kosmicznej? Każdy z tego typu programów będzie przecież musiał być niezwykle drogi.

W chwili obecnej, podobnie jak pół wieku temu, o tym, czy superciężkie systemy o nośności setek ton pozostaną w fazie koncepcji bądź projektów, czy też wejdą do użytku, zadecyduje zatem to, czy znajdą się dla nich możliwe do sfinansowania misje. Mówimy tu jednak nie o samych kosztach wyniesienia ładunków na orbitę, które mogą być relatywnie niewielkie, lecz o wydatkach na opracowanie i budowę tych ładunków, a potem na ich długotrwałą eksploatację - w tym zaś zakresie sytuacja jest bardzo niejasna. Warto na marginesie dodać, że nad własnymi koncepcjami systemów o nośności powyżej 100 ton pracują i Rosjanie ${ }^{379}$, i Chińczycy $^{380}$, lecz ich droga do sukcesu jest zapewne jeszcze długa. Ponadto oba te kraje stoją przed tym samym problemem sensownej w ujęciu ekonomicznym, czy choćby tylko politycznym, misji dla tak kosztownych systemów.

Podkreślić należy, że Falcon 9 i Falcon Heavy to niewątpliwie zwiastuny nowej ery w wykorzystaniu kosmosu. Jedną z jej głównych, dających się już dziś rozpoznać cech jest szybki spadek kosztów wyniesienia ładunków na orbitę. Oznaczać to będzie niewątpliwie szansę na rozszerzenie zakresu zadań i misji, które systemy można będzie sfinansować i zrealizować. To zaś spowoduje, że wzrośnie ogólny poziom wykorzystania kosmosu, a konsekwentnie i jego znaczenie. Przyniesie to oczywiście także zmiany z punktu widzenia systemów pracujących na potrzeby bezpieczeństwa narodowego, będą one mogły być tańsze, większe i zdolne do bardziej skutecznego wykonywania większej liczby funkcji. Unowocześnienie technologii startowych pozwoli także rozwinąć procedury szybkiego uzupełniania konstelacji satelitarnych lub szybkiego wzmacniania istniejących systemów w razie potrzeby.

W projekty systemów nośnych nowej generacji zaangażowanych jest wiele amerykańskich przedsiębiorstw. Z najważniejszych oprócz SpaceX

379 A. Zak, Russia Is Now Working on a Super Heavy Rocket of Its Own, Popular Mechanics, 8.02.2018, https://www.popularmechanics.com/space/rockets/a16761777/rus sia-super-heavy-rocket/.

380 A. Jones, China Reveals Details for Super-Heavy-Lift Long March 9 and Reusable Long March 8 Rockets, SpaceNews, 5.07.2018, https://spacenews.com/china-reveals-detailsfor-super-heavy-lift-long-march-9-and-reusable-long-march-8-rockets/. 
wymienić trzeba w pierwszej kolejności Blue Origin, należącą do miliardera Jeffa Bezosa, z jej zaawansowanym projektem rakiety New Glenn o nośności do 45 ton w wersji skonfigurowanej do ponownego wykorzystania. Inny zaawansowany konkurent to Orbital ATK z funkcjonującym systemem startowym Antares i statkiem towarowym Cygnus - po przejęciu przez Northrop Grumman w 2018 roku firma ta znana jest pod nazwą NG Innovation Systems. Inne, mniej znane przedsiębiorstwa rozwijające usługi startowe to między innymi Relativity Space, Rocket Crafters, Firefly Aerospace, Virgin Orbit, Vector Space Systems, z których oczywiście niektóre zapewne zbankrutują, ale kilka prawdopodobnie odniesie mniejszy lub większy sukces. Warto dodać, że i w innych krajach prywatne przedsiębiorstwa podejmują się rozwoju systemów nośnych, na przykład w Japonii, Wielkiej Brytanii, Nowej Zelandii, Hiszpanii, na Tajwanie, w Malezji oraz w Chinach.

Rosnąca konkurencja i zwiększające się potrzeby zmuszają także ULA, tradycyjnego dostawcę usług startowych dla amerykańskich instytucji i przedsiębiorstw, do innowacji. Opracowuje on zatem nowy model rakiety nośnej, Vulcan, która wprawdzie ma być systemem jednorazowego użytku, ale mimo to ma on być znacznie bardziej ekonomiczny od dotychczasowych produktów firmy. Symptomatyczne, że partnerem ULA w tym projekcie jest Blue Origin, mający dostarczyć opracowane przez siebie silniki.

Podsumowując, należy przede wszystkim zauważyć, że wciąż nie wiadomo, czy ta nowa era, sygnowana powstaniem nowej generacji systemów nośnych, będzie miała kolejne fazy charakteryzujące się dalszym przyrostem możliwości systemów startowych. Czy istotnie w najbliższych latach wystartuje Starship Elona Muska, czy pojawią się kolejne podobne propozycje? To będzie zależało zarówno od pokonania barier technologicznych, jak i od tego, czy zostaną wynalezione misje, które tak potężne rakiety nośne miałyby pełnić w ekonomicznie sensowny sposób. Inaczej mówiąc, jeśli takie środki wynoszenia ładunków na orbitę będą technicznie wykonalne, to czy kogokolwiek będzie stać na ich użytkowanie. Czy nie powtórzy się zatem sytuacja z Saturnem V, dla którego zabrakło dającej się sfinansować misji. Jest to bodaj nawet ważniejsze pytanie, niż to, czy nowe, superciężkie systemy nośne będą w stanie dalej obniżyć koszty wyniesienia na orbitę przysłowiowego jednego kilograma ładunku. 
Systemy satelitarne - rewolucja miniaturyzacyjna, nowe misje

Omówione powyżej systemy startowe służą do wynoszenia na orbitę komponentów systemów kosmicznych, a zatem wzrost masy możliwej do wyniesienia w jednym starcie i spadek ceny jednostkowej ma ogromny wpływ na użyteczność aplikacji kosmicznych. Opisana powyżej ewolucja w tym zakresie jest zatem podstawą zwiększania dostępności, a więc upowszechniania usług satelitarnych oraz ewentualnie tworzenia nowych misji dla ich nowych generacji. Inaczej mówiąc, można wynosić coraz więcej i coraz taniej, a to, co jeszcze niedawno było za drogie, staje się powoli realną perspektywą.

Nie jest to jednak jedyny warunek wzrostu możliwości i efektywności systemów kosmicznych - zdolność do wysyłania w kosmos coraz więcej i coraz taniej o tym nie przesądza. Podstawową kwestią pozostaje efektywność kosztowa wyprodukowania i eksploatacji systemu orbitalnego, a zatem to, co daje się sfinansować w danych warunkach ekonomicznych i politycznych; albo dlatego, że się to opłaca przedsiębiorstwu, albo dlatego, że rząd gotów jest ponieść określone koszty, uwzględniając wielowymiarową użyteczność polityczną (międzynarodowy prestiż, zaspokojenie oczekiwań wyborców, także w sensie zapewnienia zatrudnienia) i praktyczną (misje militarne, wywiadowcze, naukowe oraz w sektorze służby publicznej).

Użyteczność z kolei wiąże się przede wszystkim z samymi parametrami technicznymi systemów kosmicznych, które sukcesywnie rosną. Satelity i ich konstelacje zdolne są zatem do coraz lepszego wykonywania powierzonych im misji, a skoro systemy są coraz lepsze, zwiększa się gotowość do ich sfinansowania. Drugą, bodaj ważniejszą stroną tego medalu jest spadek kosztów poszczególnych komponentów systemu, zarówno w sektorze orbitalnym, jak i naziemnym oraz w łączności i w sektorze urządzeń będących odbiornikami usług satelitarnych. Jednym $\mathrm{z}$ najnowszych trendów w tej dziedzinie jest opracowywana przez czołowe firmy technologia, dzięki której orbitery będą zdolne do zmiany parametrów swoich misji między innymi przez zdolność do przeprogramowania ich $w$ czasie pobytu na orbicie ${ }^{38_{1}}$. Dotychczas każdy wystrzelony satelita

381 A. St on e, Are Reprogrammable Satellites Ready for Prime Time?, CRISRnet, 5.04.2019, https:/www.c4isrnet.com/c2-comms/satellites/2019/04/o5/are-reprogrammablesatellites-ready-for-prime-time/. 
działa w sposób niezmienny przez cały czas swojego funkcjonowania. Zdolność do zmiany przynajmniej części parametrów oprogramowania umożliwi więc ewolucję usługi satelitarnej w miarę ewolucji potrzeb. Zwiększy się zatem jeszcze bardziej użyteczność danego orbitera, jego efektywność kosztowa wzrośnie, ponieważ będzie mógł, po części przynajmniej, optymalizować dostarczaną przez siebie usługę w zależności od zmieniających się potrzeb.

Jednym z kluczowych czynników spadku kosztów orbiterów jest miniaturyzacja obniżająca masę, którą trzeba wynieść w kosmos. Rozwój w tym zakresie trwa zresztą od zarania ery kosmicznej, stały postęp w tej dziedzinie był jedną z przyczyn ciągłego wzrostu możliwości amerykańskich systemów satelitarnych. W ostatnich dekadach miniaturyzacja jednak znacząco przyspieszyła, można nawet mówić o swoistej rewolucji w tym zakresie. Pojawiły się w związku z tym relatywnie niewielkie satelity, które wprawdzie różnie się klasyfikuje ${ }^{382}$, ale najbardziej ogólne zbiorcze określenie to mały satelita (SmallSat). Mimo niewielkich rozmiarów, często liczonych zaledwie w kilogramach lub w dziesiątkach kilogramów, zdolne są do wykonywania skomplikowanych misji. Przykładowo, satelity budowanej obecnie konstelacji Starlink należącej do SpaceX, które mają dostarczać szerokopasmowy Internet bezpośrednio do indywidualnych terminali na Ziemi, ważą około $227 \mathrm{~kg}$ każdy. W tak niewielkim pojeździe mieści się nie tylko system nadawczo-odbiorczy zdolny zapewnić transmisję ogromnej ilości danych, ale także bardzo duże baterie słoneczne, napęd, układy nawigacji i przeciwdziałania kolizjom ${ }^{38_{3}}$.

Czynnikiem sprawczym tego procesu jest ogólny rozwój nauki i techniki, a szczególnie technologii materiałowych, napędów, systemów transmisji danych, sensorów i jednostek sterujących. W efekcie systemy satelitarne wykonują zadania coraz lepiej, coraz bardziej niezawodnie i coraz

382 SmallSat - według definicji NASA to obiekty ważące mniej niż $180 \mathrm{~kg}$. Por. What Are SmallSats and CubeSats?, NASA, 26.02.2015, https://www.nasa.gov/content/whatare-smallsats-and-cubesats. UNOOSA używa klasyfikacji zaczynającej się od pojęcia „minisatelita”, czyli obiektu o masie $1000 \mathrm{~kg}$ i mniejszej, por. Guidance on Space Object Registration and Frequency Management for Small and Very Small Satellites, UNOOSA/ ITU, 2015, s. 2, http://www.unoosa.org/documents/pdf/psa/bsti/2015_Handout-onSmall-SatellitesE.pdf. Por. także obszerna baza danych: nanosats.eu, http://www. nanosats.eu/.

38. Starlink, Starlink, 2019, https://www.starlink.com/. 
dłużej. Komponenty systemów satelitarnych, zarówno kosmiczne, jak i naziemne, oraz odbiorniki usług satelitarnych są coraz mniejsze, a jednocześnie zdolne do pełnienia swoich funkcji coraz bardziej efektywnie. Zmniejszaniu podlegają zatem kluczowe elementy orbiterów, takie jak: źródła zasilania, nadajniki, napędy niezbędne do utrzymania pozycji, oraz komponenty misji: sensory różnego rodzaju, urządzenia nadawczo-odbiorcze czy też nadajniki systemów pozycjonowania. Praktycznym skutkiem jest to, że w jednym orbiterze można zmieścić więcej urządzeń, czyniąc go bardziej efektywnym bądź bardziej wszechstronnym, bądź też można budować coraz mniejsze orbitery, wykonujące ten sam zakres funkcji.

Wykorzystywane są obie drogi. Pierwszą podążają przede wszystkim tradycyjni dostawcy usług satelitarnych, głównie w sektorze telekomunikacyjnym, oraz rządy finansujące obiekty militarne lub też naukowe bądź obsługujące sektor publiczny. Druga droga (zmniejszanie orbiterów, dzięki czemu ogranicza się zarówno ich koszt jednostkowy, jak i koszt wyniesienia) prowadzi do bardzo szybkiego rozwoju w sektorze smallsats, które w pełni mogą wykonywać nawet bardzo złożone zadania ${ }^{3{ }^{8}}$. Dzięki temu na ich pozyskanie mogą sobie pozwolić podmioty, które nie mają budżetów liczących setki milionów czy miliardy dolarów. A zatem dziś małe satelity umieszczane są na orbitach dla małych firm, ośrodków badawczych czy uniwersytetów, możliwe jest także ich pozyskiwanie i użytkowanie przez osoby indywidualne na prywatne potrzeby ${ }^{385}$. Liczba małych satelitów rośnie więc rokrocznie, na przykład obecnie na orbitach wokółziemskich działa prawie 600 obiektów klasyfikowanych jako nanosatelity ${ }^{386}$, czyli pojazdy ważące od 1 do $10 \mathrm{~kg}^{387}$. Oprócz tego rozpoczyna się tworzenie ogromnych konstelacji satelitarnych, które docelowo mają liczyć

384 I. Klotz, Small Satellites Take On Big Missions, „Aviation Week \& Space Technology", 20.08.2018, http://aviationweek.com/aviation-week-space-technology/small-sate llites-take-big-missions.

385 Zob. CubeSat 101. Basic Concepts and Processes for First-Time CubeSat Developers, NASA, October 2017, https://www.nasa.gov/sites/default/files/atoms/files/nasa_csli_ cubesat_101_508.pdf.

$386 \mathrm{Na}$ 10.06.2019 580 obiektów definiowanych jako nanosat (spomiędzy 1185 wystrzelonych do tego czasu) znajdowało się na orbitach $w$ stanie operacyjnie sprawnym. Za: nanosats.eu, 10.06.2019, http://www.nanosats.eu/.

38; What Are SmallSats and CubeSats?... 
setki, a nawet tysiące orbiterów. W ten sposób liczba małych satelitów rośnie lawinowo, a według niektórych ocen w ciągu dekady będzie ich co najmniej dziesięciokrotnie więcej ${ }^{388}$.

Miniaturyzacja współgra także, co jest zresztą ogólną cechą rozwoju współczesnej techniki, ze spadkiem kosztu komponentów, w miarę jak coraz bardziej efektywne technologie upowszechniają się i sukcesywnie tanieją. Zjawiska te kumulują się tak, że następuje bardzo szybki przyrost możliwości przy jednoczesnym spadku kosztów produkcji systemów kosmicznych i ich komponentów. Można zatem mówić, choć trudniej to uchwycić w sposób tak wyraźny jak w przypadku kosztów wynoszenia satelitów na orbitę, o spadku kosztu wykonania danej „jednostkowej misji". Na przykład dostarczenie jednego zdjęcia satelitarnego kosztuje znacznie mniej niż dekadę temu, przy jednoczesnym poprawieniu efektywności tejże misji, czyli przykładowe zdjęcie będzie znacznie wyższej jakości. Wszystko to kumuluje się dalej ze spadkiem jednostkowego kosztu wyniesienia oraz zwiększeniem masy możliwej jednorazowo do wprowadzenia na orbitę, dając w efekcie bardzo szybki przyrost możliwości i efektywności systemów satelitarnych.

Powstawanie wspomnianych już dużych konstelacji satelitarnych, nazywanych nawet megakonstelacjami, jest najbardziej spektakularnym przejawem zachodzących obecnie zmian i jednym $z$ najbardziej znaczących zjawisk w ramach współczesnego etapu eksploracji kosmosu. Nowego typu systemy satelitarne mają służyć przede wszystkim:

- szybkiej i łatwo dostępnej komunikacji telefonicznej, dzięki przystępnej cenie uzupełniając, a nawet częściowo zastępując telefonię komórkową,

- powszechnie dostępnej i taniej transmisji danych poprzez internet oraz

- szybkiemu dostępowi do zobrazowania satelitarnego w czasie zbliżonym do rzeczywistego.

Jedna z najbardziej zaawansowanych konstelacji należy do OneWeb, firmy założonej przez przedsiębiorcę z branży IT Grega Wylera. W lutym 2019 roku rozmieściła ona z powodzeniem pierwsze sześć satelitów

388 I. Klotz, Tsunami of Smallsats Creating Opportunities and Problems, „Aviation Week \& Space Technology", 28.02.2018, http://aviationweek.com/aviation-week-space-tech nology/tsunami-smallsats-creating-opportunities-and-problems. 
z planowanej konfiguracji prawie 700 orbiterów. Mają one zapewnić globalnie dostępny szerokopasmowy Internet - OneWeb obiecuje rozpocząć dostarczanie usług w 2020 roku, a w 2021 objąć nimi cały świat ${ }^{389}$. Z kolei SpaceX pracuje nad wspomnianą już konstelacją Starlink, złożoną według aktualnych planów z 4425 satelitów ${ }^{390}$, pierwsze 60 wystrzelono już w maju 201939. Jeśli firma utrzyma zapowiadane maksymalne tempo startów, to już w 2020 roku na orbitach powinno znajdować się dość orbiterów, by dostarczyć szerokopasmowy Internet na obszarze Ameryki Północnej392. SpaceX projektuje także kolejne konstelacje, jedna z nich ma się składać z ponad 7000 satelitów, jest też wiele innych podobnych propozycji, głównie amerykańskich, ale nie tylko393.

W zakresie komercyjnego obrazowania istnieje już pewna liczba przedsiębiorstw, które oferują lub zamierzają oferować swoje usługi. Jako przykład wymienić można założoną już w 2010 roku Planet Labs, która dostarcza zdjęcia satelitarne powierzchni Ziemi. Firma dysponuje ponad 140 satelitami trzech typów, wyposażonymi w teleskopy o rozdzielczości 5, 3 i $0,8 \mathrm{~m}^{394}$, wraz z odpowiednim zestawem urządzeń łączności.

Wiele analiz przewiduje, że w przeciwieństwie do dużych konstelacji telefonii komórkowej, które nie odniosły sukcesu w latach dziewięćdziesiątych, obecne przedsięwzięcia mają wielkie szanse na ekonomiczny sukces. Są one bowiem nastawione na zaoferowanie bardzo tanich usług na obszarach, gdzie zapotrzebowanie jest powszechne, jak w przypadku Internetu. Nie bez znaczenia jest też fakt, że są one dziełem miliarderów-wizjonerów, zainteresowanych nie tylko zyskiem³95, działających zatem inaczej niż klasyczne korporacje.

389 OneWeb, OneWeb, 2019, https://www.oneweb.world/.

390 C. Henry, FC Approves SpaceX Constellation, Denies Waiver for Easier Deployment Deadline, SpaceNews, 29.03.2018, https://spacenews.com/us-regulators-approve-spa cex-constellation-but-deny-waiver-for-easier-deployment-deadline/.

391 Starlink Mission, SpaceX, 24.05.2019, https://www.spacex.com/news/2019/05/24/ starlink-mission.

392 Starlink...

393 Por. w miarę aktualną i kompletną listę projektów, za: T. J. Muelhaupt [et al.], op. cit., s. 8 1.

394 Planet Imagery and Archive, Planet Labs, 2019, https://www.planet.com/products/ planet-imagery/.

395 S. J. Ga rber, J. A. Ved da, Déjà Vu or Sea Change? Comparing Two Generations of Large Satellite Constellation Proposals, „The Space Review”, 1.07.2019, http://www.thespa cereview.com/article/3747/1. 
Ogromną zaletą wielkich konstelacji satelitarnych ma być duża elastyczność, podatność na zmiany konfiguracji, ewolucję misji i inne podobne cechy. A to dlatego, że pojedynczy satelita ma być relatywnie tani; jego zastąpienie nowszym modelem lub orbiterem wykonującym inną funkcję nie będzie trudnością. Dodawanie nowych elementów w ramach rekonfiguracji systemu także nie będzie dużym problemem. Nawet utrata części konstelacji nie będzie zagrożeniem dla całości, ponieważ może ona mieć znaczną redundancję, można ją także szybko uzupełniać.

Trudno przecenić wszystkie te możliwości, które w najbliższej dekadzie mogą stać się rzeczywistością, a które przyniosą prawdopodobnie radykalną zmianę $\mathrm{w}$ powszechności aplikacji satelitarnych. A to przede wszystkim dlatego, że drugą, komplementarną stroną miniaturyzacji systemów kosmicznych jest upowszechnienie odbiorników usług satelitarnych. Zmniejszyły się one do takich rozmiarów, a jednocześnie staniały na tyle, że stały się bardzo łatwo dostępne, co szczególnie widać w przypadku odbiorników GPS. Dziś zatem miliardy indywidualnych osób, pojazdów i innych obiektów podłączone są do systemu nawigacji satelitarnej, w dodatku do setek milionów odbiorników satelitarnych sygnałów telewizyjnych, upowszechnionych jeszcze w XX wieku. W najbliższej przyszłości podobnie łatwo i tanio mają być dostępne usługi łączności dwustronnej oraz transmisji pakietów danych. Kolejne miliardy odbiorników zostaną zatem „przypięte” do systemów satelitarnych, a wszystko to dzięki konstelacjom setek bądź tysięcy niewielkich orbiterów współpracujących z miliardami zminiaturyzowanych odbiorników.

Cechą charakterystyczną dzisiejszego stanu eksploracji kosmosu wyznaczanego w dużej mierze przez rozwój technologii orbitalnych jest także to, że otwierają się przed ludzkością niemałe perspektywy co do zwiększenia liczby misji, które będą mogły być realizowane w przestrzeni okołoziemskiej w ekonomicznie opłacalny sposób. Spadek kosztów wyniesienia ładunków i budowy obiektów orbitalnych może także spowodować, że w nadchodącej dekadzie pojawią się na orbitach bądź w punktach libracyjnych duże konstrukcje mające zupełnie nowe możliwości. Najbardziej realistycznymi, będącymi już w fazach prototypowych nowymi misjami systemów kosmicznych są turystyka i produkcja specjalnych materiałów w stanie nieważkości.

W dziedzinie turystyki najbardziej zaawansowana jest firma Bigelow Aerospace, założona przez Roberta T. Bigelowa, właściciela sieci hoteli 
w USA. Proponuje ona budowę baz kosmicznych składających się z elastycznych, rozkładanych modułów, które służyć mogą do wielu celów, między innymi oferowane są jako kosmiczne hotele. Pierwsze eksperymentalne obiekty tego typu przedsiębiorstwo umieściło na orbicie okołoziemskiej w 2006 i 2007 roku $^{396}$, a w 2016 roku do ISS przycumowano moduł BEAM, który służy jako eksperymentalne przedłużenie habitatu stacji ${ }^{397}$. Docelowym obiektem firmy jest 23-tonowy segment B330, który może służyć, wedle różnych planów, albo jako moduł komercyjny zainstalowany na ISS, albo jako osobna stacja, złożona $\mathrm{z}$ jednego lub dwóch segmentów ${ }^{398}$. Testy naziemne modułu już się rozpoczęły399, a obecne projekty przewidują umieszczenie pierwszych $\mathrm{z}$ nich na orbicie już w 2021 roku $^{400}$.

Inny przykład to firma Orion Span, która także oferuje modułowe stacje kosmiczne pod nazwą Aurora, mogące służyć do różnych celów ${ }^{401}$. Według planów z 2018 roku pierwsza z nich miałaby znaleźć się na orbicie już $w 2021$ roku $^{402} \mathrm{i}$ oferować usługi typy hotelowego - rezerwacje na pobyty trwające do 12 dni są otwarte, choć bez podawania terminów ${ }^{403}$. Prawdopodobieństwo realizacji projektu w zakładanym czasie jest jednak niskie w związku ze słabym obecnie technicznym zaawansowaniem projektu, niemniej jednak jest on obiecujący.

W dziedzinie produkcji materiałów o szczególnych cechach użytkowych od 2017 roku na ISS odbywają się eksperymenty produkcji nowego

396 Genesis Program, Bigelow Aerospace, 2019, https://bigelowaerospace.com/pages/ genesis/.

397 NASA Extends Expandable Habitat's Time on the International Space Station, NASA, 4.12.2017, https://www.nasa.gov/feature/nasa-extends-beam-s-time-on-the-internatio nal-space-station.

398 B330, Bigelow Aerospace, 2019, https://www.bigelowspaceops.com/\#.

399 M. Wall, NASA Puts Bigelow Aerospace's Giant Inflatable Space Habitat Prototype to

the Test, Space.com, 13.09.2019, https://www.space.com/bigelow-aerospace-spacehabitat-nasa-test.html.

400 D. Richardson, Bigelow Aerospace Spawns Spinoff Company to Market Its Space Stations, "SpaceFlight Insider”, 21.02.2018, https://www.spaceflightinsider.com/or ganizations/bigelow-aerospace/bigelow-aerospace-spawns-spinoff-company-to-mar ket-its-space-stations/.

401 About Orion Span, Orion Span, 2019, https://www.orionspan.com/about. 402 M. Wall, 'Luxury Space Hotel' to Launch in 2021, Space.com, 5.04.2018, https://www.

space.com/40207-space-hotel-launch-2021-aurora-station.html. 1(1)3 Orion Span, Orion Span, 2019, https://www.orionspan.com/. 
typu włókien optycznych w technologii ZBLAN, które mają mieć znacznie lepsze właściwości od tradycyjnych, opartych na związkach krzemu, dzięki temu, że zostaną wyprodukowane w warunkach mikrograwita$\mathrm{cji}^{404}$. Ambitne plany ma też przedsiębiorstwo Axiom Space, które już od 2020 roku miało rozpocząć budowę stacji kosmicznej, mającej służyć jako platforma badawcza, a następnie po 2027 roku produkować metodą druku 3D podzespoły o unikalnych właściwościach ${ }^{405}$. W 2019 roku przedsiębiorstwo to we współpracy z NASA testowało kluczowe dla swojego projektu technologie ${ }^{406}$ i zbierało fundusze na dalszy rozwój. Szersze zastosowanie produkcji materiałów w kosmosie będzie jednak wymagało istotnych modyfikacji prawnych zarówno w dziedzinie prawa międzynarodowego, jak i uregulowań narodowych ${ }^{407}$.

Poza wymienionymi przykładami jest jeszcze oczywiście bardzo wiele przedsiębiorstw, które starają się pozyskać środki na rozwinięcie nowych form działalności w kosmosie. Szczególne nowe usługi zamierza dostarczać firma ConnectX, która chce umieścić na orbicie konstelację satelitów zawierających bezpieczne serwery do przechowywania danych cyfrowych walut ${ }^{408}$. Z kolei firma Iceye ${ }^{409}$ to startup założony w 2014 roku przez Rafała Modrzewskiego i Pekkę Laurilę i choć nie jest to przedsiębiorstwo amerykańskie, warto o nim wspomnieć ze względu na nowatorskie rozwiązania. Iceye oferuje mianowicie natychmiastowe dostarczanie zobrazowania satelitarnego realizowane przy pomocy niewielkich satelitów o masie około $100 \mathrm{~kg}$, wyposażonych $\mathrm{w}$ radary o syntetycznej

404 H. Kasap, Exotic Glass Fiber from Space, „Upward” 2018, vol. 3, nr 3, s. 2-7, https:// upward.issnationallab.org/volume-3/volume-3-issue-3/.

405 M. Wall, ist Private Space Station Will Become an Off-Earth Manufacturing Hub,

Space.com, 5.01.2017, https://www.space.com/37079-axiom-commercial-space-station-manufacturing.html.

406 D. Messier, Axiom Space Tests Key Space Station Acrylic Sample on ISS in Alpha Space's MISSE Facility, Parabolic Arc, 15.05.2019, http://www.parabolicarc.com/2019/05/ 15/axiom-space-tests-key-space-station-acrylic-sample-iss-alpha-spaces-missefacility/.

407 Por. na przykład K. Muzyka, Space Manufacturing and Trade: Addressing Regulatory Issues, "Astropolitics" 2019, vol. 17, nr 3, s. 141-163.

408 The ConnectX Private Satellite Network Solution, ConnectX, 2019, https://connectx. $\mathrm{com} /$.

409 Iceye, Iceye, 2019, https://www.iceye.com/. 
aperturze $\mathrm{z}$ rozdzielczością do $0,5 \mathrm{~m}^{410}$. Docelowo ma powstać konstelacja 18 takich pojazdów.

Dalszym potencjalnym obszarem eksploatacji kosmosu jest górnictwo, które ma polegać na pozyskiwaniu $\mathrm{z}$ asteroid surowców mineralnych, choć na pierwsze próby $w$ tym zakresie trzeba będzie zapewne nieco poczekać, mimo że nie jest to nowy temat. Wykorzystanie kosmosu jako nowego obszaru pozyskiwania zasobów, które kurczą się na Ziemi, było przedmiotem poważnych rozważań już w latach siedemdziesiątych XX wieku ${ }^{411}$.

\section{Podsumowanie i perspektywy}

Współcześnie coraz częściej spotykamy się z poglądem, że eksploracja przestrzeni okołoziemskiej przez człowieka wchodzi w nową, jakościowo odmienną fazę. Używa się przy tym chwytliwych określeń, takich jak Space 2.0 ${ }^{412}$, NewSpace ${ }^{413}$ lub Druga Era Wieku Kosmosu ${ }^{414}$. Bez względu na nazwę mamy, jak się zdaje, do czynienia z prawdopodobnie trwałym procesem polegającym na tym, że szybko zmienia się sposób i charakter wykorzystania przestrzeni okołoziemskiej przez człowieka. Reasumując główne cechy charakterystyczne tego procesu, które pojawiły się powyżej i które składają się na obraz współczesnego etapu wykorzystania kosmosu i jego najbliższych perspektyw, należałoby zauważyć, że:

- znacząco spada cena jednostkowa „usługi orbitacyjnej”,

- wzrosła masa możliwa do jednorazowego wyniesienia na orbitę,

- spada masa pojedynczych orbiterów przy jednoczesnym zwiększaniu, często radykalnym, ich efektywności,

410 D. Messier, ICEYE Releases World-First Under 1-Meter Resolution Radar Imagery from SAR Microsatellites, Parabolic Arc, 9.08.2019, http://www.parabolicarc. $\mathrm{com} / 2019 / 08 / 09 /$ iceye-releases-world-first-under-1-meter-resolution-radar-imageryfrom-sar-microsatellites/.

411 D. A. Day, Forces of Darkness and Light, „The Space Review”, 10.12.2018, http://www. thespacereview.com/article/3621/1.

412 Por. na przykład R. Pyle, Space 2.o. How Private Spaceflight, a Resurgent NASA, and International Partners Are Creating a New Space Age, Dallas 2019.

\$1.3 Por. na przykład T. J. Muelhaupt [et al.], op. cit., s. 8 .

$+1+$ Second Era of Space Age, por. na przykład M. Sn ead, Disruptive American "Astrologistics”, „The Space Review”, 19.12.2018, http://www.thespacereview.com/article/3605/1. 
- spada, często znacząco, cena pojedynczych satelitów dzięki obniżaniu kosztów komponentów oraz dzięki efektowi skali,

- z tych samych przyczyn spada cena terminali odbiorczych usług satelitarnych.

Podstawowym i najważniejszym efektem tego procesu jest radykalny spadek cen usług satelitarnych, który następuje i będzie szybko przebiegał dalej, oczywiście jeśli wszystkie widoczne obecnie procesy będą zachodziły bez przeszkód. Efektem będzie lawinowo przebiegający proces rozpowszechniania się usług satelitarnych, skutkujący wzrostem ich użyteczności bezpośredniej i pośredniej. To właśnie, jak się zdaje, jest cechą nowego etapu eksploracji kosmosu, na którego progu najprawdopodobniej właśnie się znajdujemy.

Należy jednak wymienić istotne przeszkody na drodze do tej świetlanej przyszłości, które każą zachować przynajmniej pewną dozę sceptycyzmu co do charakteru nowego etapu rozwoju eksploracji kosmosu. Może on bowiem uzyskać oczekiwane cechy, czyli dać ludzkości jakościowo nowe narzędzia dzięki wykorzystaniu nowych możliwości aplikacji kosmicznych. Może jednak wyglądać inaczej, ponieważ nie wszystkie oczekiwania muszą się spełnić. Problemy, o których mowa, mogą mieć charakter ekonomiczny, polityczny i społeczny.

Po pierwsze, z ekonomicznego punktu widzenia wiele procesów może potoczyć się inaczej, niż to się planuje. Oczywiście twórcy projektów megakonstelacji z pewnością dobrze obliczyli ostateczną cenę swoich usług poprzez przekalkulowanie ich przez globalny efekt skali. Niemniej jednak usługi, o których mowa, są już dostarczane innymi metodami, i to bardzo skutecznie oraz tanio. Pojawia się więc pytanie, czy cena i jakość usług nowej generacji dostarczanych z kosmosu będzie atrakcyjna na tyle, aby setki milionów użytkowników miały na nie przejść. Nie chodzi bowiem o to, by na przykład pokryć Internetem dotychczas niepokryte obszary, bo tam nie ma wielu ewentualnych płacących odbiorców, w każdym razie nie tylu, by uzasadnić koszty ogromnych konstelacji. Ich twórcom chodzi raczej o to, aby przekonać użytkowników dotychczasowej infrastruktury do zmian. Nawet twórca OneWeb, Greg Wyler, który jest znany z własnej ambicji, by dostarczyć Internet do biednych krajów, czyli tam, gdzie go nie ma, w pierwszej kolejności swoimi usługami zamierza objąć terytorium USA. Oferta będzie zatem musiała być znacząco lepsza w stosunku do nadawców naziemnych, co wobec jakości najnowszych rozwiązań 
telekomunikacyjnych nie jest wcale pewne. Drugim problemem ekonomicznym jest prawdopodobieństwo, że świat wejdzie bądź już wszedł w okres długotrwałych zaburzeń ekonomicznych połączonych z niepokojami społecznymi. Pojawia się zatem kolejne pytanie, czy stan rozwoju gospodarek i społeczeństw będzie $\mathrm{w}$ długiej perspektywie czasowej na tyle wysoki, że podtrzyma powszechny popyt na oferowane przez przemysł telekomunikacyjny usługi. Inaczej mówiąc, przemysł ten nakręca się przez wzrost ilości przesyłanych danych - co jednak, kiedy ich ilość spadnie, kiedy sytuacja gospodarcza zmusi abonentów internetu czy telefonii komórkowej do ograniczania ilości transferowanych danych?

Po drugie, problemy polityczne megakonstelacji mogą być dwojakiego rodzaju. Pierwszy dotyczy globalnego rozpowszechniania usług telekomunikacyjnych, w tym Internetu, w sytuacji kiedy rządy wielu krajów, niektóre bardzo wpływowe, mogą z wielu powodów nie życzyć sobie transmitowania tych usług na ich terytoria. W efekcie pojawi się konieczność rozwiązania problemów prawnych, ale także technicznych, czyli skonfigurowanie konstelacji i ich oprogramowania, tak aby obywatele danego kraju, na przykład Chin czy Rosji, nie mogli skorzystać z ich usług. W skrajnym przypadku może dojść do sabotowania przez władze tych państw funkcjonowania nowych konstelacji. Już sama zapowiedź takiego działania mogłaby poderwać zaufanie potencjalnych klientów na całym świecie i skłonić ich do pozostania przy sprawdzonych usługach. Druga kwestia dotyczy konstelacji służących do obrazowania na potrzeby komercyjne. Główne pytanie, zasadniczo związane z polityką wewnętrzną poszczególnych państw, będzie dotyczyło granic prywatności obywateli. Pojawia się problem, co prywatne firmy mogą pozyskiwać w drodze obserwacji satelitarnych oraz czym się mogą na drodze komercyjnej dzielić i z kim. Inaczej mówiąc, przywykliśmy do faktu, że rządy i agencje wywiadowcze zdolne są nam „zaglądać na podwórka”, ale czy będziemy się godzić na to, aby mogły to czynić władze lokalne czy nawet sąsiedzi? Świadomość powszechności dostępu do takich usług może wywołać poważne polityczne zaburzenia w krajach wysoko rozwiniętych.

I wreszcie po trzecie, pojawiają się kwestie społeczne ogólniejszej natury, związane ze stanem współczesnych społeczeństw, szczególnie zachodnich, ale nie tylko. Szybki rozwój technologiczny powoduje kumulowanie się $w$ świadomości ludzkiej irracjonalnych, ale zupełnie naturalnych obaw. Jednocześnie populacje na wszystkich kontynentach 
targane są niespotykaną od dziesięcioleci ilością napięć wewnętrznych, wywołanych, po części przynajmniej, przez ten rozwój, ale także związanych z różnymi szybko przebiegającymi zjawiskami gospodarczymi i politycznymi oraz z zagrożeniami środowiska naturalnego. Wydaje się, że już dziś można dostrzec na Zachodzie, ale nie tylko, symptomy swego rodzaju frustracji rozwojowej, skutkującej między innymi wzrostem skłonności do wiary w nadprzyrodzone albo uproszczone wyjaśnienia różnych problemów, której drugą stroną jest spadek zaufania do naukowych i racjonalnych wyjaśnień. Powszechne aplikacje kosmiczne mogą paść ofiarą takich właśnie postaw - wielu potencjalnych konsumentów może czysto irracjonalnie i z niechęcią odrzucić usługi kosmiczne, szczególnie wtedy, jeśli nie będą one radykalnie bardziej atrakcyjne od tradycyjnych.

Wymieniając powyższe, ogólne przeszkody na drodze rozwoju nowego etapu eksploatacji kosmosu, nie zamierzamy oczywiście przesądzać, że Space 2.o jest skazany na niepowodzenie. Niemniej jednak gwoli wyważonego poglądu należy o tym pamiętać. Dodać można, że autor niniejszych słów jest umiarkowanym optymistą co do perspektyw rozwoju eksploracji kosmosu, a w szczególności orbity okołoziemskiej. Optymizm ten wynika głównie z faktu, że Space 2.o jest kreowany przede wszystkim przez sektor komercyjny oraz wielkie wizje często dość ekscentrycznych osób, które jednak dowiodły swoich zdolności do tworzenia ogromnych przedsięwzięć, często od zera. Te wizje, poparte ogromnymi zasobami, mogą popchnąć rozwój skuteczniej, niż dotychczas robiły to rządy z ich wąską perspektywą nastawioną na bezpieczeństwo i międzypaństwową konkurencję. Dzięki tym cechom Space 2.o, wspomniane powyżej ogólne zagrożenia dla procesu rozwoju nowych zastosowań przestrzeni kosmicznej mogą zostać przezwyciężone. Jeśli zatem na przykład Elon Musk rzeczywiście tworzy Starlink po to, aby uzyskać środki na rozwój eksploracji Marsa ${ }^{415}$, to z pewnością zrobi wszystko, aby wizja jego życia została zrealizowana. A więc najprawdopodobniej nie tylko uda mu się stworzyć opłacalną megakonstelację, ale jest duża szansa, że dochody z niej faktycznie pozwolą mu na prowadzenie prac nad projektem marsjańskim. Według obecnych wyliczeń Starlink, który do 2027 roku ma wejść do użytku w pełnym zakresie, ma kosztować około 10 mld USD, ale docelowe

415 S. J. Garber, J. A. Vedda, op. cit. 
dochody mają sięgać 30-50 mld USD rocznie ${ }^{416}$. Z takimi kwotami można szukać niekomercyjnych misji dla superciężkich rakiet i realizować niebotyczne projekty, zważywszy, że budżet NASA ma w 2020 roku wynieść 22,6 mld USD ${ }^{417}$.

Dla porządku należy jeszcze wymienić bardziej praktyczne, dające się dziś dostrzec przeszkody w rozwoju nowej ery kosmicznej. Jest to oczywiście daleko niepełny katalog, nowe trudności pojawiają się wraz z postępem technologii, wdrażaniem usług i poszukiwaniem kolejnych rozwiązań.

Zwróćmy zatem w pierwszej kolejności uwagę, że plany budowy nowych konstelacji zakładają obecnie umieszczenie nawet kilkunastu tysięcy orbiterów na kilku podobnych orbitach. Stanowić to będzie niewątpliwie poważny problem w kontekście zarządzania ich ruchem oraz związanych z tym kwestii prawnych ${ }^{418}$, a zatłoczenie orbit może zagrażać zderzeniami satelitów ze sobą oraz $\mathrm{z}$ istniejącymi śmieciami kosmiczny$\mathrm{mi}^{419}$. To z kolei doprowadzić może do powstania kolejnych śmieci. Lawinowy wzrost liczby orbiterów oczekiwany w najbliższej dekadzie oznacza więc także znaczne zwiększenie prawdopodobieńst wa katastrof, a zatem, w ostatecznym rozrachunku, wystąpienia efektu Kesslera, przynajmniej na niektórych orbitach.

Idąc dalej, zauważamy, że konstelacje nanosatelitarne, czyli złożone z orbiterów o masie 1-10 kg, którym jeszcze niedawno wróżono wielką karierę, nie rozwijają się zgodnie z przewidywaniami. Wiele obiecujących startupów zbankrutowało, a te, które zdołały rozmieścić swoje systemy, mają często kłopoty $z$ finansowaniem i z efektywnością działańn ${ }^{420}$. To

+16 D. Mosher, Elon Musk Just Revealed New Details about Starlink, a Plan to Surround Earth with 12,000 High-speed Internet Satellites. Here's How It Might Work, „Business Insider”, 16.05.2019, https://www.businessinsider.com/spacex-starlink-sa tellite-internet-how-it-works-2019-5?IR=T.

417 Forward to the Moon: NASA's Strategic Plan for Human Exploration, NASA, 9.04.2019, https://www.nasa.gov/sites/default/files/atoms/files/america_to_the_moon_2024_ artemis_20190523.pdf.

418 B. Gerałt, Zderzenie z realiami. Starlink i dylematy ery megakonstelacji, Space24, 26.09.2019, https://www.space24.pl/zderzenie-z-realiami-starlink-i-dylematy-ery-me gakonstelacji-analiza.

119 T. J. Muelhaupt [et al.], op. cit., s. 81-82.

420 A. Gelain, Opinion: When It Comes to Nanosatellites, The Hype Is Over, „Aviation Week \& Space Technology", 20.05.2019, https://aviationweek.com/space/opinion- 
sugeruje ostrożność w podejściu do możliwości technicznych, które same z siebie nie dadzą komercyjnego efektu. Budowane przedsięwzięcie musi zatem mieć zapewnioną misję, o czym bardzo często wspominamy.

I wreszcie zwiększające się obroty przemysłu kosmicznego i rosnący „ruch” w kosmosie prowadzą więc do bardzo szybkiego przyrostu technicznych zdolności startowych i liczby pojazdów na orbicie. Infrastruktura z tym związana jest jednak mocno rozproszona, ponadto rozwój organizacji państwowej i międzynarodowej kontroli nad „ruchem” w kosmosie może nie nadążyć za lawinowo rosnącymi potrzebami. Niektórzy eksperci wskazują zatem na brak zintegrowanej logistyki wysiłku kosmicznego w Stanach Zjednoczonych ${ }^{421}$, która nie przystaje do możliwości technicznych, jakie dziś mamy. Z drugiej jednak strony, jeśli popatrzymy na akty prawne regulujące w USA komercyjną działalność kosmiczną, zauważymy, że uchwalano je zasadniczo bez większych sporów. Świadczy to zarówno o znaczeniu przemysłu kosmicznego, jak i o generalnej zgodzie co do kierunku jego rozwoju. Podkreśla się, że „[...] legislacje dotyczące komercyjnego wykorzystania kosmosu w większości skupiały się na rzetelnym i zasadniczo ponadpartyjnym podejściu do problemów w duchu poszukiwania sposobów na promowanie i wspieranie rozwoju kosmicznego sektora komercyjnego"422. Jeśli taki stan rzeczy się utrzyma, można oczekiwać relatywnie szybkiego rozwiązania podstawowych problemów logistycznych przez władze USA, za którymi pójdą inne państwa i gremia międzynarodowe.

Z dotychczasowych rozważań można zatem wyciągnąć szereg ogólnych i szczegółowych wniosków, które charakteryzują perspektywy ewolucji eksploracji kosmosu przez człowieka w świetle rozważań niniejszego podrozdziału. Z wniosków ogólnych najistotniejsze są następujące.

Po pierwsze, jedną z głównych cech współczesnego etapu rozwoju eksploracji kosmosu jest umocnienie się przemysłu kosmicznego jako ważnej gałęzi gospodarki. W 2018 roku przemysł kosmiczny przyniósł 277 mld USD dochodów komercyjnych, a po uwzględnieniu wydatków budżetów

when-it-comes-nanosatellites-hype-over?NL=AW-05\&Issue $=A W$-05_20190522_AW -05_581\&sfvc4enews $=42 \& \mathrm{cl}=$ article_3\&utm_rid $=C P E N 1000001539178 \& u t m$ mam paign=19693\&utm_medium=email\&elq2=eagcf6620eg94923b42aoof6505e95f 3 .

421 M. Snead, op. cit.

422 C. Knip fer, Congress and Commerce in the Final Frontier (part 2), „The Space Review”, 17.12.2019, http://www.thespacereview.com/article/3625/1. 
rządowych i wydatków na loty załogowe było to 360 mld USD ${ }^{423}$. W świecie działa prawie 2000 przedsiębiorstw z branży kosmicznej ${ }^{424}$, z których część zapewne nie ma żadnego znaczenia, część to startupy bez szans na rozwój, niemniej jednak liczba jest imponująca. Oznacza to niewątpliwie istnienie ogromnego potencjału rozwojowego drzemiącego w przemyśle kosmicznym ${ }^{425}$. Oparty jest on przede wszystkim na nadziejach na znaczne zyski, które są najpewniejszym i aktualnym w każdym momencie historycznym motorem rozwoju technologii oraz form organizacji działalności gospodarczej w kierunku jej optymalizacji.

Po drugie, synergia ewolucji systemów nośnych i miniaturyzacji przekłada się na rosnącą dostępność kosmosu, obniżając zarówno cenę samych systemów kosmicznych, jak i, co za tym idzie, cenę usług. To z kolei wpływa na ich upowszechnienie, a zatem na wzrost dochodów przedsiębiorstw kosmicznych, zarówno w sektorze startowym, jak i usługowym. Rośnie zatem liczba orbiterów, systemów satelitarnych i klientów dostarczanych przez nie usług. Proces ten mogą, naszym zdaniem, zatrzymać jedynie katastrofalne wydarzenia, takie jak poważne konflikty zbrojne skutkujące atakami na cele kosmiczne lub inne dramatyczne wypadki inicjujące efekt Kesslera, bądź też głębokie i długotrwałe zaburzenia gospodarczo-społeczne, które ograniczą zapotrzebowanie na usługi kosmiczne i gotowość do sfinansowania nowych misji.

Po trzecie wreszcie, nagromadzenie kapitału, połączone z kumulującą się coraz szybciej wiedzą techniczną wraz $z$ determinacją w poszukiwaniu nowych rozwiązań prowadzić będzie najprawdopodobniej do dalszego, szybkiego rozwoju technologii kosmicznych. Istnieje zatem prawdopodobieństwo, że nastąpią kolejne jakościowe przełomy w zakresie technologii kosmicznych. Szczególnie dotyczyć to może nowych napędów, takich jak na przykład żagle słoneczne wykorzystujące ciśnienie słonecznego wiatru do utrzymania satelity na orbicie ${ }^{426}$, być może pojawi

4232019 State of the Satellite Industry, Satellite Industry Association, 2019, https://www. sia.org/wp-content/uploads/2019/05/2019-SSIR-2-Page-20190507.pdf.

4241958 według organizacji NewSpace Hub, stan z początku sierpnia 2019, za: wynik wyszukiwania, NewSpace Hub, 2019, https://newspacehub.co/search?type=Company. 425 Por. na przykład obszerne i aktualne opracowanie: J. Greason, J. C. Bennett, The Economics of Space: An Industry Ready to Launch, Reason Foundation, April 2019, https://reason.org/wp-content/uploads/economics-of-space.pdf.

+26 M. Carreau, Light Sail-2 Uses Sunlight to Control a Small Satellite, „Aviation Week

\& Space Technology", 2.08.2019, https://aviationweek.com/space/light-sail-2-uses-sun 
się także kosmiczny napęd nuklearny. Nowe materiały mogą także uczynić bardziej ekonomiczną budowę dużych konstrukcji kosmicznych.

Wnioski bardziej szczegółowe są następujące.

Po pierwsze, jesteśmy sceptyczni co do użyteczności, przynajmniej w perspektywie dekady, superciężkich rakiet o nośności powyżej 100 ton. Nie ma dla nich misji i zapewne w tej perspektywie czasowej nie będzie. Nie oznacza to jednak, że rakiety te nie powstaną, lecz raczej to, że pozostaną wyjątkiem, realizującym jednostkowe, bardzo drogie misje. Mogą to być albo niedochodowe projekty eksploracji załogowej poza orbitę Zie$\mathrm{mi}$, albo bardzo drogie projekty komercyjne, takie jak turystyka do dużych stacji kosmicznych i na Księżyc bądź, w odleglejszej perspektywie, pozyskiwanie surowców $z$ asteroid. Realizacja tych misji zależeć będzie od stanu gospodarek państw zdolnych do ich sfinansowania oraz od determinacji korporacji, a w szczególności tych należących do miliarderów-wizjonerów, takich jak: Musk, Bezos czy Wyler.

I po drugie, oprócz aplikacji, które wchodzą w fazę realizacji, takich jak megakonstelacje telekomunikacyjne, lub znajdują się w fazie eksperymentów, jak komercyjne stacje orbitalne, możliwe są w dalszej przyszłości i inne rodzaje zadań dla systemów kosmicznych. Najbliżej w kolejce do realizacji stoi zapewne wspominane już parokrotnie pozyskiwanie minerałów z asteroid. Realizacja misji tego typu będzie zależała jednak nie tylko od technologii, ale i od ceny tych minerałów na Ziemi, która rośnie w miarę postępującej eksploatacji istniejących złóż. W dalszej perspektywie znajduje się zgłaszana czasem koncepcja generowania w kosmosie energii elektrycznej, która mogłaby być następnie przesyłana na Ziemię w postaci mikrofal.

5.2. Stany Zjednoczone a aktualne zagrożenia dla bezpieczeństua w kosmosie

W niniejszym podrozdziale zajmiemy się nieco dokładniej technicznym $\mathrm{i}$ organizacyjnym wymiarem problemu bezpieczeństwa $w$ kosmosie. Należy to traktować jako uszczegółowienie i egzemplifikację zarówno

light-control-small-satellite?utm_rid=CPEN1000001539178\&utm_campaign $=20$ 696\&utm_medium=email\&elq2=4c9528db1e6f 429e9c2es6ed392ea2b6. 
tematyki zagrożeń, jak i tej, która odnosi się do działań nakierowanych na przeciwdziałanie negatywnym trendom, podnoszonym ogólniej w poprzednich rozdziałach. Omówimy zatem syntetycznie zagrożenia dla bezpieczeństwa systemów kosmicznych, katalogując następnie ich ewentualne konsekwencje. W dalszej kolejności dokonamy przeglądu teoretycznie możliwych i faktycznie rozważanych środków zaradczych. I wreszcie spróbujemy ocenić, na ile środki owe mogą być skuteczne. Nie zastanawiamy się tu zatem nad kwestią samej przewagi Stanów Zjednoczonych i tego, w jakim zakresie ona maleje, lecz nad tym, w jakim stopniu zagrożone jest wykorzystywanie przez USA istniejącego i perspektywicznego potencjału kosmicznego i co z tego wynika.

Dodać należy, że zagrożenia, o których będzie mowa, dotyczą także innych państw aktywnych przestrzeni okołoziemskiej oraz innych podmiotów, komercyjnych i niekomercyjnych, działających w kosmosie. Jednak omawiając szczegóły działań i koncepcji, odnosimy się jedynie do Stanów Zjednoczonych, ponieważ to USA są przedmiotem naszych badań, a ponadto na szersze potraktowanie tematu nie ma w tej pracy miejsca.

\section{Zagrożenia dla bezpieczeństwa systemów kosmicznych}

Bezpieczeństwo w kosmosie odnosi się do stanu zagrożenia systemów kosmicznych, na które jest lub może być wywierane negatywne oddziaływanie - jak wiemy, prawdopodobieństwo zaistnienia takich zakłóceń szybko rośnie. W konsekwencji doprowadzić to może do ograniczenia bądź likwidacji usług komercyjnych oraz do osłabienia lub zanegowania kluczowych zdolności państw $w$ dziedzinie bezpieczeństwa narodowego. Poniżej zreasumujemy istniejące metody takiego oddziaływania wraz z ogólną oceną ich wpływu na bezpieczeństwo systemów kosmicznych USA. Należy przy tym pamiętać, co bardzo ważne i co będziemy podkreślać, że ze względu na charakterystyczne cechy przestrzeni okołoziemskiej nie można oderwać bezpieczeństwa systemów wojskowych od niewojskowych. A to dlatego, że jakiekolwiek perturbacje orbit bądź zniszczenie systemów cywilnych może oddziaływać i na systemy wojskowe poprzez wzrost prawdopodobieństwa kolizji czy to z uszkodzonym satelitą, czy też ze szczątkami zniszczonych orbiterów. Jak wiemy, każda taka kolizja zwiększa prawdopodobieństwo przyszłych wypadków, a ich 
łańcuch może ostatecznie spowodować degradację poszczególnych orbit. Planowany znaczny przyrost liczby satelitów, które mają pracować na podobnych orbitach, zwiększa prawdopodobieństwo takiego przypadku w przyszłości. Dlatego też, omawiając zagrożenia dla systemów kosmicznych, nie można brać pod uwagę jedynie ewentualnych działań podejmowanych bezpośrednio przeciwko nim, lecz musimy uwzględnić wszystkie zagrożenia dla wszystkich systemów kosmicznych. Inaczej mówiąc, gdy omawiamy problem bezpieczeństwa w kosmosie, nie możemy wyabstrahować z niego wymiaru wojskowego, musimy ujmować rzecz całościowo.

Zwracamy także szczególną uwagę na to, że zagrożenie dla systemów kosmicznych pojawić się może nie tylko ze strony państw, ale także, co jest coraz bardziej prawdopodobne, ze strony uczestników niepaństwowych. Co więcej, negatywne oddziaływania to nie tylko potencjalna możliwość, ale bez mała codzienność, zarówno w odniesieniu do ataków, które można przypisać państwom, jak i tym przeprowadzanym przez uczestników niepaństwowych. Zagrożenia bezpieczeństwa systemów kosmicznych mogą także występować jako niezamierzone następstwa działań państwa czy też innego uczestnika niepaństwowego.

Przechodząc do analizy zagrożeń dla bezpieczeństwa w kosmosie ${ }^{427}$, należy w pierwszej kolejności zauważyć, że wszystkie trzy komponenty systemów kosmicznych, czyli orbitery, łącza oraz infrastruktura naziemna, mogą zostać narażone na negatywne oddziaływanie. We wszystkich tych przypadkach może także wystąpić, choć nie zawsze musi, zagrożenie dla bezpieczeństwa w kosmosie. Zgodnie z przyjętą przez nas definicją tego pojęcia oznacza to zagrożenie dla niezakłóconego funkcjonowania i fizycznego istnienia orbiterów. Nie mówimy natomiast o efektywności systemów w relacji do potrzeb i oczekiwań co do zadań przez nie wykonywanych.

\section{A zatem:}

- infrastruktura naziemna może ulec zniszczeniu bądź w różny sposób może nastąpić umniejszenie skuteczności jej działania; w efekcie satelity, którymi infrastruktura ta zawiaduje, mogą ograniczyć wykonywa-

427 Szczegółowa klasyfikacja por. także: T. Harrison, K. Johnson, T. G. Roberts, Space Threat Assessment 2019, Center for Strategic \& International Studies, April 2019, s. 2-7, https://csis-prod.s3.amazonaws.com/s3fs-public/publication/190404_SpaceThreat Assessment_interior.pdf. 
nie swoich funkcji, stracić część lub wszystkie zdolności, a nawet ulec zniszczeniu; to ostatnie polegać może na zejściu z orbity i zniszczeniu $w$ atmosferze lub zderzeniu $z$ innymi satelitami, co jest szczególnie prawdopodobne w przypadku bardziej zatłoczonych orbit;

- łącze może zostać przerwane lub zakłócone poprzez ograniczenie jego efektywności ze skutkami opisanymi powyżej; może także nastąpić szczególna sytuacja polegająca na przejęciu łącza przez wrogi podmiot; może on wykorzystać je do podania satelicie fałszywych komend, które doprowadzą do błędnego wykonywania przez satelitę jego funkcji bądź nawet jego zniszczenia poprzez doprowadzenie do deorbitacji lub zderzenia $z$ innym satelitą;

- orbiter może zostać uszkodzony lub zniszczony albo przez uszkodzenie lub zniszczenie jego oprogramowania, albo poprzez oddziaływanie fizyczne.

Istnieje szereg metod, za pomocą których dokonywać można ataków na infrastrukturę naziemną, łącze bądź orbiter. Podzielić je można w sposób najbardziej ogólny następująco:

- atak przez cyberprzestrzeń na oprogramowanie systemu kosmicznego, zarówno komponentu naziemnego, jak i orbitera,

- atak przy użyciu oddziaływania elektromagnetycznego, polegający na zagłuszaniu sygnału satelity bądź przejęciu tego sygnału poprzez stację nadawczo-odbiorczą atakującego; szczególnym przypadkiem tej metody jest zakłócanie bądź fałszowanie sygnału satelitarnego skierowanego do odbiorcy usługi satelitarnej; systemy optyczne także mogą być zaatakowane $w$ ten sposób poprzez oślepienie wiązką lasera, co jest mniej więcej równoważne zagłuszeniu urządzenia nadawczo-odbiorczego pracującego $\mathrm{w}$ paśmie radiowym;

- atak zmierzający do dokonania fizycznych uszkodzeń bądź zniszczenia komponentów systemu satelitarnego czy to za pomocą klasycznych środków, takich jak materiały wybuchowe lub bezpośrednie uderzenie, czy też z wykorzystaniem oddziaływania elektromagnetycznego, czyli przede wszystkim lasera, potencjalnie także przy pomocy mikrofal. Wszystkie te metody w różnym zakresie dostępne są zarówno uczestnikom państwowym, jak i niepaństwowym, omówimy je w dalszej kolejności bardziej szczegółowo. Powtórzymy jeszcze przedtem bardzo ważną kwestię, że ich zastosowanie może zagrozić bezpieczeństwu w kosmosie zarówno intencjonalnie, kiedy dany podmiot chce takie zagrożenie 
stworzyć, jak i przypadkowo, w ramach działalności nakierowanej na inne cele.

Negatywne oddziaływanie na systemy satelitarne poprzez cyberprzestrzeń możliwe jest dlatego, że systemy te są jej częścią, ponieważ są pośrednio lub bezpośrednio podłączone do Internetu. Pomimo stosowanych zabezpieczeń różnego rodzaju systemy kosmiczne są zatem wrażliwe na wiele form ataku na ich wirtualne komponenty, zarówno te znajdujące się na Ziemi, jak i w kosmosie. Uważa się często, że „[...] bez mała każdy sprawny haker jest współcześnie potencjalnym zagrożeniem, a dobry haker może uszkodzić lub zniszczyć samego satelitę" ${ }^{428}$. W ten sposób może zatem zostać zaburzona praca całego systemu poprzez zakłócenie łączności czy też wyłączenie lub ograniczenie działania sensorów lub innych systemów krytycznych dla misji danego orbitera - w skrajnym przypadku efektem może być jego zniszczenie.

Analizując przykładowe cyberataki na systemy satelitarne ${ }^{429}$, możemy wyraźnie dostrzec, że szczególnie wrażliwe są satelity komercyjne. Ataki na obiekty wojskowe mogły zostać przynajmniej po części utajnione, mimo to można jednak bezpiecznie założyć, że są znacznie rzadsze. Eksperci Chatham House przedstawiają następującą typologię źródeł cyberzagrożeń dla systemów satelitarnych:

- kraje dążące do uzyskania przewagi wojskowej w kosmosie lub próbujące ukraść wartości intelektualne w strategicznych ilościach i dysponujące wystarczającą mocą obliczeniową, aby na przykład łamać zabezpieczenia systemów [informatycznych],

- przestępczość zorganizowana, która poszukuje zysków finansowych i często dysponuje znacznymi zasobami,

- grupy terrorystyczne, które starają się realizować swoje cele, nawet jeśli oznaczałoby to kolizje satelitów wywołujące katastrofalne skutki w postaci szczątków kosmicznych prowadzących do efektu kaskado-

428 M. Kleiman, S. McNeil, Red Lines in Outer Space, "The Space Review", 5.03.2012, http://www.thespacereview.com/article/2038/1.

429 Obszerna lista incydentów, por. D. M. Phillips, An Architecture, System Engineering, and Acquisition Approach for Space System Software Resiliency, doctoral thesis, The School of Engineering and Applied Science of The George Washington University, 19.01.2018, s. 33-41, https://scholarspace-etds.library.gwu.edu/downloads/7w62 f83zc?locale=en. 
wego [...], który uniemożliwiłby wszystkim aktorom wykorzystanie kosmosu,

- pojedynczy hakerzy, którzy chcą dowieść swoich zdolności i pochwalić się nimi,

- jakakolwiek kombinacja organizacji i osób wymienionych powyżej430.

Ponieważ instalacje wojskowe $z$ natury rzeczy są na ogół lepiej zabezpieczone niż komercyjne, wycinek cyberprzestrzeni, który należy do wojska, jest niewątpliwie lepiej chroniony niż obszary cywilne. Stany Zjednoczone wydatkują znaczne środki finansowe na tworzenie i utrzymanie ofensywnych i defensywnych narzędzi cyberwojny i struktur nimi zarządzających, nie oznacza to jednak pełnego bezpieczeństwa amerykańskich systemów komputerowych, w tym systemów satelitarnych. Te ostanie, a raczej ich komponent orbitalny, są ponadto $w$ gorszej sytuacji niż inne elementy infrastruktury informatycznej sił zbrojnych. A to dlatego, że satelita wyniesiony na orbitę działa na niej wiele lat z pierwotną, niezmienną architekturą informatyczną. Tymczasem na Ziemi narzędzia służące włamaniom i przejmowaniu systemów komputerowych rozwijają się bardzo szybko, w miarę jak ewoluuje informatyka i cybernetyka. Oznacza to, że starsze systemy satelitarne, nawet te wojskowe, są coraz bardziej wrażliwe na atak $z$ przestrzeni wirtualnej. Ewentualna realizacja wspomnianej powyżej koncepcji reprogramowalnych systemów orbitalnych być może nieco zmieni ten obraz, ale siłą rzeczy dotyczy to przyszłości, ponieważ proces wypierania starych technologii przez nowe, bezpieczniejsze trwać będzie lata.

Podsumowując ten wątek, należy zauważyć, że w przypadku zagrożeń z cyberprzestrzeni, amerykańskie systemy kosmiczne pracujące na rzecz bezpieczeństwa narodowego w wymiarze zewnętrznym są w pewnym, trudnym zresztą do określenia stopniu, podatne na bezpośrednie ataki z przestrzeni wirtualnej. Stan ten zapewne się utrzyma, choć poziom tej podatności może ulegać zmianom. Ewentualni sprawcy tego typu ataków muszą jednak dysponować znacznymi zasobami i bardzo nowoczesnymi narzędziami, przy czym stopień ich zaawansowania będzie musiał wzrastać, bo wzrastać będzie także poziom zabezpieczeń. Natomiast

430 D. Livingstone, P. Lewis, Space, the Final Frontier for Cybersecurity?, The Royal Institute of International Affairs, September 2016, s. 9. 
zagrożenie pośrednie, wynikające $z$ możliwych cyberataków na cywilne systemy orbitalne, w wyniku których może dochodzić do kolizji, wzrasta w miarę zwiększania się liczby celów w postaci rosnącej liczby cywilnych orbiterów.

Oddziaływanie elektromagnetyczne na systemy satelitarne polega na zakłócaniu pracy urządzeń nadawczo-odbiorczych przede wszystkim poprzez ich zagłuszanie. Co do zasady jest to proste, wystarczy użyć nadajnika pracującego na odpowiedniej częstotliwości, którego moc będzie wyższa niż moc sygnału. W tej grupie oddziaływań należy także umieścić oślepianie wiązką lasera optycznych urządzeń obserwacyjnych - mówimy w tym przypadku o mocy oddziaływania nieprowadzącej do nieodwracalnego, fizycznego uszkodzenia czy zniszczenia komponentu satelity. Zagłuszanie oraz oślepianie rozumiemy zatem w tym miejscu jako czasowe ograniczenie lub wyłączenie funkcji orbitera, inne przypadki rozważymy poniżej. Zastosowanie tych metod nie powoduje zatem trwałych uszkodzeń, prowadzi jedynie do czasowej degradacji funkcji systemu satelitarnego. Polegać to może na przykład na uniemożliwieniu mu pracy w trakcie przelotu nad określonym obszarem Ziemi. W związku z tym bezpieczeństwo systemów zagrożone jest $w$ tym sensie, że w wyniku wrogiego działania nie mogą one w pełni realizować swojej misji.

Tego rodzaju nieniszczące oddziaływania kieruje się głównie przeciwko wojskowym satelitom zwiadowczym, aby zapobiec zdobyciu przez nie określonych informacji. W miarę rozwoju zwiadu optycznego, także cywilnego obrazowania, należy spodziewać się wzrostu liczby incydentów tego typu, skierowanych także przeciwko satelitom komercyjnym. Opisane metody oddziaływania elektromagnetycznego stosunkowo rzadko mogą skutkować ryzykiem kolizji ze względu na ograniczony okres trwania. Niemniej jednak zagłuszanie sygnałów komunikacyjnych satelity, szczególnie w dłuższym czasie, może doprowadzić do dysfunkcji układów odpowiedzialnych za utrzymywanie go na orbicie, a co za tym idzie zwiększyć ryzyko kolizji, ze wszystkimi znanymi skutkami dla bezpieczeństwa w kosmosie. Możliwość taka jest jednak raczej hipotetyczna.

Zagłuszanie, przejmowanie i fałszowanie sygnałów systemów satelitarnych łączących infrastrukturę naziemną i orbitery jest oczywiście łatwiejsze w stosunku do systemów cywilnych, choć z drugiej strony relatywnie mało praktyczne, chyba że z punktu widzenia czysto destrukcyjnych celów, na przykład w ramach walki organizacji terrorystycznych 
bądź wywrotowych. Natomiast taka forma ataku jest niejako oczywistością w stosunku do systemów wojskowych, w ramach prowadzonej w czasie trwania działań wojennych walki radioelektronicznej, lub też, z mniejszą intensywnością, w czasie pokoju. Wojskowe systemy satelitarne są jednak w dużej mierze zabezpieczone przeciwko tego typu zakłócaniu ich pracy, mają przecież zachować sprawność właśnie w warunkach toczących się działań z wykorzystaniem środków radioelektronicznych, zatem czułość i rozdzielczość ich urządzeń nadawczo-odbiorczych jest jedną z ich podstawowych cech.

Jak wspomniano, szczególną formą negatywnego oddziaływania elektromagnetycznego na systemy kosmiczne jest fałszowanie sygnałów skierowanych do terminali odbiorczych usługi satelitarnej. Współcześnie w największym stopniu dotyczy to systemów pozycjonujących, których sygnały regularnie są fałszowane, co najczęściej przypisuje się Federacji Rosyjskiej ${ }^{431}$. Amerykańska administracja morska wydała także ostrzeżenia dotyczące fałszowania sygnału GPS w cieśninie Ormuz i Zatoce Omańskiej432, co z kolei można zapewne przypisać Iranowi.

Działania zagłuszające $\mathrm{i}$ fałszujące sygnały $\mathrm{w}$ paśmie radiowym są oczywiście dostępne państwom wysoko rozwiniętym, które posiadają precyzyjne instrumenty prowadzenia walki radioelektronicznej. Urządzenia takie mogą także znajdować się w posiadaniu zasobnych w środki finansowe organizacji przestępczych, terrorystycznych i wywrotowych. W ich jednak przypadku użycie takiego narzędzia nie jest zbyt wygodne, ponieważ nadajnik zakłócający dużej mocy łatwo jest namierzyć i zniszczyć precyzyjnym atakiem lub przejąć w wyniku działań wojskowych jednostek specjalnych lub sił policyjnych.

Lasery natomiast, które mogą służyć oślepianiu satelitów obserwacyjnych, są relatywnie łatwo dostępne. Siły zbrojne każdego praktycznie kraju mogą pokusić się o rozwinięcie takiego uzbrojenia, Federacja

431 Por. na przykład E. Groll, Russia Is Tricking GPS to Protect Putin, „Foreign Policy”, 3.04.2019, https://foreignpolicy.com/2019/04/o3/russia-is-tricking-gps-to-protectputin/.

432 MSCI Advisory. 2019-012-Persian Gulf, Strait of Hormuz, Gulf of Oman, Arabian Sea, Red Sea-Threats to Commercial Vessels by Iran, U.S. Department of Transportation, Maritime Administration, 8.07.2019, https://www.maritime.dot.gov/content/2019-012 -persian-gulf-strait-hormuz-gulf-oman-arabian-sea-red-sea-threats-commercial-ves sels. 
Rosyjska ujawniła nawet operacyjnie sprawny system bojowy Pierieswiet $^{433}$, który najprawdopodobniej jest właśnie laserem służącym do oślepiania satelitów na potrzeby strategiczne bądź taktyczne.

Biorąc powyższe pod uwagę, można bezpiecznie założyć, że wszystkie najbardziej rozwinięte kraje są w stanie znacznie zakłócić pracę systemów satelitarnych na wycinkach LEO przebiegających ponad ich terytoriami oraz na dużych fragmentach orbity geostacjonarnej. Ponadto wyraźny jest obecnie trend do upowszechniania się tego typu możliwości w miarę rozwoju odpowiednich komercyjnie osiągalnych technologii. Stają się one zatem dostępne dla państw mniej zaawansowanych technicznie, wydaje się nawet, że mogą one już być w zasięgu i aktorów niepaństwowych. Na legalnym rynku bowiem można stosunkowo łatwo pozyskać bardzo precyzyjne urządzenia śledzące dla amatorskiej astronomii oraz bazy danych zawierające szczegółowe informacje dotyczące ruchu satelitów. Montaże takie można następnie sprzęgać z dostępnymi komercyjnie laserami małej mocy, które mogą być zdolne „[...] do “oślepienia» lub zakłócenia pracy satelity"434.

Ostatnią z metod, którą wymieniliśmy jako służącą do negatywnego oddziaływania na systemy orbitalne, jest fizyczne uszkadzanie lub niszczenie orbiterów. Może to nastąpić w wyniku:

- przejścia fali uderzeniowej wywołanej bliską eksplozją,

- uderzenia ciała stałego, na przykład odłamka głowicy wybuchowej lub kinetycznego urządzenia przechwytującego, lub też

- wystawienia na odpowiednio długi okres naświetlania wiązką lasera o odpowiedniej mocy.

W tym ostatnim przypadku pojawia się cienka granica $z$ nieniszczącym odziaływaniem na systemy optyczne opisanym powyżej. W konkretnej sytuacji od mocy lasera i czasu naświetlania może bowiem zależeć, czy dane urządzenie obserwacyjne zostanie tylko czasowo oślepione, czy też jego obiektyw zostanie fizycznie uszkodzony, choćby przez to, że zmatowieje od wysokiej temperatury.

433 M. Ka massa, Zagadkowy „Pierieswiet”. Bojowy laser Rosji pod okiem satelitów, Space24, 22.08.2018, https://www.space24.pl/damen/zagadkowy-pierieswiet-bojowy-laser -rosji-pod-okiem-satelitow-analiza.

434 Space Security Index 2014, Spacesecurity.org, 2014, s. 74, http://spacesecurityindex. org/wp-content/uploads/2014/11/Space-Security-Index-2014.pdf. 
Istnieje ponadto teoretyczna możliwość doprowadzenia do zniszczenia satelity po jego przejęciu przez cyberprzestrzeń poprzez jego deorbitację lub doprowadzenia do zderzenia $z$ innym obiektem.

Główne mocarstwa kosmiczne, czyli USA, Rosja, Chiny i Indie, zademonstrowały już, że posiadają technologie, które można zastosować do uszkadzania bądź niszczenia obiektów orbitalnych. Można także bezpiecznie założyć, że pozostałe kraje działające w kosmosie również mogłyby pokusić się o ich opracowanie, jeśli tylko zapadłyby odpowiednie polityczne decyzje. Ponadto w świecie rozprzestrzeniają się technologie mogące posłużyć do atakowania celów na orbicie, takie jak rakiety balistyczne dalekiego zasięgu, nowoczesne systemy obliczeniowe i naprowadzające oraz lasery o coraz większej mocy. W związku z tym poszerza się grono państw, które mogłyby sięgnąć po środki umożliwiające fizyczne uszkadzanie bądź niszczenie satelitów. Potencjalnie i uczestnicy niepaństwowi mogliby próbować pozyskać odpowiednie urządzenia i pokusić się o opracowanie odpowiednich systemów.

Podstawowymi środkami przeciwsatelitarnymi służącymi uszkadzaniu bądź niszczeniu orbiterów są dwa rodzaje systemów, które już wymieniliśmy $\mathrm{w}$ trakcie dotychczasowych rozważań: broń przeciwsatelitarna bazowania kosmicznego (co-orbital $A S A T$ ) oraz broń przeciwsatelitarna bazowania naziemnego (direct ascent $A S A T$ ).

Pierwszy rodzaj sprowadza się do umieszczania na orbicie satelitów specjalnie przeznaczonych do atakowania innych orbiterów. W teorii mogą one mieć formą wyrzutni pocisków czy kosmicznych stanowisk laserowych, ale do rozmieszczenia takiego uzbrojenia jest jeszcze daleko, więc w tym miejscu nie ma potrzeby się nim zajmować. Natomiast możliwe dziś do realizacji są działania polegające na tym, że atakujący satelita zbliża się do swojego celu, a następnie wywołuje eksplozję ładunku wybuchowego, niszcząc bądź uszkadzając cel, lub ewentualnie zderza się z nim z tym samym skutkiem.

Mocarstwa kosmiczne, które opanowały metody i procedury precyzyjnego manewrowania statków kosmicznych, w oczywisty sposób zdolne są do stworzenia takiej broni. Pewne prace rozwojowe były już zresztą realizowane, chociaż nigdy nie doszło do rozmieszczenia operacyjnie sprawnych systemów bojowych tego typu. Mimo to główne mocarstwa kosmiczne niewątpliwie mają możliwości, by relatywnie szybko je opracować, choć z punktu widzenia mocarstw broń taka nie jest zbyt 
praktyczna. A to dlatego, że dedykowany satelita-niszczyciel będzie na ogół rozpoznawalny po charakterystyce orbity, wyglądzie i właściwościach emisji elektromagnetycznych. Będzie to zatem broń dobrze widoczna dla urządzeń obserwacyjnych drugiej strony, może więc zostać łatwo zniszczona, zanim zostanie użyta, lub też po aktywizacji, czyli po rozpoczęciu manewrowania w kierunku celu. Oczywiście tego typu uzbrojenie satelitarne może być zamaskowane pod postacią cywilnego satelity, na przykład jako jeden $\mathrm{z}$ wielu cubesatów konstelacji telekomunikacyjnej. Może nawet brać udział w pracy tejże konstelacji, tak aby maskowanie było kompletne. Ale i to nie byłoby praktyczne, ponieważ w przypadku takiego pełnego zamaskowania na pokładzie satelity znajdzie się minimalna ilość miejsca na paliwo i ładunek wybuchowy oraz urządzenia naprowadzania i łączności. Gdyby zaś miał być tylko atrapą cywilnego satelity, na przykład udawać niesprawny element konstelacji, to tym bardziej nie ujdzie uwagi systemów śledzących, w szczególności gdy nagle zacznie manewrować.

Satelity tego typu mogłyby także znaleźć się w rękach aktorów niepaństwowych; wobec znanej proliferacji małych systemów satelitarnych nie jest to niedostępne dla odpowiednio zasobnych podmiotów takich jak organizacje przestępcze czy terrorystyczne. W ich przypadku aktywacja takiego obiektu nie dawałaby informacji o jego celu, a wobec trudności w przypisaniu tego działania konkretnemu podmiotowi jedyną opcją przeciwdziałania jego samobójczej misji byłoby zniszczenie go, z wiadomymi negatywnymi skutkami dla bezpieczeństwa w kosmosie. Można więc uznać broń w postaci satelity-niszczyciela za potencjalnie atrakcyjną dla niektórych aktorów niepaństwowych, użyteczną w ramach niektórych destrukcyjnych celów. Dlatego też należy spodziewać się prób pozyskania takich urządzeń przez aktorów niepaństwowych, być może takie starania już zaistniały. Wobec rozpowszechnienia się technologii małych satelitów, a w szczególności łatwo dostępnych na rynku cubesatów, stworzenie na ich bazie zabójczej broni przeciwsatelitarnej bazowania kosmicznego na potrzeby organizacji przestępczych bądź terrorystycznych należy uznać za realistyczne, choć niewątpliwie niezwykle trudne. Problemem bowiem jest nie tylko pozyskanie sprawnego orbitera wyposażonego w silniki umożliwiające mu intensywne manewrowanie. Uczestnik niepaństwowy musiałby stworzyć także naziemną infrastrukturę kontroli albo poprzez użycie komercyjnych kanałów łączności, albo 
poprzez fizyczne stworzenie własnego systemu. W każdym wypadku takie działania byłyby możliwe do wykrycia - im dłużej system by istniał i pracował, szanse na to by rosły. Pozostaje także wąskie gardło startowe, czyli kontrola w postaci państwowej rejestracji wystrzeliwanych satelitów i fakt, że zdolności umieszczania na orbicie ładunków wciąż należą do kilku zaledwie państw i nielicznych korporacji prywatnych. To sito jednak może okazać się nieszczelne i możliwe do pokonania dla zasobnych w środki grup. Państwowy system kontroli i rejestracji startów podlega i będzie podlegał napięciom w związku z przyrostem liczby orbiterów, a w szczególności utworzeniem i rozwojem megakonstelacji, oraz zwiększeniem liczby podmiotów oferujących usługi wynoszenia na małych satelitów na orbity. O potencjalnych możliwościach umieszczenia na orbicie nielegalnego pojazdu z ładunkiem niszczącym przez uczestnika niepaństwowego świadczy choćby fakt, że w 2018 roku stwierdzono, iż w przestrzeni okołoziemskiej znalazły się cztery cubesaty niezatwierdzone wcześniej przez odpowiednie władze ${ }^{435}$.

Drugi rodzaj broni przeciwsatelitarnej, najbardziej praktyczny i rozwinięty przez główne mocarstwa kosmiczne, to systemy bazowania lądowego. Obejmują one współcześnie istniejącą broń przeciwsatelitarną, w formie pocisków rakietowych, które odpalane z wyrzutni naziemnych bezpośrednim lotem docierają do orbity satelity-celu i go niszczą. Dokonują tego albo za pomocą ładunku wybuchowego, albo bezpośrednim uderzeniem, w trakcie którego głowica pocisku przekazuje celowi znaczną ilość energii kinetycznej wynikającej z jego prędkości sięgającej kilku kilometrów na sekundę. Trudności w zakresie tej technologii sprowadzają się w największej mierze do tego, że oba obiekty, satelita i pocisk przechwytujący, poruszają się z wielkimi prędkościami. Naprowadzanie na cel wymaga zatem wysoce precyzyjnych urządzeń określających położenie satelity i czułych, a jednocześnie szybkich efektorów, kierujących pociskiem przechwytującym. Obecnie cztery kraje wykazały, że dysponują taką technologią, choć żaden $\mathrm{z}$ nich nie rozmieścił operacyjnie sprawnego uzbrojenia w ilościach, które miałyby znaczenie $\mathrm{z}$ punktu widzenia

435 E. Howell, Four Cubesats Snuck into Orbit Without Regulatory Approval, FCC Says, Space.com, 16.03.2018, https://www.space.com/40001-four-cubesats-unauthorizedlaunch-fcc.html\#?utm_source=sdc-newsletter\&utm_medium=email\&utm_campaign $=20180317$-sdc. 
wojskowego. To ostatnie zdanie nie w pełni jednak odnosi się do USA, ponieważ kraj ten dysponuje zaawansowanym systemem obrony przeciwrakietowej (BMDS), którego niektóre, licznie jednak rozmieszczone komponenty, a w szczególności pociski $\mathrm{SM}_{3}$ i THAAD teoretycznie nadają się do niszczenia systemów satelitarnych. Wprawdzie USA nieodmiennie zaprzeczają, aby taka misja przyświecała BMDS, niemniej jednak w 2008 roku pocisk SM3 zniszczył schodzącego z orbity amerykańskiego satelitę, o którym twierdzono, że jego upadek może wywołać zagrożenie na Ziemi. Był to jednak niewątpliwie pretekst do demonstracji siły, po tym, jak rok wcześniej Chiny dokonały skutecznej próby przeciwsatelitarnej. Bronią tego typu dysponuje także Rosja, która prawdopodobnie opracowuje nowe jej rodzaje ${ }^{436}$, oraz Indie, które w 2019 roku przeprowadziły udany test systemu przeciwsatelitarnego.

Tego typu uzbrojenie jest $\mathrm{z}$ wielu powodów bardziej praktyczne niż inne środki walki rozmieszczone w kosmosie, gdyż jest szybkie w działaniu i możliwe do zakamuflowania na Ziemi. Co do zasady przeznaczone jest jednak do atakowania celów, które znajdują się ponad terytorium bądź zamorskimi instalacjami, albo jednostkami morskimi należącymi do danego państwa. Jedynie najbardziej zaawansowane kraje, dysponujące globalną siecią śledzenia i naprowadzania bądź odpowiednimi platformami powietrznymi lub kosmicznymi, mogą pokusić się o stworzenie broni zdolnych atakować orbitery na odległych od punktu startu pocisku przechwytującego fragmentach orbity. Na razie jednak tylko USA mają zdolność zaatakowania niskiej orbity nad całym globem, a być może także orbity geostacjonarnej.

Wydawałoby się, że technologia niezbędna do budowy broni przeciwsatelitarnej bazowania naziemnego jest domeną tylko największych potęg. Jak dotąd faktycznie tak jest, ale proliferacja systemów bojowych tego rodzaju to raczej kwestia czasu. Technika rakiet balistycznych, obejmująca coraz bardziej precyzyjne systemy kierowania i naprowadzania, rozwija się i rozpowszechnia w świecie. Mniej zamożni uczestnicy stosunków międzynarodowych mogą ponadto sięgnąć po koncepcje prostsze niż stosowane w zaawansowanych konstrukcjach amerykańskich czy

436 Por. na przykład M. Kamassa, Antysatelitarne oblicze rosyjskiego myśliwca? Niejasne testy MiGa-31, Space24, 6.10.2018, https://www.space24.pl/antysatelitarne-obli cze-rosyjskiego-mysliwca-mig-31-obiektem-potajemnych-prob. 
rosyjskich, a więc łatwiej dostępne. Jedną z nich, często przywoływaną w tego typu rozważaniach, jest pellet ASAT ${ }^{437}$, co należałoby przetłumaczyć jako „śrut przeciwsatelitarny”. Technologia ta była już rozważana w czasie zimnej wojny, lecz zarzucono ją jako mniej zaawansowaną i mniej pewną, choć przy współcześnie dostępnych środkach śledzenia satelitów może ona wrócić do łask. Polega ona na tym, że przeciwsatelitarny pocisk rakietowy, zbliżając się do punktu, w którym wedle obliczeń ma znaleźć się satelita-cel, uwalnia chmurę niewielkich, niekierowanych obiektów. Rozszerza się ona następnie i w chwili, kiedy przetnie trajektorię satelity, może mieć już sporą średnicę, co znacząco zwiększy prawdopodobieństwo trafienia. Na przykład rakieta balistyczna średniego zasięgu dysponująca ładunkiem użytecznym o masie jednej tony może wynieść ponad 6000 kulek stalowych o średnicy $4 \mathrm{~cm}$ na wysokość orbitalną z prędkością kilku kilometrów na sekundę. Każda z tych „śrucin” będzie zaś miała energię kinetyczną wystarczającą do zniszczenia lub przynajmniej poważnego uszkodzenia, względnie zaburzenia ruchu każdego satelity na niskiej orbicie. Oczywiście metoda ta wymaga i rakiety o odpowiednich parametrach pod względem nośności, i skutecznych środków naprowadzania. Integracja potrzebnych technologii wcale nie jest rzeczą prostą, stanowi jednak, przynajmniej w teorii, potencjalnie skuteczną na niskich orbitach alternatywę. A zatem zaawansowane w technice rakietowej kraje, jak: Pakistan, Korea Północna czy Iran, mogą pokusić się o skonstruowanie w najbliższych latach broni bazującej na tej zasadzie. W dalszej kolejności mogliby ją pozyskać i uczestnicy niepaństwowi, choć w ich przypadku byłoby to raczej trudne, choć zapewne nie niemożliwe.

Technologie laserowe także ulegają proliferacji, można zatem przypuszczać, że nie tylko wielkie mocarst wa mają lub mogą łatwo opracować metody uszkadzania satelitów za pomocą promienia lasera. I mniejsze kraje oraz uczestnicy niepaństwowi także mogą pokusić się o zdobycie tego typu zdolności, opartych na komercyjnie dostępnych technologiach samych laserów oraz ich naprowadzania na cel. Oczywiście moc urządzeń i precyzja śledzenia satelity musi być większa niż w przypadku jedynie oślepienia jego sensorów przez wiązkę lasera, gdyż czas naświetlania musi być dłuższy. Dlatego też umiejętność uszkadzania orbiterów w ten sposób jest i będzie mniej dostępna niż w przypadku słabszych oddziały- 
wań oślepiających, ponieważ konieczne będzie zintegrowanie droższych i bardziej skomplikowanych urządzeń.

Dla porządku wymienić można jeszcze jedną prostą technikę antysatelitarną, która w konsekwencji także może prowadzić do zagrożenia bezpieczeństwa w kosmosie. Stacje naziemne służące do kontroli satelitów mogą zostać na różne sposoby fizycznie zniszczone bądź uszkodzone, co może w konsekwencji prowadzić nie tylko do zaburzenia ich funkcji, ale w dłuższym okresie do deorbitacji i/lub kolizji między satelitami. Systemy wojskowe są jednak dobrze przed tym zabezpieczone ${ }^{438}$, mają także znaczną redundancję, trudno sobie zatem wyobrazić, aby - poza wojną na pełną skalę - całość wojskowej infrastruktury naziemnej została zniszczona. Może ona jednak ulec uszkodzeniu w wyniku fizycznego ataku, co mogłoby ograniczyć skuteczność pracy systemów. Infrastruktura cywilna także może zostać zaatakowana, a jako mniej zabezpieczona jest bardziej narażona na odniesienie uszczerbku. To z kolei mogłoby się pośrednio przyczynić do zagrożenia bezpieczeństwa innych systemów orbitalnych. Ataki na naziemną infrastrukturę systemów satelitarnych mogą prowadzić wrogie państwa, czy to poprzez otwarte działania, czy za sprawą działań specjalnych, jest to jednak ograniczone do otwartego konfliktu. Aktorzy niepaństwowi zaś z jednej strony mogą mieć większą gotowość do przeprowadzenia ataków na infrastrukturę naziemną systemów satelitarnych $w$ ramach realizacji swoich strategii, $z$ drugiej natomiast - z natury rzeczy mają oni mniejsze zasoby i zdolności, aby takowe akcje prowadzić.

Podsumowując, należy stwierdzić, że z punktu widzenia bezpieczeństwa własnych systemów satelitarnych USA muszą liczyć się z szerokim spektrum negatywnego oddziaływania, w wyniku którego mogą one ulec uszkodzeniu lub nawet zniszczeniu, a ich funkcje mogą zostać ograniczone lub całkowicie wyłączone. Środki odpowiednie do podjęcia takich działań niewątpliwie mają do dyspozycji albo też mogą je rozwinąć pozostałe mocarstwa kosmiczne: Federacja Rosyjska ${ }^{439}$, Chiny ${ }^{400}$ i Indie ${ }^{411}$. Potencjalnie, a prawdopodobnie także w rzeczywistości, dostęp do nie-

438 Space Security Index 2014 ..., s. 69.

439 Więcej szczegółów, por. na przykład T. Harrison, K. Johnson, T. G. Roberts, op. cit. 440 Więcej szczegółów, por. na przykład ibidem, s. 8-16.

441 Więcej szczegółów, por. na przykład ibidem, s. 37-38. 
których technik przeciwsatelitarnych mają i inne państwa, w szczególności te, które aspirują do roli mocarstw kosmicznych ${ }^{42}$, a nawet uczestnicy niepaństwowi. Proliferacja środków negatywnego oddziaływania będzie także postępować, co należy uznać za nieuchronne - jest to jedna $\mathrm{z}$ najważniejszych obserwacji, którą należy szczególnie wyraźnie podkreślićc43.

Postępująca proliferacja technik i strategii przeciwsatelitarnych jest zjawiskiem, które w największym bodaj stopniu definiuje współczesny stan bezpieczeństwa w kosmosie i dynamikę zmian w tym zakresie. Przypomnijmy, że jeszcze niedawno środki negatywnego oddziaływania na systemy satelitarne były $w$ dyspozycji jedynie najbardziej zaawansowanych państw, a w związku z tym „[...] możliwe było przypisanie im odpowiedzialności za ataki z relatywną łatwością i pewnością"444. Przypisanie zaś odpowiedzialności za atak konkretnemu krajowi mogło rodzić poważne konsekwencje polityczne i/lub groźbę kontrakcji mogącej prowadzić do z natury rzeczy nieprzewidywalnej w skutkach eskalacji, z całym wachlarzem niepewności, zagrożeń i niebezpieczeństw immanentnych w takiej sytuacji. To właśnie, w dużej mierze, powstrzymywało główne państwa od wrogich działań w kosmosie oraz przeciwko systemom kosmicznym drugiej strony. Ta, wydawałoby się, utrwalona, stabilna sytuacja braku codziennych zagrożeń dla systemów kosmicznych nie dawała asumptu do złożonych działań defensywnych - przygotowywano jedynie wojskowe systemy satelitarne do pracy w sytuacji zakłóceń wynikających z otwartego konfliktu. Inaczej mówiąc, główne mocarstwa, pozostając w relatywnej równowadze strategicznej, nie prowadziły intensywnych wrogich działań przeciwko systemom satelitarnym drugiej strony, stan ten mógł zmienić tylko otwarty konflikt.

Tymczasem współcześnie sytuacja się komplikuje głównie dlatego, że rozszerzyła się paleta oddziaływań przeciwsatelitarnych. Szczególnie ważne jest to, że doszło do niej wiele technik, których zastosowanie jest znacznie trudniejsze do przypisania do konkretnego podmiotu. Na

442 Z. Shabbir, A. Sarosh, Counterspace Operations and Nascent Space Powers, „Astropolitics" 2018, vol. 16, nr 2, s. 119-140.

443 Obszernie o współczesnych systemach przeciwsatelitarnych, por. B. We e de n, V. Sa m son, Global Counterspace Capabilities: An Open Source Assessment, Secure World Foundation, April 2018, https://swfound.org/media/206118/swf_global_counterspace _april2018.pdf.

$+4+$ M. Kleiman, S. McNeil, op. cit. 
przykład państwa działające w cyberprzestrzeni poprzez wyspecjalizowane, utajnione agendy albo za pośrednictwem uczestników niepaństwowych, bądź nawet pojedynczych „wolnych strzelców”, mogą z większą swobodą podejmować działania szkodzące innym krajom, ponieważ ryzyko, że zostaną im one w jednoznaczny sposób przypisane, jest niewielkie. Jednocześnie owe techniki, szczególnie ataki z cyberprzestrzeni, są relatywnie łatwe w sensie dostępności narzędzi oraz ich ceny. Dlatego też aktorzy niepaństwowi sięgają po nie szeroko w różnych celach, im tėz z natury rzeczy jest szczególnie trudno przypisać określone działania, zwłaszcza w cyberprzestrzeni.

A zatem rozwijające się zdolności techniczne i relatywnie niskie ryzyko działań w cyberprzestrzeni sprzyja atakom na systemy satelitarne. Podobnie, choć nieco $\mathrm{w}$ mniejszym zakresie, rozpowszechniają się inne zdalne odziaływania w postaci zagłuszania czy przejmowania sygnału, ponieważ jest relatywnie trudno określić ich sprawców; szczególnie wtedy, kiedy są to działania nieskutkujące fizycznym uszkodzeniem bądź zniszczeniem systemów satelitarnych. Nic zatem dziwnego, że USA odczuwają rosnącą niepewność, czy będą w kluczowych momentach w stanie użyć swoich zdolności kosmicznych. Działania mające za zadanie odwrócić ten trend są zatem jednym z głównych amerykańskich priorytetów.

Konsekwencje ewentualnego wystąpienia zagrożen dla bezpieczeństwa amerykańskich systemów kosmicznych

Fakt, że amerykańskie systemy kosmiczne są coraz bardziej zagrożone, wpływa, co oczywiste, na wiarygodność militarnych i politycznych strategii budowanych $w$ dużej mierze właśnie na zdolnościach wynikających z zastosowań satelitarnych. Jest to niejako oczywiste stwierdzenie, które wynika z przedstawionych powyżej rozważań, warto jednak powtórzyć, że

[o]d pogoni za terrorystami w odległych częściach świata do zabezpieczenia wiarygodnego odstraszania nuklearnego Stany Zjednoczone używają systemów kosmicznych we wszystkich rodzajach operacji wojskowych. Obecna strategia wojskowa USA polega na zdolności do projekcji siły na 
całym świecie i na wielkie odległości - zdolności kosmiczne wspierają to w sposób unikalny ${ }^{44}$.

Zatem już samo zagrożenie funkcjonowania systemów satelitarnych, a szczególnie faktyczne ograniczenie ich zdolności bądź ich unieszkodliwienie, musi wpłynąć negatywnie na wszystkie działania sił zbrojnych $\mathrm{i}$ innych instytucji zajmujących się bezpieczeństwem zewnętrznym Ameryki. W skrajnym przypadku może się okazać, że niektórych z kluczowych dla bezpieczeństwa misji w ogóle nie będzie się dało wykonać, wiele strategii i konkretnych działań stanie zatem pod znakiem zapytania.

$\mathrm{Z}$ dotychczasowych rozważań wynika w pewnej mierze to, jakie byłyby konkretne konsekwencje ograniczenia skuteczności działania bądź eliminacji amerykańskich systemów kosmicznych. W szczególności da się to wyczytać z opisu misji, jakie mają wykonywać systemy satelitarne i z ich miejsca w strategii bezpieczeństwa i w polityce zagranicznej USA. Warto jednak wymienić skutki ewentualnego ograniczenia albo wyłączenia amerykańskich systemów kosmicznych wraz z ich szerszym kontekstem. Pozwoli nam to uszeregować problemy, przed jakimi USA mogą w najbliższym czasie stanąć lub z którymi już w jakiejś mierze się borykają. Innymi słowy, mówimy o bezpośrednich i pośrednich konsekwencjach wystąpienia zagrożeń, które już dziś wpływają na stan bezpieczeństwa kosmicznego, zwłaszcza na stan bezpieczeństwa amerykańskich systemów satelitarnych.

$\mathrm{Z}$ punktu widzenia podstawowych elementów strategii bezpieczeństwa narodowego widzimy następujące efekty ewentualnego spadku skuteczności funkcjonowania systemów orbitalnych.

Po pierwsze, w ramach obrony terytorium USA ograniczeniu ulegnie efektywność wczesnego ostrzegania przed różnego rodzaju atakami, czy to rakietowymi przy użyciu pocisków dalekiego zasięgu startujących z odległych lądów, czy z wykorzystaniem uzbrojenia lotniczego bądź pocisków odpalanych z okrętów podwodnych.

Po drugie, w ramach szerszego problemu efektywności sił zbrojnych, ulegnie ona redukcji poprzez ograniczenie skuteczności łączności na wszystkich szczeblach organizacyjnych, utrudnienie prowadzenia nawigacji przez jednostki floty (pojazdy, samoloty, ludzi i uzbrojenie precy- 
zyjne) oraz skuteczności pozyskiwania informacji o stanie przeciwnika oraz środowiska. Wszystko to przełoży się na ograniczenie skuteczności realizacji konkretnych misji sił zbrojnych w ramach ich wszystkich zadań bojowych i niebojowych. Oznaczać to będzie osłabienie efektywności amerykańskich sił zbrojnych jako siły bojowej, z całą złożonością politycznych i militarnych konsekwencji tego faktu.

Po trzecie, należy zwrócić uwagę, że najbardziej ucierpi ten komponent sił zbrojnych, który wykonuje zadania ekspedycyjne. Po pierwsze dlatego, że w jego przypadku przewaga technologiczna odgrywa szczególnie wielką rolę, jako że skonfrontowany jest on częstokroć z liczniejszymi przeciwnikami, na ogół dobrze już przygotowanymi do przeciwstawiania się USA. Po drugie zaś dlatego, że odległość od centrów logistyki i dowodzenia, która dziś nie jest wielkim problemem dla efektywności prowadzenia działań, znów nabierze znaczenia szczególnie w przypadku zakłócenia działania systemu łączności.

Po czwarte, w związku ze spadkiem skuteczności sił zbrojnych zmniejszy się ich rola jako instrumentu wsparcia polityki zagranicznej. To z kolei przełoży się na generalne osłabienie efektywności tejże polityki.

Po piąte, ograniczenie skuteczności zbierania informacji polityczno-strategiczno-ekonomicznej o potencjalnych oraz faktycznych przeciwnikach utrudni i tak niełatwy proces kształtowania doktryny użycia sił zbrojnych i planowania konkretnych ich działań. To dalej ograniczy siłom zbrojnym skuteczność realizacji działań bojowych i niebojowych, stawiając niektóre misje pod znakiem zapytania. W sensie politycznym, co bardzo ważne, szczególnym skutkiem będzie tu wzrost niepewności co do stanu sił i intencji globalnych konkurentów i przeciwników regionalnych.

Po szóste, niejako na marginesie, choć jest to bardzo ważna kwestia, należy dodać ekonomiczne następstwa ograniczenia efektywności amerykańskich systemów satelitarnych, które mogą być bardzo poważnym zagrożeniem dla gospodarki USA ${ }^{446}$.

Skutkiem powyższych ograniczeń może być ogólne zmniejszenie się zdolności obronnych USA oraz osłabienie możliwości popierania przez nie

446 Na przykład 30-dniowa przerwa w działaniu GPS może oznaczać dla amerykańskich przedsiębiorstw nawet 30-45 mld USD strat w zależności od pory roku, za: Economic Benefits of the Global Positioning System (GPS), RTI Report Number 0215471, June 2019, https://www.rti.org/sites/default/files/gps_finalreport.pdf. 
swoich interesów w skali globalnej. Przy czym należy brać tu pod uwagę zarówno funkcję odstraszania realizowaną przez siły zbrojne, jak i problemy faktycznego prowadzenia przez nie działań zbrojnych. Dotyczy to także poszerzonego odstraszania, które obejmuje sojuszników oraz prowadzenia działań obronnych $w$ ramach realizacji zobowiązań sojuszniczych. Dalszym skutkiem może być także generalne osłabienie zdolności politycznego oddziaływania Stanów Zjednoczonych w świecie, a zatem zdolności do popierania ich interesów, także ekonomicznych. Ostatecznym efektem będzie osłabienie pozycji USA jako globalnego mocarstwa.

Ujmując rzecz bardziej szczegółowo, w wymiarze bezpieczeństwa regionalnego główne praktyczne konsekwencje zaburzeń w działaniu systemów orbitalnych wiązałyby się z kwestią zmiany charakteru amerykańskiej obecności w poszczególnych częściach świata. Najwyraźniej zapewne widoczne byłoby to $w$ regionach, gdzie USA mają obecnie najważniejsze interesy, oraz na obszarach najbardziej zapalnych, które zresztą w dużej mierze pokrywają się ze sobą. Wymienić tu należy następujące skutki spadku efektywnej siły bojowej amerykańskich sił zbrojnych:

- osłabienie amerykańskich gwarancji bezpieczeństwa dla sojuszników i partnerów,

- osłabienie zdolności oddziaływania i przeciwdziałania destabilizacji przez regionalnych graczy starających się zmienić istniejący status quo,

- zmniejszenie atrakcyjności amerykańskiej soft power.

Skutkiem tych procesów byłby zapewne wzrost napięcia i potencjału konfliktowego w poszczególnych częściach świata, w szczególności tam, gdzie obecność USA jest ważnym czynnikiem stabilizacji, na przykład w Europie i na Dalekim Wschodzie. Wszędzie tam lokalne lub sąsiadujące mocarstwa, dla których obecność USA była zawsze główną przeszkodą w realizacji planów mocarstwowych, mogłyby zwiększyć swoje zdolności do podważania amerykańskich pozycji, co oznaczałoby postępującą destabilizację. Gwoli kompletności wywodu trzeba zauważyć, że w tej perspektywie mogą jednocześnie pojawiać się czynniki stabilizacyjne, na przykład wpływ innych mocarstw, lub porządkujące działanie mocarstw lokalnych, osłabienie USA jest tu tylko jednym z czynników destabilizacji, który nie musi przeważać.

Powyższe rozważania mają oczywiście charakter modelowy i bardzo teoretyczny. $W$ realnej sytuacji faktyczne ograniczenia zależałyby 
od tego, jakie konkretnie systemy kosmiczne zostałyby naruszone bądź zniszczone i w jakim stopniu. Kluczowe byłoby także to, na ile dałoby się je w danej sytuacji zastąpić innego typu środkami i z jaką skutecznością przejęłyby one zadania uszkodzonych systemów kosmicznych. Uwzględnić też należałoby i to, że w konkretnej sytuacji ewentualnej kosmicznej wymiany ciosów lub zanieczyszczenia części orbit także ewentualni przeciwnicy ucierpieliby w zakresie swoich zdolności kosmicznych, a zatem możliwe osłabienie dotyczyłoby nie tylko USA. Dlatego też podkreślamy, że powyższy katalog to tylko lista potencjalnych następstw, które mogą się ziścić w pełni, częściowo, lub też w ogóle nie zaistnieć.

Ewentualne zaburzenia $\mathrm{w}$ funkcjonowaniu systemów satelitarnych USA lub też ich całkowite wyłączenie dotyczyłoby także innych krajów, a więc należy postrzegać ten problem również w szerszej perspektywie bezpieczeństwa międzynarodowego, zarówno w wymiarze globalnym, jak i regionalnym oraz lokalnym. Po pierwsze, wskazany powyżej proces osłabienia wpływów i zdolności oddziaływania Ameryki zmieniłby radykalnie globalną i regionalną dynamikę strategiczną, oddziałując destabilizująco na porządek międzynarodowy - przynajmniej w krótkoi średniookresowej perspektywie. Po drugie, ograniczenie dopływu informacji na temat zamiarów i potencjałów militarnych poszczególnych państw mogłoby mieć znaczenie dla każdego kraju i odnosiłoby się do każdego regionu, zwiększając ogólną niepewność w relacjach międzynarodowych. Ponadto skutkiem działań negujących militarne zdolności satelitarne byłyby i perturbacje gospodarcze wynikające $z$ ograniczeń $\mathrm{w}$ funkcjonowaniu systemów cywilnych. Wpłynęłoby to z kolei znacząco na zwiększenie potencjału destabilizacji gospodarki światowej i ekonomii poszczególnych krajów, a co za tym idzie - na stan bezpieczeństwa międzynarodowego.

Skutkiem ogólnym tych procesów byłby wzrost napięcia związany ze wzrostem nieprzejrzystości stosunków strategicznych, przede wszystkim między głównymi mocarstwami, ale nie tylko. Dalszą konsekwencją byłoby także zapewne zwiększenie prawdopodobieństwa konfliktów o różnym natężeniu, choćby dzięki mniejszej kontrolowalności sytuacji sprzyjających eskalacjom. Niewątpliwym następstwem wzrostu nieufności w stosunkach międzynarodowych byłby także przyspieszający wyścig zbrojeń, jako że zwiększanie zdolności militarnych jest nader częstym rozwiązaniem dylematu bezpieczeństwa. Zaburzenia gospodarcze sprzy- 
jałyby także niepewności społeczeństw co do ich losu, czyniąc je bardziej podatnymi zarówno na wewnętrzne konflikty, jak i na obawy co do zagrożeń zewnętrznych. To ostatnie może być też szeroko wykorzystywane jako instrument wewnętrznej i międzynarodowej gry politycznej. Ostatecznym efektem tych wszystkich procesów byłby dalszy wzrost potencjału niestabilności stosunków międzynarodowych, kumulujący się z następstwami destabilizacji ekonomicznej.

Powyższe rozważania są tylko najbardziej ogólnym modelem tego, co stać się może w sytuacji znacznego zaburzenia pracy systemów orbitalnych. Oczywiście opisane procesy i tak występują i mogą się pogłębiać niezależnie od stanu bezpieczeństwa kosmicznego. Jednak w świetle naszych dotychczasowych ustaleń wydaje się, że można przyjąć, iż istotny spadek efektywności działania systemów kosmicznych Stanów Zjednoczonych, zarówno wojskowych, jak i cywilnych, byłby znaczącym czynnikiem katalizującym lub pogłębiającym i przyspieszającym negatywne trendy w bezpieczeństwie globalnym. Między innymi dlatego, że wiązałoby się to najprawdopodobniej $z$ ograniczeniami wykorzystania systemów satelitarnych przez inne kraje oraz podmioty komercyjne, a także ze spadkiem dostępności usług satelitarnych.

Reasumując, przypomnijmy, że ze względu na rolę systemów kosmicznych $\mathrm{w}$ amerykańskiej strategii bezpieczeństwa i $\mathrm{w}$ ramach bieżącej realizacji celów polityki zagranicznej, ograniczenie ich działalności czy, w szczególności, całkowita ich utrata byłyby bardzo niebezpieczne dla Stanów Zjednoczonych. Oznaczałoby to bowiem naruszenie podstaw amerykańskich strategii i utrudnienie, w zależności od stopnia degradacji systemów kosmicznych, realizacji bieżących misji. To zmniejszenie amerykańskich zdolności mogłoby być w jakiejś mierze złagodzone w sytuacji, gdyby ucierpiał także ewentualny przeciwnik i jego zdolności kosmiczne. Nie w każdym jednak przypadku potencjalnego konfliktu ów przeciwnik może w ogóle ucierpieć. Szczególnie dotyczy to uczestników niepaństwowych bądź państw, które nie mają własnych poważnych interesów w kosmosie. W takiej sytuacji działania w celu ograniczenia skuteczności amerykańskich systemów kosmicznych mogą być niezwykle atrakcyjną, asymetryczną odpowiedzią na amerykańską przewagę. To uprawdopodabnia zastosowanie przynajmniej niektórych technik przeciwsatelitarnych, a nawet świadomą próbę uruchomienia kaskady kolizji prowadzącej do efektu Kesslera ze wszystkimi tego konsekwencjami. 


\section{Przeciwdziałanie zagrożeniom systemów kosmicznych - wybrane aspekty teoretyczne i praktyczne}

W teorii istnieje wiele sposobów zmniejszania wrażliwości systemów kosmicznych poprzez zwiększanie poziomu zabezpieczeń $\mathrm{w}$ każdym $\mathrm{z}$ ich trzech segmentów. Poniżej przedstawimy je w najbardziej ogólny sposób, a następnie pokażemy przykłady konkretnych działań podejmowanych w Stanach Zjednoczonych w tym zakresie wraz z oceną ich perspektyw.

Segment orbitalny, czyli właściwy satelita, może zostać wzmocniony tak, aby zwiększyć jego odporność na wzrost temperatury wynikający $\mathrm{z}$ ataku laserem czy przed uderzeniem ciała stałego. Można także obniżyć poziom wykrywalności danego obiektu poprzez jego maskowanie, choć z natury rzeczy metoda ta nie będzie w pełni skuteczna, szczególnie wobec adwersarzy dysponujących najbardziej zaawansowanymi środkami przeciwsatelitarnymi. Żaden kamuflaż nie zabezpieczy ponadto satelity przed przypadkowym zniszczeniem w kolizji z kosmicznym śmieciem bądź innym orbiterem.

Z kolei infrastrukturę naziemną można zabezpieczać przed fizycznymi atakami na dwa sposoby. Po pierwsze, w sensie strukturalnym, poprzez tworzenie bardziej odpornych budowli, anten, urządzeń transmisyjnych etc. Po drugie zaś, w sensie organizacyjnym, można wzmacniać system ochrony obiektowej, poczynając od ochrony przed sabotażem, na obronie przeciwlotniczej i przeciwrakietowej kończąc. Osobną kwestią jest obrona infrastruktury przed atakami z cyberprzestrzeni, która także może być wzmacniana na różne sposoby.

Łącze może natomiast zostać odpowiednio zakodowane, można zwiększać moc i selektywność urządzeń nadawczo-odbiorczych, by zabezpieczyć łącze przed zagłuszeniem. Można także stosować specjalnego typu nadajniki generujące fale radiowe o specjalnych właściwościach ${ }^{447}$, rotacje częstotliwości i inne techniki walki radioelektronicznej.

W przypadku systemów pracujących na rzecz znacznej liczby odbiorników usług satelitarnych, takich jak komunikacyjne bądź pozycjonujące, skuteczność działania zależy od tego, jak są one zabezpieczone,

447 Por. na przykład A. Stone, Air Force Looks for Help on New, Hard-to-jam, Satellite Waveform, C4ISRNet, 4.10.2018, https://www.c4isrnet.com/c2-comms/satellites/2018/10/ 05/air-force-looks-for-help-on-new-hard-to-jam-satellite-waveform/. 
przede wszystkim przed zagłuszeniem lub sfałszowaniem sygnału. I tu można wykonać wiele działań, od wykorzystywania zaawansowanych algorytmów kodowania, poprzez wzmacnianie mocy i czułości urządzeń, do stosowania selektywnych i odpornych na zakłócenia anten - dotyczy to zarówno łączności, jak i pozycjonowania ${ }^{44^{8}}$.

Szczególną metodą zwiększenia odporności systemów satelitarnych jest wprowadzenie do nich redundancji. W najbardziej ogólnych kategoriach polega to na tym, że system posiada taką liczbę elementów i tak są skonstruowane połączenia pomiędzy nimi, że utrata ich części nie spowoduje ograniczenia pracy całości. Można tę metodę stosować wobec każdego segmentu systemu satelitarnego, choć szczególną rolę i znaczenie ma ona w przypadku najbardziej wrażliwego segmentu, jakim jest system orbitalny.

Istniejące konstelacje wojskowe oczywiście zawsze mają zapasowe elementy na wypadek awarii. Są one na ogół nieliczne, mogą zatem nie wystarczyć, jeśli w wyniku wrogiego oddziaływania odmówi pracy duża część systemu. Obecne amerykańskie wojskowe systemy orbitalne $w$ praktyce nie nadają się do działań w sytuacji, kiedy kosmos stanie się polem walki. Konstruowane $\mathrm{z}$ poczuciem bezpieczeństwa składają się przede wszystkim z dużych obiektów ${ }^{449}$, realizujących z wielką precyzją i kompleksowo całe spektrum zadań. Jest ich oczywiście w sumie dużo, gdyż wykonują bardzo wiele różnych funkcji, jednak poszczególne konstelacje są stosunkowo nieliczne, co czyni je wrażliwymi na atak. Na przykład najnowsza rozmieszczana obecnie konstelacja satelitów łączności wojskowej docelowo ma liczyć jedynie sześć orbiterów ${ }^{450}$.

Aby zatem radykalnie zmniejszyć wrażliwość systemów orbitalnych wobec współczesnych zagrożeń, redundancja musi polegać nie tylko na

448 Por. na przykład P. Zi emnicki, IAI zabezpieczy platformy bojowe przed zakłóceniami sygnału GPS, Space24, 2.02.2017, http://www.space24.pl/iai-zabezpieczy-platformybojowe-przed-zakloceniami-sygnalu-gps.

$4+9$ J. Sankara n, "Big, Fat, Juicy Targets” - the Problem with Existing Early-warning Satellites. And a Solution, "Bulletin of the Atomic Scientists”, 30.09.2019, https://the bulletin.org/2019/09/big-fat-juicy-targets-the-problem-with-existing-early-warningsatellites.

450 T. Malik, Jam-Resistant US Military Communications Satellite Lifts Off in Midnight-Hour Launch, Space.com, 17.10.2018, https://www.space.com/41819-atlas-v-launches -jam-resistant-aehf 4 -military-satellite.html?utm_source=sdc-newsletter\&utm_me dium=email\&utm_campaign=20181017-sdc. 
zabezpieczeniu przed awarią za pomocą nielicznych jednostek zapasowych. Musi także prowadzić do znacznego zwiększenia liczby potencjalnych celów, tak aby zmusić przeciwnika do zwielokrotnienia wysiłku. Jednocześnie musi obejmować zdolność do szybkiego uzupełnienia przetrzebionych wrogim działaniem konstelacji. Inaczej mówiąc, system orbitalny powinien być tak rozproszony przestrzennie i tak zwielokrotniony oraz zdolny do regeneracji, aby w razie starcia doprowadzić do wyczerpania środków bojowych przeciwnika, zanim on ograniczy działanie bądź wyłączy system.

W Stanach Zjednoczonych podejmuje się wiele różnych kroków na rzecz zwiększenia odporności systemów kosmicznych, choć, jak niektórzy uważają, odbywa się to niewystarczająco odważnie, polegając wciąż zbytnio na utartych technologiach i sposobach organizacji systemów kosmicznych ${ }^{45}$. W pierwszej kolejności chodzi zatem o uodpornienie ich na zakłócenia i na ataki cybernetyczne oraz wzmocnienia konstrukcyjne ograniczające skutki niektórych, nieniszczących ataków energetycznych.

Jednak z natury rzeczy satelity są i będą wystawione także na bezpośredni atak, poruszając się po odsłoniętych, łatwych do przewidzenia torach, nie są zdolne do stosowania podstawowych strategii „przeżycia” na polu walki związanych $\mathrm{z}$ maskowaniem i manewrem. Inna podstawowa strategia „przeżywalności”, jaką jest fizyczne wzmocnienie odporności konstrukcji, czyli opancerzenie wrażliwego systemu lub jego części, także jest dostępna dla systemów satelitarnych tylko w pewnym zakresie, ze względu na znane ograniczenia masowe. Wprawdzie obecnie restrykcje te ulegają złagodzeniu, ale nie do takiego stopnia, by móc zasadniczo zmienić sytuację. Innymi słowy, w dającej się przewidzieć przyszłości trudno sobie wyobrazić ciężko opancerzone orbitery, zdolne do przyjęcia szeregu ciosów od systemów ASAT i jednocześnie nieprzerwanie podtrzymujące swoją pracę, albo też pojazdy mogące wykonywać błyskawiczne uniki, bądź też „niewidzialne” dla przeciwnika.

Dlatego téz najistotniejszym zapewne czynnikiem „przeżywalności” konstelacji satelitarnych, jaki jest rozważany i badany w USA, jest two-

451 Por. na przykład M. Rogers, Launching the Sixth Branch of the US Armed Forces, Defense News, 6.07.2018, https://www.defensenews.com/space/2018/07/o6/launchingthe-sixth-branch-of-the-us-armed-forces/. 
rzenie systemów rozproszonych. Wprawdzie nie eliminuje to całkowicie zagrożenia o charakterze kinetycznym, stanowi jednak asymetryczną na nie odpowiedź. Zmusza bowiem potencjalnego przeciwnika do radykalnego zwiększenia potencjału niezbędnego do ewentualnych negatywnych oddziaływań oraz wydłużenia czasu trwania i zwiększenia skuteczności działań przeciwko systemom satelitarnym. Wydaje się, że taka przede wszystkim jest przyszłość zabezpieczenia ciągłości wykorzystania aplikacji kosmicznych w sytuacji wzrostu zagrożenia ich fizycznym uszkodzeniem bądź zniszczeniem.

Dezagregacja systemów satelitarnych może zostać osiągnięta na kilka różnych sposobów, raport Dowództwa Kosmicznego USAF wymienia następujące metody: frakcjonowanie, dezagregacja funkcjonalna, stosowanie ładunków dodatkowych, wieloorbitowość i wieloprzestrzennośćc ${ }^{52}$.

Frakcjonowanie oznacza dekompozycję systemu w moduły, które kontaktują się bezprzewodowo i zachowują zdolności oryginalnego, monolitycznego systemu. Inaczej mówiąc, wiele niezależnych komponentów systemu satelitarnego, wykonujących różne elementy jego misji, współpracuje ze sobą na orbicie, można je zatem łatwiej i taniej uzupełniać bądź zastępować niż w przypadku utraty bądź konieczności wymiany całego dużego satelity.

Funkcjonalna dezagregacja odnosi się do rozproszenia sensorów lub poszczególnych misji cząstkowych, które byłyby realizowane przez jednego satelitę pomiędzy różne systemy. Na przykład satelita telekomunikacyjny, wykonujący dziś kompleksowo zadanie transmisji sygnałów radiowych, może być zastąpiony przez odrębne pojazdy służące do komunikacji taktycznej, operacyjnej i strategicznej. Dzięki temu nie tylko uzyskałoby się efekt dezagregacji, ale jeszcze uprościłaby się sama konstrukcja platform, które wobec tego łatwiej będzie wymienić i uzupełniać.

Strategia ładunków dodatkowych (hosted payloads) to koncepcja podobna do powyższej, polega na umieszczaniu niewielkich ładunków na pojazdach, które już wykonują określoną misję, zostaną zatem i tak

452 W oryginale: Fractionation, Functional Disaggregation, Hosted Payloads, Multi-Orbit, and Multi-Domain, za: Resiliency and Disaggregated Space Architectures, White Paper, U.S. Air Force Space Command, s. 11, https://fas.org/spp/military/resiliency.pdf. 
rozmieszczone. Ładunek dodatkowy korzysta z zasilania i niektórych innych systemów satelity nosiciela, ale wykonuje odrębną misję. W ten sposób dane zadanie może wykonywać bardzo wiele różnych obiektów należących do różnych konstelacji, tworząc pożądaną redundancję systemu jako całości. Szczególnym sposobem realizacji takiej koncepcji jest umieszczanie ładunków wojskowych na orbiterach należących do komercyjnych systemów satelitarnych. Taką zasadę już przetestowano w ramach projektu Commercially Hosted Infra Red Program (CHIRP) ${ }^{453}$ polegał on na umieszczeniu na cywilnym satelicie telekomunikacyjnym sensora podczerwieni przeznaczonego do ostrzegania o startach rakiet balistycznych.

Wieloorbitalna dezagregacja polega na umieszczaniu satelitów danej konstelacji na różnych płaszczyznach orbitalnych, aby utrudnić przeciwnikowi wypracowanie odpowiedniego rozwiązania niszczącego całą strukturę. Dezagregacja wieloprzestrzenna polega natomiast na umieszczaniu urządzeń wykonujących określone zadanie $w$ różnych przestrzeniach operacyjnych, nie tylko w kosmosie, tak aby się uzupełniały i mogły $w$ razie potrzeby wzajemnie się zastępować.

Wszystkie te koncepcje mają oczywiście swoje dobre i złe strony, nie każda $\mathrm{z}$ nich może być $\mathrm{z}$ powodzeniem zastosowana $\mathrm{w}$ danej sytuacji. Jednak twórcze podejście $\mathrm{z}$ tej perspektywy do konkretnych typów zadań i rodzajów misji może znacząco zwiększyć odporność systemów kosmicznych, szczególnie na ich fizyczne zniszczenie w wyniku ataku lub degradacji orbit. Aktualnie prowadzi się szereg mniej lub bardziej zaawansowanych badań rozwojowych, które dotyczą między innymi konstelacji składającej się z setek małych satelitów, a przeznaczonej do wykrywania celów balistycznych i szybowców hipersonicznych o nazwie Hypersonic and Ballistic Tracking Space Sensor (HBTSS), opracowywanych wspólnie przez MDA, DARPA i SDA ${ }^{454}$. Jeszcze rozleglejsza koncepcja kompleksowej sieci zapewniających realizowanie praktycznie wszystkich zadań

453 M. Gruss, U.S. Air Force Decision To End CHIRP Mission Was Budget Driven, SpaceNews, 12.12.2013, https://spacenews.com/38628us-air-force-decision-to-end-chirp-mis sion-was-budget-driven/.

454 N. Strout, The Small Sat Solution to Hypersonic Weapons, Explained, C4ISRnet, 6.08.2019, https://www.c4isrnet.com/battlefield-tech/2019/o8/o6/the-small-sat-solu tion-to-hypersonic-weapons-explained. 
systemów kosmicznych opracowywana jest w ramach SDA ${ }^{455}$, a bazuje na projekcie Blackjack ${ }^{456}$ prowadzonym przez DARPA.

Inną obiecującą metodą przeciwdziałania negatywnym oddziaływaniom na systemy satelitarne jest skrócenie zarówno czasu ich opracowywania, jak i okresu, który spędzają w kosmosie. Koncepcja ta polega na tym, że z jednej strony satelity kolejnych generacji byłyby opracowywane na podstawie wspólnych założeń konstrukcyjnych, z drugiej zaś - zakłada się, że nie musiałyby być najbardziej jak to możliwe zaawansowane technicznie i niejako wyprzedzać rozwój technologii u przeciwnika z intencją utrzymania nad nim przewagi przez długie lata. Według tej nowej filozofii należy zmieniać generacje szybko, rozmieszczając to, co aktualnie najlepsze i dostępne. Ta zwiększona rotacja ma utrzymać skuteczność i odporność całości systemu dzięki szybkiej jego adaptacji do zmieniającego się środowiska bezpieczeństwa kosmicznego i ewoluujących potrzeb. Według tej koncepcji czas opracowania generacji satelitów ma ulec skróceniu z 6 do 3-4 lat, a czas ich życia na orbicie z 20-25 do 4-8 lat ${ }^{457}$.

Wszystkie te metody mogą jednak okazać się niewystarczające, mimo zabezpieczeń systemy kosmiczne mogą zostać unieszkodliwione, co może nastąpić, zanim nowe generacje bardziej odpornych satelitów staną się rzeczywistością. Równolegle podejmuje się zatem działania zmierzające do wypracowania procedur, strategii i taktyk działania na wypadek poważnej degradacji lub wręcz unieszkodliwienia systemów orbitalnych ${ }^{458}$. Dlatego

[r]ządy powoli inwestują w zabezpieczenie elektroniki, budowanie „atawistycznych form działania" (lub też systemów zapasowych) i w trening personelu do działania przez długi czas bez podstawowej komunikacji,

455 Idem, The Pentagon's New Space Agency Has an Idea about the Future, $\mathrm{C}_{4}$ ISRmet, 3.07.2019, https://www.c4isrnet.com/battlefield-tech/2019/07/03/the-pentagons-newspace-agency-has-an-idea-about-the-future/.

456 P. Th o mas, Blackjack, DARPA, 2019, https://www.darpa.mil/program/blackjack.

45? A. Mehta, The Air Force Wants Satellites that Grow Fast, Die Young, Defense News, 19.09.2019, https://www.defensenews.com/digital-show-dailies/air-force-association/ 2019/09/18/the-air-force-wants-satellites-that-grow-fast-die-young.

$458 \mathrm{Na}$ przykład poprzez tworzenie nowoczesnych systemów nawigacyjnych opartych na zasadach sprzed epoki satelitarnej, por. na przykład P. Ziemnicki, GPS na celowniku hakerów. Czas na powrót radia?, Space24, 10.08.2017, https://www.space24.pl/ gps-na-celowniku-hakerow-czas-na-powrot-radia-komentarz. 
nawigacji i innych usług zależnych od systemów satelitarnych, które dziś są podstawą życia w epoce cyfrowej.

Oprócz rządów niektóre organizacje rozwijają plany działania związane $\mathrm{z}$ bezpieczeństwem kosmicznym na wypadek utraty usług satelitarnych. Siły zbrojne, kompanie żeglugowe i firmy logistyczne inwestują w systemy nawigacji bezwładnościowej mającej zastąpić GPS. Co więcej, Airbus i Facebook sugerują zastosowanie napędzanych energią słoneczną samolotów bezzałogowych lub aerostatów wysokościowych, by zapewnić łączność internetową oraz inne usługi „pseudosatelitarne” jako alternatywę dla polegania na przestrzeni kosmicznej ${ }^{459}$.

Podsumowując, należy jednak zauważyć, że mimo świadomości zagrożeń i mimo istnienia wielu koncepcji zwiększenia odporności systemów kosmicznych na negatywne oddziaływanie $w$ istocie niewiele się zmienia w tym zakresie. Po pierwsze dlatego, że z natury rzeczy dopiero nowe generacje satelitarne będą mogły być bezpieczniejsze. Po drugie zaś, wspomniane koncepcje pozostają na tak wczesnych etapach rozwojowych, że trudno dziś wyrokować, w którą stronę podąży ich ewolucja w kolejnych dekadach. Można zatem powtórzyć za amerykańskimi autorami:

Narodowa Strategia Obronna z 2018 roku mówi, że siły zbrojne będą priorytetowo traktować „odporność, odbudowę i działania operacyjne”, aby zabezpieczyć zasoby kosmiczne. Jednak wciąż pozostaje do pełnego zdefiniowania, jakie szczegółowe kroki Departament Obrony ma zamiar podjąć w celu zwiększenia bezpieczeństwa systemów kosmicznych w całym spektrum zagrożeń stwarzanych przez potencjalnych przeciwników ${ }^{460}$.

5.3. Perspektywa dalszej militaryzacji kosmosu - debata nad bronią kosmiczną

W tych z dotychczasowych rozważań, które plasują się w perspektywie prognostycznej, pomijaliśmy w zasadzie kwestię ewentualnej dalszej militaryzacji kosmosu, dotykając jej zaledwie w kilku punktach. A to dlate-

459 J. Black, Our Reliance on Space Tech Means We Should Prepare for the Worst, Defense News, 12.03.2018, https://www.defensenews.com/space/2018/03/12/our-reliance -on-space-tech-means-we-should-prepare-for-the-worst/.

460 T. Harrison, K. Johnson, T. G. Roberts, op. cit., s. 42. 
go, że problem ten zamierzamy poruszyć osobno i wobec tego bardziej szczegółowo. Jest to bowiem wyjątkowo ważna kwestia, która w wielkim stopniu zadecyduje o przyszłości bezpieczeństwa kosmicznego. Inaczej mówiąc, pojawia się dziś ważkie pytanie, czy militaryzacja kosmosu pozostanie na dzisiejszym, biernym poziomie, czy też pojawi się broń kosmiczna - jeśli tak, to na jakich zasadach będzie działać, jak ją będziemy definiować, jakie będą jej cechy charakterystyczne $z$ punktu widzenia pełnionej funkcji, a zatem jaka będzie użyteczność kosmicznych systemów uzbrojenia.

W niniejszym podrozdziale postaramy się względnie kompleksowo, ale jednocześnie syntetycznie odpowiedzieć na te pytania. W tym celu w pierwszej kolejności zastanowimy się nad definicją broni kosmicznej i nad tym, czym ona może być, jakie są organizacyjno-techniczne uwarunkowania jej ewentualnego funkcjonowania, jakie może wykonywać zadania, a zatem w jaki sposób może być użyteczna. Następnie postaramy się przedstawić w ogólnych kategoriach główne argumenty w toczącej się w Stanach Zjednoczonych dyskusji na temat uzbrojenia orbity okołoziemskiej. Całość uzupełni krótkie podsumowanie i ocena perspektyw dalszej militaryzacji kosmosu.

\section{Militaryzacja czynna kosmosu - broń na orbicie}

W rozdziale pierwszym omawialiśmy ogólnie kwestię militaryzacji kosmosu, podkreślając, że współcześnie proces ten ma wyłącznie charakter bierny. Oznacza to, że broń kosmiczna sensu stricto, czyli bazowana w kosmosie, nie istnieje, choć były i są nadal prowadzone badania nad kluczowymi technologiami, które mogą posłużyć do opracowania tego rodzaju uzbrojenia.

Na marginesie przypomnijmy, że istnieją systemy broni służące prowadzeniu walki w kosmosie, choć jest to uzbrojenie stacjonujące na Ziemi, czyli obrona przeciwrakietowa i broń przeciwsatelitarna. Żaden kraj nie zdecydował się jednak jeszcze na rozmieszczenie broni ASAT w istotnych ze strategicznego punktu widzenia ilościach, w dużej mierze z powodów politycznych, ale też ekonomicznych. Operacyjne rozmieszczenie takiego uzbrojenia musiałoby się wiązać się nie tylko z wyprodukowaniem odpowiedniej ilości sprzętu, czyli sensorów, efektorów i specyficznej 
infrastruktury logistycznej dla określonej liczby jednostek bojowych. Musiałaby także powstać konkretna doktryna walki przeciwsatelitarnej, umiejscowiona w szerszym kontekście doktryny wojskowej i polityki bezpieczeństwa narodowego. Wymagałoby to także przydzielenia znacznej liczby ludzi, stworzenia zaplecza szkoleniowego i infrastruktury bazowania dla konkretnych jednostek oraz taktyki walki wraz z licznymi, szczegółowymi procedurami. Wszystko to jest bardzo złożonym i niezmiernie kosztownym zadaniem, którego nikt się jeszcze nie podjął.

Powtórzmy zatem, że $w$ niniejszym podrozdziale zajmiemy się tym wymiarem militaryzacji kosmosu, który określamy mianem „militaryzacji czynnej” lub „weaponizacji” ${ }^{66}$. W języku angielskim słowo weaponization wywodzi się od czasownika weaponize, który na ogół oznacza przystosowanie czegoś do użycia jako broń ${ }^{462}$. Drugie znaczenie, które z powyższym koresponduje, to zainstalowanie broni tam, gdzie jej nie było ${ }^{463}$, a zatem $w$ naszym przypadku na stałych orbitach okołoziemskich. Będziemy się ponadto szeroko dowoływać do problematyki broni przeciwsatelitarnej, która jest niemożliwym do pominięcia kontekstem, w jakim musimy rozważać bronie kosmiczne.

Klasyfikujemy zatem broń kosmiczną, czyli znajdującą się na orbicie okołoziemskiej lub mogącą ją osiągnąć, jako systemy służące do zwalczania:

- obiektów naziemnych/podziemnych i nawodnych/podwodnych,

- obiektów poruszających się w atmosferze lotem aerodynamicznym,

- obiektów poruszających się lotem balistycznym w atmosferze i poza nią,

- obiektów znajdujących się na orbitach okołoziemskich.

Broń należąca do trzech pierwszych kategorii dotychczas nie została opracowana mimo istniejących teoretycznych podstaw i podejmowanych w czasie zimnej wojny i później prac badawczych. Przyczyny tego stanu rzeczy są, jak się zdaje, następujące.

461 Mamy świadomość, że słowo to brzmi niezbyt dobrze, lecz będziemy go czasem używać dla płynności wywodu.

462 Na przykład słownik Merriam-Webster podaje definicję: to adapt for use as a weapon of war, za: Weaponize, Merriam-Webster, 2019, https://www.merriam-webster.com/ dictionary/weaponization\#other-words.

463 Lexico, powtarzając powyższe znaczenie jako pierwsze, dodaje drugą definicję: install weapons in, za: Weaponize, Lexico, 2019, https://www.lexico.com/en/definition/ weaponize. 
Po pierwsze, koszty rozwoju. Opracowanie systemów broni kosmicznej tego rodzaju wydawało się niezwykle drogie, należało pokonać wiele barier technologicznych, które wynikały z konieczności skonstruowania zupełnie nowych systemów naprowadzania i kierowania broni kosmicznych oraz samych orbiterów będących nosicielami tej broni. Spodziewane koszty rosły lawinowo w przypadku planów budowy obiektów załogowych.

Po drugie, koszty rozmieszczenia. Każda broń satelitarna, w szczególności jej rodzaje konstruowane na potrzeby walki z celami na ziemi/wodzie, w atmosferze i na trajektoriach balistycznych wymagałaby zastosowania ogromnych konstelacji. Poruszający się po orbicie satelita bojowy znajduje się nad danym celem tylko przez krótki czas, więc aby uzbrojenie w każdym momencie mogło zostać użyte przeciwko niemu, na danej trajektorii musi znaleźć się wiele pojazdów. Ponadto ich liczba musi być zwielokrotniona, aby uzyskać „pokrycie” celu nawet w wypadku zniszczenia części konstelacji. Jeśli terytorium przeciwnika jest duże, liczba orbit musi być odpowiednia, aby zachować zdolność do zaatakowania całości, co oznacza kolejne jednostki uzbrojenia. Szczególnie systemy bojowe rozmieszczone w celu minimalizacji czasu reakcji na niskich orbitach musiałyby być bardzo rozbudowane przestrzennie i składać się z dziesiątek lub setek pojazdów, z których każdy byłby niezwykle kosztowny. Podobnie rzecz się ma z systemami zarządzania konstelacjami bojowymi w postaci infrastruktury naziemnej i przekaźników satelitarnych. Całość systemu broni kosmicznej musiałaby być zatem niezmiernie złożona zarówno z powodu charakterystyki ruchu po orbicie, jak i w związku z niezbędną redundancją systemów, które musiałyby być gotowe do funkcjonowania nawet w przypadku poniesienia strat bojowych.

Po trzecie, realia operacyjne. Broń kosmiczna zajmuje wprawdzie ultimate high ground, niemniej jednak jest ona w ten sam ostateczny sposób widoczna i wobec tego wystawiona na atak. Ze znanych nam powodów jej opancerzanie i wzmacnianie niewiele mogło pomóc, a o skutecznym maskowaniu nie było mowy w realiach technicznych zimnej wojny. W związku z tym zdawano sobie sprawę, że relatywnie proste i tanie, w porównaniu do samej broni orbitalnej, systemy ASAT bazowania naziemnego byłyby $w$ stanie łatwo dosięgnąc systemów znajdujących się w kosmosie i zniszczyć je albo tuż po rozpoczęciu walk w ramach danego konfliktu, albo na zasadzie uderzenia prewencyjnego. 
Biorąc powyższe pod uwagę, strony zimnowojennej konfrontacji nie zdecydowały się na bardzo drogie, ale w istocie mało użyteczne uzbrojenie, mające ponadto ogromny potencjał destabilizacyjny. Nie zostało ono zatem wprowadzone do służby pomimo istniejących możliwości technicznych.

Współcześnie jednak opracowanie i rozmieszczenie broni kosmicznej przeznaczonej do atakowania celów na ziemi, morzu, w powietrzu i na trajektoriach balistycznych wydaje się nieco bardziej realistyczne niż pół wieku temu. A to przede wszystkim ze względu na przebiegające obecnie zmiany w technologii kosmicznej, o których szeroko wspominaliśmy.

Po pierwsze, koszty opracowania. Dziś byłyby one prawdopodobnie znacznie mniejsze, choć zapewne także astronomiczne, ponieważ współczesne technologie kosmiczne są ogólnie tańsze i jednocześnie bardziej efektywne. Co więcej, wiele rozwiązań niezbędnych do budowy broni kosmicznych już istnieje w wojsku lub może zostać zaadaptowanych z rozwiązań cywilnych. A zatem jeśli przełożyć wydatki na opracowanie i rozmieszczenie systemów uzbrojenia kosmicznego na realny koszt konkretnych misji, byłby on współcześnie znacznie mniejszy.

Po drugie, koszty rozmieszczenia. Znane nam dobrze procesy, czyli spadek kosztów wyniesienia, a przede wszystkim miniaturyzacja powodują, że można pokusić się o opracowanie stosunkowo niewielkich satelitów, które mogłyby wykonywać z powodzeniem zadania bojowe różnego rodzaju. Jest to możliwe między innymi dlatego, że w ogóle nie trzeba brać pod uwagę systemów załogowych, ponieważ automatyczne będą z pewnością wystarczająco skuteczne. Mimo to każda konstelacja satelitów bojowych musiałaby liczyć setki lub tysiące orbiterów, by zapewnić odpowiednią siłę ognia i redundancję z jednoczesnym ciągłym pokryciem celów przez odpowiednią liczbę środków bojowych - bardzo pouczające w tym zakresie są symulacje dotyczące ewentualnej obrony przeciwrakietowej ${ }^{464}$. Wszystko to oznaczałoby ogromne wydatki niezbędne do osiągnięcia zamierzonych efektów, choć zapewne już bardziej realistyczne niż choćby w czasach „gwiezdnych wojen” z lat osiemdziesiątych.

464 Th. G. Roberts, Space-Based Missile Defense: How Much Is Enough?, „Aerospace Security, Center for Strategic \& International Studies", 13.03.2019, https://aerospace.csis. org/data/space-based-missile-interceptors/. 
Po trzecie, realia operacyjne. W tym wymiarze sytuacja także się zmienia, choć wciąż nie fundamentalnie. Współczesna technika nadal nie potrafi zapewnić satelitom odpowiedniego wzmocnienia konstrukcyjnego ani ukryć je w sposób wystarczający. Wprawdzie technologie obniżonej wykrywalności istnieją, ale mają one ograniczone zastosowanie do tak wyeksponowanego obszaru, jakim jest orbita okołoziemska. Ułatwieniem jest jedynie fakt, że współczesne kosmiczne systemy bojowe składać by się mogły $\mathrm{z}$ megakonstelacji, które z natury rzeczy są trudnym celem, ponieważ wymagają znacznej ilości środków przechwytujących do ich wyeliminowania. To z kolei utrudniłoby ewentualną walkę systemom ASAT i wymagałoby zbudowania i rozmieszczenia ich w znacznej ilości oraz zadbanie o odpowiednio dużą szybkostrzelność. Niemniej jednak istnieją relatywnie proste metody masowego oślepiania satelitów, w postaci wybuchów termojądrowych w wysokich warstwach atmosfery lub na niskich orbitach, które mogłyby tworzyć chmury zakłóceń uniemożliwiających lub znacznie utrudniających walkę systemom kosmicznym wszelkiego typu.

Drugim zasadniczym typem broni kosmicznej są systemy przeciwsatelitarne bazowania kosmicznego, ale one zostały już omówione w poprzednim rozdziale przy okazji analizowania współczesnych zagrożeń bezpieczeńst wa w kosmosie. Stwierdziliśmy, że ich zbudowanie jest prawdopodobne, obserwuje się ponadto próby technologii, które mogłyby być przydatne $w$ tego typu broni, dokonywane zarówno przez Chiny ${ }^{465}$, jak i Rosję̨66. Pamiętajmy jednak, że większość rozważań dotyczących charakterystycznych cech broni kosmicznych przedstawionych w akapitach powyżej odnosi się i do tego typu uzbrojenia. Dla odpowiedniej skuteczności wymagają one znacznych konstelacji, kosztownych i niewątpliwie niełatwych do opracowania, a jednocześnie wrażliwych na atak, ponieważ ich przeznaczenie będzie na ogół znane przeciwnikowi.

Podsumujmy. Broń kosmiczna służąca do walki z celami na ziemi/morzu, w powietrzu i na trajektoriach balistycznych, jeśli zostanie rozmieszczona, będzie miała znaczną przewagę w wielu sytuacjach, niemniej

465 Challenges to Security in Space, U.S. Defense Information Agency, January 2019, s. 21, https://www.dia.mil/Portals/27/Documents/News/Military\%20Power\%20Publica tions/Space_Threat_V14_020119_sm.pdf.

t66 Ibidem, s. 29. 
jednak realia techniczno-ekonomiczno-operacyjne powodują, że współcześnie ma ona wciąż wątpliwą wartość. Mimo to jednak rozważa się jej skonstruowanie, podobnie jak rozważa się rozmieszczenie uzbrojenia kosmicznego do walki w kosmosie, czyli środków przeciwsatelitarnych bazowania kosmicznego. W tym ostatnim przypadku niektóre podstawowe metody prowadzenia działań przeciwsatelitarnych przez pojazdy orbitalne są już wstępnie testowane przez główne mocarstwa kosmiczne.

Państwa rozmieszczające broń kosmiczną muszą jednak liczyć się z tym, że najprawdopodobniej zrobi to także przeciwnik. Muszą zatem jednocześnie stworzyć efektywne systemy ASAT i rozmieścić je ze świadomością, że wróg także uczyni to samo. Uruchomione zostałyby zatem niewątpliwie dwa nierozerwalnie powiązane ze sobą wyścigi zbrojeń. Pierwszy to broń kosmiczna służąca do ataków na cele naziemne, powietrzne i balistyczne vs taka sama broń kosmiczna, czyli powtórka ze strategicznego wyścigu zbrojeń nuklearnych z czasów zimnej wojny. Polegałoby to na rozmieszczaniu coraz to nowszych i liczniejszych konstelacji broni, by zwiększyć zagrożenie zasobów naziemnych przeciwnika, który oczywiście robiłby to samo. Drugi zaś wyścig zbrojeń w sytuacji rozmieszczenia broni satelitarnych to systemy ASAT wszelkiego typu vs broń kosmiczna, czyli, kontynuując zimnowojenną analogię, wyścig środków strategicznej obrony przeciwlotniczej/przeciwrakietowej i ofensywnych środków napadu powietrznego. Oznaczałoby to rozmieszczanie kolejnych generacji systemów obronnych mających wyeliminować broń kosmiczną adwersarza, zarówno tę przeznaczoną do ataków na cele naziemne/powietrzne/balistyczne, jak i realizującą funkcje ASAT. Przeciwnik oczywiście będzie robił to samo.

A zatem, w bardziej praktycznych kategoriach, jeśli broń kosmiczna w ogóle się pojawi, zapewne w pierwszej kolejności będzie to uzbrojenie przeciwsatelitarne bazowania kosmicznego. Prawdopodobnie będą to najpierw relatywnie proste satelity-samobójcy lub ewentualnie orbitery zdolne do uwalniania niewielkich obiektów, które będą niszczyć satelity przeciwnika energią kinetyczną uderzenia, ewentualnie wspartą niewielkim ładunkiem wybuchowym. W tym ostatnim przypadku pociski mogą albo mieć napęd, dzięki czemu samodzielnie zmienią orbitę i zaatakują cel, albo też zostaną niejako „wystrzelone” na określoną trajektorię spotkania z celem i zbliżając się do niego, wykonają sekwencję samonaprowadzania. 
Jednak w przypadku pojawienia się takich broni w arsenale jednego mocarstwa druga strona, co oczywiste, natychmiast zrobi wszystko, aby przeciwdziałać zagrożeniu. Już zatem w chwili otrzymania wiarygodnych informacji o budowie orbitalnej broni przeciwsatelitarnej „po drugiej stronie" rozpoczną się prace zarówno nad asymetryczną, jak i symetryczną odpowiedzią. Pierwsza kontrakcja polegać będzie na opracowaniu technik negujących broń przeciwsatelitarną bazowania kosmicznego w postaci aktywnych i pasywnych środków samoobrony satelitów, o czym już faktycznie się myśli w USA ${ }^{467}$. Druga zaś forma przeciwdziałania to opracowanie i rozmieszczenie własnych systemów orbitalnych i naziemnych mających zagrozić satelitom przeciwnika.

Opisany mechanizm zadziała ze zwielokrotnioną mocą w sytuacji, jeśli w dalszej przyszłości rozpocznie się opracowywanie systemów broni kosmicznych przeznaczonych do atakowania celów naziemnych/ powietrznych/balistycznych. Jest to raczej odległa perspektywa, chyba że pojawią się trudne dziś do przewidzenia przełomy technologiczne. Mógłby nim być na przykład efektywny napęd wielośrodowiskowy, który umożliwiłby skonstruowanie „samolotu kosmicznego”. Obiekt taki poruszałby się w powietrzu, a jednocześnie byłby zdolny do wejścia na orbitę i manewrowania tam z większą swobodą, niż czynią to współczesne satelity - jest to jednak melodia przyszłości, choć koncepcje takich napędów istnieją.

Argumenty „za” tworzeniem broni kosmicznych

W debacie na temat czynnej militaryzacji kosmosu, która toczy się w Stanach Zjednoczonych, przedstawia się szereg argumentów na rzecz podjęcia takiego kierunku rozwoju spacepower. Byłoby to radykalne odejście od zasady sanctuary, która była motywem przewodnim całej polityki USA od czasów Eisenhowera i która do dziś kształtuje amerykańską politykę bezpieczeństwa kosmicznego, a zatem i stan amerykańskiej spacepower. W ujęciu syntetycznym główne motywy, jakie się przytacza, racjonalizując taki krok, są następujące.

46- US Air Force: „Rodzime satelity potrzebujq zdolności samoobrony”, Space24, 28.02.2019, https://www.space24.pl/us-air-force-rodzime-satelity-potrzebuja-zdolnosci-samoob rony. 
Po pierwsze, podstawowy argument jest oczywiście taki, że bronie kosmiczne będą w stanie, przynajmniej w teorii, wykonać wiele misji bojowych lepiej niż tradycyjne, będą mogły także wykonywać zadania dotychczas niemożliwe, na przykład zwalczanie pocisków balistycznych już w fazie ich startu ${ }^{468}$. Będą zatem użyteczne ze strategicznego punktu widzenia, zarówno jako czynnik odstraszania, jak i środek prowadzenia walki.

Po drugie, historia dowodzi, że nie da się powstrzymać rozwoju uzbrojenia - pojawiające się nowe technologie prędzej czy później znajdują się na polu walki. Wprawdzie w czasie zimnej wojny niektóre technicznie wykonalne rodzaje broni nie powstały, ale tylko dlatego, że prosty, dwubiegunowy układ sił umożliwiał w pewnych okolicznościach takie samoograniczenie stron konfliktu. Współcześnie jednak strategiczna równowaga jest znacznie bardziej złożona, ponieważ więcej podmiotów ma dostęp do ważnych technologii wojskowych. Niektóre z państw, które należy tu wziąć pod uwagę, są w dodatku mało przewidywalne bądź wręcz niestabilne, uwzględnić należy także aktorów niepaństwowych. Dylematy bezpieczeństwa, przed którymi stoją uczestnicy stosunków międzynarodowych, są zatem bardziej skomplikowane, a logika braku zaufania i wielostronnej podejrzliwości w stosunkach międzynarodowych nieuchronnie prowadzi do wykorzystania każdej okazji do tworzenia militarnych przewag, czy to z agresywnych, czy też defensywnych pobudek. W związku z tym broń kosmiczna powstanie dlatego, że jest możliwa, i jest to w pewnym sensie naturalne. A zatem, co oczywiste, Ameryka musi ją opracować pierwsza, ponieważ, jak chcą niektórzy, „[w]yścig kosmiczny XXI wieku już trwa [...]”469, nie można więc zostać w tyle.

Po trzecie, uzyskanie przez USA przewagi w kosmosie dzięki opracowaniu broni kosmicznych wpłynie na stabilizację przestrzeni międzynarodowej. Jest to tradycyjny pogląd, wypowiadany między innymi przez Everetta Dolmana, który przyznaje, że militarna hegemonia USA w kosmosie będzie przedmiotem kontestacji innych państw, lecz nie podejmą

468 J. Judson, Space-based Laser Weapons Could Ultimately Take Out Missile Threats in Boost Phase, Defense News, 14.08.2018, https://www.defensenews.com/digital-showdailies/smd/2018/o8/14/space-based-laser-weapons-could-ultimately-take-out-mis sile-threats-in-boost-phase/.

469 Kongresman Micheal Waltz dla „Foreign Policy”: L. Seligman, "The 21st-Century Space Race Is On', „Foreign Policy”, 10.04.2019, https://foreignpolicy.com/2019/04/10/ the-2ist-century-space-race-is-on-michael-waltz-space-force/. 
one realistycznych przeciwdziałań, ponieważ nie będą w stanie wygenerować sił i środków po temu ${ }^{470}$. Ten sposób podtrzymania stabilności poprzez siłę jest częstym argumentem $w$ ramach myślenia realistycznego. Tym chętniej jest on podejmowany, im słabsza jest Ameryka w stosunku do tak zwanej reszty świata, a w szczególności wobec swoich najważniejszych globalnych konkurentów.

Po czwarte, przewaga USA w kosmosie maleje, co ma znane nam poważne konsekwencje. W związku z tym koncentracja na opracowaniu broni kosmicznej może mieć wiele pozytywnych skutków, niejako ubocznych. Po pierwsze, zapewni to znaczny rozwój nowoczesnych technologii, po drugie spowoduje radykalny i szybki przyrost nowych zupełnie zdolności kosmicznych, po trzecie, w ramach pracy nad bronią kosmiczną opracuje się i ofensywne, i defensywne techniki, które będą mogły sprzyjać obronie systemów satelitarnych skuteczniej niż dotychczasowa praktyka sanctuary. Inaczej mówiąc, przewiduje się zaplanowany skok technologiczny, podobny do tego $\mathrm{z}$ lat siedemdziesiątych i osiemdziesiątych, kiedy to aplikowano nowe technologie i utrwalano jakościową przewagę amerykańskiego oręża, czego ikonami były GPS, pociski manewrujące i noktowizja, tak wyeksponowane w czasie pierwszej wojny w Zatoce Perskiej.

Po piąte, nie należy także zapominać o interesach kompleksu wojskowo-przemysłowego, który przymierza się do nowych dochodów, ale jednocześnie ma argumenty w postaci konieczności utrzymania miejsc pracy, podtrzymania i modernizacji amerykańskiej bazy przemysłowej. Innymi słowy, pomnażanie spacepower w ujęciu wojskowym poprzez przenoszenie jej w kolejne wymiary to nie tylko proste zwiększanie siły militarnej USA, ale także praca na rzecz kompleksowego rozwoju Ameryki.

I wreszcie po szóste, niebagatelne są kwestie polityczne, będące w dużej mierze pokłosiem powyższych rozważań, które sprowadzają się do intensywnego promowania w przestrzeni publicznej i politycznej przekonania o zagrożeniu, wynikającym ze spadku przewagi technologicznej USA i rozrostu możliwości militarnych przeciwników ${ }^{41}$. Istnieje na ten

470 Por. na przykład E. C. Dolma n, H. F. Cooper, Jr., Increasing the Military Uses of Space, [w:] Toward a Theory of Spacepower..., s. 381-382.

47 Por. na przykład B. Lendon, China Could Overwhelm US military in Asia in Hours, Australian Report Says, CNN, 20.08.2019, https://edition.cnn.com/2019/08/20/asia/ australia-china-us-military-report-intl-hnk/index.html. 
temat wiele sążnistych raportów instytucji rządowych ${ }^{472}$, a także rozmaitych think tanków ${ }^{473}$. Bez względu na to, na ile przedstawiane fakty odpowiadają rzeczywistości, stają się one rzeczywistością dla społeczeństwa, które gotowe jest wierzyć w istnienie space gap, na wzór bomber gap i missile gap z lat pięćdziesiątych, mogącej doprowadzić do „kosmicznego Pearl Harbor"474. Jest to notabene jeden z elementów szerszej argumentacji, daje się bowiem zaobserwować kolejne podobne zjawiska w postaci postrzegania cyber capabilities gap ${ }^{475}$ i hypersonics gap ${ }^{476}$.

Podsumowując, można powiedzieć, że istnieje silna motywacja, wsparta rozległą argumentacją, do rozpoczęcia poważnych prac nad broniami kosmicznymi. Eksploatuje się przy tym nie tylko motywy dotyczące klasycznych pojęć z zakresu bezpieczeństwa narodowego postrzeganych w duchu silnie realistycznym. Mniej może eksponowane, ale bardzo nośne są argumenty ekonomiczne dotyczące ogólnych perspektyw rozwojowych kraju. Wszystko to pada na podatny grunt społeczny i polityczny, publiczność jest coraz bardziej przestraszona, co nakłada się na lęki i frustracje wynikające $z$ obaw o indywidualny byt w sytuacji coraz bardziej niestabilnej gospodarki.

Ostatecznie - taki jest zasadniczy wniosek z powyższych argumentów - z punktu widzenia kluczowych amerykańskich interesów i amerykańskiej spacepower, czyli dla utrzymania korzyści z eksploatacji kosmosu, należałoby i tak nieuchronne powstanie broni kosmicznej przyspieszyć i natychmiast objąć prowadzenie w nowym wyścigu zbro-

472 Por. na przykład Annual Report to Congress: Military and Security Developments Involving the People's Republic of China 2019, U.S. Department of Defense, 2019, https://me dia.defense.gov/2019/May/02/2002127082/-1/-1/1/2019\%20CHINA\%20MILITARY\%20 POWER\%20REPORT\%2o(1).PDF lub Challenges to Security in Space...

473 Por. na przykład T. Harrison, K. Johnson, T. G. Roberts, op. cit.

474 Funkcjonujące przynajmniej od dwóch dekad pojęcie odnoszące się do ewentualnego zaskakującego i obezwładniającego ataku na amerykańską infrastrukturę kosmiczną, por. na przykład Report of the Commission to Assess United States National Security Space Management and Organization. Executive Summary, U.S. Congress, 11.01.2001, https://fas.org/spp/military/commission/executive_summary.pdf.

475 M. Hutchison, F. Waage, D. Bennett, Cyber Resiliency: Bridging a Cyber Capabil-

ity Gap in 2025, "Small Wars Journal”, 2019, https://smallwarsjournal.com/jrnl/art/ cyber-resiliency-bridging-a-cyber-capability-gap-in-2025.

476 Por. M. Czajkowski, Hypersonic Missiles - a Political Multipurpose Weapon, „Analizy ZBN UJ" 2019, vol. 43, nr 4, 15.03.2019, http://www.zbn.inf.uj.edu.pl/analizy. 
jeń. Aby zapobiec „kosmicznemu Pearl Harbor”, należy zatem podjąć działania uprzedzające, które albo w ogóle zniechęcą przeciwników do militaryzacji czynnej, a zatem USA pozostaną zbrojnym strażnikiem wolności kosmosu, albo też konkurenci podejmą wyścig, ale od samego początku będą pozostawać na straconych pozycjach. W każdym wypadku adwersarze nie będą już zagrażać przewadze USA, które w przyszłości zdolne będą wygrać każdą wojnę w kosmosie, tak jak obecnie mogą to uczynić na Ziemi. To z kolei zapewni odpowiedni poziom odstraszania przed ewentualnym podjęciem zamachu na amerykańską infrastrukturę kosmiczną.

Argumenty „przeciw” tworzeniu broni kosmicznych

Powyższe argumenty są głęboko zakorzenione w myśleniu realistycznym i w ramach tego paradygmatu wydają się bardzo mocne. Istnieją jednak i inne poglądy na problematykę broni kosmicznej, sięgające do odmiennych szkół myślenia, ponadto można i w ramach realizmu znaleźć powody, by negować sens tworzenia tego typu uzbrojenia. Syntetycznie można argumenty te sklasyfikować w ramach następujących tematów.

Po pierwsze, najważniejsze jest to, że jeśli broń kosmiczna zostanie zbudowana, to może także zostać użyta, co oznacza zanieczyszczenie orbit różnego rodzaju szczątkami. Jest to tym bardziej prawdopodobne, że weaponizacja kosmosu pociągnie za sobą automatycznie raczej szybki rozwój broni przeciwsatelitarnej bazowania naziemnego. Prawdopodobieństwo wywołania efektu Kesslera w wyniku użycia broni w kosmosie jest ponadto tym wyższe, im więcej tej broni będzie się tam znajdować. W takiej sytuacji straty, być może niepowetowane, poniosą wszystkie strony ewentualnej wojny czy innego rodzaju konfliktu, a w dodatku dojdzie do strat gospodarczych na globalną skalę, być może nawet będą one miały formę głębokiej recesji z niemożliwymi do przewidzenia skutkami. Co więcej, degradacja orbit nie musi wynikać z wojny w kosmosie, może zdarzyć się przypadkiem, jest bowiem całkowicie pewne, że każda broń zawodzi i zawsze są możliwe wypadki z jej udziałem. Można zatem prędzej czy później spodziewać się dysfunkcyjnych satelitów wojskowych eksplodujących na orbitach lub przypadkowo atakujących realne cele w ramach ćwiczeń lub poza nimi. Świadomość tych faktów może działać 
mitygująco na główne mocarstwa kosmiczne, mamy więc logicznie uzasadnioną interesami państw i korzyściami ekonomicznymi motywację do ograniczenia zbrojeń.

Po drugie, broń kosmiczna nie przyczyni się do zdobycia jakiejkolwiek przewagi, lecz będzie miała efekt destabilizujący. Przede wszystkim dlatego, że nadzieja, iż Ameryka technologicznie ponownie oddali się od swoich głównych rywali, jest iluzoryczna. Przeciwnicy zrobią wszystko, aby ewentualne nowe przewagi USA wynikające $z$ rozmieszczenia broni kosmicznych zniwelować symetrycznymi i asymetrycznymi środkami. Już dziś zresztą tak czynią, antycypując rozwój wydarzeń. Wysoce prawdopodobne jest zatem to, że rozwijając broń kosmiczną, kosztem ogromnego wysiłku otrzymamy w ciągu dekady lub dwóch kolejną wersję równowagi strategicznej, tym razem w kosmosie, w dodatku do tradycyjnej równowagi wzajemnego zniszczenia przy użyciu broni jądrowej. Powrócą zatem wszystkie niebezpieczne rozważania o counterforce i countervalue 477 oraz pokusy $w$ rodzaju use it or lose it. $\mathrm{Z}$ tą jednak poprawką, że nowa wersja równowagi strategicznej będzie znacznie groźniejsza, ponieważ broń będzie działać szybciej i bardziej nieuchronnie. W związku z tym, w razie kryzysu bądź eskalacji, rządy będą miały większy problem z odpowiednio szybką interpretacją zamiarów przeciwnika, większa będzie zatem presja na podjęcie działań, zanim będzie za późno.

Po trzecie, wskazaliśmy już na czynniki, które powodują, że broń kosmiczna z przyczyn operacyjnych jest niepraktyczna z powodu jej wrażliwości na zniszczenie i dlatego, że jej skonstruowanie i rozmieszczenie byłoby niewątpliwie bardzo kosztowne. Te cechy są ewidentnym argumentem przeciwko budowie broni kosmicznych, ponieważ „[...] utrzymywanie zagrożenia dla celów kosmicznych jest znacznie łatwiejsze i tańsze niż ich obrona [...]" ${ }^{478}$, co powoduje również, że systemy satelitarne w funkcji defensywnej będą całkowicie nieefektywne ${ }^{479}$.

I wreszcie po czwarte, inną stroną tego medalu jest fakt, że wiele klasycznych, lecz znacznie tańszych i praktyczniejszych w użyciu systemów

477 Znane ze strategii nuklearnej terminy oznaczające odpowiednio: działania przeciwko ofensywnemu zbrojeniu przeciwnika (na przykład bazy lotnictwa strategicznego lub silosy ICBM) oraz działania przeciwko wartościowym dla niego celom (na przykład centra populacyjne lub ośrodki gospodarcze).

478 J. P. Finch, op. cit., s. 18.

479 Y. Butt, op. cit. 
uzbrojenia wykona określone zadania niewiele gorzej ${ }^{480}$. Oczywiście w niektórych sytuacjach broń kosmiczna może dać kluczową przewagę jej dysponentowi, ale pytanie o jej efektywność sprowadza się do szerszych kwestii: w ilu konkretnych misjach broń kosmiczna będzie radykalnie lepsza, w ilu znacznie lepsza, w ilu trochę lepsza, a w ilu jej użycie nie przyniesie żadnych korzyści. Należy zatem bardzo ostrożnie przekalkulować relację kosztu i efektywności zarówno w wymiarze ekonomicznym, jak i operacyjnym, biorąc pod uwagę bardzo wiele różnych czynników.

Podsumowując, w dyskusji nad bronią kosmiczną argumenty przeciwko jej rozmieszczaniu sprowadzają się przede wszystkim do kwestii praktycznych, związanych z realiami operacyjnymi oraz kosztami, a także do problematyki bezpieczeństwa międzynarodowego. Uznaje się, że potencjalne korzyści w czysto wojskowym wymiarze nie przeważą kosztów i nie uzasadniają ryzyka destabilizacji równowagi strategicznej oraz prawdopodobieństwa utraty możliwości korzystania z części bądź całości przestrzeni okołoziemskiej.

\section{Podsumowanie i prognoza}

Rozważając militaryzację kosmosu i jej ewentualną przyszłą ewolucję, można przyjąć wiele perspektyw w celu przeprowadzenia oceny. Można także dokonywać jej na kilku poziomach związanych z charakterem tejże militaryzacji. Nie wnikając $w$ inne kwestie, przyjmiemy perspektywę interesów bezpieczeństwa narodowego USA, tak jak definiują je najbardziej podstawowe dokumenty i tak jak je się na ogół postrzega w literaturze. Zajmiemy się przy tym, zgodnie z tematyką niniejszego podrozdziału, militaryzacją czynną. Inaczej mówiąc, zastanowimy się nad tym, w jaki sposób ewentualne umieszczenie broni na orbicie okołoziemskiej przez Stany Zjednoczone przyczyni się do zwiększenia bądź zmniejszenia poziomu bezpieczeństwa narodowego USA, postrzeganego z punktu widzenia najbardziej żywotnych interesów Ameryki.

180 Naprzykładzieobrony przeciwrakietowej por. na przykład Th. G. Robert s, Why a Space-based Missile Interceptor System Is Not Viable, "Bulletin of the Atomic Scientists” 2018, vol. 74, $\mathrm{nr} 4$, https://www.tandfonline.com/doi/full/10.1080/00963402.2018.1486597. 
Pierwszym i najważniejszym punktem odniesienia, jaki należy w tym miejscu przyjąć, jest to, co często powtarzamy, czyli fakt ogromnego uzależnienia bezpieczeństwa USA od niezakłóconej pracy systemów kosmicznych. Bez względu na to, na ile amerykańska przewaga spada i w jakim tempie, zarówno dziś, jak i w dającej się przewidzieć przyszłości systemy kosmiczne pozostaną kluczem do efektywnego działania sił zbrojnych USA i wykonywania przez nie misji bojowych i niebojowych. Dotyczy to w pierwszej kolejności ich funkcji podstawowych, czyli obrony terytorium kraju, zagranicznych interesów Ameryki oraz jej sojuszników poprzez odstraszanie, rozszerzone odstraszanie, a w razie potrzeby poprzez prowadzenie działań zbrojnych. Również w funkcji wspierania polityki zagranicznej siły zbrojne realizują rozległe zadania, powiązane zresztą funkcjonalnie $\mathrm{z}$ wcześniej wymienioną funkcją podstawową i tu także stosowanie systemów kosmicznych jest jednym $\mathrm{z}$ podstawowych czynników skuteczności działań.

W związku z powyższym można bez przesady powiedzieć, że skuteczne i niezakłócone działanie systemów kosmicznych jest jednym z podstawowych czynników bezpieczeństwa USA i skuteczności polityki zagranicznej kraju. Niebagatelne są też kwestie gospodarcze, ponieważ systemy kosmiczne bezpośrednio i pośrednio przynoszą dochody wielu amerykańskim przedsiębiorstwom i pracującym w nich ludziom, niezbędne są ponadto do funkcjonowania współczesnego społeczeństwa. Powtarzaliśmy te kwestie wielokrotnie, trzeba jednak w tym miejscu jeszcze raz z całą mocą podkreślić, że jakiekolwiek zagrożenie dla systemów kosmicznych, bez względu na to, z jakiego kierunku mogłoby się pojawić i jaki miałoby charakter, stanowi niezwykle poważną groźbę dla podstawowych interesów bezpieczeństwa oraz ekonomicznych i społecznych Stanów Zjednoczonych. Ameryka musi więc zrobić wszystko, aby zapewnić bezpieczeństwo w kosmosie, i to nie tylko systemom własnym, ale także należącym do innych krajów, z powodu znanych nam realiów związanych z możliwością degradacji niektórych orbit, a nawet wystąpienia efektu Kesslera.

W świetle powyższego Stany Zjednoczone powinny przede wszystkim starać się, aby nie powstały bronie przeciwsatelitarne, jest to podstawowa i pierwotna kwestia. Z punktu widzenia USA kosmos nie może przekształcić się w strefę otwartej walki, choć jednocześnie należy dostrzec, że już nią w pewnym zakresie jest. Toczy się ona jednak jak dotąd za 
pomocą nieniszczących metod, choć może oczywiście także spowodować niepożądane skutki w postaci sporadycznego niszczenia lub fizycznego uszkadzania orbiterów. Jest to jednak znacznie mniej prawdopodobne, niż gdyby gdziekolwiek w świecie pojawiała się doktryna i wola polityczna zastosowania niszczącej broni przeciwsatelitarnej. Inaczej mówiąc, w chwili kiedy rozpowszechnią się systemy ASAT bazowania naziemnego, pojawi się automatycznie istotne ryzyko, że zostaną one użyte, nawet w ramach niechcianej eskalacji lub w wyniku manipulacji, prowokacji, bądź sabotażu. Taki scenariusz byłby dla Stanów Zjednoczonych bardzo niekorzystny, więc jak dotąd odżegnują się one od intencji produkcji i rozmieszczania takiego uzbrojenia, aby nie wywoływać wyścigu zbrojeń w tym zakresie. Stąd też częste zapewnienia, że BMDS nie jest bronią przeciwsatelitarną i nie ma taką być.

Wydaje się ponadto, że mimo twierdzeń pojawiających się w różnych raportach i enuncjacjach politycznych, jakoby konkurenci Ameryki, czyli Chiny i Rosja, uczynili już z kosmosu warfighting domain ${ }^{4{ }^{8}}$, w istocie nie odzwierciedla to rzeczywistych intencji tych krajów - nie dążą one raczej do zniszczenia systemów satelitarnych Stanów Zjednoczonych. Zarówno ChRL, jak i FR prowadzą wprawdzie wspomniane już badania rozwojowe, być może nawet są gotowe do bojowego rozmieszczenia systemów przeciwsatelitarnych bazowania naziemnego, niemniej jednak w ich interesie nie leży uruchamianie wyścigu zbrojeń w tej dziedzinie. Po pierwsze dlatego, że byłby on bardzo kosztowny, oba kraje mają dość innych kłopotów i wydatków. Po drugie dlatego, że wyścig taki byłby przegrany już na starcie, ponieważ Amerykanie mają bardzo rozbudowany system przeznaczony do walki w kosmosie w postaci BMDS, który można łatwo dostosować do zwalczania satelitów. Należy się spodziewać, że w takiej funkcji będzie się on charakteryzował znaczną skutecznością, a rozwijane dziś jego nowe komponenty będę jeszcze bardziej efektywne. Po trzecie wreszcie, w przypadku posiadania przez wszystkie strony rozbudowanych broni przeciwsatelitarnych w sytuacji kryzysu lub konfliktu wszyscy jego uczestnicy w krótkim czasie pozbawiliby się nawzajem zdolności satelitarnych. Mogłoby to także nastąpić w wyniku niechcianej eskalacji, która sama z siebie mogłaby nawet mieć niewielką skalę, ale i tak byłaby w sta-

+8I Por. na przykład President Donald J. Trump Is Unveiling... 
nie wywołać efekt Kesslera przynajmniej dla niektórych orbit. Być może, gdyby coś takiego się wydarzyło dziś, Stany Zjednoczone byłyby bardziej poszkodowane niż na przykład Chiny. Ale to się może niebawem zmienić, ponieważ Państwo Środka bardzo szybko rozwija swoje zdolności kosmiczne niezbędne do popierania swojej globalnej polityki zagranicznej i rozszerzającej się polityki bezpieczeństwa oraz z przyczyn ekonomicznych i prestiżowych. Można zatem zaryzykować tezę, że i Rosja, i Chiny są, podobnie jak USA, uzależnione w ramach swoich podstawowych interesów od własnych systemów kosmicznych i stan ten będzie się pogłębiać. Podobnie jak USA nie są zatem zainteresowane wejściem do użytku i rozpowszechnieniem broni przeciwsatelitarnej bazowania naziemnego. Ich prace rozwojowe $w$ tej materii można uznać jedynie za swego rodzaju polisę ubezpieczeniową na przyszłość oraz komunikat dla USA, sugerujący istnienie faktycznego parytetu w zdolnościach przeciwsatelitarnych, lub też, że mógłby on powstać. Warto pamiętać, że aby takowy parytet zaistniał, Chińczycy czy Rosjanie nie muszą mieć tylu zaawansowanych broni przeciwsatelitarnych co USA, muszą tylko mieć ich wystarczająco dużo, by spowodować znaczne straty w kluczowych amerykańskich systemach kosmicznych.

W podsumowaniu tego wątku nieuchronnie nasuwa nam się przytaczany powyżej argument, że opracowanie i rozmieszczenie przez USA jakiejkolwiek broni kosmicznej natychmiast uruchomi asymetryczne i symetryczne odpowiedzi przeciwników, szczególnie Rosji i Chin. W pierwszej kolejności będzie to szybki rozwój broni przeciwsatelitarnej bazowania naziemnego, a w dalszym ciągu i broni kosmicznej. W rezultacie ziści się w sposób ostateczny i nieodwołalny śmiertelne zagrożenie dla amerykańskich systemów kosmicznych, a co za tym idzie - fundamenty skuteczności amerykańskiej strategii bezpieczeństwa i globalnej polityki państwa zostaną poważnie zagrożone.

A zatem, odpowiadając na zasadnicze, postawione powyżej pytanie, należy stwierdzić, że tworzenie i rozmieszczanie broni kosmicznych nie leży w interesie Stanów Zjednoczonych. I odnosi się to bez wyjątku i do broni przeciwsatelitarnej, i do przeznaczonej do rażenia celów naziemnych, powietrznych i balistycznych. A to dlatego, że abstrahując już od kosztów, trudności technicznych i niewątpliwego długiego czasu powstawania takich broni, sama deklaracja zamiaru ich rozwinięcia i podjęcie poważnych prac w tym kierunku natychmiast wywoła efekty opisane 
powyżej, czyli szybki rozwój ASAT wszelkich wersji ze wszystkimi. To z kolei postawi pod znakiem zapytania żywotność kluczowych zdolności militarnych USA.

Rozwiązaniem kwestii bezpieczeństwa w kosmosie nie są zatem tradycyjne militarne środki, lecz wielokierunkowe działania na rzecz bezpieczeństwa wrażliwego środowiska kosmicznego, jak przekonująco argumentuje James Clay Moltz w swojej klasycznej książce ${ }^{4^{82}}$ i na co wskazują inni eksperci, na przykład dyplomaci zaangażowani w kwestie związane $\mathrm{z}$ wykorzystaniem kosmosu ${ }^{4^{8}}$. I z takiego też punktu widzenia problem broni kosmicznej winien być w pierwszej kolejności postrzegany. W tym kontekście uważamy zatem, że dla Stanów Zjednoczonych najbardziej logiczną i korzystną polityką jest solenne wyrzeczenie się broni kosmicznych i zaangażowanie dyplomatyczne na rzecz wypracowania odpowiednich rozwiązań międzynarodowych, które miałyby na celu powszechne bezpieczeństwo systemów kosmicznych z jednej strony, a z drugiej - kontynuowanie działań na rzecz zwiększenia przeżywalności systemów kosmicznych. Nie są to nowe propozycje ${ }^{484}$, lecz wciąż aktualne. Uważamy, że USA winny iść właśnie $w$ tym kierunku, który jest bardziej zgodny $\mathrm{z}$ ich interesami niż pogłębianie militaryzacji kosmosu.

Warto przy okazji odnieść się do znanego argumentu zwolenników dalszej militaryzacji kosmosu mówiącego, że alokacja znacznych środków na rozwój nowych technologii miałaby pozytywny skutek w postaci przyspieszenia rozwoju technologicznego i utrzymania amerykańskiej czołowej pozycji w kosmosie. Jak wspominaliśmy, zwolennicy broni kosmicznych uważają, że inwestując w ten rodzaj uzbrojenia, można osiągnąć efekt podobny do gwałtownego skoku technologicznego dokonanego w latach siedemdziesiątych, a szczególnie osiemdziesiątych, swego rodzaju efekt "gwiezdne wojny 2.0". Te nadzieje zapewne spełniłyby się

482 J. C. Moltz, The Politics of Space Security: Strategic Restraint and the Pursuit for National Interests, Stanford 2011.

483 G. L. Schulte, A. M. Sch affer, Enhancing Security by Promoting Responsible Behavior in Space, „Strategic Studies Quarterly”, Spring 2012, s. 9-17, https://www.airuniversity. af.edu/Portals/10/SSQ/documents/Volume-o6_Issue-1/schulte.pdf.

${ }_{484}$ Por. na przykład obszerny raport: L. Grego, D. Wright, Securing the Skies: Ten Steps the United States Should Take to Improve the Security and Sustainability of Space, Union of Concerned Scientist, November 2010, https://www.ucsusa.org/sites/default/ files/legacy/assets/documents/nwgs/securing-the-skies-full-report-1.pdf. 
w pewnym zakresie, ale pełnej powtórki z przeszłości nie można się spodziewać. Dziś bowiem realia związane z kreacją najnowocześniejszych technologii, także tych przynoszących zwiększanie zdolności kosmicznych, są inne niż w czasie zimnej wojny. Przede wszystkim dlatego, że współcześnie znacznie większą rolę odgrywają cywilne centra rozwoju technologicznego, także te powiązane $\mathrm{z}$ największymi korporacjami pracującymi głównie na potrzeby cywilne, szczególnie w sektorze IT oraz kosmicznym. A zatem można bardzo łatwo wyobrazić sobie znaczny skok technologiczny w zakresie wykorzystania kosmosu, jeśli zamiast na wątpliwie skuteczne bronie kosmiczne Stany Zjednoczone alokują odpowiednie kwoty na badania cywilne. Dobrze dofinansowana NASA i inne państwowe instytucje wraz $z$ przemysłem prywatnym są niewątpliwie w stanie wygenerować potężny impuls dla rozwoju technologicznego, swego rodzaju efekt Apollo 2.o. Dziś skutki pozytywne byłyby zapewne jeszcze większe niż w latach sześćdziesiątych i siedemdziesiątych, ponieważ pozycja korporacji działających w przemyśle kosmicznym i ich osiągnięcia są takie, że miałyby one w tym partnerstwie o wiele silniejszą pozycję, niż mieli poddostawcy pierwszego programu księżycowego, tacy jak Grumman czy Boeing. Partnerzy prywatni mogliby zatem ukierunkować rozwój technologii kosmicznych i form organizacyjnych eksploracji kosmosu tak, aby oprócz bezpośrednich korzyści w postaci rozwoju techniki i postępu nauki jednocześnie generować większe zyski i nie dopuścić do marnotrawstwa, jakim było porzucenie programu Apollo. Wszystko działoby się bowiem z bardziej pragmatyczną, a mniej polityczną wizją. Można zatem wyobrazić sobie partnerską współpracę szczodrze finansowanej przez państwo NASA, z całym jej potencjałem nagromadzonej wiedzy i doświadczenia, z bogatymi firmami prywatnymi, takimi jak: SpaceX, Blue Orgin, Sierra Nevada czy Bigelow Aerospace. W efekcie mogłyby pojawić się misje dla superciężkich systemów startowych, takich jak duże platformy orbitalne, przyspieszyć mogłyby także zaawansowane badania astrofizyczne i planetologiczne. Także eksploracja załogowa mogłaby być szybciej rozwijana, a zatem szybki powrót ludzi na Księżyc stałby się bardziej prawdopodobny. Można by pokusić się i o podjęcie wyzwania eksploatacji asteroid, a nawet tworzenia stałych kolonii na Księżycu, a w dalszej kolejności na Marsie. W efekcie takich działań skok technologiczny, jakiego dokonałaby Ameryka, byłby niewątpliwie ogromny. Notabene ogólne koszty byłyby znacznie mniejsze, nie marnowano by 
bowiem pieniędzy na setki czy tysiące orbiterów megakonstelacji broni kosmicznych i dziesiątki tysięcy jednostek amunicji dla setek wyrzutni systemów przeciwsatelitarnych. Oczywiście nie sądzimy, aby taki scenariusz był szczególnie prawdopodobny w sensie politycznym, wskazujemy jedynie na bardziej rozsądną alternatywę dla koncepcji stymulowania rozwoju technologicznego poprzez finansowanie eksploatacji kosmosu zamiast niewiele wnoszących zbrojeń.

Do powyższych, zasadniczych ocen można dodać jeszcze inne ogólne, ważne uwagi dotyczące ewentualnej militaryzacji czynnej kosmosu. Dotyczą one niektórych szerszych kontekstów bezpieczeństwa międzynarodowego.

Po pierwsze, ewentualność, że w wyniku ataku przeciwsatelitarnego dojdzie do wywołania efektu Kesslera, może nie być wystarczająco przekonująca dla niektórych podmiotów. Ich ośrodki decyzyjne mogą albo nie wierzyć w taką możliwość, albo nie zwracać na nią uwagi. To ostatnie może w szczególności dotyczyć krajów, które są relatywnie najmniej uzależnione od systemów kosmicznych, albo też takich państw. Ponadto niektóre rządy mogą godzić się na ewentualne straty gospodarcze czy nawet zniszczenia wynikające $\mathrm{z}$ militarnego lub niemilitarnego odwetu innych uczestników stosunków międzynarodowych. W takich okolicznościach odstraszanie polegające na groźbie takiego właśnie odwetu w przypadku akcji przeciwko systemom satelitarnym USA może nie być wystarczające. Dlatego też nie można uniknąć modyfikacji sposobów przetrwania systemów satelitarnych i utrzymania przez nie funkcjonalności bez względu na to, czy główne mocarstwa rozwiną w istotny sposób systemy przeciwsatelitarne, czy też nie.

Po drugie, zniszczenie nawet wszystkich systemów kosmicznych w wyniku działań zbrojnych lub wywołanego nimi efektu Kesslera nie jest egzystencjalnym zagrożeniem dla jakiegokolwiek kraju, a tym bardziej dla całej ludzkości. Mimo ewentualnych strat gospodarczych i materialnych w postaci części infrastruktury krytycznej straty ludzkie byłyby zapewne niewielkie. To może być dodatkowym argumentem ułatwiającym decyzję o podjęciu rozwoju broni kosmicznych oraz broni przeciwsatelitarnych. Szczególnie jeśli weźmiemy pod uwagę tych uczestników stosunków międzynarodowych, którzy mają szczególne poczucie zagrożenia czy z innych powodów gotowi są na podjęcie ryzyka. 
Po trzecie, z punktu widzenia bezpieczeństwa międzynarodowego broń kosmiczna w sposób raczej nieunikniony zdestabilizuje równowage strategiczną ${ }^{485}$. Dotyczyć to będzie jednak nie tylko kosmosu, ponieważ to, co dzieje się na orbitach okołoziemskich, związane jest ściśle z ziemskim środowiskiem bezpieczeństwa, każda zaś jego destabilizacja będzie przyczyniała się do zmniejszenia ogólnego stanu bezpieczeństwa USA. Inaczej mówiąc, naruszenie równowagi $w$ ramach bezpieczeństwa $w$ kosmosie zsumowałoby się $\mathrm{z}$ innymi współcześnie zachodzącymi czynnikami destabilizacji. To z kolei sprzyjałoby dalszej erozji amerykańskiego globalnego przywództwa - ograniczenie roli Ameryki w świecie postępowałoby zatem jeszcze szybciej.

Po czwarte wreszcie, Stany Zjednoczone podejmują działania, które mogą być odczytane jako zaawansowane prace badawcze na temat broni bazowania kosmicznego ${ }^{486}$. To z kolei może oznaczać, że Stany Zjednoczone straciły już wiarę w możliwość utrzymania zasady sanktuarium w kosmosie lub też uznały ją za niekorzystną dla siebie, choć jeszcze tego jednoznacznie nie zadeklarowały. Inaczej mówiąc, możliwe, że zbrojenia w przestrzeni kosmicznej już się rozpoczęły, a wspomniane prace chińskie i rosyjskie są jedynie reakcją na ten fakt. Nie mamy jednak odpowiednio wiarygodnych informacji na ten temat, co zresztą naturalne, trudno więc o jednoznaczne wnioski.

Można zatem pokusić się o syntetyczne przestawienie pewnego rodzaju rekomendacji dla polityki USA w dziedzinie militaryzacji kosmosu, wynikające $z$ analizy ich własnych interesów w tym zakresie.

1. Należy w pierwszej kolejności jasno podtrzymywać deklarację, iż Ameryka nie zamierza budować jakichkolwiek systemów ASAT, a także zadeklarować, że USA podtrzymują politykę sanctuary w stosunku do kosmosu, a zatem nie będą rozwijać jakiejkolwiek broni orbitalnej. BDMS musi być nadal przedstawiany jako czysto defensywna broń przeciwrakietowa. Aby to ostatnie zapewnienie było wiarygodne, USA powinny zainicjować rozmowy o wszechstronnym ograniczeniu dotyczącym rakiet

485 Por. szczegółowe rozważania na ten temat: M. Czajkowski, Wpływ militaryzacji Kosmosu na globalnq równowagę strategicznq, „Krakowskie Studia Międzynarodowe” 2015, nr 1, s. 75-93.

486 S. Ghoshroy, The X-37B: Backdoor Weaponization of Space?, „Bulletin of the Atomic Scientists" 2015, vol. 71, nr 3, s. 19-29. 
balistycznych, a zatem i obrony przeciwrakietowej. Rozmowy takie na pewno będą trudne, potrwają lata, a ich wynik nie jest pewny, ale pomogą wykazać dobrą wolę Stanów Zjednoczonych i ich odpowiedzialne podejście do bezpieczeństwa.

2. USA powinny jednocześnie podjąć działania dyplomatyczne, mające na celu wzmocnienie prawa kosmicznego w kierunku całkowitej eliminacji broni kosmicznej i przeciwsatelitarnej - inaczej mówiąc, „[...] czas już na kontrolę zbrojeń w kosmosie" ${ }^{487}$. Bez względu na to, jak długo takie uregulowania by powstawały i jakie trudności by stały przed procesem negocjacyjnym, należy podjąć ten wysiłek. Trudności, o których mowa, to przede wszystkim potencjalne problemy $z$ weryfikacją ewentualnych postanowień dotyczących broni przeciwsatelitarnych bazowania naziemnego. Przy odpowiednim poziomie dobrej woli i zastosowaniu nowoczesnych środków technicznych nie byłoby to jednak, jak się zdaje, przeszkodą nie do pokonania.

3. Stany Zjednoczone powinny także, niejako tytułem zabezpieczenia, pracować nad niektórymi komponentami broni kosmicznej, lecz utrzymując raczej niskie zaawansowanie procesów badawczych. Trzeba bowiem pamiętać, że BMDS, nawet w wypadku jego ograniczenia, pozostanie wystarczająco skuteczny jako swego rodzaju polisa ubezpieczeniowa. Innymi słowy, może on natychmiast odpowiedzieć na kosmiczne Pearl Harbor, jeśli jakikolwiek kraj zdołałby w tajemnicy przygotować się do przeprowadzenia takiej operacji przeciwko Stanom Zjednoczonym.

4. USA muszą intensywnie pracować nad różnymi metodami wzmacniania, maskowania, zwiększania zdolności manewrowych i uodparniania na zakłócenia oraz cyberataki przeciwko satelitom wojskowym. Szczególnym środkiem winna być dezagregacja przyszłych generacji systemów wojskowych. Takie działania będą nie tylko dalszym zabezpieczeniem przeciwko niespodziankom ze strony obcych mocarstw. Dadzą także szansę na zniweczenie ograniczonych ataków przeprowadzanych przez wrogie państwo niebędące mocarstwem kosmicznym lub aktora niepaństwowego. Inaczej mówiąc, rozległe systemy, z natury bardzo trudne do wyłączenia bez znacznego potencjału środków negatywnego odziaływania mogą zniechęcić do ataków na nie ze względu na swoją istotę i własny sposób działania.

487 L. J. Korb, The Focus of US Military Efforts in Outer Space Should Be ... Arms Control, "Bulletin of the Atomic Scientists” 2019, vol. 75, nr 4, s. 149. 
Przenosząc nasze rozważania na plan prognostyczny, dostrzegamy podstawowe pytanie: czy broń kosmiczna powstanie, czy też nie? Odpowiedź jest oczywiście bardzo trudna, co wynika zresztą zarówno z rozważań niniejszego rozdziału, jak i z poprzednich. Mamy bowiem do czynienia ze splotem sprzecznych argumentów różnej wagi i znaczenia oraz jednoczesnych nacisków ze strony wielu wpływowych kół. W tle zaś znajdują się znane nam dobrze i trudne do prognozowania kwestie związane z percepcją bezpieczeństwa narodowego przez kluczowych uczestników stosunków międzynarodowych. Można zatem jedynie próbować zważyć znane za i przeciw i zanalizować je w świetle istniejących okoliczności, choć końcowy efekt pozostanie warunkowy i odwoływalny.

Wydaje się nam zatem, że rozmieszczenie kosmicznych broni w ilościach, które miałyby znaczenie, wraz z rozwinięciem odpowiedniej infrastruktury i stworzeniem doktryny inkorporującej nowy rodzaj uzbrojenia do strategii bezpieczeństwa narodowego nie nastąpi. USA nie zdobędą się na taki krok, mimo że mogą nim grozić lub nawet uczynić pewne gesty w tym kierunku. Stanie się tak przede wszystkim dlatego, że bronie kosmiczne są niepraktyczne, co wyznacza ich niska efektywność kosztowa $\mathrm{w}$ relacji do innych środków bojowych. $\mathrm{W}$ dodatku weaponizacja kosmosu zagraża bezpieczeństwu międzynarodowemu i narodowemu wszystkich krajów ze względu na jej destabilizujący potencjał. Taki jest, jak się zdaje, najbardziej prawdopodobny scenariusz najbliższej, dającej się przewidzieć przyszłości.

Szerzej mówiąc, sądzimy, że istnieją dwa najbardziej prawdopodobne warianty losu projektów broni kosmicznych. Pierwszy, najprostszy, jest taki, że po dłuższej i burzliwej dyskusji Waszyngton oficjalnie zrezygnuje z broni kosmicznych. Drugi, bardziej prawdopodobny, polega na tym, że nie przekreśli się definitywnie rozwoju uzbrojenia do bazowania na orbicie, lecz jedynie efektywnie zamrozi się jego rozwój. W takiej sytuacji $w$ ramach militaryzacji kosmosu będziemy mieli do czynienia tylko $\mathrm{z}$ istniejącymi dziś systemami ASAT bazowania naziemnego oraz z tymi, które powstaną w najbliższej przyszłości. Nie zostaną one jednak zadeklarowane $w$ doktrynie jako broń, nie zostaną wyprodukowane w znaczących ilościach i nie wejdą do powszechnego użycia. Kosmos pozostanie wtedy polem walki jedynie systemów nieniszczących i ewentualnie obrony przeciwrakietowej.

Pewnym, choć już mniej prawdopodobnym wariantem rozwoju sytuacji jest to, że zdrowy rozsądek jednak nie przeważy i poważne bada- 
nia nad bronią kosmiczną zostaną podjęte, choćby po to, aby zadowolić przemysł i wyborców. Jest jednak wysoce prawdopodobne, że będą one trwały bardzo długo, ze względu na stopień złożoności problemu i techniczne oraz finansowe wyzwania, które niewątpliwie się pojawią. Amerykański przemysł obronny jest ponadto dobrze znany z tego, że procesy badawczo-rozwojowe, choć prowadzą do perfekcyjnych rozwiązań, są jednak bardzo długotrwałe, a znaczne przekroczenia kosztów są normą. W efekcie przeciwnicy USA, a w szczególności Chiny i Rosja, będą w stanie rozmieścić znaczne ilości systemów przeciwsatelitarnych bazowania naziemnego, zanim jeszcze amerykańska broń kosmiczna powstanie. Szybki rozwój ASAT będzie zatem zmuszał konstruktorów broni kosmicznej do adaptacji, które pociągną za sobą kolejne koszty i czas, przeciwnik tymczasem także będzie się adaptował. Pojawi się zatem trudna do przyjęcia sytuacja polegająca na tym, że opracowywać się będzie bardzo drogą broń, która w teorii ma przynieść przewagę, w rzeczywistości zanegowaną jeszcze przed jej rozmieszczeniem. Taki, zdawałoby się, absurdalny obrót spraw jest całkiem możliwy, historia wojskowości zna podobne przypadki ${ }^{48}$. Notabene dowodziłoby to jeszcze wyraźniej niepraktyczności broni kosmicznych. W skrajnym przypadku mogłoby dojść do długotrwałego i zupełnie jałowego wyścigu pomiędzy opracowywaną i przepracowywaną przez dekady bronią kosmiczną a istniejącą i rozmieszczoną bronią przeciwsatelitarną kolejnych generacji. W tego typu scenariuszu najbardziej prawdopodobnym efektem byłoby ostateczne zarzucenie projektów uzbrojenia satelitarnego, z jedynym pozytywnym skutkiem w postaci opracowania pewnych użytecznych technologii. W takim wypadku pojawiłby się jednak ważny efekt negatywny, którym byłoby rozpowszechnienie systemów ASAT ze wszystkimi konsekwencjami tego stanu rzeczy.

Dla porządku należy jednak dodać, że mogą także nastąpić takie przełomy technologiczne, które zniweczą powyższe scenariusze i albo przyspieszą, albo opóźnią powstanie broni kosmicznych. Rozwój technologii

$488 \mathrm{Na}$ przykład ZSRR od 1970 roku pracował nad systemem strategicznej obrony przeciwrakietowej drugiej generacji A-135, który ostatecznie uruchomiono dopiero w 1995 roku. Tymczasem USA własny system o podobnych możliwościach wprowadziły do służby w 1975 roku, a następnie po kilku miesiącach, w lutym 1976 roku rozpoczęły jego demontaż, uznając, że jest niepraktyczny. Por. M. Czajkowski, Obrona przeciwrakietowa..., s. 127 i 131. 
5. STANY ZJEDNOCZONE A BEZPIECZEŃSTWO KOSMICZNE - WYBRANE PROBLEMY

jest w dłuższej pespektywie nieprzewidywalny, szczególnie że zawsze wiąże się z ekonomicznym i społecznym zapotrzebowaniem, które także ewoluuje w niekoniecznie przewidywalnych kierunkach. 


\section{Podsumowanie}

Przestrzeń kosmiczna, a w szczególności orbita okołoziemska, jest dziś dla ludzkości domeną rutynowej działalności. Prawie 9000 sztucznych obiektów wyniesionych dotychczas $w$ kosmos $^{489}, \mathrm{z}$ których prawie 2000 jest aktywnych, przynosiło i przynosi codzienne korzyści. Kosmiczne zastosowania są oczywistością do tego stopnia, że większość użytkowników na ogół nie wie, jak często pośrednio bądź bezpośrednio korzysta z aplikacji kosmicznych. Kosmiczna ekonomia jest już ściśle zintegrowana $\mathrm{z}$ gospodarką światową na wielu różnych płaszczyznach. W perspektywie są kolejne zastosowania, kolejne możliwości, rozwija się technika, dzięki której dostęp do aplikacji kosmicznych tanieje, rozpowszechniają się one zatem w coraz szybszym tempie.

Nie jest to jednak rozwój pozbawiony zagrożeń, sam jego dalszy przebieg nie jest gwarantowany. Specyfika mechaniki orbitalnej i sposobu wykorzystania przestrzeni okołoziemskiej powoduje, że „tuż za rogiem” czai się groźba egzystencjalna dla wszystkich kosmicznych zastosowań. Mowa oczywiście o potencjalnej degradacji niektórych orbit i utrudnieniu bądź uniemożliwieniu ich wykorzystania. W skrajnym wypadku można mówić o kosmicznym Armagedonie, w trakcie którego w krótkim czasie dojdzie do unicestwienia wszystkich systemów satelitarnych, ze wszystkimi tego konsekwencjami. Wprawdzie autorowi niniejszej pracy

4898704 według stanu z początku sierpnia 2019, według katalogu UNOOSA, za: Online Index of Objects Launched into Outer Space, UNOOSA, 2019, http://www.unoosa.org/ oosa/osoindex/search-ng.jspx. 
nie są znane jakiekolwiek szczegółowe matematyczne modele ewentualnego efektu Kesslera, pozostaje on zatem koncepcją wysoce teoretyczną, by nie rzec spekulatywną. Niemniej jednak, stosując podstawową logikę i przyjmując bardzo ogólne założenia, można uznać, że co do zasady prawdopodobieństwo zjawisk opisanych przez Donalda Kesslera jeszcze w 1978 roku $^{490}$ nie jest pomijalne, a być może nawet jest znaczne.

W związku z powyższym bezpieczeństwo w kosmosie, a zatem bezpieczeństwo systemów kosmicznych, nie może być ujmowane jedynie w perspektywie jednego kraju, jego narodowego bezpieczeństwa i egoistycznych interesów. Całość infrastruktury orbitalnej jest w równy sposób zagrożona efektami ewentualnych kolizji satelitów, które mogą być spowodowane umyślnymi działaniami albo zaistnieć przypadkowo jako wynik działań nakierowanych na inny cel. Przypomina to nieco zmiany w myśleniu o bezpieczeństwie, jakie przyniosła broń jądrowa, która zagroziła wyniszczeniem ludzkości i jej infrastruktury, bez względu na przynależność narodową, poglądy czy stosunek indywiduów lub ich grup do określonych problemów bezpieczeństwa. W przypadku systemów kosmicznych mogą one zniknąć lub zostać znacznie przetrzebione bez względu na ich przeznaczenie, rolę dla ludzkości czy też przynależność państwową. Różnica zasadnicza jest taka, że nuklearny Holocaust oznaczałby całkowitą zagładę ludzkości, kosmiczny zaś, mimo zniszczenia systemów orbitalnych, jedynie zaburzyłby, zapewne znacznie, funkcjonowanie ludzkości, ale nie oznaczałby automatycznie jej końca.

Powyższe konstatacje wymagają spojrzenia na bezpieczeństwo kosmiczne $z$ innej perspektywy niż dotychczasowa, jako na dobro całej ludzkości w oderwaniu od jednostkowych i egoistycznych interesów. Im bliżej zatem przyglądamy się problemom bezpieczeństwa, nawet z wąskiego, państwocentrycznego i militarnego punktu widzenia, tym wyraźniej widzimy konieczność rozważania ich w ramach tego, co nazwaliśmy na początku tej książki trzecim wymiarem definicyjnym bezpieczeństwa kosmicznego - jest to jednak kwestia dalszych badań.

Z punktu widzenia bezpieczeństwa narodowego Stanów Zjednoczonych przestrzeń kosmiczna jest obszarem nie do przecenienia, wydaje się,

490 D. J. Kessler, B. G. Cour-Palais, Collision Frequency of Artificial Satellites: The Creation of a Debris Belt, „Journal of Geophysical Research” 1978, vol. 86, nr A6, s. $2637-2646$. 
że wykazaliśmy to bardzo jasno. Siły zbrojne polegają na niej w ogromnej mierze $w$ ramach realizacji powierzonych sobie zadań bojowych i niebojowych, a także w praktyce wspierania polityki zagranicznej. Jednocześnie jednak zauważamy, że w wyniku rosnących zdolności kosmicznych innych krajów nie tylko uzyskują one analogiczne do amerykańskich atrybuty w dziedzinie wojskowej, zmniejszając technologiczny dystans do USA, ale także są coraz bardziej zdolne do zanegowania amerykańskich zdolności. I choć Stany Zjednoczone utrzymują przewagę w zakresie zastosowań kosmicznych, hegemonia USA w tej dziedzinie odchodzi już w przeszłość. W efekcie przewaga militarna, której jednym z fundamentalnych elementów są zdolności kosmiczne, nie jest już tak absolutna jak jeszcze dekadę czy dwie temu. Proces ten zapewne będzie się pogłębiał, choć trudno przewidzieć jego skalę i tempo.

Jednocześnie wydaje się, że w USA nie ma czystej i jasnej wizji dalszego etapu rozwoju kosmosu w ogóle, a w wymiarze bezpieczeństwa w szczególności. Dominuje poczucie zagrożenia wynikające z przekonania, że amerykańska przewaga się kurczy ${ }^{491}$ i będzie się kurczyć, podejmowana polityka ma zaś charakter reaktywny i sprowadza się do pospiesznego i nieco histerycznego poszukiwania sposobów na podtrzymanie dominacji Ameryki w kosmosie. To także bardzo istotny wniosek z naszych rozważań, wspominany już we wstępie: jedyną praktyczną odpowiedzią Stanów Zjednoczonych na trudną sytuację, w której się znalazły, jest wzmacnianie istniejących instrumentów, głównie militarnych, aby nie dopuścić do zmiany równowagi. To jednak może się nie udać, adaptacja i zmiana nastawienia na multilateralne podejście byłaby znacznie bardziej perspektywicznie skuteczna w świetle długofalowych interesów USA. Nie spodziewamy się jednak, aby szybko nastąpiła, choć istnieje potencjał w tym kierunku.

Nie ma zatem szerszej wizji przyszłości, nawet prestiżowo traktowana przez prezydenta Trumpa kwestia powrotu ludzi na Księżyc nie ma solidnych podstaw organizacyjnych i finansowych, jest zatem w dużej mierze kwestią wewnątrzpolityczną ${ }^{492}$. Nie wiadomo zatem, jak za dekadę lub

491 Por. na przykład G. Autry, S. Kwast, America Is Losing the Second Space Race to China, „Foreign Policy”, 22.08.2019, https://foreignpolicy.com/2019/o8/22/america-islosing-the-second-space-race-to-china/.

192 R. Handberg, Déjà Vu as Space Policy, „The Space Review”, 1.04.2019, http://www. thespacereview.com/article/3685/1. 
dwie będzie wyglądała amerykańska spacepower - jedynym przejawem szerszego myślenia jest, skądinąd dla Ameryki tradycyjne, podejście każące poszukiwać rozwoju w sektorze prywatnym. I faktycznie wykorzystuje on otwarte przez wysiłek państwa drogi do samodzielnego kształtowania technologii $w$ ramach potrzeb komercyjnych bądź związanych $\mathrm{z}$ rozlicznymi wizjami bogatych pasjonatów. W efekcie jednak pojawia się pewnego rodzaju rozdwojenie jaźni przejawiające się w przepaści pomiędzy dynamicznie rozwijającym się Space 2.0 a państwem postrzegającym przede wszystkim zagrożenia z zewnątrz. Oczywiście bardzo trudno jest zmienić ten stan rzeczy, nie jest to zresztą niczym dziwnym, jednak niewątpliwie i hamuje to rozwój koncepcji wykorzystania kosmosu przez państwo dla realizacji jego interesów, i zagraża komercyjnemu wykorzystywaniu przestrzeni okołoziemskiej. Nie bez znaczenia jest tu zresztą niewątpliwie także tradycyjne dla Ameryki postrzeganie stosunków światowych i globalnej polityki głównie poprzez pryzmat siły militarnej.

Rozwój amerykańskiej spacepower, rozumianej w świetle tematyki niniejszej pracy głównie w wymiarze militarnym, którego jednak nie można całkiem wyabstrahować od innych perspektyw, można zatem próbować przewidywać, uwzględniając zarówno pozytywne czynniki, jak i ograniczenia. Można też zastosować ujęcie względne, czyli odnieść amerykańskie zdolności kosmiczne do zdolności potencjalnych przeciwników oraz do ich zdolności negacyjnych. Oprócz tego można zastosować perspektywę jednostronną, czyli analizować to, czym jest spacepower dla Ameryki, dla jej rozwoju gospodarczego i społecznego oraz dobrobytu obywateli. Każde z tych spojrzeń ma swoje wady i zalety, każde w jakiejś mierze pojawiło się w naszych dotychczasowych rozważaniach. W tym miejscu warto pokusić się jedynie o próbę najbardziej syntetycznego i lapidarnego scharakteryzowania stanu i perspektyw amerykańskiej spacepower w najbardziej ogólnych kategoriach.

Najważniejszą chyba kwestią dotyczącą najszerzej pojętego bezpieczeństwa kosmicznego jest fakt, że samo wykorzystanie przestrzeni kosmicznej stoi dziś pod wielkim znakiem zapytania. Radykalnie rosną bowiem możliwości techniczne i organizacyjne w zakresie wykorzystania kosmosu, ale wzrostowi temu odpowiada znaczny przyrost i liczby, i powagi zagrożeń. Mamy, jak się zdaje, do czynienia z jakościowymi przemianami, których nie da się dobrze przewidywać. Zasadnicze zatem pytanie, czy przestrzeń okołoziemska pozostanie użyteczna dla ludzkości, czy 
też nastąpi jej częściowa bądź całkowita degradacja, pozostaje w gruncie rzeczy otwarte. Można jedynie próbować spekulować, że z jednej strony radykalny wzrost znaczenia zastosowań kosmicznych, szczególnie cywilnych, skłoni mocarstwa kosmiczne do ostrożności i odpowiedzialnego postępowania $w$ dziedzinie bezpieczeństwa w kosmosie. $Z$ drugiej jednak strony $\mathrm{z}$ tych samych powodów mniejsze kraje i uczestnicy niepaństwowi mogą być bardzo mocno zainteresowani zakłócaniem tego bezpieczeństwa. Uważamy zatem, że w najbliższej dekadzie nastąpi zanieczyszczenie niektórych orbit, które ograniczy skuteczność niektórych systemów satelitarnych i spowoduje także pewne perturbacje na Ziemi. Nie sądzimy jednak, aby doszło do takich zniszczeń w infrastrukturze orbitalnej, które zanegowałyby samą zasadę wykorzystania kosmosu przez człowieka. Otwarte pozostaje też pytanie, czy uzależnienie od wykorzystania kosmosu przez ludzkość jako taką oraz przez państwa w ramach ich polityk bezpieczeństwa pogłębi się i wyjdzie poza ramy wyznaczane prze obecne i znajdujące się w trakcie opracowywania zastosowania kosmiczne.

Podkreślić w tym miejscu należy kwestię broni kosmicznej i broni przeciwsatelitarnej, które są ze sobą nierozerwalnie związane ${ }^{493}$. Oznacza to, że ewentualne wprowadzenie do służby broni kosmicznej automatycznie spowoduje rozmieszczenie systemów przeciwrakietowych. To z kolei, jak wykazywaliśmy, radykalnie zwiększy prawdopodobieństwo degradacji przynajmniej niektórych orbit okołoziemskich. A zatem ewentualna dalsza czynna militaryzacja kosmosu będzie kolejnym czynnikiem uprawdopodabniającym czarne scenariusze rozwoju eksploracji kosmosu.

W związku z powyższym zdolność USA do działania w kosmosie także stoi pod znakiem zapytania. Próby jej podtrzymania i utrwalenia realizowane w wąskim militarnym wymiarze pewności w tej materii nie przyniosą. Podobnie zresztą jak negocjacje oraz ewentualna dobra wola mocarstw, ponieważ zawsze pozostanie możliwość, że do degradacji orbit przyczynią się mniejsze państwa, które nie mają wiele, albo zgoła nic, do stracenia, bądź uczestnicy niepaństwowi. I do tego trzeba przywyknąć, co między innymi oznacza konieczność przygotowywania się na orbitalny Armagedon, który w większym lub mniejszym zakresie zapewne nastąpi w ciągu dekady. Taka więc będzie w najbliższym czasie natura

49.3 Por. na przykład rozważania wybitnego fizyka: R. R. Garwin, Taming Antisatellite and Space Weapons, „Bulletin of the Atomic Scientists”, 29.05.2007. 
spacepower, coraz bardziej warunkowa i niepewna, mimo rosnącego jej znaczenia i rosnącego jej wpływu na rozwój państw i społeczeństw oraz realizację potrzeb bezpieczeństwa narodowego. I będzie tak dopóty, dopóki nie zostaną wynalezione i wdrożone metody szybkiego „sprzątania" orbit bądź też skutecznego zabezpieczenia istniejących systemów satelitarnych. Jest to jednak kwestia przyszłości, której nie da się dziś przewidzieć. 


\section{Bibliografia}

Niniejsza bibliografia podzielona jest według tradycyjnego schematu, należy jednak sprecyzować zawartość niektórych kategorii. Pod pojęciem „publicystyka" rozumiemy, z jednym wyjątkiem, artykuły w periodykach fachowych, często autorstwa bardzo znanych specjalistów, które wyrażają opinie i oceny autorów, ale nie mają formalnie charakteru naukowego, ponieważ nie są recenzowane. "Informacyjne materiały internetowe" są to natomiast pozycje zawierające wyłącznie fakty i przytaczane są jedynie jako źródła konkretnych informacji.

\section{Źródła}

Air Force Future Operating Concept, U.S. Air Force, September 2015, https://www. af.mil/Portals/ı/images/airpower/AFFOC.pdf (6.08.2018).

Ballistic Missile Defense Review, U.S. Department of Defense 2010, http://www. defense.gov/bmdr/docs/BMDR\%20as\%20of\%2026JAN10\%200630_for\%20 web.pdf (24.07.2010).

A Cooperative Strategy for $21^{\text {st }}$ Century Seapower, U.S. Navy, March 2015, http:// www.navy.mil/local/maritime/150227-CS21R-Final.pdf (6.08.2018).

Declaration of the First Meeting of Equatorial States (Deklaracja z pierwszego spotkania państw równikowych) Adopted on December 3, 1976, The Bogota Declaration, https://bogotadeclaration.wordpress.com/declaration-of-1976/ (7.02.2018).

Definition and Delimitation of Outer Space: Views of States Members and Permanent Observers of the Committee. Austria, COPUOS, 03.03.2017, http://www. unoosa.org/oosa/oosadoc/data/documents/2017/aac.105/aac.1051112add.3_o. html (19.01.2018). 
General Marshall's Report: The Winning of the War in Europe and the Pacific, U.S. War Department, 1945.

Guidance on Space Object Registration and Frequency Management for Small and Very Small Satellites, UNOOSA/ITU, 2015, http://www.unoosa.org/docu ments/pdf/psa/bsti/2015_Handout-on-Small-SatellitesE.pdf (10.08.2019).

International Co-operation in the Peaceful Uses of Outer Space, Rezolucja ZO ONZ 1472 (XIV), 12.12.1959, http://www.unoosa.org/pdf/gares/ARES_14_1472E. pdf (13.01.2017).

International Co-operation in the Peaceful Uses of Outer Space, Rezolucja ZO ONZ 1721 (XVI), 20.12.1961, http://www.unoosa.org/pdf/gares/ARES_16_1721E.pdf. International Co-operation in the Peaceful Uses of Outer Space, UN General Assembly Resolution, 16/1721, 1085th plenary meeting, 20.12.1961, http://www. unoosa.org/oosa/en/ourwork/spacelaw/treaties/resolutions/res_16_1721. html (21.08.2016).

Konwencja o międzynarodowej odpowiedzialności za szkody wyrzq̨dzone przez obiekty kosmiczne, przyjęta rezolucją ZO ONZ 2777 (XXVI) 29.11.1971.

Konwencja o rejestracji obiektów wystrzelonych w przestrzeń kosmiczną, przyjęta rezolucją ZO ONZ 3235 (XXIX) 12.11.1974.

Kopernik, astronomia, astronautyka. Przewodnik encyklopedyczny, pod red. Włodzimierza Zonna, Warszawa 1973.

Missile Defense Review, U.S. Department of Defense, January 2019, https://me dia.defense.gov/2019/Jan/17/2002080666/-1/-1/1/2019-MISSILE-DEFENSEREVIEW.PDF (20.01.2019).

MSCI Advisory. 2019-012-Persian Gulf, Strait of Hormuz, Gulf of Oman, Arabian Sea, Red Sea-Threats to Commercial Vessels by Iran, U.S. Department of Transportation, Maritime Administration, 8.07.2019, https://www.mari time.dot.gov/content/2019-012-persian-gulf-strait-hormuz-gulf-oman-ara bian-sea-red-sea-threats-commercial-vessels (9.08.2019).

The National Military Strategy of the United States of America, U.S. Joint Chiefs of Staffs, June 2015, http://www.jcs.mil/Portals/36/Documents/Publications/ National_Military_Strategy_2015.pdf (23.05.2016).

Nanosats Database, https://airtable.com/shrafcwXODMMKeRgU/tbldJoOBP 5 w INOJQY?blocks=hide (4.09.2019).

National Security Strategy, The White House, Washington, February 2015, https: //www.whitehouse.gov/sites/default/files/docs/2015_national_security_ strategy.pdf (23.05.2016).

National Security Strategy, The White House, Washington, December 2017, https://www.whitehouse.gov/wp-content/uploads/2017/12/NSS-Final-12-182017-0905.pdf (31.07.2018).

National Space Policy, The White House, 28.06.2010, https://www.whitehouse. gov/sites/default/files/national_space_policy_6-28-10.pdf (23.05.2016).

National Security Space Strategy, Department of Defense and Office of the Director of National Intelligence, January 2011, https://www.dni.gov/files/docu 
ments/Newsroom/Reports\%20and\%2oPubs/2011_nationalsecurityspacestra tegy.pdf (23.05.2016).

Nuclear Posture Review, U.S. Department of Defense, February 2018, https://me dia.defense.gov/2018/Feb/02/2001872886/-1/-1/1/2018-NUCLEAR-POSTURE -REVIEW-FINAL-REPORT.PDF (23.07.2019).

Online Index of Objects Launched into Outer Space, UNOOSA, 2019, http://www. unoosa.org/oosa/osoindex/search-ng.jspx (5.08.2019).

Porozumienie o ratowaniu astronautów, powrocie astronautów i zwrocie obiektów wystrzelonych w przestrzeń kosmicznq, przyjęte rezolucją ZO ONZ 2345 (XXII) 19.12.1967.

Porozumienie rządzq̨ce działalnościq̨ państw na Księżycu i innych ciałach niebieskich, przyjęte rezolucją ZO ONZ 34/68 5.12.1979.

Preliminary Statement of U.S. Policy on Outer Space, National Security Council, 20.06.1958, http://marshall.wpengine.com/wp-content/uploads/2013/o9/ NSC-5814-Preliminary-U.S.-Policy-on-Outer-Space-18-Aug-1958.pdf (25.05.2019).

President Donald J. Trump Is Building the United States Space Force for a 21st Century Military, The White House, 9.08.2018, https://www.whitehouse.gov/ briefings-statements/president-donald-j-trump-building-united-states-spa ce-force-21st-century-military/ (14.08.2018).

President Donald J. Trump Is Unveiling an America First National Space Strategy, The White House, 23.03.2018, https://www.whitehouse.gov/briefings-state ments/president-donald-j-trump-unveiling-america-first-national-spacestrategy/ (2.08.2018).

President Donald J. Trump Will Make America a Leader in Space Exploration Again, The White House, 11.12.2017, https:/www.whitehouse.gov/briefingsstatements/president-donald-j-trump-will-make-america-leader-space-ex ploration/ (2.08.2018).

Presidential Memorandum on Reinvigorating America's Human Space Exploration Program, White House, 11.12.2017, https://www.whitehouse.gov/presidentialactions/presidential-memorandum-reinvigorating-americas-human-spaceexploration-program/ (23.07.2019).

Question of the Peaceful Use of Outer Space, Rezolucja ZO ONZ 1348 (XIII) 13.12.1958, http://www.unoosa.org/pdf/gares/ARES_13_1348E.pdf(13.01.2017). Space Operations, Joint Publication 3-14, Joint Chiefs of Staffs, 29.05.2013, http:// www.dtic.mil/dtic/tr/fulltext/u2/1013622.pdf (14.08.2018).

Space Operations, Joint Publication 3-14, Joint Chiefs of Staffs, 10.04.2018, https:// www.jcs.mil/Portals/36/Documents/Doctrine/pubs/jp3_14.pdf (11.04.2019). Space Policy Directive-2, Streamlining Regulations on Commercial Use of Space, The White House, 24.05.2018, https:/www.whitehouse.gov/presidential-ac tions/space-policy-directive-2-streamlining-regulations-commercial-usespace/ (2.08.2018). 
Space Policy Directive-3, National Space Traffic Management Policy, The White House, 18.06.2018, https://www.whitehouse.gov/presidential-actions/spacepolicy-directive-3-national-space-traffic-management-policy/ (2.08.2018). Space Resource Exploration and Utilization Act of 2015, U.S. Congress, 2015, https: //www.govtrack.us/congress/bills/114/s976 (6.02.2018).

Space Security Index 2014, spacesecurity.org 2014, http://spacesecurityindex. org/wp-content/uploads/2014/11/Space-Security-Index-2014.pdf (10.03.2018) Status of International Agreements Relating to Activities in Outer Space as at 1 January 2019, COPUOS, 1.04.2019, http://www.unoosa.org/documents/pdf/ spacelaw/treatystatus/AC105_C2_2019_CRPo3E.pdf (9.05.2019).

Summary of the 2018 National Defense Strategy of the United States of America, U.S. Department of Defense, 2018, https://dod.defense.gov/Portals/1/Docu ments/pubs/2018-National-Defense-Strategy-Summary.pdf (16.07.2019).

Text of a Memorandum from the President to the Secretary of Defense Regarding the Establishment of the United States Space Command, The White House, 18.12.2018, https://www.whitehouse.gov/briefings-statements/text-memoran dum-president-secretary-defense-regarding-establish ment-united-statesspace-command/ (24.07.2019).

Text of Space Policy Directive-4: Establishment of the United States Space Force, White House, 19.02.2019, https://www.whitehouse.gov/presidential-actions/ text-space-policy-directive-4-establishment-united-states-space-force/ (24.07.2019).

Traktat o zasadach rządzących działalnością państw w ramach eksploracji i wykorzystania przestrzeni kosmicznej, łącznie z Księżycem i innymi ciałami niebieskimi, przyjęty rezolucją ZO ONZ 2222 (XXI) 19.12.1966.

Układ o zakazie prób broni nuklearnej $w$ atmosferze, $w$ przestrzeni kosmicznej i pod wodą (Treaty Banning Nuclear Weapon Tests in the Atmosphere, in Outer Space and Under Water, w skrócie Limited Test Ban Treaty - LTBT), podpisany 5.08.1963, wszedł w życie 10.10.1963.

U.S. Army Operating Concept. Win in a Complex World, TRADOC Pamphlet 525-3-1, Department of the Army Headquarters, United States Army Training and Doctrine Command, 31.10.2014, http://www.tradoc.army.mil/tpubs/ pams/tp525-3-1.pdf (6.08.2018)

USC Satellite Database, Union of Concerned Scientists, 31.03.2019, https://www. ucsusa.org/nuclear-weapons/space-weapons/satellite-database (4.09.2019). 
Raporty

Alternatives for Future U.S. Space-Launch Capabilities, A CBO Study, Congress of United States, Congressional Budget Office, October 2006, https://www. cbo.gov/sites/default/files/109th-congress-2005-2006/reports/10-09-space launch.pdf (11.08.2018).

Annual Report to Congress: Military and Security Developments Involving the People's Republic of China 2019, U.S. Department of Defense, 2019, https://media.defense.gov/2019/May/02/2002127082/-1/-1/1/2019\%20CHINA\%2oMILI TARY\%20POWER\%2oREPORT\%20(1).PDF (20.08.2019).

Ballistic Missile Defense Technologies, OTA-ISC-254, U.S. Congress, Office of Technology Assessment, U.S. Government printing Office, Washington DC, September 1985.

Challenges to Security in Space, U.S. Defense Information Agency, January 2019, https://www.dia.mil/Portals/27/Documents/News/Military\%2oPower\%20 Publications/Space_Threat_V14_020119_sm.pdf (20.08.2019).

Economic Benefits of the Global Positioning System (GPS), RTI Report Number 0215471, June 2019, https://www.rti.org/sites/default/files/gps_finalreport. pdf (16.09.2019).

Final Report on Organizational and Management Structure for the National Security Space Components of the Department of Defense, Report to Congressional Defense Committees, U.S. Department of Defense, 9.08.2018, https:// media.defense.gov/2018/Aug/o9/2001952764/-1/-1/1/ORGANIZATIONALMANAGEMENT-STRUCTURE-DOD-NATIONAL-SECURITY-SPACECOMPONENTS.PDF (14.08.2018).

Greason Jeff, Bennett James C., The Economics of Space: An Industry Ready to Launch, Reason Foundation, April 2019, https://reason.org/wp-content/up loads/economics-of-space.pdf (14.08.2019).

Grego Laura, Wright David, Securing the Skies: Ten Steps the United States Should Take to Improve the Security and Sustainability of Space, Union of Concerned Scientist, November 2010, https://www.ucsusa.org/sites/default/files/legacy/ assets/documents/nwgs/securing-the-skies-full-report-1.pdf (22.09.2019).

Harrison Todd, Johnson Kaitlyn, Roberts Thomas G., Space Threat Assessment 2019, Center for Strategic \& International Studies, April 2019, https://csis-prod. s3.amazonaws.com/s3fs-public/publication/190404_SpaceThreatAssess ment_interior.pdf (9.08.2019).

Historical Tables, Budget of U.S. Government, U.S. Office of Management and Budget, 2010, https:/www.govinfo.gov/content/pkg/BUDGET-2010-TAB/pdf/ BUDGET-2010-TAB.pdf (7.09.2019).

Industrial Capabilities. Annual Report to the Congress, Fiscal Year 2018, Office of the Under Secretary of Defense for Acquisition and Sustainment, Office of the Deputy Assistant Secretary of Defense for Industrial Policy, 
23.05.2019, https://www.businessdefense.gov/Portals/51/Documents/Resour ces/2018\%20AIC\%20RTC\%2005-23-2019\%20-\%2oPublic\%2oRelease.pdf?ver =2019-06-07-111121-457 (22.09.2019).

Pollpeter Kevin [et al.], China Dream, Space Dream: China's Progress in Space Technologies and Implications for the United States. A Report Prepared for the U.S.-China Economic and Security Review Commission, University of California's Institute on Global Conflict and Cooperation, 2.03.2015, https://www. uscc.gov/Research/china-dream-space-dream-chinas-progress-space-tech nologies-and-implications-united-states (21.08.2019).

Preliminary Design of an Experimental World-Circling Spaceship, Report no. SM11827, Douglas Aircraft Company, Inc., 2.05.1946.

Providing for the Common Defense, United States Institute of Peace, 2018, https: //www.usip.org/sites/default/files/2018-11/providing-for-the-common-de fense.pdf (17.07.2019).

Report of the Commission to Assess United States National Security Space Management and Organization. Executive Summary, U.S. Congress, 11.01.2001, https://fas.org/spp/military/commission/executive_summary.pdf (22.08.2019). Report by the Technological Capabilities Panel of the Science Advisory Committee, 14.02.1955, [w:] Foreign Relations of the United States, 1955-1957, National Security Policy, vol. 19, s. 41-55, https://history.state.gov/historicaldocuments/ frus1955-57v19/d9 (16.05.2019).

Resiliency and Disaggregated Space Architectures, White Paper, U.S. Air Force Space Command, https://fas.org/spp/military/resiliency.pdf (14.08.2018).

Weeden Brian, Samson Victoria, Global Counterspace Capabilities: An Open Source Assessment, Secure World Foundation, April 2018, https://swfound. org/media/206118/swf_global_counterspace_april2018.pdf (19.08.2019).

\section{Książki}

Baucom Donald R., Origins of SDI 1944-1983, Lawrence 1992, https://doi.org/10. 2307/2080541.

Boyne Walter J., The Influence of Air Power upon History, Gretna 2003.

Burns Richard Dean, The Missile Defense Systems of George W. Bush: A Critical Assessment, Santa Barbara-Denver-Oxford 2010.

Burrows William E., This New Ocean: The Story of the First Space Age, Modern Library Paperbacks, Random House Publishing Group. Kindle Edition.

Critical Issues in the History of Spaceflight, ed. Steven J. Dick, Roger D. Launius, Washington 2006.

Czajkowski Marek, Obrona przeciwrakietowa w stosunkach międzynarodowych,

Kraków 2013. 
Dolman Everett C., Astropolitik: Classical Geopolitics in the Space Age, London 2002, Taylor and Francis Kindle Edition 2005.

The Fallacy of Star Wars, ed. John Tirman, New York 1984.

Gansler Jacques S., Ballistic Missile Defense. Past and Future, Washington 2010. Johnson-Freese Joan, Space as a Strategic Asset, New York 2007.

Johnson-Freese Joan, Space Warfare in the 21st Century: Arming the Heavens,

New York 2017, https://doi.org/10.4324/9781315529172.

Lambakis Steven, On the Edge of Earth: The Future of American Space Power, Lexington 2001.

Lonnquest John C., Winkler David F., To Defend and Deter: The Legacy of the United States Cold War Missile Program, Special Report N-97/o1, Champaign, IL 1996.

Lyall Francis, Larsen Paul B., Space Law, New York 2016.

McDougall Walter A., The Heavens and the Earth: A Political History of the Space Age, Baltimore 1997.

Moltz James Clay, The Politics of Space Security: Strategic Restraint and the Pursuit for National Interests, Stanford 2011.

Mowthorpe Matthew, The Militarization and Weaponization of Space, New YorkToronto-Oxford 2014.

Nye Joseph S., Bound to Lead: The Changing Nature of American Power, New York 1990.

Oberg Jim, Space Power Theory, Washington 1999.

Peoples Columba, Justifying Missile Defence, Cambridge University Press 2010 (Kindle Edition).

Phillips Dewanne Marie, An Architecture, System Engineering, and Acquisition Approach for Space System Software Resiliency, doctoral thesis, The School of Engineering and Applied Science of The George Washington University, 19.01.2018, https://scholarspace-etds.library.gwu.edu/downloads/7w62f833c? locale=en (12.03.2018).

Piszkiewicz Dennis, The Nazi Rocketeers. Dreams of Space and Crimes of War, Mechanicsburg 2007.

Polkowska Małgorzata, Prawo kosmiczne w obliczu nowych problemów wspótczesności, Warszawa 2011.

Pyle Rod, Space 2.0. How Private Spaceflight, a Resurgent NASA, and International Partners Are Creating a New Space Age, Dallas 2019.

Richelson Jeffrey T., America's Space Sentinels: DSP Satellites and National Security, Lawrence 1999, https://doi.org/10.2307/2652325.

Al-Rodhan Nayef, Meta-Geopolitics of Outer Space: An Analysis of Space Power, Security and Governance, London 2012.

Sheehan Michael, The International Politics of Space, Routledge 2007, https:// doi.org/10.4324/9780203933909. 
Toward a Theory of Spacepower, ed. Charles D. Lutes [et al.], Washington 2011, http://www.dtic.mil/dtic/tr/fulltext/u2/a546585.pdf (24.07.2014).

Wong Wilson W. S., Fergusson James, Military Space Power. A Guide to the Issues, Santa Barbara-Denver-Oxford 2010.

Wright David, Grego Laura, Gronlund Lisbeth, The Physics of Space Security, Cambridge, MA 2005.

Yanarella Ernest J., The Missile Defense Controversy: Technology in Search of the Mission, Lexington 2002.

Ziarnick Brent, Developing National Power in Space: A Theoretical Model, Jefferson 2015.

Artykuły naukowe

Basu Arindrajit, Kurlekar Arthad, Highway to the Danger Zone: United States Legislative Framework Regulating the Commercial Space Sector, „Astropolitics" 2016, vol. 14, nr 1, s. 59-6o, https://doi.org/10.108o/14777622.2016.1149382. Beinart Peter, Think Again: Ronald Reagan, „Foreign Policy”, 7.06.2010.

Bundy McGeorge [et al.], Arms Control: The President's Choice: Star Wars or Arms Control, „Foreign Affairs”, Winter 1983/84, https://doi.org/10.4324/978 0429307591-9.

Burris Matthew, Astroimpolitic: Organizing Outer Space by the Sword, „Strategic Studies Quarterly" 2013, vol. 7, nr 3, https://doi.org/10.2139/ssrn.2414521.

Burrows William E., The Star Wars Debate: Ballistic Missile Defense: The Illusion of Security, „Foreign Affairs”, Spring 1984, https://doi.org/10.2307/20041910. Butt Yousaf, Can Space Weapons Protect U.S. Satellites?, „The Bulletin of Atomic Scientists", 22.07.2008, https://thebulletin.org/2008/o7/can-space-weaponsprotect-u-s-satellites/ (12.09.2019).

Cohen Michael L., Gettin the Gipper Wrong, „Foreign Policy”, 8.03.2012, http:// www.foreignpolicy.com/articles/2012/03/o8/gettin_the_gipper_wrong (9.03.2012).

Czajkowski Marek, Non-State Actors and Space Security, „Вісник Львівського університету. Серія “Міжнародні відносини”, „Visnyk of the Lviv University. Series International Relations" 2018, nr 44.

Czajkowski Marek, Nowy wyścig kosmiczny XXI w. - USA, Chiny i Rosja, „Krakowskie Studia Międzynarodowe" 2018, nr 1, s. 117-141.

Czajkowski Marek, Wpływ militaryzacji Kosmosu na globalnq równowagę strategicznq, „Krakowskie Studia Międzynarodowe” 2015, nr 1, s. 75-93.

Daec Wilfred P., The Navy's Spy Missions in Space, "Naval History Magazine" 2008, vol. 22, nr 2.

Dolman Everett C., New Frontiers, Old Realities, "Strategic Forces Quarterly" 2012, vol. 6, nr 1, s. 78-96. 
Dolman Everett C., Cooper Henry F., Jr., Increasing the Military Uses of Space, [w:] Toward a Theory of Spacepower, ed. Charles D. Lutes [et al.], Washington 2011, http://www.dtic.mil/dtic/tr/fulltext/u2/a546585.pdf (24.07.2014).

Finch James P., Bringing Space Crisis Stability Down to Earth, „Join Forces Quarterly" 2015, nr 76, s. 15-20.

Freier Nathan, The Darker Shade of Gray: A New War Unlike Any Other, „Center for Strategic \& International Studies”, 27.07.2018, https://www.csis.org/anal ysis/darker-shade-gray-new-war-unlike-any-other (7.08.2018).

Garwin Richard R., Taming Antisatellite and Space Weapons, „Bulletin of the Atomic Scientists", 29.05.2007.

Ghoshroy Subrata, The X-37B: Backdoor Weaponization of Space?, „Bulletin of the Atomic Scientists" 2015, vol. 71, nr 3, s. 19-29, https://doi.org/10.1177/oo9 6340215581360 .

Grego Laura, A History of Anti-Satellite Programs, Union of Concerned Scientists, January 2012, s. 2, https://www.ucsusa.org/sites/default/files/legacy/ assets/documents/nwgs/a-history-of-ASAT-programs_lo-res.pdf (7.09.2019).

O'Hanlon Michael, Petraeus David, America's Awesome Military, „Foreign Affairs", September/October 2016.

Hecht J., A „Star Wars" Sequel? The Allure of Directed Energy for Space Weapons, "Bulletin of the Atomic Scientists" 2019, vol. 74, nr 10, s. 162-170, https://doi. org/10.1080/00963402.2019.1628507.

Johnson Stephen B., The History and Historiography of National Security Space, [w:] Critical Issues in the History of Spaceflight, eds. Steven J. Dick, Roger D. Launius, Washington 2006, s. 481-548.

Jones Harry W., The Recent Large Reduction in Space Launch Cost, ICES-201881, 48th International Conference on Environmental Systems 8-12.07.2018, Albuquerque, New Mexico.

Kessler Donald J., Cour-Palais Burton G., Collision Frequency of Artificial Satellites: The Creation of a Debris Belt, "Journal of Geophysical Research" 1978, vol. 86, nr A6, s. 2637-2646, https://doi.org/10.1029/JAo83iAo6po2637.

Kirk Grayson, National Power and Foreign Policy, „Foreign Affairs”, July 1945, http://www.foreignaffairs.com/articles/70436/grayson-kirk/national-powerand-foreign-policy (7.01.2013).

Kopeć Rafał, Broń antysatelitarna. U progu drugiego etapu militaryzacji kosmosu, „Politeja” 2018, vol. 53, nr 2, s. 45-71, https://doi.org/10.12797/Politeja.15.20 18.53.04.

Kopeć Rafał, Geostationary Belt - State's Territory or Province of Mankind?, „Przegląd Narodowościowy” („Review of Nationalities”) 2018, nr 8, https:// doi.org/10.2478/pn-2018-oo11.

Korb Lawrence J., The Focus of US Military Efforts in Outer Space Should Be ... Arms Control, „Bulletin of the Atomic Scientists” 2019, vol. 75, nr 4, s. 148150, https://doi.org/10.1080/o0963402.2019.1628471. 
Kupchan Charles A., The Clash of Exceptionalisms: A New Fight Over an Old Idea, „Foreign Affairs”, March/April 2018.

Launius Roger D., National Security: Space and the Course of Recent U.S. History, The $49^{\text {th }}$ Harmon Memorial Lecture, United States Air Force Academy, 2006, http://www.usafa.edu/df/dfh/docs/Harmon49.pdf (5.04.2016).

Livingstone David, Lewis Patricia, Space, the Final Frontier for Cybersecurity?,

The Royal Institute of International Affairs, September 2016.

Mandelbaum Michael, The New Containment, „Foreign Affairs”, March/April 2019. Masters Jonathan, Sea Power: The U.S. Navy and Foreign Policy, Council on Foreign Relations, 19.08.2019, https://www.cfr.org/backgrounder/sea-power-usnavy-and-foreign-policy (20.08.2019).

Mead Walter Russell, The Big Shift, „Foreign Affairs”, May/June 2018.

Muelhaupt Theodore J. [et al.], Space Traffic Management in the New Space Era, „Journal of Space Safety Engineering" 2019, vol. 6, nr 2, s. 80-87, https://doi. org/10.1016/j.jsse.2019.05.007.

Muzyka Kamil, Space Manufacturing and Trade: Addressing Regulatory Issues, „Astropolitics" 2019, vol. 17, nr 3, s. 141-163, https://doi.org/10.1080/14777622. 2019.1675431.

Norris Robert S., Kristensen Hans M., The Cuban Missile Crisis: A Nuclear Order of Battle, October and November 1962, "The Bulletin of Atomic Scientists" 2012, vol. 68, nr 8, s. 85-91, https://doi.org/10.1177/o096340212464364.

Pfaltzgraff Robert L., Jr., International Relations Theory and Spacepower, [w:] Toward a Theory of Spacepower, ed. Charles D. Lutes [et al.], Washington 2011, s. 29-44, http://www.dtic.mil/dtic/tr/fulltext/u2/a546585.pdf (24.07.2014).

Roberts Thomas G., Space-Based Missile Defense: How Much Is Enough?, „Aerospace Security, Center for Strategic \& International Studies", 13.03.2019, https://aerospace.csis.org/data/space-based-missile-interceptors/(22.08.2019). Roberts Thomas G., Why a Space-based Missile Interceptor System Is Not Viable, „Bulletin of the Atomic Scientists” 2018, vol. 74, nr 4, https://doi.org/10.108o/ oog63402.2018.1486597.

Al-Rodhan Nayef, Meta-Geopolitics: The Relevance ofGeopolitics in the DigitalAge, E-international Relations, 25.05.2014, https://www.e-ir.info/2014/05/25/me ta-geopolitics-the-relevance-of-geopolitics-in-the-digital-age/ (14.08.2018). Sankaran Jaganath, Limits of the Chinese Antisatellite Threat to the United States, "Strategic Studies Quarterly" 2014, vol. 8, nr 4, s. 20-47.

Sariak George, Between a Rocket and a Hard Place: Military Space Technology and Stability in International Relations, „Astropolitics” 2017, vol. 15, nr 1, https:// doi.org/10.1080/14777622.2017.1288509.

Schulte Gregory L., Schaffer Audrey M., Enhancing Security by Promoting Responsible Behavior in Space, „Strategic Studies Quarterly”, Spring 2012, s. 9-17, https://www.airuniversity.af.edu/Portals/10/SSQ/documents/Volume-o6_ Issue-1/schulte.pdf (11.09.2019). 
Shabbir Zaeem, Sarosh Ali, Counterspace Operations and Nascent Space Powers, „Astropolitics” 2018, vol. 16, nr 2, s. 119-140, https://doi.org/10.1080/14777622. 2018.1486792.

Sheldon John B., Gray Colin S., Theory Ascendant? Spacepower and the Challenge of Strategic Theory, [w:] Toward a Theory of Spacepower, ed. Charles D. Lutes [et al.], Washington 2011, s. 300-313, http://www.dtic.mil/dtic/tr/fulltext/u2/ a546585.pdf (24.07.2014).

Schelling Thomas C., The Role of Deterrence in Total Disarmament, „Foreign Affairs", April 1962, https://doi.org/10.2307/20029563.

Sumida Jon, Old Thoughts, New Problems: Mahan and the Consideration of Spacepower, [w:] Toward a Theory of Spacepower, ed. Charles D. Lutes [et al.], Washington 2011, s. 4-14, http://www.dtic.mil/dtic/tr/fulltext/u2/a546585.pdf (24.07.2014).

Thornberry Mac, Krepinevich Andrew F., Jr., Preserving Primacy, „Foreign Affairs", September/October 2016.

Troxell John F., Military Power and the Use of Force, [w:] U.S. Army War College Guide to Strategic Issues, ed. J. B. Bartholomees, Carlise, PA 2012.

Waiting for Artemis I Schedule Update, Official Decision on SLS Green Run, NASA spaceflight.com, 8.07.2019, https://www.nasaspaceflight.com/2019/07/wait ing-artemis-1-schedule-decision-sls-green-run/ (2.08.2019).

Walker Dinah, Trends in U.S. Military Spending, Council on Foreign Relations, 15.07.2014, https://www.cfr.org/report/trends-us-military-spending (9.06.2019).

Wheeler Winslow, Not All That It Can Be, „Foreign Policy”, 11.10.2012, http://www. foreignpolicy.com/articles/2012/10/11/not_all_that_it_can_be (12.10.2012).

Zakaria Fareed, The Future of American Power, „Foreign Affairs” 2008, vol. 87, nr 3.

Zapata Edgar, The State of Play US Space Systems Competitiveness. Prices, Productivity, and Other Measures of Launchers $\mathcal{E}$ Spacecraft, Presentation to the Future In-Space Operations (FISO) Seminar October 11, 2017, NASA 2017, https://ntrs.nasa.gov/archive/nasa/casi.ntrs.nasa.gov/20170009967.pdf (12.08.2018). 


\section{Publicystyka}

The 36-Hour War: Arnold Report Hints at the Catastrophe of the Next Great Conflict, „Life”, 19.12.1945, s. 27-35.

Autry Greg, Kwast Steve, America Is Losing the Second Space Race to China, „Foreign Policy”, 22.08.2019, https://foreignpolicy.com/2019/o8/22/americais-losing-the-second-space-race-to-china/ (23.08.2019).

Black James, Our Reliance on Space Tech Means We Should Prepare for the Worst,

Defense News, 12.03.2018, https://www.defensenews.com/space/2018/03/ 12/our-reliance-on-space-tech-means-we-should-prepare-for-the-worst/ (18.03.2018).

Brown Mike, SpaceX Starship: Those 30-Minute, Cross-Planet Flights Will Be Punishing, „Inverse”, 27.07.2019, https://www.inverse.com/article/57135-spacexstarship-rockets-will-get-you-from-paris-to-nyc-in-30-minutes (10.08.2019). Brumfield Ben, U.S. Reveals Secret Plans for '6os Moon Base, CNN, 25.07.2014, http://edition.cnn.com/2014/o7/24/us/196os-moon-military-base/ (26.07.2014). Burns Robert, Pentagon Redoing Space Defenses, but Will Trump Demand More?, Defense News, 4.08.2018, https:/www.defensenews.com/space/2018/o8/03/ pentagon-redoing-space-defenses-but-will-trump-demand-more/ (7.08.2018).

Carey Bill, FAA Mulls Recommendations For Planned GPS Interference, „Aviation Week \& Space Technology", 1.08.2018, http://aviationweek.com/commercialaviation/faa-mulls-recommendations-planned-gps-interference (8.08.2018).

Carreau Mark, Light Sail-2 Uses Sunlight to Control a Small Satellite, „Aviation Week \& Space Technology", 2.08.2019, https://aviationweek.com/space/lightsail-2-uses-sunlight-control-small-satellite?utm_rid=CPEN1000001539178 \&utm_campaign $=20696 \&$ utm_medium $=$ email\&elq2 $=4$ c9528dbre6f 429 egc2 e56ed392ea2b6 (5.08.2019).

Carreau Mark, NASA Eager To Share Low Earth Orbit, „Aviation Week \& Space Technology", 19.09.2019, https://aviationweek.com/world-satellite-businessweek/nasa-eager-share-low-earth-orbit (22.09.2019).

Czajkowski Marek, Hypersonic Missiles - a Political Multipurpose Weapon, „Analizy ZBN UJ" 2019, vol. 43, nr 4, 15.03.2019, http://www.zbn.ina przykładuj.edu. $\mathrm{pl} /$ documents/92718966/141790394/Czajkowski+-+Analizal/1cfa6113-361a4ef8-b3d9-53bc659c6cdi (11.09.2019).

Day Dwayne A., Forces of Darkness and Light, „The Space Review”, 10.12.2018, http://www.thespacereview.com/article/3621/1 (5.08.2019).

Dura Maksymilian, Nadchodzi wojna w kosmosie? Chiny i Rosja zagrożeniem dla amerykańskich satelitów, Defence24, 5.02.2018, http://www.defence24.pl/nad chodzi-wojna-w-kosmosie-chiny-i-rosja-zagrozeniem-dla-amerykanskichsatelitow (7.02.2018). 
Garber Stephen J., Vedda James A., Déjà Vu or Sea Change? Comparing Two Generations of Large Satellite Constellation Proposals, "The Space Review”, 1.07.2019, http://www.thespacereview.com/article/3747/1 (6.08.2019).

Gelain Antoine, Opinion: When It Comes to Nanosatellites, The Hype Is Over, „Aviation Week \& Space Technology”, 20.05.2019, https://aviationweek.com/ space/opinion-when-it-comes-nanosatellites-hype-over? $\mathrm{NL}=\mathrm{AW}$-05\&Issue $=$ AW-05_20190522_AW-05_581\&sfvc4enews $=42 \& \mathrm{cl}=$ article_3\&utm_rid= CPEN10oooo1539178\&utm_campaign=19693\&utm_medium $=$ email\&elq2 $=e a$ 9cf6620e994923b42aoof6505e95f3 (5.08.2019).

Gerałt Bartłomiej, Zderzenie z realiami. Starlink i dylematy ery megakonstelacji, Space24, 26.09.2019, https://www.space24.pl/zderzenie-z-realiami-starlinki-dylematy-ery-megakonstelacji-analiza (27.09.2019).

Gould Joe, Space Force 'Not the Way to Go,' Says Key Democrat, Defense News, 13.08.2018, https://www.defensenews.com/congress/2018/o8/13/space-forcenot-the-way-to-go-says-key-democrat/ (31.07.2019).

Groll Elias, Russia Is Tricking GPS to Protect Putin, „Foreign Policy”, 3.04.2019, https://foreignpolicy.com/2019/04/03/russia-is-tricking-gps-to-protect-pu tin/ (10.09.2019).

Gruss Mike, U.S. Air Force Decision To End CHIRP Mission Was Budget Driven, SpaceNews, 12.12.2013, https://spacenews.com/38628us-air-force-decisionto-end-chirp-mission-was-budget-driven/ (8.08.2019).

Handberg Roger, Shaping Up: The Future of US Space Transportation, „The Space Review", 9.03.2015, http://www.thespacereview.com/article/2710/1 (8.08.2016).

Handberg Roger, Déjà Vu as Space Policy, „The Space Review”, 1.04.2019, http:// www.thespacereview.com/article/3685/1 (3.04.2019).

Henry Caleb, FCC Approves SpaceX Constellation, Denies Waiver for Easier Deployment Deadline, SpaceNews, 29.03.2018, https://spacenews.com/us-reg ulators-approve-spacex-constellation-but-deny-waiver-for-easier-deploy ment-deadline/ (12.08.2018).

Howell Elizabeth, Delta IV Heavy: Powerful Launch Vehicle, Space.com, 20.04.2018, https://www.space.com/4036o-delta-iv-heavy.html (11.08.2018). Howell Elizabeth, Four Cubesats Snuck into Orbit Without Regulatory Approval, FCC Says, Space.com, 16.03.2018, https://www.space.com/400o1-four-cube sats-unauthorized-launch-fcc.html\#?utm_source=sdc-newsletter\&ut m medium=email\&utm_campaign=20180317-sdc (18.03.2018).

Hutchison Matthew, Waage Frederick, Bennett Dan, Cyber Resiliency: Bridging a Cyber Capability Gap in 2025, „Small Wars Journal”, 2019, https://small warsjournal.com/jrnl/art/cyber-resiliency-bridging-a-cyber-capability-gapin-2025 (11.09.2019).

Insinna Valerie, One Possible Job for SpaceX's BFR Rocket? Taking the Air Force's Cargo in and Out of Space, Defense News, 2.08.2018, https://www.de 
fensenews.com/space/2018/o8/o2/one-possible-job-for-spacexs-bfr-takingthe-air-forces-cargo-in-and-out-of-space/ (11.08.2018).

Jones Andrew, China Reveals Details for Super-Heavy-Lift Long March 9 and Reusable Long March 8 Rockets, SpaceNews, 5.07.2018, https://spacenews.com/ china-reveals-details-for-super-heavy-lift-long-march-9-and-reusable-longmarch-8-rockets/ (5.08.2019).

Judson Jen, Space-based Laser Weapons Could Ultimately Take Out Missile Threats in Boost Phase, Defense News, 14.08.2018, https://www.defense news.com/digital-show-dailies/smd/2018/o8/14/space-based-laser-weaponscould-ultimately-take-out-missile-threats-in-boost-phase/ (18.08.2019).

Kamassa Marcin, Antysatelitarne oblicze rosyjskiego myśliwca? Niejasne testy MiGa-31, Space24, 6.10.2018, https://www.space24.pl/antysatelitarne-oblicze -rosyjskiego-mysliwca-mig-31-obiektem-potajemnych-prob (10.10.2018).

Kamassa Marcin, Zagadkowy „Pierieswiet”. Bojowy laser Rosji pod okiem satelitów, Space24, 22.08.2018, https://www.space24.pl/damen/zagadkowy-pierie swiet-bojowy-laser-rosji-pod-okiem-satelitow-analiza (25.08.2019).

Kasap Haylie, Exotic Glass Fiber from Space, „Upward” 2018, vol. 3, nr 3, https:// upward.issnationallab.org/volume-3/volume-3-issue-3/ (6.08.2019).

Kleiman Matthew, McNeil Sonia, Red Lines in Outer Space, „The Space Review”, 5.03.2012, http://www.thespacereview.com/article/2038/1 (10.03.2018).

Klotz Irene, NASA Says No Moon Landing Without Orion And SLS, „Aviation Week \& Space Technology", 12.07.2019, https://aviationweek.com/apollo/ nasa-says-no-moon-landing-without-orion-and-sls?utm_rid=CPEN1000oo 1539178\&utm_campaign=20427\&utm_medium=email\&elq2 $=8 \mathrm{c} 7 \mathrm{a} 114 \mathrm{a} 6$ ofa 4 d7eb4bfyfb4a81725c5 (1.08.2019).

Klotz Irene, Small Satellites Take On Big Missions, „Aviation Week \& Space Technology", 20.08.2018, http://aviationweek.com/aviation-week-space-technol ogy/small-satellites-take-big-missions (23.08.2018).

Klotz Irene, Tsunami of Smallsats Creating Opportunities and Problems, „Aviation Week \& Space Technology", 28.02.2018, http://aviationweek.com/avi ation-week-space-technology/tsunami-smallsats-creating-opportunitiesand-problems (26.03.2018).

Knipfer Cody, Congress and Commerce in the Final Frontier (part 1), „The Space Review", 10.12.2018, http://www.thespacereview.com/article/3619/1 (1.08.2019). Knipfer Cody, Congress and Commerce in the Final Frontier (part 2), „The Space Review", 17.12.2019, http://www.thespacereview.com/article/3625/1 (5.08.2019). Lendon Brad, China Could Overwhelm US Military in Asia in Hours, Australian Report Says, CNN, 20.08.2019, https://edition.cnn.com/2019/o8/20/asia/australia-china-us-military-report-intl-hnk/index.html (20.08.2019).

Malik Tariq, Jam-Resistant US Military Communications Satellite Lifts Off in Midnight-Hour Launch, Space.com, 17.10.2018, https://www.space.com/41819at las-v-launches-jam-resistant-aehf 4 -military-satellite.html?utm_ 
source=sdc-newsletter\&utm_medium=email\&utm_campaign=20181017-sdc (16.08.2019).

DiMascio Jen, Hudson Lee, What Was in the Space Force Report, What Wasn't, and What It Mean, „Aviation Week \& Space Technology”, 14.08.2018, http:// aviationweek.com/defense/what-was-space-force-report-what-wasn-t-andwhat-it-means? NL=AW-05\&Issue $=A W-05 \_20180815 \_A W-05 \_23 \& s f v c 4 e$ news $=42 \& \mathrm{cl}=$ article_1\&utm_rid $=C P E N 1000001539178 \&$ utm_campaign $=$ 16036\&ut m_medium=email\&elq2 =ee77e 4 e 4079c485d84409eccofdc48c7 (19.08.2018).

Mehta Aaron, The Air Force Wants Satellites that Grow Fast, Die Young, Defense News, 19.09.2019, https://www.defensenews.com/digital-show-dailies/airforce-association $/ 2019 / 09 / 18 /$ the-air-force-wants-satellites-that-grow-fastdie-young (22.09.2019).

Mehta Aron, The Pentagon's National Military Strategy Is Done, and It's Unclear if the Public Will Ever See It, Defense News, 13.02.2019, https://www.defense news.com/pentagon/2019/02/13/the-pentagons-national-military-strategyis-done-and-its-unclear-if-the-public-will-ever-see-it/ (16.07.2019).

Mehta Aaron, Space Command to Launch Aug. 29, Defense News, 20.08.2019, https://www.defensenews.com/space/2019/08/20/space-command-to-launch -aug-29/ (22.08.2019).

Messier Doug, Axiom Space Tests Key Space Station Acrylic Sample on ISS in Alpha Space's MISSE Facility, Parabolic Arc, 15.05.2019, http://www.paraboli carc.com/2019/05/15/axiom-space-tests-key-space-station-acrylic-sampleiss-alpha-spaces-misse-facility/ (12.08.2019).

Messier Doug, ICEYE Releases World-First Under 1-Meter Resolution Radar Imagery from SAR Microsatellites, Parabolic Arc, 9.08.2019, http://www.para bolicarc.com/2019/o8/og/iceye-releases-world-first-under-1-meter-resolu tion-radar-imagery-from-sar-microsatellites/ (12.08.2019).

Mosher Dave, Elon Musk Just Revealed New Details about Starlink, a Plan to Surround Earth with 12,000 High-speed Internet Satellites. Here's How It Might Work, „Business Insider”, 16.05.2019, https://www.businessinsider.com/spa cex-starlink-satellite-internet-how-it-works-2019-5?IR=T (11.08.2019).

Norris Guy, Starhopper Verifies Raptor Performance for Starship, "Aviation Week \& Space Technology", 29.08.2019, https://aviationweek.com/world-sa tellite-business-week/starhopper-verifies-raptor-performance-starship (30.08.2019).

Richardson Derek, Bigelow Aerospace Spawns Spinoff Company to Market Its Space Stations, „SpaceFlight Insider”, 21.02.2018, https://www.spaceflight insider.com/organizations/bigelow-aerospace/bigelow-aerospace-spawnsspinoff-company-to-market-its-space-stations/ (10.08.2019).

Rogers Mike, Launching the Sixth Branch of the US Armed Forces, Defense News, 6.07.2018, https://www.defensenews.com/space/2018/07/06/launching-thesixth-branch-of-the-us-armed-forces/ (8.08.2018). 
Roulo Claudette, Space Force to Become Sixth Branch of Armed Forces, U.S. Department of Defense, 9.08.2018, https://www.defense.gov/News/Arti cle/Article/1598071/space-force-to-become-sixth-branch-of-armed-forces/ (14.08.2018).

Sankaran Jaganath, „Big, Fat, Juicy Targets” - the Problem with Existing Early-warning Satellites. And a Solution, "Bulletin of the Atomic Scientists”, 30.09.2019, https://thebulletin.org/2019/o9/big-fat-juicy-targets-the-problem -with-existing-early-warning-satellites/ (2.10.2019).

Seligman Lara, 'The 21st-Century Space Race Is On', „Foreign Policy”, 10.04.2019, https://foreignpolicy.com/2019/04/10/the-21st-century-space-race-is-on-mi chael-waltz-space-force/ (12.04.2019).

Snead Mike, Disruptive American „Astrologistics”, „The Space Review”, 19.11.2018, http://www.thespacereview.com/article/3605/1 (5.08.2019).

Stone Adam, Are Reprogrammable Satellites Ready for Prime Time?, CRISRnet, 5.04.2019, https://www.c4isrnet.com/c2-comms/satellites/2019/04/o5/are-re programmable-satellites-ready-for-prime-time/ (5.08.2019).

Stone Adam, Air Force Looks for Help on New, Hard-to-jam, Satellite Waveform, C4ISRNet, 4.10.2018, https://www.c4isrnet.com/c2-comms/satellites/ 2018/10/o5/air-force-looks-for-help-on-new-hard-to-jam-satellite-wave form/ (16.08.2019).

Strout Nathan, Is the Space Development Agency Here to Stay?, C4ISRnet, 2.08.2019, https://www.c4isrnet.com/battlefield-tech/space/2019/08/o1/isthe-space-development-agency-here-to-stay/ (3.08.2019).

Strout Nathan, The Pentagon's New Space Agency Has an Idea about the Future, C4ISRmet, 3.07.2019, https://www.c4isrnet.com/battlefield-tech/2019/ $07 / 03 /$ the-pentagons-new-space-agency-has-an-idea-about-the-future/ (5.07.2019).

Strout Nathan, The Small Sat Solution to Hypersonic Weapons, Explained, C4 ISRnet, 6.08.2019, https://www.c4isrnet.com/battlefield-tech/2019/o8/o6/thesmall-sat-solution-to-hypersonic-weapons-explained/ (8.08.2019).

Thomas Paul, Blackjack, DARPA, 2019, https://www.darpa.mil/program/black jack (10.09.2019).

Wall Mike, 1st Private Space Station Will Become an Off-Earth Manufacturing Hub, Space.com, 5.07.2017, https://www.space.com/37079-axiom-commer cial-space-station-manufacturing.html (12.08.2018).

Wall Mike, 'Luxury Space Hotel' to Launch in 2021, Space.com, 5.04.2018, https://www.space.com/40207-space-hotel-launch-2021-aurora-station.html (12.08.2018).

Wall M., NASA Puts Bigelow Aerospace's Giant Inflatable Space Habitat Prototype to the Test, Space.com, 13.09.2019, https://www.space.com/bigelow-aero space-space-habitat-nasa-test.html.

Walt Stephen M., Restraint Isn't Isolationism - and It Won't Endanger America, „Foreign Policy”, 22.07.2019, https://foreignpolicy.com/2019/07/22/restraint- 
isnt-isolationism-and-it-wont-endanger-america-offshore-balancing-quin cy-institute/ (23.07.2019).

Zak Anatoly, Here Is the Soviet Union's Secret Space Cannon, Popular Mechanics, 16.11.2015, https://www.popularmechanics.com/military/weapons/a18187/ here-is-the-soviet-unions-secret-space-cannon/ (31.05.2019).

Zak Anatoly, Russia Is Now Working on a Super Heavy Rocket of Its Own, Popular Mechanics, 8.02.2018, https://www.popularmechanics.com/space/rockets/ a16761777/russia-super-heavy-rocket/ (5.08.2019).

Ziarnick Brent, Garretson Peter, Starfleet Was Closer Than You Think, „The Space Review", 16.03.2015, http://www.thespacereview.com/article/2714/1 (16.04.2015).

Ziemnicki Paweł, IAI zabezpieczy platformy bojowe przed zakłóceniami sygnału GPS, Space24, 2.02.2017, http://www.space24.pl/iai-zabezpieczy-platformybojowe-przed-zakloceniami-sygnalu-gps (12.03.2018).

Ziemnicki Paweł, GPS na celowniku hakerów. Czas na powrót radia?, Space24, 10.08.2017, https://www.space24.pl/gps-na-celowniku-hakerow-czas-na-pow rot-radia-komentarz (22.08.2018).

\section{Informacyjne materiały internetowe}

2019 State of the Satellite Industry, Satellite Industry Association, 2019, https:// www.sia.org/wp-content/uploads/2019/05/2019-SSIR-2-Page-20190507.pdf (5.08.2019).

A9/A10, Encyclopedia Astronautica, 2016, http://www.astronautix.com/a/a9aio. html (2.09.2016).

A9/A10/A11/A12, Encyclopedia Astronautica, 2016, http://www.astronautix.com/ a/agaioanial2.html (2.09.2016).

About Orion Span, Orion Span, 2019, https://www.orionspan.com/about (11.08.2019).

Atlas V, ULA, 2018, https://www.ulalaunch.com/rockets/atlas-v (2.08.2019). Atlas A, Encyclopedia Astronautica, 2016, http://www.astronautix.com/a/atlasa.

html (2.09.2016).

Astrografia, Słownik języka polskiego PWN, https://sjp.pwn.pl/szukaj/astrogra fia.html (1.05.2019).

B330, Bigelow Aerospace, 2019, https://www.bigelowspaceops.com/\# (10.08.2019). Capabilities $\mathcal{E}$ Services, SpaceX, 2016, http://www.spacex.com/about/capabilities (8.08.2016).

Cislunar, Merriam-Webster, 2016, http://www.merriam-webster.com/dictionary/ cislunar (15.08.2016).

The ConnectX Private Satellite Network Solution, ConnectX, 2019, https://con nectx.com/ (5.08.2019). 
Counterspace Weapons 101, Center for Strategic and International Studies, 4.04.2019, https://aerospace.csis.org/aerospace101/counterspace-weapons-101/ (13.04.2019).

CubeSat 101. Basic Concepts and Processes for First-Time CubeSat Developers, NASA, October 2017, https://www.nasa.gov/sites/default/files/atoms/files/ nasa_csli_cubesat_101_508.pdf (18.03.2018).

Delta IV, United Launch Alliance, 2019, https://www.ulalaunch.com/rockets/ delta-iv (31.07.2019).

Education Curriculum on Space Law, UNOOSA, 2014, http://www.unoosa.org/ res/oosadoc/data/documents/2014/stspace/stspace64_o_html/st_space_ 064E.pdf (16.01.2018).

Elon Musk Will Update the Status of Starship Development on August 24, Arstechnica, 4.08.2019, https://arstechnica.com/science/2019/o8/elon-muskwill-update-the-status-of-starship-development-on-august-24/ (5.08.2019). Forward to the Moon: NASA's Strategic Plan for Human Exploration, NASA, 9.04.2019, https:/www.nasa.gov/sites/default/files/atoms/files/america_to_ the_moon_2024_artemis_20190523.pdf (20.05.2019).

Falcon 9, SpaceX, 2019, https://www.spacex.com/falcong (28.03.2019).

Falcon 9 Family, Gunter's Space Page, 2019, https://space.skyrocket.de/doc_lau_ fam/falcon-9.htm (31.07.2019).

Falcon Heavy, SpaceX, https://www.spacex.com/falcon-heavy (12.04.2019).

Genesis Program, Bigelow Aerospace, 2019, https://bigelowaerospace.com/pag es/genesis/ (10.08.2019).

Height of ISS, Heavens-Above, 2019, http://www.heavens-above.com/IssHeight. aspx (4.09.2019).

Hiroc, Encyclopedia Astronautica, 2016, http://www.astronautix.com/h/hiroc. html (2.09.2016).

Iceye, Iceye, 2019, https://www.iceye.com/ (12.08.2019).

Jupiter- $C$, Encyclopedia Astronautica, 2016, http://www.astronautix.com/j/jupi terc.html (31.08.2016).

Kosmiczna przestrzeń, Encyklopedia PWN, https:/encyklopedia.pwn.pl/haslo/ kosmiczna-przestrzen;3926141.html (10.04.2019).

Making Life Multiplanetary, SpaceX, 2018, https://www.spacex.com/mars (17.08.2018).

NASA Extends Expandable Habitat's Time on the International Space Station, NASA, 4.12.2017, https://www.nasa.gov/feature/nasa-extends-beam-s-timeon-the-international-space-station (10.08.2019).

NewSpace Hub, 2019, https://newspacehub.co/search?type=Company (5.08.2019). OneWeb, OneWeb, 2019, https://www.oneweb.world/ (6.08.2019).

Orbital Launches of 2001, Gunter's Space Page, 2019, https://space.skyrocket.de/ doc_chr/lau2001.htm (1.08.2019).

Orion Span, Orion Span, 2019, https://www.orionspan.com/ (11.08.2019). 
Planet Imagery and Archive, Planet Labs, 2019, https://www.planet.com/products/planet-imagery/ (14.08.2019).

Profile, Jamesoberg.com, 2016, http://www.jamesoberg.com/profile.html (6.06.2016).

Roberts Thomas G., History of the NASA Budget, Aerospace Security, 4.06.2019, https://aerospace.csis.org/data/history-nasa-budget/.

Saturn V, Encyclopedia Astronautica, 2016, http://www.astronautix.com/s/saturn.htm (2.05.2016).

Score, Encyclopedia Astronautica, 2016, http://www.astronautix.com/s/score. html (2.05.2016).

Soviet Cosmonauts Carried a Shotgun Into Space, War Is Boring, 24.08.2017, https://warisboring.com/soviet-cosmonauts-carried-a-shotgun-into-space/ (31.05.2019).

Space Foundation Report Reveals Global Space Economy at $\$ 329$ Billion in 2016, Space Foundation, 3.08.2017, https://www.spacefoundation.org/2017/08/03/ space-foundation-report-reveals-global-space-economy-329-billion-2016 (14.03.2018).

Space law, Encyclopaedia Britannica, 27.12.2017, https://www.britannica.com/ topic/space-law (13.01.2018).

Space Law: Resolutions, UNOOSA, 2019, http://www.unoosa.org/oosa/en/our work/spacelaw/resolutions.html (6.09.2019).

Space Projects, SpaceForest, 2018, https://spaceforest.pl/portfolio/space-pro jects/ (21.01.2018).

Space Shuttle, Encyclopedia Astronautica, 2017, http://www.astronautix.com/s/ spaceshuttle.html (11.08.2018).

Starlink, Starlink, 2019, https://www.starlink.com/ (11.08.2019).

Starlink Mission, SpaceX, 24.05.2019, https://www.spacex.com/news/2019/05/24/ starlink-mission (10.08.2019).

STP-2 Mission, SpaceX, 2019, https://www.spacex.com/stp-2 (10.08.2019).

STP-2 Mission, SpaceX, 26.06.2019, https://www.spacex.com/news/2019/o6/26/ stp-2-mission (2.08.2019).

Thor, Encyclopedia Astronautica, 2016, http://www.astronautix.com/t/thor. html (31.08.2016).

US Air Force: "Rodzime satelity potrzebujq zdolności samoobrony”, Space24, 28.02.2019, https://www.space24.pl/us-air-force-rodzime-satelity-potrzebu ja-zdolnosci-samoobrony (1.03.2019).

US Ship Force Levels, 1886-present, Naval History and Heritage Command, 17.11.2017, https://www.history.navy.mil/research/histories/ship-histories/us -ship-force-levels.html (6.06.2019).

Wall Mike, European Satellite Dodges Potential Collision with SpaceX Starlink Craft, Space.com, 3.09.2019, https://www.space.com/spacex-starlink-esa-sa tellite-collision-avoidance.html?utm_source=sdc-newsletter\&utm_medium =email\&utm_campaign=20190904-sdc (5.09.2019). 
Weaponize, Lexico, 2019, https://www.lexico.com/en/definition/weaponize (18.09.2019).

Weaponize, Merriam-Webster, 2019, https://www.merriam-webster.com/dictio nary/weaponization\#other-words (18.09.2019).

What Are SmallSats and CubeSats?, NASA, 26.02.2015, https://www.nasa.gov/ content/what-are-smallsats-and-cubesats (28.02.2018). 


\section{Indeks osobowy}

Al-Rodhan Nayef 38

Arnold Henry „Hap” 134

Asimov Isaac 15

Autry Greg 333

Bartholomees J. Boone 196

Basu Arindrajit 77

Baucom Donald R. 171

Bennett Dan 316

Bennett James C. 277

Bezos Jeff 262, 278

Bigelow Robert T. 268

Black James 306

Boyne Walter J. 132

Bradbury Ray 15

Brahe Tycho de 130

Braun Wernher von 129, 131-132, 143-

144, 147

Brown Mike 260

Brumfield Ben 166

Burns Richard Dean 173

Burns Robert 224

Burris Matthew 49

Burrows William E. 23, 131-133, 137 , 144-146, $15^{8}$

Butt Yousaf 113,318
Carey Bill 237

Carreau Mark 242, 277

Chruszczow Nikita 140, 159, 161-163

Ciołkowski Konstantin 130-131

Clarke Arthur C. 15

Clausewitz Carl von 50

Cooper Henry F. Jr. 315

Cour-Palais Burton G. 332

Czajkowski Marek 13, 99, 116, 177-178, 316, 326, 329

Cziomer Erhard 24

Daec Wilfred P. 159

Day Dwayne A. 271

Dick Steven J. 39

DiMascio Jen 230

Dolman Everett C. 16, 22-23, 43-49, 62, 70, 79, 136, 314-315

Douhet Giulio 39, 45

Dura Maksymilian 120

Eisenhower Dwight D. 137-140, 143$144,153,155,165,167,214,249,313$

Fergusson James 175

Finch James P. 122, 318 
Frankowski Paweł 23

Freier Nathan 200

Gagarin Jurij 161, 165

Galileusz 130

Gansler Jacques S. 171

Garber Stephen J. 267, 274

Garretson Peter 64, 166

Garwin Richard R. 335

Gelain Antoine 275

Gerałt Bartłomiej 275

Ghoshroy Subrata 326

Goddard Robert 130-131, 133

Gould Joe 232

Górbiel Andrzej 24

Gray Colin S. 40, 42-43, 49

Greason Jeff 277

Grego Laura 23, 88, 90, 97, 169, 291, 323

Grissom Virgil 161

Groll Elias 285

Gronlund Lisbeth 23, 88, 90, 97, 291

Gruss Mike 304

Gruszczak Artur 24

Handberg Roger 23, 88, 333

Harrison Todd 280, 292, 295, 306, 316 Hays Peter L.

Hecht J. 115

Heinlein Robert A. 15, 135

Henry Caleb 267

Howell Elizabeth 259, 289

Hubble Edwin 130

Hudson Lee 230

Hutchison Matthew 316

Insinna Valerie 260

Johnson Kaitlyn 280, 292, 295, 306, 316 Johnson Lyndon B. 168

Johnson Stephen B. 39, 128, 135, 158, 169

Johnson-Freese Joan 16, 100
Jones Andrew 261

Jones Harry W. 255

Judson Jen 314

Kamassa Marcin 286, 290

Kármán Theodore von 133

Kasap Haylie 270

Kennan George 135

Kennedy John Fitzgerald 29, 157, 162, 165-166, 169

Kepler Johannes 85-86, 130

Kessler Donald J. 332

Kirk Grayson 187

Kleiman Matthew 282, 293

Klotz Irene 257, 265-266

Kłosowicz Robert 24

Knipfer Cody 240, 276

Kopeć Rafał 23, 37, 77, 112, 115

Kopernik Mikołaj 130

Korb Lawrence J. 327

Korolow Sergiej P. 161

Krepinevich Andrew F., Jr. 203

Kristensen Hans M. 140, 161

Kupchan Charles A. 187

Kurlekar Arthad 77

Kwast Steve 333

Lambakis Steven 16, 23

Larsen Paul B. 73

Launius Roger D. 23, 39, 134

Laurila Pekka 270

Lem Stanisław 15

Lendon Brad 315

Lewis Patricia 283

List Friedrich 45

Livingstone David 283

Lutes Charles D. 22

Lyall Francis 73

Mackinder Halford John 45-46

Mahan Alfred Thayer 27, 39-41, 45, 50, 183-184, 188 
Malik Tariq 301

Mandelbaum Michael 203

Marshall George C. 186

Masters Jonathan 192, 236

McDougall Walter A. 13, 23, 48, 133 ,

137, 140-141, 144-146, 155, 157, 160, $163,165,167$

McNamara Robert S. 165-166

McNeil Sonia 282, 293

Mead Walter Russell 200-201

Mehta Aaron 213, 229, 305

Messier Doug 270-271

Mitchell Billy 39, 45

Modrzewski Rafał 270

Moltz James Clay 23, 323

Monroe James 182

Mosher Dave 275

Mowthorpe Matthew 136, 153, 167, 173-174

Muelhaupt Theodore J. 224, 267, 271, 275

Musk Elon 258, 260, 262, 274, 278

Muzyka Kamil 270

Newton Isaac 85, 130

Niedielin Mitrofan 160

Nixon Richard Milhous 157

Norris Guy 260

Norris Robert S. 140, 161

Nye Joseph S. 32

O'Hanlon Michael 204

Obama Barack 214, 218, 220

Oberg Jim 16, 40-42

Oberth Hermann 130-131

Pence Mike 226

Peoples Columba 173

Petraeus David 204

Pfaltzgraff Robert L., Jr. 29

Phillips Dewanne Marie 282

Piszkiewicz Dennis 131
Polkowska Małgorzata 23, 62, 67, 141

Pollpeter Kevin 123

Porębski Andrzej 24

Pyle Rod 271

Reagan Ronald 171

Richardson Derek 269

Roberts Thomas G. 155, 165, 280, 292, 295, 306, 310, 316, 319

Rogers Mike 302

Roulo Claudette 226

Samson Victoria 293

Sankaran Jaganath 122, 301

Sariak George 110, 120

Sarosh Ali 293

Schaffer Audrey M. 323

Schelling Thomas C. 119

Schulte Gregory L. 323

Seligman Lara 314

Seversky Aleksander de 39, 45

Shabbir Zaeem 293

Sheehan Michael 160

Sheldon John B. 40, 42-43, 49

Shepard Alan 161

Słomczyńska Irma 24

Snead Mike 271, 276

Spykman Nicolas 45

Stone Adam 263, 300

Strout Nathan 230, 304

Strugacki Arkadij 15

Strugacki Boris 15

Sumida Jon 40

Thomas Paul 305

Thornberry Mac 203

Tirman John 172

Trenchard Hugh 39

Troxell John F. 196

Truman Harry S. 136

Trump Donald 201, 205, 214, 218-222, 224, 226, 232, 257, 333 
Vedda James A. 267, 274

Verne Jules 15, 130

Waage Frederick 316

Walker Dinah 187

Wall Mike 245, 269-270

Walt Stephen M. 202

Watkins James 171

Weeden Brian 23, 293

Wells Herbert George 15, 130-131

Wheeler Winslow 197
Wong Wilson W. S. 175

Wright David 23, 88, 90, 97, 291, 323

Wyler Greg 266, 278

Zak Anatoly 177, 261

Zakaria Fareed 198

Zapata Edgar 260

Ziarnick Brent 49-54, 64, 166

Ziemnicki Paweł 301, 305

Zonn Włodzimierz 19 


\section{Outer Space in the Security Strategy of the United States}

This book contributes to a necessary effort to understand the impact of human activities in outer space on international security. Its specific task is to grasp the changing role of space applications for the security of the United States. It is not, however, a treatise on military doctrine or modern warfare, neither it is a handbook on technology. Instead, it utilizes paradigms of international relations to extract the political dimension out of this so highly technical issue.

The book contains five chapters. In the first chapter, we find the analysis of some theoretical and legal aspects of the relationship between human activities in outer space and security with its multiple dimensions. The considerations of chapter two revolve around the science and technology of space applications with special attention to security issues. It is not, however, a technical manual but rather the comprehensive, general description of the characteristics of outer space presented for the sake of comprehensiveness of the whole argument. Chapter three contains a description of the historical background, which means the evolution of military space applications. But again, it does not provide detailed technical knowledge but rather concentrates on the political and strategic dimension. Chapter four is the essential part of the book as it depicts the space security policy of the United States against the background of the general international strategy of the U.S. And finally, chapter five contains some thoughts about specific issues related to the space security.

The most general findings expressed in this book are as follows. Firstly, the core elements of the United States international strategy and for- 
eign policy rely heavily on the unhampered use of space applications. But, secondly, the capabilities that these applications provide with, are increasingly contested by many international players. These competitors not only have the abilities to negate some of the American space-borne capabilities, but also create their own, similar. The latter contributes greatly to the narrowing of the technology advantage of the U.S. over its peers. And thirdly, this problematic situation will persist, compelling the United States to at least try to reverse the process of loosing of what is sometimes called the space hegemony.

Keywords: international relations, international security, space security, U.S. security strategy, space law 
W serii Societas pod redakcją Bogdana Szlachty ukazały się:

1. Grzybek Dariusz, Nauka czy ideologia. Biografia intelektualna Adama Krzyżanowskiego, 2005.

2. Drzonek Maciej, Między integracjq a europeizacja. Kościół katolicki w Polsce wobec Unii Europejskiej w latach 1997-2003, 2006.

3. Chmieliński Maciej, Max Stirner. Jednostka, spoleczeństwo, państwo, 2006.

4. Nieć Mateusz, Rozważania o pojęciu polityki w kręgu kultury attyckiej. Studium z historii polityki i myśli politycznej, 2006.

5. Nahum Sokołów. Życie i legenda, oprac. Andrzej A. Zięba, 2006.

6. Porębski Leszek, Między przemoca a godnościa. Teoria polityczna Harolda D. Lasswella, 2007.

7. Mazur Grzegorz, Życie polityczne polskiego Lwowa 1918-1939, 2007.

8. Węc Janusz Józef, Spór o kształt instytucjonalny Wspólnot Europejskich $i$ Unii Europejskiej 1950-2005. Między ideq ponadnarodowości a wspólpraca międzyrzadowa. Analiza politologiczna, 2006.

9. Karas Marcin, Integryzm Bractwa Kapłańskiego św. Piusa X. Historia i doktryna rzymskokatolickiego ruchu tradycjonalistycznego, 2008.

10. European Ideas on Tolerance, red. Guido Naschert, Marcin Rebes, 2009.

11. Gacek Łukasz, Chińskie elity polityczne w XX wieku, 2009.

12. Zemanek Bogdan Stanisław, Tajwańska tożsamość narodowa w publicystyce politycznej, 2009.

13. Lenczarowicz Jan, Jałta. W kręgu mitów zalożycielskich polskiej emigracji politycznej 1944-1956, 2009.

14. Grabowski Andrzej, Prawnicze pojęcie obowiazywania prawa stanowionego. Krytyka niepozytywistycznej koncepcji prawa, 2009.

15. Kich-Masłej Olga, Ukraina w opinii elit Krakowa końca XIX - pierwszej połowy XX wie$k u, 2009$.

16. Citkowska-Kimla Anna, Romantyzm polityczny w Niemczech. Reprezentanci, idee, model, 2010.

17. Mikuli Piotr, Sady a parlament $w$ ustrojach Australii, Kanady i Nowej Zelandii (na tle rozwiazań brytyjskich), 2010.

18. Kubicki Paweł, Miasto w sieci znaczeń. Kraków i jego tożsamości, 2010.

19. Żurawski Jakub, Internet jako współczesny środek elektronicznej komunikacji wyborczej $i$ jego zastosowanie w polskich kampaniach parlamentarnych, 2010.

20. Polscy eurodeputowani 2004-2009. Uwarunkowania działania i ocena skuteczności, red. Krzysztof Szczerski, 2010.

21. Bojko Krzysztof, Stosunki dyplomatyczne Moskwy z Europa Zachodniq w czasach Iwana III, 2010.

22. Studia nad wielokulturowością, red. Dorota Pietrzyk-Reeves, Małgorzata Kułakowska, Elżbieta Żak, 2010.

23. Bartnik Anna, Emigracja latynoska w USA po II wojnie światowej na przykladzie Portorykańczyków, Meksykanów i Kubańczyków, 2012.

24. Transformacje w Ameryce Łacinskiej, red. Adam Walaszek, Aleksandra Giera, 2011.

25. Praszałowicz Dorota, Polacy w Berlinie. Strumienie migracyjne i spoleczności imigrantów. Przeglad badań, 2010. 
26. Głogowski Aleksander, Pakistan. Historia i współczesność, 2011.

27. Brążkiewicz Bartłomiej, Choroba psychiczna w literaturze i kulturze rosyjskiej, 2011.

28. Bojenko-Izdebska Ewa, Przemiany w Niemczech Wschodnich 1989-2010. Polityczne aspekty transformacji, 2011.

29. Kolodziej Jacek, Wartości polityczne. Rozpoznanie, rozumienie, komunikowanie, 2011.

30. Nacjonalizmy różnych narodów. Perspektywa politologiczno-religioznawcza, red. Bogumil Grott, Olgierd Grott, 2012.

31. Matyasik Michał, Realizacja wolności wypowiedzi na podstawie przepisów i praktyki wUSA, 2011.

32. Grzybek Dariusz, Polityczne konsekwencje idei ekonomicznych w myśli polskiej 18691939, 2012.

33. Woźnica Rafal, Bulgarska polityka wewnętrzna a proces integracji $z$ Uniq Europejską, 2012.

34. Slufińska Monika, Radykałowie francuscy. Koncepcje $i$ dzialalność polityczna wXX wie$k u, 2012$.

35. Fyderek Łukasz, Pretorianie i technokraci w rezimie politycznym Syrii, 2011.

36. Węc Janusz Józef, Traktat lizboński. Polityczne aspekty reformy ustrojowej Unii Europejskiej w latach 2007-2009, 2011.

37. Rudnicka-Kassem Dorota, John Paul II, Islam and the Middle East. The Pope's Spiritual Leadership in Developing a Dialogical Path for the New History of Christian-Muslim Relations, 2012.

38. Bujwid-Kurek Ewa, Serbia w nowej przestrzeni ustrojowej. Dzieje, ustrój, konstytucja, 2012.

39. Cisek Janusz, Granice Rzeczypospolitej $i$ konflikt polsko-bolszewicki $w$ świetle amerykańskich raportów dyplomatycznych $i$ wojskowych (1919-1921), 2012.

40. Gacek Łukasz, Bezpieczeństwo energetyczne Chin. Aktywność państwowych przedsiębiorstw na rynkach zagranicznych, 2012.

41. Węc Janusz Józef, Spór o ksztalt ustrojowy Wspólnot Europejskich $i$ Unii Europejskiej w latach 1950-2010. Między ideq ponadnarodowości a współpraca międzyrzadowa. Analiza politologiczna, 2012.

42. Międzycywilizacyjny dialog wświecie słowiańskim wXX i XXI wieku. Historia - religia kultura - polityka, red. Irena Stawowy-Kawka, 2012.

43. Ciekawość świata, ludzi, kultury... Księga jubileuszowa ofiarowana Profesorowi Ryszardowi Kantorowi z okazji czterdziestolecia pracy naukowej, red. Renata Hołda, Tadeusz Paleczny, 2012.

44. Węc Janusz Józef, Pierwsza polska prezydencja w Unii Europejskiej. Uwarunkowania procesy decyzyjne - osiagnięcia i niepowodzenia, 2012.

45. Zemanek Adina, Córki Chin i obywatelki świata. Obraz kobiety w chińskich czasopismach o modzie, 2013.

46. Kamiński Eva, Rezeption japanischer Kultur in Deutschland. Zeitgenössische Keramik als Fallstudie, 2012.

47. Obeidat Hayssam, Stabilność układu naftowego $w$ warunkach zagrożeń konfliktami $w$ świetle kryzysu w latach siedemdziesiatych XX i na progu XXI wieku, 2012.

48. Scigaj Paweł, Tożsamość narodowa. Zarys problematyki, 2012.

49. Głogowski Aleksander, Af-Pak. Znaczenie zachodniego pogranicza pakistańsko-afgańskiego dla bezpieczeństwa regionalnego w latach 1947-2011, 2012. 
50. Miżejewski Maciej, Ochrona pluralizmu w polityce medialnej Wtoch, 2013.

51. Jakubiak Łukasz, Referendum jako narzędzie polityki. Francuskie doświadczenia ustrojowe, 2012.

52. Skuteczność polskiej prezydencji w Unii Europejskiej. Założone cele $i$ ich realizacja, red. Krzysztof Szczerski, 2012.

53. Stosunki państwo-Kościół w Polsce 1944-2010. Studia i materiały, red. Rafał Łatka, 2013.

54. Gacek Łukasz, Trojnar Ewa, Pokojowe negocjacje czy twarda gra? Rozwój stosunków ponad Cieśning Tajwańskq, 2013.

55. Sondel-Cedarmas Joanna, Nacjonalizm wloski. Geneza i ewolucja doktryny politycznej (1896-1923), 2013.

56. Rudnicka-Kassem Dorota, From the Richness of Islamic History, 2013.

57. Fudała Piotr, Fyderek Łukasz, Kurpiewska-Korbut Renata, Budowanie parlamentaryzmu. Doświadczenia z Afganistanu, Iraku i Kurdystanu irackiego, 2012.

58. Dardziński Piotr, Kapitalizm nieobjawiony. Doktryna ładu społecznego, politycznego i ekonomicznego w myśli Wilhelma Röpkego (1899-1966), 2013.

59. The Taiwan Issues, ed. Ewa Trojnar, 2012.

60. Rebes Marcin, Między respondere $i$ imputatio. Martina Heideggera i Józefa Tischnera hermeneutyka odpowiedzialności $w$ horyzoncie ontologii, agatologii $i$ aksjologii, cz. I: 2014; cz. II, III: 2018.

61. Kurpiewska-Korbut Renata, Społeczność międzynarodowa wobec Kurdów irackich, 2014.

62. Pietrzyk-Reeves Dorota, Ład rzeczypospolitej. Polska myśl polityczna XVI wieku a klasyczna tradycja republikańska, 2012.

63. Matykiewicz-Włodarska Aleksandra, Marion Gräfin Dönhoff. Idee i refleksje polityczne, 2012.

64. Reczyńska Anna, Braterstwo a bagaż narodowy. Relacje w Kościele katolickim na ziemiach kanadyjskich do I wojny światowej, 2013.

65. Wspótczesne transformacje. Kultura, polityka, gospodarka, red. Monika Banaś, Joanna Dziadowiec, 2013.

66. Grott Olgierd, Instytut Badań Spraw Narodowościowych i Komisja Naukowych Badań Ziem Wschodnich w planowaniu polityki II Rzeczypospolitej Polskiej na Kresach Wschodnich, 2013.

67. Teoretyczne i praktyczne problemy kultury politycznej. Studia i szkice, red. Monika Banaś, 2013.

68. Podejścia badawcze i metodologie w nauce o polityce, red. Barbara Krauz-Mozer, Paweł Scigaj, 2013.

69. Narratives of Ethnic Identity, Migration and Politics. A Multidisciplinary Perspective, eds. Monika Banaś, Mariusz Dzięglewski, 2013.

70. Promoting Changes in Times of Transition and Crisis: Reflections on Human Rights Education, eds. Krzysztof Mazur, Piotr Musiewicz, Bogdan Szlachta, 2013.

71. Bar Joanna, Po ludobójstwie. Państwo i spoleczeństwo w Rwandzie 1994-2012, 2013.

72. Włochy wielokulturowe. Regionalizmy, mniejszości, migracje, red. Karolina Golemo, 2013.

73. Stany Zjednoczone wczoraj $i$ dziś. Wybrane zagadnienia społeczno-polityczne, red. Agnieszka Małek, Paulina Napierała, 2013.

74. Plichta Pawel, Estera w kulturach. Rzecz o biblijnych toposach, 2014.

75. Czekalska Renata, Wartości autoteliczne w kulturze symbolicznej na przykładzie indyjsko-polskich spotkań literackich, 2013. 
76. Włodarski Bartosz, Szkola Nauk Politycznych UJ 1920-1949, 2015.

77. Arabska wiosna w Afryce Pólnocnej. Przyczyny, przebieg, skutki, red. Ewa Szczepankiewicz-Rudzka, 2014.

78. Bajor Piotr, Partnerstwo czy czlonkostwo? Polityka euroatlantycka Ukrainy po 1991 r., 2014.

79. Gabryś Marcin, Kijewska-Trembecka Marta, Rybkowski Radosław, Soroka Tomasz, Kanada na przelomie XX $i$ XXI wieku. Polityka, spoleczeństwo, edukacja, red. Marta Kijewska-Trembecka, 2014.

80. Trojnar Ewa, Tajwan. Dylematy rozwoju, 2015.

81. Głogowski Aleksander, Policja Państwowa i inne instytucje bezpieczeństwa na Wileńszczyźnie w latach 1918-1939, 2015.

82. Krzyżanowska-Skowronek Iwona, Teorie zmiany na przykładzie wloskiej polityki wschodniej, 2015.

83. Rysiewicz Mikołaj, Monarchia, lud, religia. Monarchizm konserwatywnych środowisk politycznych Wielkiej Emigracji w latach 1831-1848, 2015.

84. Szymkowska-Bartyzel Jolanta, Nasza Ameryka wyobrażona. Polskie spotkania z amerykańskq kulturq popularnq po roku 1918, 2015.

85. Napierała Paulina, In God We Trust. Religia w sferze publicznej USA, 2015.

86. Paluszkiewicz-Misiaczek Magdalena, Szacunek $i$ wsparcie. Kanadyjski system opieki nad weteranami, 2015.

87. Детерминанты и перспективы политики еөропейской интеграции Республики Молдова, под научной редакцией Петра Байора, 2015.

88. Eastern Chessboard. Geopolitical Determinants and Challenges in Eastern Europe and the South Caucasus, eds. Piotr Bajor, Kamila Schöll-Mazurek, 2015.

89. Mazur Wojciech, Pod wiatr. Francja $i$ lotnictwo wojskowe II Rzeczypospolitej (19211938), 2015.

90. Węc Janusz Józef, Traktat lizboński. Polityczne aspekty reformy ustrojowej Unii Europejskiej w latach 2007-2015, 2016.

91. Fyderek Łukasz, Autorytarne systemy polityczne świata arabskiego. Adaptacja i inercja w przededniu Arabskiej Wiosny, 2016.

92. Kwieciński Rafal, Zjednoczenie Chin? Proces reintegracji Wielkich Chin na przełomie XX i XXI w., 2016.

93. Grabowski Marcin, Rywalizacja czy integracja? Procesy i organizacje integracyjne $w$ regionie Azji i Pacyfiku na przełomie XX i XXI wieku, 2015.

94. Laidler Paweł, Turek Maciej, Cena demokracji. Finansowanie federalnych kampanii wyborczych w Stanach Zjednoczonych Ameryki, 2016.

95. Bajor Piotr, Contemporary Azerbaijan in Social and Political Dimension, 2016.

96. Balwierz Ida, Czasopismo "Apollo". Jego miejsce $i$ rola w odrodzeniu poezji $i$ kultury arabskiej, 2016.

97. Bajor Piotr, Kierunek Zachód. Polityka integracji europejskiej Ukrainy po 1991 roku, 2015.

98. Polska i Rumunia w Europie Srodkowej w XX i XXI wieku. Studia, materialy i eseje poświęcone pamięci prof. dra hab. Wojciecha Rojka. Polonia și România in Europa Centrală in secolele XX si XXI. Studii, materiale şi eseuri dedicate in memoriam prof. univ. dr. Wojciech Rojek, red. Agnieszka Kastory, Henryk Walczak, 2017.

99. Mazur Wojciech, Lot ku burzy. Polska w przygotowaniach mocarstw Zachodu do wojny powietrznej marzec-sierpień 1939 roku, 2017. 
100. Gabryś Marcin, Soroka Tomasz, Canada as a Selective Power. Canada's Role and International Position after 1989, 2017.

101. Głuszek Alicja, Współpraca amerykańsko-meksykańska w zwalczaniu handlu ludźmi na przetomie XX $i$ XXI wieku, 2017.

102. Paleczny Tadeusz, Relacje międzykulturowe $w$ dobie kryzysu ideologii i polityki wielokulturowości, 2017.

103. Czubik Agnieszka, Dziwisz Dominika, Szczepankiewicz-Rudzka Ewa, Tarnawski Marcin, Nowe wyzwania dla ochrony praw czlowieka, 2017.

104. Gabryś Marcin, Przewodnik po konstytucji Kanady. Część pierwsza. Akt Konstytucyjny z 1867 roku, 2016.

105. Porębski Leszek, Technika w perspektywie społecznej, 2017.

106. Gabryś Marcin, Przewodnik po konstytucji Kanady. Część druga. Akt Konstytucyjny z 1982 roku, 2017.

107. Dulak Michał, Demokratyczna legitymizacja polskiej polityki europejskiej. Analiza systemowa, 2017.

108. Turek Maciej, Prawybory prezydenckie w USA. Bilans czterech dekad, 2017.

109. Oblicza Ameryki. Szkice o spoleczeństwie, kulturze i polityce Stanów Zjednoczonych, red. Paulina Napierała, Rafał Kuś, 2016.

110. Kuś Rafał, Retoryka polityczna Richarda Nixona, 2016.

111. Modrzejewska Magdalena, Josiah Warren - the First American Anarchist. "The Remarkable American", 2016.

112. Mazur Wojciech, Niebo rozwianych nadziei. Zachodni sojusznicy wobec wojny powietrznej $w$ Polsce we wrześniu 1939 roku, 2018.

113. Małek Agnieszka, Polityka migracyjna Wloch w latach 1861-2011, 2017.

114. Kastory Agnieszka, Rola Obywatelskiego Klubu Parlamentarnego w kształtowaniu polskiej polityki wschodniej w latach 1989-1991, 2018.

115. Kułakowska Małgorzata, W poszukiwaniu spójności wspólnotowej. Polityka rządu brytyjskiego w latach 2001-2010, 2018.

116. Biliński Piotr, Waclaw Tokarz 1873-1937. Historyk walk o niepodległość, 2018.

117. Golemo Karolina, Małek Agnieszka, Wlochy - mozaika kultur, 2018.

118. Modrzejewska Magdalena, Stephen Pearl Andrews - anarchia $i$ spoleczeństwo. Studia $z$ amerykańskiego anarchizmu indywidualistycznego, 2016.

119. Podsumowanie VIII kadencji PE. Wyzwania integracji europejskiej w latach 2014-2019, red. Agnieszka Nitszke, Janusz Józef Węc, 2019.

120. Bajor Piotr, Gruszczak Artur, Między wiedzq a władza. Bezpieczeństwo w erze informacji, 2019.

121. Security Outlook 2018, ed. Artur Gruszczak, 2019.

122. Kulpińska Joanna, Transatlantyckie trendy migracyjne na przestrzeni stulecia. Studium przypadku wychodźstwa z powiatu strzyżowskiego, 2019.

123. Rebes Marcin, Od epistemologii do ontologii. Hermeneutyka wolności Martina Heideggera $w$ dyskusji $z$ Immanuelem Kantem, 2019.

124. Prawa czlowieka wobec wyzwań wspólczesnego świata, red. Ewa Szczepankiewicz-Rudzka, Agnieszka Czubik, Dominika Dziwisz, 2019.

125. Górska Katarzyna, Miasto, barrios i kultura popularna w Peru - tożsamość kulturowa nowych mieszkańców Limy, 2020.

126. Marta Kania, Projekt Qhapaq Nan. Wyzwania nowego modelu polityki wobec dziedzictwa kulturowego ludów tubylczych, 2019. 


